\title{
Distribution of Fission Products in Peach Bottom HTGR Fuel Element F03-01
}

\author{
F. F. Dyer \\ R. P. Wichner \\ W. J. Martin \\ L. L. Fairchild
}




\section{Printed in the United States of America. Available from National Technical Information Service \\ U.S. Department of Commerce 5285 Port Royal Road, Springfield, Virginia 22161}

Price: Printed Copy $\$ 10.75$; Microfiche $\$ 3.00$

This report was prepared as an account of work sponsored by an agency of the United States Government. Neither the United States Government nor any agency thereof, nor any of their employees, contractors, subcontractors, or their employees, makes any warranty, express or implied, nor assumes any legal liability or responsibility for any third party's use or the results of such use of any information, apparatus, product or process disclosed in this report, nor represents that its use by such third party would not infringe privately owned rights. 


\section{DISCLAIMER}

This report was prepared as an account of work sponsored by an agency of the United States Government. Neither the United States Government nor any agency Thereof, nor any of their employees, makes any warranty, express or implied, or assumes any legal liability or responsibility for the accuracy, completeness, or usefulness of any information, apparatus, product, or process disclosed, or represents that its use would not infringe privately owned rights. Reference herein to any specific commercial product, process, or service by trade name, trademark, manufacturer, or otherwise does not necessarily constitute or imply its endorsement, recommendation, or favoring by the United States Government or any agency thereof. The views and opinions of authors expressed herein do not necessarily state or reflect those of the United States Government or any agency thereof. 


\section{DISCLAIMER}

Portions of this document may be illegible in electronic image products. Images are produced from the best available original document. 
Contract No. W-7405-eng-26

CHEMICAL TECHNOLOGY DIVISION

HTGR BASE TECHNOLOGY PROGRAM

HTGR Chemistry Studies (189a 01329 )

DISTRIBUTION OF FISSION PRODUCTS IN PEACH BOTTOM

HTGR FUEL ELEMENT FO3-OI
F. F. Dyer ${ }^{*}$
R. P. Wichner
W. J. Martin
L. L. Fairchild

*Analytical Chemistry Division

Date Published: May 1978

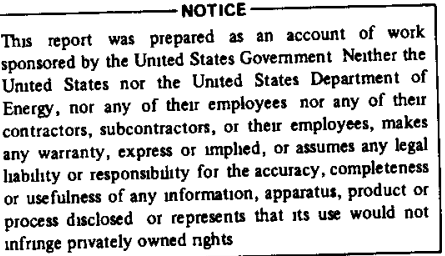

process disclosed or represents the
infruge privately owned nghts

OAK RIDGE NATIONAL IABORATORY

Oak Ridge, Tennessee 37830 operated by

UNION CARBIDE CORPORATION

for the

DEPARTMENT OF ENERGY 
•

.

-

$\cdot$
$:$

. 


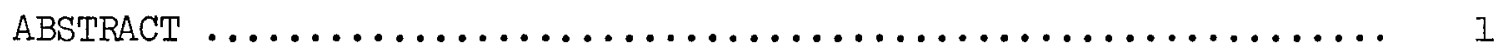

1. INTRODUCTION $\ldots \ldots \ldots \ldots \ldots \ldots \ldots \ldots \ldots \ldots \ldots \ldots \ldots \ldots \ldots \ldots$

2. FUEL-ELEMENT DESCRIPTION $\ldots \ldots \ldots \ldots \ldots \ldots \ldots \ldots \ldots \ldots \ldots \ldots$

2.1 Design Dimensions and Specifications $\ldots \ldots \ldots \ldots \ldots \ldots \ldots$

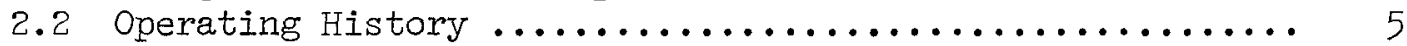

3. PHOTOGRAPHIC DESCRIPTION AND METROLOGY .................. 9

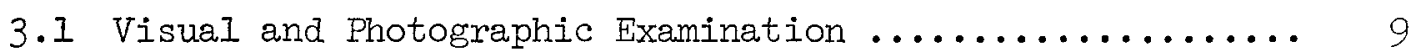

3.2 Metrology of Sleeve, Spine, and Fuel Compacts ......... 30

4. DISTRIBUTION OF GAMMA-EMITTING RADIONUCLIDES ........... 40

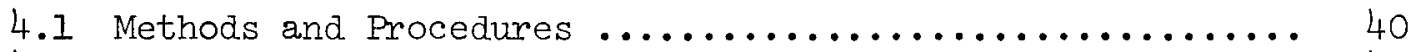

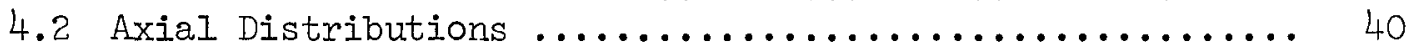

4.2.1 Fuel compacts ......................... 40

4.2.2 Sleeve, spine, and bottom connector .......... 53

4.2.3 Axial distributions in the top reflector ....... 63

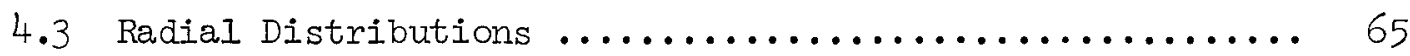

5. DISTRIBUTIONS of ${ }^{3}$, ${ }^{14} \mathrm{C}$, AND ${ }^{90}{ }_{\mathrm{Sr}} \ldots \ldots \ldots \ldots \ldots \ldots \ldots \ldots$

5.I Axial Distributions in the Top Reflector ............ 93

5.2 Radial Distributions in the Sleeve, Spine, and

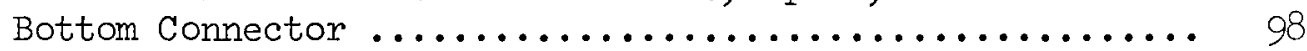

6. EXAMTIATION OF FUEL PARTICLES $\ldots \ldots \ldots \ldots \ldots \ldots \ldots \ldots \ldots \ldots \ldots$

6.I Fission Product and Heavy-Metal Inventories in Fuel

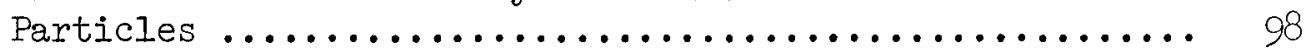

6.2 Metallographic Examination of Fuel Compacts ........... 117

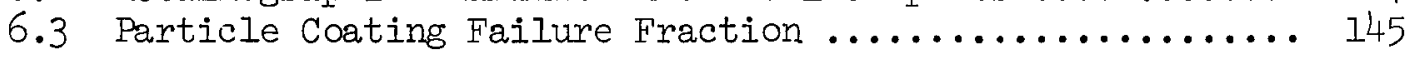

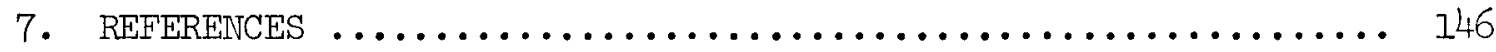

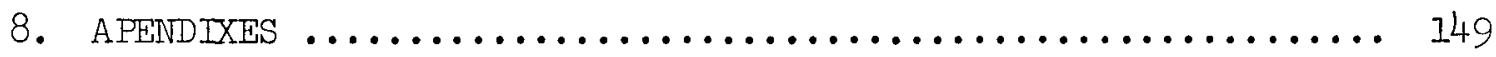

8.1 Appendix A: Measured Axial Distribution of GammaEmitters in the Sleeve, Spine, and Bottom Connector in Planes 1 and 2 . 
8.2 Appendix B: Update of Fission Product Inventories in the Fuel Compacts of Elements EO6-OI and Ell-O7 ...... 247

8.3 Appendix C: Update of Primary Circuit Report (ORN-5I88); Estimates of ${ }^{134} \mathrm{Cs}$ and ${ }^{137} \mathrm{Cs}$ in

Peach Bottom HTGR Steam Generators at End of Life ...... 253

8.3.1 Miscellaneous errata and additions ............ 253

8.3.2 Inventories of ${ }^{134} \mathrm{Cs}$ and ${ }^{137} \mathrm{Cs}$ in Peach

Bottom HTGR steam generators at final

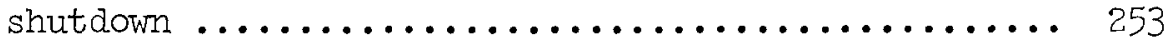




\title{
DISTRIBUTION OF FISSION PRODUCTS IN PEACH BOTTOM
}

HTGR FUEL ELEMENT FO3-O1

\author{
F. F. Dyer \\ R. P. Wichner \\ W. J. Martin \\ I. L. Fairchild
}

\section{ABSTRACT}

This is the fourth in a series of six postirradiation examinations of Peach Bottom High-Temperature Gas-Cooled Reactor driver fuel elements. Element FO3-Ol was a so-called highrhodium driver element centrally located within core 2 adjacent to a "type 2 " control rod. Although not instrumented, the element was estimated to have operated at significantly higher temperatures than the majority of the driver elements and, therefore, was expected to exhibit enhanced release and migration of fission products from the fuel into its graphite components. Because of these expectations, the examination of element FO3-OI was believed to be especially important. The element received an equivalent of 897 full-power days of irradiation prior to scheduled termination of core operation.

The examination procedures emphasized the determination of radionuclide distributions in the graphite portions of the fuel element. Axial gamma scans indicated $36 \mathrm{Ci}$ of ${ }^{137} \mathrm{Cs}$ in the sleeve of the element and $9.8 \mathrm{Ci}$ in the spine. From similar measurements, $358 \mathrm{Ci}$ of ${ }^{137} \mathrm{Cs}$ was estimated to be in the fuel, showing that $\sim 13 \%$ of it was found in the graphite components. Axial distributions also indicated that significant amounts of the total inventory of ${ }^{137} \mathrm{Cs}$ moved toward the bottom of the element during operation. The axial distribution of ${ }^{134} \mathrm{Cs}$ was similar to that of ${ }^{137} \mathrm{Cs}$.

Other nuclides found in the fuel of the element included ${ }^{95} \mathrm{Zr},{ }^{103} \mathrm{Ru},{ }^{106} \mathrm{Ru},{ }^{125} \mathrm{Sb},{ }^{141} \mathrm{Ce},{ }^{144} \mathrm{Ce},{ }^{154} \mathrm{Eu}$, and ${ }^{233} \mathrm{~Pa}$. Nuclides found in the graphite, in addition to ${ }^{134} \mathrm{Cs}$ and ${ }^{137} \mathrm{Cs}$, included ${ }^{54} \mathrm{Mn},{ }^{60} \mathrm{Co},{ }^{106} \mathrm{Ru}$, $110 \mathrm{~m}_{\mathrm{Ag}}$, ${ }^{144} \mathrm{Ce}$, and ${ }^{154} \mathrm{Eu}$. Europium154, a nuclide formed in the fuel by neutron capture in the stable fission product ${ }^{153} \mathrm{Eu}$, appeared to have been released from the fuel and migrated along the element to about the same extent as

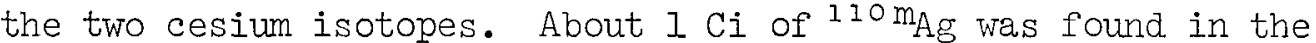
spine and sleeve of the element. None of the other nuclides appeared to have been significantly released from the fuel.

In addition to the determination of fission product distributions, the appearance of the component parts of the element was 
recorded photographically. Fuel compact and graphite dimensions were recorded at numerous locations, and metallographic examinations of the fuel were performed.

Although metrology data for the element were not obtained before irradiation, comparisons of the postirradiation dimensions with nominal preirradiation dimensions indicated that irradiation-induced changes were somewhat more extensive than observed for previously examined elements. Except for cracks in a few compacts and some pitted surfaces, the general appearance of the element did not appear to be significantly affected by the irradiation.

The fraction of particles that had failed coatings was measured in several compacts by a hot-chlorine leaching procedure and found to be of the order of $\leq 1 \%$.

\section{INTRODUCTION}

A series of postirradiation examinations of driver fuel elements withdrawn from the Peach Bottom High-Temperature Gas-Cooled Reactor (HTGR) is being undertaken in conjunction with the General Atomic Company (GAC) as part of a surveillance program for this reactor. The overall objective of the surveillance work is the verification of design procedures used for predicting fission product and temperature distributions in an HTGR.

The postirradiation examination of driver fuel elements is being conducted by ORNI; GAC will make use of results of the examination in the design verification procedures. As in ORNL-5126, ORNI-5214, and ORNL/TM5730, the present report is intended primarily to provide a documentation of the methods used as well as a graphical and tabular presentation of the results found in the examination. Very little discussion relative to critical evaluation and interpretation is included.

This report presents results of the examination of fuel element F03-01, which received 897 equivalent full-power days (EFPDs) of irradiation. Emphasis was placed on determining fission product distributions in the element, especially as a result of migration to the graphite sleeve and spine from the fuel compacts. Inventories of gamma-emitting nuclides 
in the fuel were obtained by scanning each of the 30 compacts individually. Distributions of gamma-emitting nuclides and the beta-emitters ${ }^{3} \mathrm{H},{ }^{14} \mathrm{C}$, and 90 Sr were obtained for the graphite portions of the element by axial scanning and radial dissection in a hot cell.

In addition to the measurement of fission product distributions, the following general categories of examination were performed:

1. The appearance of each component part of the element was photographically recorded.

2. Critical dimensions, such as the inner and outer sleeve and fuel compact diameters, were measured. The recorded metrology data form an essential part of the effort to validate the predictive temperature codes for HTGRs.

3. Portions of four fuel compacts were examined metallographica.1.y. 4. The failed fractions of fuel particles in four compacts were determined by a hot-chlorine leach procedure.

The fuel-element examination portion of the Peach Bottom Fission Product Surveillance Program includes four completed examinations - EO6-OI (384 EFPDs), ${ }^{1}$ EII-O7 (7OI EFPDs), ${ }^{2}$ EI4-OI (897 EFPDs), ${ }^{3}$ and FO3-OI (897 EFPDs) reported here - plus two additional 897-EFPD elements (EO1-O1 and F05-05). The last four elements of the series are core 2 end-of-life (EOL) elements. Examinations of the final two elements have been completed along with reports describing the findings; publication of these reports is expected soon. The surveillance program at ORNL has also been concerned with the measurement of fission product distributions in the primary coolant circuit during the operation of core 2, from 1970 through most of 1974. Results of these measurements were reported by F. F. Dyer et al. 4

General descriptive material concerning the reactor and driver fuel elements was obtained from the Peach Bottom HTGR Final Hazards Summary Report, ${ }^{5}$ the core 2 supplement to the FHSR, ${ }^{6}$ and a report by Turner et al. 7 which discussed the fuel performance of core 2 after 630 EFPDs. An internal GAC document ${ }^{8}$ which details the irradiation exposure, the first estimate of 
the thermal history, and results obtained in gamma scanning this element 38 days following reactor shutdown was used in the preparation of this report.

In addition to providing fuel element construction drawings, GAC assisted in the examinations described here by supplying funds to partially cover the physical examination procedures described in sect. 3 . These funds also enabled improvement of tools employed for metrology and hence provided benefit to subsequent fuel-element examinations.

The authors wish to gratefully acknowledge the support provided by the Analytical Chemistry Division, particularly to personnel in the Reactor Projects group headed by D. A. Costanzo and the Radiochemical Analyses group headed by R. R. Rickard. J. I. Botts developed the useful method for determining failed particle fractions of fuel compact samples. Hugh Parker and P. S. Gouge performed the beta-emitter analyses on the graphite samples. I. D. Bible and W. F. Rogers skillfully operated the lathe to acquire the radial graphite specimen in a hot cell by using procedures established by I. C. Bate.

In this report, as well as previous reports in this series dealing with surveillance of fission products in the Peach Bottom Reactor, the efforts of Betty Drake, who has typed and retyped, arranged, and rearranged both text and tables, are sincerely appreciated.

\section{FUEI-ELEMENT DESCRIPTION}

\subsection{Design Dimensions and Specifications}

Element FO3-OI was classified according to the Peach Bottom FHSR ${ }^{5}$ as a type 1 driver element. As such, its midale 18 fuel compacts were of the high-rhodium variety ( $1.03 \mathrm{~g}$ of rhodium per compact); the top three and bottom nine compacts were of the standard variety containing no rhodium. The element was similar to element $\mathrm{Ell}-07^{2}$ in all respects except that its dimensions were not measured before irradiation and it was a high-rhodium (type 1) rather than a low-rhodium (type 2) element. The element was also similar to Ell-07 in that it was not instrumented with thermocouples. The 
reader is referred to ref. 2 for details of assembly drawings of the element and to ref. I for an account of the composition of fuel compacts and specifications for graphite and BISO-coated fuel particles for the element.

Trace levels of the chemical elements, which could be of significance in the interpretation of observed radionuclide distributions in the graphite, were measured in archive sleeve graphite. These results are given in refs. 1 and 2 .

By referring to Fig. 2.1 of ref. 1, one may note the location of element FO3-OI in the third annular row of the F sector of the Peach Bottom core, adjacent to control rod element FO4-01.

Beginning-of-life (BOL) and EOL heavy-metal contents of element F03-O1, calculated with the GAUGE code, are given in Table 2.1-1. 8

\subsection{Operating History}

The operation of element FO3-O1 began at the startup of core 2 on July 15, 1970, and ceased on October 31, 1974, dt the end of core life. An approximation of the power history of core 2 is given in Table 2.2-1. 8 Using a rated full power level of $115.5 \mathrm{MW}(t)$ indicates that this fuel element, like element E14-01 reported in ref. 3, experienced 897 EFPDs of operation. It should be noted that element E06-01 was removed from the reactor (384. EFPDs) during the 162-day shutdown period, and element E11-07 was removed (701 EFPDs) during the 114-day shutdown. Results of the postirradiation examinations of these fuel elements are reported in refs. I and 2 respectively.

The estimated temperature trends with irradiation time at compact 16 (axial location of highest temperature) for the fuel, sleeve, and coolant are presented in Fig. $2.2-1.8$ The temperature of the spine (not shown) is assumed to be the same as that of the inside diameter of the fuel compact. The fuel temperatures on the plot are volume-averaged over fuel particles and matrix graphite. A comparison of the temperatures given in Fig. 2.2-1 for FO3-OI with corresponding temperatures for fuel element E14-01 given in Fig. 2.2-1 of ref. 3 indicates that element FO3-01 experienced temperatures $\sim 60^{\circ}$ higher than did element EI4-01. 
Table 2.1-1. Heavy-metal loadings for driver FO3-OI

\begin{tabular}{|c|c|c|}
\hline Nuclide & $\begin{array}{l}\text { BOI } \\
(\mathrm{g})\end{array}$ & $\begin{array}{l}\mathrm{EOI} \\
(\mathrm{g})\end{array}$ \\
\hline 232 Th & 1373.757 & 1316.213 \\
\hline${ }^{23} \mathrm{~Pa}$ & 0. & 2.280 \\
\hline $233_{U}$ & 0. & 32.710 \\
\hline${ }^{23}{ }^{4} \mathrm{U}$ & 0. & 2.994 \\
\hline${ }^{235} \mathrm{U}$ & 0. & 0.391 \\
\hline $234^{U}$ & 3.738 & 2.442 \\
\hline${ }^{23} 5_{\mathrm{U}}$ & 232.451 & 101.039 \\
\hline${ }^{236} \mathrm{U}$ & 1.251 & 26.708 \\
\hline $238_{U}$ & 12.110 & 10.393 \\
\hline $237_{\mathrm{Np}}$ & 0. & 2.251 \\
\hline $239_{\mathrm{Np}}$ & 0. & 0.005 \\
\hline${ }^{238} \mathrm{Pu}$ & 0. & 0.548 \\
\hline${ }^{239} \mathrm{Fu}$ & 0. & 0.371 \\
\hline $240_{P u}$ & 0. & 0.123 \\
\hline${ }^{24} I_{\mathrm{Pu}}$ & 0. & 0.172 \\
\hline
\end{tabular}

a Data taken from ref. 8. The first five rows pertain to loadings due to 232 Th. 
Table 2.2-1. Approximate power history of Peach Bottom Reactor during operation with fuel element $\mathrm{FO}_{3}-\mathrm{Ol}^{\mathrm{a}}$

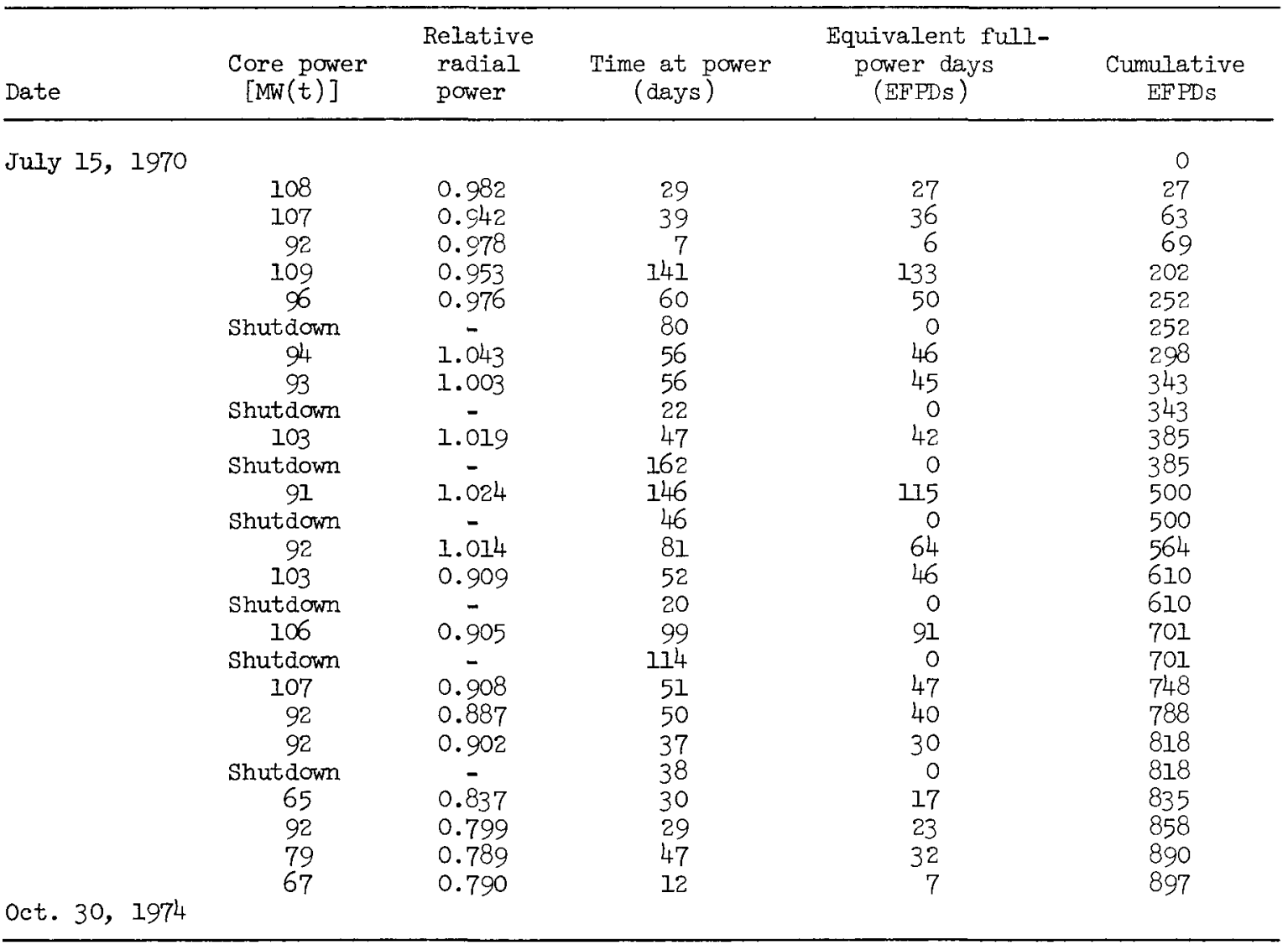

aata taken from ref. 8. 


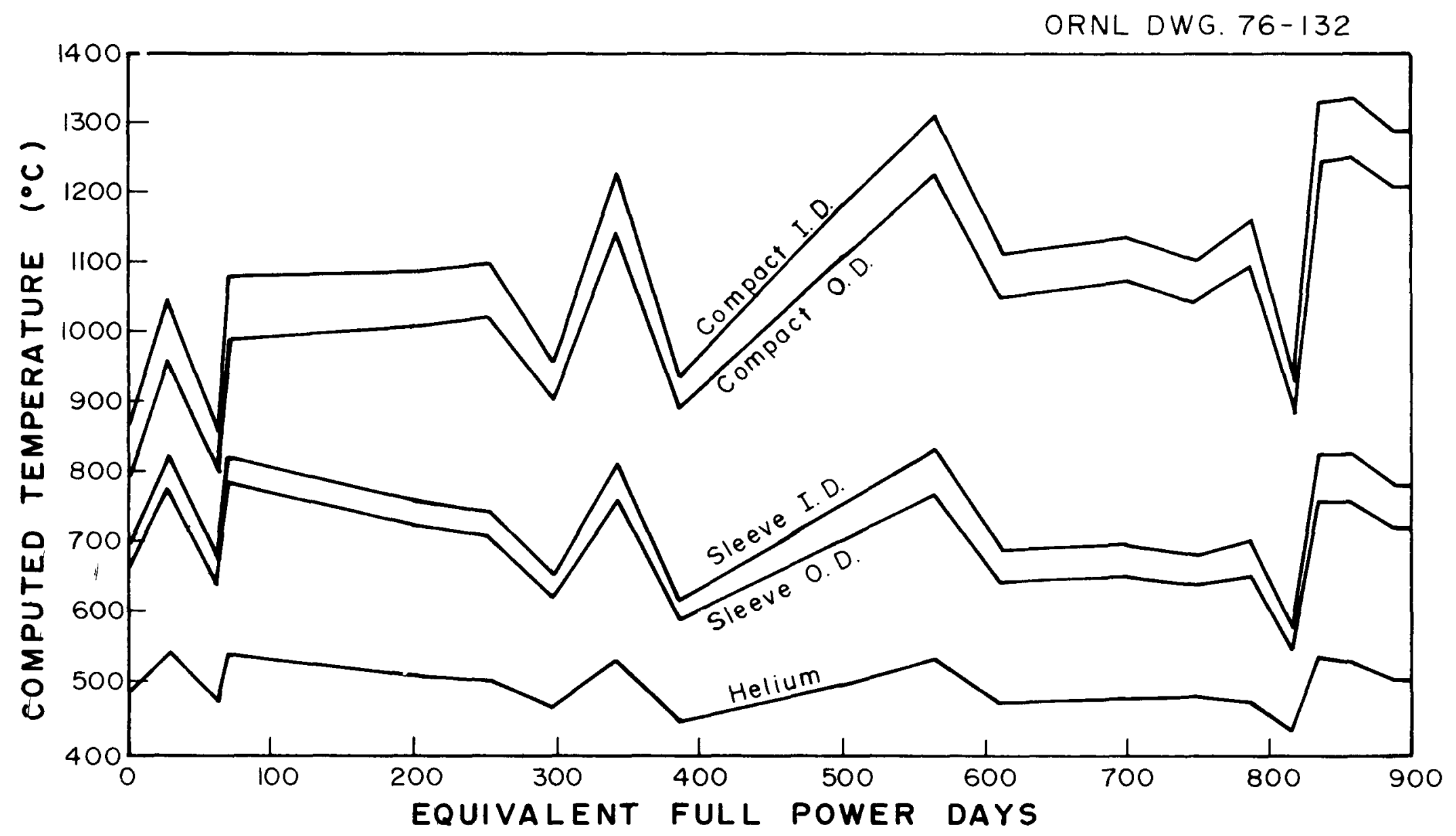

Fig. 2.2-1. Estimated temperature trends in fuel element FO3-OI at compact 16 as a function of irradiation time. 
The computed axial temperature distributions of fuel element FO3-OI at 858 EFPDs are shown in Fig. 2.2-2. Although axial temperatures were computed and giv in in ref. 8 for FO3-OI at 20 time points throughout the life of the elemc.' , only the highest temperature values at 858 EFPDs are reproduced here. At this time, the temperature profile of the inner diameter of the fueI compacts showed a low point of $\sim 520^{\circ} \mathrm{C}$ at the bottom of the core, increased to a maximum of $\sim 1340^{\circ} \mathrm{C}$ at the midplane of the core, and then decreased to $1150^{\circ} \mathrm{C}$ at the top of the core. At that time, the temperature of the inside ilameter of the sleeve ranged from $\sim 420^{\circ} \mathrm{C}$ at the bottom of the core to $\sim 890^{\circ} \mathrm{C}$ at the top.

It must be emphasized that temperatures reported in Figs. 2.2-I and 2.2-2 are preliminary and do not reflect knowledge gained from this examination. Currently, work is under way at GAC to more accurately determine operative fuel-element temperatures from postirradiation fuel element examinations, thermocouple readings on instrumented elements, and measured fuel burnup measurements.

The total thermal and fast neutron fluence distributions estimated. for fuel element FO3-OI are shown in Fig. 2.2-3. 8 The maximum thermal and fast neutron fluences, $4.2 \times 10^{22}$ neutrons $/ \mathrm{cm}^{2}$ in each case, occurred at approximately compact position 17 .

The calculated burnups, fissions per initial heavy-metal atom, are given (as percentage values) in Table 2.2-2 for each fuel compact. 8

\section{PHOTOGRAPHIC DESCRIPTION AND METROLOGY}

\section{I Visual and Photographic Examination}

The element was visually examined before and during dissection, and representative normal features and appearances were noted and photographed. In addition, all abnormal features such as cracks in the compacts and graphite spallation were photographed.

The outside of the element appeared to be normal; hence no photographs of its outer surface were made. Soot deposits on the top reflector and near spacer rings were present in amounts that appeared to be comparable 


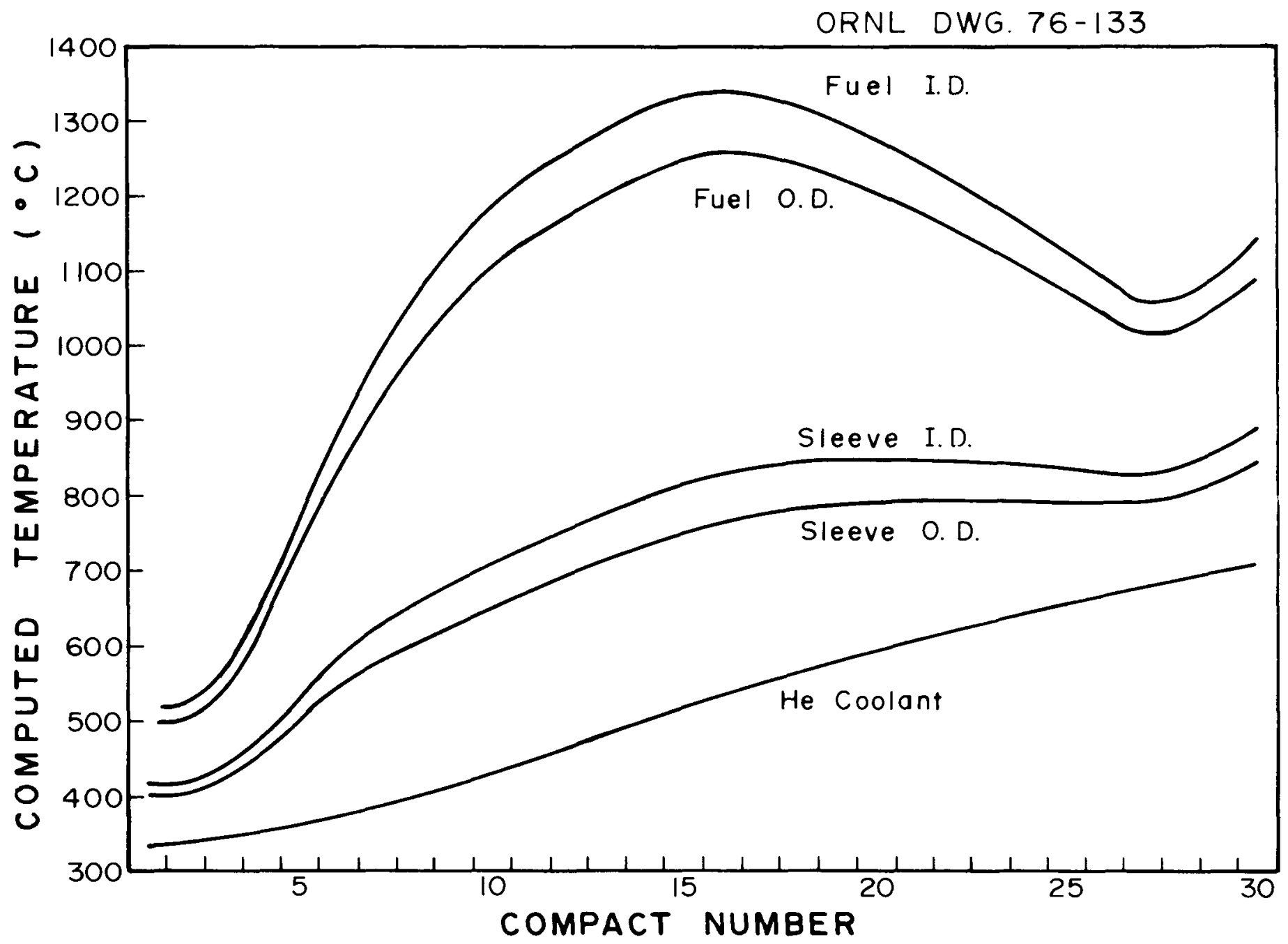

Fig. 2.2-2. Computed axial temperature proile of fuel element FO3-O1 at the end of 858 EFPDs. 


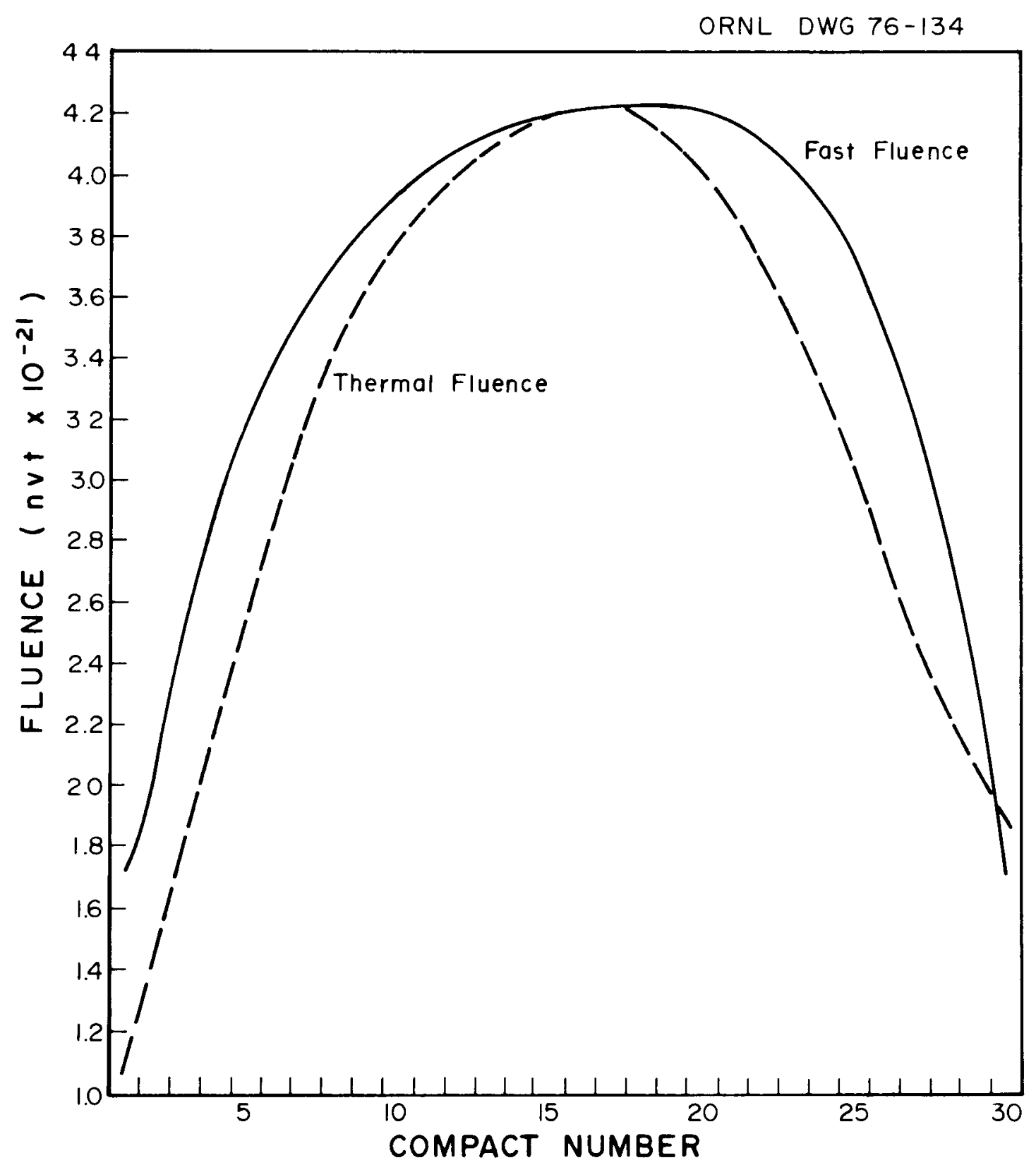

Fig. 2.2-3. Computed axial neutron fluence profile for fuel element FO3-O1 at end of life. 
Table 2.2-2. Calculated FIMA, fissions per initial heavy-metal atom ${ }^{2}$

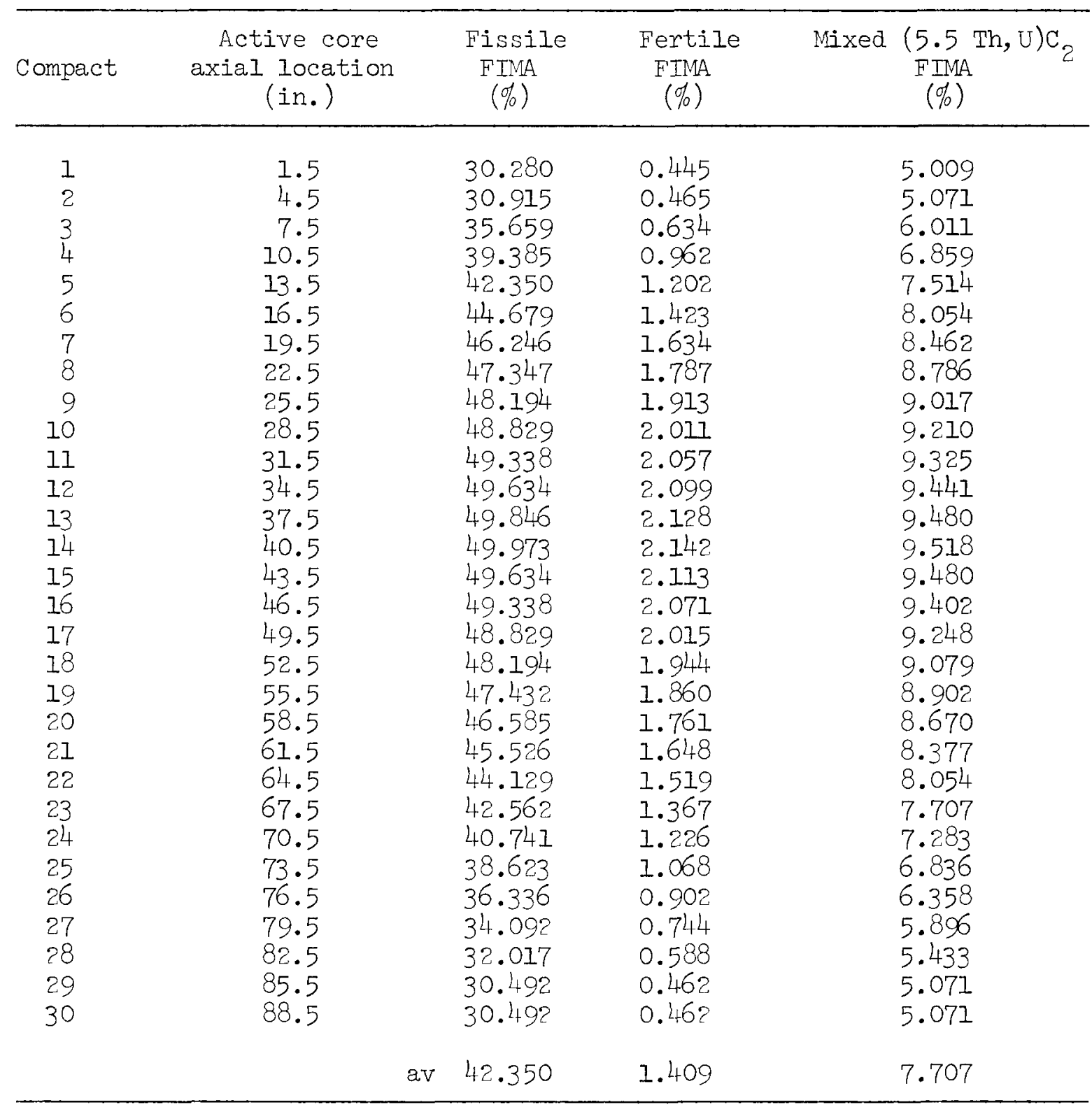

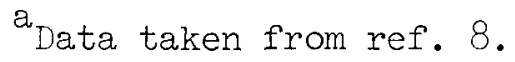


to those found on fuel elements Ell-0 $7^{2}$ and El4-01. 3 During initial dissection, the element was transversely cut at four axial locations so as to divide it into five parts consisting of the top reflector, the bottom connector, and three sleeve sections, each of which contained ten fuel compacts and one spine piece. Details ${ }^{3}$ of the disassembly of the element and the cutting procedures, which made use of a remotely operated reciprocating hacksaw, were the same as those used for fuel element E14-01. Dimensional measurements made during dissection are discussed in sect. 3.2 of this report.

Figures 3.1-1 through 3.1-6 show external views of the 30 fuel compacts, each juxtaposed with its corresponding section of spine. Before being photographed, the compacts and spines were roughly oriented so that, in each case, the side toward the camera was the same as the side of the element on which the serial number was marked. This side was designated the "zero azimuth side." On visual observation, the compact and spine surfaces did not seem to be as bright as the fuel compacts of element E14-01. 3 Considerable pitting of the compact surfaces is apparent in the above-mentioned figures, but this feature does not appear to be different between high-temperature and low-temperature regions. Cracks in compacts 6, 7, 18, and 24 are also visible in Figs. 3.1-1 through 3.1-6. Spallation of graphite was found only on the surface of the bottom of the top spine piece adjacent to compacts 21 and 22, as shown in Fig. 3.1-5. During the cutting operation to separate the fueled region into three parts, the circumferential sawing of the sleeve at compact locations 20 and 30 was inadvertently allowed to go through the sleeve and penetrate the fuel compacts slightly. Figures $3 \cdot 1-4$ and 3.1-6 show the grooves made in compacts 20 and 30 due to sawing.

Compacts 1, 9, 18, 24, and 30 were selected for more-detailed photographic documentation; views of both ends, the zero aziumth side, and the opposite side are presented in Figs. 3.1-7 through 3.1-16. Note that cracking to various extents is visible in each of these compacts. Compact 18 has a crack that runs the entire length and appears to completely penetrate the wall. The pitting observed on its exterior surfaces is also visible on the inside of the compact (Fig. 3.1-11). 

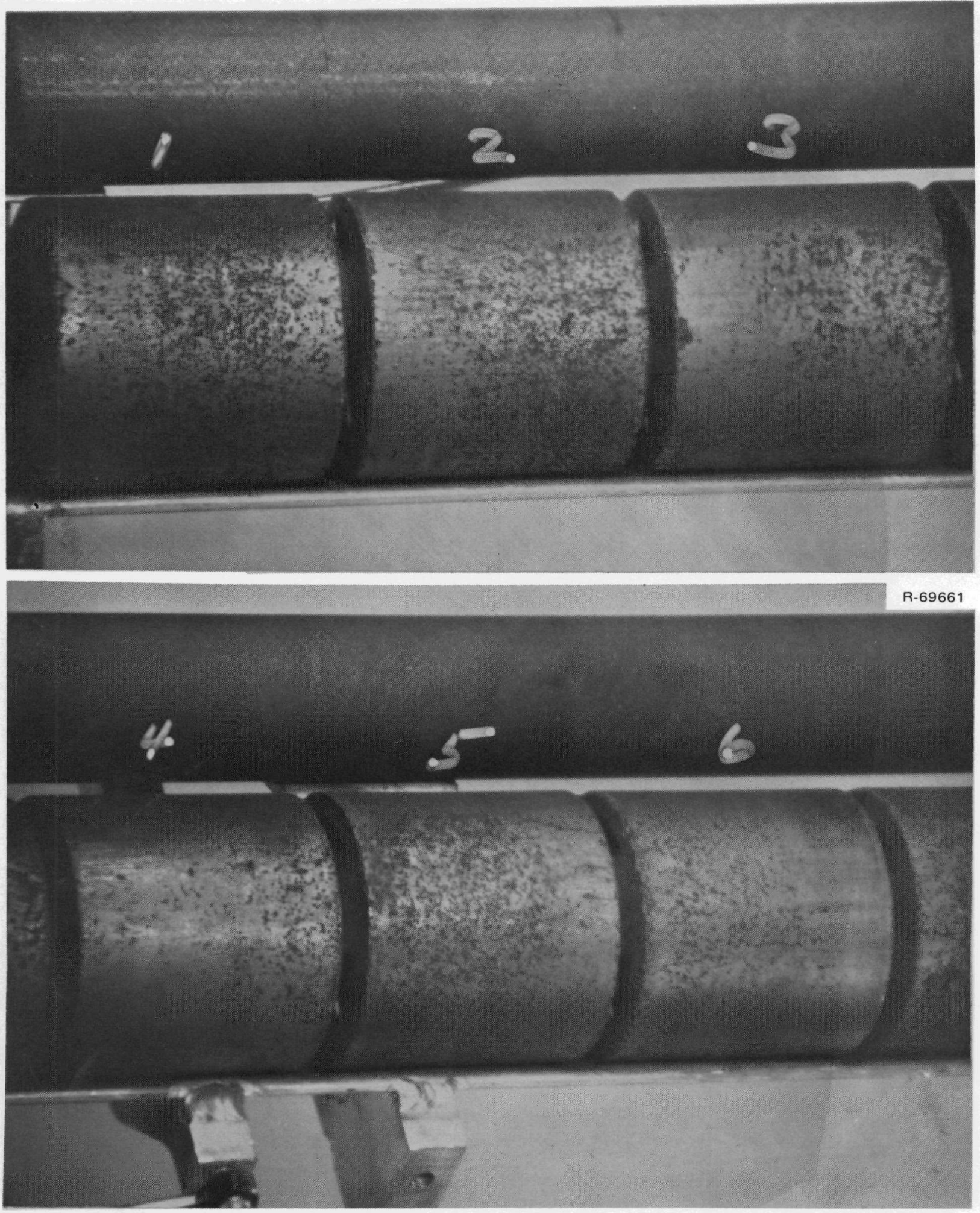

Fig. 3.1-1. Compacts 1, 2, 3 (top) and 4, 5, 6, (bottom) plus associated spine. 


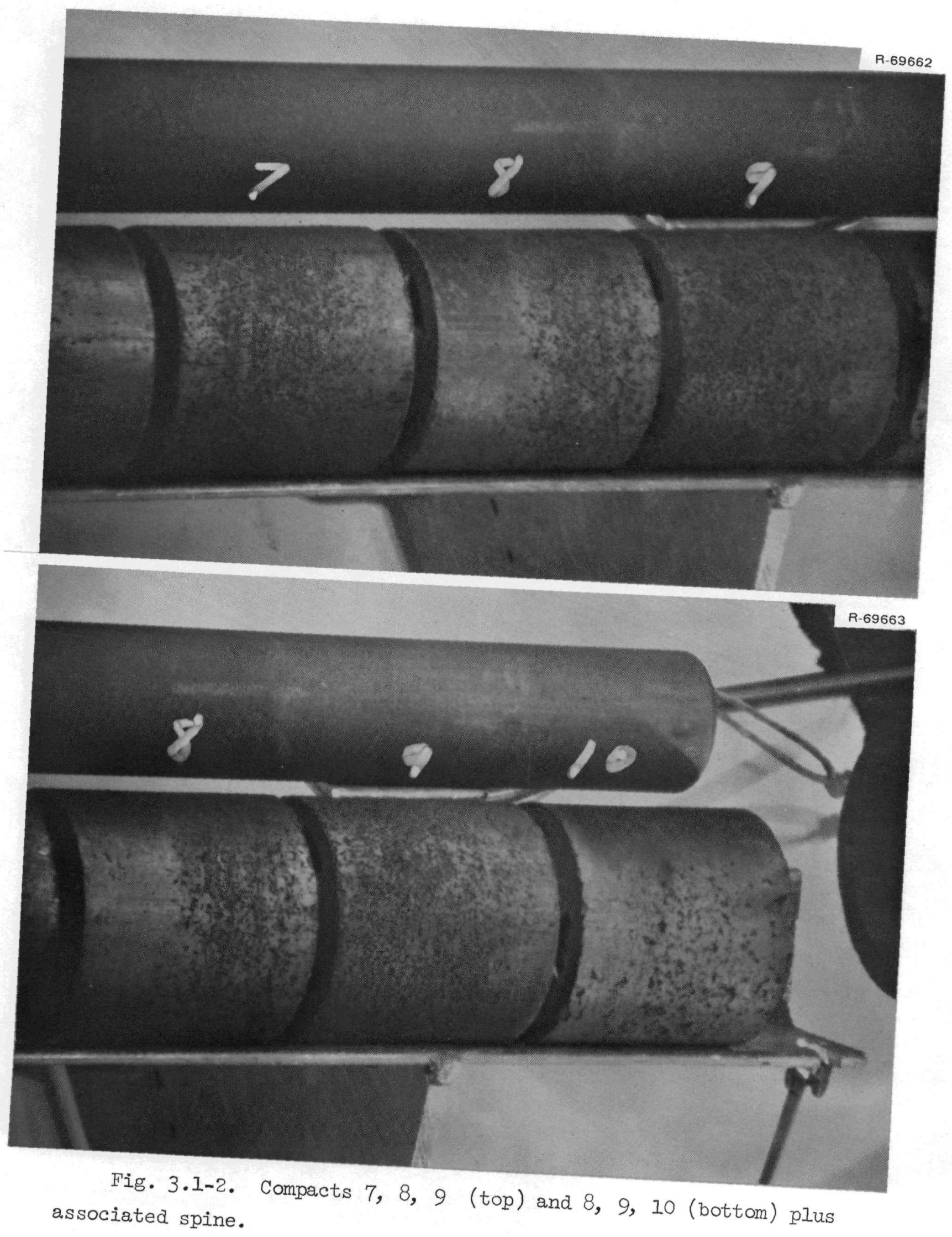



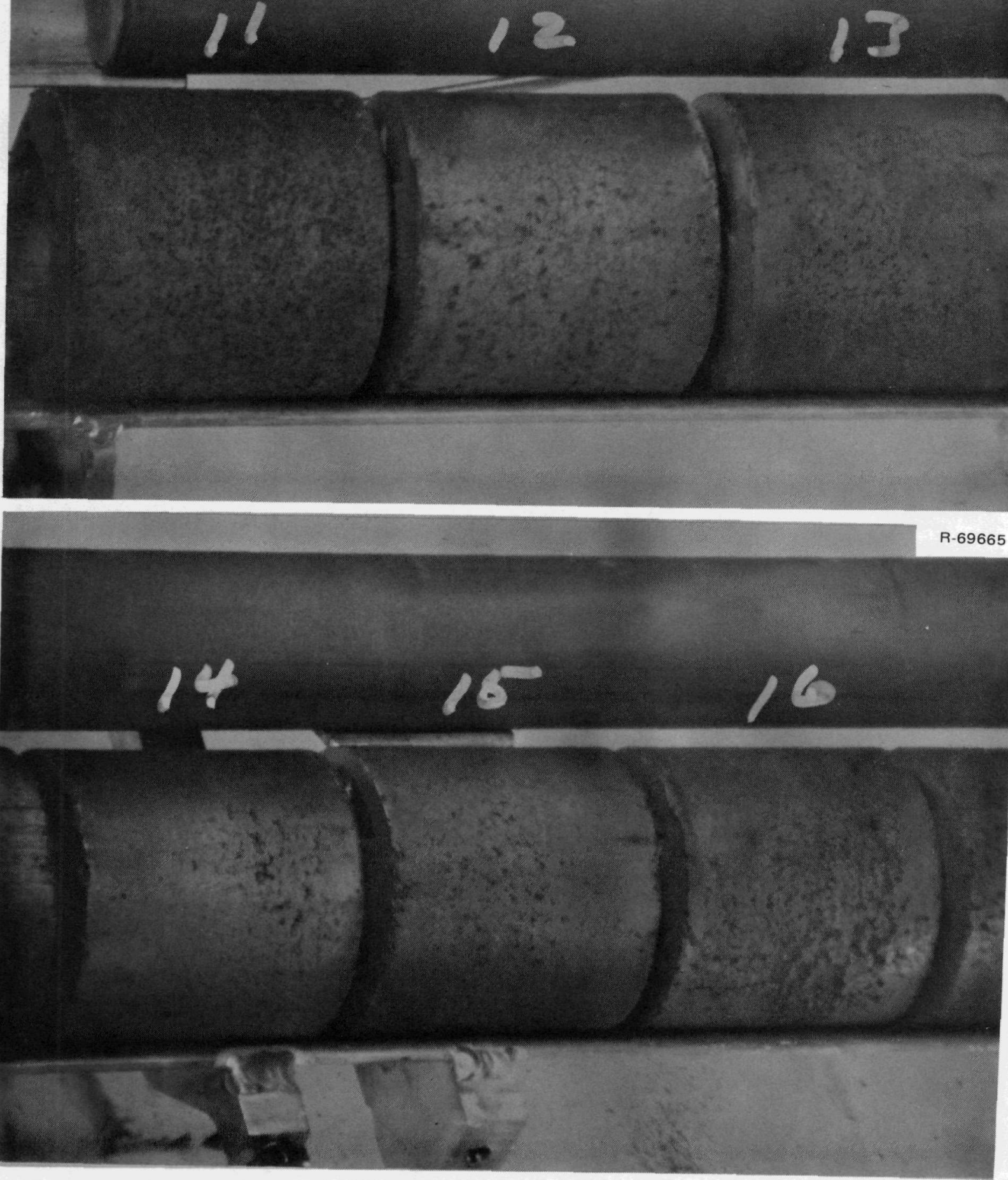

Fig. 3.1-3. Compacts 11, 12, 13 (top) and 14, 15, 16 (bottom) plus associated spine. 

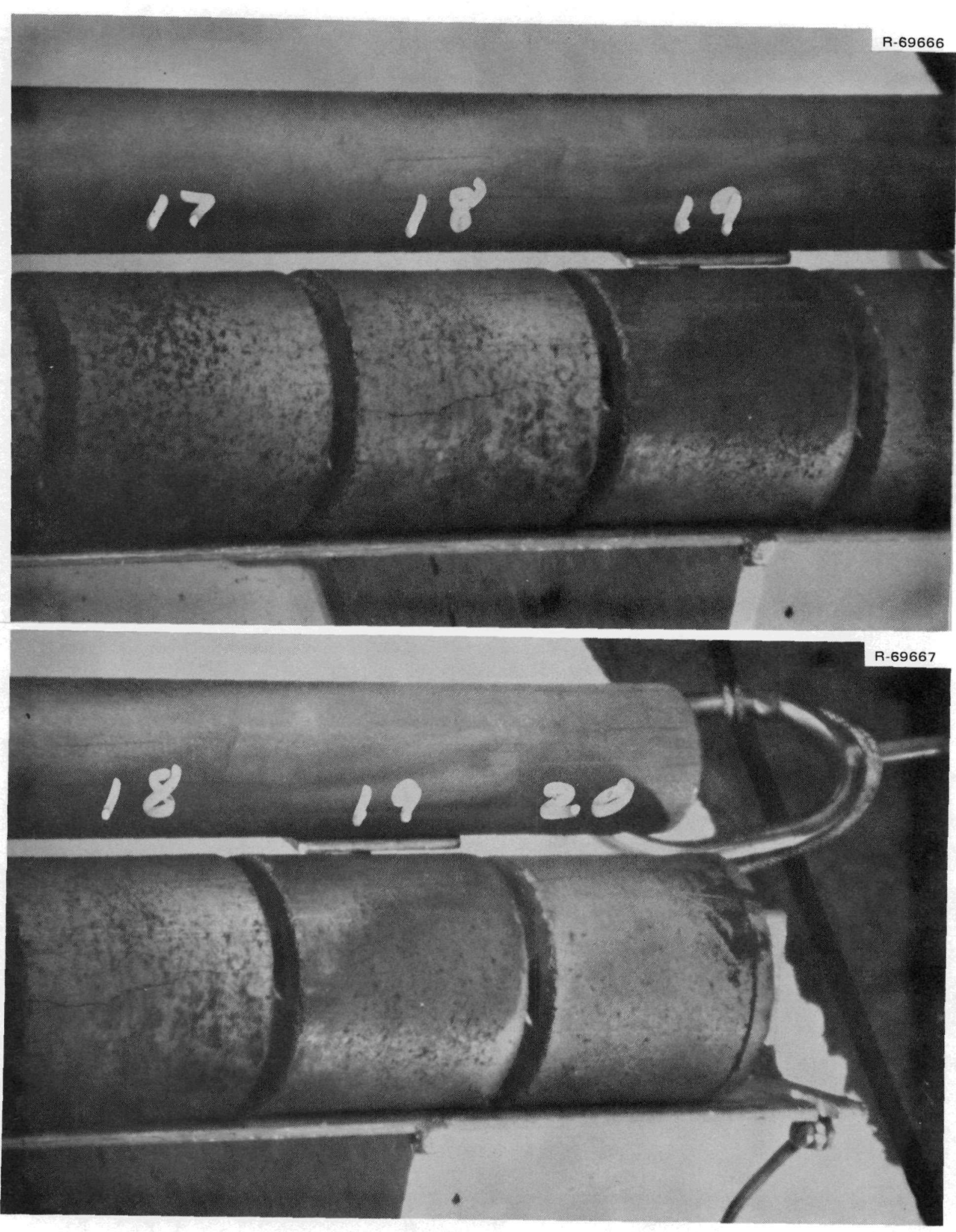

Fig. 3.1-4. Compacts 17, 18, 19 (top) and 18, 19, 20 (bottom) plus associated spine. 

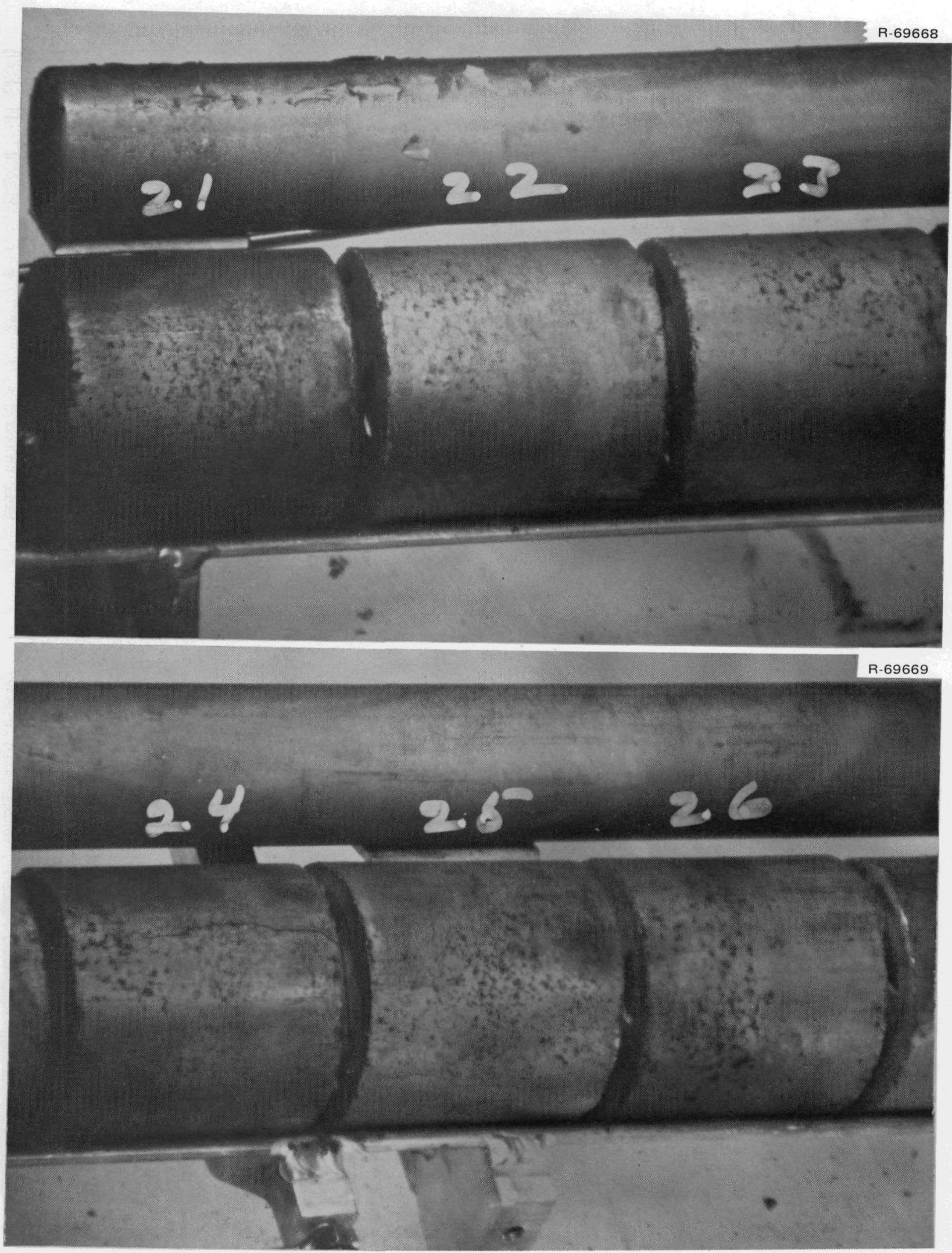

Fig. 3.1-5. Compacts 21, 22, 23 (top) and 24, 25, 26 (bottom) plus associated spine. 

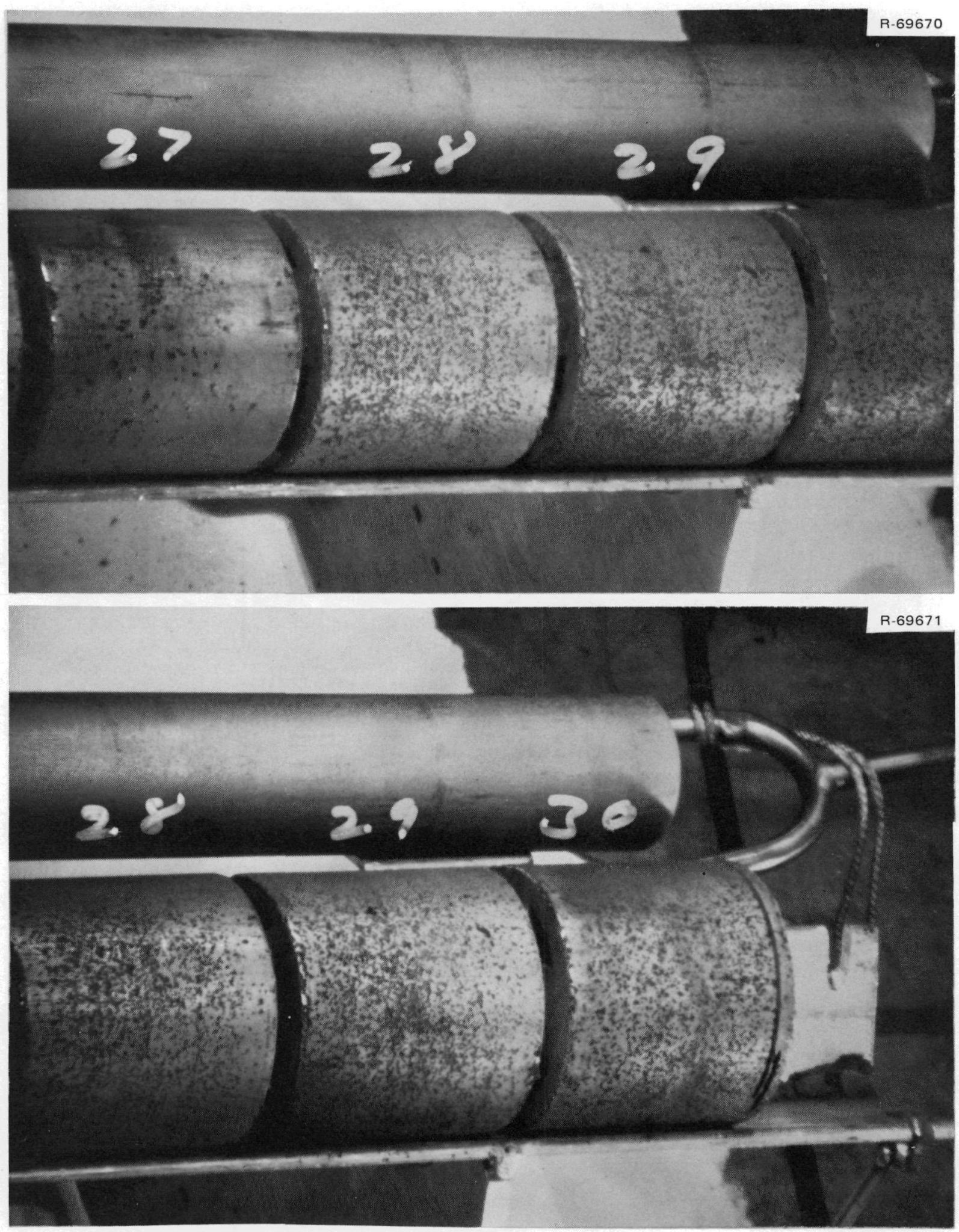

Fig. 3.1-6. Compacts 27, 28, 29 (top) and 28, 29, 30 (bottom) plus associated spine. 

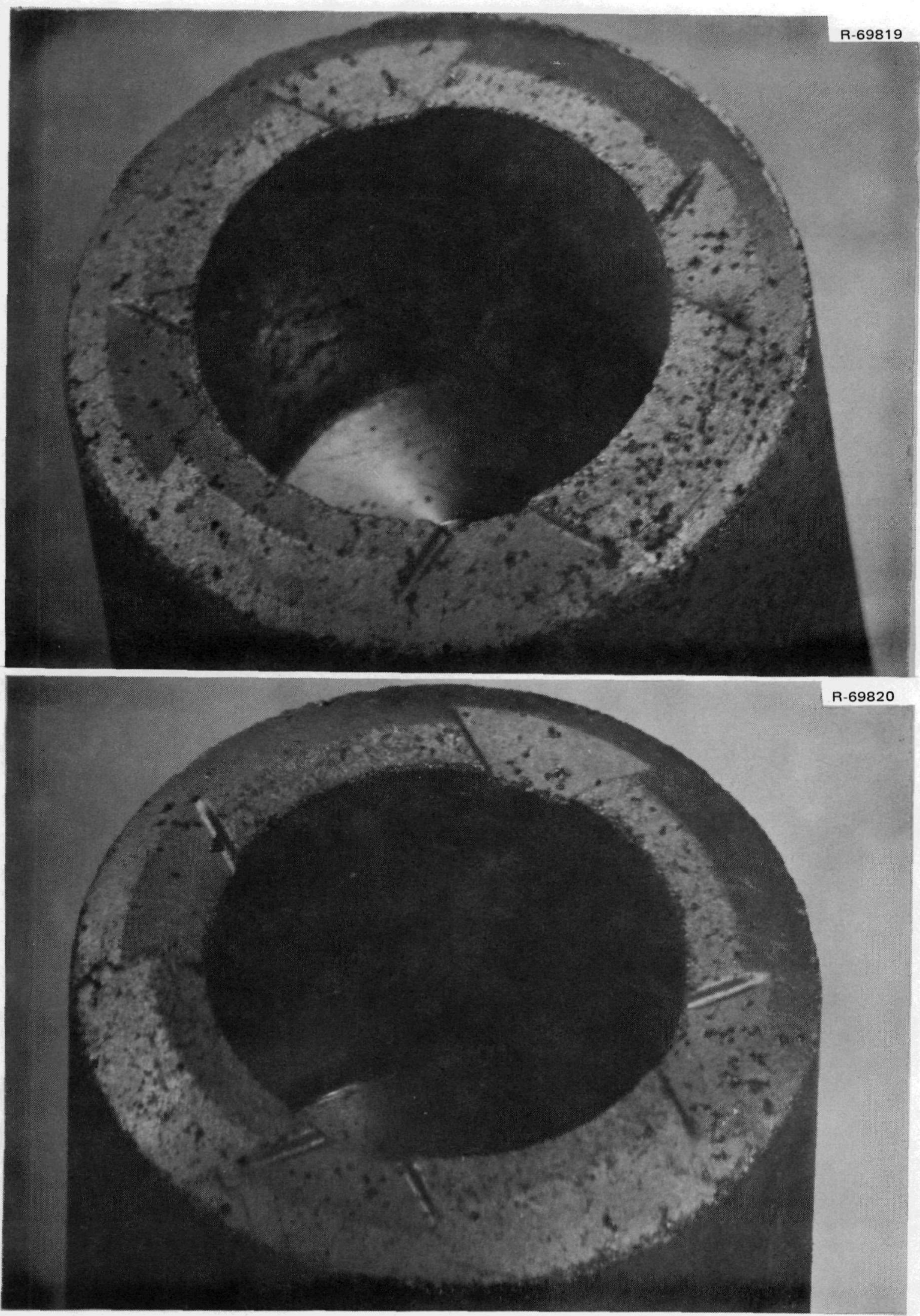

Fig. 3.1-7. View from top (upper figure) and bottom (lower figure) of compact 1 . 

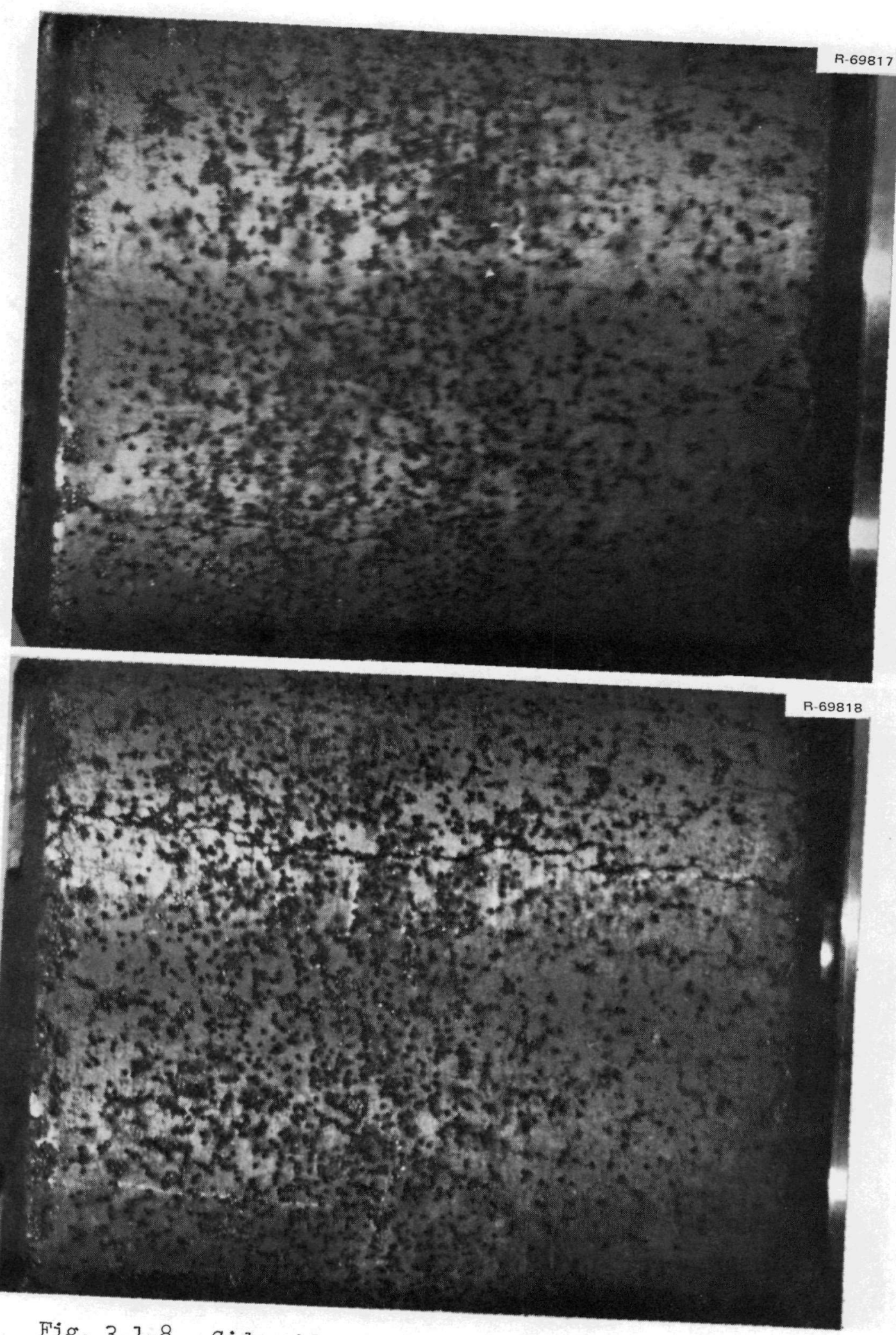

Fig. 3.1-8. Side view of compact 1 from $0^{\circ}$ azimuth (top) and $180^{\circ}$ azimuth (bottom) directions. 

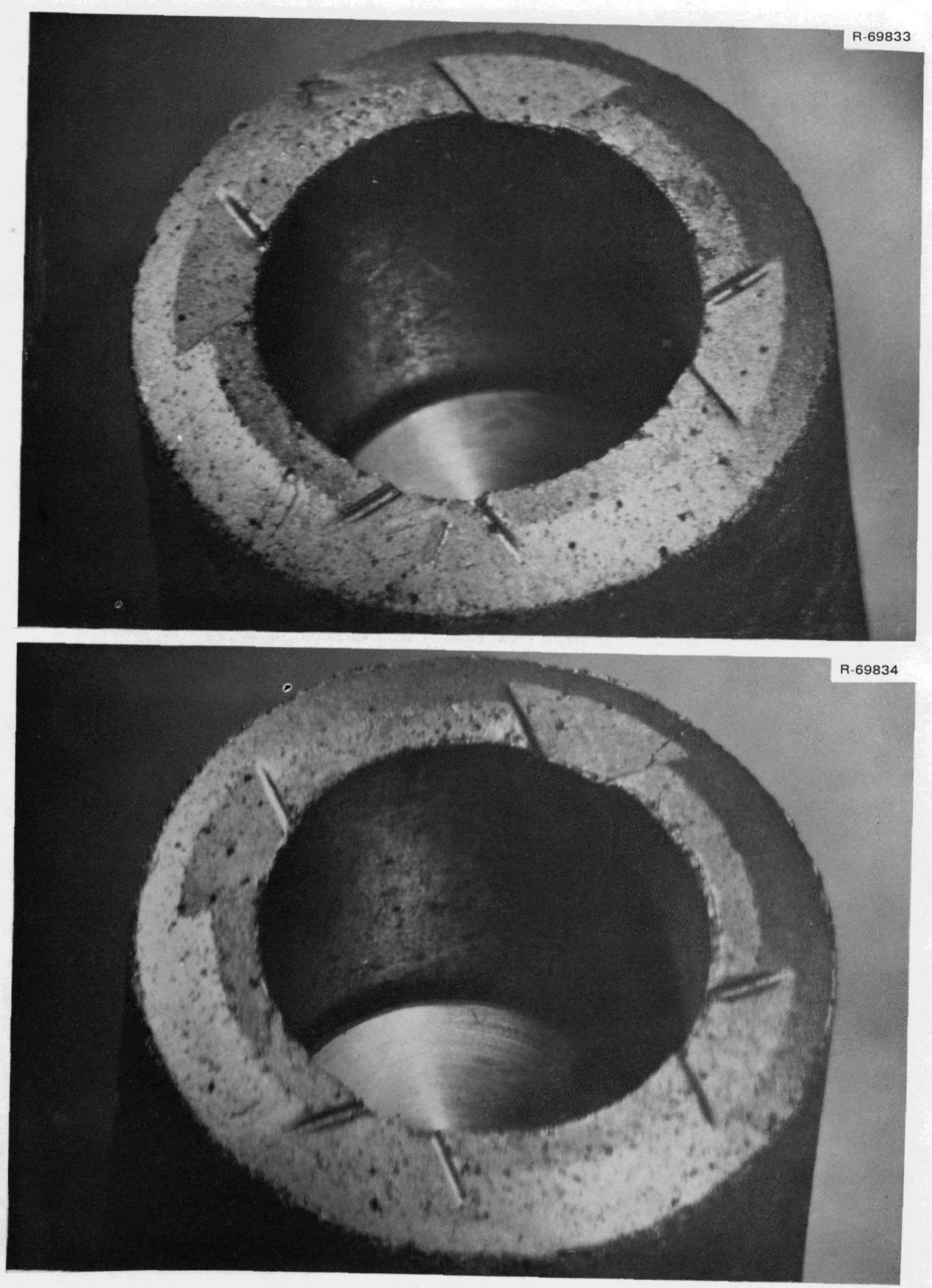

Fig. 3.1-9. View from top (upper figure) and bottom (lower figure) of compact 9 . 

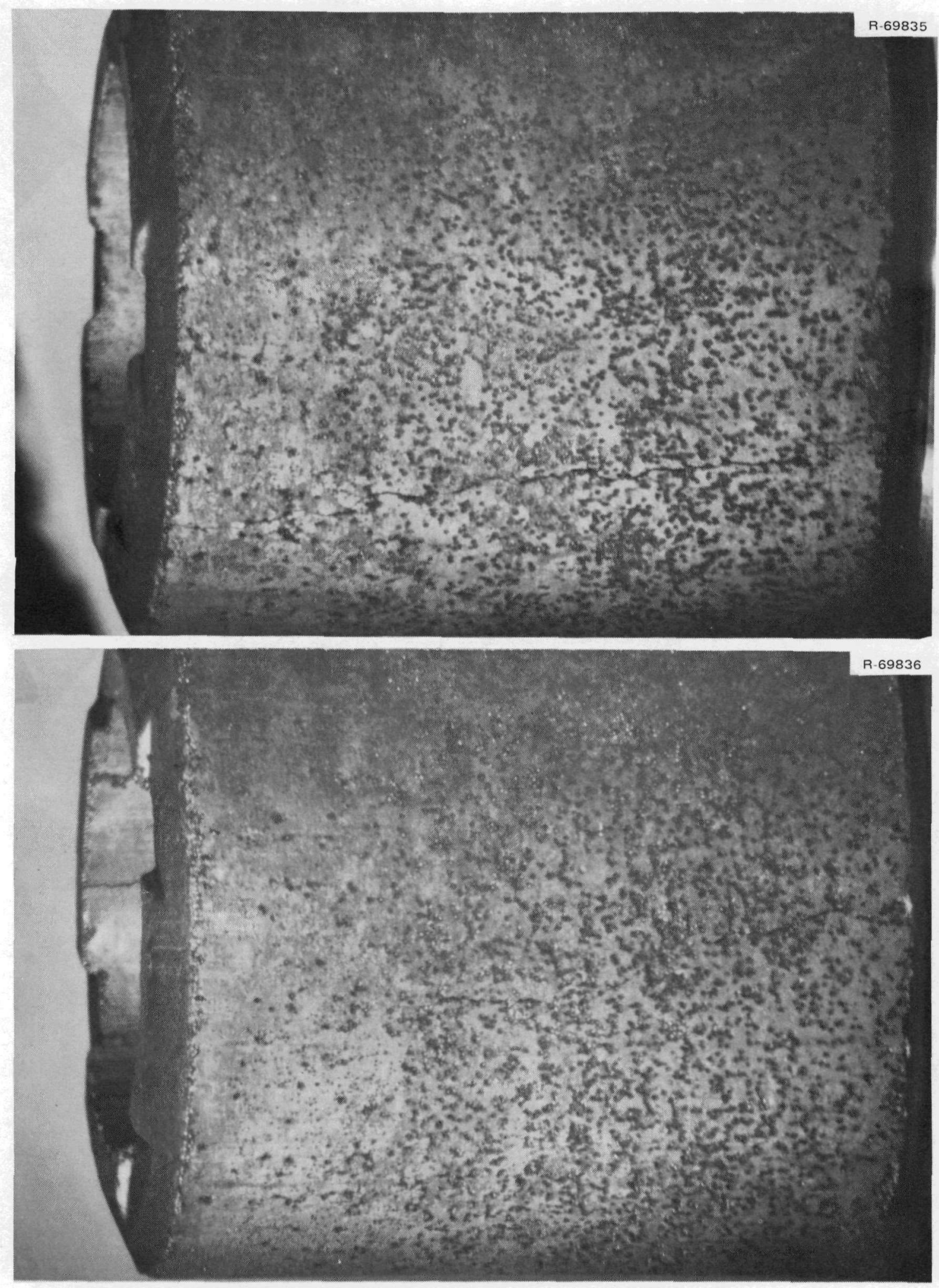

Fig. 3.1-10. Side view of compact 9 from $0^{\circ}$ azimuth (top) and $180^{\circ}$ azimuth (bottom) directions. 

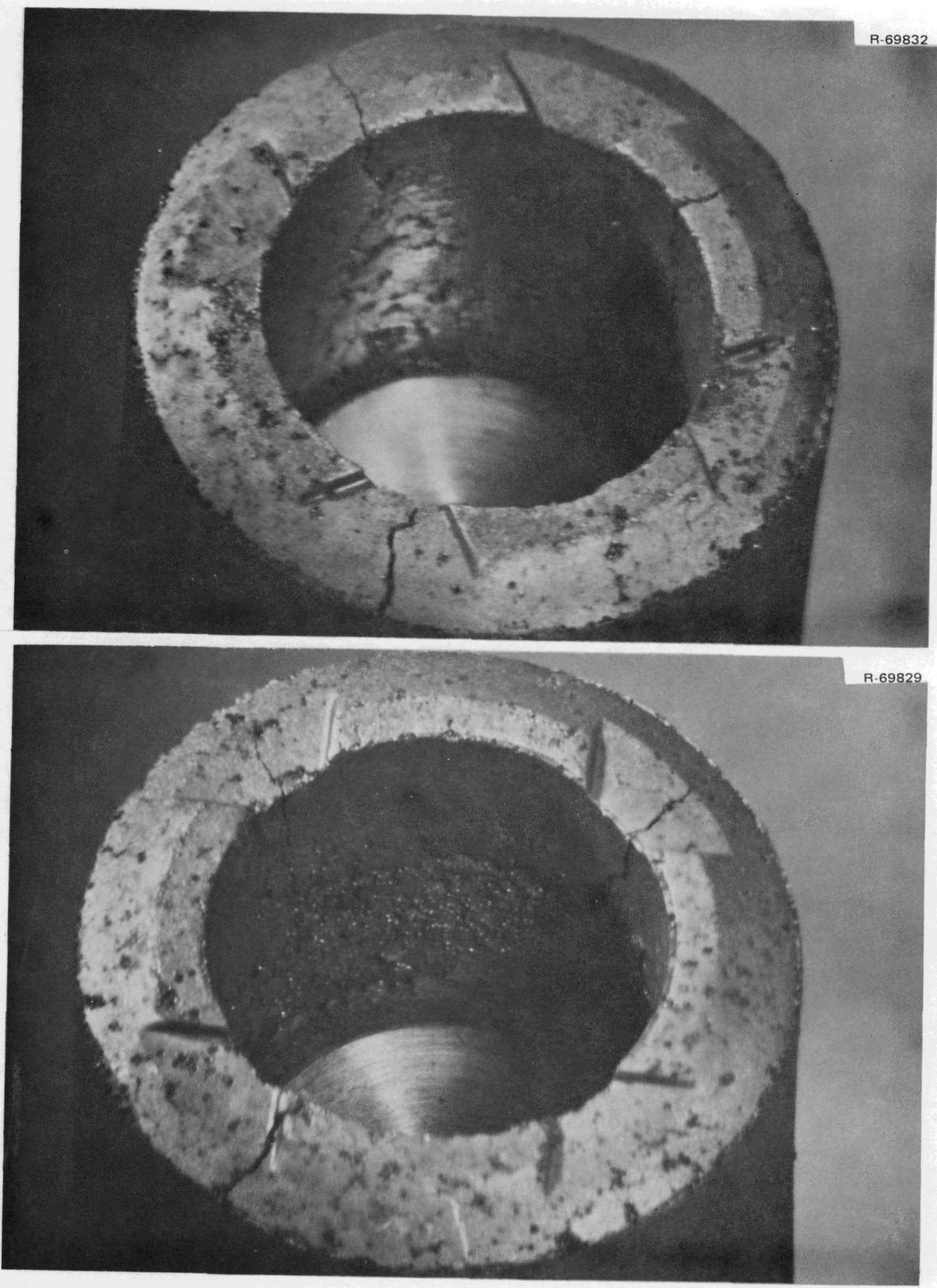

Fig. 3.1-11. View from top (upper figure) and bottom (lower figure) of compact 18 . 

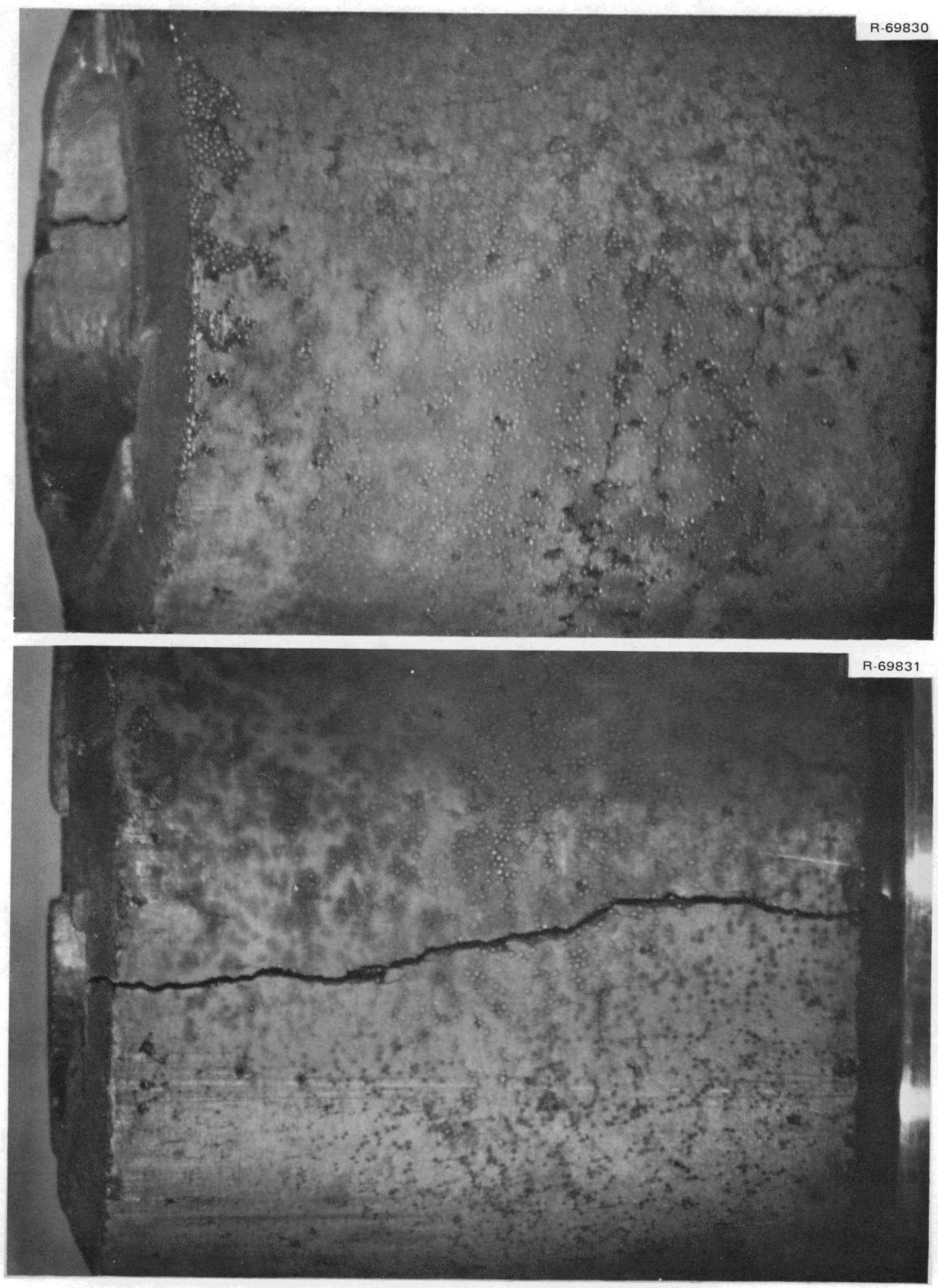

Fig. 3.1-12. Side view of compact 18 from $0^{\circ}$ azimuth (top) and $180^{\circ}$ azimuth (bottom) directions. 

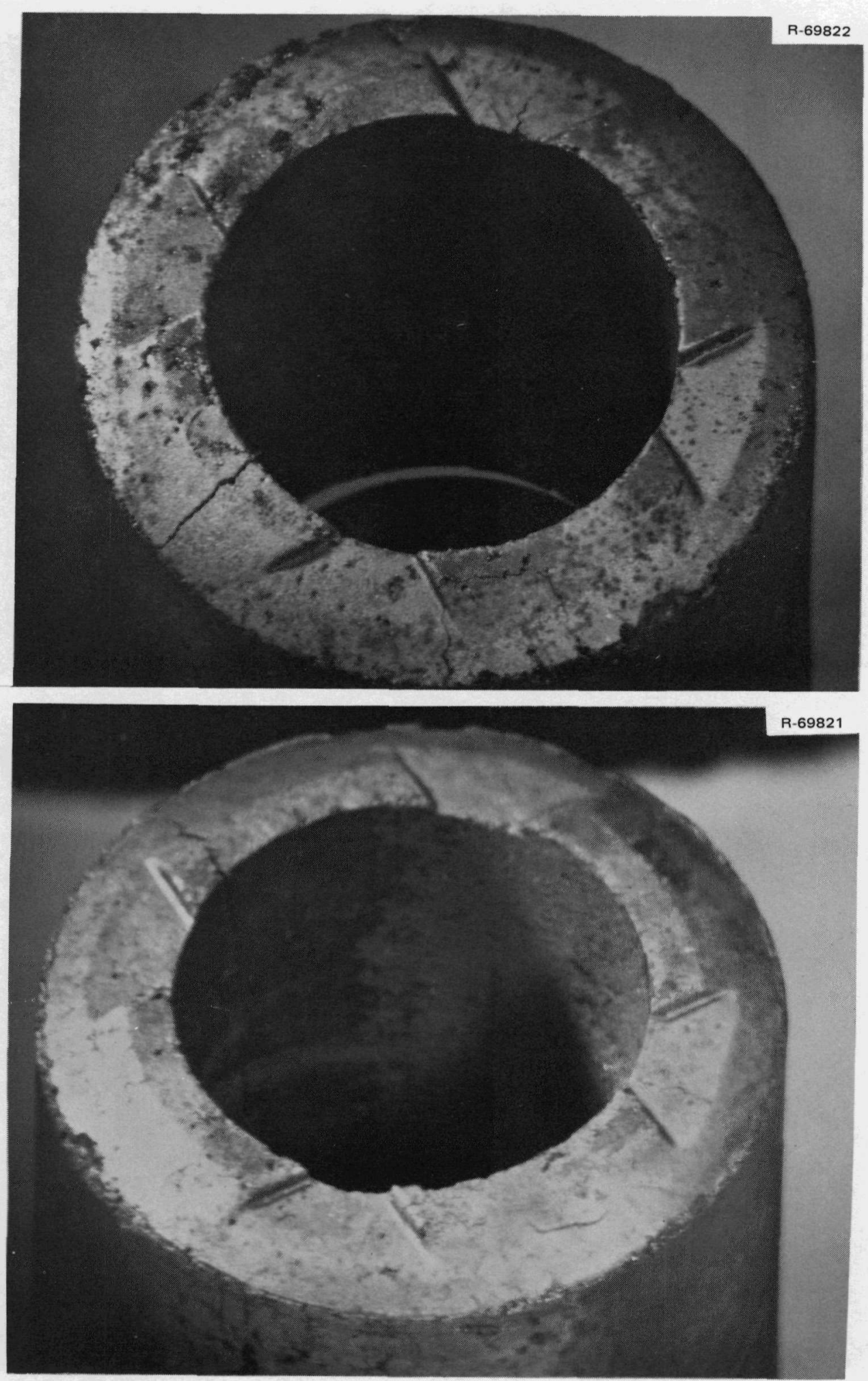

Fig. 3.1-13. View from top (upper figure) and bottom (lower figure) of compact 24 . 

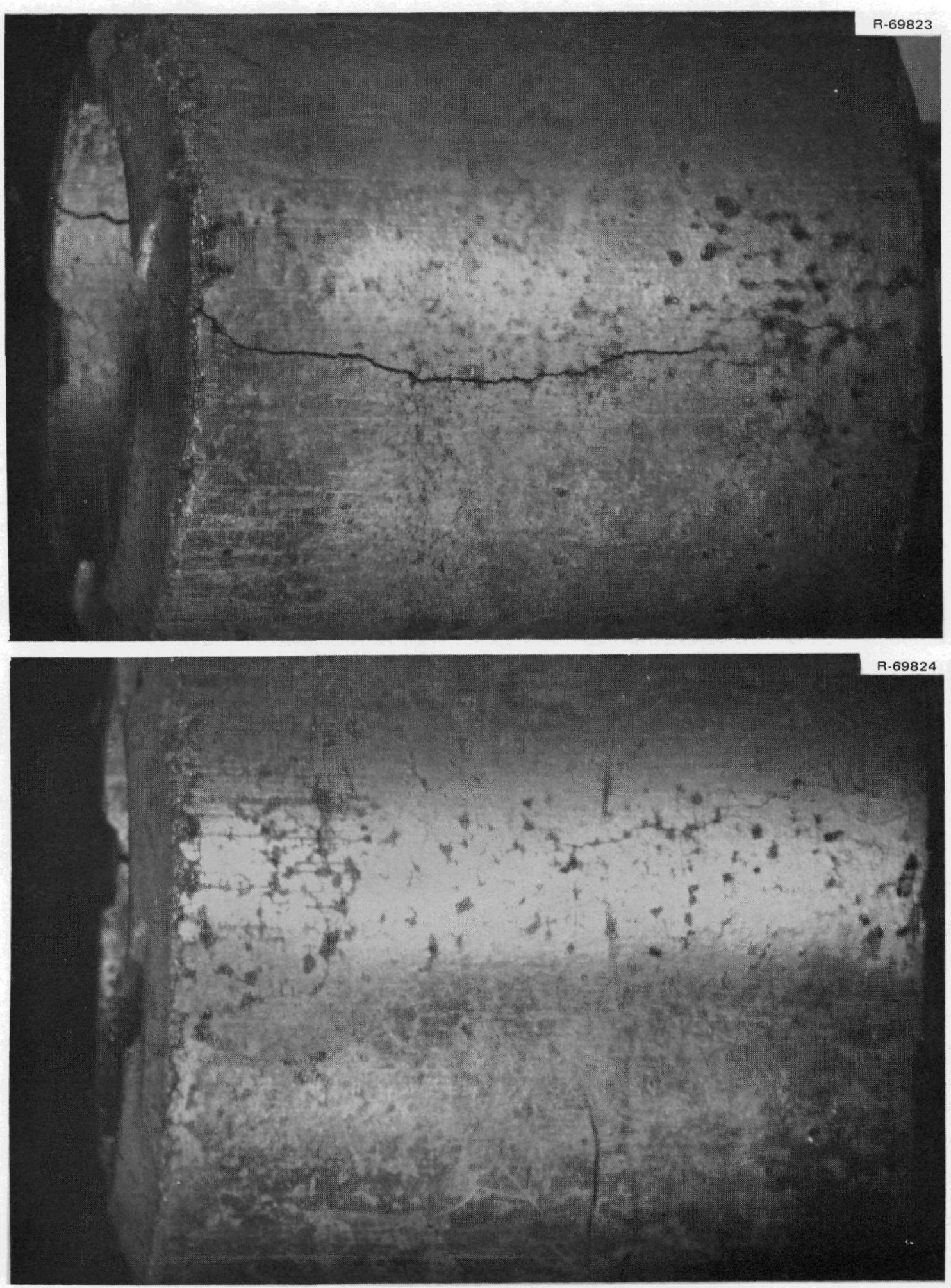

Fig. 3.1-14. Side view of compact 24 from $0^{\circ}$ azimuth (top) and $180^{\circ}$ azimuth (bottom) directions. 

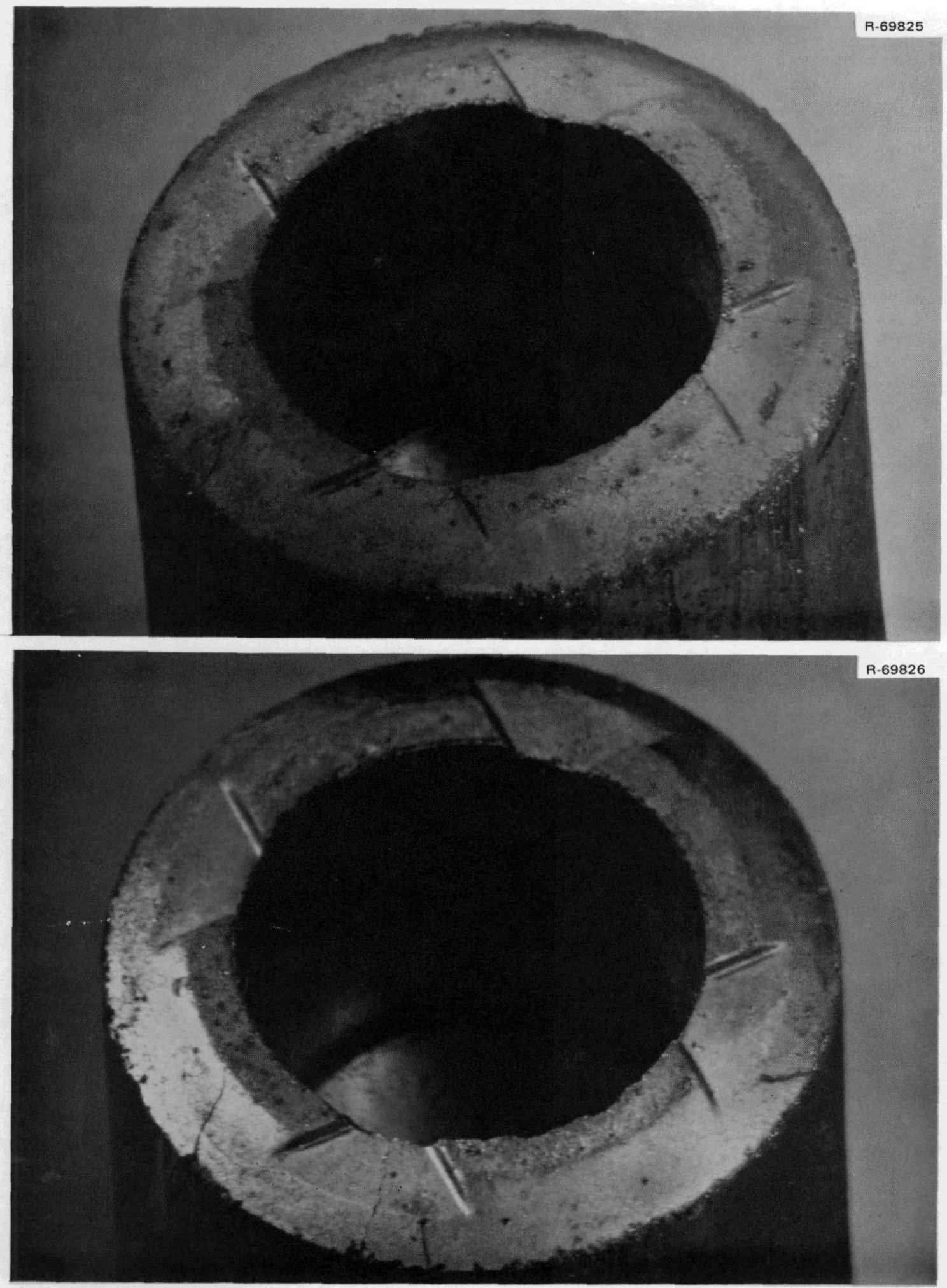

Fig. 3.1-15. View from top (upper figure) and bottom (lower figure) of compact 30 . 

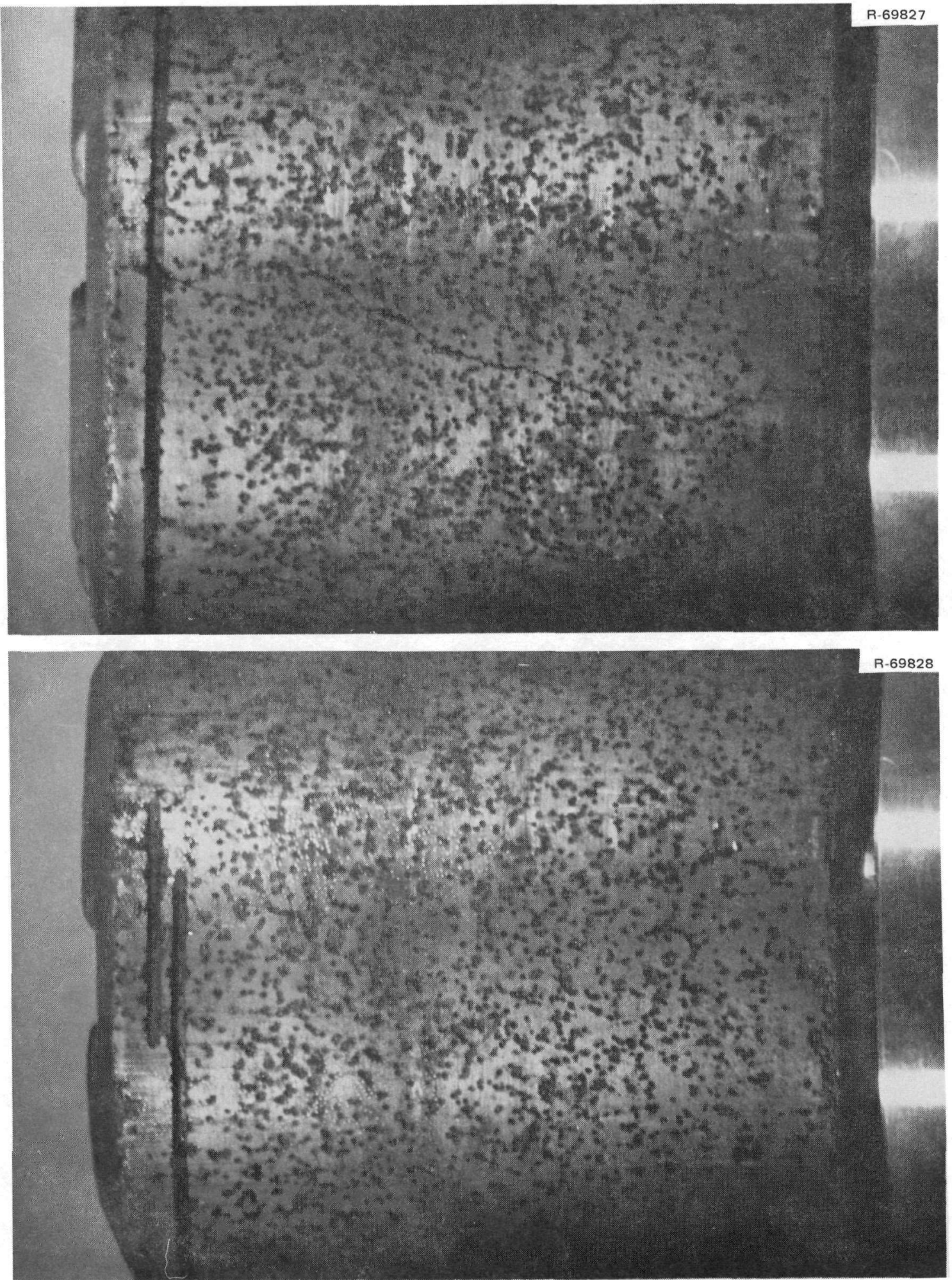

Fig. 3.1-16. Side view of compact 30 from the $0^{\circ}$ azimuth (top) and $180^{\circ}$ azimuth (bottom) directions. 
The appearance of the fuel particles over a fracture plane in compact 20 is shown in Fig. 3.1-17.

\subsection{Metrology of Sleeve, Spine, and Fuel Compacts}

No preirradiation dimensional measurements of fuel element FO3-OI were made. The results of postirradiation measurements, summarized in Tables 3.2-1 through 3.2-7, include: (1) the overall length of the element; (2) the so-called fuel compact expansion gap, which is the free distance between the top of compact 30 and the bottom of the top reflector assembly; (3) the outside and inside diameters of the sleeve at five axial locations; (4) the diameters of the spine pieces at each of three locations; (5) the length of each spine piece; (6) the outside diameters, inside diameters, and wall thicknesses of five fuel compacts in four different planes; and (7) the lengths of the 30 fuel compacts. The reader is directed to ref. 3 for an account of the metrology methods that were used for element FO3-OL. (These were the same methods that were used for element E14-01.) It should be noted that the dimensional data reported here were taken from GAC-ORNL correspondence in which the methods were described and the results tabulated. 9

Table 3.2-1 shows the postirradiation length of the element and the fuel compact expansion gap, along with nominal values of these quantities for unirradiated Peach Bottom fuel elements. Also included are the nominal preirradiation and the measured postirradiation lengths of the total 30 fuel compacts. Although the element was not dimensionally measured before it was irradiated, a comparison with nominal preirradiation dimensions indicates that the total length decreased during operation by $\sim 0.5 \%$. A comparison of the measured length of the fuel axial expansion gap after irradiation with the nominal length before irradiation indicates that the gap may have decreased by about 1.2 in. The decrease in the expansion gap was also computed by adding the estimated increase in fuel-element length to the estimated decrease in the fuel-element length to yield a value of $1.4 \mathrm{in.}$ These data indicate that the decrease in the gap was due to approximately equal changes in absolute magnitude of the element's sleeve 

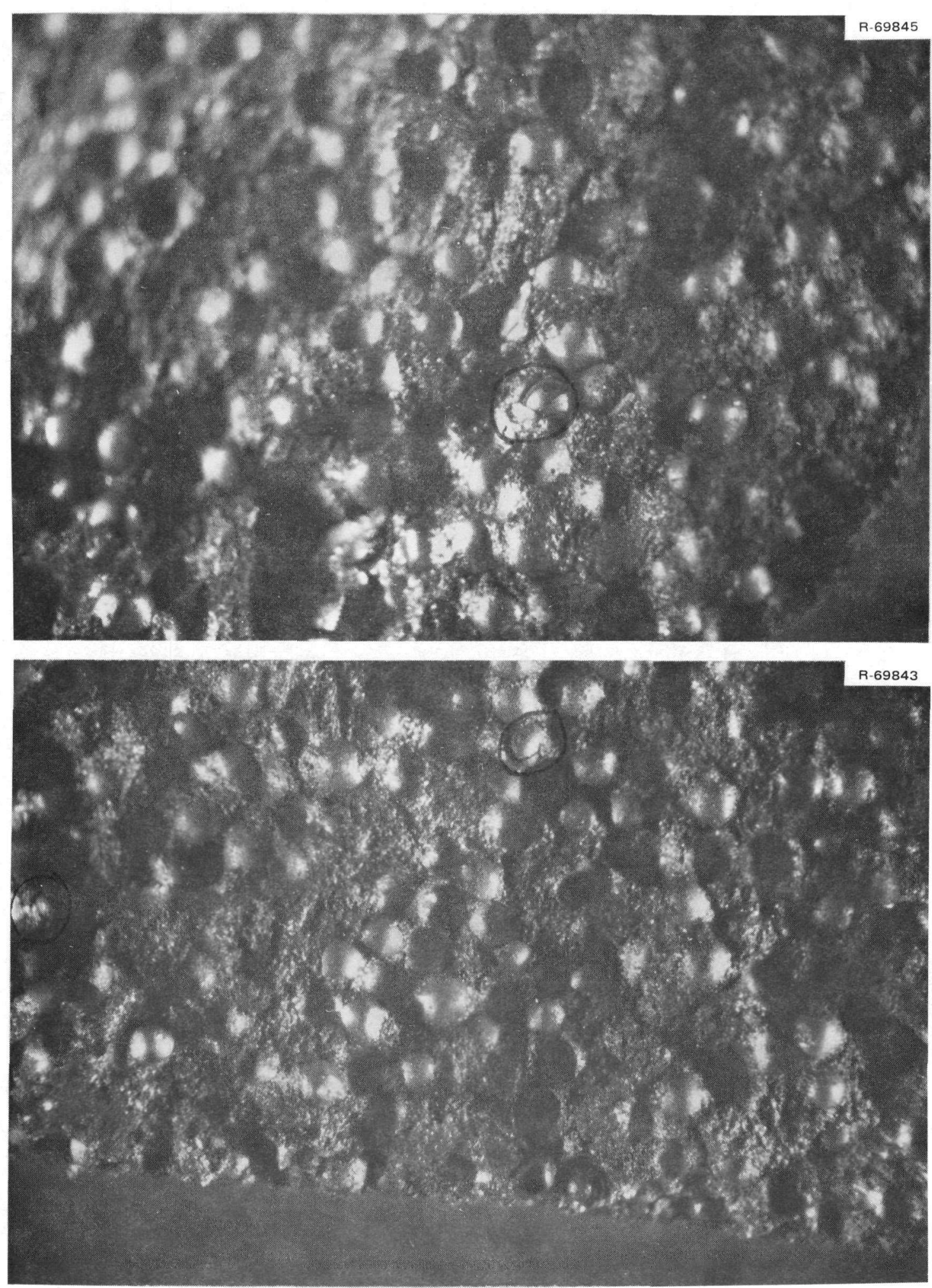

Fig. 3.1-17. Fracture plane of compact 20 (top and bottom). 
Table 3.2-1. Measurements of overall element length, fuel axial expansion gap, and overall length of fuel compacts

\begin{tabular}{|c|c|c|c|c|}
\hline & $\begin{array}{l}\text { Nominal } \\
\text { preirradiation value } \\
\text { (in.) }\end{array}$ & $\begin{array}{l}\text { Postirradiation } \\
\text { value } \\
\text { (in.) }\end{array}$ & $\begin{array}{l}\text { Difference } \\
\text { (in.) }\end{array}$ & $\begin{array}{l}\text { Percent } \mathrm{b} \\
\text { difference }\end{array}$ \\
\hline Overall length & 144.00 & 143.9 & -0.81 & -0.5 \\
\hline Fuel expansion gap ${ }^{c}$ & 4.6 & $3 \cdot 4$ & -1.2 & -26.0 \\
\hline $\begin{array}{l}\text { Total length of } \\
\text { fuel compacts }\end{array}$ & 90.0 & 90.0 & +0.63 & +0.70 \\
\hline
\end{tabular}

Values are not preirradiation measurements on FO3-O1 but were taken from design specifications of Peach Bottom fuel elements.

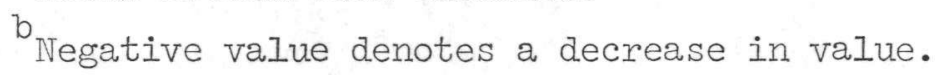

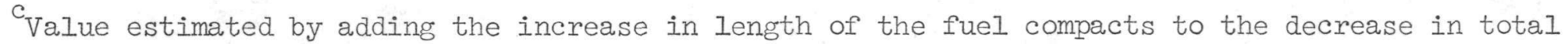
length of the element. 
Table 3.2-2. Cross-sectional dimensions of FO3-OI sleeve

\begin{tabular}{|c|c|c|c|c|c|c|c|}
\hline \multirow{2}{*}{$\begin{array}{l}\text { Location, } \\
\text { compact }\end{array}$} & & \multirow{2}{*}{$\begin{array}{l}\text { Mean } \\
\text { (in.) }\end{array}$} & \multirow{2}{*}{$\begin{array}{c}\text { Percent } \\
\text { difference }\end{array}$} & \multicolumn{4}{|c|}{ Dimension (in.) at indicated orientation of: ${ }^{b}$} \\
\hline & & & & $0^{\circ}$ & $90^{\circ}$ & $180^{\circ}$ & $270^{\circ}$ \\
\hline 1 & $\begin{array}{r}\text { OD } \\
\text { WalI } \\
\text { ID }\end{array}$ & $\begin{array}{l}3.480 \\
0.368 \\
2.745\end{array}$ & $\begin{array}{r}-0.1 \\
0.4 \\
-0.2\end{array}$ & $\begin{array}{l}3.482(2) \\
0.368(0) \\
2.744(-1)\end{array}$ & $\begin{array}{l}3.480(0) \\
0.365(-3) \\
2.745(0)\end{array}$ & $\begin{array}{ll}3.481 & (1) \\
0.368 & (0) \\
2.744 & (-1)\end{array}$ & $\begin{array}{l}3.479(-1) \\
0.370(2) \\
2.745(0)\end{array}$ \\
\hline 9 & $\begin{array}{r}\text { OD } \\
\mathrm{WaIl} \\
\mathrm{ID}\end{array}$ & $\begin{array}{l}3.468 \\
0.366 \\
2.736\end{array}$ & $\begin{array}{l}-0.5 \\
-0.1 \\
-0.6\end{array}$ & $\begin{array}{l}3.467(-1) \\
0.347(-19) \\
2.740(5)\end{array}$ & $\begin{array}{ll}3.471 & (3) \\
0.357 & (-9) \\
2.732 & (-4)\end{array}$ & $\begin{array}{ll}3.469 & (1) \\
0.381 & (15) \\
2.740 & (4)\end{array}$ & $\begin{array}{l}3.465(-3) \\
0.379(13) \\
2.733(-3)\end{array}$ \\
\hline 18 & $\begin{array}{r}\text { OD } \\
\text { Wall } \\
\text { ID }\end{array}$ & $\begin{array}{l}3.465 \\
0.367 \\
2.732\end{array}$ & $\begin{array}{r}-0.5 \\
0.0 \\
-0.7\end{array}$ & $\begin{array}{ll}3.464 & (-1) \\
0.331 & (-36) \\
2.740 & (8)\end{array}$ & $\begin{array}{l}3.469(4) \\
0.349(-18) \\
2.724(-8)\end{array}$ & $\begin{array}{ll}3.467 & (2) \\
0.395 & (28) \\
2.741 & (9)\end{array}$ & $\begin{array}{ll}3.462 & (-3) \\
0.393 & (26) \\
2.725 & (-7)\end{array}$ \\
\hline 24 & $\begin{array}{r}\text { OD } \\
\text { Wal.1 } \\
\text { ID }\end{array}$ & $\begin{array}{l}3.468 \\
0.379 \\
2.711\end{array}$ & $\begin{array}{r}-0.5 \\
3.4 \\
-1.5\end{array}$ & $\begin{array}{l}3.466(-2) \\
0.348(-31) \\
2.729(19)\end{array}$ & $\begin{array}{ll}3.472 & (4) \\
0.377 & (-2) \\
2.691 & (-20)\end{array}$ & $\begin{array}{ll}3.468 & (0) \\
0.391 & (12) \\
2.730 & (19)\end{array}$ & $\begin{array}{l}3.467(-1) \\
0.400(21) \\
2.692(-19)\end{array}$ \\
\hline 30 & $\begin{array}{r}\text { OD } \\
\text { WaII } \\
\text { ID }\end{array}$ & $\begin{array}{l}3.479 \\
0.368 \\
2.744\end{array}$ & $\begin{array}{r}-0.2 \\
0.4 \\
-0.3\end{array}$ & $\begin{array}{l}3.479(0) \\
0.362(-6) \\
2.745(1)\end{array}$ & $\begin{array}{l}3.480(1) \\
0.368(0) \\
2.743 \quad(-1)\end{array}$ & $\begin{array}{l}3.480(1) \\
0.372(4) \\
2.745(1)\end{array}$ & $\begin{array}{l}3.478(-1) \\
0.368(0) \\
2.743(-1)\end{array}$ \\
\hline
\end{tabular}

${ }^{a}$ Numbers represent the change from nominal preirradiation values, which were: $O D=3.485$ in., wall $=0.367$ in., and ID $=2.752$ in.

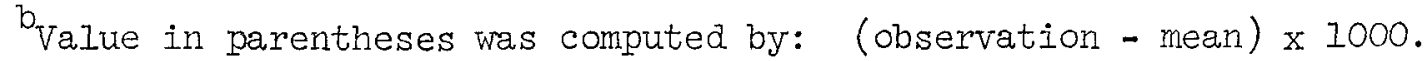


Table 3.2-3. Diameters of FO3-OI spine pieces

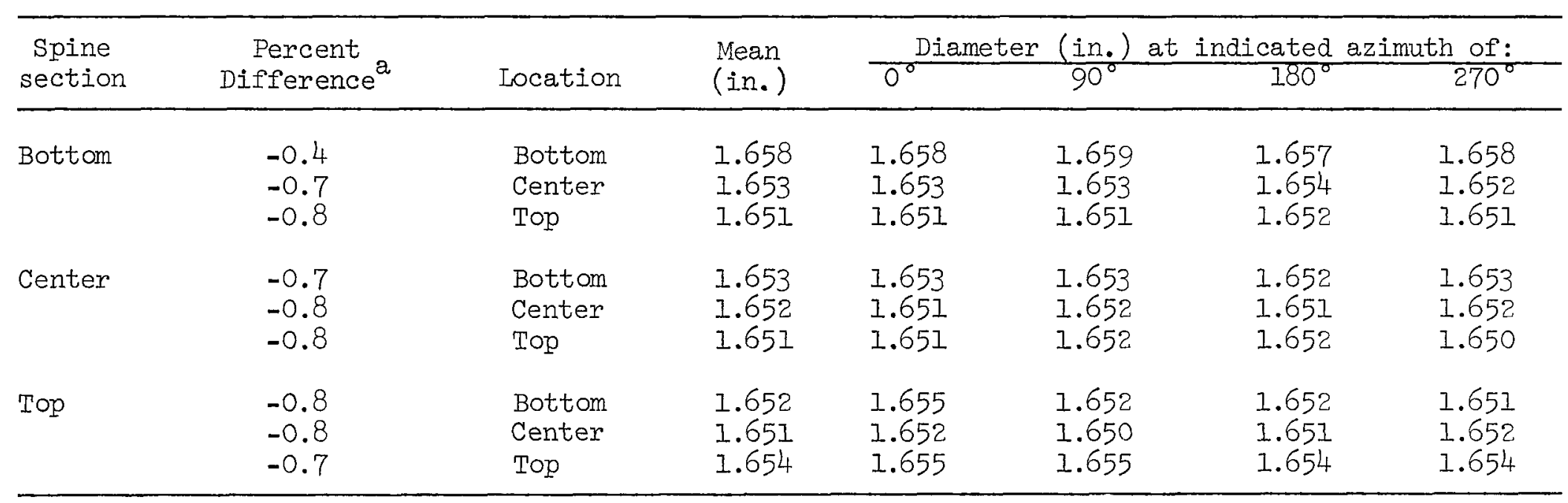

Difference between the nominal value before irradiation (1.688 in.) and the mean of the four observations. 
Table 3.2-4. Lengths of FO3-OI spine pieces

\begin{tabular}{lcc}
\hline Spine section & $\begin{array}{c}\text { Length } \\
\text { (in.) }\end{array}$ & $\begin{array}{c}\text { Percent } \\
\text { difference }\end{array}$ \\
\hline Bottom & 29.59 & -1.4 \\
Center & 29.39 & -2.0 \\
Top & 29.40 & -2.0 \\
\hline
\end{tabular}

$a_{\text {Difference between nominal length of unirradiated spine }}$ (30.0 in.) and measured postirradiation length.

Table 3.2-5. Inside and outside diameters of FO3-OI fuel compacts

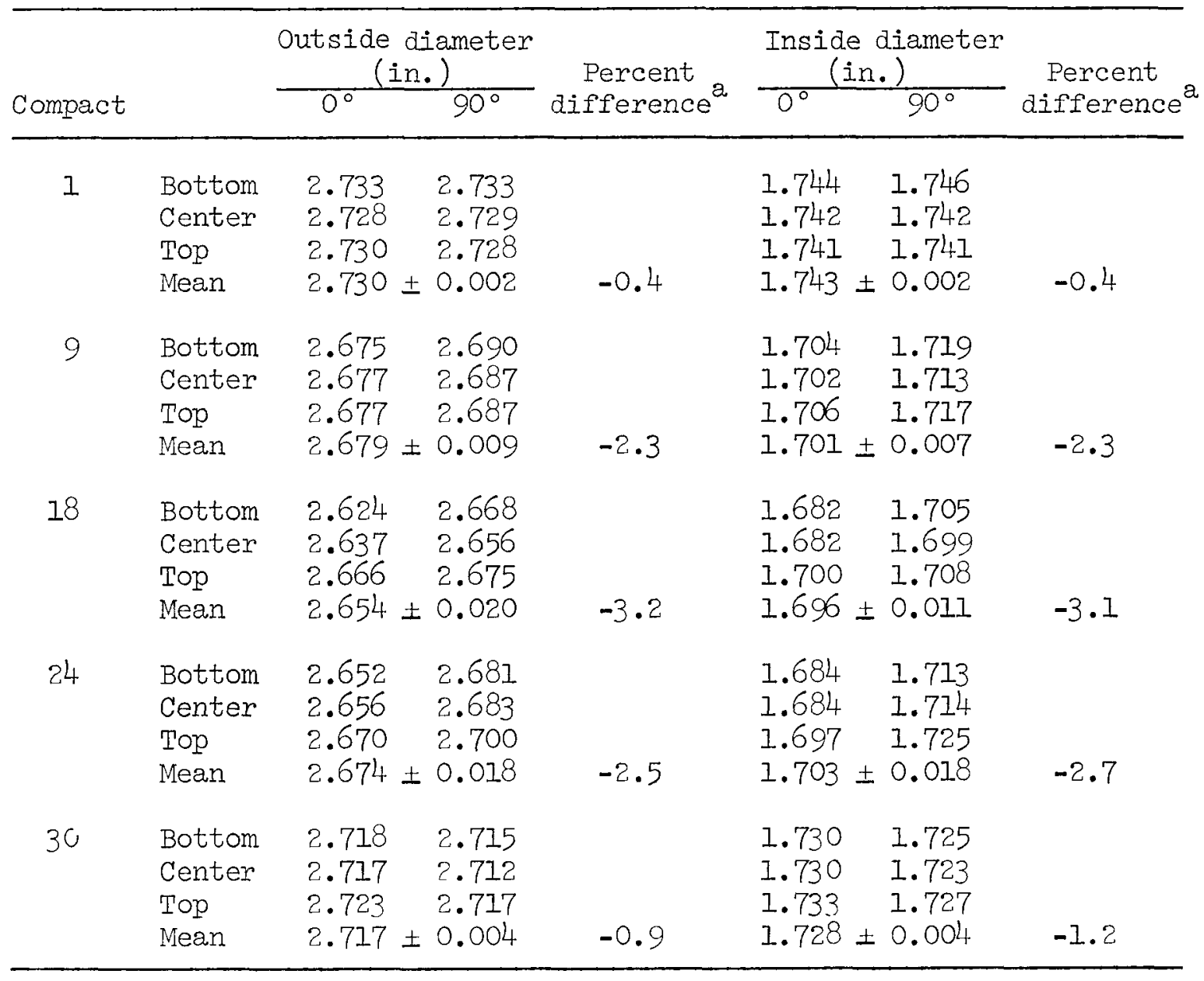

$a_{\text {Percent difference refers to the change from the preirradiation nominal }}$ values, which were: $O D=2.743 \mathrm{in.}, I D=1.750 \mathrm{in}$. 
Table 3-2-6. Measured wall thicknesses of FO3-Ol fuel compacts

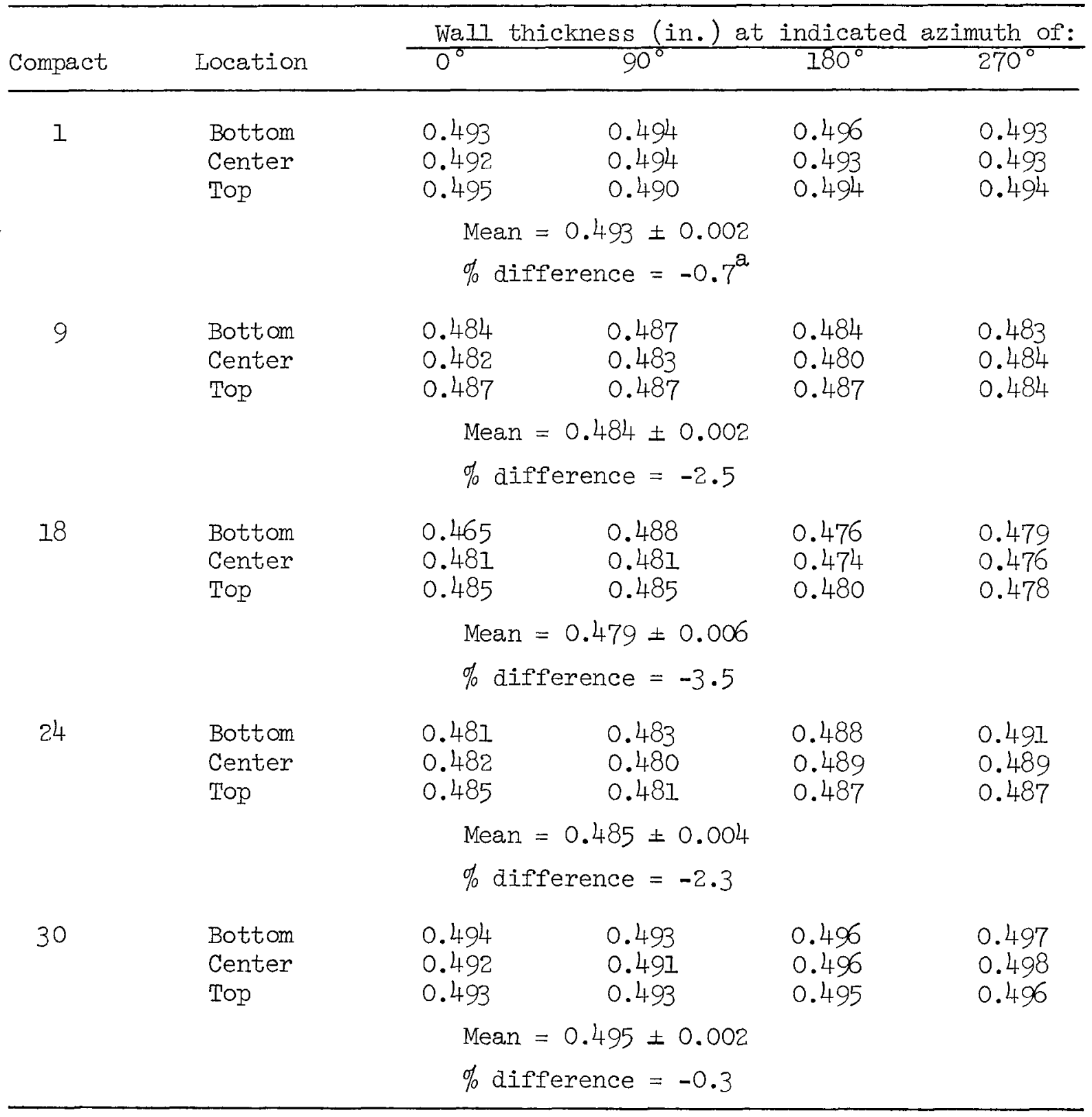

$a_{\text {Percent difference refers to the change from the preirradiation nominal }}$ value, which was $0.496 \mathrm{in}$. 
Table 3.2-7. Lengths of compacts comprising fuel element $\mathrm{FO}-01$

\begin{tabular}{|c|c|c|}
\hline Compact & $\begin{array}{c}\text { Length }^{\mathrm{a}} \\
\text { (in.) }\end{array}$ & $\begin{array}{c}\text { Percent } \\
\text { difference }\end{array}$ \\
\hline 1 & 2.991 & -0.3 \\
\hline 2 & 2.952 & -1.6 \\
\hline 3 & 3.010 & 0.3 \\
\hline 4 & 2.976 & -0.8 \\
\hline 5 & 2.983 & -0.6 \\
\hline 6 & 3.026 & 0.9 \\
\hline 7 & 3.016 & 0.5 \\
\hline 8 & 3.018 & 0.6 \\
\hline 9 & 3.023 & 0.8 \\
\hline 10 & 3.035 & 1.2 \\
\hline 11 & 3.017 & 0.6 \\
\hline 12 & 3.048 & 1.6 \\
\hline 13 & 2.995 & -0.2 \\
\hline 14 & 3.029 & 1.0 \\
\hline 15 & 3.045 & 1.5 \\
\hline 16. & 3.021 & 0.7 \\
\hline 17 & 3.043 & 1.4 \\
\hline 18 & 3.066 & 2.2 \\
\hline 19 & $B$ & \\
\hline 20 & B & \\
\hline 21 & 3.010 & 0.3 \\
\hline 22 & 3.074 & 2.5 \\
\hline 23 & 2.992 & -0.3 \\
\hline 24 & 3.119 & 4.0 \\
\hline 25 & 3.102 & 3.4 \\
\hline 26 & 3.030 & 1.1 \\
\hline 27 & 3.026 & 0.9 \\
\hline 28 & 2.985 & -0.5 \\
\hline 29 & 3.007 & 0.2 \\
\hline 30 & 2.948 & -1.7 \\
\hline
\end{tabular}

$\mathrm{a}_{\mathrm{B}}$ denotes broken compact. 
(shortening) and the fuel compacts (lengthening). The estimated changes in the length of the element and the gap seem to be consistent with observations made on previously examined fuel elements. ${ }^{2,3}$

Table 3.2-2 presents the dimensions of the sleeve, including outer diameter, wall thickness, and inner diameter, determined at locations adjacent to compacts $1,9,18,24$, and 30 . The outer diameters and wall thicknesses were measured at four azimuthal orientations, separated by $90^{\circ}$, using procedures described in ref. 3; the measured values and their means are tabulated. It should be noted that the use of the "curvature gauge" for measuring the outer diameter of a cylinder yields a value for the diameter at each orientation measured. Thus it is possible to have two estimates of the diameter from the $0^{\circ}$ to the $180^{\circ}$ azimuths and two estimates across the $90^{\circ}$ to $270^{\circ}$ azimuths, as are given in Table 3.2-2 for the sleeve. The algebraic difference between the observed quantity and the mean is given in parentheses after each diameter or wall thickness entry in the table. By examining these differences, one can readily see that the outer diameter varies with azimuth by only 0 to 0.004 in. and that the outside circumference of the element is therefore very nearly circular. Likewise, the thickness of the sleeve adjacent to compacts 1 and 30 is rather highly uniform around its circumference. On the other hand, the sleeve thickness varies significantly near compacts 9, 18, and 30. A negative sign for the tabulated differences denotes that the wall thickness is less than the mean value by the amount shown. Adjacent to compact 18, the wall thickness of the sleeve varies by at least 0.064 in. around the circumference.

Although it was not known initially whether the inside circumference of the sleeve was circular, inside diameters were derived by a method of triangulation which made use of the locations of the four points on the inside circumference that were derived from the wall thickness measurements. These inside diameters, along with a mean diameter and differences between each diameter and the mean (in parentheses), are given in Table 3.2-2. The differences between individual diameters and the mean show that the inside circumference is nearly circular near compacts 1,9 , and 30. Adjacent to compact 24 , the inner diameter between the $0^{\circ}$ and $180^{\circ}$ 
orientations is nearly $0.04 \mathrm{in}$. larger than the diameter between the $90^{\circ}$ and $270^{\circ}$ orientations. At this point, the sleeve appears to be significantly elliptical; less ellipticity is evident at compact 18. It should be noted that the extent of ellipticity is probably larger than indicated since the derived diameters are not likely to be along the major and minor axes.

The values given under the "Percent difference" column of Table 3.2-2 pertain to the difference between the nominal preirradiation and the postirradiation dimensions. The results indicate that both the outside diameter and the inside diameter decreased during irradiation, leaving the wall thickness essentially unchanged.

The diameters of the spine pieces as determined with a curvature gauge (see ref. 3) are presented in Table 3.2-3. As can be seen, the circumference appears to be highly circular. Axial variations of the diameter range up to about $0.4 \%$; and at most axial locations, the diameter is $\sim 0.7$ to $0.8 \%$ less than the nominal value of an unirradiated element.

The lengths of the spine pieces are given in Table 3.2-4. The lengths are $\sim 1.5$ to $2 \%$ less than the nominal lengths of unirradiated spines.

Measurements of the inside and outside diameters of fuel compacts 1 , 9, 18, 24, and 30 are presented in Table 3.2-5. Diameters were determined at three locations: bottom, center, and top, each at $0^{\circ}$ and $90^{\circ}$ azimuths. Means and standard deviations, computed for each of the six measurements, are also listed in the table. Both compact 1 and compact 30 appear to have circular inside and outside circumferences. Although the data for compacts 9, 18, and 24 show considerable scatter, there seems to be some evidence for a slight degree of ellipticity in these compacts. The difference between the nominal preirradiation and postirradiation dimensions indicates that both the outside diameter and the inside diameter decreased from $\sim 0.4 \%$ on the ends of the element to $\sim 3 \%$ in the midale.

The wall thicknesses of compacts 1, 9, 18, 24, and 30 are given in Table 3.2-6; the procedures and apparatus used are described in ref. 2 . Twelve measurements were made on each compact; the mean and the standard deviation of the results are tabulated under each set of data. A comparison of the mean measured wall thicknesses with the nominal value for 
unirradiated compacts ( 0.496 in.) indicates that the wall thicknesses decreased by $\sim 3.5 \%$ in the midale of the fuel element.

The lengths of all the compacts except 19 and 20 (which were broken) were measured, and the results are given in Table 3.2-7. Comparisons, given in the table, with nominal preirradiation dimensions inaicate that these lengths may have increased slightly during irradiation.

\section{DISTRIBUTION OF GAMMA-EMITITING RADIONUCLIDES}

\section{I Methods and Procedures}

The procedures used for obtaining axial and radial distributions of radionuclides in the spine and sleeve and for determining the inventories of radionuclides in the fuel compacts are described in sect. 4 of ref. 2 .

\subsection{Axial Distributions}

\subsubsection{Fuel compacts}

Ten gamma-emitting radionuclides, ${ }^{95} \mathrm{Zr},{ }^{10} \mathrm{Ru},{ }^{106} \mathrm{Ru},{ }^{125} \mathrm{Sb},{ }^{134} \mathrm{C} \cdot$

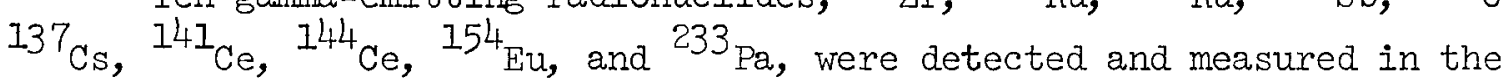
fuel. Niobium-95, the daughter of ${ }^{95} \mathrm{Zr}$, was also detected, but its inventory was not derived. Table 4.2-I lists the measured inventories of the ten radionuclides for each fuel compact. These data consist of means and standard deviations based on four observations per compact. Two observations (gamma spectra) were made at the bottom and in the middle of the compacts in the $0^{\circ}$ plane; and two, top and middle, were made in the $90^{\circ}$ plane. Values of the standard deviations of individual observations based on counting statistics are not given in Table 4.2-1; however, they are roughly summarized in Table 4.2-2. The inventories of the individual radionuclides in the total fuel are given at the bottom of each column in Table 4.2-1.

Figures 4.2-1 through 4.2-3 illustrate the axial distributions of the gamma-emitter inventories per compact. The error bars shown are the one-sigma errors, expressed as curies per compact, computed from the percent relative standard deviations given in Table 4.2-1. No attempt was 
Table 4.2-1. Fission product inventories in FO3-OI fuel compacts as of October 31, 1974 (curies per compact at end of life)

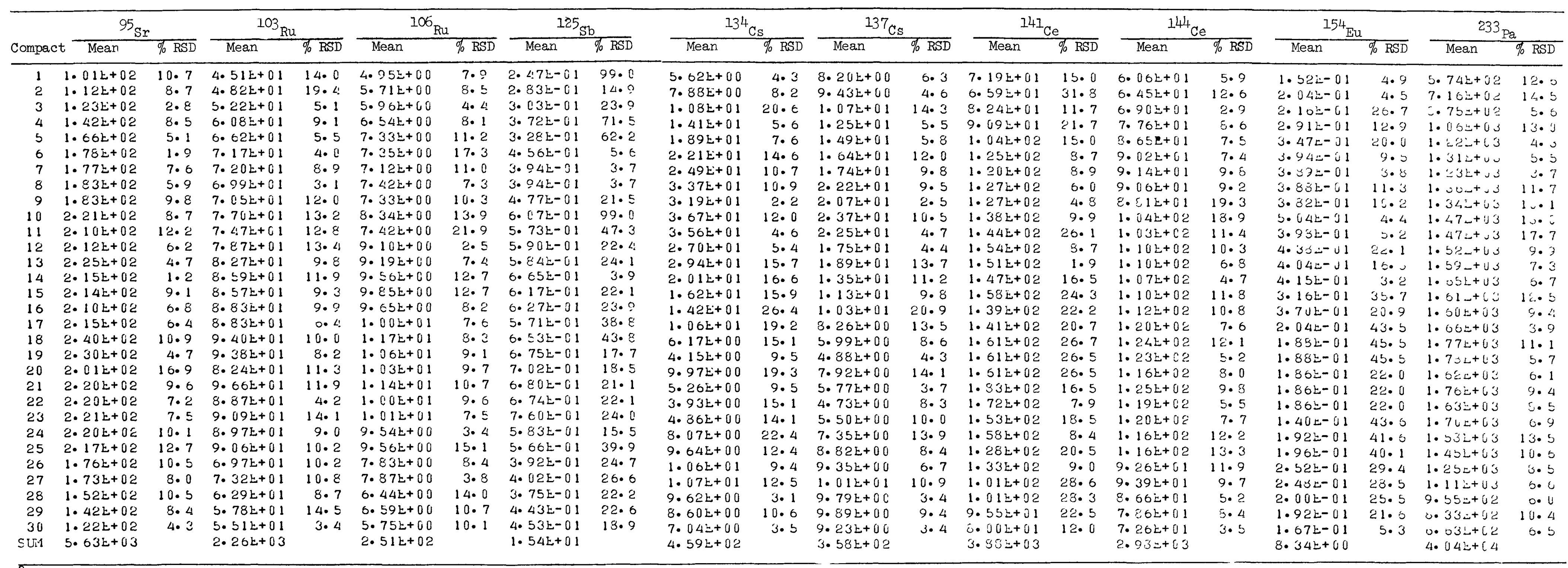

$a_{\%} \mathrm{RSD}=$ percent relative standard deviation . 
Table 4.2-2. Approximate counting statistics errors obtained for radionuclides measured in fuel compacts of FO3-OI

\begin{tabular}{lc}
\hline Radionuclide & $\begin{array}{c}\text { Percent relative } \\
\text { standard deviation }\end{array}$ \\
\hline $95 \mathrm{Zr}$ & 0.4 \\
$103_{\mathrm{Ru}}$ & 4.0 \\
$106_{\mathrm{Ru}}$ & 5.0 \\
$125_{\mathrm{Sb}}$ & 14.0 \\
$134_{\mathrm{Cs}}$ & 0.3 \\
$137_{\mathrm{Cs}}$ & 0.3 \\
$14{ }_{\mathrm{Ce}}$ & 7.0 \\
$144_{\mathrm{Ce}}$ & 3.0 \\
$154_{\mathrm{Eu}}$ & 8.0 \\
$233_{\mathrm{Pa}}$ & 3.0 \\
\hline
\end{tabular}

$a_{\text {Percent }}$ relative standard deviation was computed with the function

$$
\frac{100 \sqrt{G C+B L}}{G C-B L}
$$

where

$$
\begin{aligned}
& G C=\text { total counts in the photopeak, } \\
& B L=\text { total counts in the baseline under the peak } .
\end{aligned}
$$

The reader is referred to ref. 4 for an account of how photopeak counts are determined. 


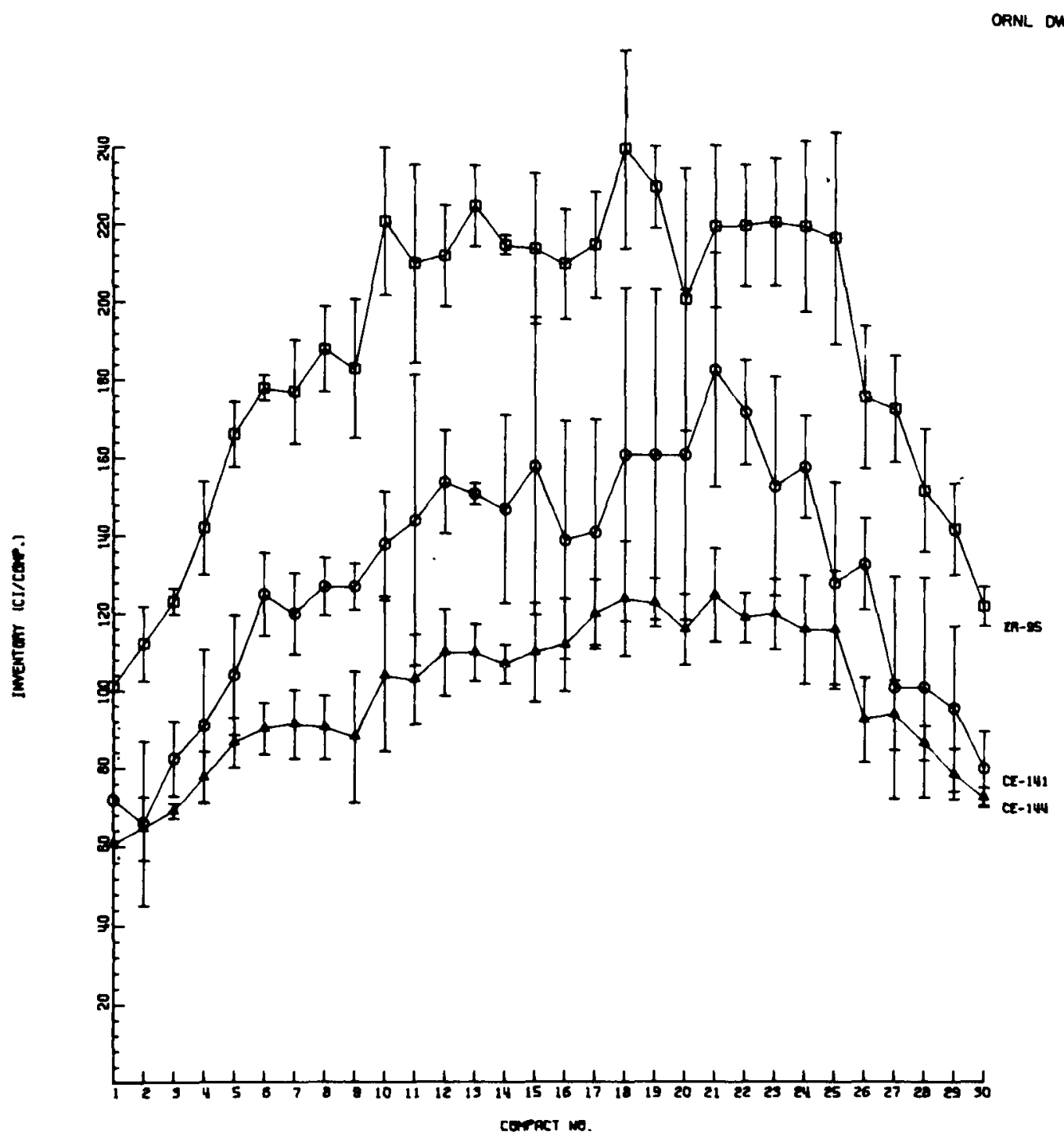

Fig. 4.2-1. Inventories of ${ }^{95} \mathrm{Zr},{ }^{14 I_{\mathrm{Ce}}}$, and ${ }^{144} \mathrm{Ce}$ per compact of element FO3-OI as of October 31, 1974. 


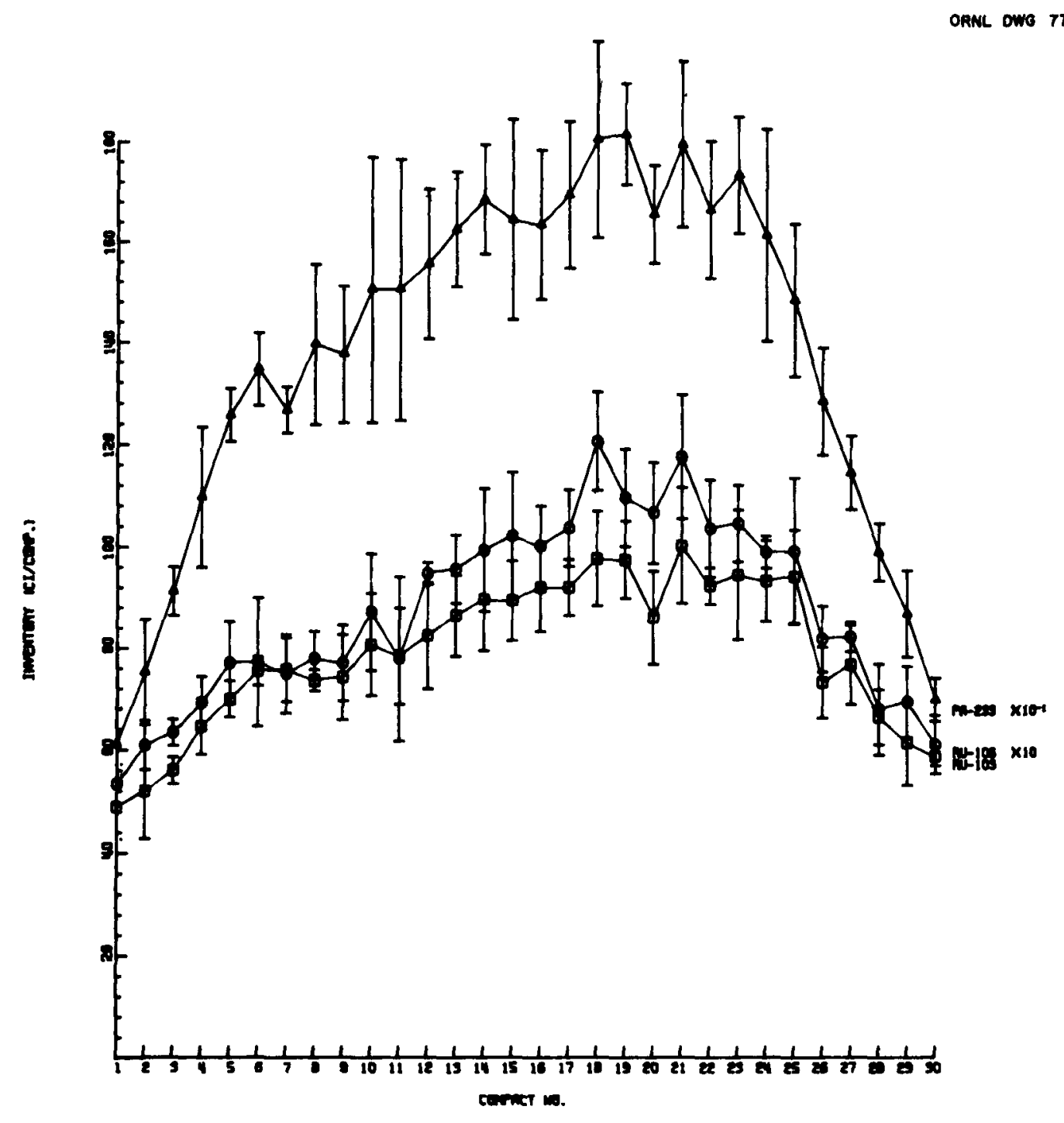

Fig. 4.2-2. Inventories of ${ }^{103} \mathrm{Ru},{ }^{106} \mathrm{Ru}$, and ${ }^{233} \mathrm{~Pa}$ per compact of element FO3-O1 as of October 31, 1974. 


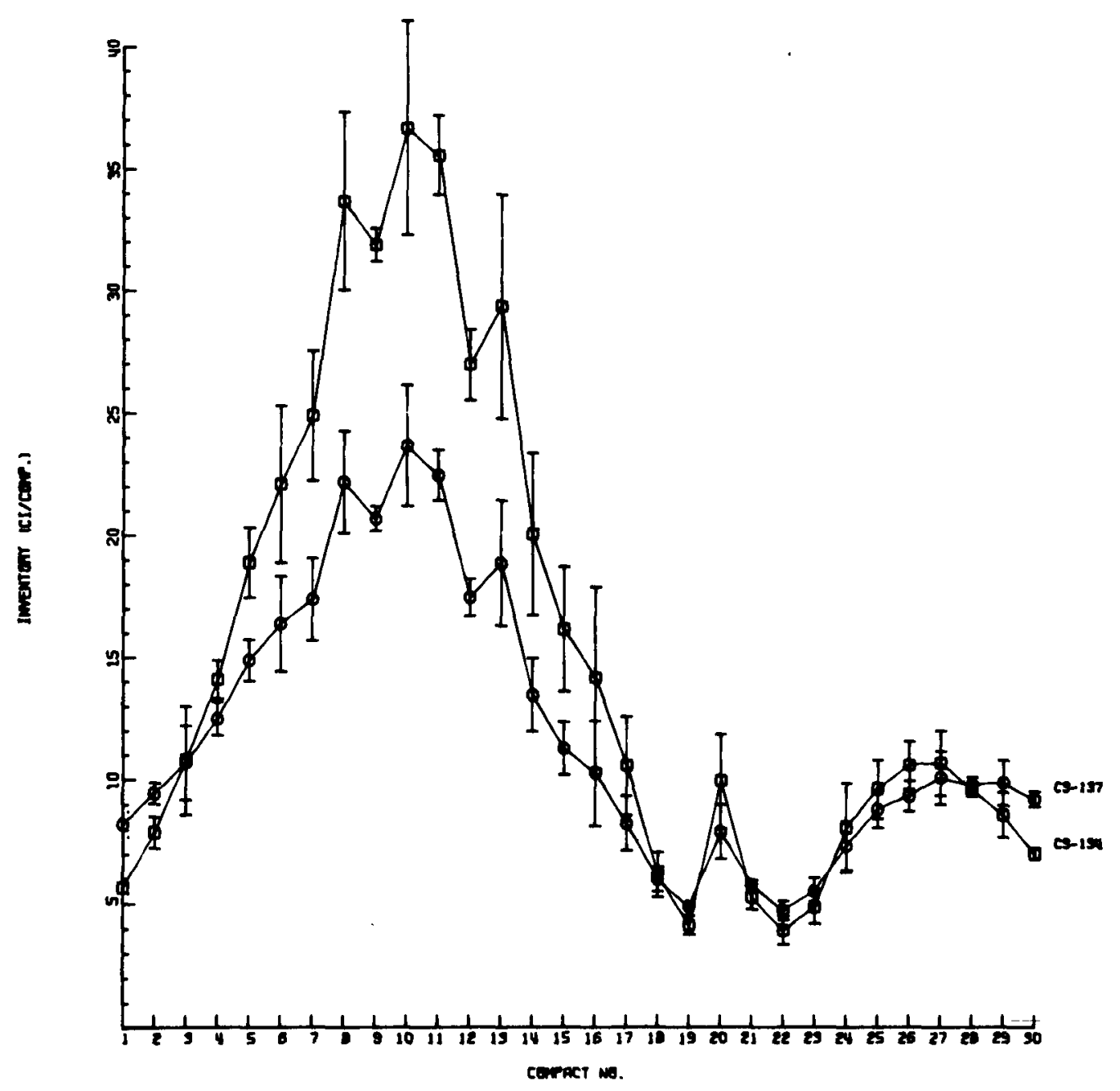

Fig. 4.2-3. Inventories of ${ }^{134} \mathrm{Cs}$ and ${ }^{137} \mathrm{Cs}$ per compact of element FO3-01 as of October 31, 1974. 
made to incorporate the counting statistics errors of Table 4.2-2 into the error bars of the plots. The gamma-emitter inventories normalized to the inventories of ${ }^{95} \mathrm{Zr}$ are plotted in Figs. 4.2-4 through 4.2-8. Since the isotope ${ }^{95} \mathrm{Zr}$ is known to be immobile in Peach Bottom fuel throughout the range of conditions observed thus far, the inventory distribution of other fission products normalized to ${ }^{95} \mathrm{Zr}$ would provide strong evidence as to whether that particular isotope had experienced significant gross movement during irradiation service.

The inventory distributions of ${ }^{95} \mathrm{Zr},{ }^{141} \mathrm{Ce}$, and ${ }^{144} \mathrm{Ce}$ (shown in Fig. 4.2-1) and ${ }^{103} \mathrm{Ru},{ }^{106} \mathrm{Ru}$, and ${ }^{23} \mathrm{~Pa}$ (shown in Fig. 4.2-2), as well as the normalized distributions of the cerium and ruthenium isotopes and $233 \mathrm{~Pa}$, indicate that no significant redistribution of these nuclides occurred. Generally, the inventory distributions of these nuclides roughly correspond to the neutron fluence experienced by the element, as depicted in Fig. 2.2-3. Because the ${ }^{233} \mathrm{U} /{ }^{235} \mathrm{U}$ ratio was larger in the central region of the element than at the ends, differences in the yields of fission products from these nuclides would slightly influence the inventory distributions. The softening of the neutron energy spectrum near the ends of the element might also affect the distributions. This latter effect, combined with the relatively large epithermal neutron capture cross section of ${ }^{233_{\text {Th }}}$ as compared with the thermal neutron capture cross section, probably accounts for the decrease in the ${ }^{233} \mathrm{~Pa} /{ }^{95} \mathrm{Zr}$ ratio near the ends of the element (see Fig. 4.2-8). Some of the scatter in the inventory profiles may result from variations in the number of fuel particles per unit volume of fuel compact. Much of the scatter, particularly in the case of the nuclides ${ }^{103} \mathrm{Ru},{ }^{106} \mathrm{Ru}$, and ${ }^{I 4 I_{C e}}$, is probably due to the poor counting statistics obtained. The inventories of ${ }^{134} \mathrm{Cs}$ and ${ }^{137} \mathrm{Cs}$ shown in Fig. 4.2-3, as well as their normalization to ${ }^{95} \mathrm{Zr}$ shown in Fig. 4.2-6, indicate that both isotopes underwent significant redistribution during irradiation. As was pointed out in ref. 2, the distribution of the ${ }^{137} \mathrm{Cs} /{ }^{95} \mathrm{Zr}$ activity ratio (barring such minor effects as differences in fission yields between ${ }^{233_{U}}$ and ${ }^{235} U$ ) would be uniform if ${ }^{137} \mathrm{Cs}$ were not released from the fuel compacts. Cesium-134, which is formed by two successive neutron reactions (first, fission to produce ${ }^{133} \mathrm{Cs}$ and, then, capture), has a profile that would, if no 


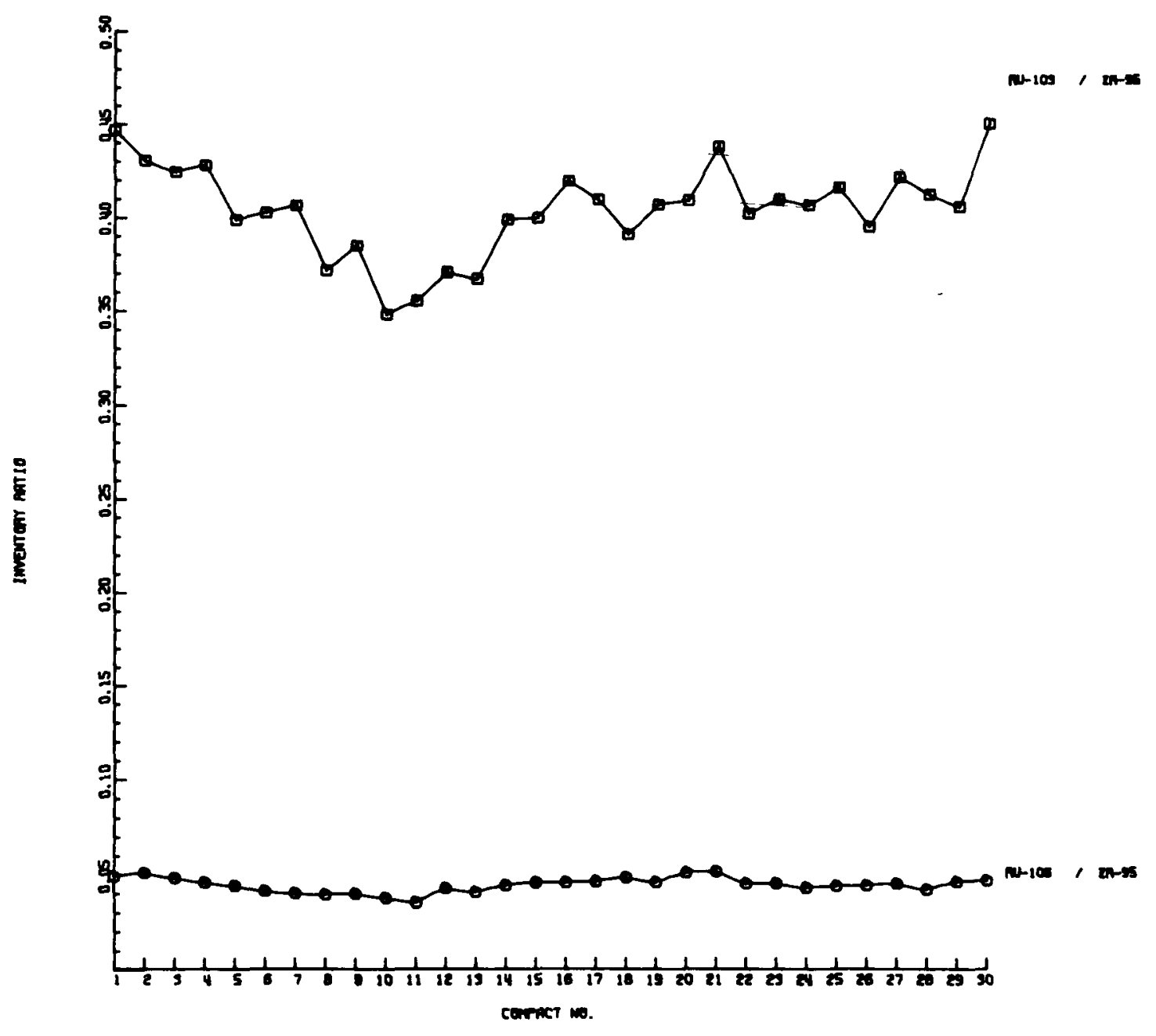

Fig. 4.2-4. Inventory ratios of ${ }^{103} \mathrm{Ru} /{ }^{95} \mathrm{Zr}$ and ${ }^{106} \mathrm{Ru} /{ }^{95} \mathrm{Zr}$ in FO3-01 fuel compacts as of October 13, 1974. 


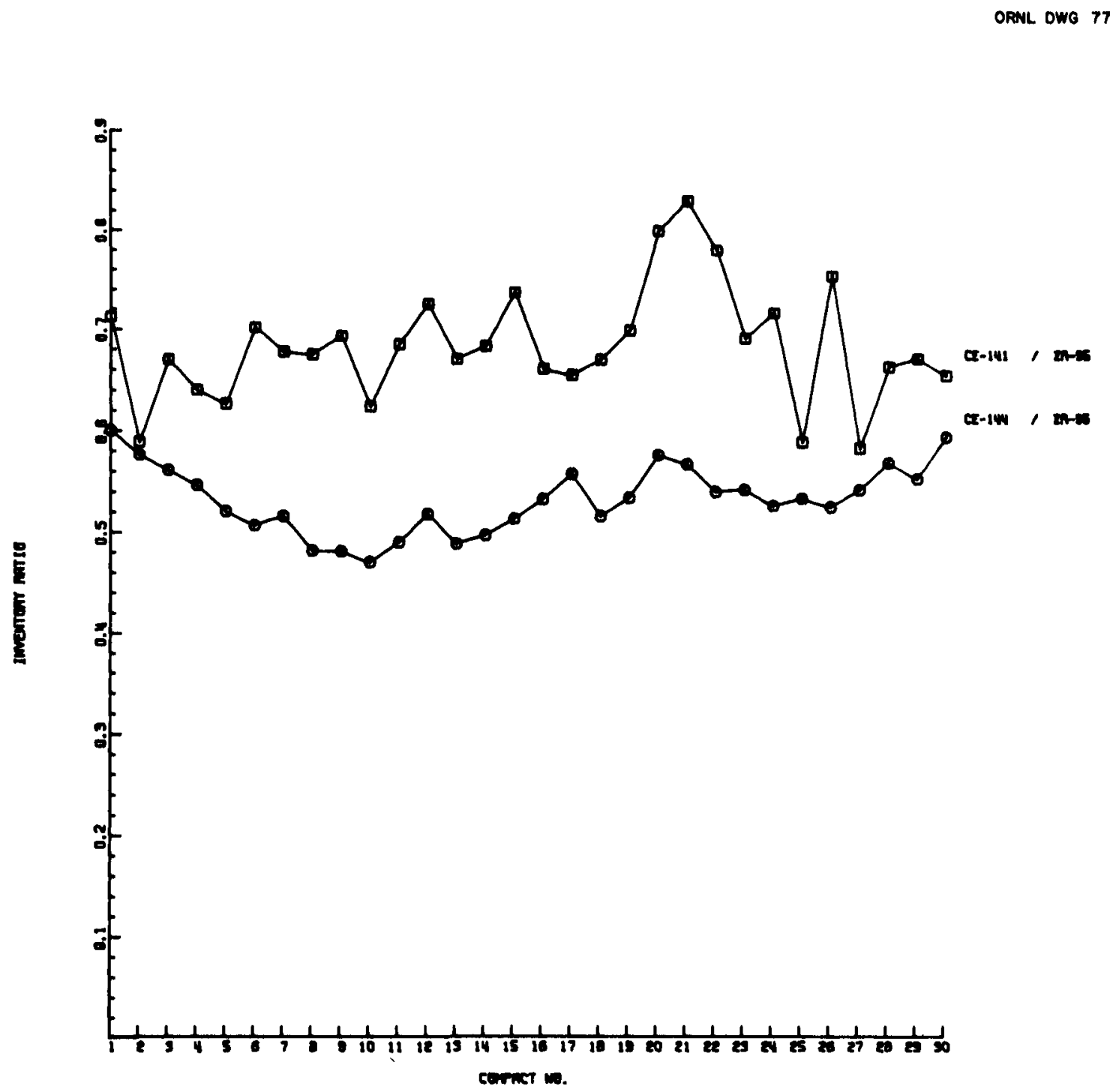

Fig. 4.2-5. Inventory ratios of ${ }^{141} \mathrm{Ce} /{ }^{95} \mathrm{Zr}$ and ${ }^{144} \mathrm{Ce} /{ }^{95} \mathrm{Zr}$ in FO3-OI fuel compacts as of October 31, 1974. 
ORNL DWG $77-1293$

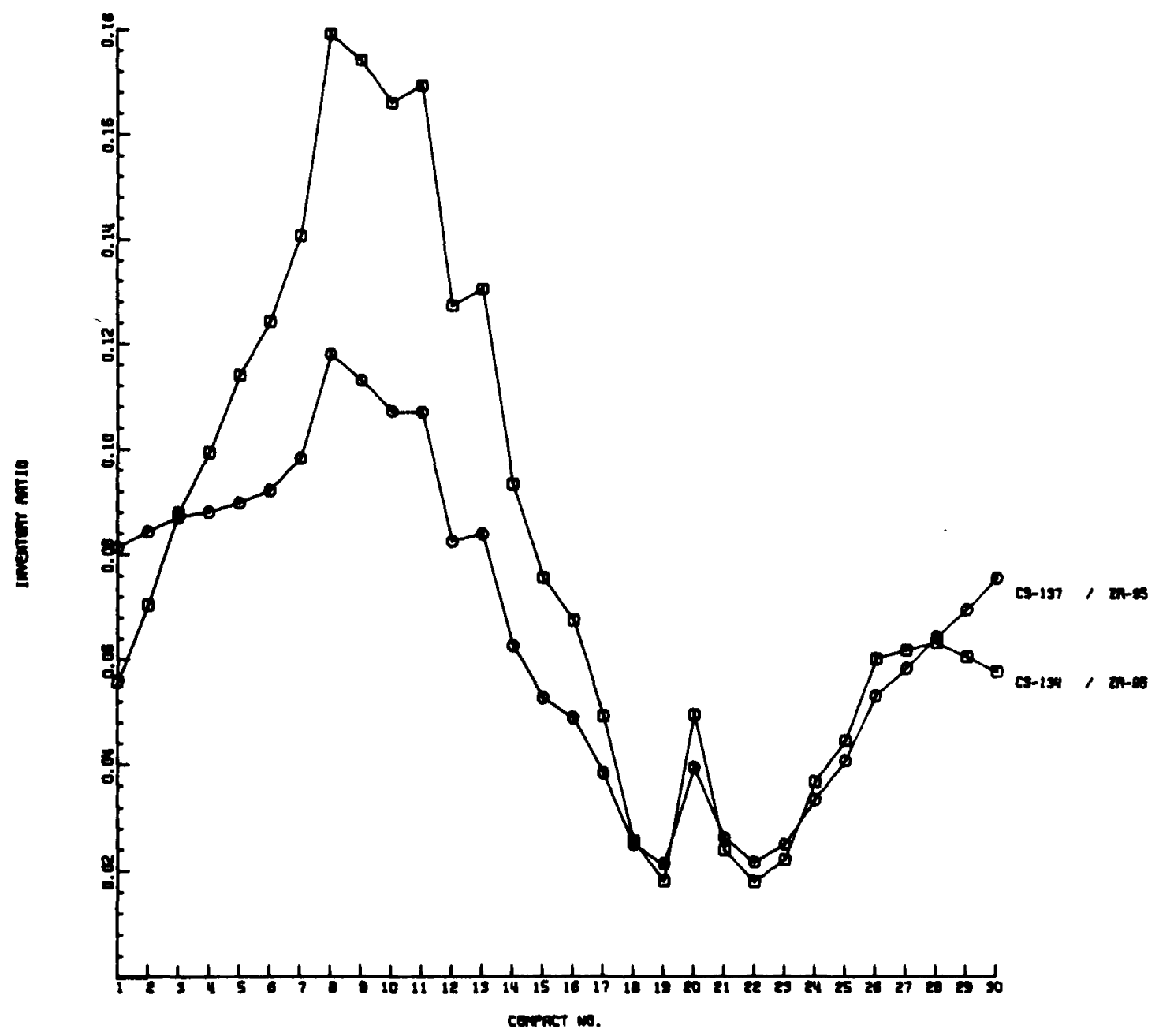

Fig. 4.2-6. Inventory ratios of ${ }^{134} \mathrm{Cs} /{ }^{95} \mathrm{Zr}$ and ${ }^{137} \mathrm{Cs} / 95 \mathrm{Zr}$ in FO3-0I fuel compacts as of Octiber 31, 1974. 


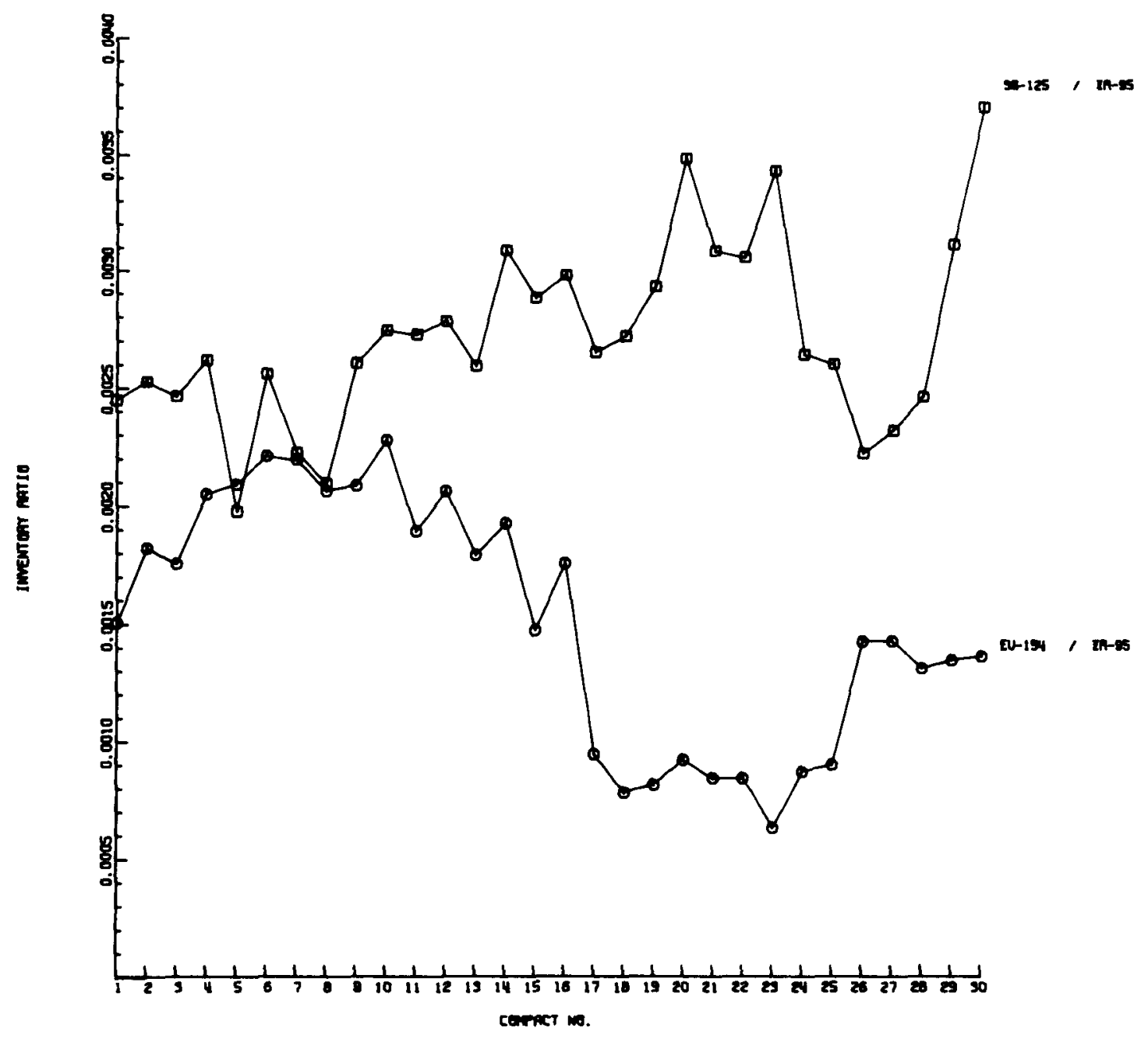

Fig. 4.2-7. Inventory ratios of ${ }^{125} \mathrm{Sb} /{ }^{95} \mathrm{Zr}$ and ${ }^{154} \mathrm{Eu} /{ }^{95} \mathrm{Zr}$ in FO3-01 fuel compacts as of October 31, 1974. 
ORNL OWG $77-1294$

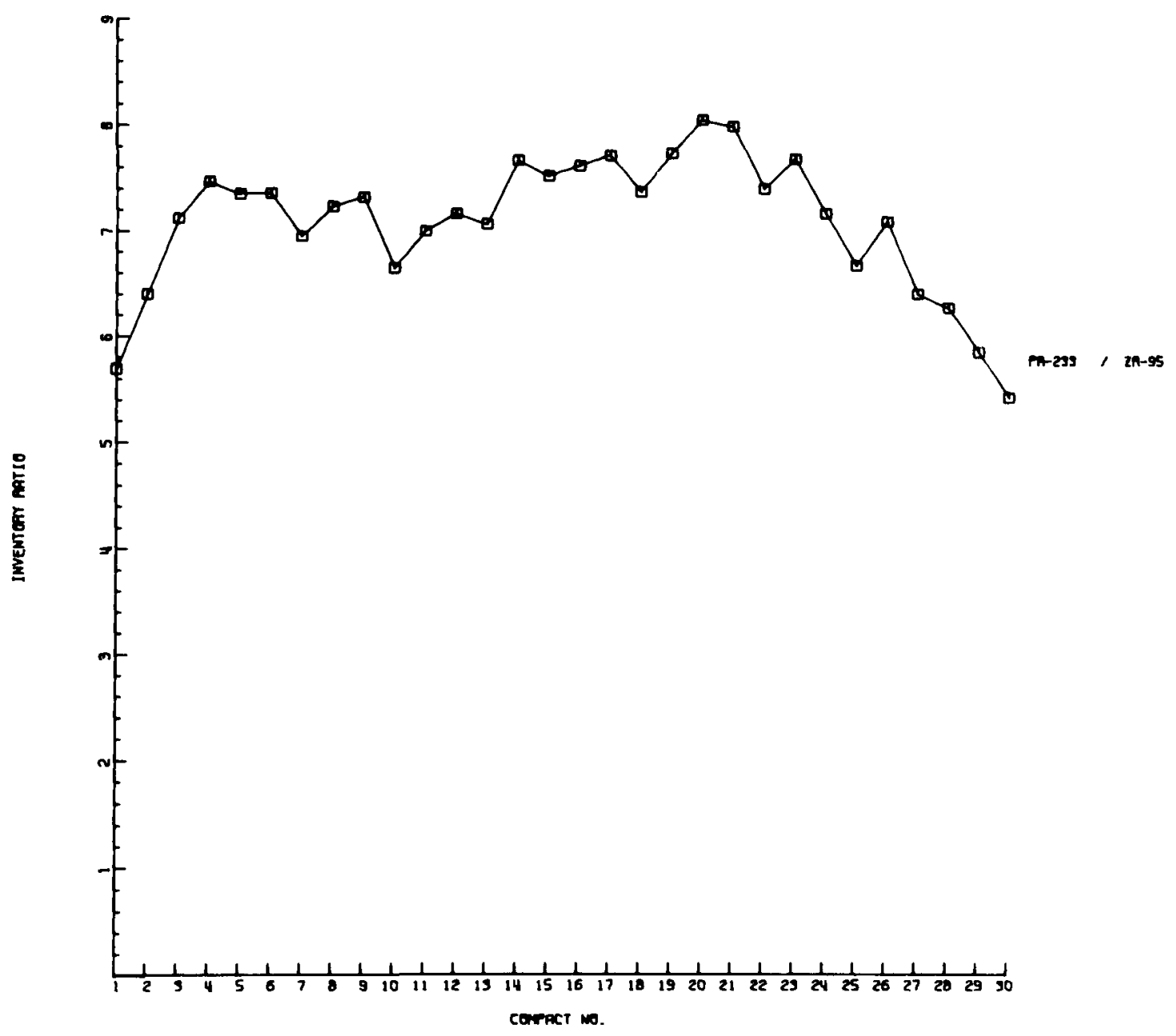

Fig. 4.2-8. Inventory ratio of ${ }^{233} \mathrm{~Pa} /{ }^{95} \mathrm{Zr}$ in $\mathrm{FO}-\mathrm{OI}$ fuel compacts as of October 31, 1974. 
redistribution occurred, roughly follow the square of the neutron flux. The profile of the ${ }^{134} \mathrm{Cs} /{ }^{95} \mathrm{Zr}$ ratio would parallel the neutron flux distribution. The relationship of the epithermal and thermal-neutron capture cross sections of ${ }^{133} \mathrm{Cs}$ is similar to that of ${ }^{232} \mathrm{Th}$; thus the neutron energy spectrum probably also affects the ${ }^{134} \mathrm{Cs}$ distribution to a significant extent. The dip in the ${ }^{137} \mathrm{Cs} / 95 \mathrm{Zr}$ ratio in the region roughly from compact 14 to compact 30 and the rise in the ratio from compact 1 to about compact 14 indicate that cesium moved from the upper to the lower part of the fuel. It is believed that cesium, vaporized in the higher-temperature regions, was transported by the purge gas to cooler regions where it condensed on the fuel and graphite. The ${ }^{137} \mathrm{Cs}$ in compacts at or near the ends of the element is believed to have suffered insignificant vaporization. Hence the ${ }^{137} \mathrm{Cs} /{ }^{95} \mathrm{Zr}$ ratio in the end compacts, along with the observed ${ }^{95} \mathrm{Zr}$ inventory in a compact whose ${ }^{137} \mathrm{Cs}$ inventory has been modified by redistribution, can be used to compute the amount of ${ }^{137} \mathrm{Cs}$ generated in the compact. The difference between the computed and observed inventories is therefore the amount of ${ }^{137} \mathrm{Cs}$ that either vaporized from or deposited on the compact. It is thus possible to make a rough mass balance calculation for the ${ }^{137} \mathrm{Cs}$ in an element by estimating the amount vaporized from the fuel and comparing this estimate with the amount estimated to be d posited on the cooler compacts plus the amount found in the spine and sleeve.

Table 4.2-3 presents results of $137_{\mathrm{Cs}}$ mass balance estimates for fuel elements FO3-OI and EII-O7 expressed both as curies and as percentages of the total ${ }^{137} \mathrm{Cs}$ in the elements. Data for Ell-07 were taken from ref. 2. Compact 30 of each element was assumed to have lost an insignificant amount of ${ }^{137} \mathrm{Cs}$; therefore, its ${ }^{137} \mathrm{Cs} /{ }^{95} \mathrm{Zr}$ ratio was selected for the calculations. This selection was based on two observations: (1) that the ${ }^{137} \mathrm{Cs} / 95 \mathrm{Zr}$ ratio in compact 30 was only slightly lower than in compact 1 , and (2) that very little ${ }^{137} \mathrm{Cs}$ was found in either element below compact 1 as well as in the graphite adjacent to compact 1 . Such evidence suggests that compact 30 may have lost a minor amount of ${ }^{137} \mathrm{Cs}$, while compact 1 may have gained a little from the redistribution. 
Table 4.2-3. Comparison of the movement of ${ }^{137} \mathrm{Cs}$ in fuel elements FO3-OI and Ell-07

\begin{tabular}{|c|c|c|c|c|}
\hline \multirow[b]{2}{*}{ Source } & \multicolumn{2}{|c|}{$\mathrm{FO} 3-\mathrm{OI}$} & \multicolumn{2}{|c|}{$\mathrm{E} 11-07$} \\
\hline & $\overline{\mathrm{Ci}}$ & $\%$ & $\overline{\mathrm{CI}}$ & $\%$ \\
\hline Sleeve & 36 & 8.9 & 17 & 4.6 \\
\hline Spine & 9.8 & 2.4 & 8.3 & $3 \cdot 3$ \\
\hline Sleeve and spine & 46 & 11 & 25 & 6.8 \\
\hline Fuel & 358 & 89 & 343 & 93 \\
\hline Element & 404 & 100 & 368 & 100 \\
\hline Deposit on fuel ${ }^{a}$ & 47 & 12 & 45 & 12 \\
\hline Deposits on graphite and fuel & 93 & 23 & 69 & 19 \\
\hline Calc. release from fuel ${ }^{a}$ & 113 & 28 & 73 & 20 \\
\hline Difference ${ }^{b}$ & 20 & 18 & 4 & 5 \\
\hline
\end{tabular}

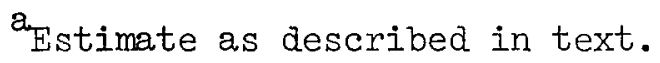

$b_{\text {Difference between the }}{ }^{137}$ Cs estimated to have been released from high-temperature fuel and that deposited on low-temperature fuel plus amount found in graphite.

As shown in Table 4.2-3 for element FO3-O1, it was estimated that $113 \mathrm{Ci}$, or $28 \%$ of the total ${ }^{137} \mathrm{Cs}$, was released by the high-temperature compacts and $93 \mathrm{Ci}$, or $23 \%$, was found in the graphite or estimated to be on the cooler fuel compacts. This balance is considered to be fairly good; however, the balance for element EII-O7, where $20 \%$ was released and $19 \%$ was found elsewhere, was much better. It is interesting to note that both elements had the same percentage of their ${ }^{137} \mathrm{Cs}$ deposited on the low-temperature fuel and in the spine, whereas element FO3-OI had almost twice as much of the cesium on its sleeve as did element Ell-07. The distribution of the ${ }^{154} \mathrm{Eu} /{ }^{95} \mathrm{Zr}$ ratio in the FO3-O1 fuel compacts depicted in Fig. 4.2-7 indicates that this nuclide redistributed similarly to the cesium isotopes. Like ${ }^{134} \mathrm{Cs},{ }^{154} \mathrm{Eu}$ is formed by two successive neutron reactions; if no release of europium took place, the ${ }^{154} \mathrm{Eu} /{ }^{95} \mathrm{Zr}$ ratio should therefore parallel the neutron fluence. No attempt was made to estimate the amount of ${ }^{154} \mathrm{Eu}$ that redistributed in the element. 
4.2.2 Sleeve, spine, and bottom connector

The sleeve was cut into three pieces, each about 30 in. long (corresponding to the three manufactured sections of the spine) and scanned axially in two planes $90^{\circ}$ apart. The spine pieces and bottom connector were similarly measured. Spectra acquired at 0.2459-in. intervals along each plane were analyzed in terms of curies per an equivalent 3 in. of

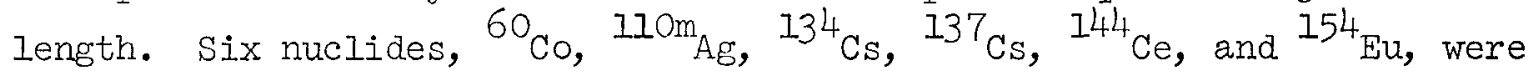
detected and measured.

These results are listed in Tables A-1 through A-18 in Appendix A. Both the observed inventory per $3 \mathrm{in}$. of length and the standard deviation based on counting statistics at each location are given. In these tables the designation (****), which appears frequently in the standard deviation c)Iumn, signifies that no direct observation of the isotope was made at the particular location, and that the given inventory value is merely the pper limit which could exist there without detection. If the observed count rates in three channels on either side of a photopeak were less than three standard deviations above the base line, established by the count rate at each end of the six-channel width, then the photopeak was judged to be "not detected." The listed "upper-limit value" was then calculated, assuming a photopeak count rate equal to the maximum, nondetectable value of three standard deviations above the base line. For the sleeve and spine, the values tabulated under the column labeled as "Distance" represent the distance from the bottom of fuel compact $I$; in the case of the bottom reflector, distance is measured from the bottom of the fuel element.

Tables 4.2-4 and 4.2-5 list the observed inventories for the sleeve and spine, respectively, expressed as curies per 3-in. segment corresponding to the length of a fuel compact. These data were derived from the gamma scan data given in Appendix A. Inventory values per 3-in. segment were obtained for each plane that was measured by apportioning the total number of scan points, normally about 264 along a plane, into 30 groups. Each group corresponded nominally to 12 scan points, although a few corresponded to 13 points. Because some of the data in Appendix A represented upper limits (as described above) rather than real measured values, the 
Table 4.2-4. Axial distribution of gamma-emitters in the sleeve of element FO3-01

(curies per compact length, corrected to October 31, 1974)

\begin{tabular}{|c|c|c|c|c|c|c|c|c|c|c|c|c|}
\hline \multirow[b]{3}{*}{ Compact } & \multicolumn{6}{|c|}{${ }^{60} \mathrm{Co}$} & \multicolumn{6}{|c|}{${ }^{11} \mathrm{Om}_{\mathrm{Ag}}$} \\
\hline & \multicolumn{3}{|c|}{ Plane 1} & \multicolumn{3}{|c|}{ Plane 2} & \multicolumn{3}{|c|}{ Plane 1} & \multicolumn{3}{|c|}{ Plane 2} \\
\hline & $\begin{array}{l}\text { Inventory } \\
\text { ( } \mathrm{C} i / 3 \text { in.) }\end{array}$ & $\begin{array}{c}\text { Errora } \\
(\%)\end{array}$ & $\mathrm{NO}^{\mathrm{b}}$ & $\begin{array}{l}\text { Inventory } \\
\text { ( } \mathrm{Ci} / 3 \text { in.) }\end{array}$ & $\begin{array}{c}\text { Error } \\
(\%)\end{array}$ & $\mathrm{NO}^{\mathrm{b}}$ & $\begin{array}{l}\text { Inventory } \\
\text { (Ci/3 in.) }\end{array}$ & $\begin{array}{c}\text { Errora } \\
(\%)\end{array}$ & $\mathrm{NO}^{\mathrm{b}}$ & $\begin{array}{l}\text { Inventory } \\
\text { (Ci/3 in.) }\end{array}$ & $\begin{array}{c}\text { Error } \\
(\%)\end{array}$ & No ${ }^{b}$ \\
\hline 1 & $3.05 E-05$ & $47 \cdot 5$ & 12 & $6 \cdot 18 \mathrm{t}-05$ & 74.9 & 12 & $2 \cdot 40 k-04$ & 23.8 & 10 & $2.02 k-04$ & 74.0 & 16 \\
\hline 2 & $2 \cdot 52 c-05$ & 22.5 & il & $2.94 t-05$ & 36.7 & 12 & $1 \cdot 17 z-03$ & $203 \cdot 4$ & 12 & $1.45 k-03$ & $205 \cdot 1$ & 11 \\
\hline 3 & $3 \cdot 33 t-05$ & 20.1 & 10 & $3.20 \leq-05$ & 37.6 & 12 & $1.89 k-03$ & 206.5 & 11 & $1.63 E-03$ & 186.3 & 12 \\
\hline 4 & $5.95=-05$ & 48.8 & 11 & $3.82 t-05$ & 20.9 & 5 & $1.01 z-02$ & $129 \cdot 1$ & 3 & $7.83 E-03$ & 133.0 & 4 \\
\hline 5 & $7.90 t-05$ & 38.2 & 3 & 5. $54 \mathrm{E}-05$ & 23.2 & 5 & $6 \cdot 54 t-03$ & $68 \cdot 0$ & 3 & $9.66 t-03$ & $114 \cdot 4$ & 4 \\
\hline 6 & $1.04 t-04$ & 0.6 & 2 & $8.29 k-05$ & 29.8 & 3 & $1.03 k-02$ & $65 . j$ & 11 & 7. $79 \mathrm{~L}-03$ & 94.2 & 12 \\
\hline 7 & $4.29 k-04$ & 39.7 & 1 & $3.73 k-04$ & 26.6 & 1 & $1.88 \mathrm{E}-02$ & 30.0 & 11 & $1.365-02$ & $30 \cdot 1$ & 12 \\
\hline 8 & $5.16 k-04$ & 99.0 & 0 & 6. $68 \mathrm{t}-04$ & 38.2 & 1 & $3 \cdot 53 \mathrm{k}-02$ & $40 \cdot 1$ & 12 & $2.69 k-02$ & 36.6 & 12 \\
\hline 9 & $2 \cdot 19 \mathrm{z}-03$ & 33.5 & 1 & $1.85 k-03$ & 99.0 & 0 & $7.09 k-02$ & 14.5 & 8 & $5.22 t-02$ & 34.7 & 11 \\
\hline 10 & $1.77 \mathrm{k}-03$ & $27 \cdot 1$ & 2 & $1.58 \mathrm{~b}-0 \mathrm{~s}$ & 31.5 & 1 & 5. $03 t-0 z$ & $21 \cdot 7$ & 6 & $4 \cdot 79 t-02$ & 23.4 & 12 \\
\hline 11 & $1.72 k-03$ & 99.0 & 0 & $8 \cdot 785-04$ & $34 \cdot 5$ & 1 & $3.85 t-02$ & $38 \cdot 4$ & 9 & 4. $t 4 k-02$ & 31.5 & 10 \\
\hline 12 & $2.98 E-03$ & 99.0 & 0 & $2 \cdot 74 t-03$ & 99.0 & 0 & $7 \cdot 27 \mathrm{E}-02$ & 53.2 & 6 & $5.20 t-02$ & 15.0 & 9 \\
\hline 13 & $2.38 t-03$ & 99.0 & 0 & $2.80 E-03$ & $18 \cdot 2$ & 4 & $5.98 E-0 E$ & $32 \cdot 4$ & 11 & $5.06 k-02$ & 33.7 & 7 \\
\hline 14 & $2.93 z-03$ & 16.9 & 3 & $2.44 t-03$ & 20.5 & 2 & 5. $14 \mathrm{k}-02$ & 19.8 & 9 & 4. $735-02$ & $28 \cdot 2$ & 8 \\
\hline 15 & $2.50 k-03$ & 13.4 & 4 & $3.25 \pm-03$ & 28.1 & 1 & $4.80 t-02$ & $34 \cdot 1$ & 4 & $3.70 \mathrm{E}-\mathrm{CE}$ & $2 \cdot 2$ & 4 \\
\hline 16 & 6. $212-03$ & $47 \cdot 1$ & 10 & 4. $78<-03$ & 33.0 & 12 & $4 \cdot 22 E-02$ & 23.8 & 5 & $4 \cdot 44 E-02$ & 17.9 & 4 \\
\hline 17 & $8.37 t-03$ & 39.5 & 12 & $4 \cdot 95=-03$ & $23 \cdot 2$ & 6 & $5 \cdot 13 \mathrm{k}-02$ & 15.0 & 3 & 4. $62 \mathrm{Z}-\mathrm{C} 2$ & 35.4 & 1 \\
\hline 18 & $1.20 k-02$ & $21 \cdot 2$ & 12 & $1.115-02$ & $47 \cdot 4$ & 11 & 5. $26 k-02$ & 28.8 & 1 & 4. $\epsilon^{\prime} E-02$ & 35.7 & 1 \\
\hline 19 & 5. $99 t-03$ & $46 \cdot 4$ & 12 & $6 \cdot 23 t-03$ & $22 \cdot 8$ & 12 & $3 \cdot 14 t-0 z$ & $34 \cdot 0$ & 1 & $4.97 t-02$ & 34.5 & 1 \\
\hline 20 & $8.77 k-03$ & 60.6 & 12 & $7.565-03$ & $27 \cdot 4$ & 12 & $2.54 L-02$ & $99 . \mathrm{C}$ & 0 & $5.27 t-0 a$ & $26 \cdot 7$ & 1 \\
\hline 21 & 5. $36 E-03$ & $39 \cdot 7$ & 13 & $5.60 t-03$ & 30.7 & 12 & 4. $025-02$ & $10 \cdot t$ & 2 & $5 \cdot 312-03$ & 37.9 & $i$ \\
\hline 22 & $0.86 k-03$ & 43.9 & 12 & $5.97 k-03$ & 26.3 & 12 & $2.01 \mathrm{E}-02$ & 99.0 & 0 & $1.95 E-02$ & 99.8 & 0 \\
\hline 23 & $5.00 z-03$ & $42 \cdot 2$ & 13 & $5.83 t-03$ & $26 \cdot 9$ & 13 & $1.48 k-02$ & 99.0 & 0 & 1. $6 \angle t-02$ & 99.0 & 0 \\
\hline 24 & $1.83 z-02$ & 72.0 & 12 & $1.48 t-02$ & 38.9 & 12 & $1.20 k-02$ & $37 \cdot 1$ & 1 & $1.28 z-0 z$ & 99.0 & 0 \\
\hline 25 & $6.58 \mathrm{E}-03$ & 22.6 & 13 & $6.38 \mathrm{E}-03$ & $24 \cdot 2$ & 13 & 1. $52 \mathrm{E}-62$ & $34 \cdot 6$ & 2 & $7 \cdot 4: 4 k-03$ & 99.0 & 0 \\
\hline 26 & $3.85 k-03$ & 37.4 & 12 & $4.252-03$ & $25 \cdot 5$ & 12 & $6.09 k-03$ & $11 \cdot 4$ & 6 & 7. $525-63$ & $41 \cdot 1$ & 4 \\
\hline 27 & 4. $06 t-03$ & 28.4 & 13 & 4. $58 t-03$ & $23 \cdot 1$ & 13 & $3.60 \mathrm{E}-\mathrm{C3}$ & $50 \cdot 0$ & 10 & $2 \cdot 70 z-03$ & 39.5 & 9 \\
\hline 28 & $3.17 t-03$ & $36 \cdot 4$ & 12 & $3.07 t-03$ & $42 \cdot 8$ & 12 & $2.28 k-03$ & 40.0 & 11 & $1.98 k-03$ & 31.9 & 12 \\
\hline 29 & $1.06 t-03$ & 57.1 & 13 & $1.10 E-03$ & 59.3 & 13 & $2.87 k-03$ & 10.8 & 13 & $2.70 t-03$ & 22.9 & 13 \\
\hline 30 & $1.88 k-04$ & 55.9 & 12 & $2.83 k-04$ & $62 \cdot 1$ & 12 & $3.09 \mathrm{E}-63$ & 42.8 & 12 & $3.03 k-63$ & $40 \cdot t$ & 12 \\
\hline $\sin ^{c}$ & $1 \cdot 14 \mathrm{~L}-01$ & & & $1.03 k-01$ & & & $8.00 t-01$ & & & 7. $4: 1 t-01$ & & \\
\hline
\end{tabular}


Table 4.2-4 (continued)

\begin{tabular}{|c|c|c|c|c|c|c|c|c|c|c|c|c|}
\hline \multirow[b]{3}{*}{ Compact } & \multicolumn{6}{|c|}{${ }^{134} \mathrm{Cs}$} & \multicolumn{6}{|c|}{${ }^{137} \mathrm{Cs}$} \\
\hline & \multicolumn{3}{|c|}{ Plane 1} & \multicolumn{3}{|c|}{ Plane 2} & \multicolumn{3}{|c|}{ Plane 1} & \multicolumn{3}{|c|}{ Plane 2} \\
\hline & $\begin{array}{l}\text { Inventory } \\
\text { ( } \mathrm{Ci} / 3 \text { in.) }\end{array}$ & $\begin{array}{c}\operatorname{Error}_{(\%)}^{2} \\
(\%)\end{array}$ & No ${ }^{b}$ & $\begin{array}{l}\text { Inventory } \\
\text { (Ci/ } 3 \text { in.) }\end{array}$ & $\begin{array}{c}\text { Error } \\
(\%)\end{array}$ & No ${ }^{b}$ & $\begin{array}{l}\text { Inventory } \\
(\mathrm{Ci} / 3 \text { in.) }\end{array}$ & $\begin{array}{l}\text { Error a } \\
(\%)\end{array}$ & No ${ }^{b}$ & $\begin{array}{l}\text { Inventory } \\
(\mathrm{Ci} / 3 \mathrm{in.})\end{array}$ & $\begin{array}{c}\text { Error }^{\mathrm{a}} \\
(\%)\end{array}$ & $\mathrm{NO}^{\mathrm{b}}$ \\
\hline 1 & $2.87 t-03$ & 67.6 & 12 & $3.56 k-03$ & 79.6 & 12 & 2. $92 \mathrm{E}-03$ & $52 \cdot 4$ & 12 & $3.50 \mathrm{~b}-03$ & 66.3 & 12 \\
\hline 2 & $1.06 \mathrm{E}-02$ & 165.8 & 12 & 7. $32 t-03$ & 135.3 & 12 & $7.23 E-03$ & 130.9 & 12 & $5.39 \mathrm{E}-03$ & 113.0 & 12 \\
\hline 3 & 3. $10 t-02$ & 145.9 & 12 & 1. $53 \mathrm{E}-02$ & 129.7 & 12 & $1.89 E-02$ & 148.2 & 12 & $1.05 \mathrm{E}-02$ & 119.8 & 12 \\
\hline 4 & $4.98 k-02$ & 109.8 & 12 & $2.55 t-02$ & 113.6 & 12 & $3.05 \mathrm{E}-02$ & 110.7 & 12 & $1.61 E-02$ & 114.7 & 12 \\
\hline 5 & $8.03 k-02$ & 15.1 & 12 & 4. $11 E-02$ & 23.9 & 12 & 4. $64 \mathrm{E}-02$ & $14 \cdot 4$ & 12 & $2.40 t-02$ & 23.7 & 12 \\
\hline 6 & $1.61 E-01$ & $27 \cdot 6$ & 12 & $1 \cdot 13 E-01$ & 27.7 & 12 & $8.74 z-02$ & 29.0 & 12 & 6. $49 t-02$ & 27.5 & 12 \\
\hline 7 & $3.98 k-01$ & 26.9 & 12 & 4. $35 \mathrm{k}-01$ & 33.0 & 12 & $2.30 \mathrm{E}-01$ & 26.7 & 12 & $2.47 E-01$ & 32.7 & is \\
\hline 8 & $1.13 E+00$ & $48 \cdot 4$ & 12 & $1.96 \mathrm{E}+00$ & 38.9 & 12 & $6030 k-01$ & $47 \cdot 5$ & 12 & $1.11 k+00$ & $38 \cdot 7$ & 12 \\
\hline 9 & 3. $48 z+00$ & 7.4 & 12 & 4. $11 E+00$ & 7. 0 & 12 & $1.97 \mathrm{t}+00$ & $7 \cdot 4$ & 12 & $2.34 t+00$ & 6.9 & 12 \\
\hline 10 & $2.56 E+00$ & 27.1 & 12 & $3.81 k+00$ & 13.4 & 12 & $1.45 k+00$ & 26.8 & 12 & $2.14 t+00$ & $13 \cdot 3$ & 12 \\
\hline 11 & 3. $40 E+00$ & 27.3 & 12 & 3. $67 \mathrm{t}+00$ & 34.2 & 12 & $1.91 k+00$ & 26.8 & 12 & $2.05 t+00$ & $34 \cdot 3$ & 12 \\
\hline 12 & 6. $12 E+00$ & $5 \cdot 4$ & 12 & 5. $66 k+00$ & 6.8 & 12 & 3. $44 \mathrm{t}+00$ & 5. 5 & 12 & $3.10 E+00$ & 7.1 & 12 \\
\hline 13 & $4.89 \mathrm{E}+00$ & 13.0 & 12 & 4. $59 \mathrm{k}+00$ & $28 \cdot 5$ & 12 & $2.70 \mathrm{E}+00$ & $13 \cdot 2$ & 12 & 2. $56 E+00$ & 27.9 & 12 \\
\hline 14 & 4. $04 k+00$ & 8.3 & 12 & 3. $39 \varepsilon+00$ & 10.9 & 12 & $2 \cdot 23 E+00$ & 8.4 & 12 & $1.90 E+00$ & $11 \cdot 1$ & 12 \\
\hline 15 & $3.78 E+00$ & 6.3 & i2 & 4. $18 E+00$ & 11.0 & 12 & $2.09 E+00$ & 6.2 & 12 & $2.33 t+00$ & 10.9 & 12 \\
\hline 16 & $4.11 E+00$ & 10.8 & 12 & 4. $20 k+00$ & $12 \cdot 3$ & 12 & $2 \cdot 27 \mathrm{E}+00$ & $10 \cdot 1$ & 12 & $2.35 t+00$ & 12.6 & 12 \\
\hline 17 & 5. $26 k+00$ & 13.1 & 12 & $4.96 k+00$ & 18.6 & 12 & $2.92 \mathrm{E}+00$ & 13.2 & 12 & $2.75 k+00$ & $18 \cdot 4$ & 12 \\
\hline 18 & $4 \cdot 72 E+00$ & 10.6 & 12 & $6.06 \xi+00$ & 15.9 & 12 & $2.65 k+00$ & 10.5 & 12 & 3. $37 k+00$ & 16.4 & 12 \\
\hline 19 & $3 \cdot 17 E+00$ & $17 \cdot 5$ & 12 & 4. $81 k+00$ & 18.0 & 12 & $1.81 E+00$ & 18.3 & 12 & $2.70 z+00$ & 18.5 & 12 \\
\hline 20 & $3.26 E+00$ & $38 \cdot 3$ & 12 & 4. $51 E+00$ & 21.6 & 12 & $1.83 k+00$ & $37 \cdot 2$ & 12 & 2. $53 k+00$ & 21.1 & 12 \\
\hline 21 & $3.72 E+00$ & 33.8 & 13 & 3. $59 t+00$ & 39.1 & 13 & 2. $10 \mathrm{E}+00$ & 33.2 & 13 & $2.04 k+00$ & 38.4 & 13 \\
\hline 22 & $2.16 E+00$ & $16 \cdot 1$ & 12 & $1.86 \mathrm{t}+00$ & 13.5 & 12 & $1.28 t+00$ & $15 \cdot 3$ & 12 & 1. $10 k+00$ & 13.1 & 12 \\
\hline 23 & $1.21 E+00$ & 21.7 & 13 & 1. $45 k+00$ & 6.5 & 13 & 7. $35 k-01$ & 20.6 & 13 & $8.84 \mathrm{E}-01$ & 6.3 & 13 \\
\hline 24 & $1.43 t+00$ & $45 \cdot 9$ & 12 & $1.17 t+00$ & 20.0 & 12 & $8.94 t-01$ & 46.2 & 12 & $7.26 \mathrm{E}-01$ & 19.5 & 12 \\
\hline 25 & $1.22 k+00$ & $28 \cdot 7$ & 13 & $9.34 \mathrm{t}-0 \mathrm{l}$ & 22.5 & 13 & 7. $89 \mathrm{E}-01$ & 29.2 & 13 & $6.01 \mathrm{E}-01$ & $22 \cdot 7$ & 13 \\
\hline 26 & 4. $55 \mathrm{E}-01$ & 21.9 & 12 & $6.37 E-01$ & 29.4 & 12 & $3 \cdot 18 k-01$ & 19.8 & 12 & $4 \cdot 33 k-01$ & 27.5 & 12 \\
\hline 27 & $1.58 k-01$ & 51.1 & 13 & $1.77 \mathrm{k}-01$ & $42 \cdot 7$ & 13 & 1. $18 k-01$ & 48.9 & 13 & $1.31 \mathrm{k}-01$ & 40.0 & 13 \\
\hline 28 & 5. $52 \mathrm{t}-02$ & 43.0 & 12 & 5. $32 \mathrm{E}-02$ & $41 \cdot 4$ & 12 & 4. $64 t-02$ & 39.5 & 12 & 4. $47 t-02$ & 40.5 & 12 \\
\hline 29 & $1.35 z-02$ & $22 \cdot 6$ & 13 & $7.85 E-03$ & 29.6 & 13 & 1. $41 \mathrm{k}-02$ & 17.6 & 13 & $8.02 z-03$ & 28.8 & 13 \\
\hline 30 & $7.41 t-03$ & 35.1 & 12 & 5. $50 \mathrm{k}-03$ & $37 \cdot 3$ & 12 & 8. $56 t-03$ & $37 \cdot 0$ & 12 & 5. $76 k-03$ & $41 \cdot 1$ & 12 \\
\hline SUM & $6 \cdot \mid 1 E+01$ & & & $6.65 t+01$ & & & $3.46 E+01$ & & & $3.77 £+01$ & & \\
\hline
\end{tabular}


Table 4.2-4 (continued)

\begin{tabular}{|c|c|c|c|c|c|c|c|c|c|c|c|c|}
\hline \multirow[b]{3}{*}{ Compact } & \multicolumn{6}{|c|}{${ }^{144} \mathrm{Ce}$} & \multicolumn{6}{|c|}{${ }^{154} \mathrm{Eu}$} \\
\hline & \multicolumn{3}{|c|}{ Plane 1} & \multicolumn{3}{|c|}{ Plane 2} & \multicolumn{3}{|c|}{ Plane 1} & \multicolumn{3}{|c|}{ Plane 2} \\
\hline & $\begin{array}{l}\text { Inventory } \\
\text { (Ci/3 in.) }\end{array}$ & $\begin{array}{c}\text { Error }^{\mathrm{a}} \\
(\%)\end{array}$ & No ${ }^{b}$ & $\begin{array}{l}\text { Inventory } \\
\text { (Ci/3 in.) }\end{array}$ & $\begin{array}{l}\operatorname{Error}^{g} \\
(\phi)\end{array}$ & No ${ }^{b}$ & $\begin{array}{l}\text { Inventory } \\
\text { ( } \mathrm{Ci} / 3 \text { in.) }\end{array}$ & $\begin{array}{c}\operatorname{Error}^{2} \\
(\phi)\end{array}$ & $\mathrm{NO}^{\mathrm{b}}$ & $\begin{array}{l}\text { Inventory } \\
\text { ( } \mathrm{Ci} / 3 \text { in.) }\end{array}$ & $\begin{array}{c}\text { Errora } \\
(\%)\end{array}$ & No ${ }^{b}$ \\
\hline 1 & 1. $36 k-02$ & 93.8 & 12 & $1.80 E-02$ & $128 \cdot 1$ & 12 & $6005 \mathrm{E}-05$ & 95.0 & 12 & $8.12 E-05$ & 109.0 & 12 \\
\hline 2 & $8.83 \mathrm{E}-03$ & 33.3 & 12 & $8.80 \mathrm{k}-03$ & $41 \cdot 3$ & 12 & $3.67 E-05$ & $34 \cdot 2$ & 9 & $3.52 E-05$ & 29.5 & 8 \\
\hline 3 & $9.112-03$ & 60.6 & 12 & $7.88 \mathrm{E}-03$ & 34.5 & 12 & $6 \cdot 74 \mathrm{E}-05$ & 53.2 & 9 & $4 \cdot 22 E-05$ & 33.6 & 3 \\
\hline 4 & $1.47 \mathrm{~L}-02$ & 33.4 & 11 & $9.72 \mathrm{E}-03$ & 43.0 & 8 & $9.02 E-05$ & $31 \cdot 1$ & 1 & $7 \cdot 78 k-05$ & 99.0 & 0 \\
\hline 5 & $2.37 \mathrm{~L}-02$ & 27.5 & 12 & $1.84 \mathrm{E}-02$ & 28.1 & 11 & 1. $48 \mathrm{t}-04$ & $15 \cdot 7$ & 3 & $1.26 \mathrm{E}-04$ & 15.8 & 4 \\
\hline 6 & $3.57 \mathrm{E}-02$ & 26.9 & ii & $2.92 E-02$ & 51.0 & 6 & 2. $43 E-04$ & 35.2 & 1 & $2.53 k-04$ & 99.0 & 0 \\
\hline 7 & $8.66 \mathrm{k}-02$ & $31 \cdot 1$ & 9 & $7.89 k-02$ & $22 \cdot 6$ & 10 & 7. $86 \mathrm{E}-04$ & 99.0 & 0 & $6.12 E-04$ & 39.9 & 1 \\
\hline 8 & $1.20 \mathrm{k}-01$ & 37.7 & 5 & $2.01 \mathrm{k}-01$ & $32 \cdot 3$ & 5 & 1. $79 t-03$ & 99.0 & 0 & $2.67 \varepsilon-03$ & 99.0 & 0 \\
\hline 9 & $3.41 E-01$ & $26 \cdot 1$ & 10 & 3. $79 \mathrm{E}-01$ & $21 \cdot 4$ & 7 & 4. $62 t-03$ & 99.0 & 0 & 5. $53 k-03$ & 99.0 & 0 \\
\hline 10 & $3.76 \mathrm{k}-01$ & 33.9 & 4 & 3. $23 k-01$ & 29.2 & 7 & $3.68 \mathrm{E}-03$ & 99.0 & 0 & $9.59 E-03$ & $24 \cdot 8$ & 1 \\
\hline 11 & $3.75 k-01$ & 33.5 & 9 & $3.47 \mathrm{E}-01$ & 43.0 & 6 & $4.98 E-03$ & 99.0 & 0 & 2. $59 \mathrm{k}-03$ & 29.8 & 1 \\
\hline 12 & $4.87 \mathrm{E}-01$ & $15 \cdot 1$ & 7 & $5 \cdot 62 \mathrm{E}-01$ & $24 \cdot 4$ & 4 & $1.45 z-02$ & 28.2 & 1 & 1. $37 \varepsilon-02$ & 13.0 & 3 \\
\hline 13 & $4.76 \mathrm{E}-01$ & 16.8 & 7 & 4. $79 E-01$ & 24.9 & 5 & $9.25 E-03$ & 10.9 & 3 & $1.01 \mathrm{E}-02$ & $32 \cdot 3$ & 5 \\
\hline 14 & $3.78 t-01$ & 13.4 & 8 & $3.89 k-01$ & 19.0 & 5 & $1.20 \mathrm{E}-02$ & 27.1 & 0 & $8.87 t-03$ & $32 \cdot 2$ & 7 \\
\hline 15 & $3.58 \mathrm{k}-0 \mathrm{i}$ & $22 \cdot 4$ & 8 & 4. $50 \mathrm{t}-01$ & $28 \cdot 8$ & 6 & 2. $00 \mathrm{E}-02$ & 39.5 & 12 & $3.19 \mathrm{~L}-02$ & 50.0 & 11 \\
\hline 16 & $5.02 k-01$ & $5 \cdot 4$ & 6 & $4 \cdot 25 k-01$ & 23.6 & 4 & $2.23 \mathrm{E}-02$ & $51 \cdot 3$ & 12 & $7 \cdot 43 \mathrm{E}-02$ & $50 \cdot 2$ & 12 \\
\hline 17 & $4.83 t-61$ & $20 \cdot 4$ & 6 & $4.89 t-01$ & $31 \cdot 9$ & 8 & $9.61 \mathrm{E}-02$ & 43.5 & 11 & $1.06 \mathrm{~b}-01$ & $17 \cdot 1$ & 12 \\
\hline 18 & $4.28 t-01$ & $20 \cdot 1$ & 9 & $4.91 \mathrm{~L}-01$ & $17 \cdot 8$ & 9 & $1.61 k-01$ & 22.4 & 12 & $1.95 \mathrm{k}-01$ & 29.6 & 12 \\
\hline 19 & $3.76 t-01$ & 18.5 & 6 & 4. $55 t-01$ & $22 \cdot 8$ & 4 & 3. $48 \mathrm{E}-01$ & $21 \cdot 4$ & 12 & $4.04 \mathrm{E}-01$ & 18.5 & 12 \\
\hline 20 & $3.02 k-01$ & $32 \cdot 1$ & 3 & $3.51 E-01$ & $16 \cdot 9$ & 5 & $3.21 k-01$ & 35.4 & 12 & $3.04 k-01$ & 37.3 & 12 \\
\hline 21 & $3.09 k-01$ & $31 \cdot 8$ & 7 & $3.91 \mathrm{E}-01$ & $22 \cdot 0$ & 9 & $2.71 t-01$ & $47 \cdot 0$ & 13 & $3.03 k-01$ & 52.2 & 13 \\
\hline 22 & $2.625-01$ & 25.9 & 7 & $2.70 k-31$ & $6 \cdot 5$ & 2 & 3. $7 \mid \varepsilon-01$ & 17.4 & 12 & $3.88 \mathrm{E}-01$ & $15 \cdot 5$ & 12 \\
\hline 23 & $2.22 t-01$ & 17.8 & 5 & $2.54 i-01$ & $17 \cdot 7$ & 3 & $3.51 E-01$ & $14 \cdot 2$ & 13 & $3.16 \mathrm{~b}-01$ & $9 \cdot 2$ & 13 \\
\hline 24 & $1.75 t-01$ & 37.0 & 5 & $1.93 E-01$ & $20 \cdot 4$ & 4 & $2 \cdot 04 k-01$ & 26.8 & 12 & $2.19 E-01$ & 23.0 & 12 \\
\hline 25 & $1.24 k-41$ & 28.8 & 8 & $1.09 k-01$ & $28 \cdot 7$ & 7 & 5. $95 \mathrm{E}-02$ & 86.8 & 13 & $6.54 \mathrm{t}-02$ & 49.9 & 13 \\
\hline 26 & $7.83 z-02$ & 34.5 & 9 & $8.04 t-02$ & 24.8 & 8 & $3.78 \mathrm{k}-02$ & 74.6 & 12 & $3.53 k-02$ & 44.6 & 12 \\
\hline 27 & $3.98 k-02$ & $31 \cdot 3$ & 10 & $3.56 E-02$ & $48 \cdot 9$ & 10 & $1.56 z-02$ & 26.9 & 13 & $1.44 t-02$ & $28 \cdot 2$ & 13 \\
\hline 28 & $3.94 t-02$ & $52 \cdot 7$ & 12 & $1.30 \mathrm{~L}-02$ & $26 \cdot 6$ & 12 & $6 \cdot 19 t-03$ & $38 \cdot 3$ & 12 & 5. $78 v-03$ & $26 \cdot 6$ & 12 \\
\hline 29 & $2.77 E-02$ & 33.7 & 13 & $1.60 \mathrm{E}-02$ & $12 \cdot 3$ & 13 & $9.14 t-04$ & 49.5 & 13 & $1.21 E-03$ & 56.3 & 13 \\
\hline $30 \mathrm{c}$ & $1.84 k-02$ & 33.9 & 12 & $1.86 E-02$ & 37.9 & 12 & $1.29 \mathrm{t}-04$ & 55.2 & 12 & 1. $73 k-04$ & 55.3 & 12 \\
\hline SLi1 & 6. $50 E+00$ & & & $6.90 t+00$ & & & $2 \cdot 34 t+00$ & & & $2 \cdot 52 t+00$ & & \\
\hline
\end{tabular}

Denotes: (1) percent relative standard deviation when NO is greater than 1 , (2) counting statistics error when No is equal to 1 , and (3) arbitrary value of 99.0 when NO is equal to zero. When No is zero, the inventory value tabulated is the mean of all of the upper-limit values (nominally 12) computed.

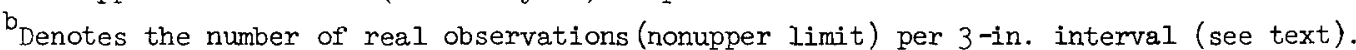

${ }^{c}$ Denotes the total inventory in the graphite component and includes upper-limit values. 
Table 4.2-5. Axial distribution of gamma-emitters in the spine of element FO3-OI

(curies per compact length, corrected to October 31, 1974)

\begin{tabular}{|c|c|c|c|c|c|c|c|c|c|c|c|c|}
\hline \multirow[b]{3}{*}{ Compact } & \multicolumn{6}{|c|}{$60_{\mathrm{Co}}$} & \multicolumn{6}{|c|}{${ }^{110 m_{A g}}$} \\
\hline & \multicolumn{3}{|c|}{ Plane 1} & \multicolumn{3}{|c|}{ Plane 2} & \multicolumn{3}{|c|}{ Plane I } & \multicolumn{3}{|c|}{ Plane 2} \\
\hline & $\begin{array}{l}\text { Inventory } \\
\text { ( } \mathrm{Ci} / 3 \text { in.) }\end{array}$ & $\begin{array}{c}\text { Errora } \\
(\%)\end{array}$ & $\mathrm{NO}^{\mathrm{b}}$ & $\begin{array}{l}\text { Inventory } \\
\text { (Ci/3 in.) }\end{array}$ & $\begin{array}{c}\text { Error } \\
(\%)\end{array}$ & $\mathrm{NO}^{\mathrm{b}}$ & $\begin{array}{l}\text { Inventory } \\
\text { (Ci/3 in.) }\end{array}$ & $\begin{array}{c}\text { Errora } \\
(\%)\end{array}$ & NO $^{b}$ & $\begin{array}{l}\text { Inventory } \\
\text { ( } \mathrm{Ci} / 3 \text { in.) }\end{array}$ & $\begin{array}{c}\text { Errora } \\
(\%)\end{array}$ & No ${ }^{b}$ \\
\hline 1 & $1.54 t-04$ & $34 \cdot 3$ & 12 & 1. $29 t-04$ & 50.5 & 12 & $1.07 t-02$ & $76 \cdot 4$ & 12 & $5 \cdot 38 E-03$ & $74 \cdot 2$ & 12 \\
\hline 2 & $3.36 k-04$ & 50.4 & 12 & 3. $56 E-04$ & 31.0 & 12 & $2.66 k-02$ & $37 \cdot 3$ & 12 & $1.51 E-02$ & $12 \cdot 7$ & $1 \%$ \\
\hline 3 & $5.69 t-04$ & 18.4 & 12 & $5.83 k-04$ & $10 \cdot 1$ & 12 & $1.67 t-02$ & 25.9 & 12 & 7. $06 \mathrm{t}-03$ & 29.7 & 12 \\
\hline 4 & 7. $63 k-04$ & 16.4 & 12 & $6.38 t-04$ & 18.9 & 12 & $7.54 E-03$ & 25.6 & 12 & $5 \cdot 34 t-03$ & $31 \cdot 0$ & 12 \\
\hline 5 & $6.04 t-04$ & $26 \cdot 6$ & 12 & $5.96 b-04$ & 21.2 & 12 & 5. $38 t-03$ & 27.8 & 12 & $0.75 k-03$ & 18.0 & 7 \\
\hline 6 & $6.98 t-04$ & 25.8 & 12 & 7. $75 E-04$ & $22 \cdot 1$ & 11 & 4. $31 k-03$ & 14.0 & 4 & $5.81 t-03$ & 10.1 & 3 \\
\hline 7 & 6. $05 t-04$ & 31.9 & 12 & 6. $16 k-04$ & $21 \cdot 0$ & 12 & $3.53 t-03$ & $3 \cdot 3$ & 2 & $3.91 E-03$ & 99.0 & 0 \\
\hline 8 & $8.69 k-04$ & 61.0 & 12 & $7 \cdot 36 E-04$ & 41.0 & 10 & $7.60 k-03$ & $35 \cdot 3$ & 1 & 4. $78=-03$ & 79.0 & 0 \\
\hline 9 & $3.69 k-03$ & 69.9 & 12 & 2. $34 t-03$ & 31.8 & 12 & $6.97 x-03$ & $99 \cdot 0$ & 0 & $7.47 k-03$ & 99.0 & $u$ \\
\hline 10 & $9.77 k-04$ & 20.3 & 9 & 8. $29 E-04$ & 22.2 & 8 & 7. $40 \leq-03$ & 99.0 & 0 & $6.79 k-03$ & 97.0 & 0 \\
\hline 11 & $1.83 t-03$ & 37.3 & 11 & $1.37 t-03$ & 7. 7 & 6 & $1.10 z-02$ & 99.0 & 0 & $1.12 \mathrm{t}-02$ & 99.0 & 0 \\
\hline 12 & $2 \cdot 14 t-03$ & 33.2 & 12 & $1.50 \mathrm{E}-03$ & $24 \cdot 7$ & 7 & $1.07 k-02$ & 99.0 & 0 & $9.84 t-03$ & 99.0 & 0 \\
\hline 13 & $3.38 t-03$ & 29.0 & 12 & $2.89 k-03$ & $30 \cdot 1$ & 12 & $1.00 k-02$ & 99.0 & 0 & $9 \cdot 18 t-03$ & 99.0 & 0 \\
\hline 14 & $2 \cdot 77 t-03$ & $17 \cdot 7$ & 12 & 1. $73 E-03$ & 32.6 & 12 & $9.19 t-03$ & 99.0 & 0 & 7. $44 k-03$ & 99.0 & 0 \\
\hline 15 & $3.21 k-03$ & $18 \cdot 7$ & 12 & $2.31 t-03$ & 31.0 & 12 & $7.21 E-03$ & 99.0 & 0 & $7.03 k-03$ & 99.5 & 0 \\
\hline 16 & $6.25 k-03$ & $22 \cdot 6$ & 12 & 5. $63 E-03$ & 32.4 & 12 & $7.67 E-03$ & 99.0 & 0 & 7. $78 k-03$ & 99.0 & 0 \\
\hline 17 & $2.98 k-03$ & $46 \cdot 5$ & 11 & $3.29 k-03$ & $48 \cdot 1$ & 11 & $1.38 k-02$ & $30 \cdot 5$ & 1 & $8.54 k-03$ & 99.0 & 0 \\
\hline 18 & $8.52 \mathrm{k}-04$ & 31.5 & 7 & $1.19 k-03$ & $31 \cdot 4$ & 6 & $6.27 t-03$ & 99.0 & 0 & 5. $63 E-03$ & 99.0 & 0 \\
\hline 19 & So $01 t-04$ & 14.9 & 6 & $4.39 t-04$ & 14.9 & 7 & 4. $48 t-03$ & $37 \cdot 1$ & 1 & 3. $52 k-03$ & 99.0 & 0 \\
\hline 20 & $4.83 t-04$ & 46.1 & 2 & $5.37 \mathrm{E}-04$ & 11.7 & 3 & $5.86 t-03$ & 99.0 & 0 & $5.00 E-03$ & 99.0 & 0 \\
\hline 21 & 5. $57\llcorner-04$ & 99.0 & 0 & $5 \cdot 67 t-04$ & 41.8 & 3 & $7 \cdot 11=-03$ & 99.0 & 0 & 7. $41 t-03$ & 35.1 & 1 \\
\hline 22 & $3.79 k-04$ & $28 \cdot 4$ & 1 & 2. $582-04$ & 39.8 & 1 & $3 \cdot 22 E-03$ & 99.0 & 0 & $2.85 E-03$ & 99.1 & I] \\
\hline 23 & $1.44 t-04$ & 20.3 & 5 & $1.37 t-04$ & 10.0 & 6 & $1.40 E-03$ & 99.0 & 0 & $1 \cdot 48 E-03$ & 99.0 & 0 \\
\hline 24 & $1.29 t-03$ & 79.9 & 11 & $1.41 \mathrm{E}-03$ & 86.4 & 12 & $8.99 E-04$ & 99.0 & 0 & $8.67 t-04$ & 99.0 & 0 \\
\hline 25 & $4.65 k-03$ & $15 \cdot 5$ & 12 & $5.09 \mathrm{E}-03$ & $12 \cdot 9$ & 12 & $9.03 k-04$ & 99.0 & 0 & $8 \cdot 17 t-04$ & 99.0 & 0 \\
\hline 26 & $2.67 k-03$ & 36.8 & 12 & $2.72 t-03$ & 37.8 & 12 & $8 \cdot 24 k-04$ & 99.0 & 0 & $6.03 t-04$ & 99.0 & 0 \\
\hline 27 & 2. $17 t-03$ & 31.0 & 12 & 2. $19 \mathrm{E}-03$ & $36 \cdot 7$ & 12 & $3 \cdot 18 E-04$ & 99.0 & 0 & $3 \cdot 13 t-04$ & 99.0 & 0 \\
\hline 28 & $2.215-03$ & $\sqrt{5.3}$ & 12 & 2. $10 \leq-03$ & 16.2 & 12 & $1.80 t-04$ & 99.0 & 0 & 1. 79 七 -04 & 99.0 & 0 \\
\hline 29 & $2.05 z-03$ & 46.2 & 13 & 1. $78 E-03$ & 37.7 & 13 & 1. $45 t-04$ & 99.0 & 0 & $1.36 t-04$ & 99.0 & 0 \\
\hline 30 & $9 \cdot 18 t-04$ & 88.0 & 12 & $7.07 \mathrm{~L}-04$ & 86.8 & 12 & $1.23 k-04$ & 16.7 & 1 & $8.10 k-05$ & $25 \cdot 8$ & 1 \\
\hline Strin & 5. $08 \mathrm{k}-02$ & & & 4. $56 \mathrm{k}=02$ & & & $1.98 t-01$ & & & 1. $58 \mathrm{~L}-01$ & & \\
\hline
\end{tabular}


Table 4.2-5 (continued)

\begin{tabular}{|c|c|c|c|c|c|c|c|c|c|c|c|c|}
\hline \multirow[b]{3}{*}{ Compact } & \multicolumn{6}{|c|}{${ }^{134} \mathrm{Cs}$} & \multicolumn{6}{|c|}{$137 \mathrm{Cs}$} \\
\hline & \multicolumn{3}{|c|}{ Plane 1} & \multicolumn{3}{|c|}{ Plane 2} & \multicolumn{3}{|c|}{ Plane 1} & \multicolumn{3}{|c|}{ Plane 2} \\
\hline & $\begin{array}{l}\text { Inventory } \\
\text { (Ci/3 in.) }\end{array}$ & $\begin{array}{c}\operatorname{Error}^{2} \\
(\%)\end{array}$ & no ${ }^{b}$ & $\begin{array}{l}\text { Inventory } \\
\text { ( } \mathrm{C} i / 3 \text { in.) }\end{array}$ & $\begin{array}{l}\text { Error } \\
(\%)\end{array}$ & No ${ }^{b}$ & $\begin{array}{l}\text { Inventory } \\
(\mathrm{Ci} / 3 \text { in. })\end{array}$ & $\begin{array}{c}\text { Errora } \\
(\%)\end{array}$ & No ${ }^{b}$ & $\begin{array}{l}\text { Inventory } \\
\text { (Ci/3 in.) }\end{array}$ & $\begin{array}{c}\text { Errora } \\
(\%)\end{array}$ & Iro ${ }^{b}$ \\
\hline 1 & $1.58 t-02$ & 63.1 & 12 & $8.70 k-03$ & 76.6 & 12 & $1.00 k-02$ & 59.0 & 12 & 5. $68 k-03$ & 85.3 & $1 E$ \\
\hline 2 & $1.17 E-01$ & $41 \cdot 4$ & 12 & $8.42 E-02$ & 38.5 & 12 & $7.86 \mathrm{E}-02$ & $39 \cdot 2$ & 12 & 5. $53 z-02$ & $35 \cdot 5$ & lé \\
\hline 3 & $3 \cdot 17 t-01$ & 15.8 & 12 & $1.83 t-01$ & 26.0 & 12 & $1.95 t-01$ & 14.3 & 12 & $1 . \mid 3 k-61$ & $24 \cdot 3$ & 12 \\
\hline 4 & $3 \cdot 34 t-01$ & $32 \cdot 1$ & 12 & $3.38 z-01$ & 17.3 & 12 & $2.00 E-01$ & 31.7 & 12 & $2 \cdot 0<z-u 1$ & 16.9 & $1 z$ \\
\hline 5 & $2.64 t-01$ & 12.0 & 12 & $4.93 k-01$ & 5.8 & 12 & $1 \cdot 56 \mathrm{E}-01$ & 11.4 & 12 & $2.911-01$ & s.s & 12 \\
\hline 6 & $3 \cdot 14 \mathrm{~L}-01$ & 15.4 & 12 & S. $44 k-01$ & 4. 0 & 12 & $1.81 \mathrm{k}-01$ & 15.0 & 12 & $3 \cdot 18 v-11$ & $3 . ?$ & $1 \approx$ \\
\hline 7 & $3.53 k-01$ & $7 \cdot 2$ & 12 & $5.37 t-01$ & 6.6 & 12 & $1.99 c-01$ & 6.5 & 12 & $3.98 t-41$ & $5 \cdot:$ & lic \\
\hline 8 & 5. $55 k-01$ & $26 \cdot 7$ & 12 & $0.96 t-01$ & 18.5 & 12 & $3 \cdot 12 k-01$ & $20 \cdot 4$ & 12 & $3.945-01$ & $17 \cdot 3$ & 12 \\
\hline 9 & 1. $\sigma_{v}=+00$ & 9.9 & 12 & $1.18 \mathrm{t}+00$ & 3.5 & 12 & $5.74 t-01$ & 9.6 & 12 & $0 \cdot S \angle L-j 1$ & $3 \cdot 5$ & lic \\
\hline 10 & $1.19 k+00$ & 8.3 & 12 & $1.072+00$ & 7.5 & 12 & $6.00 k-61$ & $5 \cdot 4$ & $1 z$ & $5.36 E-91$ & $=1$ & 16 \\
\hline 11 & $1.81 t+00$ & $04 \cdot 3$ & 12 & $1.87 k+00$ & $32 \cdot 0$ & 12 & $9.995-61$ & $65 \cdot j$ & l'c & $1 \cdot 33 k+30$ & 3200 & 12 \\
\hline 12 & $1.69 t+00$ & 3.6 & 12 & $1.53 k+00$ & 2.7 & 12 & $9 \cdot 38 t-01$ & 0.5 & 12 & $5.45 \mathrm{~L}-61$ & $3 . i$ & is \\
\hline 13 & $1.56 k+00$ & 6.9 & 12 & $1.38 t+00$ & 9.4 & 12 & $8 \cdot 55 \mathrm{t}-u 1$ & $7 \cdot 5$ & 16 & $7.53 L-61$ & 9.7 & $1=$ \\
\hline 14 & $1.41 E+00$ & 13.7 & 12 & $1.03 k+00$ & 13.2 & 12 & $7 \cdot 74 t-81$ & $13 \cdot 3$ & 1 & $5.57 t-u 1$ & $12 \cdot 3$ & $1=$ \\
\hline 15 & $1.02 t+00$ & $3 \cdot 5$ & 12 & 1. $02 E+00$ & 5.6 & 12 & 5. 59上-01 & $3 \cdot 7$ & $1 \varepsilon$ & $5 \cdot 55\llcorner-11$ & $5 \cdot i$ & l'c \\
\hline 16 & $1.05 k+00$ & 17.7 & 12 & $1.09 E+00$ & $5 \cdot 2$ & 12 & $5.74 E-01$ & 16.8 & $1 \%$ & 5. $? E-11$ & $L_{0}=$ & is \\
\hline 17 & $1.48 k+00$ & $7 \cdot 1$ & 12 & $1 \cdot 27 t+00$ & 6.3 & 12 & $8 \cdot 112-01$ & 7. 7 & 12 & $7 \cdot \sqrt{2}=-61$ & $6 \cdot 5$ & 12 \\
\hline 18 & $8.81 \mathrm{k}-01$ & $38 \cdot 7$ & 12 & 7. $27 t-01$ & 34.2 & 12 & 4. Sót-01 & 37.9 & lc & L. $0 u \leq-41$ & $34 \cdot 1$ & 12 \\
\hline 19 & $3.39 k-01$ & 6.6 & 12 & 2. $38 E-01$ & 11.1 & 12 & $1.91 k-01$ & $6 \cdot 3$ & $1:$ & $1 \cdot 51 \leq-01$ & $11 . j$ & $1=$ \\
\hline 20 & 6. $93 k-01$ & 50.2 & 12 & $5 \cdot 18 \leqslant-01$ & 55.6 & 12 & $3.90 \mathrm{E}-01$ & 51.7 & 12 & $\therefore 94=01$ & $\leq 7.9$ & $1: 2$ \\
\hline 21 & $1.10 k+00$ & 37.8 & 12 & $7.77 t-01$ & $54 \cdot 2$ & 12 & $6 \cdot 13 k-41$ & 37.4 & d'z & $4 \cdot 39 e^{-31}$ & $54 \cdot \subseteq$ & 12 \\
\hline 22 & 4. $68 z-01$ & 29.1 & 12 & $3.84 E-01$ & 25.5 & 12 & $2.70 z-0 !$ & $\varepsilon \delta \cdot \varepsilon$ & 12 & $2 \cdot 24 t-61$ & 24.3 & 12 \\
\hline 23 & $1.47 t-01$ & 46.1 & 12 & $1.58 \mathrm{k}-01$ & 27.0 & 12 & $8.74 t-02$ & $46 \cdot !$ & 12 & 9. $4: 6 z-6 c$ & $26 . ?$ & 12 \\
\hline 24 & 7. $11 t-02$ & 29.0 & 12 & 7. $00 \mathrm{EL}-02$ & 37.8 & 12 & 4. $425-0 c$ & $\varepsilon 7 \cdot c$ & 12 & $4 \cdot 31 k-02$ & 36.5 & 12 \\
\hline 25 & $7.37 \mathrm{k}-02$ & 39.6 & 12 & $0.54 t-02$ & 15.7 & 12 & $4 \cdot \leq 8 k-02$ & 40.3 & 12 & 4. 1Eb- Uc & $16 \cdot 1$ & $1 E$ \\
\hline 26 & $7.81 t-02$ & $45 \cdot 3$ & 12 & 4. $21 k-02$ & 64.7 & 12 & 5. $16 \mathrm{k}-0 \mathrm{z}$ & 43.2 & 12 & $\therefore \cdot 77$ - $0 \varepsilon$ & 33.6 & de \\
\hline 27 & $1.21 t-02$ & 96.9 & 12 & $5.78 \mathrm{~L}-03$ & 43.8 & 12 & $8 \cdot 38 t-03$ & $96 \cdot 1$ & 12 & $3.39 k-63$ & $43 \cdot 6$ & $1 \%$ \\
\hline 28 & $1.88 k-03$ & 25.2 & 12 & 1. $72 t-03$ & 33.3 & 12 & $1.29 k-03$ & $20 \cdot 2$ & 12 & $1 \cdot 14=-53$ & $36 \cdot 5$ & 12 \\
\hline 29 & $9.33 t-04$ & $30 \cdot 4$ & 13 & $8.33 k-04$ & 23.7 & 13 & $6 \cdot 15 k-0.4$ & $32 \cdot t$ & 13 & $5.20 L-64$ & $\because \approx 0<$ & 13 \\
\hline 30 & $6.20 t-04$ & 27.3 & 12 & 5. $37 t-04$ & 29.5 & 12 & 4. $23 t-04$ & co. 1 & 12 & $3 \cdot 34=-64$ & $27 \cdot 5$ & 12 \\
\hline Sun ${ }^{c}$ & $1.84 t+01$ & & & 1. $73 z+01$ & & & 1. $02 t+01$ & & & $9 \cdot 73 z+30$ & & \\
\hline
\end{tabular}


Table 4.2-5 (continued)

\begin{tabular}{|c|c|c|c|c|c|c|c|c|c|c|c|c|}
\hline \multirow[b]{3}{*}{ Compact } & \multicolumn{6}{|c|}{${ }^{144} \mathrm{Ce}$} & \multicolumn{6}{|c|}{${ }^{154} \mathrm{Eu}$} \\
\hline & \multicolumn{3}{|c|}{ Plane 1} & \multicolumn{3}{|c|}{ Plane 2} & \multicolumn{3}{|c|}{ Plane 1} & \multicolumn{3}{|c|}{ Plane 2} \\
\hline & $\begin{array}{l}\text { Inventory } \\
\text { ( } \mathrm{Ci} / 3 \mathrm{in.})\end{array}$ & $\begin{array}{c}\text { Errora } \\
(\%)\end{array}$ & NO $^{b}$ & $\begin{array}{l}\text { Inventory } \\
\text { ( } \mathrm{Ci} / 3 \text { in.) }\end{array}$ & $\begin{array}{c}\text { Errora } \\
(\%)\end{array}$ & NO $^{b}$ & $\begin{array}{l}\text { Inventory } \\
(\mathrm{Ci} / 3 \text { in.) }\end{array}$ & $\begin{array}{c}\text { Error } \\
(\%)\end{array}$ & NO ${ }^{b}$ & $\begin{array}{l}\text { Inventory } \\
\text { ( } \mathrm{Ci} / 3 \text { in.) }\end{array}$ & $\begin{array}{c}\text { Errora } \\
(\%)\end{array}$ & NO ${ }^{b}$ \\
\hline 1 & $6.49 t-03$ & $71 \cdot 4$ & 4 & $4.70 k-03$ & $35 \cdot 4$ & 4 & $2 \cdot 51 E-04$ & 19.2 & 12 & $2 \cdot 75 E-04$ & $22 \cdot 7$ & 12 \\
\hline 2 & $1.43 \mathrm{E}-02$ & 32.9 & 7 & $1 \cdot 41 k-0 z$ & $57 \cdot 0$ & 9 & 4. $24 t-04$ & $40 \cdot 3$ & 4 & $3.47 E-04$ & 28.7 & 9 \\
\hline 3 & $3.94 k-02$ & 20.5 & 6 & $3.69 \mathrm{E}-02$ & $23 \cdot 2$ & 3 & 5. $88 t-04$ & 99.0 & 0 & $6.67 t-04$ & $28 \cdot 8$ & 1 \\
\hline 4 & 4. $86 E-0 z$ & 28.7 & 8 & 4. $20 \mathrm{k}-0 \mathrm{c}$ & $21 \cdot 7$ & 6 & $6.39 E-04$ & $12 \cdot 6$ & 3 & $3.91 t-04$ & $26 \cdot 1$ & 4 \\
\hline 5 & $4 \cdot 11$ t- $0 z$ & $10 \cdot 0$ & 3 & $6.25 E-02$ & 7. 7 & 6 & $5.92 E-04$ & $7 \cdot 3$ & 4 & $1.05 k-03$ & 10.7 & 2 \\
\hline 6 & 5. $09 \mathrm{~L}-02$ & 29.5 & 4 & $7.30 L-02$ & $31 \cdot 7$ & 4 & 7. $41 \mathrm{E}-04$ & $32 \cdot 9$ & 2 & $8.83 t-04$ & 99.0 & c \\
\hline 7 & $5 \cdot 14 t-02$ & $21 \cdot t$ & 3 & $5.92 k-02$ & $24 \cdot 0$ & 10 & $6.37\llcorner-04$ & 38.9 & 1 & $8.75 k-04$ & 99.0 & 0 \\
\hline 8 & $7.20 \mathrm{E}-02$ & 25.3 & 7 & $7 \cdot 58 t-62$ & $25 \cdot 0$ & 8 & 1. $16 \mathrm{E}-03$ & 25.8 & 2 & $1.07 t-03$ & 99.0 & 0 \\
\hline 9 & $1.112-01$ & 26.8 & 4 & $1 \cdot 38 k-01$ & $15 . ?$ & 8 & $2.50 t-03$ & $22 \cdot 0$ & 4 & $2.73 E-03$ & 6.6 & 3 \\
\hline 10 & $1.465-01$ & 13.4 & 3 & $1 \cdot 45 E-01$ & $28 \cdot 2$ & 6 & $2.10 \mathrm{E}-03$ & $2 \cdot 2$ & 2 & $2 \cdot 74 k-03$ & $24 \cdot 6$ & 7 \\
\hline 11 & $1.08 z-01$ & 99.0 & j & $2 \cdot 05 t-01$ & 21.0 & 5 & $3.865-03$ & $26 \cdot 2$ & 8 & $4.72 E-03$ & 33.0 & 3 \\
\hline 12 & $1.11 \mathrm{E}-01$ & 99.0 & 0 & 1. $<11 \leqslant-01$ & $0 \cdot 5$ & 2 & $6 \cdot 78 E-03$ & 34.8 & 11 & $5 \cdot 22 t-03$ & 23.5 & 10 \\
\hline 13 & $1.912-01$ & $28 \cdot 1$ & 1 & $1.03 \mathrm{E}-61$ & $99 \cdot 1$ & 0 & $3.98 \mathrm{E}-03$ & 26.6 & 0 & $4.03 k-03$ & $17 \cdot 9$ & 8 \\
\hline 14 & $1.01 \mathrm{k}-01$ & 99.0 & 0 & $1 \cdot 44 t-01$ & $30 \cdot 2$ & 1 & $7.95 \mathrm{E}-03$ & $43 \cdot 8$ & 12 & $8.01 k-03$ & $43 \cdot 1$ & 11 \\
\hline 15 & $1.10 k-01$ & 3.2 & $\approx$ & $1.13 z-01$ & 34.8 & 1 & $8.93 E-03$ & 24.8 & 12 & $9 \cdot 72 E-03$ & $17 \cdot 1$ & 12 \\
\hline 10 & $1.23 \mathrm{E}-01$ & 11.0 & 3 & 1. $19 t-01$ & 3.8 & 4 & $9.41 \mathrm{E}-03$ & $36 \cdot c$ & 12 & $9.78 z-03$ & $32 \cdot 4$ & 12 \\
\hline 17 & $1.41 z-01$ & 10.0 & 2 & $1 \cdot 78 \mathrm{k}-01$ & $42 \cdot 8$ & 2 & $1.96 E-02$ & 13.9 & 12 & 1. $58 k-02$ & $16 \cdot 2$ & 12 \\
\hline 18 & $1 \cdot 111-01$ & 43.8 & 4 & $1.065-01$ & $10 \cdot 2$ & 2 & $1.80 \mathrm{E}-02$ & 13.0 & 12 & $1.802-02$ & $17 \cdot 9$ & 12 \\
\hline 19 & $9.54 t-02$ & $26 \cdot 0$ & 1 & $4 \cdot 98 z-02$ & 99.0 & 0 & $1.86 \mathrm{E}-02$ & $15 \cdot 3$ & 12 & $1.71 \mathrm{t}-02$ & $18 . ?$ & 12 \\
\hline 20 & 1. $2 E E-01$ & 40.8 & 2 & $8.24 t-02$ & 39.7 & 1 & $2.54 \mathrm{E}-02$ & $18 \cdot 8$ & 12 & $2 \cdot 40 k-02$ & 17.5 & 12 \\
\hline 21 & $1.33 k-01$ & $29 \cdot 1$ & 4 & $9.52 \mathrm{k}-02$ & $26 \cdot 8$ & 3 & $2.24 \mathrm{E}-02$ & $29 \cdot 1$ & 12 & $2 \cdot 03 z-02$ & 33.4 & 12 \\
\hline 22 & 7. $05 k-02$ & 52.2 & 10 & $8.295-02$ & $40 \cdot 3$ & 5 & $2 \cdot 35 t-02$ & $9 \cdot 0$ & 12 & $2 \cdot 24 i-62$ & $6 \cdot 3$ & 12 \\
\hline 23 & $3.91 k-02$ & 120.7 & 12 & $2.01 k-92$ & 47.9 & 5 & $2 \cdot 28 \mathrm{k}-02$ & $4 \cdot 0$ & 12 & $2.335-02$ & $6 \cdot 5$ & 12 \\
\hline 24 & $2.36 \mathrm{E}-02$ & 53.1 & 12 & $1.21 \mathrm{k}-02$ & 33.3 & 12 & $2 \cdot 18 t-02$ & 16.9 & 12 & $2 \cdot 16 E-02$ & 20.5 & 12 \\
\hline 25 & $1 \cdot 14 E-02$ & $24 \cdot 3$ & 10 & 1.09E- 02 & $16 \cdot 1$ & 8 & 1. $13 t-02$ & $27 \cdot 5$ & 12 & $1.01 k-02$ & $20 \cdot 4$ & 12 \\
\hline 26 & $1.32 t-02$ & 58.8 & 10 & $1.14 k-02$ & $51 \cdot 3$ & 9 & $1.04 t-02$ & 35.0 & 12 & $8 \cdot 31 k-03$ & 34.5 & 12 \\
\hline 27 & $4.74 t-03$ & 66.2 & 10 & $2.96 k-03$ & $35 \cdot 6$ & 10 & 7. $30 k-03$ & 16.9 & 12 & $6.67 k-03$ & $13 \cdot 1$ & 12 \\
\hline 28 & $2.812-03$ & $31 \cdot t$ & 12 & $2.70 t-03$ & $27 \cdot 0$ & 12 & $5.26 E-03$ & $25 \cdot 6$ & 12 & $5 \cdot 19 k-03$ & 27.0 & 12 \\
\hline 29 & $4.08 k-03$ & $9 \cdot 8$ & 13 & $3.83 k-03$ & 10.3 & 13 & $2 \cdot 34 t-03$ & 50.9 & 13 & $2 \cdot 36 \leq-03$ & 56.9 & 13 \\
\hline $\sin ^{30} \mathrm{c}$ & $\begin{array}{l}2.04 t-03 \\
2.10 t+00\end{array}$ & $37 \cdot 1$ & 12 & $\begin{array}{l}2.10 k-03 \\
2.14 k+00\end{array}$ & $42 \cdot 4$ & 12 & $\begin{array}{l}\text { 5. } 45 t-04 \\
2.60 t-01\end{array}$ & $44 \cdot 4$ & 12 & $\begin{array}{l}5.03 t-04 \\
2.49 t-01\end{array}$ & $46 \cdot 4$ & 12 \\
\hline
\end{tabular}

Denotes: (1) percent relative standard deviation when NO is greater than 1, (2) counting statistics error when No is equal to 1 , and (3) arbitrary value of 99.0 when $N O$ is equal to zero. When NO is zero, the inventory value tabulated is the mean of all of the upper-limit values (nominally 12) computed.

Denotes the number of real observations (nonupper limit) per 3 -in. interval (see text).

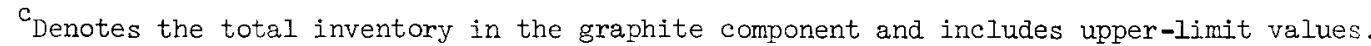


data were classified according to three categories. Category 1 consists of data for which two or more of the scan points per 3-in. interval were actual measured quantities. In this case, mean values of the observed activities were tabulated as the inventory per 3-in. interval. The errors listed in Tables 4.2-4 and 4.2-5 for category 1 data are conventional standard deviations expressed as percentages of the mean inventories. The number of measured points within each 3 -in. segment (statistically the number of degrees of freedom) is listed after each error value. Category 2 consisted of data for which only one scan point within a 3-in. segment was an actual measured quantity. In this case, the observed quantity was tabulated as the inventory per 3 in. of section and the counting statistics error for that scan point in Appendix A was tabulated as the error in Tables $4.2-4$ and 4.2-5. Category 3 represented those data in which all of the scan points per 3 in. of section consisted of upper-limit values designated in Appendix A. The mean of each of the upper-Iimit values per 3-in. interval was computed and tabulated for category 3 data, and is signified in Tables 4.2-4 and 4.2-5 with an arbitrarily assigned error of $99.0 \%$. For such data, the number of observed real values was zero and is tabulated as such.

Because the counting time interval used to acquire gamma spectra in the automated scanning of spine and sleeve (as described in sect. 4 of ref. 2) was only about $5 \mathrm{~min}$, it was thought that some improvement in the axial distributions of gamma-emitters might be realized if a limited sampling were made with longer counting times. Longer times would reduce counting statistics errors and perhaps result in the replacement of some upper-limit estimates by real-value estimates, as well as possibly allow detection of additional radionuclides if they were present at low levels. Consequently, gamma spectra of both sleeve and spine were acquired, for $2000 \mathrm{sec}$, in both planes at nine selected locations along the element adjacent to the locations of fuel compacts $3,6,9,13,16,19,23,26$, and 29.

Tables 4.2-6 and 4.2-7 present the inventories, per 3-in. segment of sleeve and spine, of the nuclides detected and measured by these so-called "long counts." Generally, these data were in good agreement with the 
Table 4.2-6. Inventories of gamma-emitting radionuclides in sleeve of fuel element FO3-OI measured by long counts (corrected to October 31,1974$)^{2}$

\begin{tabular}{|c|c|c|c|c|c|c|c|c|c|c|c|c|c|c|c|c|}
\hline \multirow[b]{2}{*}{ Compact } & \multirow[b]{2}{*}{$\begin{array}{l}\text { Distance } \\
\text { (in.) }\end{array}$} & \multirow[b]{2}{*}{ Plane } & \multicolumn{2}{|l|}{${ }^{60} \mathrm{Co}$} & \multicolumn{2}{|c|}{${ }^{106} \mathrm{Ru}$} & \multicolumn{2}{|c|}{$110 \mathrm{~m}_{\mathrm{Ag}}$} & \multicolumn{2}{|c|}{$134 \mathrm{Cs}$} & \multicolumn{2}{|l|}{$137_{\mathrm{CS}}$} & \multicolumn{2}{|c|}{${ }^{144} \mathrm{Ce}$} & \multicolumn{2}{|c|}{${ }^{154} \mathrm{Eu}$} \\
\hline & & & $\begin{array}{l}\text { Inventory } \\
(\mathrm{Ci} / 3 \text { in.) }\end{array}$ & $\underset{(\%)}{\text { Errorc }}$ & $\begin{array}{l}\text { Inventory } \\
\text { (Ci/3 in.) }\end{array}$ & $\begin{array}{c}\text { Error } \\
(\%)\end{array}$ & $\begin{array}{l}\text { Inventory } \\
\text { ( } \mathrm{C} / 3 \text { in.) }\end{array}$ & $\underset{(\%)}{\operatorname{Error}}$ & $\begin{array}{l}\text { Inventory } \\
\text { (Ci/3 in.) }\end{array}$ & $\begin{array}{c}\text { Error } \\
(\%)\end{array}$ & $\begin{array}{l}\text { Inventory } \\
(\mathrm{Ci} / 3 \mathrm{in.})\end{array}$ & $\begin{array}{c}\text { Errorc } \\
(\%)\end{array}$ & $\begin{array}{l}\text { Inventory } \\
(\mathrm{Ci} / 3 \text { in. })\end{array}$ & $\begin{array}{c}\text { Error } \\
(\%)\end{array}$ & $\begin{array}{l}\text { Inventory } \\
(\mathrm{Ci} / 3 \text { in. }\end{array}$ & $\begin{array}{c}\text { Errorc } \\
(\%)\end{array}$ \\
\hline 3 & 7.5 & $\begin{array}{c}1 \\
? \\
\text { Mean }\end{array}$ & $\begin{array}{l}3.4 \mathrm{E}-5 \\
3.7 \mathrm{E}-5 \\
3.2 \mathrm{E}-5\end{array}$ & $\begin{array}{l}4 \\
4\end{array}$ & $\begin{array}{l}4.6 E-4 \\
7.7 E-4 \\
6.2 E-4\end{array}$ & $\begin{array}{r}14 \\
8\end{array}$ & $\begin{array}{l}3.1 \mathrm{E}-4 \\
2.5 \mathrm{E}-4 \\
2.8 \mathrm{E}-4\end{array}$ & $\begin{array}{l}2 \\
2\end{array}$ & $\begin{array}{l}\text { I. } I \mathrm{E}-2 \\
6.2 \mathrm{E}-3 \\
8.4 \mathrm{E}-3\end{array}$ & $\begin{array}{l}0.2 \\
0.2\end{array}$ & $\begin{array}{l}7.5 \mathrm{E}-3 \\
4.9 \mathrm{E}-3 \\
6.2 \mathrm{E}-3\end{array}$ & $\begin{array}{l}0.2 \\
0.2\end{array}$ & $3 \cdot 7 E-3$ & 15 & $\begin{array}{l}4.1 E-5 \\
3.6 E-5 \\
3.8 E-5\end{array}$ & $\begin{array}{l}8 \\
8\end{array}$ \\
\hline 6 & 16.5 & $\begin{array}{c}1 \\
2 \\
\text { Mean }\end{array}$ & & & & & $\begin{array}{l}8.3 \mathrm{E}-3 \\
7.5 \mathrm{E}-3 \\
7.9 \mathrm{E}-3\end{array}$ & $\begin{array}{l}2 \\
2\end{array}$ & $\begin{array}{l}0.15 \\
0.11 \\
0.13\end{array}$ & $\begin{array}{l}0.1 \\
0.1\end{array}$ & $\begin{array}{l}8.9 \mathrm{E}-2 \\
6.1 \mathrm{E}-2 \\
7.5 \mathrm{E}-2\end{array}$ & $\begin{array}{l}0.1 \\
0.2\end{array}$ & & & & \\
\hline 9 & 25.5 & $\begin{array}{c}1 \\
2 \\
\text { Mean }\end{array}$ & & & & & $\begin{array}{l}3.5 \mathrm{E}-2 \\
5.8 \mathrm{E}-2 \\
4.7 \mathrm{E}-2\end{array}$ & $\begin{array}{l}6 \\
5\end{array}$ & $\begin{array}{l}3.3 \\
4.3 \\
3.8\end{array}$ & $\begin{array}{l}0.1 \\
0.1\end{array}$ & $\begin{array}{l}1.9 \\
2.1 \\
2 . ?\end{array}$ & $\begin{array}{l}0.1 \\
0.1\end{array}$ & & & & \\
\hline 13 & 37.5 & $\begin{array}{c}1 \\
? \\
\text { Mean }\end{array}$ & & & & & $\begin{array}{l}2.7 \mathrm{E}-2 \\
3.4 \mathrm{E}-2 \\
3.1 \mathrm{E}-2\end{array}$ & $\begin{array}{l}2 i \\
3\end{array}$ & $\begin{array}{l}4.7 \\
4.1 \\
4.4\end{array}$ & $\begin{array}{l}0.1 \\
0.1\end{array}$ & $\begin{array}{l}2.6 \\
2.3 \\
2.5\end{array}$ & $\begin{array}{l}0.1 \\
0.1\end{array}$ & & & & \\
\hline 16 & 460.5 & $\begin{array}{c}1 \\
n \\
\text { Mean }\end{array}$ & $\begin{array}{l}4.7 E-3 \\
5.8 E-3 \\
5.2 E-3\end{array}$ & $\begin{array}{l}6 \\
5\end{array}$ & & & $\begin{array}{l}1.2 \mathrm{E}-2 \\
1.6 \mathrm{E}-2 \\
1.4 \mathrm{E}-2\end{array}$ & $\begin{array}{l}24 \\
18\end{array}$ & $\begin{array}{l}4.8 \\
.99 \\
.1\end{array}$ & $\begin{array}{l}0.1 \\
0.1\end{array}$ & $\begin{array}{l}2.7 \\
2.6 \\
2.4\end{array}$ & $\begin{array}{l}0.1 \\
0.1\end{array}$ & & & $\begin{array}{l}2.4 \mathrm{E}-2 \\
9.5 \mathrm{E}-2 \\
5.9 \mathrm{E}-2\end{array}$ & $\begin{array}{l}4 \\
1\end{array}$ \\
\hline 19 & 55.5 & $\begin{array}{c}1 \\
2 \\
\text { Méan }\end{array}$ & $\begin{array}{l}1.8 \mathrm{E}-2 \\
9.2 \mathrm{E}-2 \\
1.3 \mathrm{E}-2\end{array}$ & $\begin{array}{l}i_{4} \\
i_{4}\end{array}$ & & & & & $\begin{array}{l}.0 \\
3.4 \\
2.7\end{array}$ & $\begin{array}{l}0.2 \\
0.1\end{array}$ & $\begin{array}{l}1.2 \\
1.9 \\
1.6\end{array}$ & $\begin{array}{l}0.2 \\
0.1\end{array}$ & & & $\begin{array}{l}0.4 \\
0.4 \\
0.4\end{array}$ & $\begin{array}{l}0.5 \\
0.5\end{array}$ \\
\hline 23 & 67.5 & $\begin{array}{c}1 \\
? \\
\text { Mean }\end{array}$ & $\begin{array}{l}3 \cdot 9 \mathrm{E}-3 \\
6.7 \mathrm{E}-3 \\
5 \cdot 3 \mathrm{E}-3\end{array}$ & $\begin{array}{l}5 \\
3\end{array}$ & & & & & $\begin{array}{l}1 . ? \\
1.5 \\
1.3\end{array}$ & $\begin{array}{l}0.2 \\
0.2\end{array}$ & $\begin{array}{l}0.7 \\
0.9 \\
0.8\end{array}$ & $\begin{array}{l}0.2 \\
0.2\end{array}$ & & & $\begin{array}{l}0.4 \\
0.3 \\
0.3\end{array}$ & $\begin{array}{l}0.6 \\
0.6 \\
0.6\end{array}$ \\
\hline 26 & 76.5 & $\begin{array}{c}1 \\
2 \\
\text { Mean }\end{array}$ & $\begin{array}{l}3.4 \mathrm{E}-3 \\
4.2 \mathrm{E}-3 \\
3.8 \mathrm{E}-3\end{array}$ & $\begin{array}{l}2 \\
2\end{array}$ & & & $\begin{array}{l}5.1 \mathrm{E}-3 \\
2.4 \mathrm{E}-3 \\
3.7 \mathrm{E}-3\end{array}$ & 19 & $\begin{array}{l}0.5 \\
0.5 \\
0.5\end{array}$ & $\begin{array}{l}0.2 \\
0.2\end{array}$ & $\begin{array}{l}0.3 \\
0.3 \\
0.3\end{array}$ & $\begin{array}{l}0.1 \\
0.2\end{array}$ & & & $\begin{array}{l}1.5 \mathrm{E}-2 \\
1.9 \mathrm{E}-? \\
1.7 \mathrm{E}-2\end{array}$ & $\begin{array}{l}2 \\
1\end{array}$ \\
\hline 29 & 85.5 & $\begin{array}{c}1 \\
2 \\
\text { Mean }\end{array}$ & $\begin{array}{l}5.0 \mathrm{E}-4 \\
6.1 \mathrm{E}-4 \\
5.6 \mathrm{E}-4\end{array}$ & $\begin{array}{l}0.9 \\
0.8\end{array}$ & $\begin{array}{l}1.6 \mathrm{E}-3 \\
1.0 \mathrm{E}-3 \\
1.3 \mathrm{E}-3\end{array}$ & $\begin{array}{l}5 \\
6\end{array}$ & $\begin{array}{l}2.9 E-3 \\
3 \cdot 2 E-3 \\
3.1 E-3\end{array}$ & $\begin{array}{l}1 \\
0.9\end{array}$ & $\begin{array}{l}1 . \mathrm{OE}-2 \\
5.2 \mathrm{E}-3 \\
7.7 \mathrm{E}-3\end{array}$ & $\begin{array}{l}0.2 \\
0.3\end{array}$ & $\begin{array}{l}\text { 1. } 1 \mathrm{E}-2 \\
5.2 \mathrm{E}-3 \\
8.3 \mathrm{E}-3\end{array}$ & $\begin{array}{l}0.1 \\
0.2\end{array}$ & $\begin{array}{l}1.3 \mathrm{E}-2 \\
5.6 \mathrm{E}-3 \\
9.1 \mathrm{E}-2\end{array}$ & $\begin{array}{r}7 \\
15\end{array}$ & $\begin{array}{l}5.6 \mathrm{E}-4 \\
6.9 \mathrm{E}-4 \\
6.2 \mathrm{E}-4\end{array}$ & $\begin{array}{l}\bar{L} \\
2\end{array}$ \\
\hline
\end{tabular}

${ }^{a}$ Measurements made by acquiring gamma spectra, for $2000 \mathrm{sec}$, in the middle of that sleeve section adjacent to the designated compact.

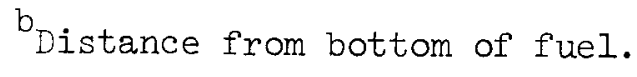

${ }^{c}$ Denotes one-sigma counting statistics error. 
Table 4.2-7. Inventories of gamma-emitting radionuclides in spine of fuel element F03-01 measured by long counts (corrected to October 31, 1974)

\begin{tabular}{|c|c|c|c|c|c|c|c|c|c|c|c|c|c|c|c|c|}
\hline \multirow[b]{2}{*}{ Compact } & \multirow[b]{2}{*}{$\begin{array}{l}\text { Distance } \\
\text { (in.) }\end{array}$} & \multirow[b]{2}{*}{ Plane } & \multicolumn{2}{|l|}{${ }^{60} \mathrm{Co}$} & \multicolumn{2}{|c|}{${ }^{106} \mathrm{Ru}$} & \multicolumn{2}{|l|}{$110 \mathrm{~m}_{\mathrm{Ag}}$} & \multicolumn{2}{|c|}{$134^{4} \mathrm{Cs}$} & \multicolumn{2}{|c|}{$137_{\mathrm{Cs}}$} & \multicolumn{2}{|l|}{$144 \mathrm{Ce}$} & \multicolumn{2}{|c|}{${ }^{154} \mathrm{Eu}$} \\
\hline & & & $\begin{array}{l}\text { Inventory } \\
\text { (Ci/3 in.) }\end{array}$ & $\begin{array}{c}\text { Error } \\
(\%)\end{array}$ & $\begin{array}{l}\text { Inventory } \\
\text { (Ci } / 3 \text { in.) }\end{array}$ & $\underbrace{\text { Error }}_{(\%)}$ & $\begin{array}{l}\text { Inventory } \\
\text { ( } \mathrm{Ci} / 3 \text { in.) }\end{array}$ & $\begin{array}{c}\text { Error } \\
(\%)\end{array}$ & $\begin{array}{l}\text { Inventory } \\
(\mathrm{Ci} / 3 \mathrm{in.})\end{array}$ & $\underset{(\%)}{\text { Error }^{c}}$ & $\begin{array}{l}\text { Inventory } \\
\text { (Ci/3 in.) }\end{array}$ & $\underset{(\%)}{\text { Error }}$ & $\begin{array}{l}\text { Inventory } \\
\text { (Ci/3 in.) }\end{array}$ & $\underset{(\%)}{\text { Error }} \mathrm{c}$ & $\begin{array}{l}\text { Inventory } \\
(\mathrm{Ci} / 3 \text { in.) }\end{array}$ & $\underset{(\%)}{\text { Error }}$ \\
\hline 3 & 7.5 & $\begin{array}{c}1 \\
2 \\
\text { Mean }\end{array}$ & $\begin{array}{l}6.2 E-4 \\
6 . O E-4 \\
6.1 E-4\end{array}$ & $\begin{array}{l}4 \\
5\end{array}$ & & & $\begin{array}{l}1.4 E-2 \\
9.8 E-3 \\
1.2 E-2\end{array}$ & $\begin{array}{l}2 \\
3\end{array}$ & $\begin{array}{l}0.18 \\
0.20 \\
0.19\end{array}$ & $\begin{array}{l}0.2 \\
0.2\end{array}$ & $\begin{array}{l}0.11 \\
0.12 \\
0.12\end{array}$ & $\begin{array}{l}0.2 \\
0.2\end{array}$ & & & & \\
\hline 6 & 16.5 & $\begin{array}{c}1 \\
2 \\
\text { Mean }\end{array}$ & $\begin{array}{l}7.4 E-4 \\
6.6 E-4 \\
6.9 E-4\end{array}$ & $\begin{array}{l}5 \\
6\end{array}$ & & & $\begin{array}{l}1.3 \mathrm{E}-3 \\
1.1 \mathrm{E}-3 \\
1.2 \mathrm{E}-3\end{array}$ & $\begin{array}{l}28 \\
33\end{array}$ & $\begin{array}{l}0.41 \\
0.54 \\
0.47\end{array}$ & $\begin{array}{l}0.1 \\
0.1\end{array}$ & $\begin{array}{l}0.23 \\
0.32 \\
0.28\end{array}$ & $\begin{array}{l}0.2 \\
0.1\end{array}$ & & & & \\
\hline 9 & 25.5 & $\begin{array}{c}1 \\
2 \\
\text { Mean }\end{array}$ & $\begin{array}{l}1.1 E-3 \\
9.5 E-4 \\
1.0 E-3\end{array}$ & $\begin{array}{l}8 \\
9\end{array}$ & & & & & $\begin{array}{l}1.2 \\
1.1 \\
1.1\end{array}$ & $\begin{array}{l}0.1 \\
0.1\end{array}$ & $\begin{array}{l}0.65 \\
0.64\end{array}$ & $\begin{array}{l}0.2 \\
0.2\end{array}$ & & & & \\
\hline 13 & 37.5 & $\begin{array}{c}1 \\
2 \\
\text { Mean }\end{array}$ & $\begin{array}{l}3 \cdot 3 \mathrm{E}-3 \\
3 \cdot 8 \mathrm{E}-3 \\
3 \cdot 5 \mathrm{E}-3\end{array}$ & $\begin{array}{l}4 \\
4\end{array}$ & & & & & $\begin{array}{l}1.5 \\
1.4 \\
1.4\end{array}$ & $\begin{array}{l}0.1 \\
0.1\end{array}$ & $\begin{array}{l}0.84 \\
0.78 \\
0.81\end{array}$ & $\begin{array}{l}0.1 \\
0.2\end{array}$ & & & $\begin{array}{l}3.5 \mathrm{E}-3 \\
2.4 \mathrm{E}-3 \\
3.0 \mathrm{E}-3\end{array}$ & $\begin{array}{r}8 \\
11\end{array}$ \\
\hline 16 & 46.5 & $\begin{array}{c}1 \\
2 \\
\text { Mean }\end{array}$ & $\begin{array}{l}8.7 E-3 \\
7.9 E-3 \\
8.3 E-3\end{array}$ & $\begin{array}{l}2 \\
2\end{array}$ & & & & & $\begin{array}{l}1.1 \\
1.1 \\
1.1\end{array}$ & $\begin{array}{l}0.2 \\
0.2\end{array}$ & $\begin{array}{l}0.60 \\
0.59 \\
0.59\end{array}$ & $\begin{array}{l}0.2 \\
0.2\end{array}$ & & & $\begin{array}{l}7.7 \mathrm{E}-3 \\
1.1 \mathrm{E}-2 \\
9.2 \mathrm{E}-3\end{array}$ & $\begin{array}{l}4 \\
3\end{array}$ \\
\hline 19 & 55.5 & $\begin{array}{c}1 \\
2 \\
\text { Mean }\end{array}$ & $3 \cdot 9 E-5$ & 3 & & & & & $\begin{array}{l}0.37 \\
0.32 \\
0.34\end{array}$ & $\begin{array}{l}0.3 \\
0.3\end{array}$ & $\begin{array}{l}0.21 \\
0.18 \\
0.19\end{array}$ & $\begin{array}{l}0.3 \\
0.3\end{array}$ & & & $\begin{array}{l}1.9 \mathrm{E}-2 \\
1.7 \mathrm{E}-2 \\
1.8 \mathrm{E}-2\end{array}$ & $\begin{array}{l}2 \\
2\end{array}$ \\
\hline 23 & 67.5 & $\begin{array}{c}1 \\
2 \\
\text { Mean }\end{array}$ & & & & & & & $\begin{array}{l}0.12 \\
0.15 \\
0.14\end{array}$ & $\begin{array}{l}0.1 \\
0.1\end{array}$ & $\begin{array}{l}\text { 7. } 1 \mathrm{E}-2 \\
9.2 \mathrm{E}-2 \\
8.2 \mathrm{E}-2\end{array}$ & $\begin{array}{l}0.1 \\
0.1\end{array}$ & & & $\begin{array}{l}2.4 E-2 \\
2.4 E-2 \\
2.4 E-2\end{array}$ & $\begin{array}{l}0.4 \\
0.4\end{array}$ \\
\hline 26 & 76.5 & $\begin{array}{c}1 \\
2 \\
\text { Mean }\end{array}$ & $\begin{array}{l}3 . O E-3 \\
3.1 E-3 \\
3 . O E-3\end{array}$ & $\begin{array}{l}0.7 \\
0.6\end{array}$ & & & & & $\begin{array}{l}6.7 \mathrm{E}-2 \\
3 \cdot 3 \mathrm{E}-2 \\
5.0 \mathrm{E}-2\end{array}$ & $\begin{array}{l}0.1 \\
0.2\end{array}$ & $\begin{array}{l}4.5 \mathrm{E}-2 \\
2.2 \mathrm{E}-2 \\
3.4 \mathrm{E}-2\end{array}$ & $\begin{array}{l}0.1 \\
0.2\end{array}$ & & & $\begin{array}{l}8.2 E-3 \\
6.2 E-3 \\
7.2 E-3\end{array}$ & $\begin{array}{l}0.6 \\
0.7\end{array}$ \\
\hline 29 & 85.5 & $\begin{array}{c}1 \\
2 \\
\text { Mean }\end{array}$ & $\begin{array}{l}3.7 \mathrm{E}-3 \\
2.6 \mathrm{E}-3 \\
3.1 \mathrm{E}-3\end{array}$ & $\begin{array}{l}0.2 \\
0.3\end{array}$ & $\begin{array}{l}3.4 \mathrm{E}-4 \\
2.9 \mathrm{E}-4 \\
3.2 \mathrm{E}-4\end{array}$ & $\begin{array}{l}9 \\
9\end{array}$ & & & $\begin{array}{l}7.2 E-4 \\
6.4 E-4 \\
6.8 E-4\end{array}$ & $\begin{array}{l}0.7 \\
0.8\end{array}$ & $\begin{array}{l}4.9 \mathrm{E}-4 \\
3.9 \mathrm{E}-4 \\
4.4 \mathrm{E}-4\end{array}$ & $\begin{array}{l}0.8 \\
0.9\end{array}$ & $2.24 \mathrm{E}-3$ & 3.4 & $\begin{array}{l}1.1 E-3 \\
9.5 E-4 \\
1.0 E-3\end{array}$ & $\begin{array}{l}0.9 \\
0.9\end{array}$ \\
\hline
\end{tabular}

a Measurements made by acquiring gamma spectra, for $2000 \mathrm{sec}$, in the middle of that sleeve section adjacent to the designated compact.

$b_{\text {Distance from bottom of fuel. }}$

${ }^{c}$ Denotes one-signa counting statistics error. 
results that were found by the automated scanning procedure (see tabulation in Appendix A). In a few instances, small amounts of ${ }^{106} \mathrm{Ru}$ and ${ }^{144} \mathrm{Ce}$ that were not found by the scanning procedure were detected by the long counts.

Small amounts of the gamma-emitting nuclides observed in the sleeve and spine were found in the bottom connector. Table 4.2-8 summarizes the nuclide inventories derived from the axial distributions in Appendix A. As can be seen, none of the nuclides are present in amounts that are significant when compared with those found in the sleeve, spine, and fuel.

Table 4.2-8. Inventories of gamma-emitting nuclides found in the bottom connector of $\mathrm{FO}-01$ (as of October 31, 1974)

\begin{tabular}{lc}
\hline Nuclide & Inventory $\left(\mathrm{C}_{\mathrm{i}}\right)$ \\
\hline${ }^{60} \mathrm{Co}$ & 0.10 \\
$11 \mathrm{Om}_{\mathrm{Ag}}$ & $<0.01$ \\
$134 \mathrm{Cs}$ & 0.03 \\
$137 \mathrm{Cs}$ & 0.01 \\
$144 \mathrm{Ce}$ & $<0.1$ \\
$154 \mathrm{Eu}$ & 0.002 \\
\hline
\end{tabular}

\subsubsection{Axial distributions in the top reflector}

Axial distributions of observed gamma-emitting nuclides in the upperelement region are given in Table 4.2-9. The top portion of this table records nuclide levels found in graphite samples drawn from the inner surface of the purge-flow inlet tube by drilling the $1 / 4-i n .(0.635-\mathrm{cm})$-diam tube out to $5 / 16 \mathrm{in}$. $(0.794 \mathrm{~cm})$. These samples thus represent deposited activity from the primary coolant, from which the purge flow is drawn directly at this point. The lower portion of the table lists the nuclide levels observed in core-drilled samples taken from the porous plug. 
Table 4.2-9. Axial distribution of gamma-emitting radionuclides found in top reflector of element FO3-Ol (corrected to October 31, 1974)

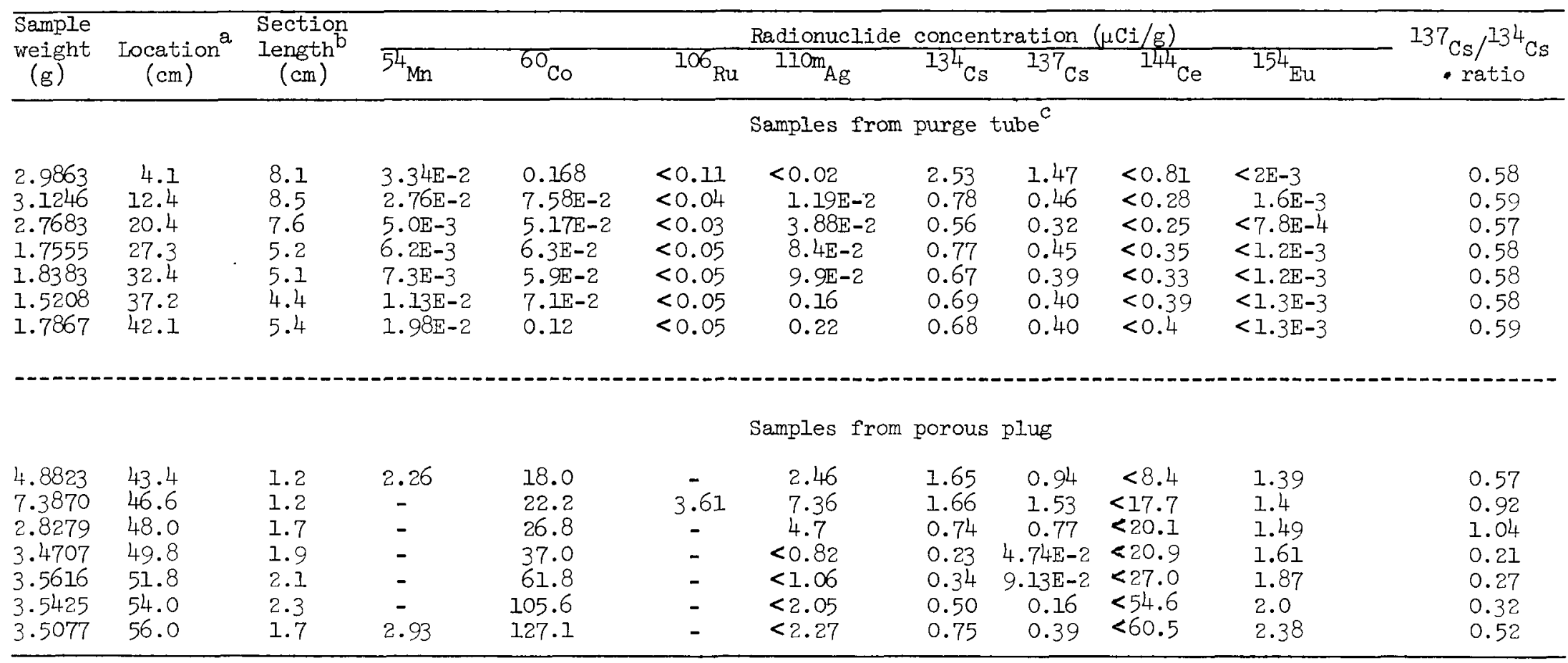

a Distance from top of element to center of section.

b Length of section.

${ }^{c}$ Data were obtained by cutting the top reflector into sections and drilling out the inner surface of purge tube and portions of the porous plug. 
The observed distributions of gamma-emitting nuclides in the sleeve and spine are plotted in Figs. 4.2-9 through 4.2-20, corresponding to the tabular data given in Appendix A. The vertical bands signify the values of the standard deviations based on counting statistics. Distributions in each of the two planes in which observations were made are shown. Frequently, the upward-facing arrow appears as a plotting point, especially in spine distributions. This denotes an upper-limit value calculated by the method discussed earlier in this section.

The axial distributions of ${ }^{137} \mathrm{Cs}$ in the sleeve, spine, and fuel compacts of element FO3-OI are plotted in Fig. 4.2-21. Similar plots presented in ref. 2 for fuel element EII-O7 and in ref. 3 for E14-OI are reproduced in Figs. 4.2-22 and 4.2-23 to permit a convenient comparison of the axial distribution of ${ }^{137} \mathrm{Cs}$ in the three fuel elements. It should be noted that the ${ }^{137} \mathrm{Cs} /{ }^{95} \mathrm{Zr}$ ratio in the fuel is plotted for elements EII-07 and E14-01 rather than the ${ }^{137} \mathrm{Cs}$ inventory per compact. AIso, the plots for these two elements include the tentative temperature profiles. It is interesting to note that the axial migration of ${ }^{137} \mathrm{Cs}$ from higherto lower-temperature fuel (see sect. 4.2-1) is also apparent in the sleeve and spine of elements FO3-01 and Ell-07. However, the migration is less pronounced in the sleeves than in the spines. No axial migration of $137 \mathrm{Cs}$ is detectable in either the fuel or the graphite of element EI4-O1 -- an observation that points to a lower operating temperature than for the other two elements.

\subsection{Radial Distributions}

The sleeve and spine were radially dissected at locations adjacent to fuel compacts 5, 12, 18, and 29 by methods described in sect. 4 of ref. 2 . Tables 4.3-1 through 4.3-8 summarize the radial distributions observed for the gamma-emitting nuclides; the distributions are plotted in Fig. 4.3-1 through $4 \cdot 3-4$.

The reader should note that many of the tabulated activity measurements are upper-limit values denoted by the "<" symbol. Although the upper-limit values are plotted, the significance of such plots is simply that the true distributions should lie somewhere below the upper-limit 


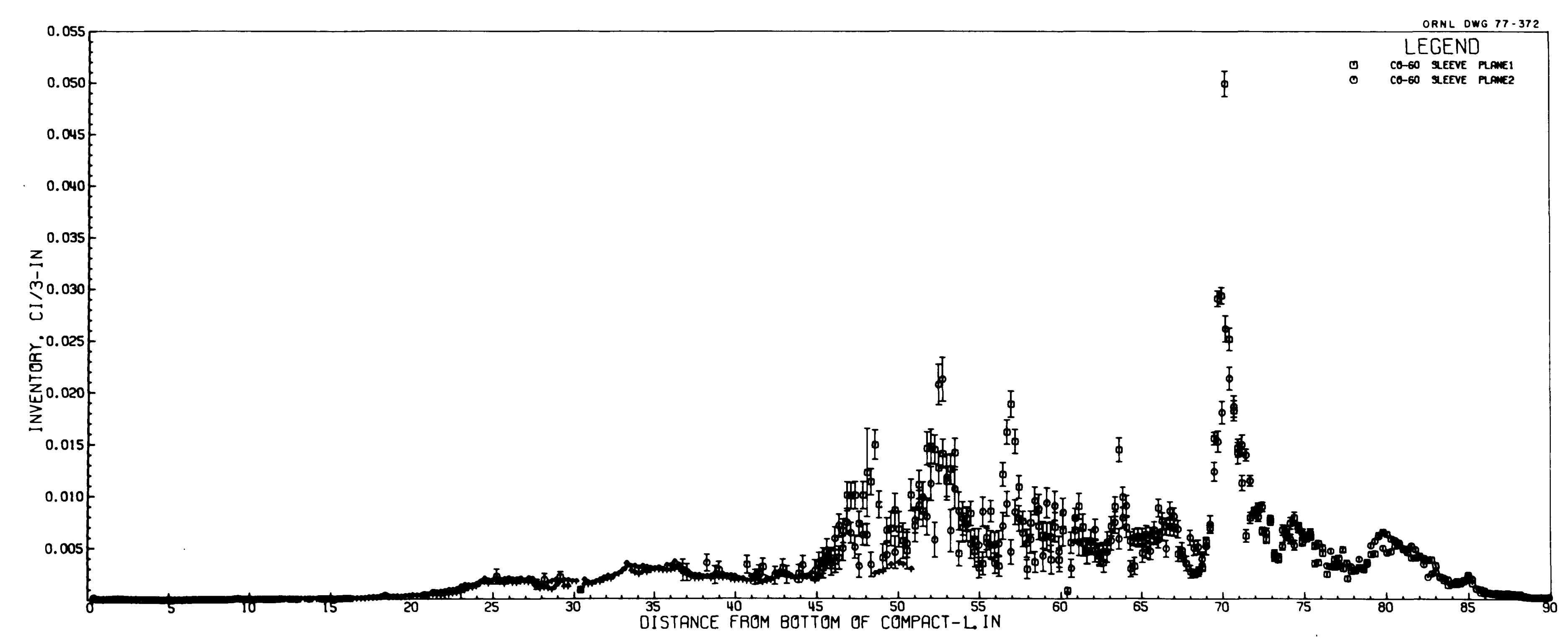

Fig. 4.2-9. Axial distribution of ${ }^{60} \mathrm{Co}$ in FO3-OI sleeve as of October 31, 1974. 


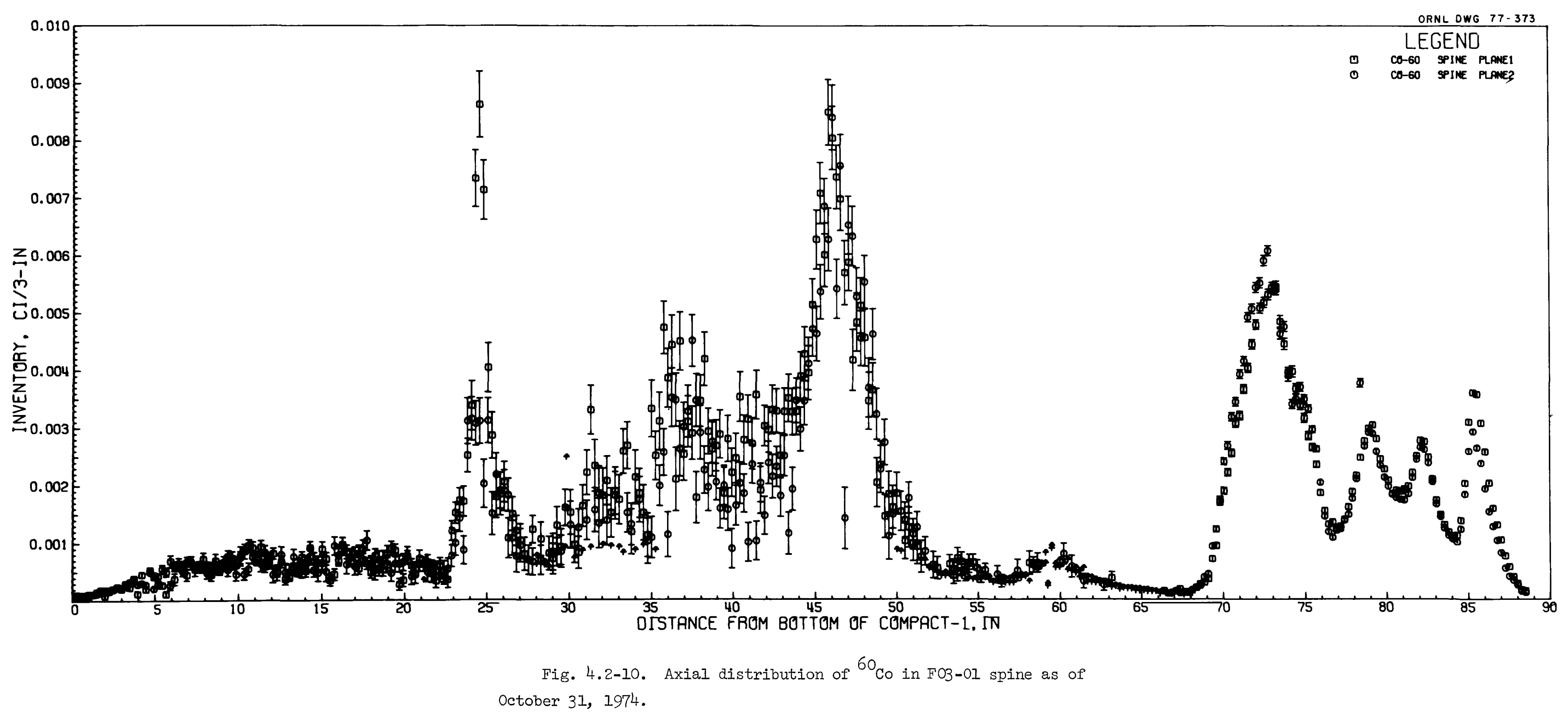




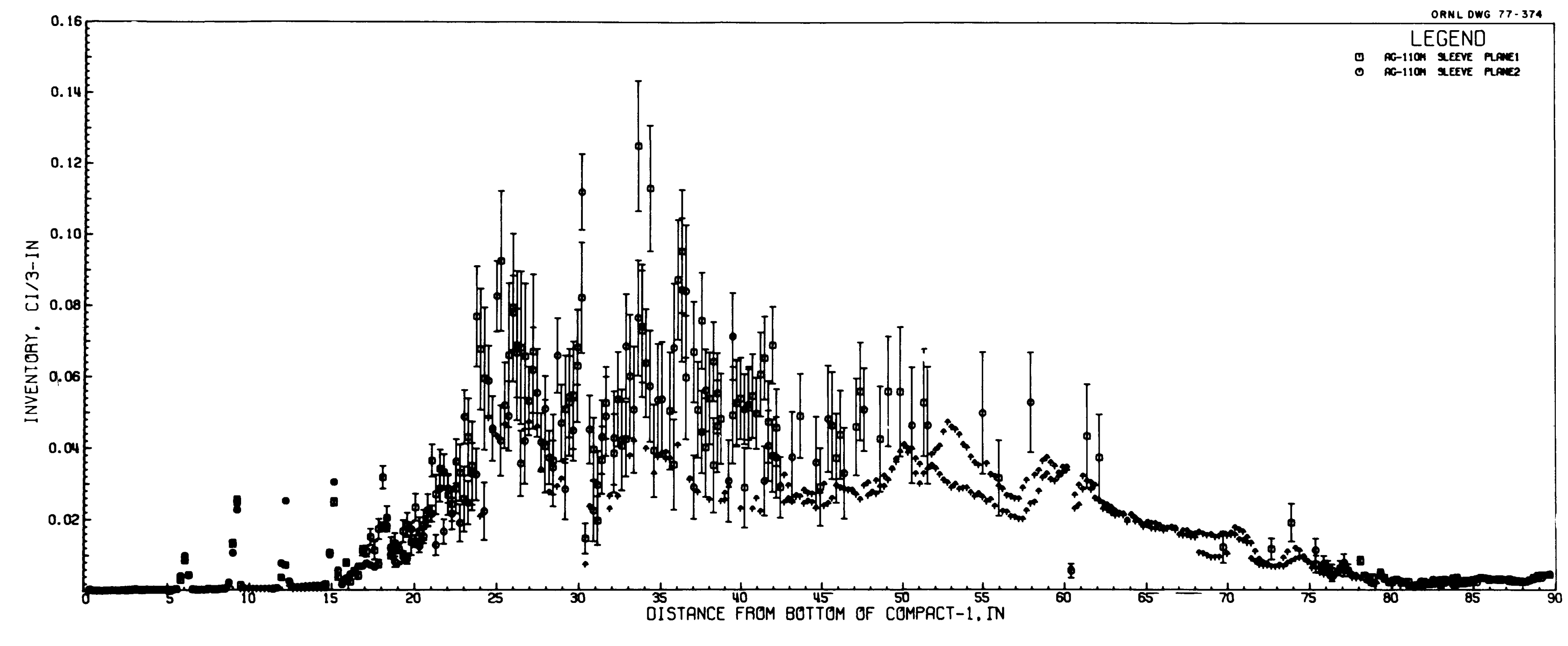

Fig. 4.2-11. Axial distribution of ${ }^{110 m_{\mathrm{Ag}}}$ in $\mathrm{FO}-01$ sleeve as of October 31, 1974. 


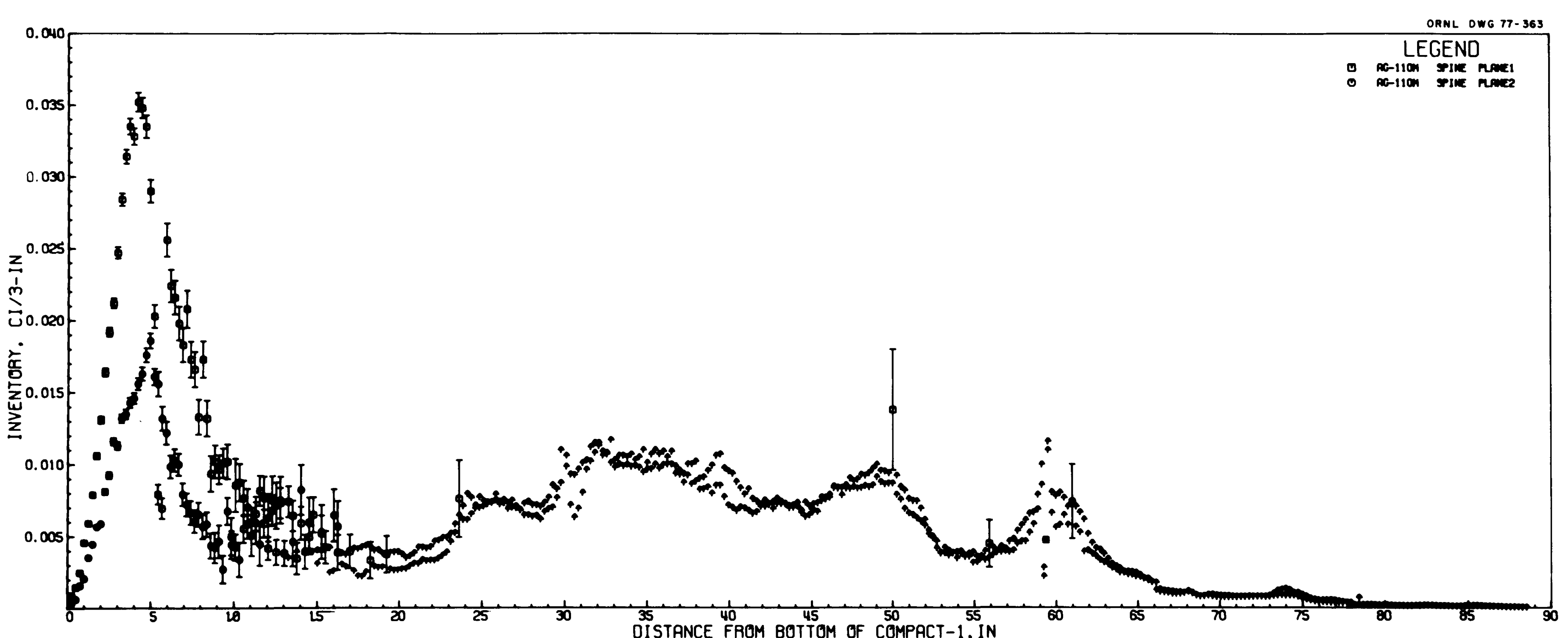




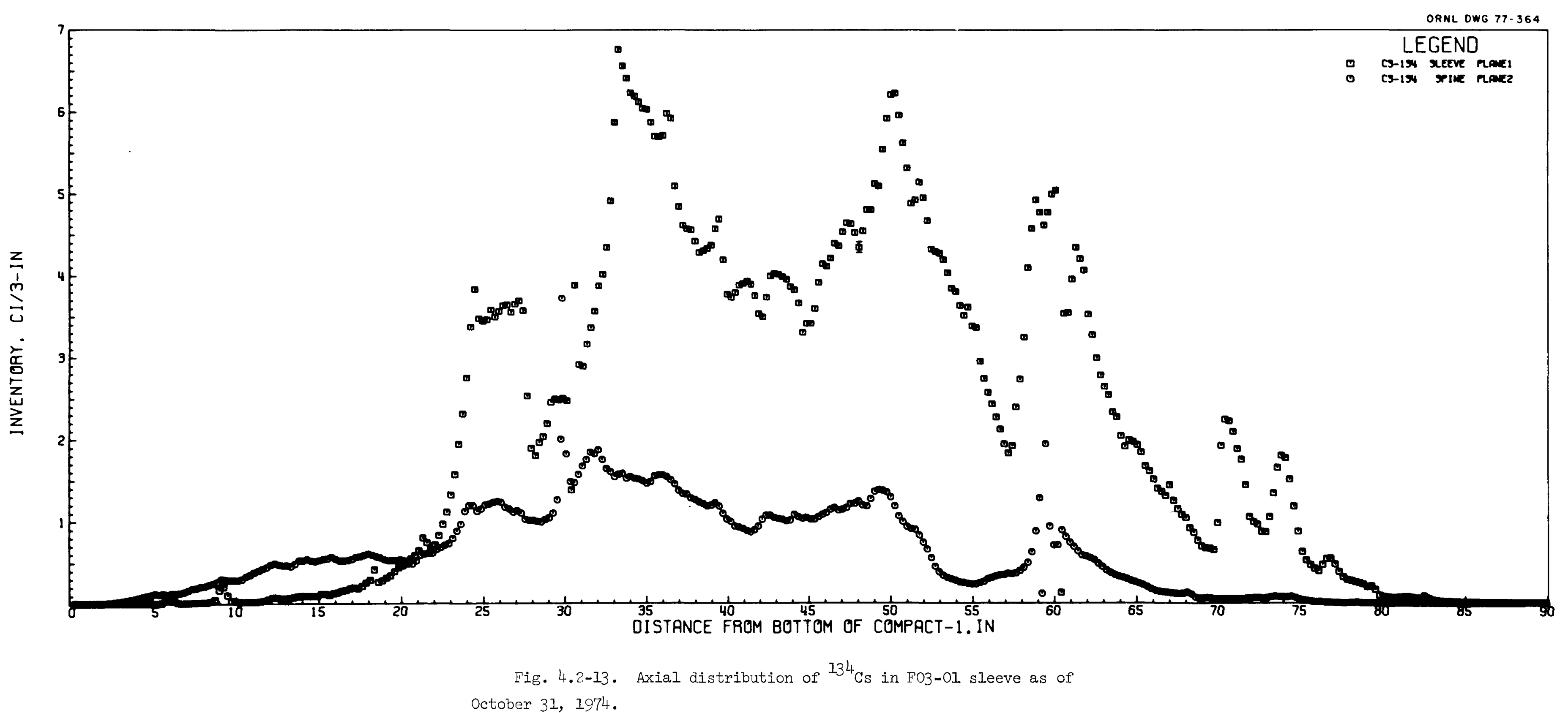




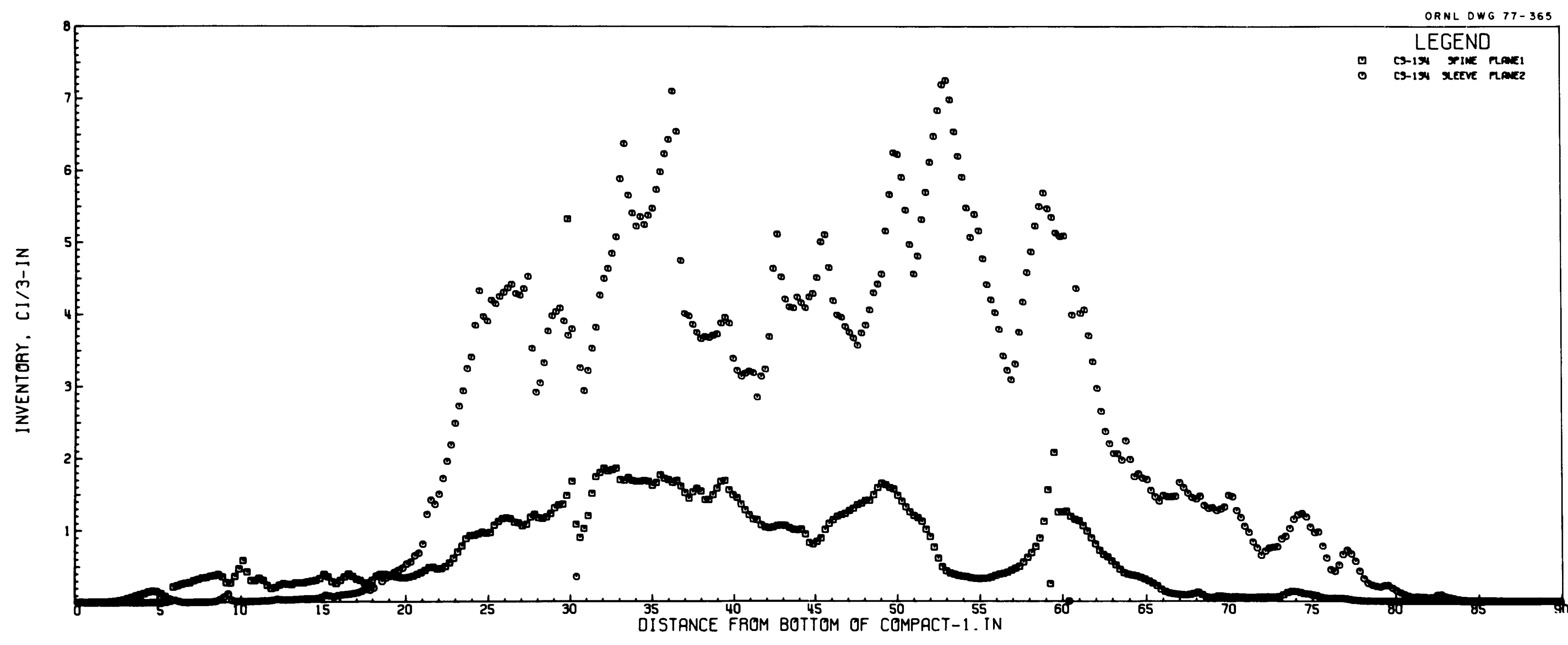

Fig. 4.2-14. Axial distribution of ${ }^{134} \mathrm{Cs}$ in FO3-01 spine as of October 31, 1974 . 


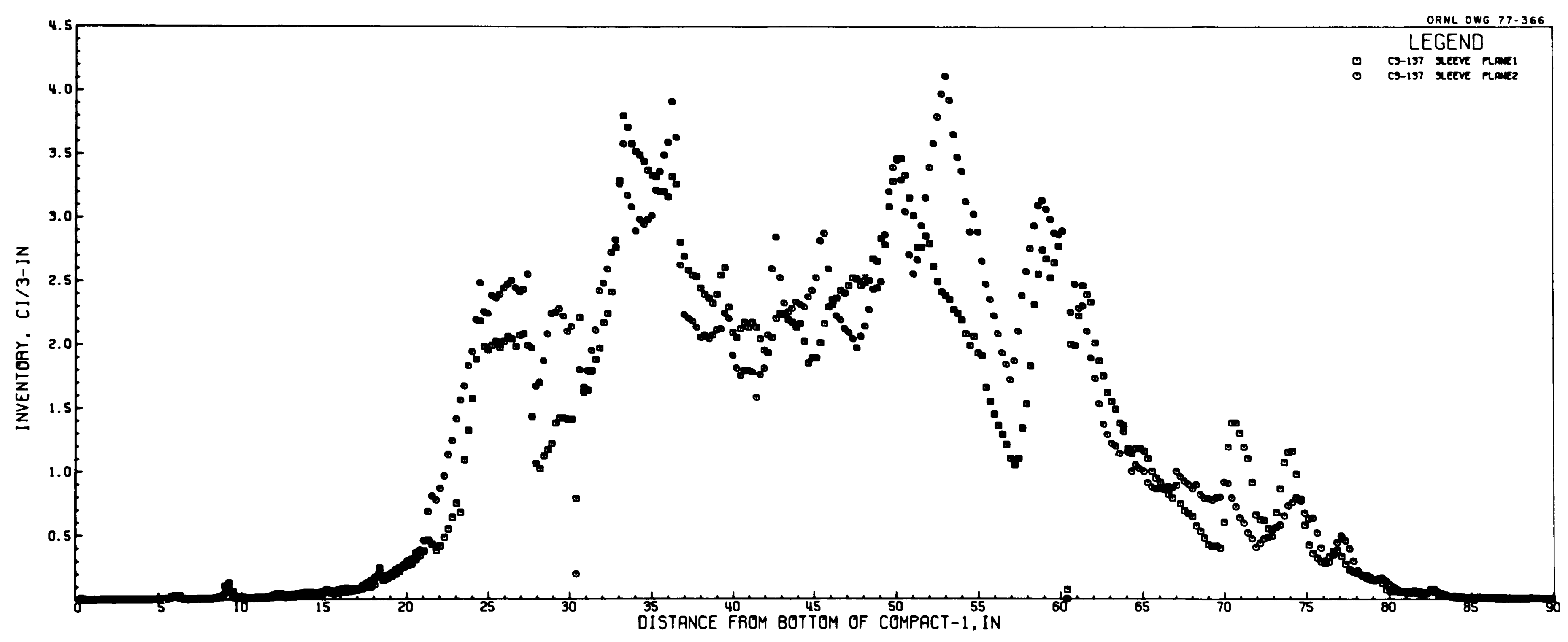

Fig. 4.2-15. Axial distribution of ${ }^{137} \mathrm{Cs}$ in FO3-Ol sleeve as of October 31, 1974 . 


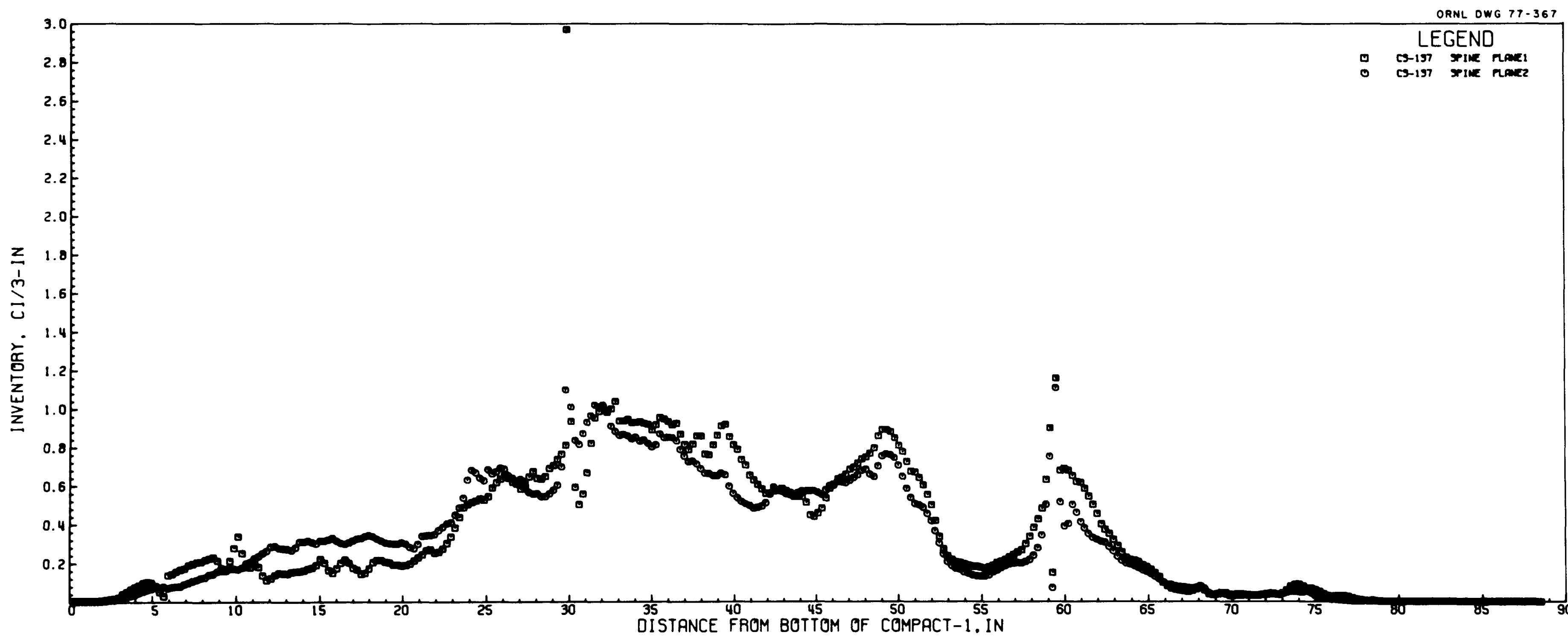

Fig. 4.2-16. Axial distribution of ${ }^{137} \mathrm{Cs}$ in FO3-Ol spine as of October 31, 1974. 


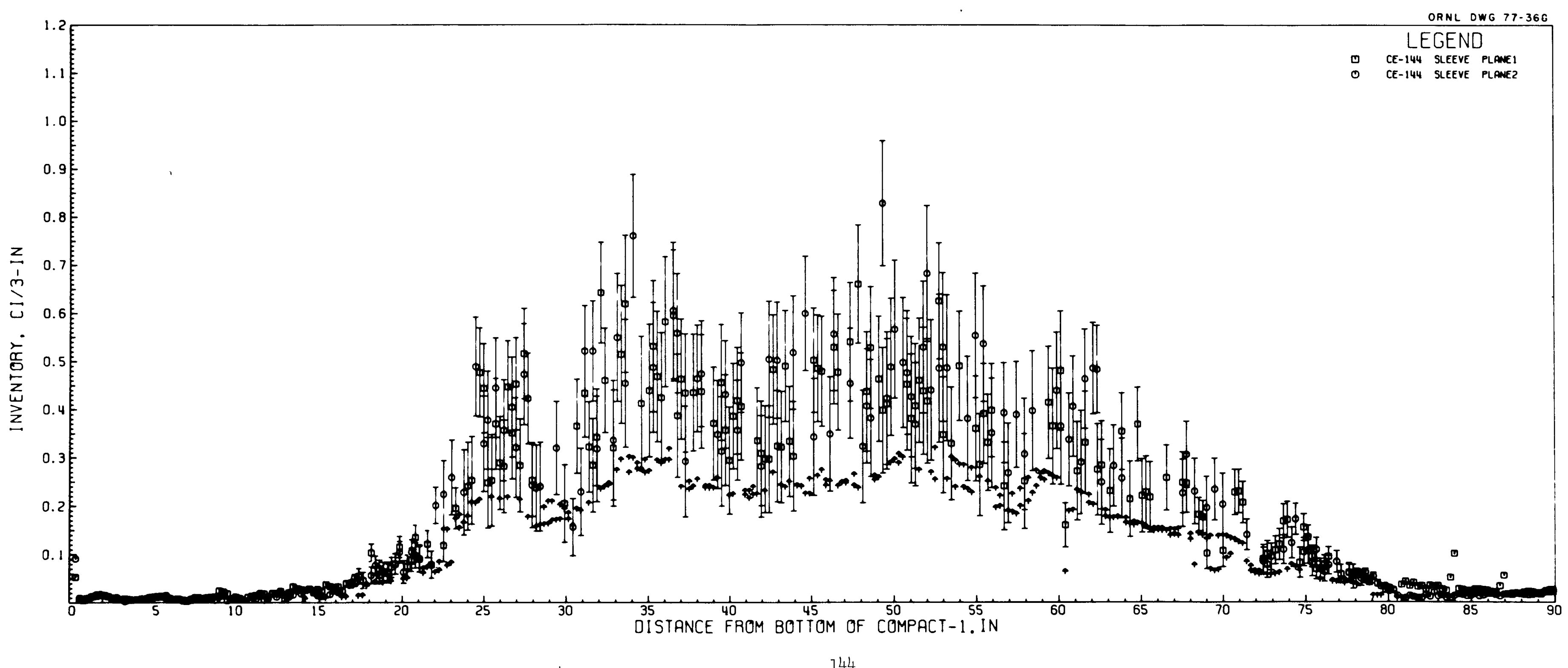

Fig. 4.2-17. Axial distribution of ${ }^{144} \mathrm{Ce}$ in FO3-01 sleeve as of October 31, 1974 . 


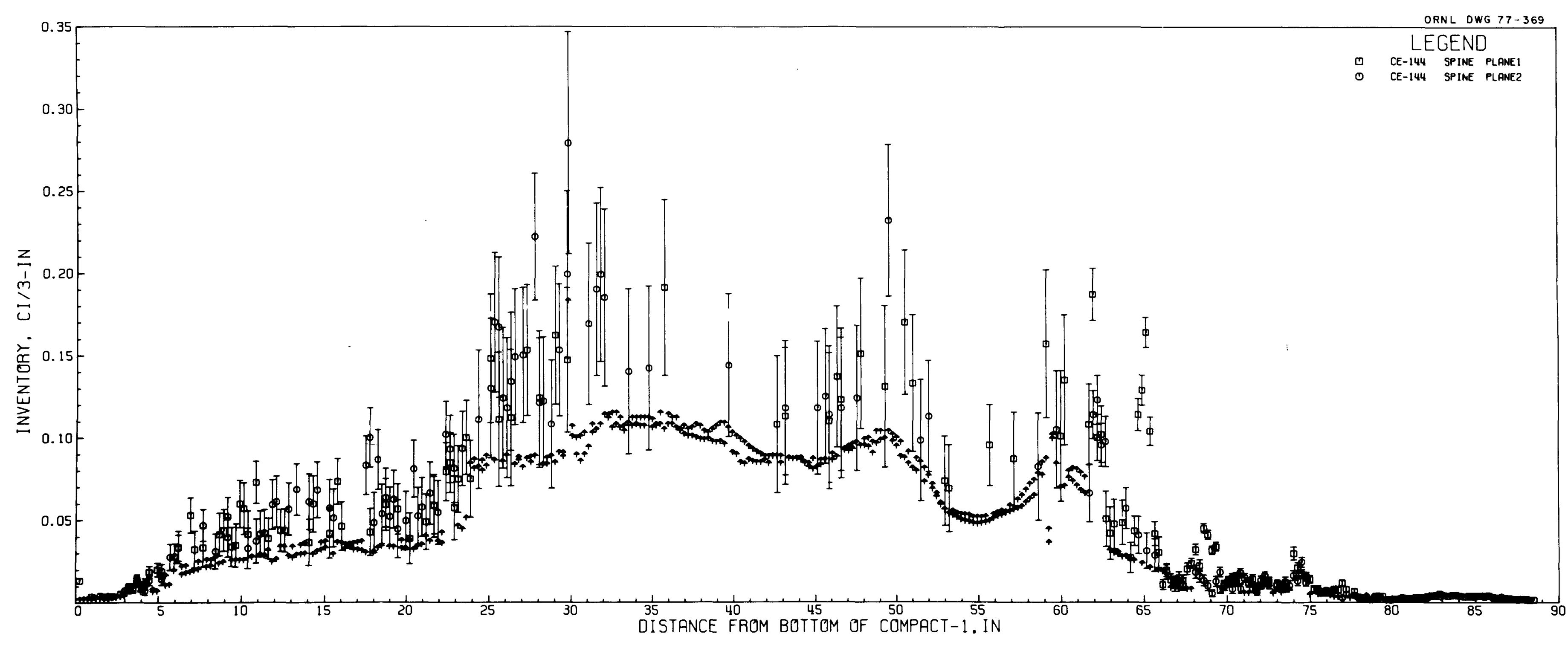

Fig. 4.2-18. Axial distribution of ${ }^{144} \mathrm{Ce}$ in $\mathrm{FO3-OI}$ spine as of October 31, 1974. 


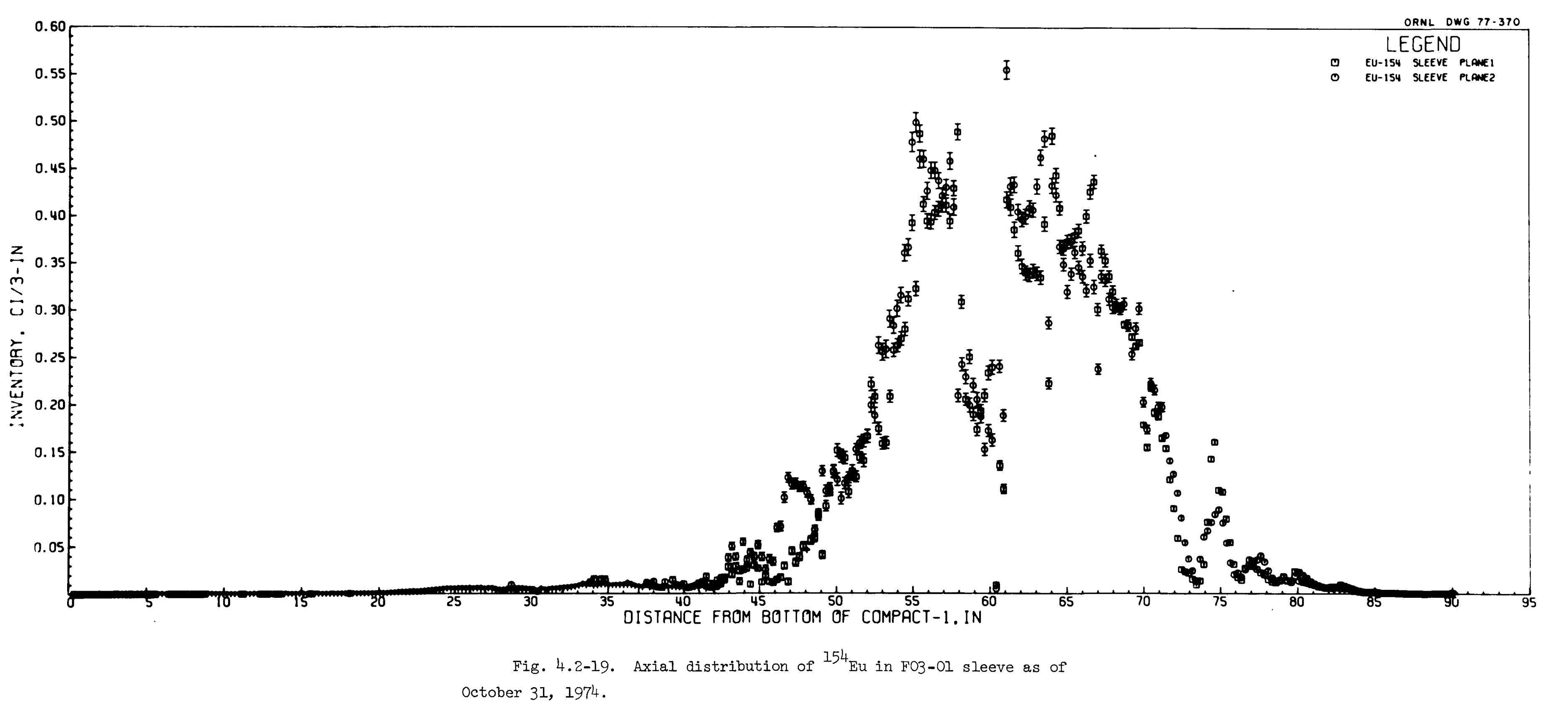




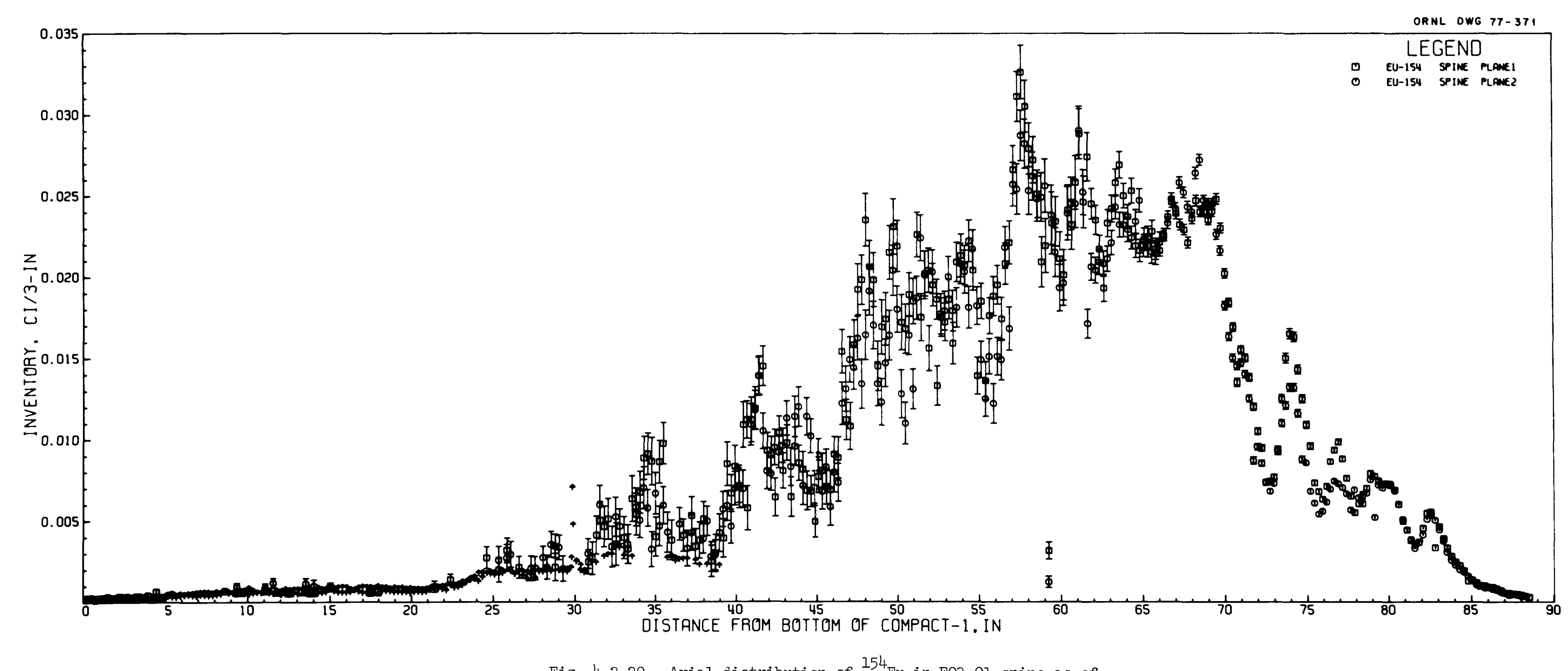

Fig. 4.2-20. Axial distribution of ${ }^{154} \mathrm{Eu}$ in FO3-Ol spine as of October 31, 1974 . 


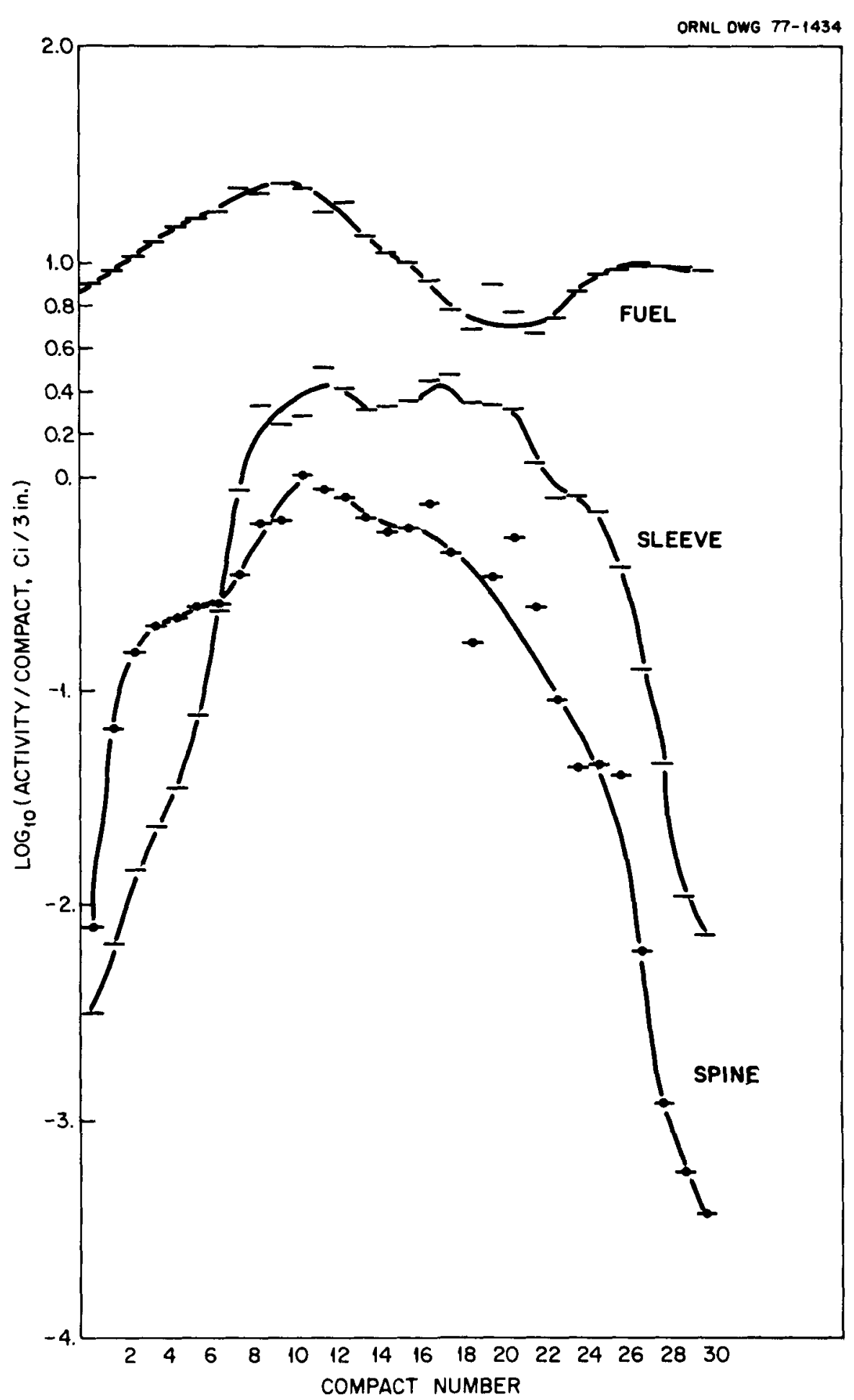

Fig. 4.2-21. Axial distributions of ${ }^{137} \mathrm{Cs}$ in the fuel, sleeve, and spine of fuel element FO3-OI as of October 31, 1974. 
ORNL DWG 76-7T7R3

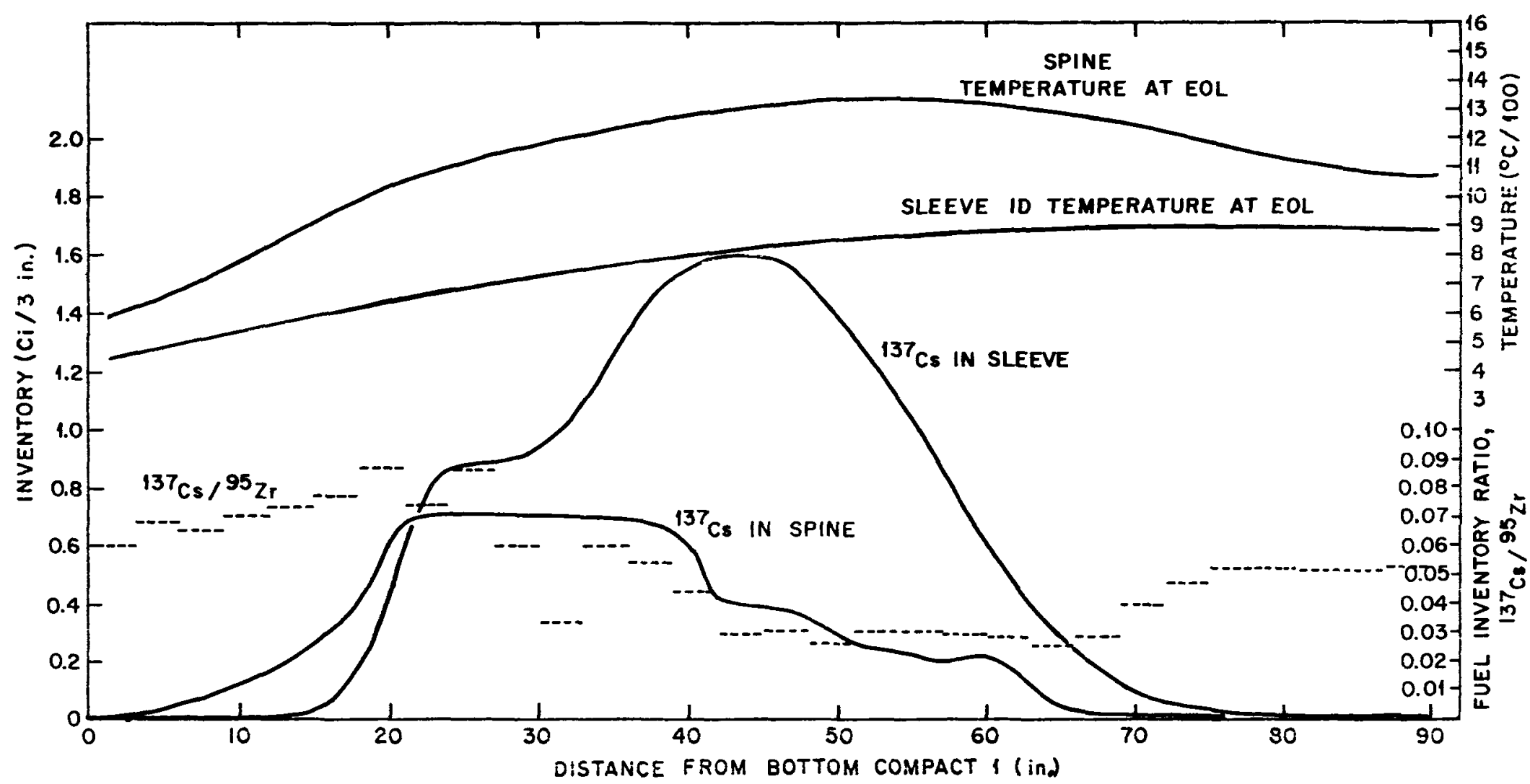

Fig. 4.2-22. Axial distribution of ${ }^{137} \mathrm{Cs}$ in sleeve and spine of element EII-07 as of September 14, 1973. 


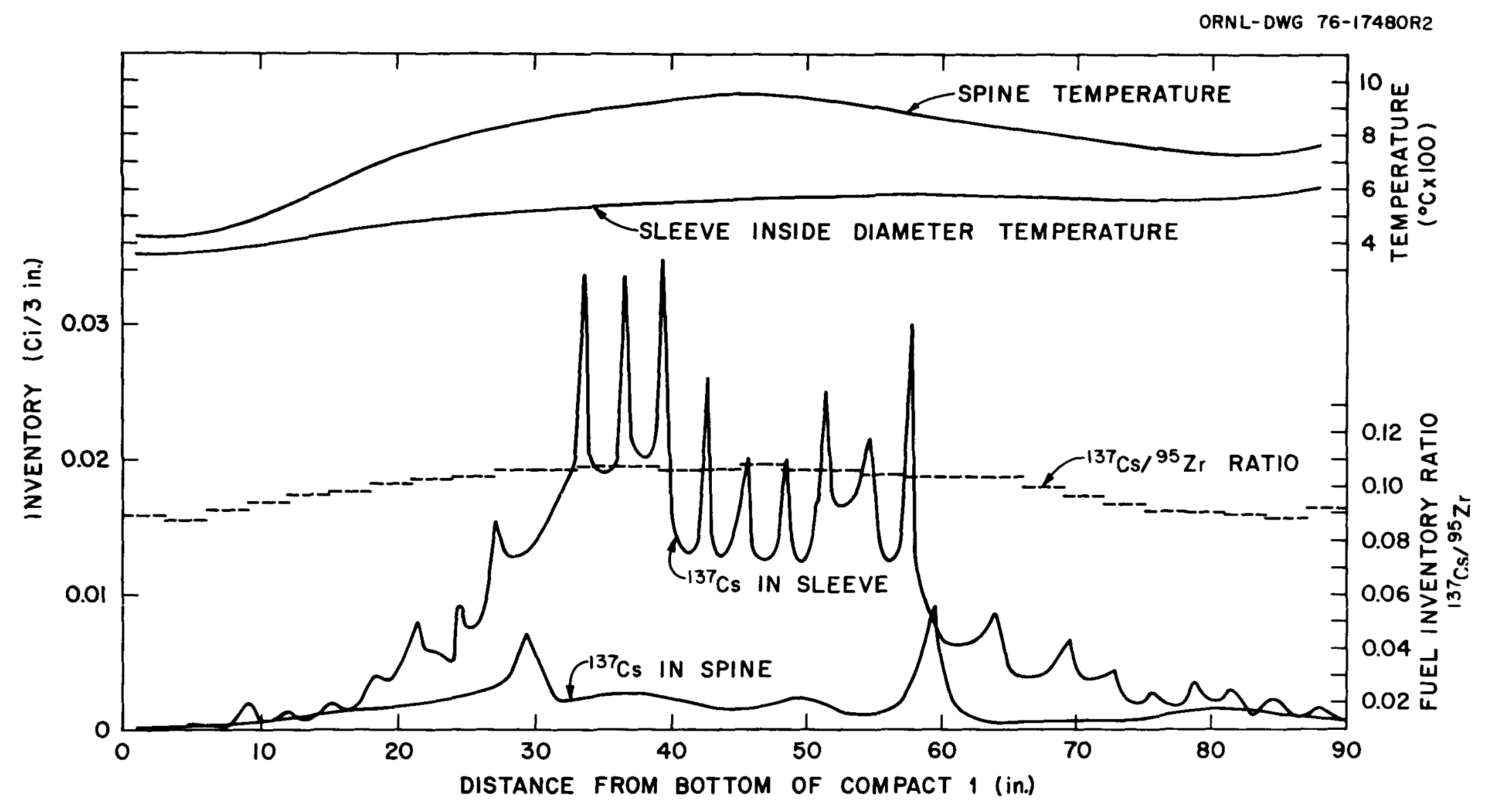

Fig. 4.2-23. Axial distribution of ${ }^{137} \mathrm{Cs}$ in sleeve, spine, and fuel of element EI4-O1 as of October 31, 1974. 
Table 4.3-1. Radial distribution of gamma-emitting radionuclides found in FO3-01 sleeve at compact 5

(corrected to October 31, 1974)

\begin{tabular}{|c|c|c|c|c|c|c|c|c|c|c|c|}
\hline & & Distance to center & & & Radionv & clide c & ncentrati & $\mathrm{n}(\mu \mathrm{Ci} / \mathrm{g}$ & & & ${ }^{137} \mathrm{Cs} /{ }^{134} \mathrm{Cs}$ \\
\hline $\begin{array}{l}\text { Thic } \\
\text { (mils) }\end{array}$ & $\begin{array}{l}\text { ness } \\
\quad(\mathrm{cm})\end{array}$ & $\begin{array}{l}\text { of cut from ID } \\
(\mathrm{cm})\end{array}$ & $54 \mathrm{Mn}$ & ${ }^{60} \mathrm{Co}^{b}$ & ${ }^{106} \mathrm{Ru}^{\mathrm{b}}$ & ${ }^{110 m_{A g}}$ & ${ }^{134} \mathrm{Cs}$ & $137_{\mathrm{Cs}}$ & ${ }^{144} \mathrm{Ce}^{\mathrm{b}}$ & $154 \mathrm{Eu}^{\mathrm{b}}$ & ratio \\
\hline 10 & 0.0254 & 0.0127 & - & 1.08 & 44.5 & 5.42 & 760 & 530 & 357 & 4.2 & 0.69 \\
\hline 10 & 0.0254 & 0.038 & - & 0.216 & $<36.9$ & $<4.0$ & 840 & 516 & - & 1.14 & 0.62 \\
\hline 18 & 0.0457 & 0.0737 & - & $<0.157$ & $<21.9$ & $<3.0$ & 720 & 428 & $<160$ & $<0.4$ & 0.60 \\
\hline 15 & 0.0381 & 0.1156 & - & $<0.061$ & $<10.9$ & $<1.0$ & 350 & 210 & $<78$ & $<0.2$ & 0.60 \\
\hline 15 & 0.0381 & 0.154 & - & $<0.036$ & $<6.66$ & $<0.8$ & 200 & 121 & $<50$ & $<0.1$ & 0.60 \\
\hline 30 & 0.0762 & 0.21 & - & $<0.016$ & $<2.82$ & $<0.3$ & 79 & 47.1 & $<20$ & $<0.05$ & 0.60 \\
\hline 30 & 0.0762 & 0.287 & - & 0.013 & 0.88 & $<0.07$ & 16.2 & $9 . \overline{6}$ & $<4$ & 0.029 & 0.59 \\
\hline 30 & 0.0762 & 0.363 & - & 0.03 & 0.16 & $<0.01$ & 2.2 & 1.31 & - & 0.028 & 0.60 \\
\hline 30 & 0.0762 & 0.516 & - & 0.04 & 0.33 & $<8 \mathrm{E}-3$ & 0.042 & 0.041 & - & 0.028 & 0.98 \\
\hline 30 & 0.0762 & 0.668 & - & 0.030 & 0.16 & $<7 \mathrm{E}-3$ & 0.034 & 0.037 & - & 0.025 & 1.09 \\
\hline 30 & 0.0762 & 0.744 & - & 0.021 & 0.16 & $<7 \mathrm{E}-3$ & 0.030 & 0.033 & - & 0.022 & 1.10 \\
\hline 30 & 0.0762 & 0.82 & - & 0.014 & 0.12 & $<6 \mathrm{E}-3$ & 0.027 & 0.029 & - & 0.018 & 1.07 \\
\hline 15 & 0.0381 & 0.87 & - & 0.018 & 0.11 & $<8 \mathrm{E}-3$ & 0.066 & 0.055 & - & 0.015 & 0.83 \\
\hline 15 & 0.0381 & 0.92 & $9 \cdot 3 \mathrm{E}-3$ & 0.049 & 0.1 & $<0.01$ & 0.20 & 0.139 & - & 0.019 & 0.70 \\
\hline 10 & 0.0254 & 0.94 & 1.16 & 1.76 & $<0.29$ & 0.82 & 3.1 & 2.19 & - & 0.074 & 0.70 \\
\hline
\end{tabular}

$a_{\text {Thickness of sample milled from sleeve. }}$

${ }^{b}$ Numbers preceded by < are upper-limit values. 
Table 4.3-2. Radial distribution of gamma-emitting radionuclides found in F03-Ol spine at compact 5

(corrected to October 31, 1974)

\begin{tabular}{|c|c|c|c|c|c|c|c|c|c|c|c|}
\hline \multicolumn{2}{|c|}{ Thickness $^{2}$} & \multirow{2}{*}{$\begin{array}{l}\text { Distance to center } \\
\text { of cut from oD } \\
(\mathrm{cm})\end{array}$} & \multicolumn{8}{|c|}{ Radionuclide concentration $(\mu \mathrm{Ci} / \mathrm{g})$} & \multirow{2}{*}{$\begin{array}{c}137 \mathrm{Cs} /{ }^{134} \mathrm{Cs} \\
\text { ratio }\end{array}$} \\
\hline (mils) & $(\mathrm{cm})$ & & $54 \mathrm{Mn}$ & ${ }^{50} \mathrm{Co}^{\mathrm{b}}$ & ${ }^{106} \mathrm{Ru}^{\mathrm{b}}$ & $110 \mathrm{~m}_{\mathrm{Ag}}^{\mathrm{b}}$ & ${ }^{134} \mathrm{Cs}$ & $137 \mathrm{Cs}$ & ${ }^{144} \mathrm{Ce}^{\mathrm{b}}$ & ${ }^{154} \mathrm{Eu}^{\mathrm{b}}$ & \\
\hline 5 & 0.0127 & 0.0064 & - & $<16$ & $<2.6 E 3$ & $<2.5 \mathrm{E} 2$ & $8.27 \mathrm{E} 4$ & $4.89 \mathrm{E}$ & $<1.7 E 4$ & $<38$ & 0.59 \\
\hline 15 & 0.0381 & 0.0318 & - & $<3$ & $<4.5 \mathrm{E} 2$ & $5.59 \mathrm{E} 2$ & $2.33 \mathrm{E}^{4}$ & $1.39 \mathrm{E} 4$ & $<3.3 \mathrm{E} 3$ & $<9$ & 0.59 \\
\hline 30 & 0.0762 & 0.0889 & - & $<2$ & $<2 . \mathrm{OE} 2$ & 74.4 & $1.01 \mathrm{E}_{4}$ & $5.98 \mathrm{E} 3$ & $<1.5 \mathrm{E} 3$ & $<3$ & 0.59 \\
\hline 30 & 0.0762 & 0.165 & - & 1.3 & $<1.05 \mathrm{E} 2$ & $<15.0$ & $4.99 \mathrm{E} 3$ & $2.92 \mathrm{E} 3$ & $<7.6 \mathrm{E} 2$ & $<2$ & 0.59 \\
\hline 30 & 0.0762 & 0.241 & - & 1.89 & $<60$ & $<6.8$ & $2.06 \mathrm{E} 3$ & $1.21 \mathrm{E3}$ & $<3.9 \mathrm{E} 2$ & $<1$ & 0.59 \\
\hline 30 & 0.0762 & 0.318 & - & 3.49 & $<38$ & $<3.7$ & $7.95 \mathrm{E} 2$ & $4.62 \mathrm{E} 2$ & $<2.3 \mathrm{E} 2$ & $<0.7$ & 0.58 \\
\hline 30 & 0.0762 & 0.394 & - & 2.82 & $<10$ & $<1.2$ & $2.95 \mathrm{E} 2$ & $1.72 \mathrm{E} 2$ & $<70$ & 1.16 & 0.58 \\
\hline 30 & 0.0762 & 0.47 & - & 2.8 & $<7$ & $<0.8$ & $1.3 \mathrm{E} 2$ & 74.4 & $<46$ & 1.17 & 0.57 \\
\hline 30 & 0.0762 & 0.546 & 0.41 & 2.45 & $<3$ & $<0.4$ & 63.7 & 36.4 & $<18$ & 1.04 & 0.57 \\
\hline 30 & 0.0762 & 0.622 & 0.3 & 2.19 & $<0.8$ & $<0.2$ & 31.4 & 17.7 & $<6$ & 0.98 & 0.56 \\
\hline 30 & 0.0762 & 0.699 & - & 2.45 & $<1.6$ & $<0.3$ & 18.6 & 10.0 & $<12$ & 1.03 & 0.54 \\
\hline 30 & 0.0762 & 0.775 & 0.37 & 2.42 & $<0.5$ & $<0.1$ & 9.9 & 5.09 & $<4$ & 1.00 & 0.51 \\
\hline 60 & 0.1524 & 0.889 & 0.27 & 2.24 & $<0.9$ & $<0.2$ & 5.6 & 2.47 & $<7$ & 1.04 & 0.44 \\
\hline 73 & 0.1854 & 1.058 & 0.26 & 1.91 & $<0.3$ & $<0.08$ & 2.4 & 0.68 & - & 0.93 & 0.29 \\
\hline 62.5 & 0.1588 & 1.62 & 0.16 & 1.23 & - & 0.13 & 9.7 & 5.52 & - & 1.04 & 0.57 \\
\hline 125 & 0.3175 & 1.86 & 0.11 & 0.99 & $<0.3$ & $<0.09$ & 2.5 & 0.92 & $<3$ & 0.94 & 0.36 \\
\hline
\end{tabular}

$a_{\text {Thickness of sample milled from spine. }}$

iNumbers preceded by < are upper-limit values. 
Table 4.3-3. Radial distribution of gamma-emitting radionuclides found in F03-01 sleeve at compact 12

(corrected to October 31, 1974)

\begin{tabular}{|c|c|c|c|c|c|c|c|c|c|c|c|}
\hline \multirow{2}{*}{\multicolumn{2}{|c|}{$\begin{array}{l}\text { Thickness } \\
\text { (mils) }(\mathrm{cm})\end{array}$}} & Distance to center & \multicolumn{8}{|c|}{ Radionuclide concentration $(\mu \mathrm{Ci} / \mathrm{g})$} & \multirow{2}{*}{$\begin{array}{c}137 \mathrm{Cs} /{ }^{134} \mathrm{Cs} \\
\text { ratio }\end{array}$} \\
\hline & & $\begin{array}{l}\text { of cut from ID } \\
(\mathrm{cm})\end{array}$ & $54 \mathrm{Mn}$ & ${ }^{60} \mathrm{Co}^{b}$ & $106_{\mathrm{Ru}} \mathrm{b}$ & $110 \mathrm{~m}_{\mathrm{Ag}} \mathrm{b}$ & $134 \mathrm{Cs}$ & $137 \mathrm{Cs}$ & ${ }^{144} \mathrm{Ce}^{\mathrm{b}}$ & ${ }^{154} \mathrm{Eu}^{\mathrm{b}}$ & \\
\hline 5 & 0.013 & 0.006 & - & 82 & $<3 \mathrm{E} 3$ & 4. $9 \mathrm{E} 3$ & $1.20 E 5$ & $7.07 E^{4}$ & $<2 E_{4}$ & 85 & 0.59 \\
\hline 10 & 0.025 & 0.025 & - & 37 & $<2.5 \mathrm{E} 3$ & $1.8 \mathrm{E} 3$ & $9.12 \mathrm{E} 4$ & $5.26 \mathrm{E} 4$ & $<1.7 \mathrm{E}^{4}$ & 95 & 0.58 \\
\hline 10 & 0.025 & 0.051 & - & 40 & $<2 \mathrm{E} 3$ & $1.4 \mathrm{E} 3$ & $8.07 \mathrm{E} 4$ & $4.68 \mathrm{E} 4$ & $<1.4 \mathrm{E}^{4}$ & 110 & 0.58 \\
\hline 10 & 0.025 & 0.076 & - & 15.8 & $<2 E 3$ & $1.13 \mathrm{E} 3$ & $6.35 \mathrm{E}_{4}$ & $3.7 \pm 4$ & $<1.4 \mathrm{E} 4$ & 156 & 0.58 \\
\hline 15 & 0.038 & 0.108 & - & $<12$ & $<2 \mathrm{E} 3$ & $1.09 \mathrm{E} 3$ & $6.13 \mathrm{E} 4$ & $3 \cdot 54 \mathrm{E} 4$ & $<1.4 \mathrm{E} 4$ & 120 & 0.58 \\
\hline 30 & 0.076 & 0.165 & - & $<7$ & $<1 \mathrm{E} 3$ & - & $4.60 \mathrm{E}^{4}$ & $2.65 \mathrm{E} 4$ & $<8 \mathrm{E} 3$ & $<21$ & 0.58 \\
\hline 30 & 0.076 & 0.24 & - & 1.72 & $<280$ & $<33$ & $2.89 \mathrm{E} 4$ & $1.65 \mathrm{E} 4$ & $<1.9 \mathrm{E} 3$ & $<4$ & 0.57 \\
\hline 30 & 0.076 & 0.32 & - & 3.55 & $<440$ & $<60$ & $1.87 \mathrm{E}^{4}$ & 1. $04 \mathrm{E}^{4}$ & $<3.2 \mathrm{E} 3$ & $<8$ & 0.56 \\
\hline 30 & 0.076 & 0.47 & - & $<1.3$ & 400 & $<24$ & $6.75 \mathrm{E} 3$ & $3.69 \mathrm{E} 3$ & $<1.5 \mathrm{E} 3$ & $<3$ & 0.55 \\
\hline 30 & 0.076 & 0.62 & - & $<0.25$ & $<46$ & $<6$ & $1.51 \mathrm{E} 3$ & 816 & $<330$ & $<0.7$ & 0.54 \\
\hline 30 & 0.076 & 0.69 & - & $<0.1$ & $<20$ & $<2$ & 550 & 298 & $<140$ & $<0.3$ & 0.54 \\
\hline 30 & 0.076 & 0.77 & - & $<0.03$ & $<4.8$ & $<0.6$ & 170 & 91.7 & $<35$ & $<0.08$ & 0.54 \\
\hline 30 & 0.076 & 0.84 & - & 0.02 & $<1.6$ & $<0.2$ & 45 & 24.2 & $<11$ & 0.04 & 0.54 \\
\hline 15 & 0.038 & 0.90 & - & 0.02 & $<0.6$ & $<0.06$ & 12.9 & 6.9 & $<4$ & 0.02 & 0.54 \\
\hline 15 & 0.038 & 0.93 & - & 0.06 & - & $<0.05$ & 6.6 & 3.6 & - & $<0.02$ & 0.54 \\
\hline 10 & 0.025 & 0.94 & 1.44 & 2.76 & $<2$ & 0.5 & 39.2 & 21.9 & $<16$ & 0.69 & 0.56 \\
\hline
\end{tabular}

$a_{\text {Thickness of sample milled from sleeve. }}$

${ }^{\mathrm{b}}$ Numbers preceded by $<$ are upper-limit values. 
Table 4.3-4. Radial distribution of gamma-emitting radionuclides found in FO3-01 spine at compact 12 (corrected to October 31, 1974)

\begin{tabular}{|c|c|c|c|c|c|c|c|c|c|c|c|}
\hline \multirow{2}{*}{\multicolumn{2}{|c|}{$\begin{array}{l}\text { Thickness } \\
\text { (mils) }(\mathrm{cm})\end{array}$}} & Distance to center & \multicolumn{8}{|c|}{ Radionuclide concentration $(\mu \mathrm{Ci} / \mathrm{g})$} & \multirow{2}{*}{$\begin{array}{c}137 \mathrm{Cs} /{ }^{134} \mathrm{Cs} \\
\text { ratio }\end{array}$} \\
\hline & & $\begin{array}{l}\text { of cut from oD } \\
(\mathrm{cm})\end{array}$ & $54 \mathrm{Mn}$ & ${ }^{60} \mathrm{Co}$ & ${ }^{106} \mathrm{Ru}^{\mathrm{b}}$ & $110 \mathrm{~m}_{\mathrm{Ag}} \mathrm{b}$ & $134 \mathrm{cs}$ & $137 \mathrm{Cs}$ & ${ }^{144} \mathrm{Ce}^{\mathrm{b}}$ & ${ }^{154} \mathrm{Eu}^{\mathrm{b}}$ & \\
\hline 7 & 0.0178 & 0.0089 & - & 25.3 & $<500$ & $<59$ & $2.53 E 4$ & $1.49 \mathrm{E} 4$ & - & 82 & 0.59 \\
\hline 15 & 0.0381 & 0.0369 & - & 16 & $<600$ & $<79$ & $2.20 \mathrm{E} 4$ & $1.27 \mathrm{E}^{4}$ & $<4.2 \mathrm{E} 3$ & 79 & 0.58 \\
\hline 30 & 0.0762 & 0.094 & - & 17.8 & $<400$ & $<64$ & $1.8 \mathrm{E} 4$ & $1.04 \mathrm{E} 4$ & $<3.1 \mathrm{E} 3$ & 73 & 0.58 \\
\hline 30 & 0.0762 & 0.170 & - & 12.6 & $<340$ & $<48$ & $1.33 \mathrm{E} 4$ & $7.6 \mathrm{E} 3$ & $<2.5 \mathrm{E} 3$ & 70 & 0.57 \\
\hline 30 & 0.0762 & 0.246 & - & 18.2 & $<280$ & $<33$ & $9.5 \mathrm{E} 3$ & $5.3 \mathrm{E} 3$ & $<2.1 \mathrm{E3}$ & 58 & 0.56 \\
\hline 30 & 0.0762 & 0.40 & - & 16.3 & $<150$ & $<18$ & $5.5 \mathrm{E} 3$ & $3.07 \mathrm{E3}$ & $<1.1 \mathrm{E} 3$ & 35 & 0.56 \\
\hline 30 & 0.0762 & 0.475 & - & 13.8 & $<77$ & $<10$ & $4.3 \mathrm{E} 3$ & $2.38 \mathrm{E} 3$ & $<5.4 \mathrm{E} 2$ & 31 & 0.55 \\
\hline 30 & 0.0762 & 0.551 & - & 11.7 & $<67$ & $<8$ & $3 \cdot 33 \mathrm{E} 3$ & $1.84 \mathrm{E} 3$ & $<4.6 \mathrm{E} 2$ & 23 & 0.55 \\
\hline 30 & 0.0762 & 0.627 & - & 9.1 & $<61$ & $<6.7$ & $2.64 \mathrm{E} 3$ & $1.44 \mathrm{E} 3$ & $<4.7 \mathrm{E} 2$ & 20 & 0.55 \\
\hline 30 & 0.0762 & 0.704 & - & 7.0 & $<55$ & $<5.8$ & 2.IF3 & $1.14 \mathrm{E} 3$ & $<3.6 \mathrm{E} 2$ & 16 & 0.54 \\
\hline 30 & 0.0762 & 0.78 & - & 4.6 & $<23$ & $<2.3$ & 1.7E3 & $9.2 \mathrm{E} 2$ & $<1.5 \mathrm{E} 2$ & 13 & 0.54 \\
\hline 60 & 0.1524 & 0.894 & - & 2.8 & $<33$ & $<3.5$ & 1.23E3 & $6.6 \mathrm{E} 2$ & $<2.2 \mathrm{E} 2$ & 10 & 0.54 \\
\hline 68 & 0.1727 & 0.98 & - & 1.29 & $<26$ & $<2.6$ & $7.9 \mathrm{E} 2$ & 4.2E2 & $<1.7 \mathrm{E} 2$ & 5.9 & 0.53 \\
\hline 62.5 & 0.1588 & 1.62 & - & 0.25 & $<12$ & $<1.1$ & $2.21 \mathrm{E} 2$ & $1.14 \mathrm{E} 2$ & $<7.8 \mathrm{E} 1$ & 1.6 & 0.52 \\
\hline
\end{tabular}

aThickness of sample milled from the spine.

$b_{\text {Numbers }}$ preceded by $<$ are upper-limit values. 
Table 4.3-5. Radial distribution of gamma-emitting radionuclides found in F03-01 sleeve at compact 18 (corrected to october 31,1974 )

\begin{tabular}{|c|c|c|c|c|c|c|c|c|c|c|c|}
\hline \multirow{2}{*}{\multicolumn{2}{|c|}{$\begin{array}{l}\text { Thickness } \\
\text { (mils) } \\
\text { (cm) }\end{array}$}} & \multirow{2}{*}{$\begin{array}{c}\text { Distance to center } \\
\text { of cut from ID } \\
(\mathrm{cm})\end{array}$} & \multicolumn{8}{|c|}{ Radionuclide concentration $(\mu \mathrm{Ci} / \mathrm{g})$} & \multirow{2}{*}{ 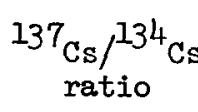 } \\
\hline & & & ${ }^{54} \mathrm{Mn}$ & $6 \mathrm{Co}^{\mathrm{b}}$ & ${ }^{106}{ }_{R u^{b}}$ & $110 \mathrm{~m}_{\mathrm{Ag}} \mathrm{b}$ & ${ }^{134} \mathrm{Cs}$ & $137_{\mathrm{Cs}}$ & ${ }^{144} \mathrm{Ce}^{\mathrm{b}}$ & $\overline{154} \mathrm{Eu}^{\mathrm{b}}$ & \\
\hline 15 & 0.038 & 0.019 & - & 670 & $<2 \mathrm{E} 3$ & $<310$ & $5.45 \mathrm{E} 4$ & $3.15 \mathrm{E}^{4}$ & $<1.6 \mathrm{E} 4$ & $1.02 \mathrm{E} 4$ & 0.56 \\
\hline 15 & 0.038 & 0.057 & - & 158 & $<1.5 \mathrm{E} 3$ & $<210$ & $4.88 \mathrm{E}^{4}$ & $2.80 \mathrm{E}^{4}$ & $<1.1 E_{4}^{4}$ & $3.04 \mathrm{E} 3$ & 0.57 \\
\hline 30 & 0.076 & 0.114 & - & 65 & $<1.1 \mathrm{E3}$ & $<179$ & $4.53 E^{4}$ & $2.62 \mathrm{E}^{4}$ & $<8.9 \mathrm{E} 3$ & $2.84 \mathrm{E} 3$ & 0.58 \\
\hline 30 & 0.076 & 0.19 & - & $<5$ & $<840$ & $<120$ & $3.30 \mathrm{OE}$ & $1.89 \mathrm{E}_{4}$ & $<6.4 \mathrm{E} 3$ & 388 & 0.57 \\
\hline 30 & 0.076 & 0.27 & - & $<3$ & $<420$ & $<68$ & $2.07 \mathrm{E}^{4}$ & $1.17 \mathrm{E}^{4}$ & $<3.3 \mathrm{E} 3$ & $<9.3$ & 0.57 \\
\hline 30 & 0.076 & 0.42 & - & $<1$ & $<155$ & $<20$ & $6.6 \mathrm{E} 3$ & $3.67 \mathrm{E} 3$ & $<1.1 \mathrm{E} 3$ & $<2.8$ & 0.56 \\
\hline 30 & 0.076 & 0.57 & - & $<0.2$ & $<35$ & $<4$ & $1.14 \mathrm{E} 3$ & 627 & $<260$ & $<0.58$ & 0.55 \\
\hline 30 & 0.076 & 0.65 & - & $<0.08$ & $<16$ & $<1.7$ & 439 & 241 & $<107$ & $<0.22$ & 0.55 \\
\hline 30 & 0.076 & 0.72 & - & $<0.03$ & $<5.9$ & $<0.6$ & 155 & 84.8 & 49.7 & $<0.09$ & 0.55 \\
\hline 30 & 0.076 & 0.80 & - & $1.5 \mathrm{E}-2$ & $<1.8$ & $<0.2$ & 49 & 26.5 & $<13$ & $<0.03$ & 0.54 \\
\hline 15 & 0.038 & 0.86 & - & $1.79 \mathrm{E}-2$ & $<0.65$ & $<0.07$ & 17 & 9.6 & $<4.4$ & 0.028 & 0.55 \\
\hline 15 & 0.038 & 0.89 & - & 3. $9 \mathrm{E}-2$ & 0.65 & $<0.05$ & 9.0 & 5.0 & - & $5.54 \mathrm{E}-2$ & 0.55 \\
\hline 11 & 0.028 & 0.93 & 1.51 & 4.02 & $<1.2$ & $<0.25$ & 31.6 & 17.9 & $<9.5$ & 0.76 & 0.57 \\
\hline
\end{tabular}

a Thickness of sample milled from sleeve.

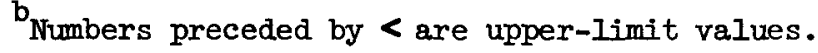


Table 4.3-6. Radial distribution of gamma-emitting radionuclides found in FO3-01 spine at compact 18 (corrected to October 31, 1974)

\begin{tabular}{|c|c|c|c|c|c|c|c|c|c|c|c|}
\hline \multirow{2}{*}{\multicolumn{2}{|c|}{$\begin{array}{l}\text { Thickness } \\
\text { (mils) }(\mathrm{cm})\end{array}$}} & Distance to center & \multicolumn{8}{|c|}{ Radionuclide concentration $(\mu \mathrm{Ci} / \mathrm{g})$} & \multirow{2}{*}{${ }_{\text {ratio }}^{137_{\text {Cs }} / 134} \mathrm{Cs}$} \\
\hline & & $\begin{array}{l}\text { of cut Irom OD } \\
(\mathrm{cm})\end{array}$ & $54 \mathrm{Mn}$ & ${ }^{60} \mathrm{Co}$ & ${ }^{106} \mathrm{Ru}^{\mathrm{b}}$ & $110 \mathrm{~m}_{\mathrm{Ag}} \mathrm{b}$ & $134 \mathrm{Cs}$ & $137 \mathrm{Cs}$ & $144 \mathrm{Ce}^{\mathrm{b}}$ & $154_{\mathrm{Eu}}$ & \\
\hline 6 & 0.015 & 0.0076 & - & 5.39 & $<340$ & $<45$ & $9.11 \mathrm{E3}$ & $5.53 \mathrm{E} 3$ & - & 760 & 0.61 \\
\hline 15 & 0.038 & 0.0343 & - & 3.31 & $<160$ & $<21$ & $5.18 \mathrm{E} 3$ & $3.12 \mathrm{E} 3$ & - & 226 & 0.60 \\
\hline 30 & 0.076 & 0.0914 & - & 3.23 & $<150$ & $<18$ & $4.74 \mathrm{E3}$ & $2.84 \mathrm{E} 3$ & $<1000$ & 101 & 0.60 \\
\hline 30 & 0.076 & 0.168 & - & 2.27 & $<143$ & $<17$ & $4.26 \mathrm{E} 3$ & $2.52 \mathrm{E} 3$ & $<1000$ & 92 & 0.59 \\
\hline 30 & 0.076 & 0.244 & - & 2.72 & $<140$ & $<16$ & $3.87 \mathrm{E} 3$ & $2.27 \mathrm{E} 3$ & $<1000$ & 92 & 0.59 \\
\hline 30 & 0.076 & 0.320 & - & 0.91 & $<130$ & $<15$ & $3.53 \mathrm{E} 3$ & $2.03 \mathrm{E} 3$ & $<1000$ & 82 & 0.58 \\
\hline 30 & 0.076 & 0.396 & - & 1.23 & $<100$ & $<12$ & $3.06 \mathrm{E} 3$ & $1.76 \mathrm{E} 3$ & $<700$ & 77 & 0.58 \\
\hline 30 & 0.076 & 0.472 & - & - & $<98$ & $<11$ & $2.75 \mathrm{E} 3$ & $1.56 \mathrm{E} 3$ & $<670$ & 73 & 0.57 \\
\hline 30 & 0.076 & 0.549 & - & 1.62 & $<97$ & $<10$ & $2.45 \mathrm{E} 3$ & $1.38 \mathrm{E} 3$ & $<650$ & 68 & 0.56 \\
\hline 30 & 0.076 & 0.625 & - & - & $<64$ & $<8$ & $2.08 \mathrm{E} 3$ & 1. $17 \mathrm{E} 3$ & $<450$ & 63 & 0.56 \\
\hline 30 & 0.076 & 0.701 & - & - & $<62$ & $<7$ & $1.91 \mathrm{E} 3$ & $1.06 \mathrm{E} 3$ & $<440$ & 62 & 0.56 \\
\hline 30 & 0.076 & 0.777 & - & 1.13 & $<61$ & $<7$ & $1.71 \pm 3$ & 960 & $<430$ & 60 & 0.56 \\
\hline 60 & 0.152 & 0.892 & - & 0.72 & $<33$ & $<4$ & $1.10 \mathrm{E} 3$ & 600 & $<238$ & 42 & 0.55 \\
\hline 68 & 0.173 & 1.054 & - & 1.03 & $<40$ & $<4$ & $1.15 \mathrm{E} 3$ & 630 & $<282$ & 49 & 0.55 \\
\hline 62.5 & 0.159 & 1.715 & - & 0.49 & $<23$ & $<2$ & 620 & 330 & $<169$ & 38 & 0.53 \\
\hline 125 & 0.318 & 1.95 & - & 0.59 & $<21$ & $<2$ & 576 & 300 & $<156$ & 36 & 0.53 \\
\hline
\end{tabular}

$a_{\text {Thickness of sample milled from spine. }}$

$b_{\text {Numbers }}$ preceded by < are upper-limit values. 
Table 4.3-7. Radial distribution of gamma-emitting radionuclides found in F03-01 sleeve at compact 28 (corrected to October 31, 1974)

\begin{tabular}{|c|c|c|c|c|c|c|c|c|c|c|c|}
\hline \multicolumn{2}{|c|}{ Thickness $^{\mathrm{a}}$} & Distance to center & & \multicolumn{7}{|c|}{ Radionuclide concentration $(\mu \mathrm{Ci} / \mathrm{g})$} & \multirow{2}{*}{${ }_{\text {ratio }}^{137} \mathrm{Cs} /{ }^{134} \mathrm{Cs}$} \\
\hline (mils) & $\begin{array}{l}\text { ness } \\
(\mathrm{cm})\end{array}$ & $\begin{array}{l}\text { of cut Irom ID } \\
(\mathrm{cm})\end{array}$ & $54 \mathrm{Mn}$ & ${ }^{60} \mathrm{Co}^{\mathrm{b}}$ & ${ }^{106} \mathrm{Ru}^{\mathrm{b}}$ & $110 \mathrm{~m}_{\mathrm{Ag}} \mathrm{b}$ & $13{ }^{4} \mathrm{Cs}$ & $137_{\text {Cs }}$ & ${ }^{144} \mathrm{Ce}^{\mathrm{b}}$ & $154_{\mathrm{Eu}} \mathrm{b}$ & \\
\hline 15 & 0.0381 & 0.019 & - & 290 & - & $<32$ & $1.44 \mathrm{E} 3$ & $1.2 \mathrm{E} 3$ & $2.5 \mathrm{E3}$ & 390 & 0.83 \\
\hline 15 & 0.0381 & 0.057 & - & 250 & $<120$ & 79 & $1.31 \mathrm{E3}$ & $1.10 \mathrm{E} 3$ & $<1.1 \mathrm{E3}$ & 362 & 0.84 \\
\hline 15 & 0.0381 & 0.095 & - & 86 & $<76$ & 42 & $1.03 \mathrm{E} 3$ & 860 & $<600$ & 148 & 0.84 \\
\hline 30 & 0.0762 & 0.152 & - & 4.9 & $<34$ & $17 \cdot 5$ & 590 & 495 & $<240$ & 22 & 0.83 \\
\hline 30 & 0.0762 & 0.23 & - & $<0.05$ & $<11$ & 3.7 & 279 & 229 & $<75$ & $<0.2$ & 0.82 \\
\hline 30 & 0.0762 & 0.30 & - & $<0.02$ & $<4$ & $<0.53$ & 130 & 106 & $<30$ & $<0.7$ & 0.81 \\
\hline 30 & 0.0762 & 0.46 & - & $<6.9 \mathrm{E}-3$ & $<1.2$ & $<0.14$ & 32.7 & 25.9 & $<8$ & $3 \cdot 3 E-2$ & 0.79 \\
\hline 30 & 0.0762 & 0.61 & - & $<2.3 \mathrm{E}-3$ & $<0.4$ & $<0.04$ & 9.1 & 6.9 & $<2.8$ & 1.3E-2 & 0.76 \\
\hline 30 & 0.0762 & 0.69 & - & $1.7 \mathrm{E}-3$ & $<0.23$ & $<0.02$ & 5.3 & 3.9 & $<1.5$ & $5 \cdot 3 \mathrm{E}-3$ & 0.75 \\
\hline 30 & 0.0762 & 0.76 & - & $<1.3 E-3$ & $<0.22$ & $<0.02$ & 2.72 & 1.98 & $<1.3$ & 6.9E-3 & 0.73 \\
\hline 30 & 0.0762 & 0.84 & 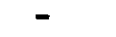 & $3 \cdot 2 \mathrm{E}-3$ & $<0.11$ & $<0.01$ & 1.64 & 1.13 & $<0.7$ & $8.4 \mathrm{E}-3$ & 0.69 \\
\hline 15 & 0.0381 & 0.89 & - & 0.033 & $<0.35$ & 0.059 & 7.2 & 4.5 & $<2.5$ & 0.29 & 0.63 \\
\hline 15 & 0.0381 & 0.93 & 0.014 & 0.078 & $<0.16$ & 0.032 & 1.62 & 0.93 & $<1.2$ & 0.079 & 0.57 \\
\hline 16 & 0.0406 & 0.97 & 1.02 & 1.63 & $<0.48$ & 0.21 & 7.1 & 4.2 & - & 0.53 & 0.59 \\
\hline
\end{tabular}

a Thickness of sample milled from sleeve.

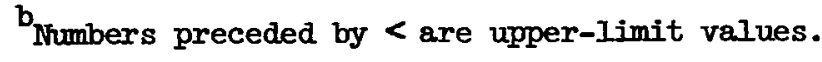


Table 4.3-8. Radial distribution sf gammamemitting radionuclides found in F03-01 spine at compact 28 (corrected to October 31, 1977)

\begin{tabular}{|c|c|c|c|c|c|c|c|c|c|c|c|}
\hline \multirow{2}{*}{\multicolumn{2}{|c|}{$\begin{array}{l}\text { Thickness } \\
(\mathrm{mils}) \quad(\mathrm{cm})\end{array}$}} & & \multicolumn{8}{|c|}{ Radionuclide concentration $(\mu \mathrm{Ci} / \mathrm{g})$} & \multirow{2}{*}{$\begin{array}{c}137_{\mathrm{Cs}} /{ }^{134} \mathrm{Cs} \\
\text { ratio }\end{array}$} \\
\hline & & $\begin{array}{l}\text { of cut from OD } \\
(\mathrm{cm})\end{array}$ & $54 \mathrm{Mn}$ & ${ }^{60} \mathrm{Co}$ & ${ }^{106} \mathrm{Ru}^{\mathrm{b}}$ & $110 \mathrm{~m}_{\mathrm{Ag}}^{\mathrm{b}}$ & $134 \mathrm{Cs}$ & $137 \mathrm{Cs}$ & \multicolumn{2}{|c|}{$144 \mathrm{Ce}^{\mathrm{b} 154} \mathrm{Eu}$} & \\
\hline 6 & 0.0152 & 0.0076 & - & 80.4 & $1.09 \mathrm{E} 2$ & $<4.0$ & 97 & 91 & $9.3 \mathrm{E} 2$ & 99 & 0.94 \\
\hline 15 & 0.0381 & 0.0343 & - & 16.9 & - & $<1.0$ & 15 & 12.1 & - & 36 & 0.80 \\
\hline 30 & 0.0762 & 0.091 & - & 15.2 & $<2.6$ & $<0.8$ & 9.3 & 6.9 & $<28$ & 30 & 0.75 \\
\hline 30 & 0.0762 & 0.168 & - & 12.5 & - & $<0.2$ & 8.1 & 5.9 & $<7$ & 23 & 0.73 \\
\hline 30 & 0.0762 & 0.244 & - & 11.0 & - & $<0.4$ & 6.5 & 4.6 & $<15$ & 19 & 0.71 \\
\hline 30 & 0.0762 & 0.396 & - & 9.4 & - & $<0.4$ & 4.2 & 2.7 & $<14$ & 14.1 & 0.66 \\
\hline 30 & 0.0762 & 0.472 & - & 8.5 & $<0.9$ & $<0.3$ & 3.4 & 2.0 & $<10$ & 11.8 & 0.60 \\
\hline 30 & 0.0762 & 0.549 & - & 7.7 & - & $<0.3$ & 2.6 & 1.5 & $<9$ & 9.7 & 0.55 \\
\hline 30 & 0.0762 & 0.625 & - & 7.4 & $<0.9$ & $<0.3$ & 2.2 & 1.09 & $<9$ & 8.7 & 0.49 \\
\hline 30 & 0.0762 & 0.701 & - & 7.1 & - & $<0.3$ & 1.8 & 0.77 & $<9$ & $7 \cdot 3$ & 0.42 \\
\hline 30 & 0.0762 & 0.777 & - & 6.6 & $<0.8$ & $<0.3$ & 1.6 & 0.60 & $<9$ & 6.3 & 0.37 \\
\hline 60 & 0.1524 & 0.892 & 0.13 & 6.0 & $<0.6$ & $<0.2$ & 1.3 & 0.39 & $<6$ & 5.0 & 0.29 \\
\hline 68 & 0.1727 & 1.054 & 0.11 & 5.3 & - & $<0.2$ & 1.16 & 0.21 & $<6$ & 3.6 & 0.18 \\
\hline 62.5 & 0.1588 & 1.70 & - & 1.9 & - & $<0.08$ & 1.13 & 0.18 & $<2$ & 1.1 & 0.16 \\
\hline
\end{tabular}

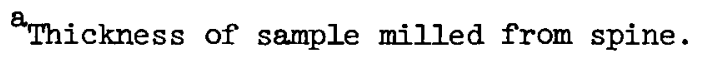

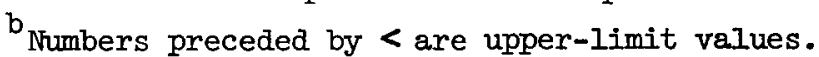




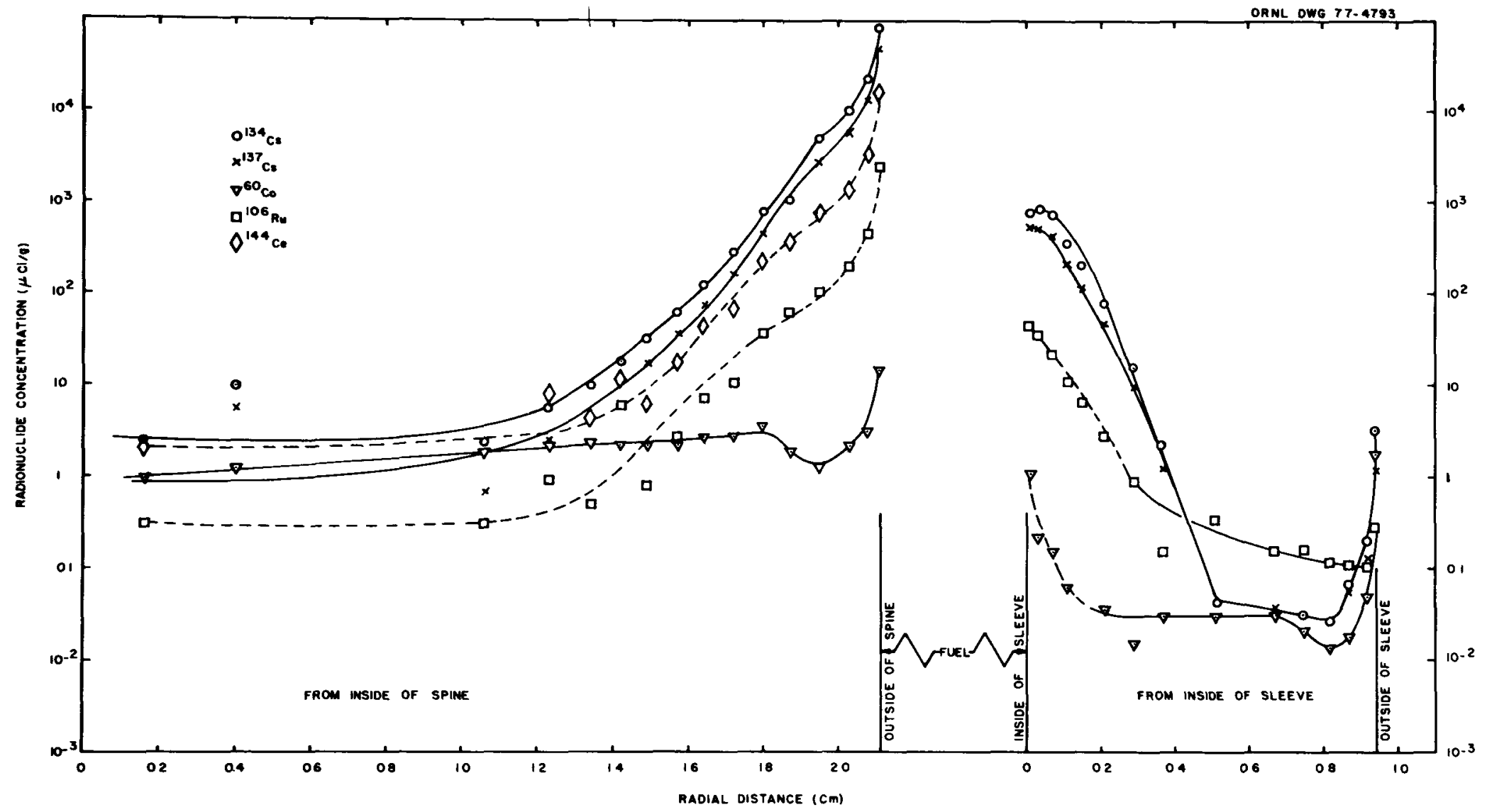

Fig. 4.3-1. Radial distribution of gamma-emitting radionuclides found at compact 5 in element FO3-O1 (corrected to October 31, 1974). 


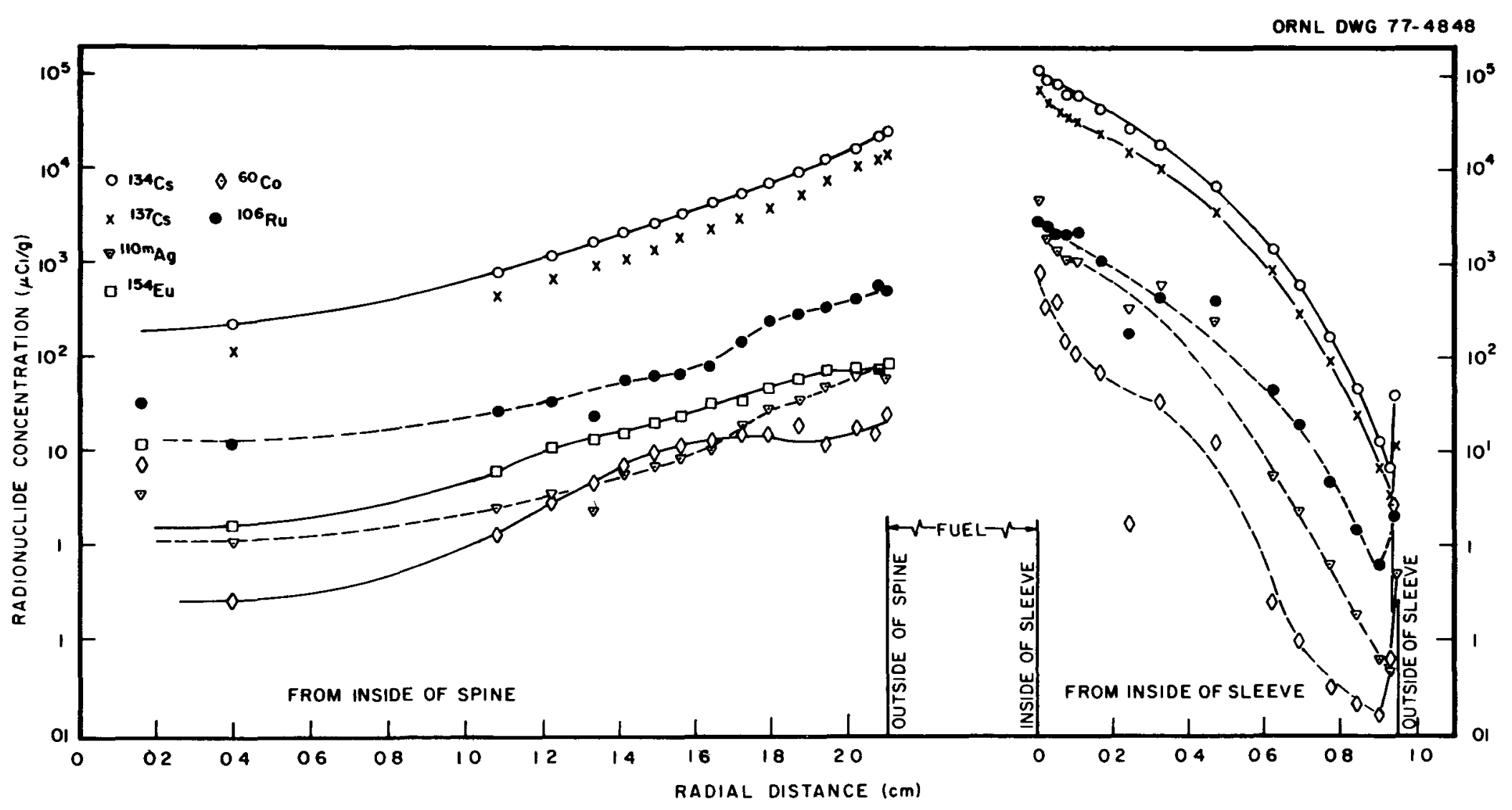

Fig. 4.3-2. Radial distribution of gamma-emitting radionuclides at compact 12 in element FO3-01 (corrected to October 31, 1974). 


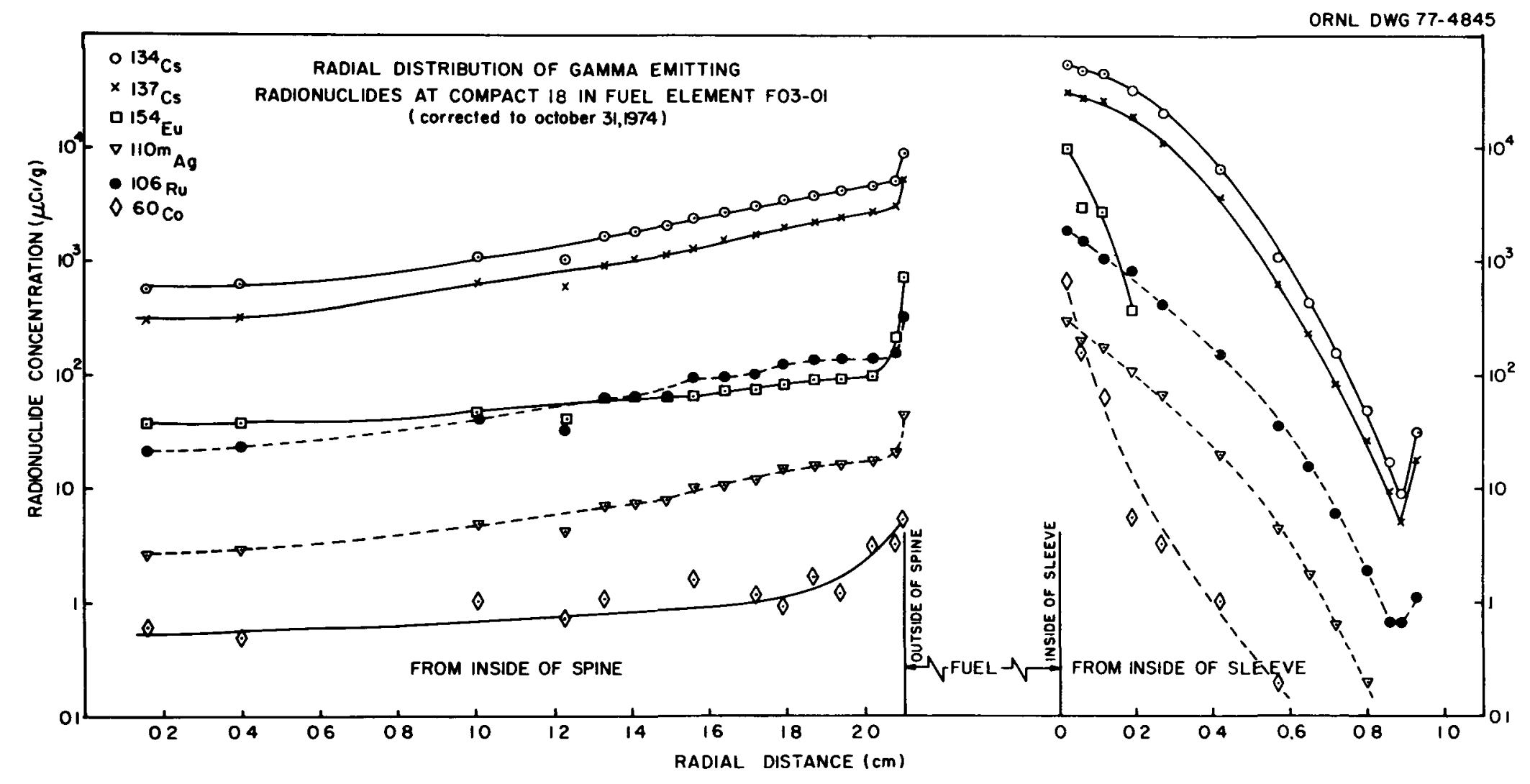

Fig. 4.3-3. Radial distribution of gamma-emitting radionuclides at compact 18 in element FO3-O1 (corrected to October 31, 1974). 


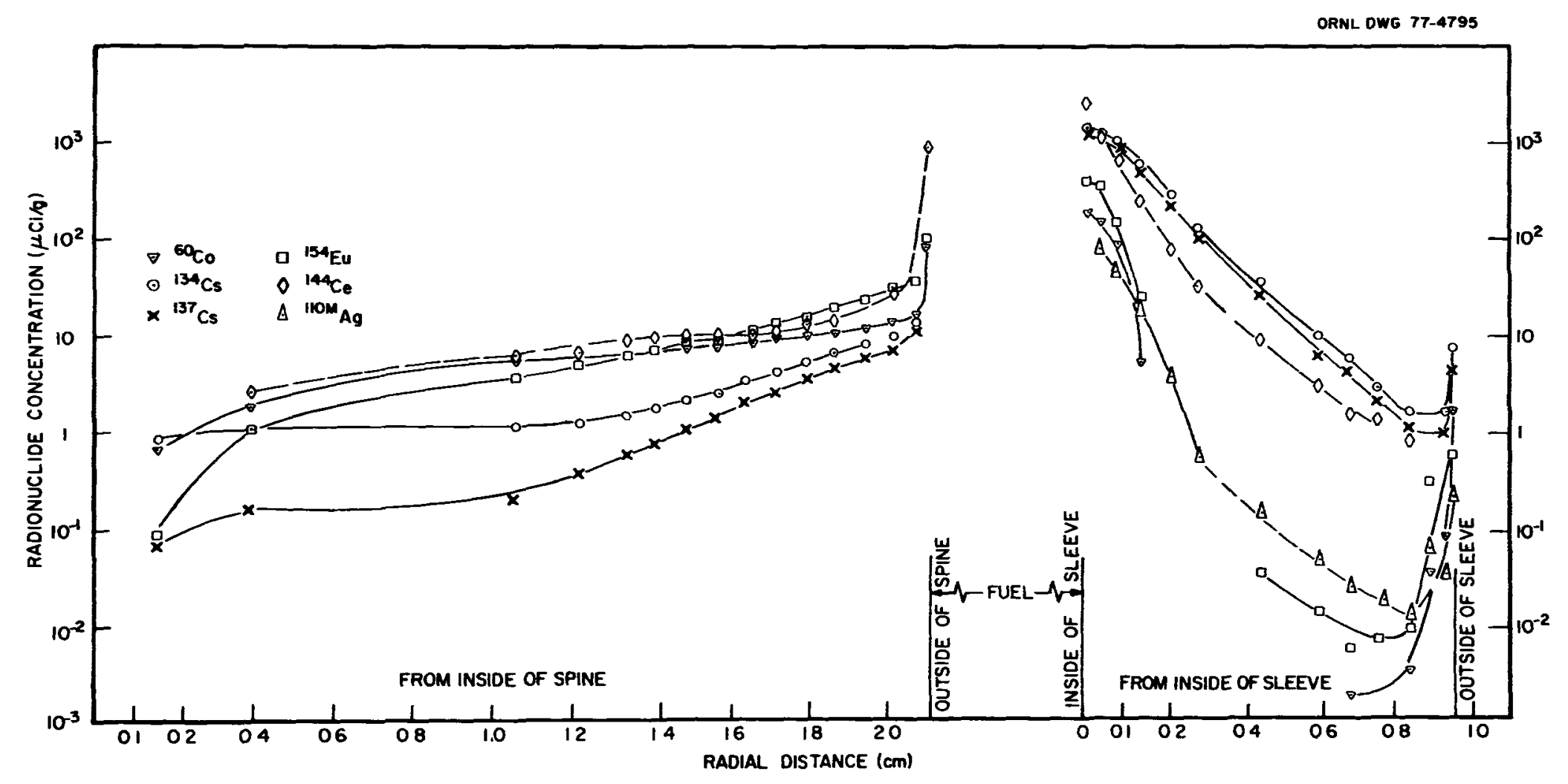

Fig. 4.3-4. Radial distribution of gamma-emitting radionuclides at compact 28 in element F03-01 (corrected to October 31, 1974). 
values; the actual profiles are unknown. Generally, the nuclides ${ }^{106} \mathrm{Ru}$, $110 \mathrm{~m}_{\mathrm{Ag}}$, and ${ }^{144} \mathrm{Ce}$ are the only ones represented as upper limits. Since the upper-limit values derived for these nuclides are governed by the nuclides that are present in larger concentrations, principally ${ }^{134} \mathrm{Cs}$ and ${ }^{137} \mathrm{Cs}$, the upper-limit profiles usually follow the profiles of the cesium isotopes.

The ${ }^{137} \mathrm{Cs} /{ }^{134} \mathrm{Cs}$ ratios given in the radial distribution tables are plotted in Fig. 4.3-5. Some of the factors that influence this ratio are discussed in the report describing the examination of fuel element Ell-07 (ref. 2). The ${ }^{137} \mathrm{Cs} /{ }^{134} \mathrm{Cs}$ ratio in the higher-temperature regions of the element, which varies only slightly from the surfaces adjacent to the fuel to the inside of the spine and to the outside of the sleeve, evidently indicates that the migration of metallic species of ${ }^{137} \mathrm{Cs}$ and ${ }^{134} \mathrm{Cs}$ is the predominant mode of cesium transfer. In the spine at compact Iocation 28 , the rapid decrease of the ratio indicates that the migration of ${ }^{133} \mathrm{Xe}$ is relatively more important in regulating the levels of ${ }^{134} \mathrm{Cs}$. The strange behavior of the ratio in the sleeve at compact location 5 is not presently understood.

The bottom connector was radially dissected just below the point where it was joined to the sleeve. The observed radial distributions are given in Table $4.3-9$.

$$
\text { 5. DISTRIBUTIONS OF }{ }^{3} \text {, }{ }^{14} \mathrm{C}, \text { AND }{ }^{90} \mathrm{Sr}
$$

\subsection{Axial Distributions in the Top Reflector}

Axial distributions of the beta-emitters ${ }^{3} \mathrm{H},{ }^{14} \mathrm{C}$, and ${ }^{90} \mathrm{Sr}$ were determined only in samples removed from the inside of the purge-gas entrance tube and the porous plug in the top reflector of the element. The radiochemical methods used to effect these analyses are outlined in Sect. 5 of ref. 2. The results of the measurements are listed in Table 5.1-1 and plotted in Fig. 5.1-1. It is interesting to note that the levels of both ${ }^{3} \mathrm{H}$ and ${ }^{14} \mathrm{C}$ increase markedly from the top of the element to the bottom of the porous plug, whereas ${ }^{90} \mathrm{Sr}$ is fairly constant except at the 


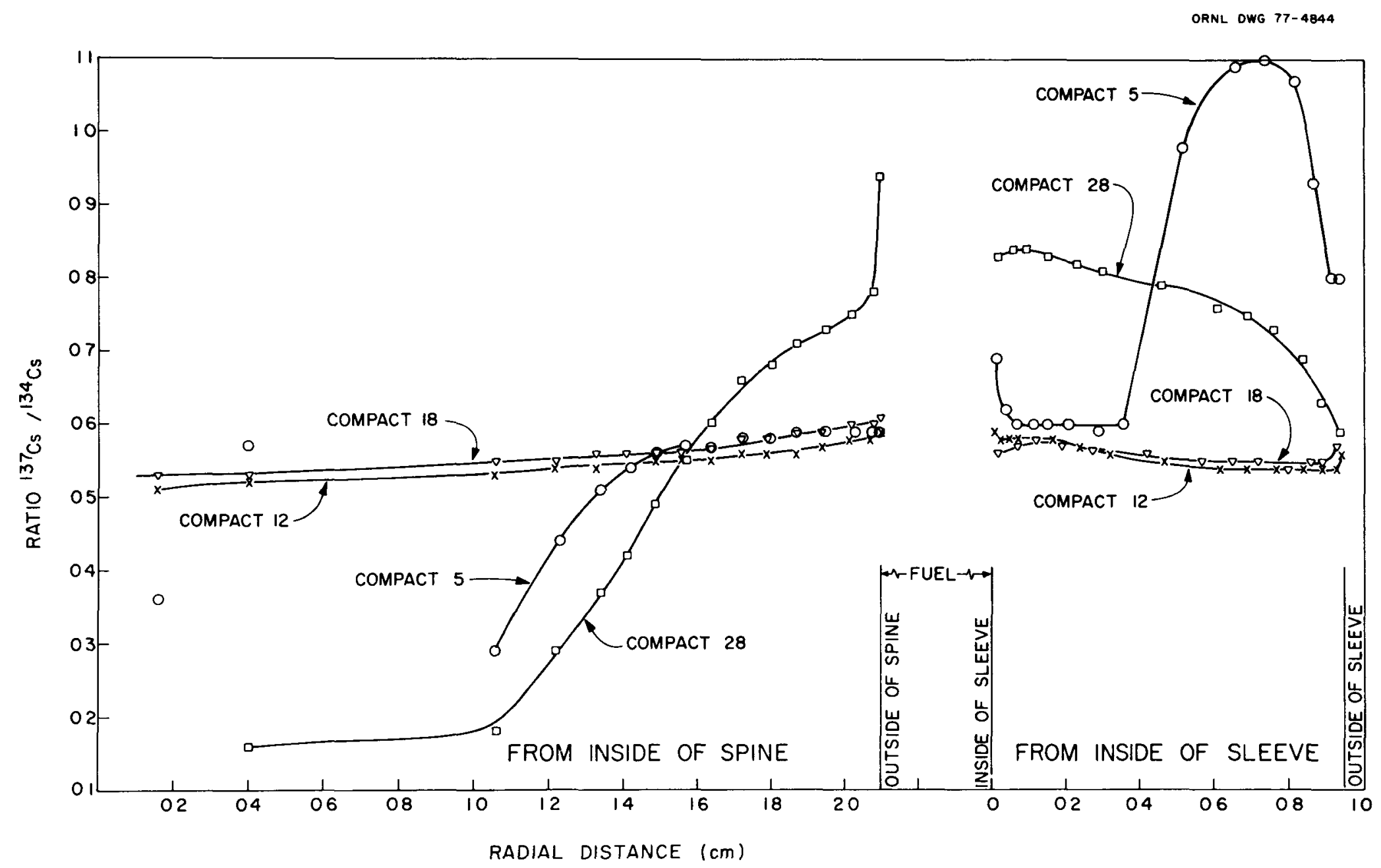

Fig. 4.3-5. Radial distribution of the ${ }^{137} \mathrm{Cs} /{ }^{134} \mathrm{Cs}$ ratio at compacts 5, 12, 18, and 28 in element FO3-O1 (corrected to October 31, 1974). 
Table 4.3-9. Radial distribution of gammamemitting radionuclides found in F03-01 bottom connector

(corrected to October 31, 1974)

\begin{tabular}{|c|c|c|c|c|c|c|c|c|c|c|c|}
\hline \multirow{2}{*}{\multicolumn{2}{|c|}{$\begin{array}{l}\text { Thickness } \\
\text { (mils) }(\mathrm{cm})\end{array}$}} & Distance to center & \multicolumn{8}{|c|}{ Radionuclide concentration $(\mu \mathrm{Ci} / \mathrm{g})$} & \multirow{2}{*}{${ }_{\text {ratio }}^{137} \mathrm{Cs} /{ }^{134} \mathrm{Cs}$} \\
\hline & & $\begin{array}{l}\text { of cut Irom } 10 \\
(\mathrm{~cm})\end{array}$ & $54 \mathrm{Mn}$ & ${ }^{60} \mathrm{Co}$ & ${ }^{106} \mathrm{Ru}$ & $110 \mathrm{~m}_{\mathrm{Ag}} \mathrm{b}$ & $134 \mathrm{Cs}$ & $137 \mathrm{Cs}$ & ${ }^{144} \mathrm{Ce}^{\mathrm{b}}$ & $154_{\mathrm{Eu}^{\mathrm{b}}}$ & \\
\hline 20 & 0.0508 & 0.025 & 0.028 & 0.17 & $<0.093$ & 0.082 & 2.30 & 1.83 & $<0.63$ & 0.023 & 0.80 \\
\hline 40 & 0.1016 & 0.107 & - & $5.2 \mathrm{E}-3$ & $<5 \mathrm{E}-3$ & $2.43 E-3$ & $2.79 \mathrm{E}-2$ & $2.51 \mathrm{E}-2$ & - & $<3.5 \mathrm{E}-4$ & 0.90 \\
\hline 40 & 0.1016 & 0.203 & $1.84 \mathrm{E}-3$ & $7.88 \mathrm{E}-3$ & $<3 E-3$ & - & $8.68 \mathrm{E}-3$ & $6.76 \pm-3$ & - & $6.92 \mathrm{E}-4$ & 0.78 \\
\hline 60 & 0.1524 & 0.330 & - & $3 \cdot 56 \mathrm{E}-3$ & $<1.9 \mathrm{E}-3$ & $6.13 E-4$ & $1.02 \mathrm{E}-2$ & $7.72 \mathrm{E}-3$ & - & $2.51 E-4$ & 0.76 \\
\hline 60 & 0.1524 & 0.635 & - & $2.94 \mathrm{E}-3$ & $<1.02 \mathrm{E}-3$ & $<4.1 \mathrm{E}-4$ & $3.04 E-3$ & $2.09 \mathrm{E}-3$ & $<1.2 \mathrm{E}-2$ & $<1.38 \mathrm{E}-4$ & 0.69 \\
\hline 60 & 0.1524 & 0.940 & - & $4.09 \mathrm{E}-3$ & $<1.5 \mathrm{E}-3$ & $<6.7 \mathrm{E}-4$ & $2.55 E-3$ & $1.80 \mathrm{E}-3$ & $<1.47 \mathrm{E}-2$ & $<8.37 \mathrm{E}-5$ & 0.71 \\
\hline 60 & 0.1524 & 1.245 & - & $3.22 \mathrm{E}-3$ & $<3.3 E-4$ & $<1.08-4$ & $1.63 \mathrm{E}-3$ & $1.06 \mathrm{E}-3$ & - & $3.14 \mathrm{E}-5$ & 0.65 \\
\hline 60 & 0.1524 & 1.549 & - & $3.49 E-3$ & $<1.4 \mathrm{E}-3$ & $<5.2 \mathrm{E}-4$ & $1.70 \mathrm{E}-3$ & $1.09 \mathrm{E}-3$ & $<1.43 \mathrm{E}-2$ & $<1.49 \mathrm{E}-4$ & 0.64 \\
\hline 60 & 0.1524 & 1.854 & - & $3.14 \mathrm{E}-3$ & $<1.7 \mathrm{E}-3$ & - & $2.50 \mathrm{E}-3$ & $1.68 \mathrm{E}-3$ & $<1.58 \mathrm{E}-2$ & $<8.71 E-5$ & 0.67 \\
\hline 60 & 0.1524 & 2.159 & - & $3.47 \mathrm{E}-3$ & $<3.5 \mathrm{E}-3$ & $<9.5 \mathrm{E}-4$ & $9.83 E-3$ & $6.98 \mathrm{E}-3$ & $<3.4 \mathrm{E}-2$ & $7.78 E-3$ & 0.71 \\
\hline 60 & 0.1524 & 2.464 & - & $3 \cdot 1 E-3$ & $<2 . \mathrm{OE}-3$ & $<7 . \mathrm{OE}-4$ & $4.39 \mathrm{E}-3$ & $3.26 \mathrm{E}-3$ & $<1.7 \mathrm{E}-2$ & $<2.24 \mathrm{E}-4$ & 0.74 \\
\hline 62.5 & 0.1588 & 3.553 & - & $5.9 \mathrm{E}-3$ & $<5.8 \mathrm{E}-3$ & 1. $39 \mathrm{E}-2$ & $1.17 \mathrm{E}-2$ & $9.4 \mathrm{E}-3$ & - & $<1.17 \mathrm{E}-3$ & 0.80 \\
\hline 62.5 & 0.1588 & 3.712 & - & $5.4 \mathrm{E}-2$ & $<1.12 \mathrm{E}-2$ & $1.66 \mathrm{E}-2$ & $4.66 \mathrm{E}-2$ & $4.25 \mathrm{E}-2$ & - & $1.6 \mathrm{E}-3$ & 0.91 \\
\hline
\end{tabular}

a Thickness of sample milled from spine.

Numbers preceded by < are upper-limit values. 
Table 5.1-1. Axial distribution of beta-emitting radionuclides found in $\mathrm{FO}-\mathrm{Ol}$ top reflector (corrected to October 31, 1974)

\begin{tabular}{|c|c|c|c|c|}
\hline $\begin{array}{l}\text { Location }^{2} \\
\quad(\mathrm{~cm})\end{array}$ & $\begin{array}{l}\text { Section } \\
\text { length } \\
(\mathrm{cm})\end{array}$ & $\frac{\text { Radionuclide }}{3_{\mathrm{H}}}$ & $\frac{\text { concentration }}{{ }^{14} \mathrm{C}}$ & $\frac{(\mu \mathrm{C} i / g)}{90_{\mathrm{Sr}}}$ \\
\hline \multicolumn{5}{|c|}{ Samples from purge hole ${ }^{c}$} \\
\hline 4.1 & 8.1 & 0.86 & 0.034 & 0.053 \\
\hline 12.4 & 8.5 & 1.0 & 0.025 & 0.039 \\
\hline 20.4 & 7.6 & 1.38 & 0.053 & 0.007 \\
\hline $27 \cdot 3$ & 5.2 & 2.04 & 0.072 & 0.011 \\
\hline 32.4 & 5.1 & 2.08 & 0.089 & $\leq 0.003$ \\
\hline 37.2 & 4.4 & 2.66 & 0.118 & 0.041 \\
\hline 42.1 & 5.4 & 2.99 & 0.172 & 0.010 \\
\hline \multicolumn{5}{|c|}{ Samples from porous plug } \\
\hline 43.4 & 1.2 & 22.73 & 0.969 & 0.259 \\
\hline 46.6 & 1.2 & 27.88 & 2.72 & 0.716 \\
\hline 48.0 & 1.7 & 24.22 & 0.667 & 0.14 \\
\hline 49.8 & 1.9 & 33.7 & 0.296 & 0.06 \\
\hline 51.8 & 2.1 & 51.9 & 0.346 & 0.024 \\
\hline 54.0 & 2.3 & 91.3 & 0.394 & 0.027 \\
\hline 56.0 & 1.7 & 157.3 & 0.308 & 0.138 \\
\hline
\end{tabular}

aistance from top of element to center of the section. $\mathrm{b}_{\text {Length }}$ of section.

${ }^{C}$ Data were obtained by cutting the top reflector into sections and drilling the inner surface of purge tube and portions of the porous plug. 
ORNL DWG 77-1616

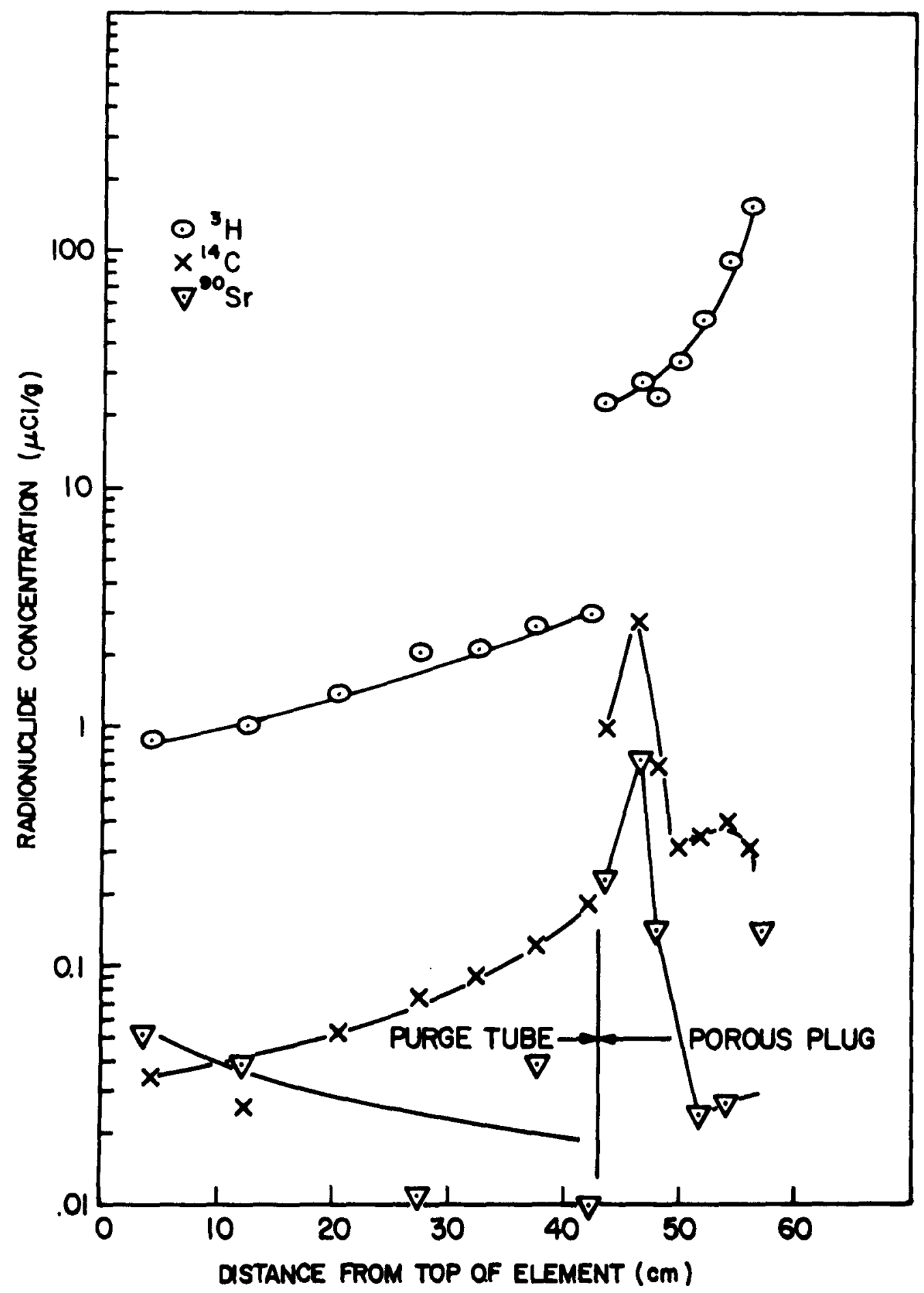

Fig. 5.1-1. Axial distribution of beta-emitting radionuclides in F03-01 top reflector (corrected to October 31, 1974). 
top and bottom of the porous plug -- a behavior similar to that observed for ${ }^{137}$ Cs, as shown in Table 4.2-9.

\subsection{Radial Distributions in the Sleeve, Spine, and Bottom Connector}

Radial distributions of ${ }^{3} \mathrm{H},{ }^{14} \mathrm{C}$, and ${ }^{90} \mathrm{Sr}$ measured in the sleeve and spine adjacent to fuel compacts 5, 12, 18, and 28 are listed in Tables 5.2-1 through 5.2-8 and plotted in Figs. 5.2-1 through 5.2-4.

Radial distributions of ${ }^{3} \mathrm{H}$ and ${ }^{14} \mathrm{C}$ observed in the bottom connector are listed in Table 5.2-9. Strontium-90 measurements in these specimens were not attempted.

\section{FXAMINATION OF FUEL PARTICLES}

\subsection{Fission Product and Heavy-Metal Inventories in Fuel Particles}

The total amounts of fission products were measured in a series of fuel particles recovered from fuel compacts 2, 13, 19, and 28. Fission product inventories are given in Table 6.1-1. Two particles were selected from each of these compacts, and the heavy-metal radionuclides ${ }^{233} \mathrm{U},{ }^{239} \mathrm{Pu}$, ${ }^{241} \mathrm{Am}$, and ${ }^{244} \mathrm{Cm}$ were determined by alpha spectroscopy. Thorium-232 was measured colorimetrically. Inventories of these nuclides are listed in Table 6.1-2. The abundances of the uranium isotopes ${ }^{23} \mathrm{U},{ }^{23}{ }^{\mathrm{U}} \mathrm{U},{ }^{23} \mathrm{U}$, ${ }^{236} \mathrm{U}$, and ${ }^{238} \mathrm{U}$ were determined by mass spectroscopy; the results are presented in Table 6.1-3. From the amount of ${ }^{23} 3_{U}$ found by alpha spectroscopy and its isotopic abundance measured by mass spectroscopy, we computed the inventories of the total uranium and the other uranium isotopes. The inventories of all the heavy-metal nuclides, expressed in atoms per pair of particles, are summarized in Table 6.1-4. The results of similar measurements for fuel particles from compacts 2, 9, 13, 16, 19, 20, 24, and 28 of fuel element Ell-07 are reported in Tables $6.1-3,6.1-5$, and 6.1-6. In this instance, however, ${ }^{232} \mathrm{Th}, 233_{\mathrm{U}}$ (except for compact 16 ), and isotopic abundances of uranium isotopes were not determined. 
Table 5.2-1. Radial distribution of beta-emitting radionuclides found in FO3-Ol sleeve at compact 5

(corrected to October 31, 1974)

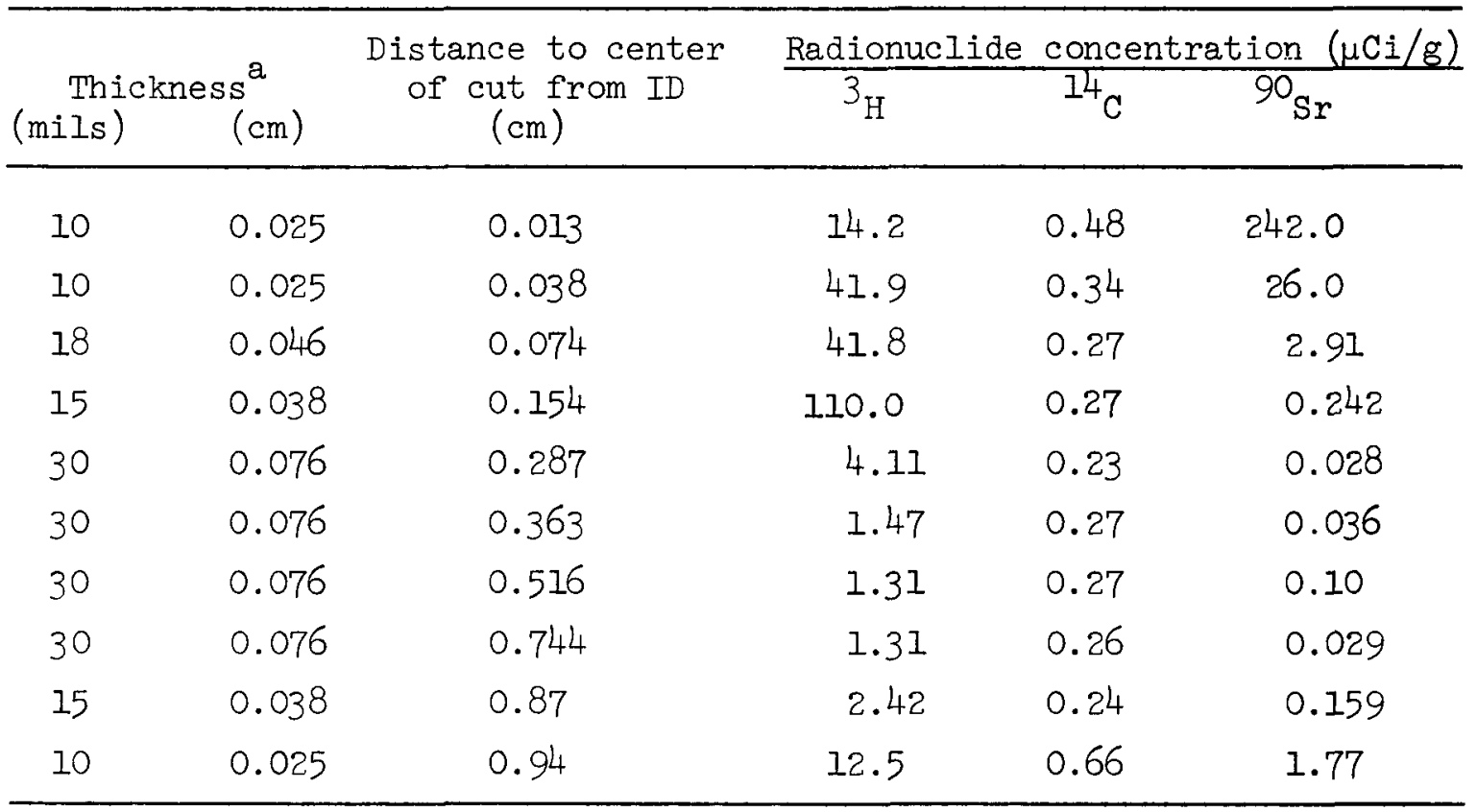

$a_{\text {Thickness of sample milled from sleeve. }}$ 
Table 5.2-2. Radial distribution of beta-emitting radionuclides found in FO3-Ol spine at compact 5 (corrected to October 31, 1974)

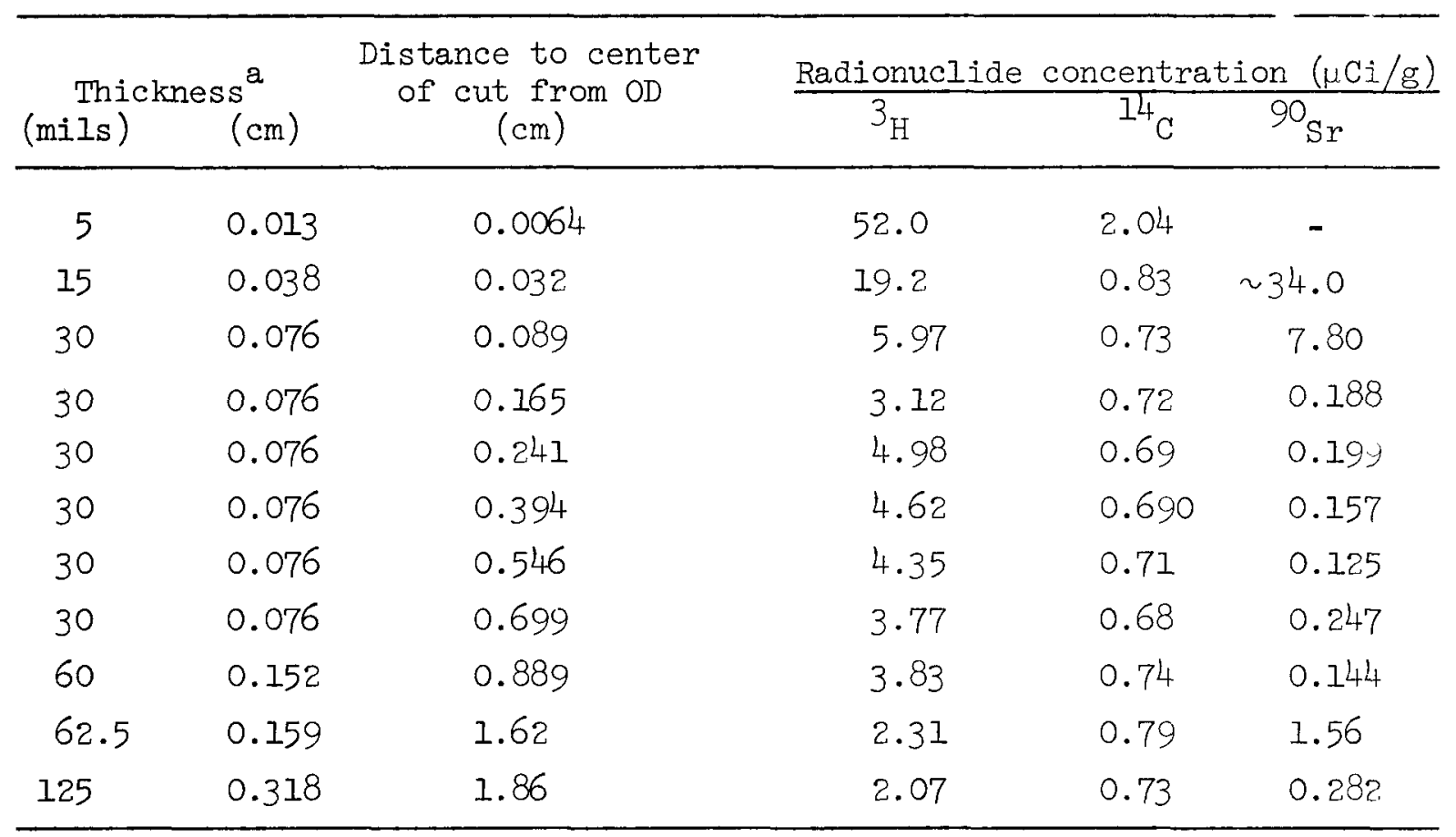

$a_{\text {Thickness of sample milled from spine. }}$ 
Table 5.2-3. Radial distribution of beta-emitting radionuclides found in FO3-O1 sleeve at compact 12

(corrected to October 31, 1974)

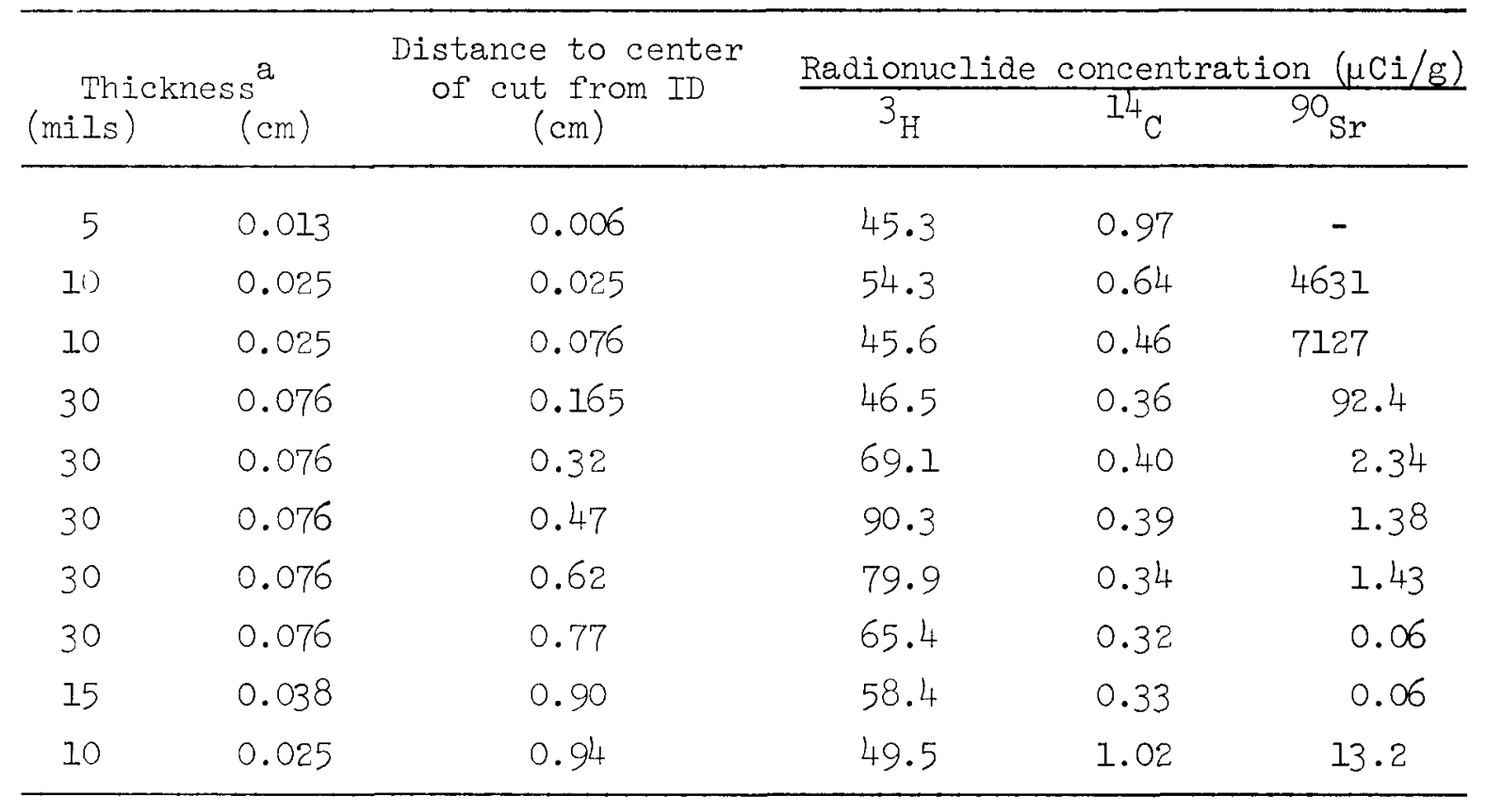

$a_{\text {Thickness of sample milled from sleeve. }}$ 
Table 5.2-4. Radial distribution of beta-emitting radionuclides found in $\mathrm{FO}-\mathrm{Ol}$ spine at compact 12

(corrected to October 31, 1974)

\begin{tabular}{|c|c|c|c|c|c|}
\hline \multicolumn{2}{|c|}{$\begin{array}{c}\text { Thickness }^{a} \\
(\text { mils })(\mathrm{cm})\end{array}$} & \multirow{2}{*}{$\begin{array}{c}\begin{array}{c}\text { Distance to center } \\
\text { of cut from OD } \\
(\mathrm{cm})\end{array} \\
0.0089\end{array}$} & \multirow{2}{*}{$\frac{\frac{\text { Radionuclide }}{3_{\mathrm{H}}}}{15.9}$} & $\frac{\text { concentration }}{{ }^{14} \mathrm{C}}$ & \multirow{2}{*}{$\frac{\frac{(\mu \mathrm{Ci} / \mathrm{g})}{90 \mathrm{Sr}}}{-}$} \\
\hline 7 & 0.018 & & & 2.25 & \\
\hline 15 & 0.038 & 0.037 & 12.0 & 0.899 & 3200 \\
\hline 30 & 0.076 & 0.094 & 6.31 & 0.787 & 2500 \\
\hline 30 & 0.076 & 0.170 & 6.68 & 0.865 & 2300 \\
\hline 30 & 0.076 & 0.246 & 6.14 & 0.881 & 1900 \\
\hline 30 & 0.076 & 0.400 & 5.42 & 0.873 & 1510 \\
\hline 30 & 0.076 & 0.551 & 4.76 & 0.940 & 1220 \\
\hline 30 & 0.076 & 0.704 & 4.66 & 0.955 & 738 \\
\hline 60 & 0.152 & 0.894 & 3.73 & 0.850 & 489 \\
\hline 62.5 & 0.159 & 1.62 & 2.54 & 0.912 & 149 \\
\hline 125 & 0.318 & 1.86 & 2.48 & 0.892 & 99 \\
\hline
\end{tabular}

$a_{\text {Thickness of sample milled from spine. }}$ 
104

Table 5.2-5. Radial distribution of beta-emitting radionuclides found in FO3-01 sleeve at compact 18

(corrected to October 31, 1974)

\begin{tabular}{|c|c|c|c|c|c|}
\hline $\begin{array}{l}\text { Thicknes } \\
\text { (mils) }\end{array}$ & $(\mathrm{cm})$ & $\begin{array}{l}\text { Distance to center } \\
\text { of cut from ID } \\
(\mathrm{cm})\end{array}$ & $\frac{\text { Radionuclide }}{3_{\mathrm{H}}}$ & $\frac{\text { concentrat }}{{ }^{14} \mathrm{C}}$ & $\frac{\text { ion }(\mu \mathrm{Ci} / \mathrm{g})}{90_{\mathrm{Sr}}}$ \\
\hline 15 & 0.038 & 0.019 & 17.7 & 0.52 & $1.28 \mathrm{E} 5$ \\
\hline 15 & 0.038 & 0.057 & 16.7 & 0.41 & $1.46 \mathrm{E} 5$ \\
\hline 30 & 0.076 & 0.114 & 19.8 & 0.42 & $7 \cdot 38 \mathrm{E} 4$ \\
\hline 30 & 0.076 & 0.27 & 21.1 & 0.30 & $4.16 \mathrm{E} 3$ \\
\hline 30 & 0.076 & 0.42 & 29.6 & 0.35 & 4.1 \\
\hline 30 & 0.076 & 0.57 & 45.8 & 0.37 & $3 \cdot 5$ \\
\hline 30 & 0.076 & 0.72 & 71.1 & 0.35 & 0.07 \\
\hline 15 & 0.038 & 0.86 & 47.8 & 0.34 & 1.0 \\
\hline 11 & 0.028 & 0.93 & 43.5 & 0.72 & 21.7 \\
\hline
\end{tabular}

$a_{\text {Thickness of sample milled from sleeve. }}$ 
Table 5.2-6. Radial distribution of beta-emitting radionuclides found in FO3-01 spine at compact 18

(corrected to october 31, 1974)

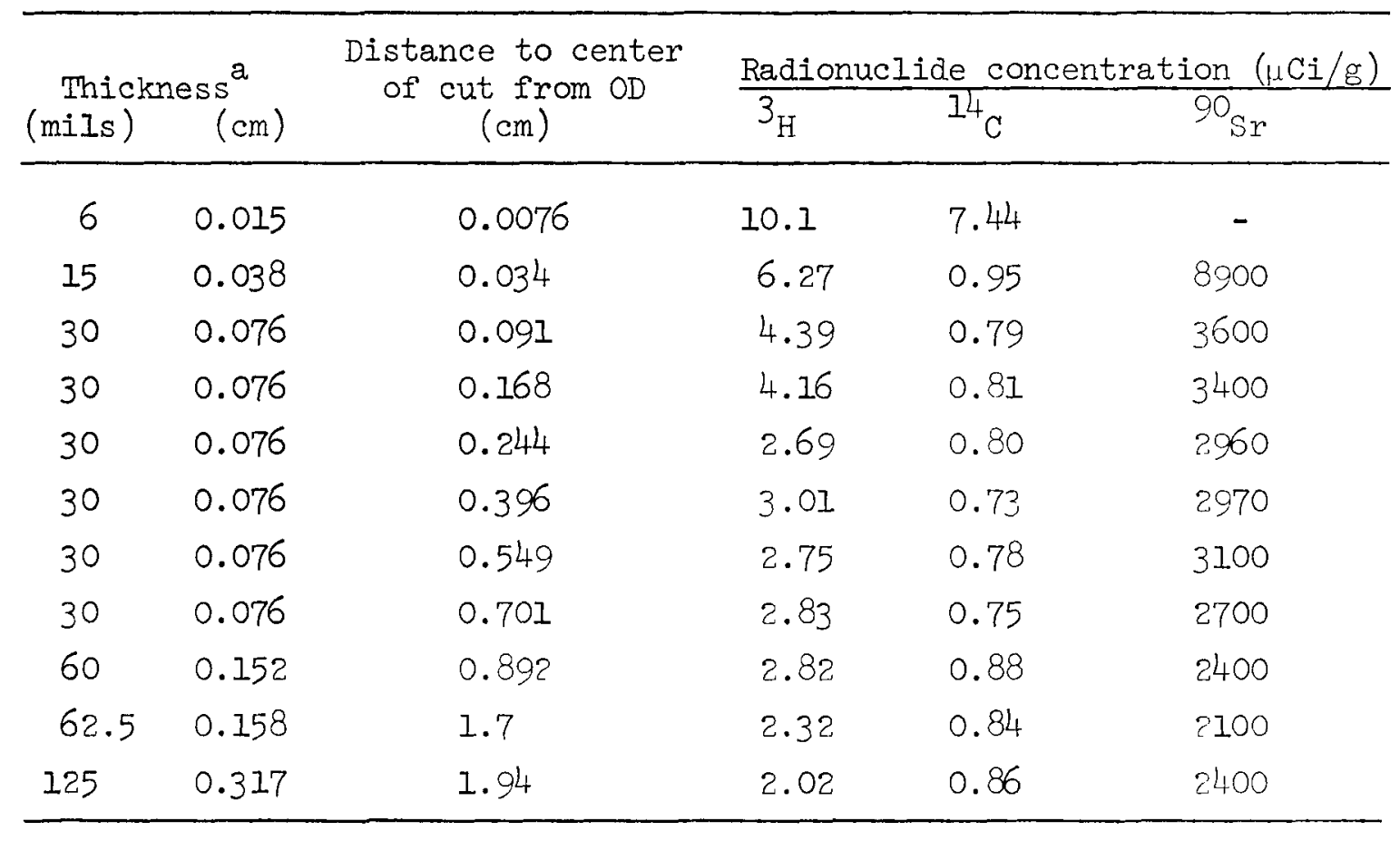

$a_{\text {Thickness of sample milled from spine. }}$ 
Table 5.2-7. Radial distribution of beta-emitting radionuclides found in FO3-OI spine at compact 28

(corrected to October 31, 1974)

\begin{tabular}{cccccc}
\hline $\begin{array}{c}\text { Thickness } \\
(\mathrm{mils})\end{array}$ & $(\mathrm{cm})$ & $\begin{array}{c}\text { Distance to center } \\
\text { of cut from oD } \\
(\mathrm{cm})\end{array}$ & \multicolumn{2}{c}{ Radionuclide concentration $(\mu \mathrm{Ci} / \mathrm{g})$} \\
\hline 6 & 0.015 & 0.0076 & 14.2 & 6.04 & $90_{\mathrm{Sr}}$ \\
\hline 15 & 0.038 & 0.0343 & 7.03 & 1.03 & 7300 \\
30 & 0.076 & 0.0914 & 1.94 & 0.54 & 2000 \\
30 & 0.076 & 0.168 & 1.87 & 0.52 & 1400 \\
30 & 0.076 & 0.244 & 1.93 & 0.56 & 1380 \\
30 & 0.076 & 0.396 & 1.46 & 0.65 & 1200 \\
30 & 0.076 & 0.549 & 1.25 & 0.53 & 910 \\
30 & 0.076 & 0.701 & 1.12 & 0.59 & 540 \\
60 & 0.152 & 0.892 & 0.87 & 0.64 & 350 \\
62.5 & 0.158 & 1.7 & 0.52 & 0.52 & 230 \\
125 & 0.317 & 1.94 & 0.47 & 0.54 & 19 \\
\hline
\end{tabular}

$a_{\text {Thickness of sample milled from spine. }}$ 
Table 5.2-8. Radial distribution of beta-emitting radionuclides found in FO3-O1 sleeve at compact 28 (corrected to october 31, 1974)

\begin{tabular}{cccccc}
\hline \multicolumn{2}{c}{$\begin{array}{c}\text { Thickness } \\
\text { (mils) }\end{array}$} & $(\mathrm{cm})$ & $\begin{array}{c}\text { Distance to center } \\
\text { of cut from ID } \\
(\mathrm{cm})\end{array}$ & \multicolumn{2}{c}{ Radionuclide concentration $(\mu \mathrm{Ci} / \mathrm{g})$} \\
\hline 15 & 0.038 & 0.019 & 0.17 & 0.003 & $1.2 \mathrm{E} 4$ \\
15 & 0.038 & 0.057 & 16.0 & 0.31 & $9.5 \mathrm{E} 3$ \\
30 & 0.076 & 0.152 & 13.5 & 0.22 & 519 \\
30 & 0.076 & 0.30 & 14.1 & 0.21 & 0.03 \\
30 & 0.076 & 0.46 & 10.1 & 0.21 & 0.17 \\
30 & 0.076 & 0.61 & 22.6 & 0.21 & 0.06 \\
30 & 0.076 & 0.76 & 34.5 & 0.21 & $\sim 0.02$ \\
15 & 0.038 & 0.89 & 42.2 & 0.21 & 5.9 \\
15 & 0.038 & 0.97 & 33.9 & 0.53 & 9.6 \\
\hline
\end{tabular}

$a_{\text {Thickness of sample milled from sleeve. }}$ 


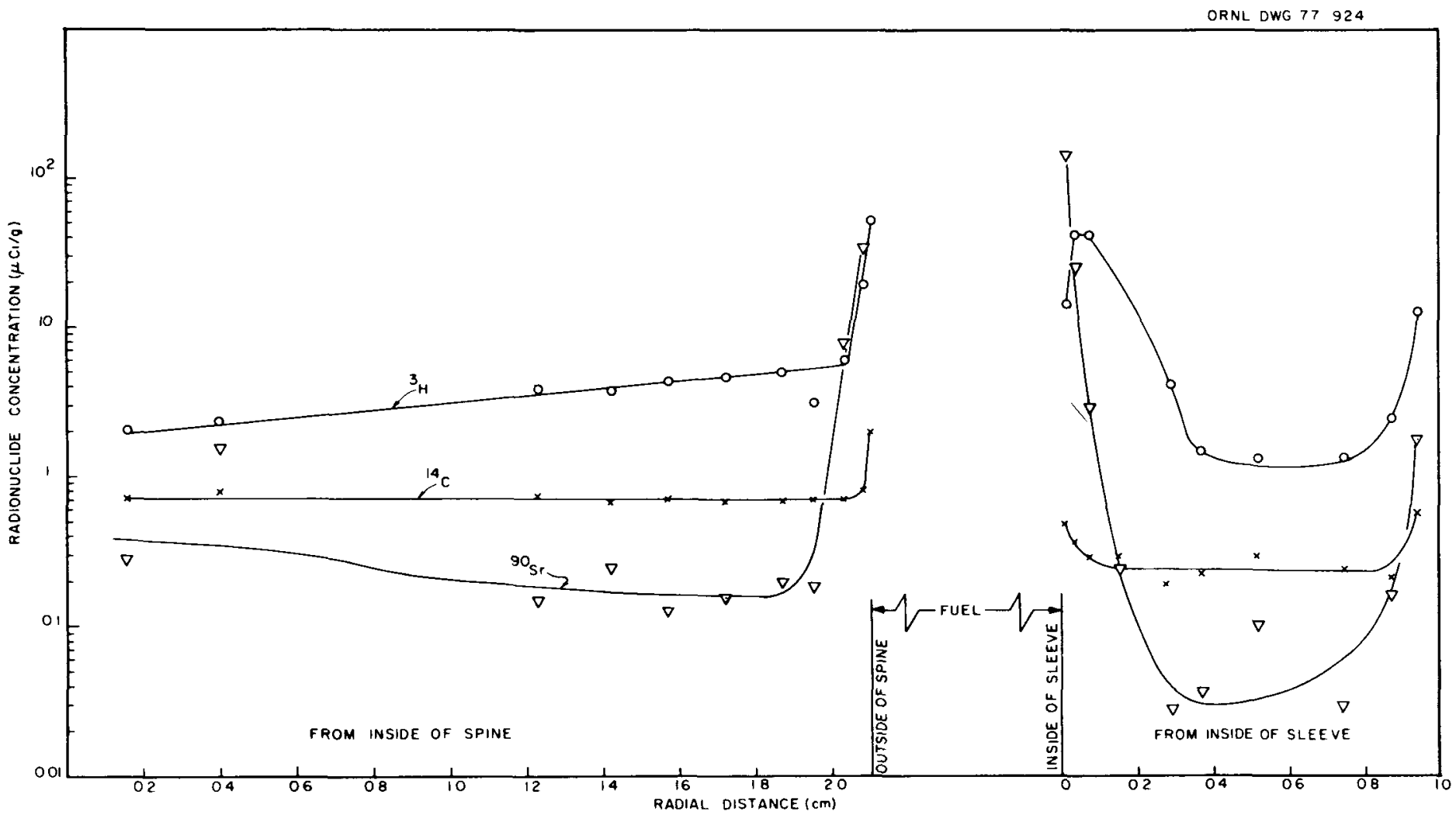

Fig. 5.2-1. Radial distribution of beta-emittine radionuclides in element FO3-OI at compact 5 (correcter to october 1,$]^{\prime} / 74$ ). 


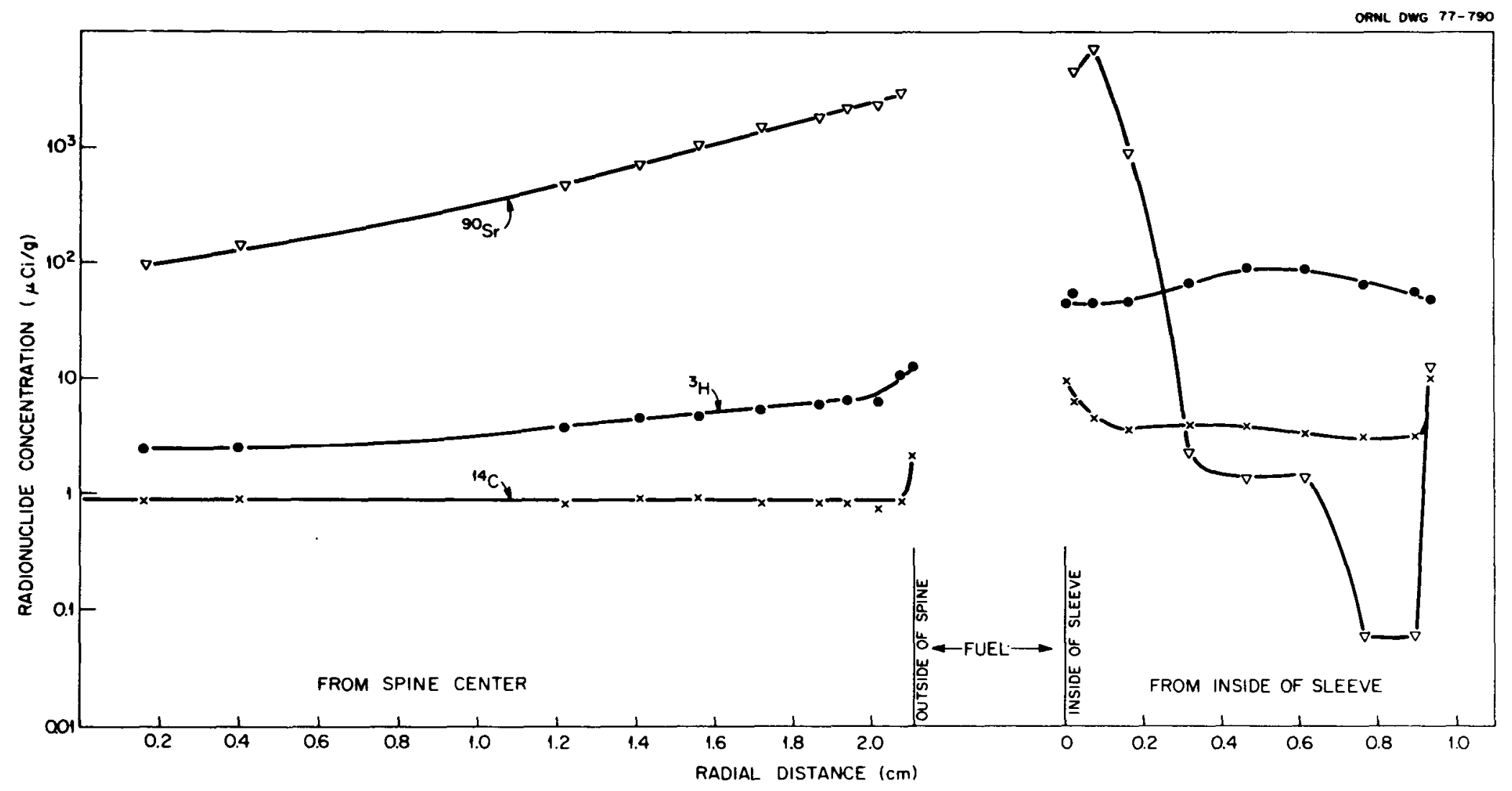

Fig. 5.2-2. Radial distribution of beta-emitting radionuclides in element FO3-O1 at compact 12 (corrected to October 31, 1974). 


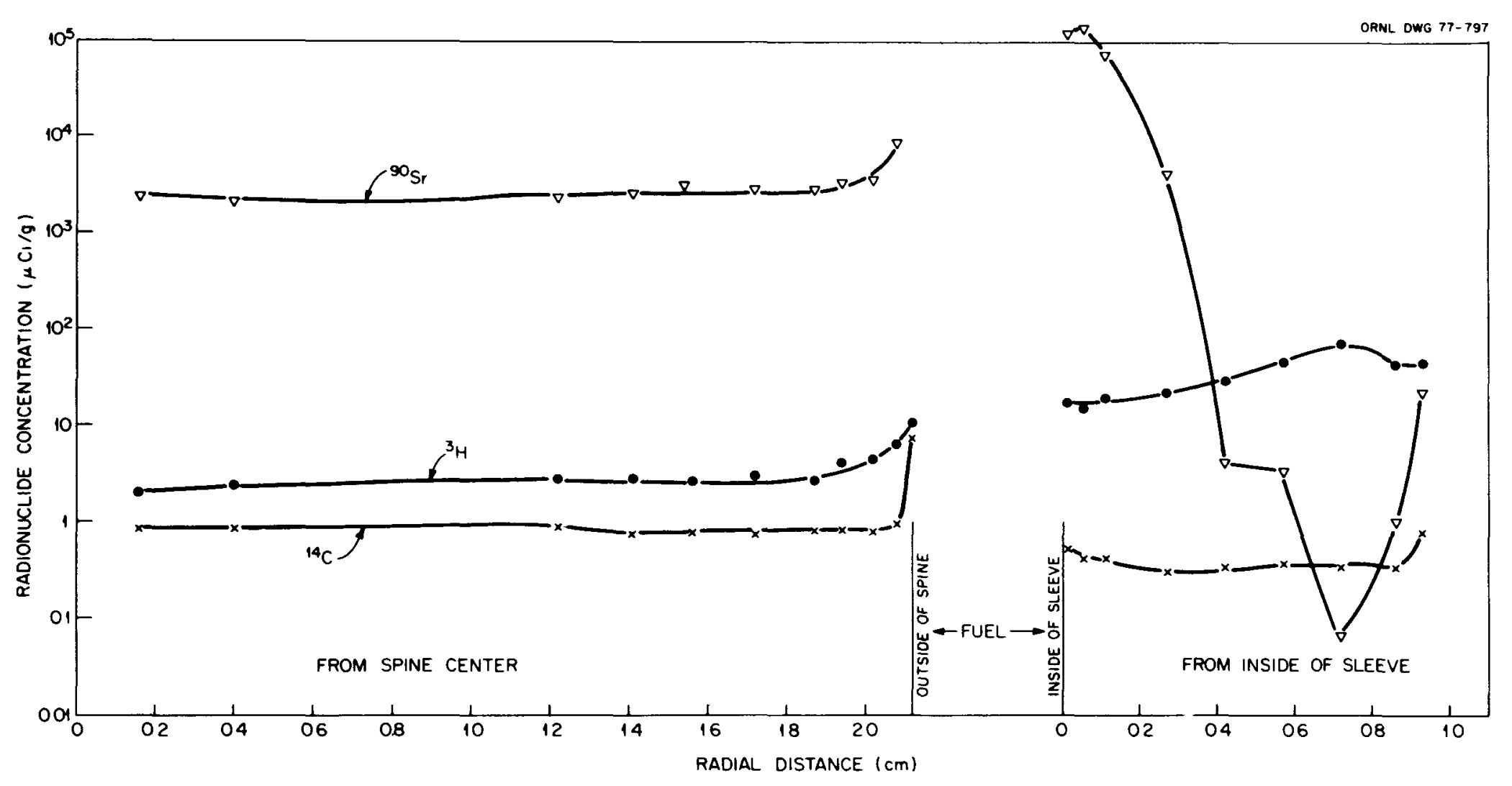

Fig. 5.2-3. Radial distribution of beta-emitting radionuclides in element FO3-O1 at compact 18 (corrected to October 31, 1974). 


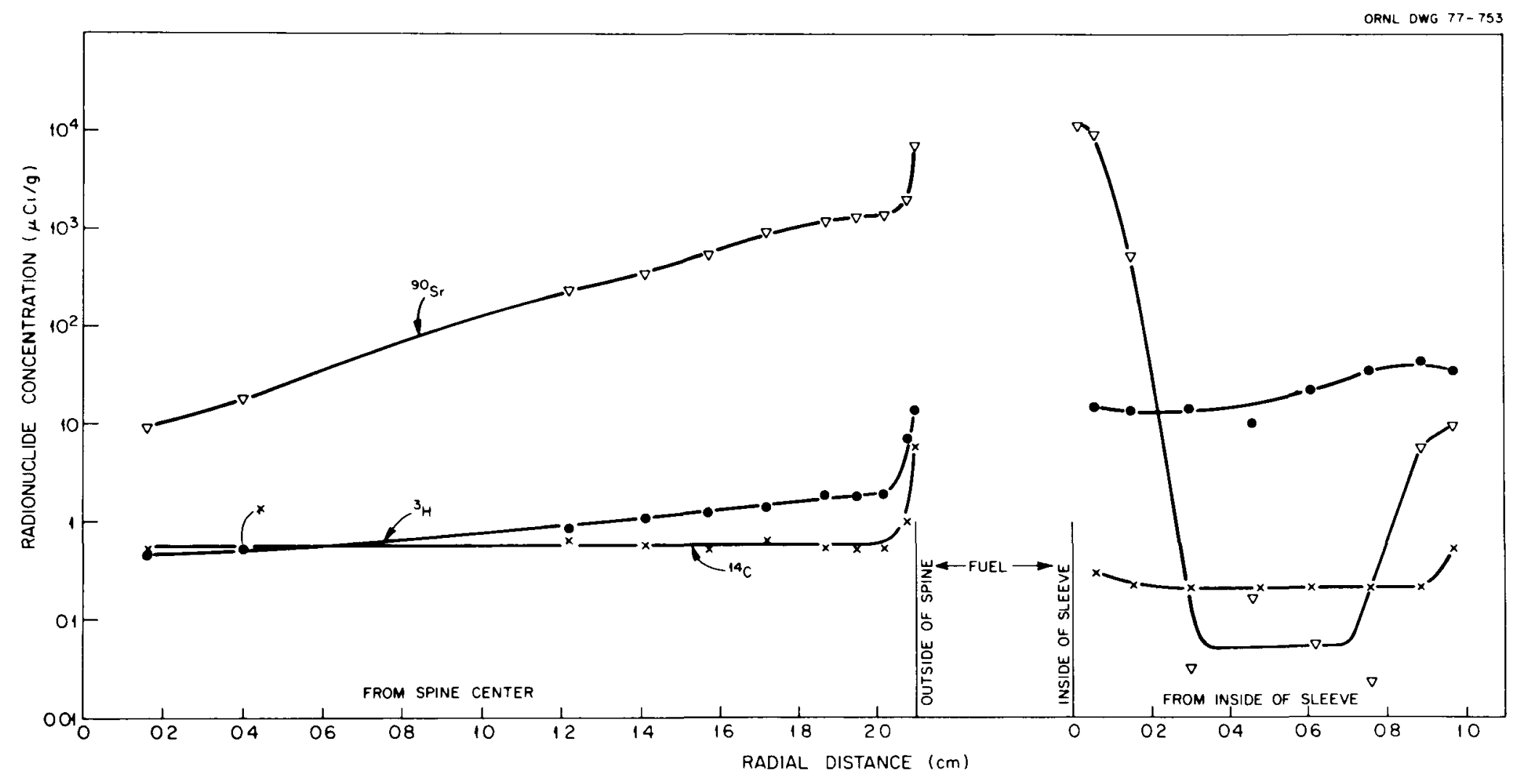

Fig. 5.2-4. Radial distribution of beta-emitting radionuclides in element FO3-OI at compact 28 (corrected to nctober 31, 1974). 
Table 5.2-9. Radial distribution of beta-emitting radionuclides found in $\mathrm{FO}-\mathrm{Ol}$ bottom connector

$$
\text { (corrected to October 31, 1974) }
$$

\begin{tabular}{|c|c|c|c|c|}
\hline $\begin{array}{l}\text { Thic. } \\
\text { (mils) }\end{array}$ & $e^{e s s^{a}}(\mathrm{~cm})$ & $\begin{array}{c}\text { Distance to center } \\
\text { of cut from OD } \\
(\mathrm{cm})\end{array}$ & $\frac{\text { Radionuclide }}{3_{\mathrm{H}}}$ & $\frac{\text { concentration }(\mu \mathrm{Ci} / \mathrm{s})}{{ }^{14} \mathrm{C}}$ \\
\hline 20 & 0.0508 & 0.025 & 3.84 & 0.049 \\
\hline 40 & 0.1016 & 0.107 & 0.238 & 0.034 \\
\hline 40 & 0.1016 & 0.203 & 0.206 & 0.028 \\
\hline 60 & 0.1524 & 0.330 & 0.212 & $0.03 I$ \\
\hline 60 & 0.1524 & 0.940 & 0.217 & 0.019 \\
\hline 60 & 0.1524 & 1.549 & 0.219 & 0.022 \\
\hline 60 & 0.1524 & 2.159 & 0.233 & 0.020 \\
\hline 60 & 0.1524 & 2.464 & 0.232 & 0.022 \\
\hline 62.5 & 0.1588 & 3.553 & 0.256 & 0.028 \\
\hline 62.5 & 0.1588 & 3.712 & 0.469 & 0.025 \\
\hline
\end{tabular}

arhickness of sample milled from the bottom connector. 
Table 6.1-1. Inventories of fission products in single fuel particles of element $\mathrm{FO}-\mathrm{OI}$

(corrected to October 31, 1974)

\begin{tabular}{|c|c|c|c|c|c|c|c|}
\hline \multirow[b]{2}{*}{ Compact } & \multirow{2}{*}{$\begin{array}{c}\text { Particle } \\
\text { No. }\end{array}$} & \multicolumn{6}{|c|}{ Radionuclide concentration ( $\mu \mathrm{Ci} /$ particle) } \\
\hline & & ${ }^{106} \mathrm{Ru}$ & $125 \mathrm{Sb}$ & $134 \mathrm{Cs}$ & $137_{\mathrm{Cs}}$ & ${ }^{144} \mathrm{Ce}$ & ${ }^{154} \mathrm{Eu}$ \\
\hline \multirow[t]{4}{*}{2} & 1 & 11.7 & 0.64 & 15.3 & 18.8 & 146 & 0.40 \\
\hline & 2 & 10.6 & 0.62 & 11.9 & 15.0 & 114 & 0.36 \\
\hline & 3 & 10.9 & 0.88 & 14.9 & 18.4 & 135 & 0.41 \\
\hline & 4 & 10.6 & 0.61 & 13.3 & 16.4 & 128 & 0.38 \\
\hline \multirow[t]{4}{*}{13} & 1 & 44.4 & 2.98 & 123.5 & 78.6 & 455 & 1.96 \\
\hline & 2 & 45.1 & 3.14 & 115.7 & 74.4 & 511 & 1.87 \\
\hline & 3 & 53.5 & 2.84 & 138.5 & 88.3 & 547 & 1.94 \\
\hline & 4 & 39.8 & 2.27 & 102.1 & 66.3 & 386 & 1.21 \\
\hline \multirow[t]{4}{*}{19} & 1 & 41.7 & 2.20 & 95.5 & 62.5 & 414.7 & 0.93 \\
\hline & 2 & 14.5 & 1.20 & 6.6 & 7.5 & 68.8 & - \\
\hline & 3 & 14.4 & 1.16 & 7.1 & 7.2 & 60.0 & - \\
\hline & 4 & 23.3 & 1.92 & 11.8 & 12.2 & 114.8 & - \\
\hline \multirow[t]{4}{*}{28} & 1 & 19.0 & 1.41 & 7.4 & 8.5 & 69 & - \\
\hline & 2 & 10.5 & 0.70 & 13.9 & 14.2 & 110 & 0.13 \\
\hline & 3 & 25.0 & I. 58 & 36.3 & 35.5 & 285 & 0.60 \\
\hline & 4 & 9.7 & 0.58 & 14.1 & 14.3 & 112 & 0.20 \\
\hline
\end{tabular}


Table 6.1-2. Heavy-metal radionuclides determined in FO3-O1 fuel particles by alpha spectroscopy

\begin{tabular}{cccccc}
\hline \multirow{2}{*}{ Compact } & $\begin{array}{c}\text { Particle } \\
\text { No. }\end{array}$ & \multicolumn{4}{c}{ Radionuclide concentration $(\mu \mathrm{Ci} /$ two particles) } \\
\cline { 3 - 6 } $233_{\mathrm{U}}$ & ${ }^{238} \mathrm{Pu}$ & ${ }^{241_{\mathrm{Am}}}$ & ${ }^{244} \mathrm{Cm}$ \\
13 & $1-2$ & 0.0156 & 0.276 & 0.0743 & 0.001 \\
19 & $1-2$ & 0.0391 & 4.59 & 0.60 & 0.13 \\
28 & $1-2$ & 0.0121 & 1.19 & 0.229 & 0.021 \\
\hline
\end{tabular}

Table 6.1-3. Abundances of uranium isotopes found in

fuel particles by mass spectroscopy

\begin{tabular}{lccccccc}
\hline \multirow{2}{*}{$\begin{array}{c}\text { Fuel } \\
\text { element }\end{array}$} & Compact & $\begin{array}{c}\text { Particle } \\
\text { No. }\end{array}$ & $233_{U}$ & $234_{U}$ & $235_{U}$ & ${ }^{236_{U}}$ & ${ }^{238_{U}}$ \\
\hline F03-01 & 2 & $1-2$ & 13.25 & 1.39 & 67.63 & 9.74 & 7.98 \\
F03-01 & 13 & $1-2$ & 24.50 & 3.51 & 45.78 & 18.78 & 7.43 \\
F03-01 & 19 & $1-2$ & 25.09 & 3.54 & 4.4 .40 & 17.82 & 9.15 \\
F03-01 & 18 & $1-2$ & 20.22 & 2.68 & 52.86 & 15.40 & 8.84 \\
E11-07 & 16 & 1 & 21.36 & 2.87 & 52.00 & 16.39 & 7.38 \\
\hline
\end{tabular}


Table 6.1-4. Heavy-metal inventories in FO3-01 fuel particles

\begin{tabular}{|c|c|c|c|c|c|c|c|c|c|c|}
\hline \multirow[b]{2}{*}{ Compact } & \multirow{2}{*}{$\begin{array}{l}\text { Particle } \\
\text { No. }\end{array}$} & \multicolumn{9}{|c|}{ Atoms/pair of particles } \\
\hline & & $232_{\text {Th }}$ & $233_{U}$ & $234 \mathrm{U}$ & $235_{U}$ & $236_{\mathrm{U}}$ & $238_{U}$ & ${ }^{238} \mathrm{Pu}$ & $24 I_{A m}$ & ${ }^{244} \mathrm{Cm}$ \\
\hline 2 & $1-2$ & $4.41 \mathrm{EIT}$ & $4.15 \mathrm{E} 15$ & $4.35 \mathrm{E} 14$ & $2.12 E 16$ & $3.05 \mathrm{E} 15$ & $2.50 \mathrm{E} 15$ & $4.08 \mathrm{EI3}$ & $5.29 E 13$ & $\sim 5 E 10$ \\
\hline 13 & $1-2$ & $8.57 \mathrm{E} 17$ & $1.04 \mathrm{E} 16$ & $1.49 \pm 15$ & $1.94 \mathrm{EI} 6$ & 7.97EI5 & $3.15 \mathrm{E} 15$ & $6.79 \mathrm{E} 14$ & $4.37 \mathrm{E} 14$ & 4.3EI2 \\
\hline 19 & $1-2$ & $5.19 E 17$ & $3.22 \mathrm{E} 15$ & $4.54 \mathrm{EI} 4$ & $5.70 \mathrm{E} 15$ & $2.29 \mathrm{E} 35$ & 1.17E15 & $3.76 \mathrm{E} 14$ & $1.67 \mathrm{E} 14$ & 7.0 EII \\
\hline 28 & $1-2$ & $2.37 \mathrm{E} 17$ & $3.98 \mathrm{E} 15$ & $5.27 \mathrm{EI} 4$ & $1.04 \mathrm{E} 16$ & $3.03 \mathrm{EI}$ & $1.74 E 15$ & $7.79 E 13$ & $2.60 E 14$ & 2.2EII \\
\hline
\end{tabular}


Table 6.1-5. Inventories of fission products and heavy metals in fuel particles of element EII-07 (corrected to September 14, 1.973)

\begin{tabular}{|c|c|c|c|c|c|c|c|c|}
\hline \multirow[b]{2}{*}{ Compact } & \multirow{2}{*}{$\begin{array}{l}\text { Particle } \\
\text { No. }\end{array}$} & \multicolumn{7}{|c|}{ Radionuclide concentration ( $\mu \mathrm{Ci} /$ particle) } \\
\hline & & ${ }^{95} \mathrm{zr}$ & ${ }^{106} \mathrm{Ru}$ & ${ }^{125} \mathrm{Sb}$ & ${ }^{134} \mathrm{Cs}$ & ${ }^{137} \mathrm{Cs}$ & $144 \mathrm{Ce}$ & 154 \\
\hline \multirow[t]{13}{*}{2} & $I$ & - & 19.6 & 1.0 & 18.3 & 25.4 & 248 & 0.45 \\
\hline & 2 & 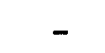 & 13.5 & 0.67 & 10.1 & 15.1 & 153 & 0.27 \\
\hline & $2 \mathrm{~A}$ & - & 15.1 & 0.73 & 11.4 & 17.0 & 171 & 0.29 \\
\hline & 3 & - & 17.6 & 0.88 & 14.9 & 21.4 & 217 & 0.37 \\
\hline & $1-2$ & - & 22.7 & 1.09 & 16.9 & 24.5 & 252 & 0.52 \\
\hline & $3-4$ & - & 18.9 & 0.91 & 15.4 & 22.1 & 212 & 0.35 \\
\hline & $5-6$ & - & 21.7 & 1.02 & 15.1 & 20.8 & 312 & 0.28 \\
\hline & $7-8$ & - & 11.8 & - & 10.9 & 16.1 & 119 & - \\
\hline & $9-10$ & - & 17.5 & & 77.8 & 40.7 & 297 & \\
\hline & $11-12$ & - & 32.0 & 1.65 & 26.2 & 38.5 & 421 & 0.64 \\
\hline & $13-14$ & - & 31.7 & $1 .{ }^{-1}$ & 26.7 & 39.4 & 396 & 0.50 \\
\hline & $15-16$ & - & 26.4 & $1 . \%$ & 20.6 & 30.0 & 309 & 0.47 \\
\hline & $17-18$ & - & 20.8 & 1.14 & 17.1 & 25.6 & 239 & 0.31 \\
\hline \multirow{8}{*}{9} & 1 & - & 19.3 & - & 55.9 & 69.1 & 161 & 1.0 \\
\hline & 2 & $1+59$ & 24.1 & 1.54 & 38.4 & 29.0 & 268 & 0.39 \\
\hline & 3 & 585 & 28.8 & 1.87 & 47.6 & 36.6 & 335 & 0.65 \\
\hline & 4 & 442 & 22.6 & 1.10 & 36.9 & 27.8 & 246 & 0.59 \\
\hline & 5 & 247 & 15.1 & 0.92 & 21.6 & 16.3 & 146 & 0.29 \\
\hline & 6 & 188 & 7.5 & 0.67 & 15.3 & 11.9 & 98 & 0.20 \\
\hline & 7 & 400 & 19.6 & 1.07 & 32.6 & 24.6 & 239 & 0.51 \\
\hline & 8 & 398 & 20.7 & 1.14 & 35.3 & 26.5 & 246 & 0.58 \\
\hline \multirow[t]{15}{*}{13} & 1 & - & 17.1 & 1.08 & 16.1 & 13.1 & 94 & 0.11 \\
\hline & $I \mathrm{~A}$ & - & 14.8 & 0.88 & 15.3 & 12.3 & 74 & 0.08 \\
\hline & 2 & - & 11.8 & 0.75 & 17.7 & 13.0 & 94 & 0.11 \\
\hline & $2 \mathrm{~A}$ & - & 13.9 & 0.86 & 12.3 & 10.3 & 84 & 0.04 \\
\hline & 3 & - & 10.7 & 0.70 & 11.4 & 9.1 & 76 & 0.04 \\
\hline & $3 \mathrm{~A}$ & - & 8.4 & 0.43 & 7.4 & 8.9 & 94 & 0.16 \\
\hline & $1-2$ & - & 24.2 & 1. 4 & 36.6 & 31.5 & 233 & 0.34 \\
\hline & $3-4$ & - & 25.6 & 1.65 & 37.5 & 27.7 & 180 & - \\
\hline & $5-6$ & _ & 41.6 & 1.65 & 52.3 & 45.8 & 329 & - \\
\hline & $7-8$ & - & 40.2 & 2.33 & 70.6 & 50.2 & 375 & 0.92 \\
\hline & $9-10$ & - & 72.7 & 4.32 & 142.2 & 98.5 & 769 & 2.57 \\
\hline & $11-12$ & - & 20.2 & 1.90 & 59.1 & 41.4 & 351 & 0.51 \\
\hline & $13-14$ & - & 39.0 & 2.05 & 63.0 & 44.3 & 400 & 1.01 \\
\hline & $15-16$ & - & 37.9 & 1.51 & 62.2 & 44.2 & 389 & 0.99 \\
\hline & $17-18$ & - & 30.4 & 1.94 & 61.4 & 44.2 & 430 & 0.96 \\
\hline \multirow[t]{8}{*}{16} & & & & 2.69 & & & 305 & - \\
\hline & 2 & 668 & 38.8 & 2.42 & 50.1 & 36.8 & 258 & - \\
\hline & 3 & 622 & 30.9 & 2.08 & 53.5 & 37.9 & 343 & 0.81 \\
\hline & 4 & 17 & - & - & 0.95 & 0.65 & 32 & 0.05 \\
\hline & 5 & 712 & 35.6 & 2.52 & 58.9 & 41.7 & 389 & 1.00 \\
\hline & 6 & 370 & 18.3 & 1.07 & 31.8 & 22.2 & 172 & 0.25 \\
\hline & 7 & 748 & 42.9 & 2.43 & 42.5 & 31.6 & 311 & - \\
\hline & 8 & 645 & 35.9 & 2.28 & 35.1 & 26.1 & 246 & \\
\hline
\end{tabular}


Table 6.1-5 (continued)

\begin{tabular}{|c|c|c|c|c|c|c|c|c|}
\hline \multirow[b]{2}{*}{ Compact } & \multirow{2}{*}{$\begin{array}{l}\text { Particle } \\
\text { No. }\end{array}$} & \multicolumn{7}{|c|}{ Radionuclide concentration ( $\mu \mathrm{Ci} /$ particle) } \\
\hline & & ${ }^{95} \mathrm{Zr}$ & ${ }^{106} \mathrm{Ru}$ & ${ }^{125} \mathrm{Sb}$ & ${ }^{134} \mathrm{Cs}$ & $137 \mathrm{Cs}$ & ${ }^{l+1} \mathrm{Ce}$ & $15+$ un \\
\hline \multirow[t]{7}{*}{16} & 9 & 255 & 13.9 & 0.94 & $23 \cdot 5$ & 16.9 & 135 & 0.5 \\
\hline & 10 & 269 & 13.5 & 0.83 & 23.5 & 16.6 & 128 & 0.17 \\
\hline & 1 & - & 45.4 & 2.82 & 34.3 & 28.0 & 265 & 0.13 \\
\hline & 2 & - & 16.0 & 1.11 & 15.7 & 12.7 & 96 & 0.05 \\
\hline & $2 \mathrm{~A}$ & - & 28.9 & 1.81 & 2.2 .7 & 19.6 & 147 & 0.05 \\
\hline & 3 & - & 31.3 & 1.96 & 22.1 & 18.2 & 206 & 0.08 \\
\hline & $3 \mathrm{~A}$ & - & 37.1 & 2.30 & 16.8 & 16.7 & 111 & 0.04 \\
\hline \multirow[t]{9}{*}{20} & $1-2$ & - & 50.9 & 2.86 & 17.3 & 21.9 & 288 & - \\
\hline & $3-4$ & - & 60.6 & 4.08 & 22.6 & 28.0 & 369 & - \\
\hline & $5-6$ & - & 39.0 & 2.24 & 14.1 & 17.6 & 223 & - \\
\hline & $7-8$ & - & 51.6 & 3.75 & 21.6 & 25.7 & 209 & - \\
\hline & $9-10$ & - & 48.8 & 2.84 & 18.2 & 21.6 & $P 58$ & - \\
\hline & $11-12$ & - & 34.4 & 2.21 & 13.2 & 15.8 & 881 & - \\
\hline & $13-14$ & - & 41.1 & 5.86 & 13.5 & 16.8 & 250 & - \\
\hline & $15-16$ & - & 37.0 & 1.81 & 11.5 & 14.0 & 281 & - \\
\hline & $17-18$ & - & 52.5 & 3.23 & 18.5 & 24.0 & 279 & - \\
\hline \multirow[t]{9}{*}{24} & $1-2$ & - & 35.1 & 2.03 & 32.2 & 30.5 & 285 & 0.30 \\
\hline & $3-4$ & - & 36.1 & 2.03 & 48.9 & 41.3 & 330 & 0.23 \\
\hline & $5-6$ & - & 26.8 & 1.77 & 37.3 & 31.9 & 246 & 0.38 \\
\hline & $7-8$ & - & 61.2 & 3.09 & 77.8 & 66.6 & 487 & 0.36 \\
\hline & $9-10$ & - & 44.6 & 2.30 & 56.0 & 47.8 & 445 & 0.67 \\
\hline & $11-12$ & - & 59.3 & 2.90 & 81.3 & 68.4 & 608 & 0.50 \\
\hline & $13-14$ & - & 25.0 & 1.25 & 36.2 & 31.3 & 219 & 0.07 \\
\hline & $15-16$ & - & 39.6 & 1.75 & 53.4 & 46.1 & 376 & 0.53 \\
\hline & $17-18$ & - & 50.2 & 2.01 & 65.5 & 56.3 & 425 & 0.77 \\
\hline \multirow[t]{17}{*}{28} & $1(2)^{a}$ & 662 & 32.6 & 2.23 & 29.3 & 36.4 & 388 & 0.32 \\
\hline & 2 & 230 & 11.8 & 0.64 & 10.6 & 13.1 & 138 & 0.13 \\
\hline & 3 & 295 & 16.0 & 0.85 & 14.3 & 17.3 & 189 & 0.22 \\
\hline & 4 & 197 & 11.2 & 0.74 & 10.0 & 12.2 & 126 & 0.13 \\
\hline & 5 & 233 & 11.8 & 0.70 & 11.0 & 13.6 & 141 & 0.12 \\
\hline & 6 & 174 & 9.7 & 0.52 & 3.5 & 10.3 & 33 & - \\
\hline & 7 & 224 & 10.7 & - & 9.8 & 12.0 & 129 & - \\
\hline & 8 & 252 & 13.9 & 0.61 & 12.5 & 15.4 & 161 & 0.16 \\
\hline & 9 & 311 & 15.0 & 1.13 & 13.3 & 16.3 & 168 & 0.22 \\
\hline & 10 & 226 & 12.0 & - & 11.0 & 13.4 & 126 & - \\
\hline & 11 & 269 & 13.3 & 0.72 & 12.3 & 15.1 & 151 & 0.13 \\
\hline & 12 & 200 & 8.9 & 0.63 & 9.0 & 11.3 & 115 & 0.13 \\
\hline & $I \mathrm{~A}$ & - & 9.0 & $0.3 i$ & 7.9 & 9.7 & 98 & 0.08 \\
\hline & 2 & - & 8.3 & 0.47 & 8.0 & 9.8 & 100 & 0.07 \\
\hline & $2 A$ & - & 16.3 & 0.91 & 16.4 & 20.0 & 202 & 0.26 \\
\hline & 3 & - & 19.5 & 1.07 & 18.0 & 22.6 & 235 & 0.18 \\
\hline & $3 A$ & - & 25.2 & 1.10 & 21.0 & 25.9 & 279 & 0.20 \\
\hline
\end{tabular}

$a_{\text {Two particles counted. }}$ 
Table 6.1-6. Inventories of heavy-metal nuclides found in Ell-07 fuel particles by alpha spectroscopy

\begin{tabular}{|c|c|c|c|c|c|}
\hline Compact & $\begin{array}{c}\text { Particle } \\
\text { No. }\end{array}$ & $\frac{\text { Radionuclide }}{233_{U}}$ & $\frac{\text { concentration }}{238 \mathrm{Pu}}$ & $\frac{1(\mu \mathrm{Ci} / \text { two }}{24 I_{\mathrm{Am}}}$ & $\frac{\text { particles) }}{244 \mathrm{Cm}}$ \\
\hline 2 & $1-2$ & 0.024 & 0.018 & 0.172 & $<9 E-4$ \\
\hline 13 & $2-3$ & 0.030 & 0.0073 & 0.446 & $<2 \mathrm{E}-3$ \\
\hline 16 & $1-2$ & 0.035 & 0.76 & & $<5 E-4$ \\
\hline 28 & $1 A-2$ & 0.027 & 0.019 & 0.124 & $<4 E-4$ \\
\hline
\end{tabular}

The procedure used to measure the heavy-metal nuclides was briefly as follows. The sample consisting of two particles that had been analyzed for gamma-emitters was dissolved in a Teflon-lined pressure vessel containing $8 \mathrm{M} \mathrm{HHO}_{3}$ and a small amount of perchloric acid. The resulting solution was nearly evaporated, perchloric acid was added, and heating was continued to ensure that the plutonium was in the hexavalent state. The solution was made $6 \mathrm{M}$ in $\mathrm{HCl}$ and quantitatively transferred to an anion exchange resin column; then a fraction containing the curium was eluted with $6 \mathrm{M} \mathrm{HCI}$. Americum-24I and some of the daughters of $232_{\mathrm{U}}$, principally ${ }^{228} \mathrm{Th}$ and ${ }^{244} \mathrm{Ra}$, also eluted with the curium. Curium-244 was measured by alpha spectroscopy after being separated from the other alpha-emitters on a IaF 3 precipitation. The plutonium in the column was eluted with a solution that was 4 M in $\mathrm{HCl}$ and $0.1 \mathrm{M}$ in $\mathrm{NH}_{4} I$. The iodide ion reduced the plutonium to Pu(III). Uranium was then eluted with 0.01 M HCl. Plutonium-238 and ${ }^{233} \mathrm{U}$ were measured by alpha spectroscopy.

\subsection{Metallographic Examination of Fuel Compacts ${ }^{*}$}

Representative photomicrographs obtained from samples of fuel compacts 2, 18, and 29 are presented in this section. The reader should keep in mind that any such collection of photomicrographs would naturally overemphasize

\footnotetext{
* These examinations were performed by the Remote Metallography Group of the Metals and Ceramics Division in the High-Radiation-Ievel Examination Iaboratory.
} 
the failed particles or other nonnormal features since it is desired to display the modes of failure. Although a number of typical particles are included, one does not obtain a proper estimate of the failed fuel fraction by scanning through this series. Determinations of the failed particle fraction by a hot-chlorine leaching procedure are presented in sect. 6.3.

The fuel particles in all Peach Bottom HTGR driver elements were of the type designated as BISO with kernels composed of mixed (Th, U) $\mathrm{C}_{2}$. Compacts 1 through 9 (numbered from the bottom of the core) and 27 through 30 were the so-called "standard compacts" with an initial Th/U ratio of 5.5 and no burnable poison. The central compacts, numbered 10 through 26 , had the same amounts of thorium and uranium as did the standard compacts and, additionally, $1.03 \mathrm{~g}$ of rhodium per compact. More complete specifications of the fuel compacts are given in ref. 1 as well as in the summary presented in Sect. 2.2 of ref. 6. No migration rate studies were made on FO3-OI particles.

The photomicrographs (Figs. 6.2-1 through 6.2-26) are presented in three sets, one for each of the three compacts. The operating conditions for these three compacts at end of life may be observed from Figs. 2.2-2 and 2.2-3, where it is seen that compact 18 sustained the highest fast and thermal fluences and highest temperature. Compact 2 at end of life had the lowest temperature and neutron fluence.

While the neutron fluence profiles presented in Fig. 2.2-3 may be considered to be reasonably accurate, the temperatures presented in Fig. 2.2-2 are highly preliminary. At present, ongoing work at GAC is endeavoring to more accurately specify Peach Bottom fuel service temperatures.

Each of the three sets of photomicrographs begins with $50 \mathrm{X}$ collective views of polished sections of the compacts which were taken near the inside and outside diameters and at the midsection of the wall of the compacts; these views include about 6 to 12 fuel particles. The collective views depict the general condition of a few particles and the matrix graphite. Most of the photographs of single particles, which follow the collective views, were taken at 200x; however, a few were taken at 500x. Most pictures were made with normal lighting, although polarized light was used in a few cases. 

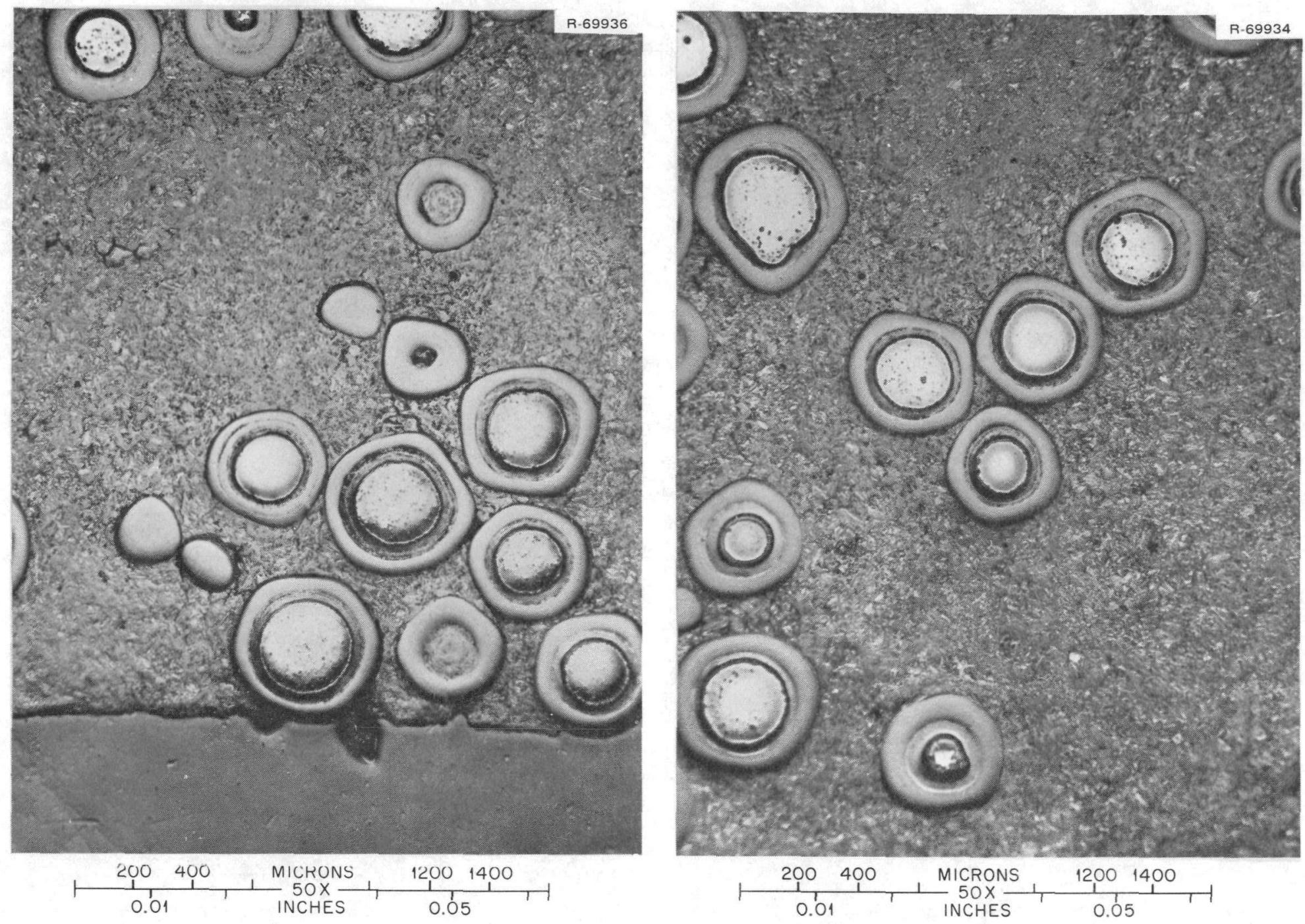

Fig. 6.2-1. Collective view near inside diameter (left) and midsection (right) of compact 2. Magnification 50X. 

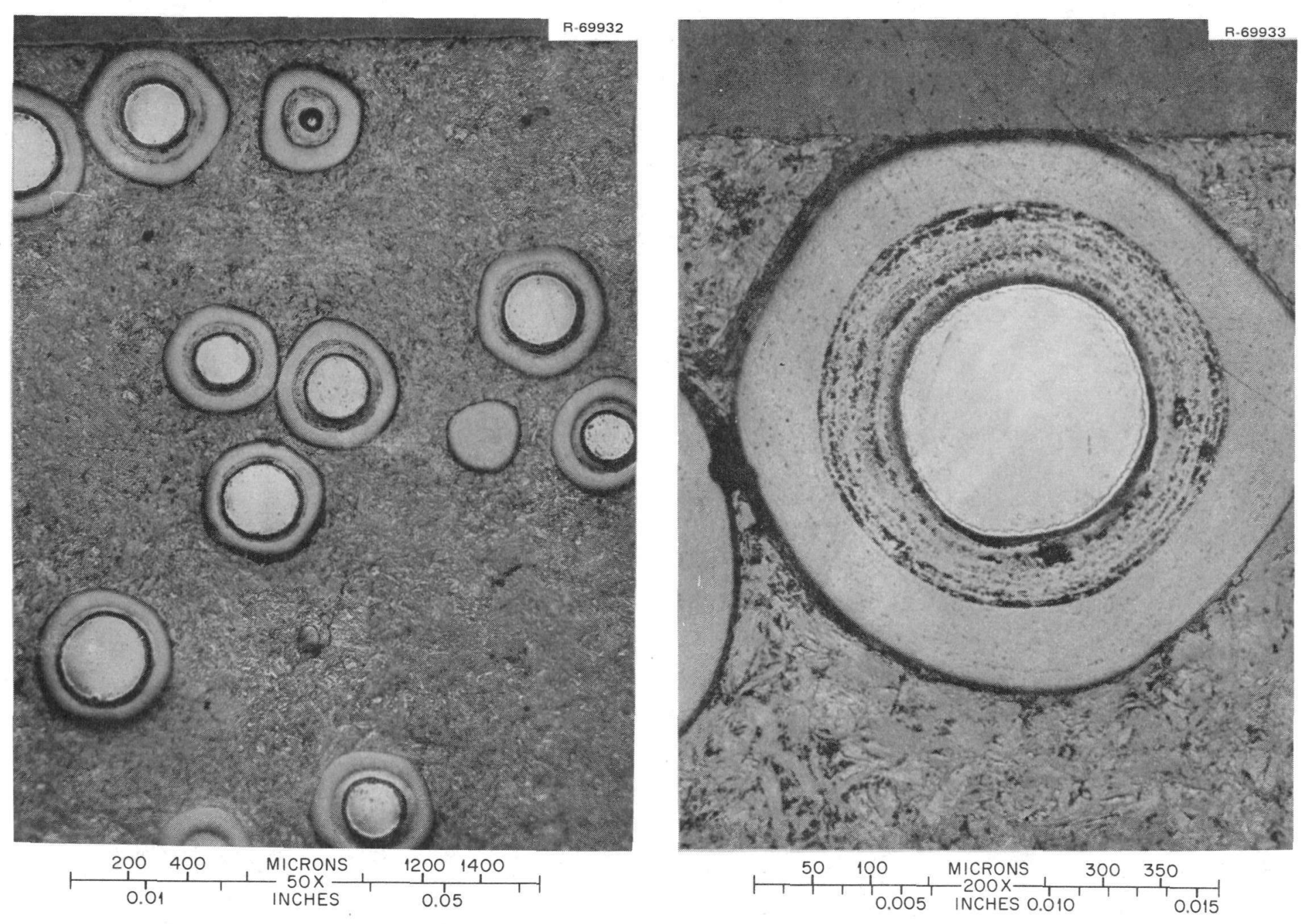

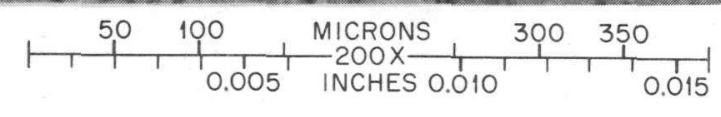

Fig. 6.2-2. Collective view near outside diameter (left) and intact particle (right) near outer diameter of compact 2. Magnification: left, 50x; right, 200x. 

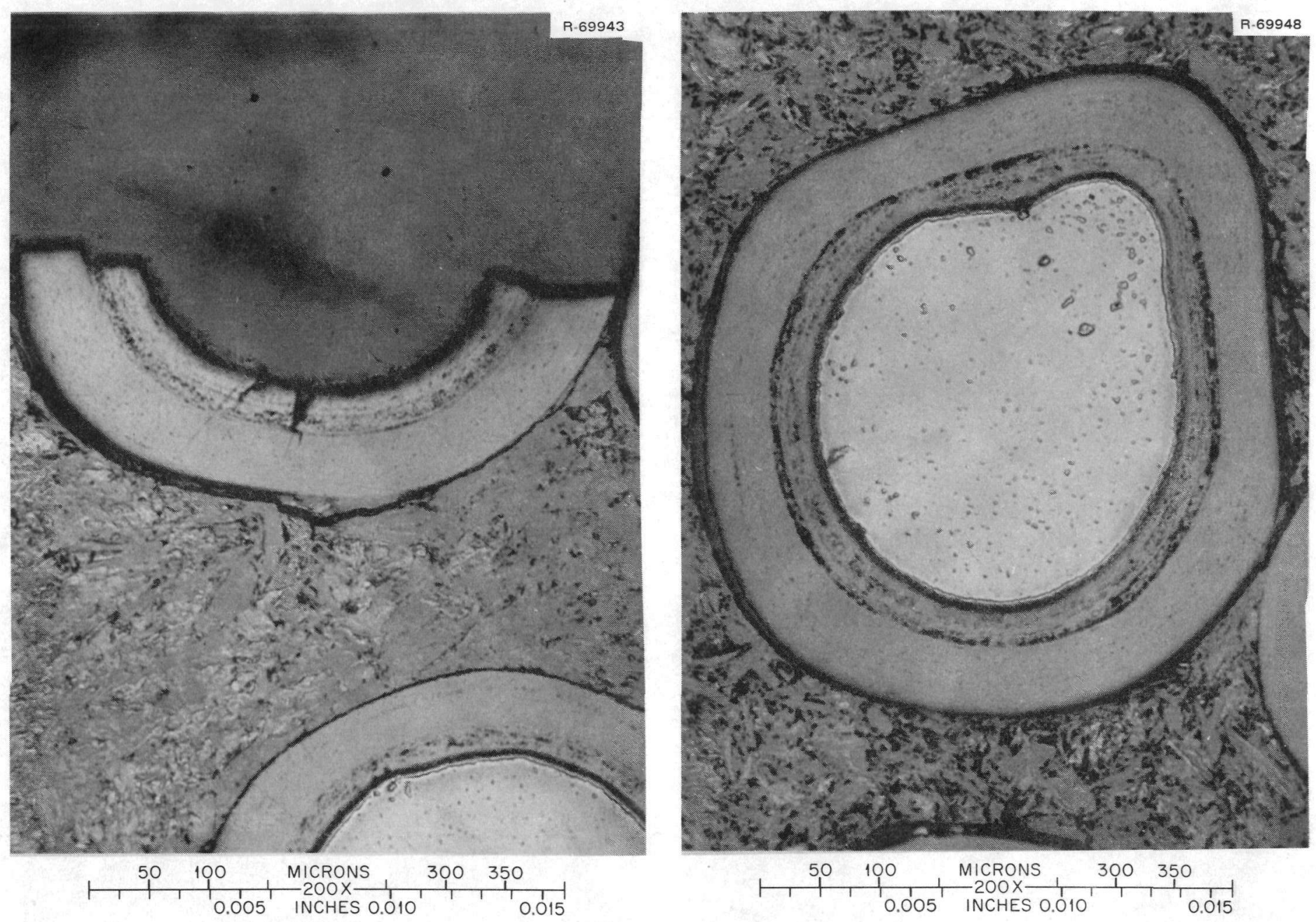

Fig. 6.2-3. Remains of broken particle of compact 2 showing (left) buffer and pyrolytic graphite layers, and (right) distorted but intact particle. Magnification 200x. 

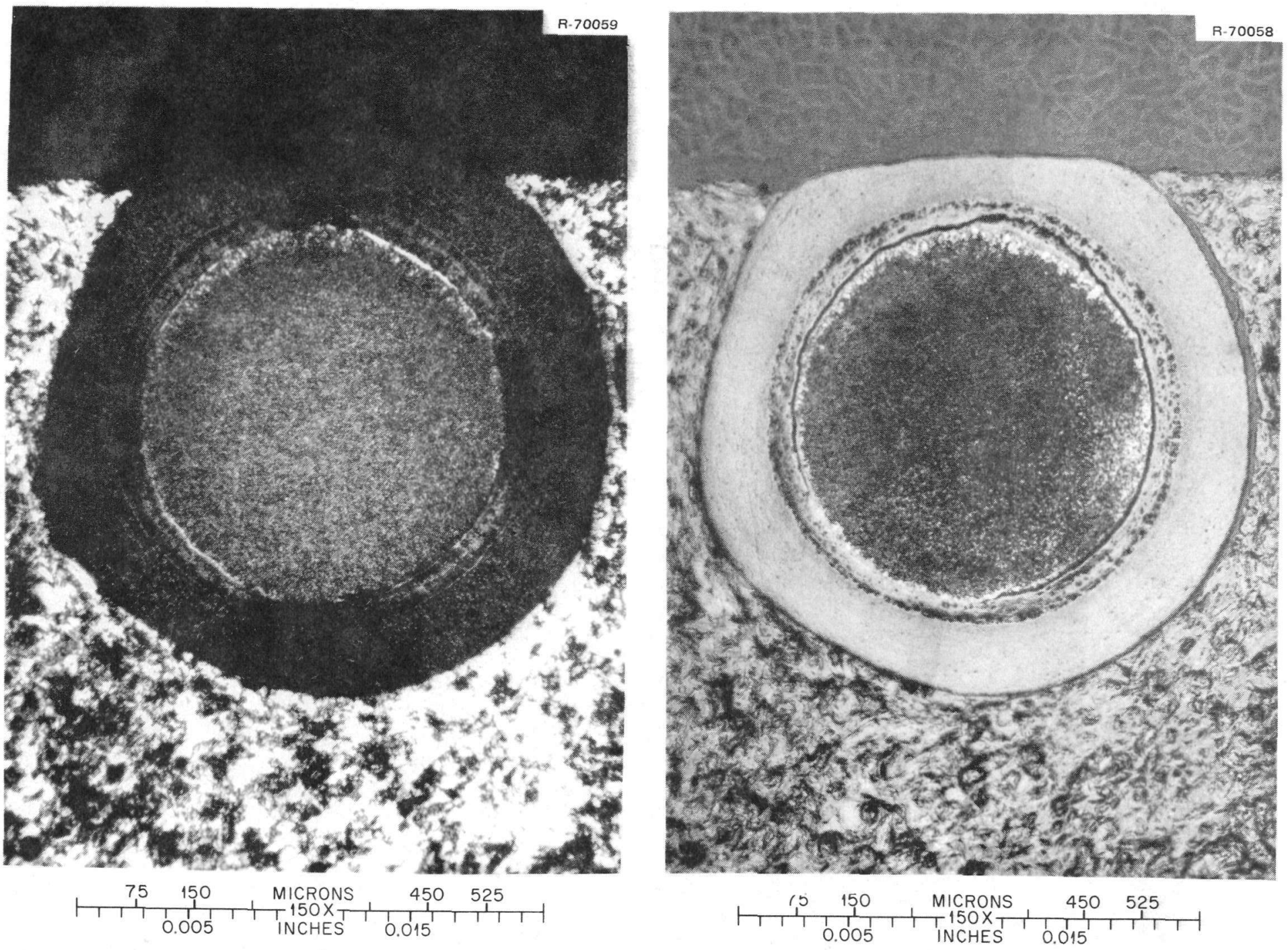

Fig. 6.2-4. Intact particle of compact 2 shown in normal (left) and polarized (right) light. Magnification $200 \mathrm{x}$. 

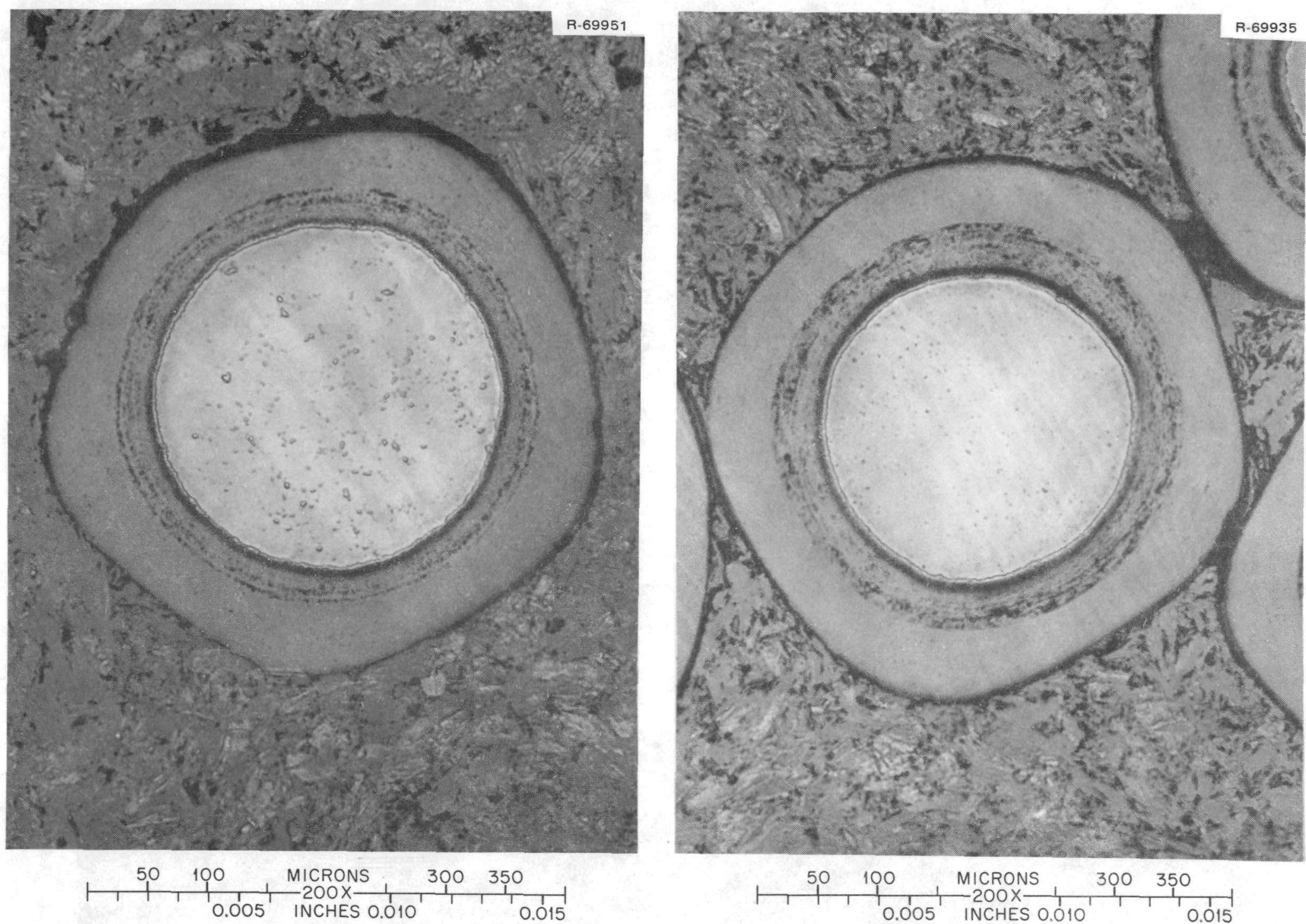

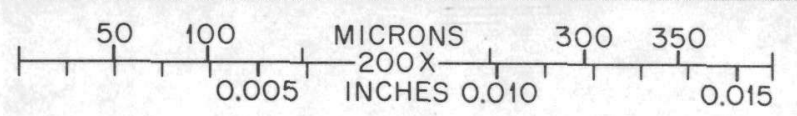

Fig. 6.2-5. Intact particles of compact 2. Magnification 200X. 

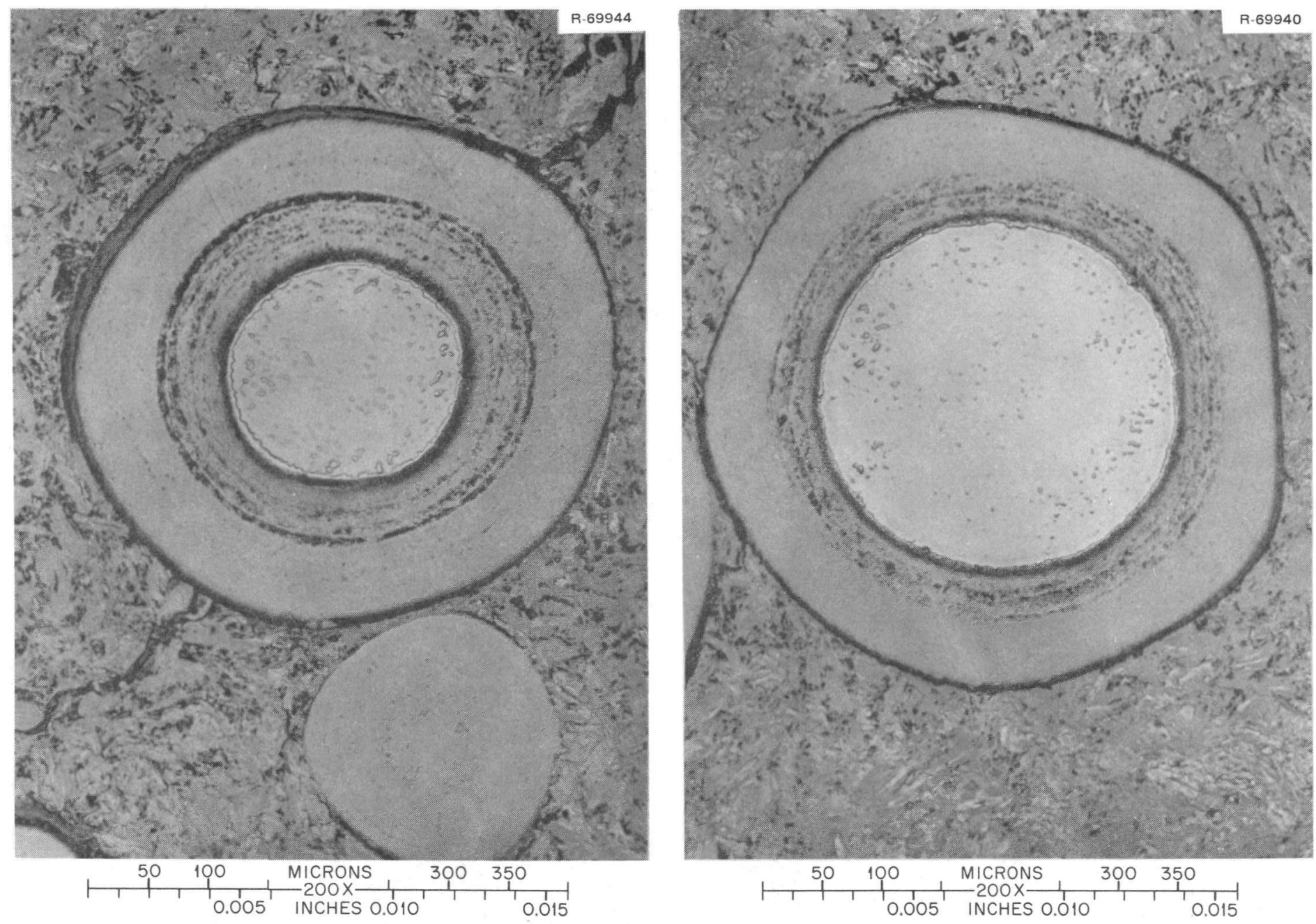

Fig. 6.2-6. Two intact particles of compact 2. Particle at right has abnormally small kernel and is in the path of a matrix crack. Magnification 200x. 

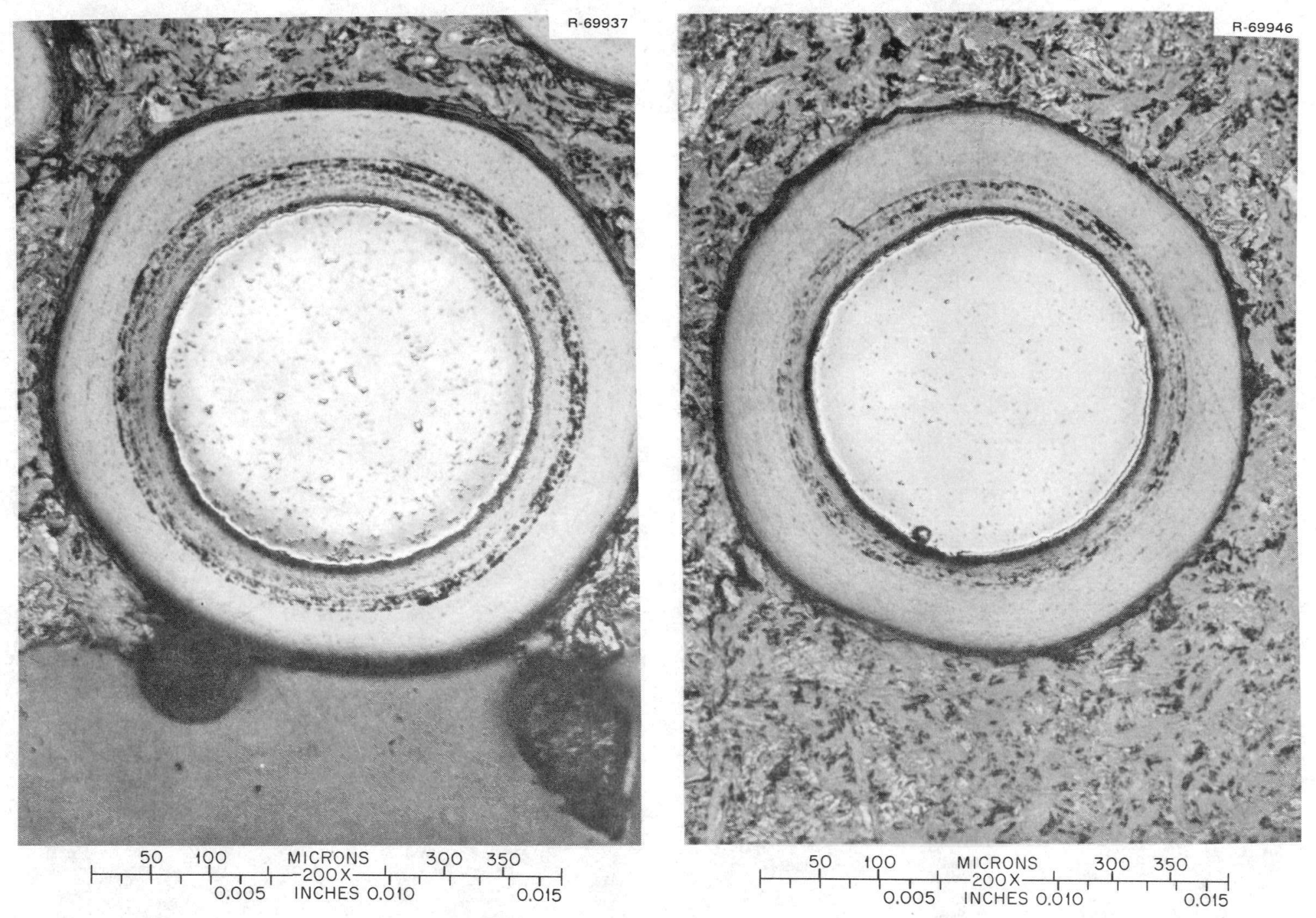

Fig. 6.2-7. Particles of compact 2. Particle at right shows apparent beginning of coating crack. Magnification $200 \mathrm{X}$. 

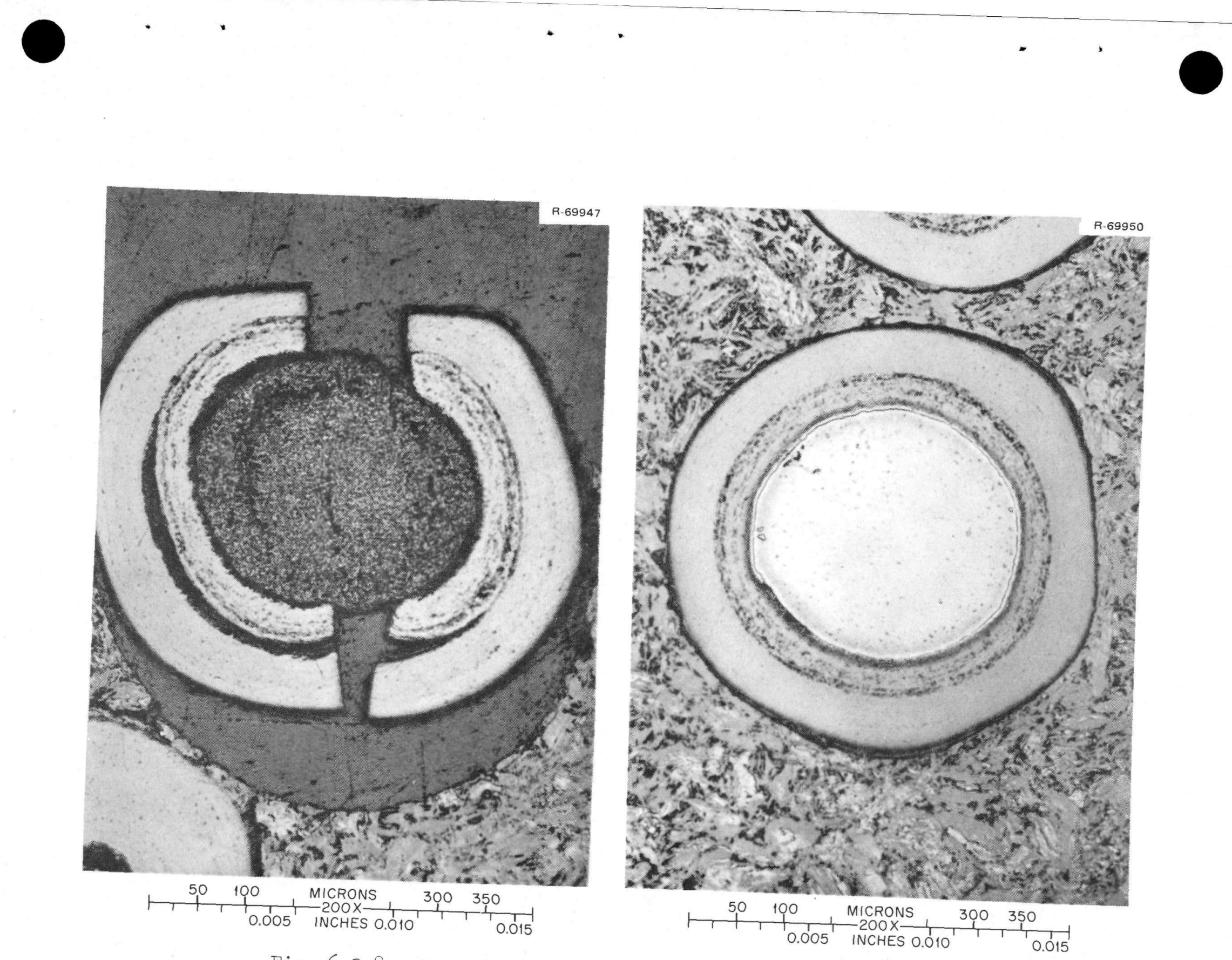

Fig. 6.2-8. Severely cracked (left) and intact (right) particles of compact 2. Magnification 200X. 


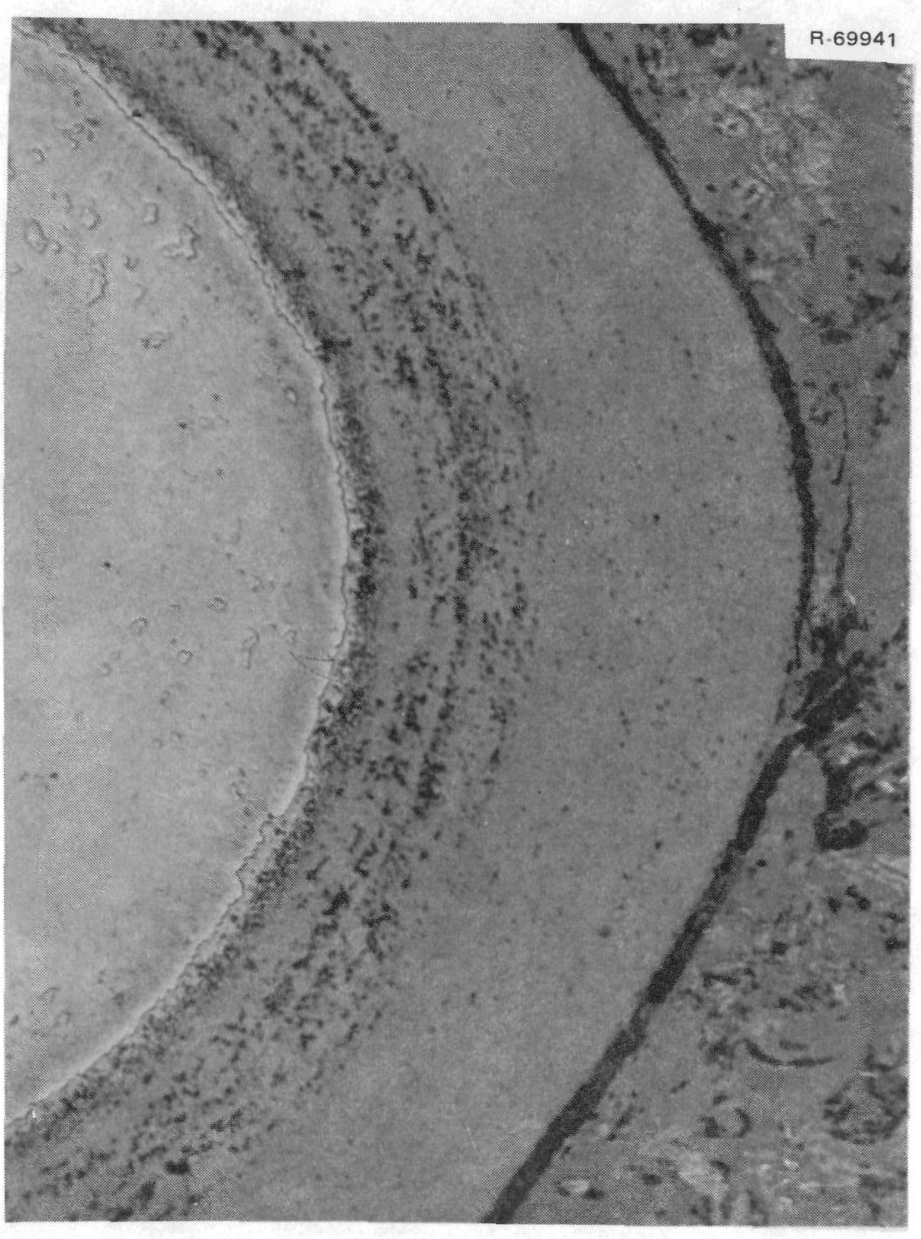

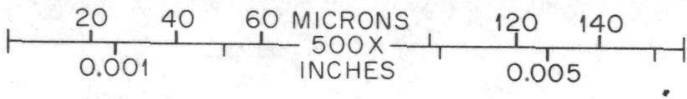

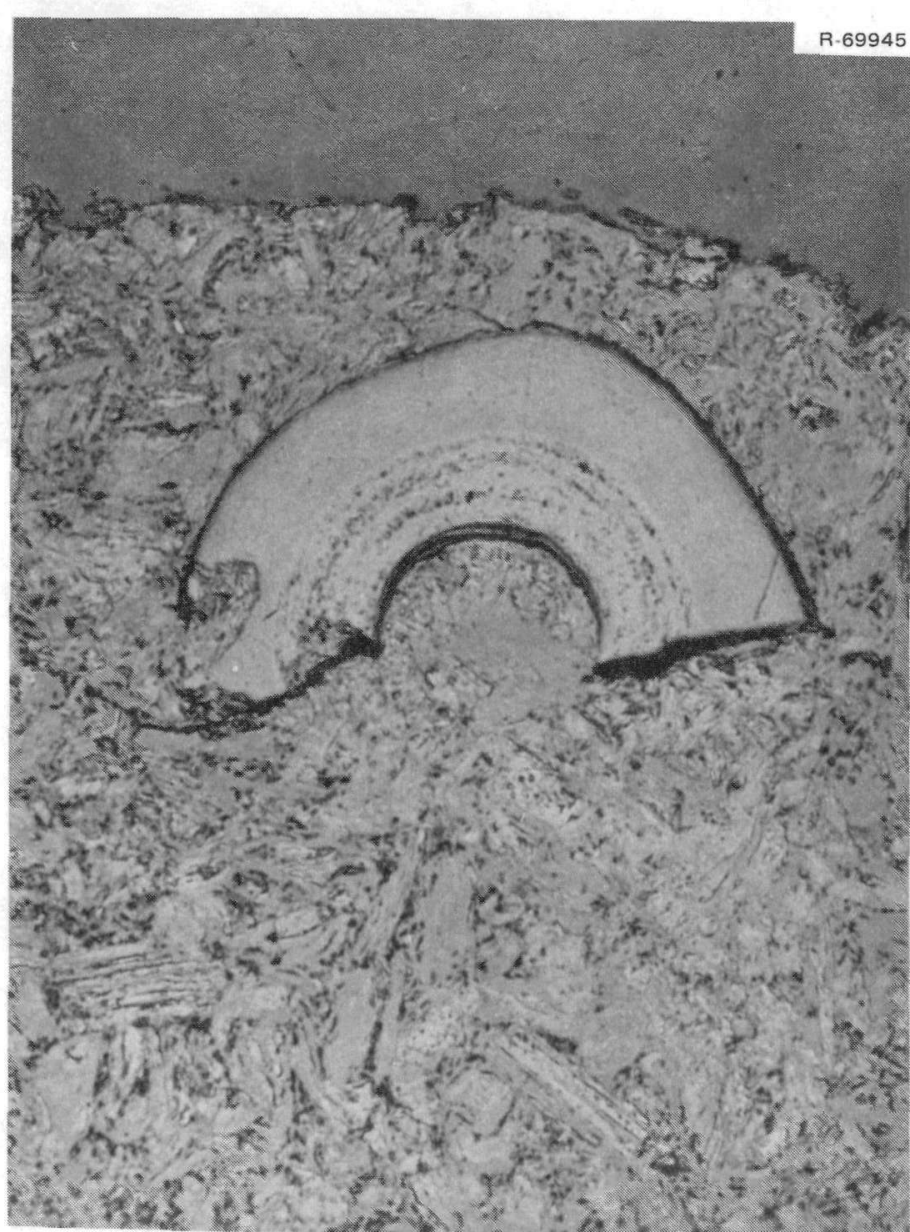

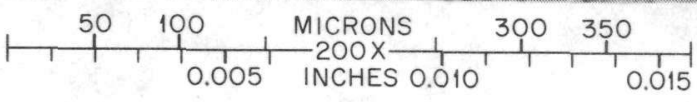

Fig. 6.2-9. Remains of cracked particle of compact 2 (right) and enlarged view of its particle coating (left). Magnification: left, 500x; right, 200x. 


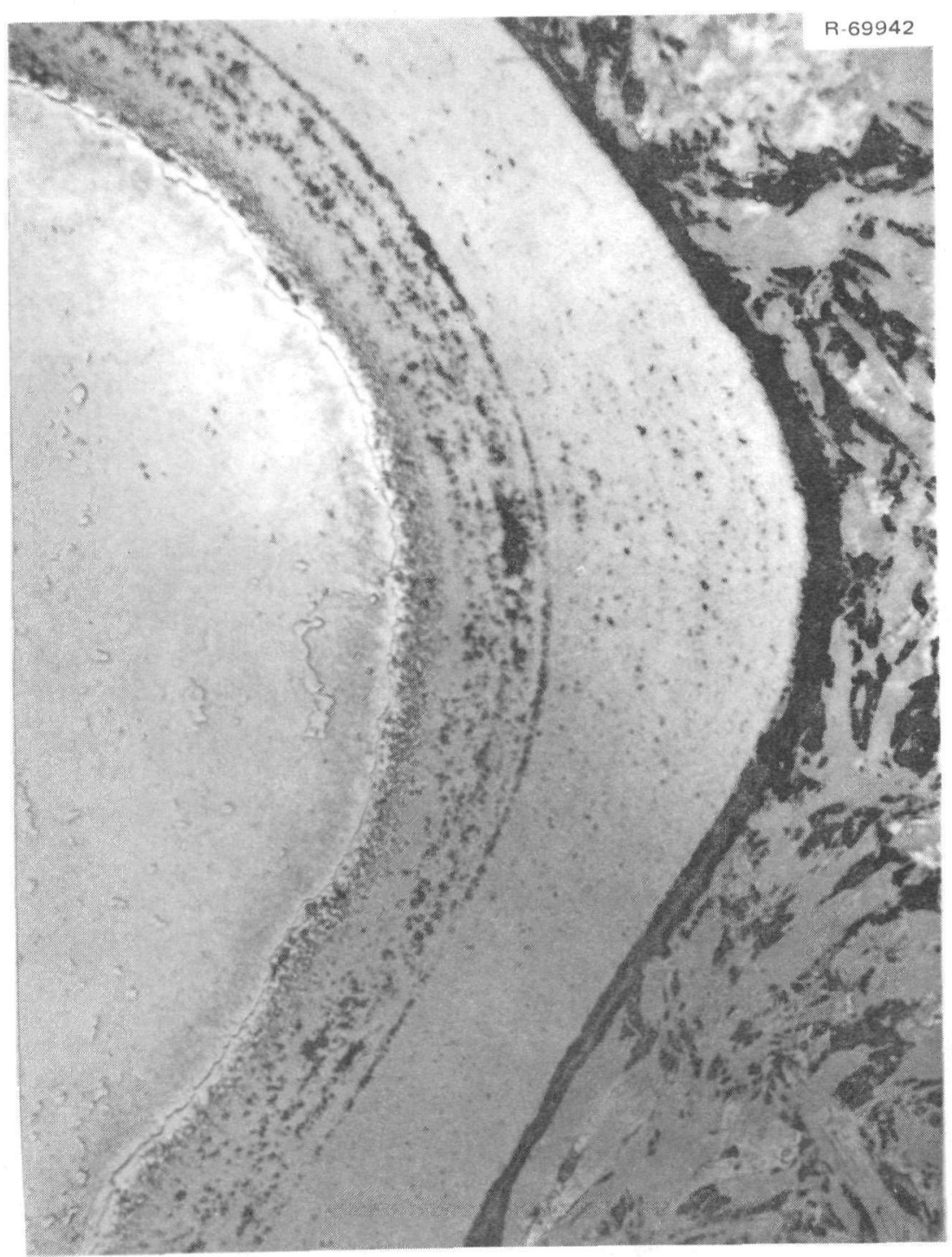

$$
\begin{array}{llll}
20 & 40 & 60 \text { MICRONS } & 120,140 \\
1,1 & 1,500 \times & 1,1 \\
\hline 0.001 & \text { INCHES } & 0.005
\end{array}
$$

Fig. 6.2-10. Particle coating in compact 2. Magnification 500X. 

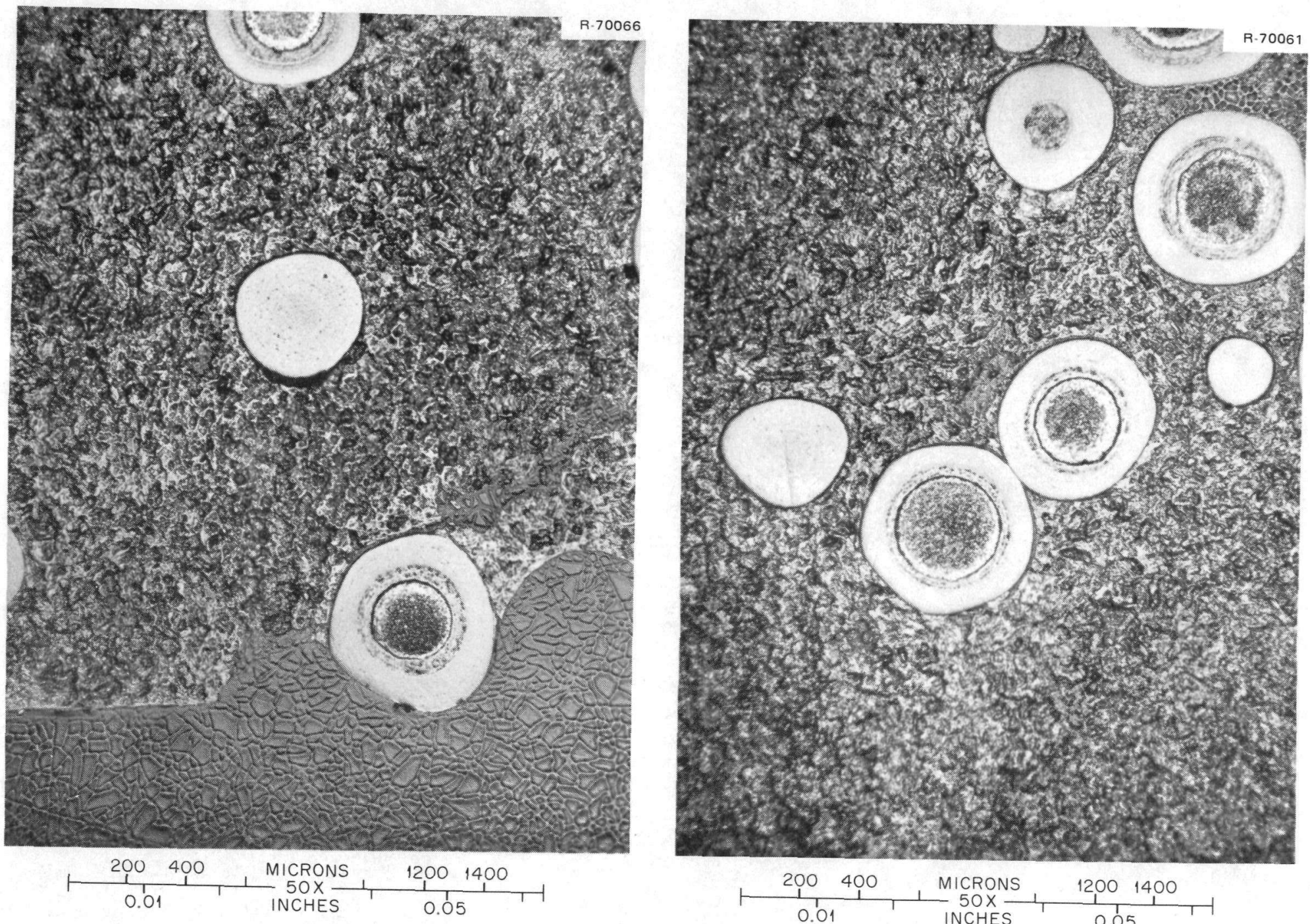

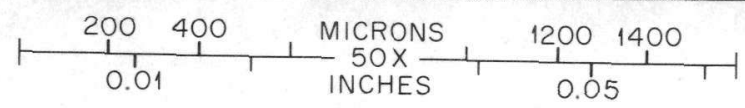

Fig. 6.2-11. Collective views of compact 18 near inner diameter (left) and midsection (right). Magnification 50X. 

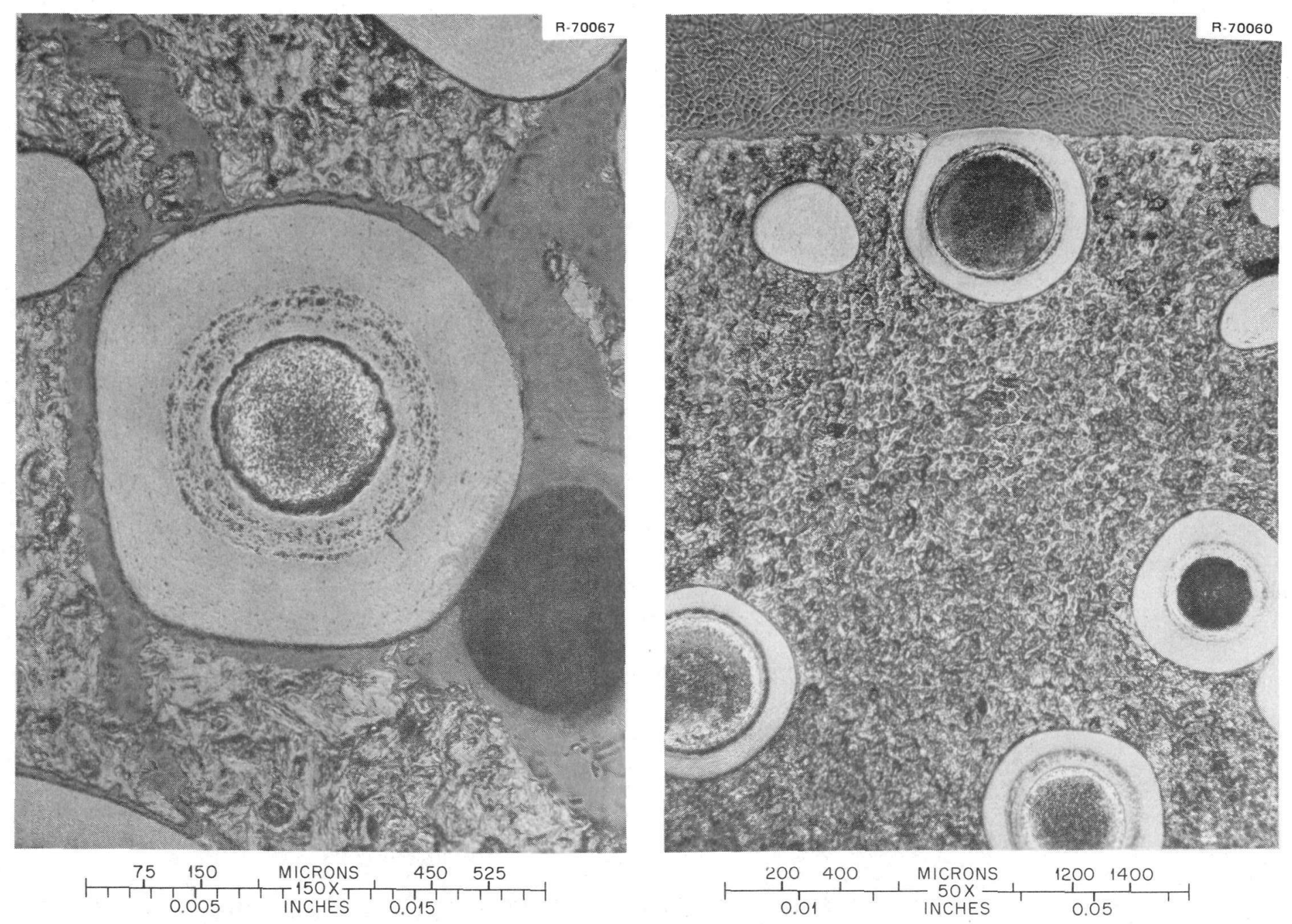

Fig. 6.2-12. Collective view of compact 18 near outside diameter (right), and single particle with small kernel (left). Magnification: left, 150x; right, 50x. 

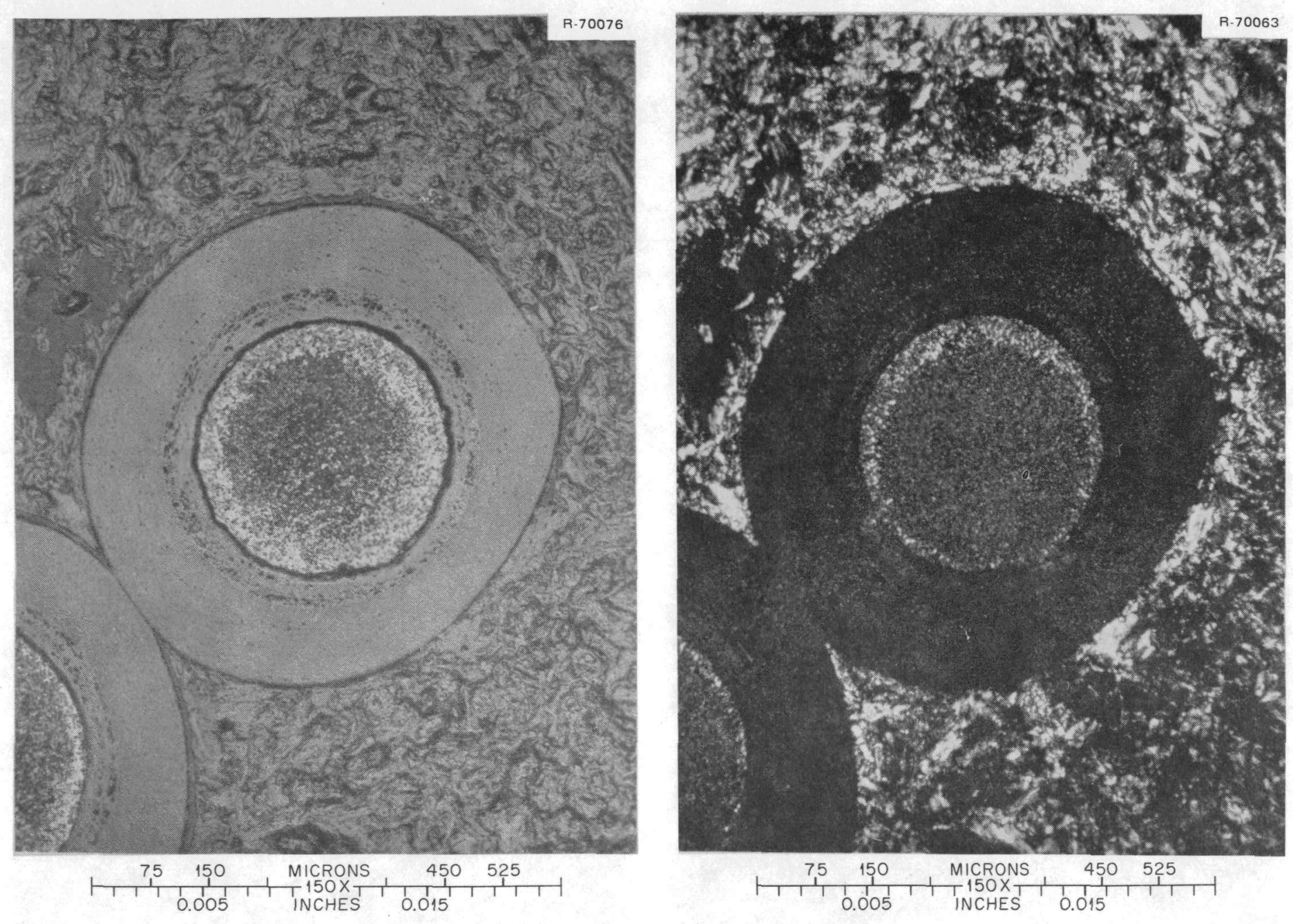

Fig. 6.2-13. Single particle near outer diameter of compact 18 showing shrinkage around entire kernel viewed with normal (left) and polarized (right) light. Magnification 150X. 

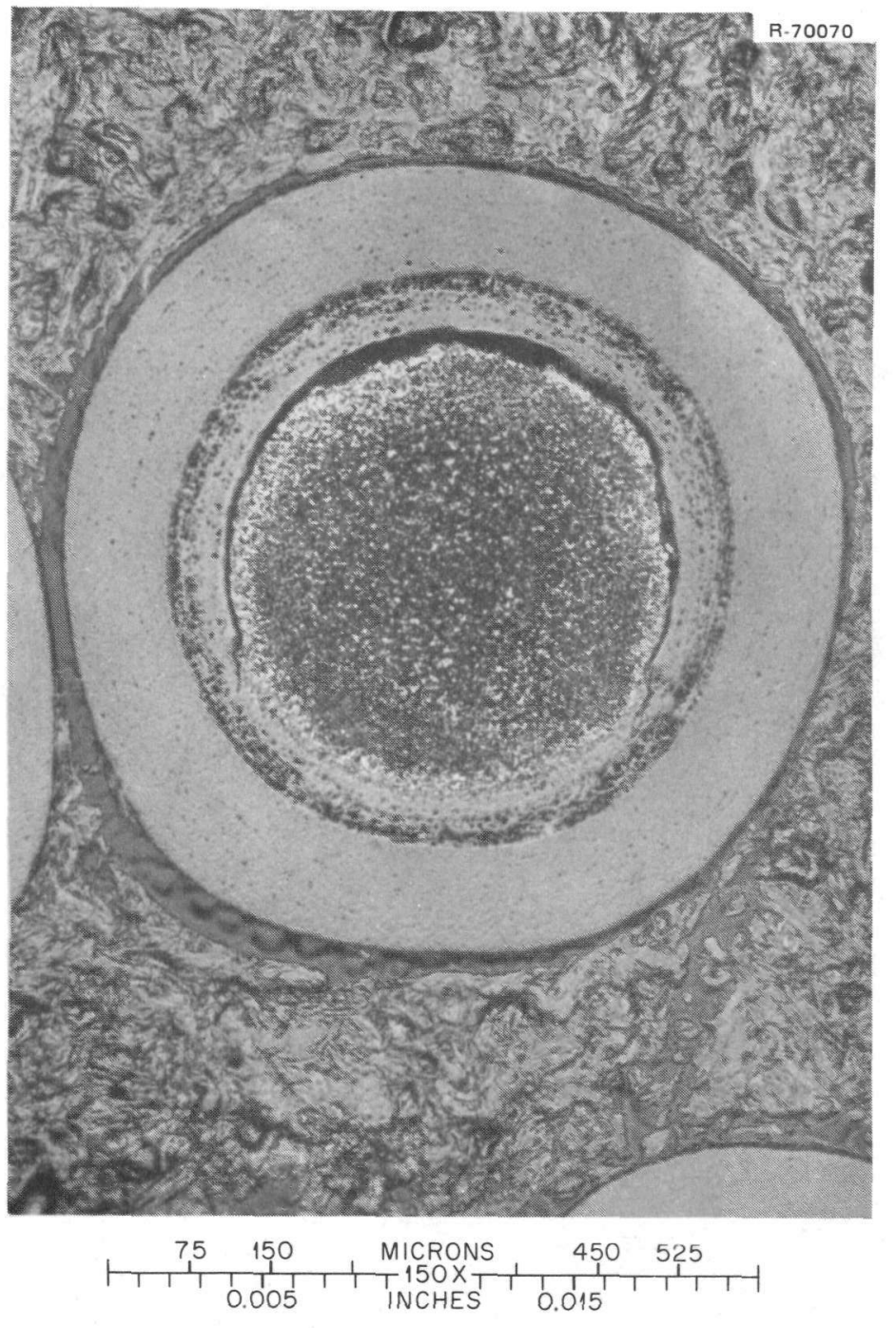
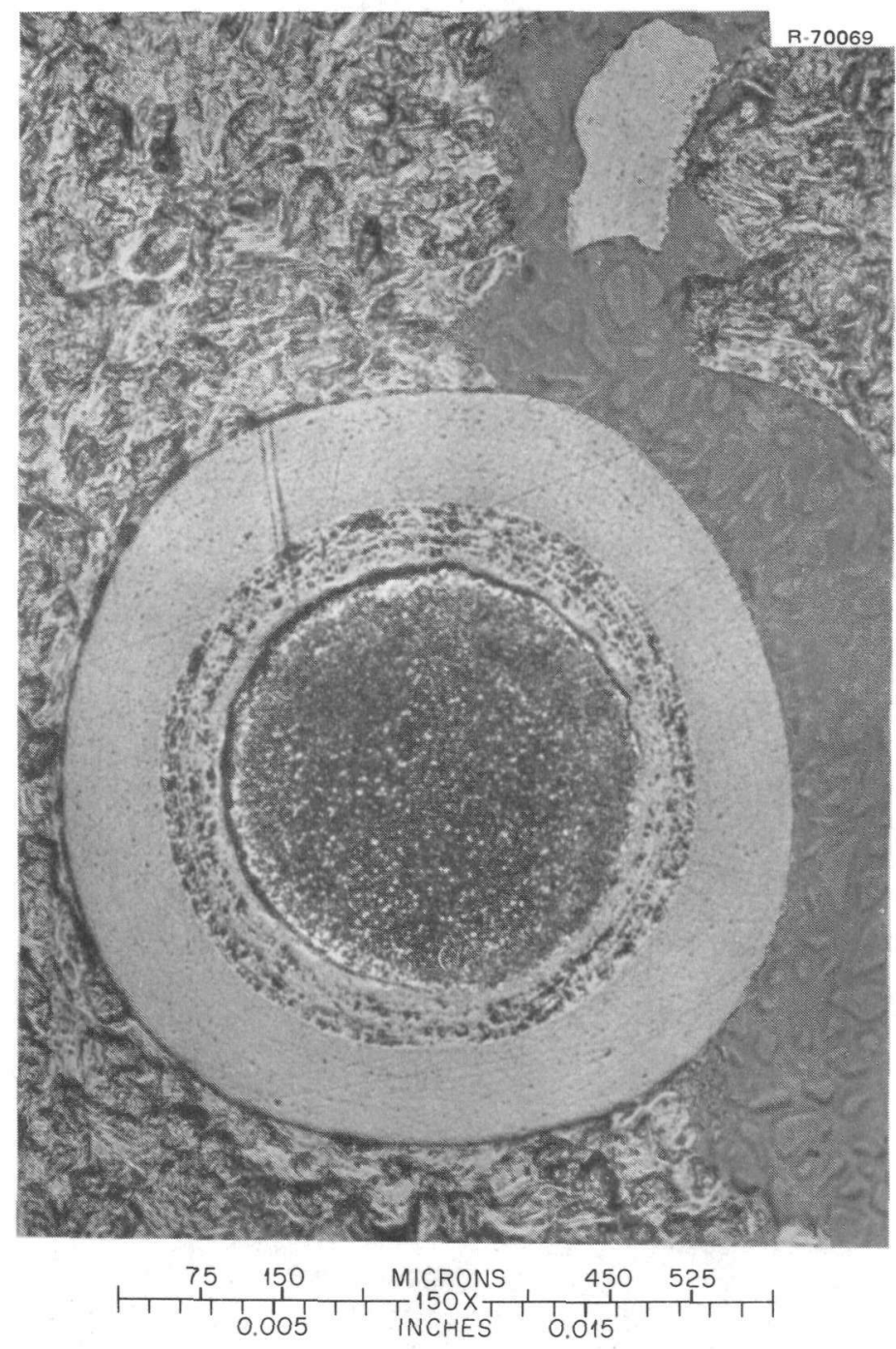

Fig. 6.2-14. Two particles near the outer diameter of compact 18 showing kernel and buffer separation. Magnification I50x. 

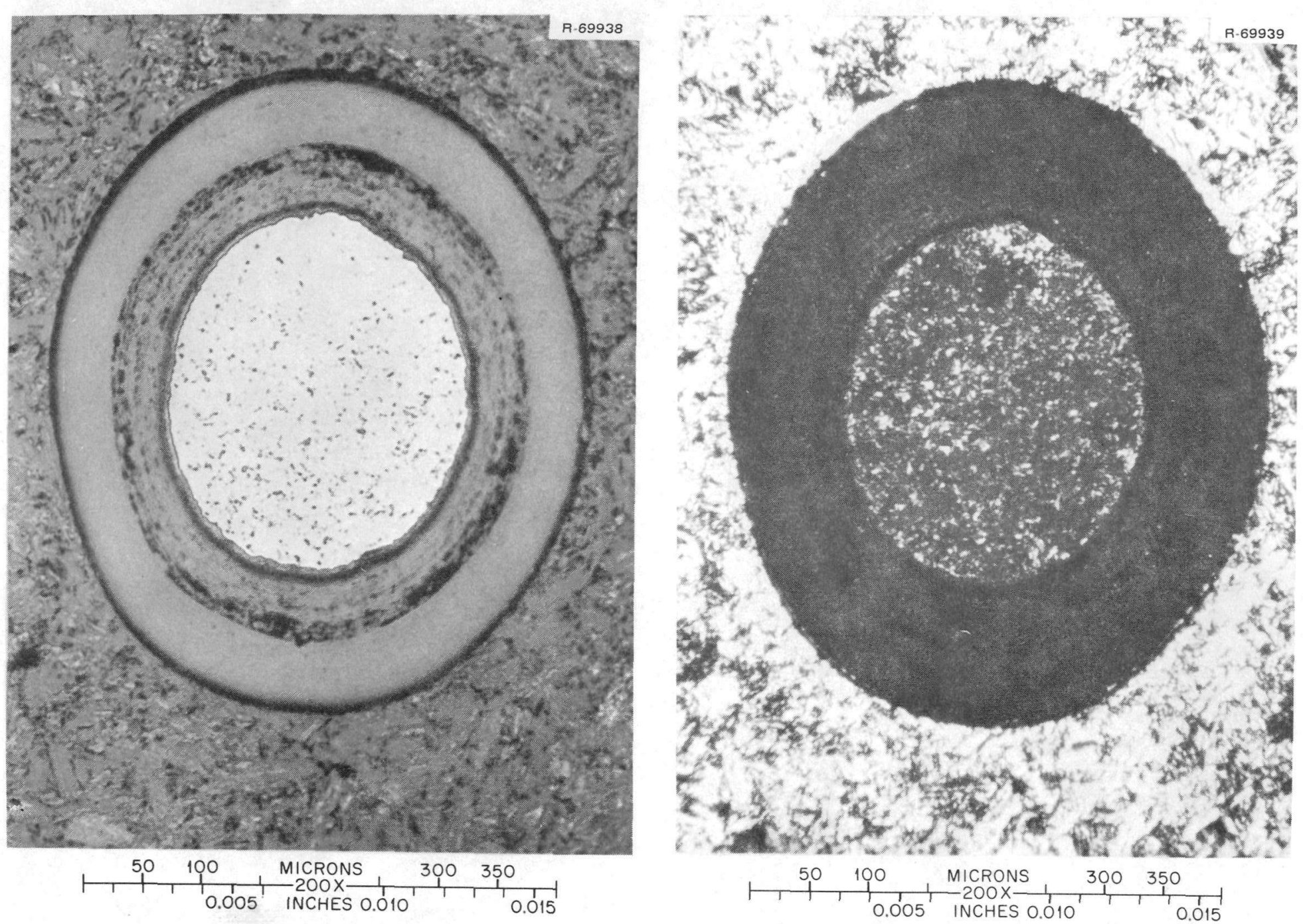

Fig. 6.2-15. Particle near outside diameter of compact 18 viewed with polarized (left) and normal (right) light. Magnification 150X. 


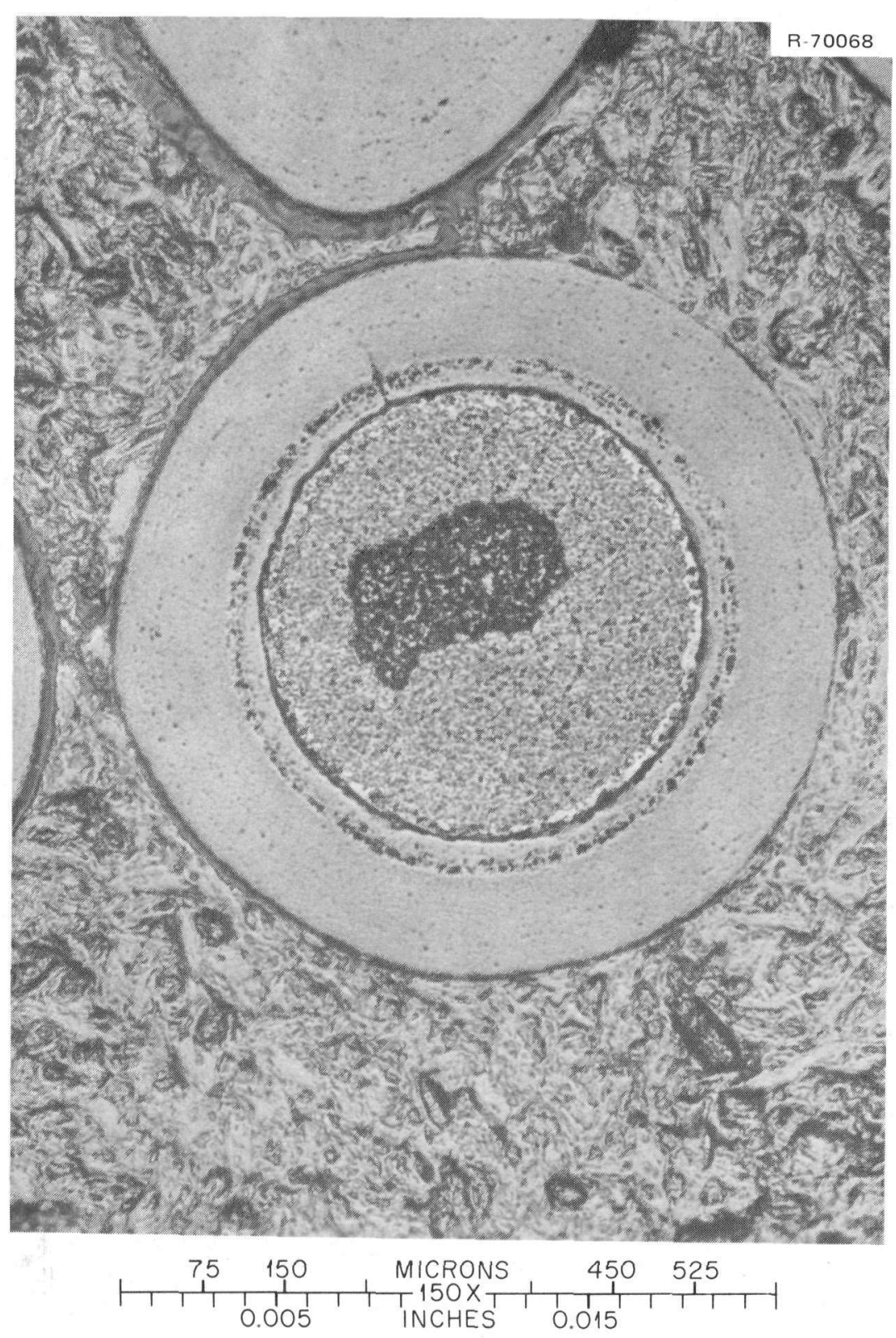

Fig. 6.2-16. Particle near midsection of compact 18 with crack through buffer. Magnification 150x. 

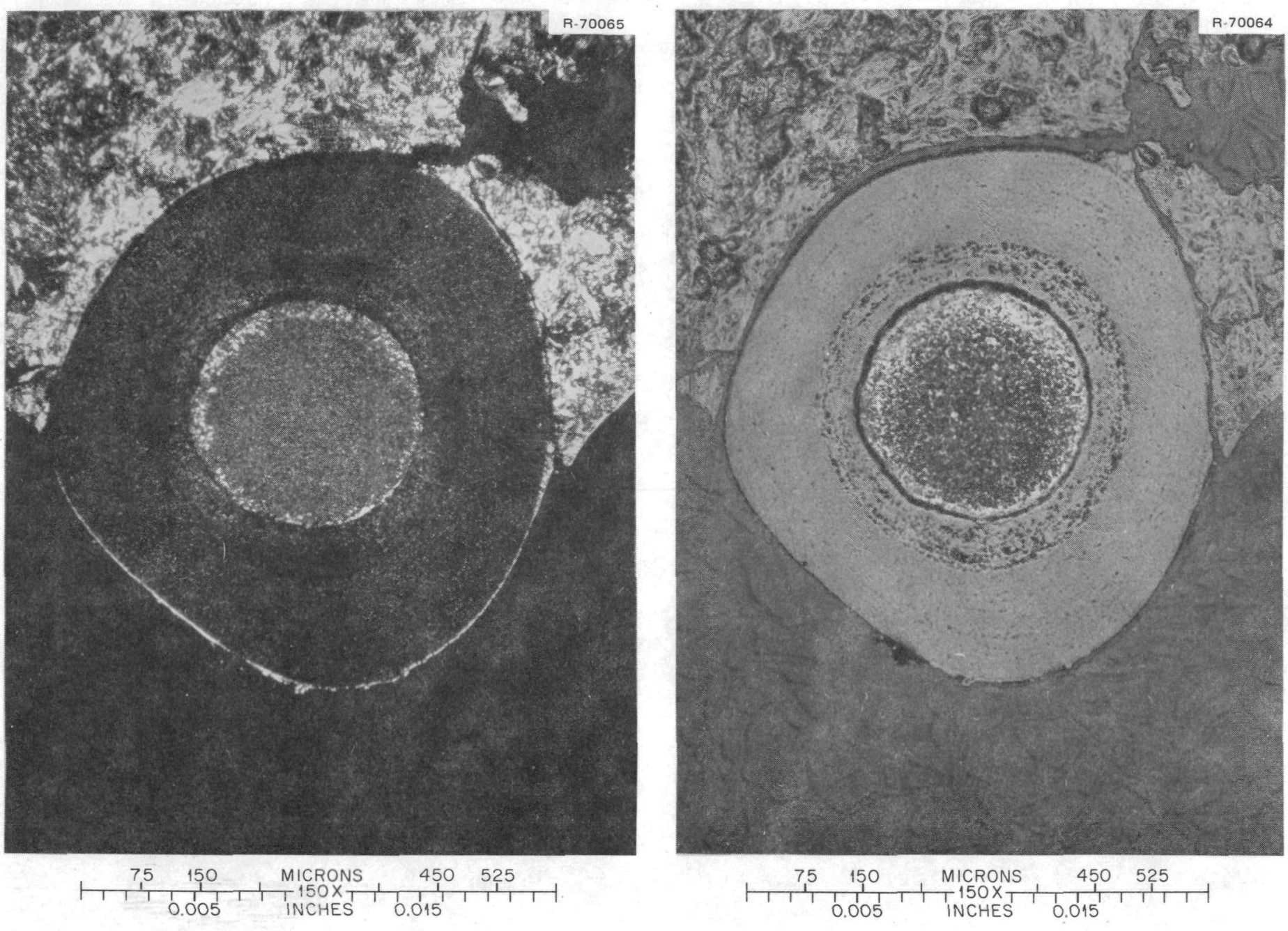

Fig. 6.2-17. Particle near inner diameter of compact 18 with small kernel viewed with polarized (left) and normal (right) light. Magnification 150X. 

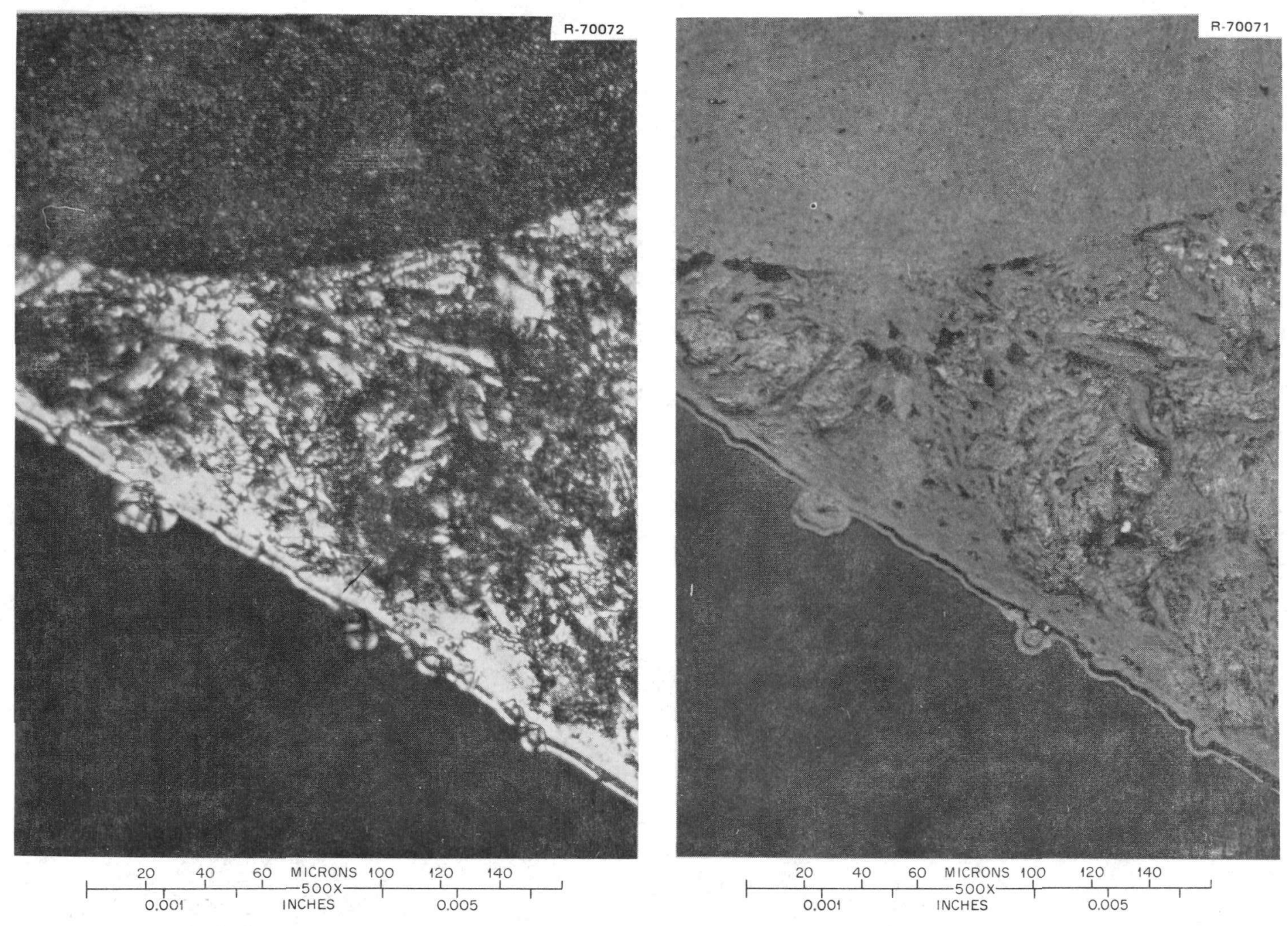

Fig. 6.2-18. Graphite matrix and particle pyrocarbon near inner diameter of compact 18 viewed with polarized (left) and normal (right) light. Magnification 500x. 

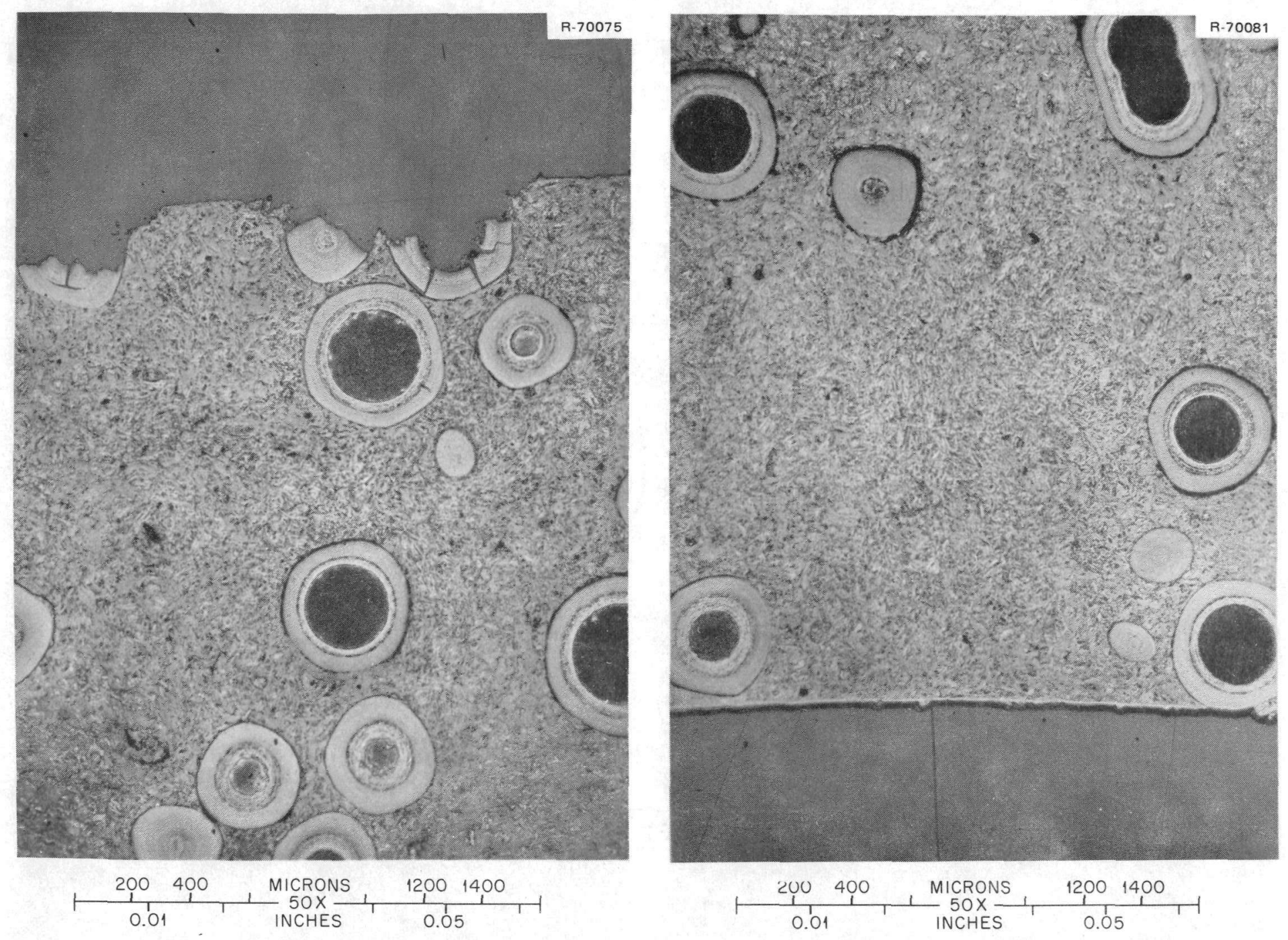

Fig. 6.2-19. Collective view of compact 29 near outside diameter (left) and inside diameter (right). Magnification 50X. 


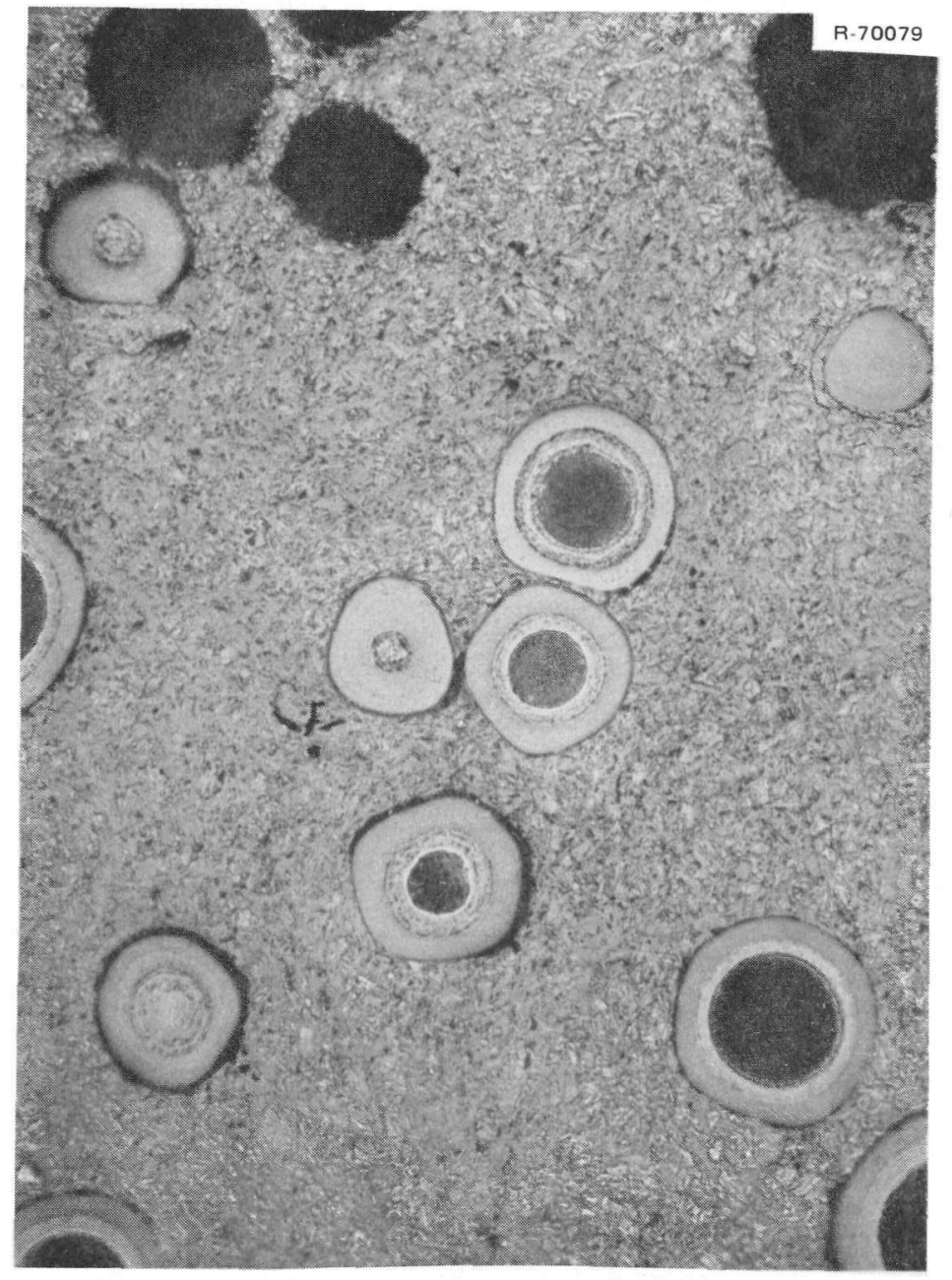

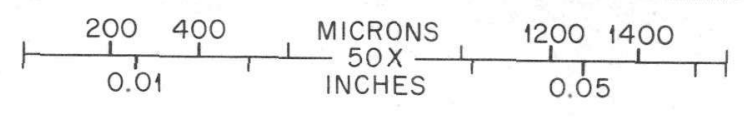

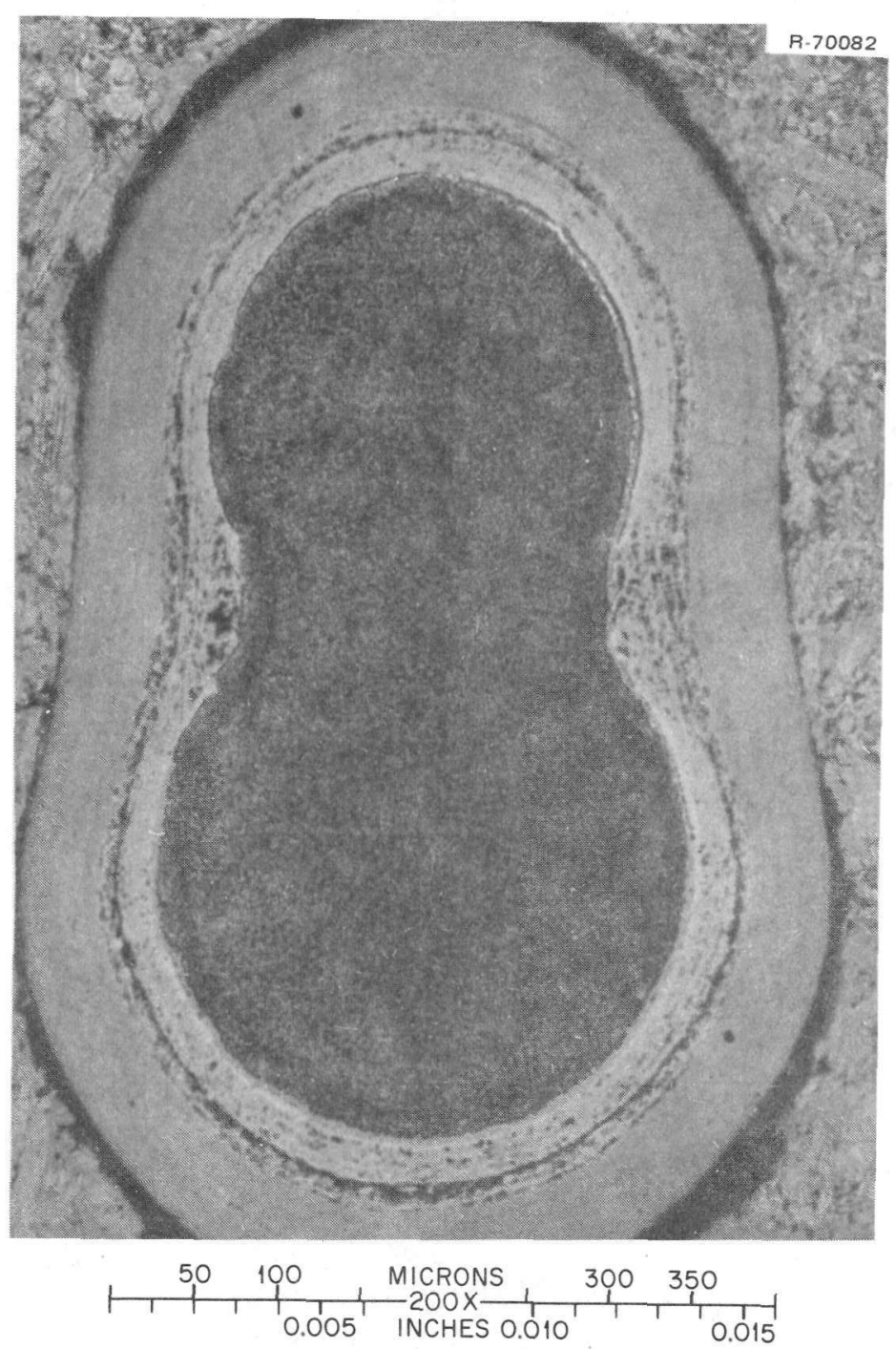

Left, collective view near midsection shown at 50X; right, twin particle near outside diameter shown at 200x. 


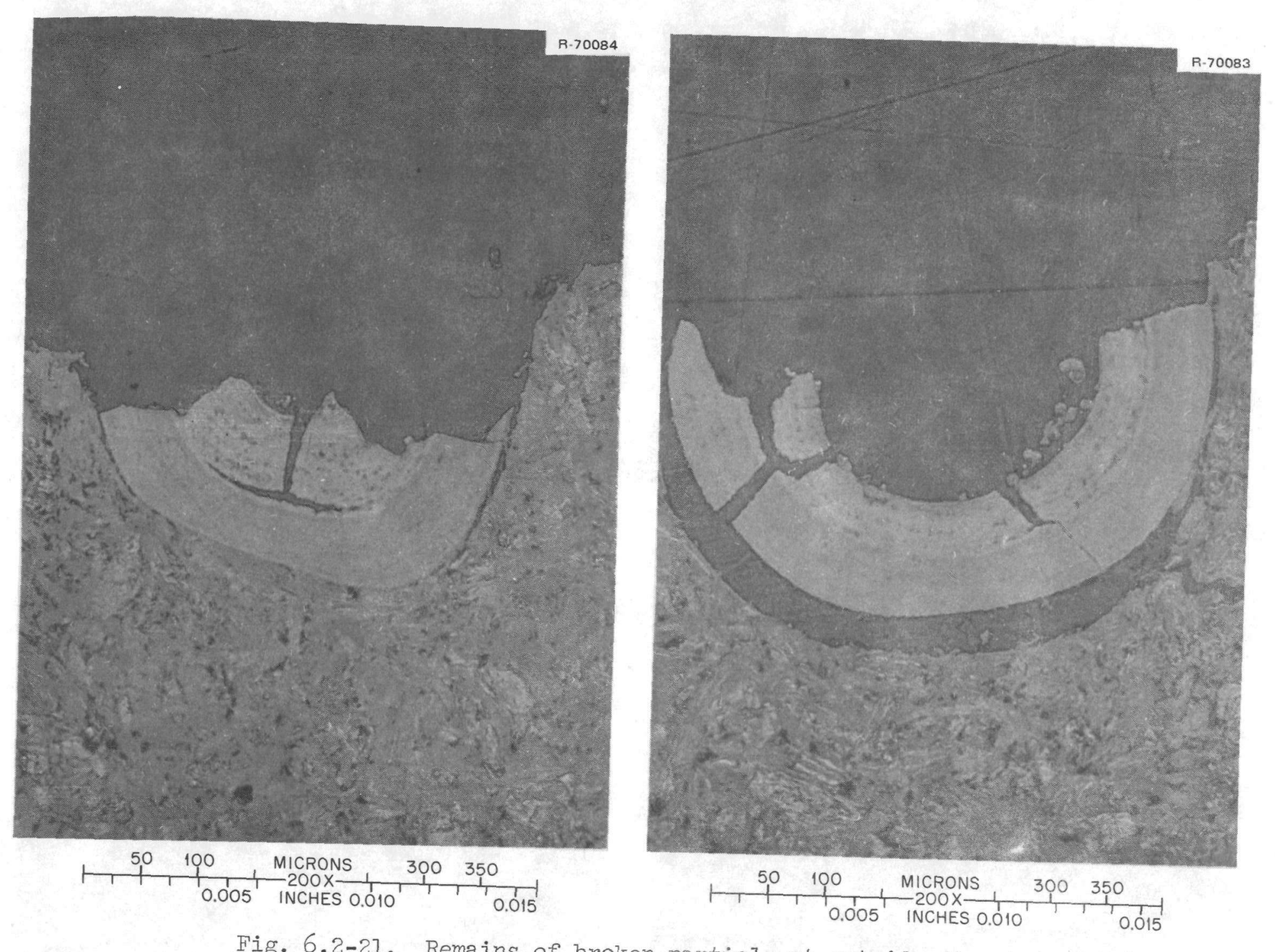
compact 29. Magnification 200x. 

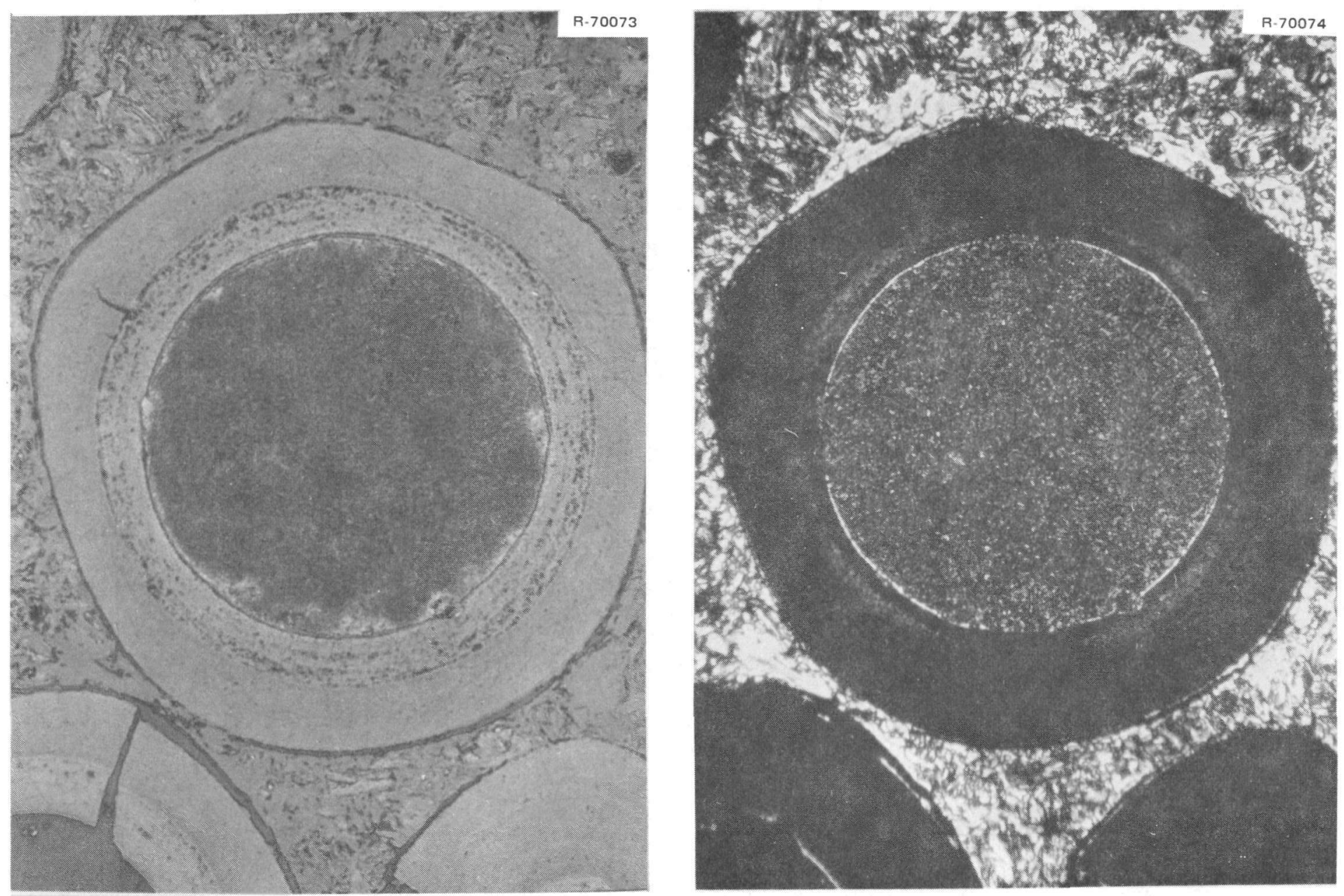

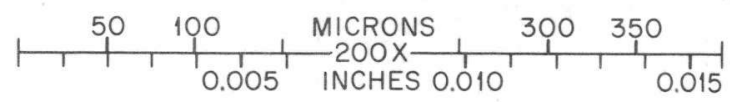

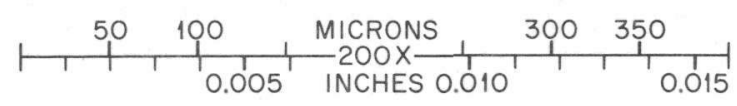

Fig. 6.2-22. Intact particle near outside diameter of compact 29

viewed with normal (left) and polarized (right) light. Magnification 200X. 

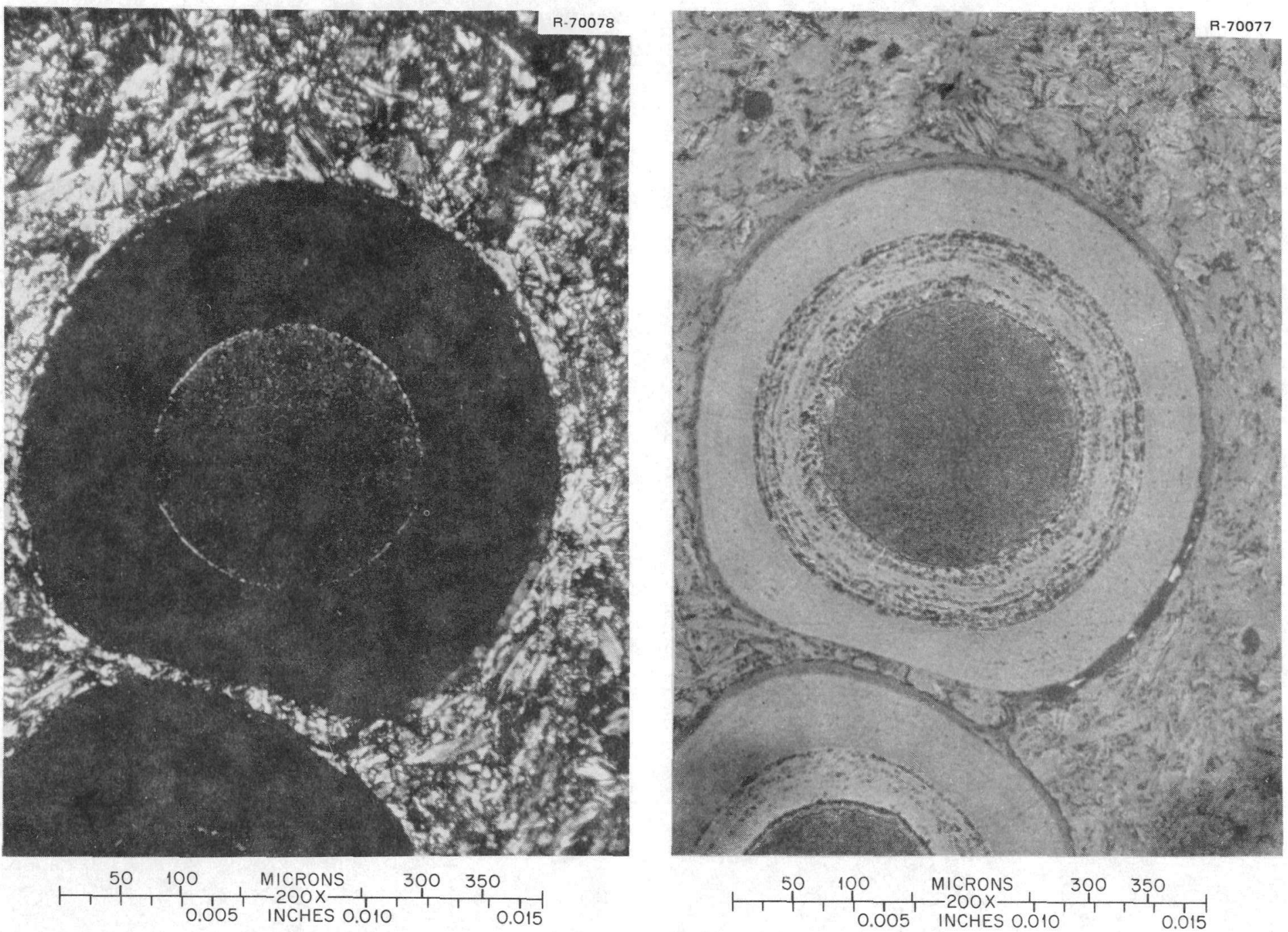

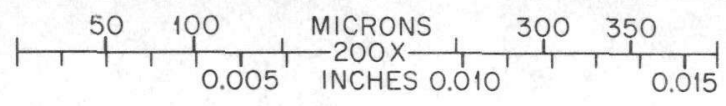

Fig. 6.2-23. Intact particle near midsection of compact 29 viewed with polarized (left) and normal (right) light. Magnification 200x. 

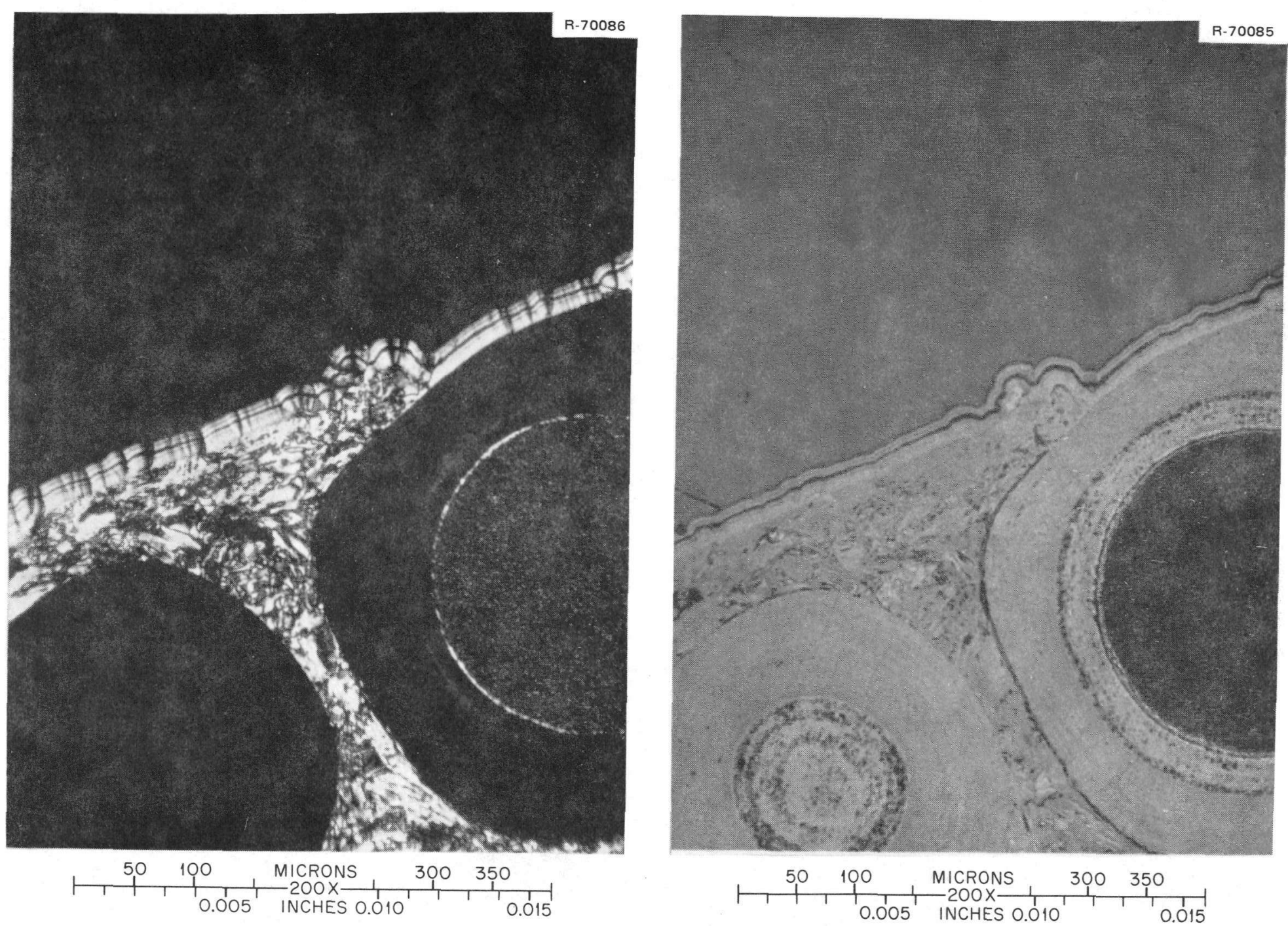

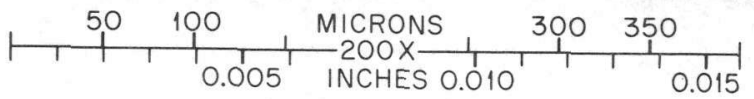

Fig. 6.2-24. Two particles at the inside diameter of compact 29

viewed under polarized (left) and normal (right) light. Magnification 200x. 

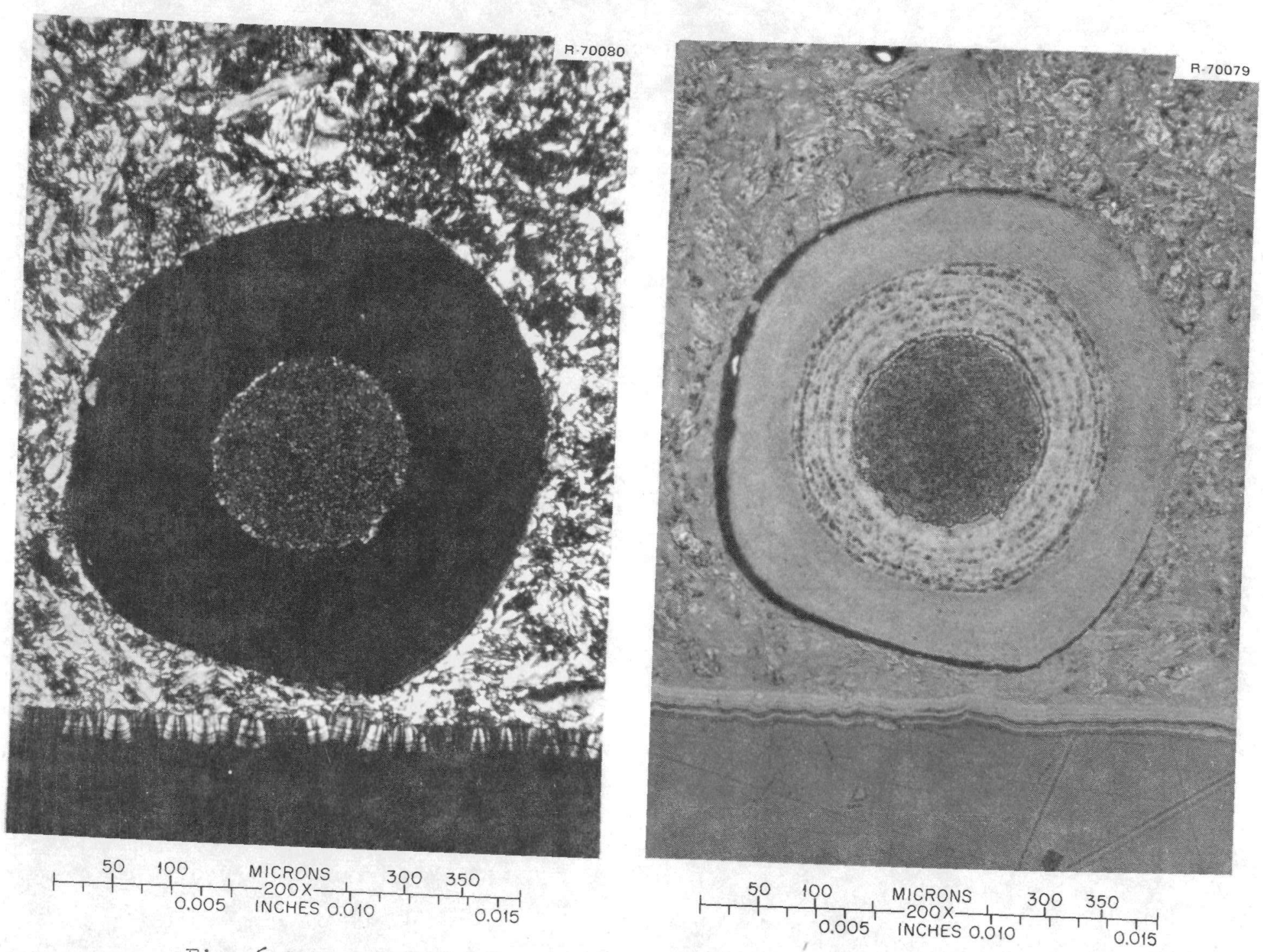

Fig. 6.2-25. Intact particle near inside diameter of compact 29

viewed with polarized (left) and normal (right) light. Magnification 200x. 

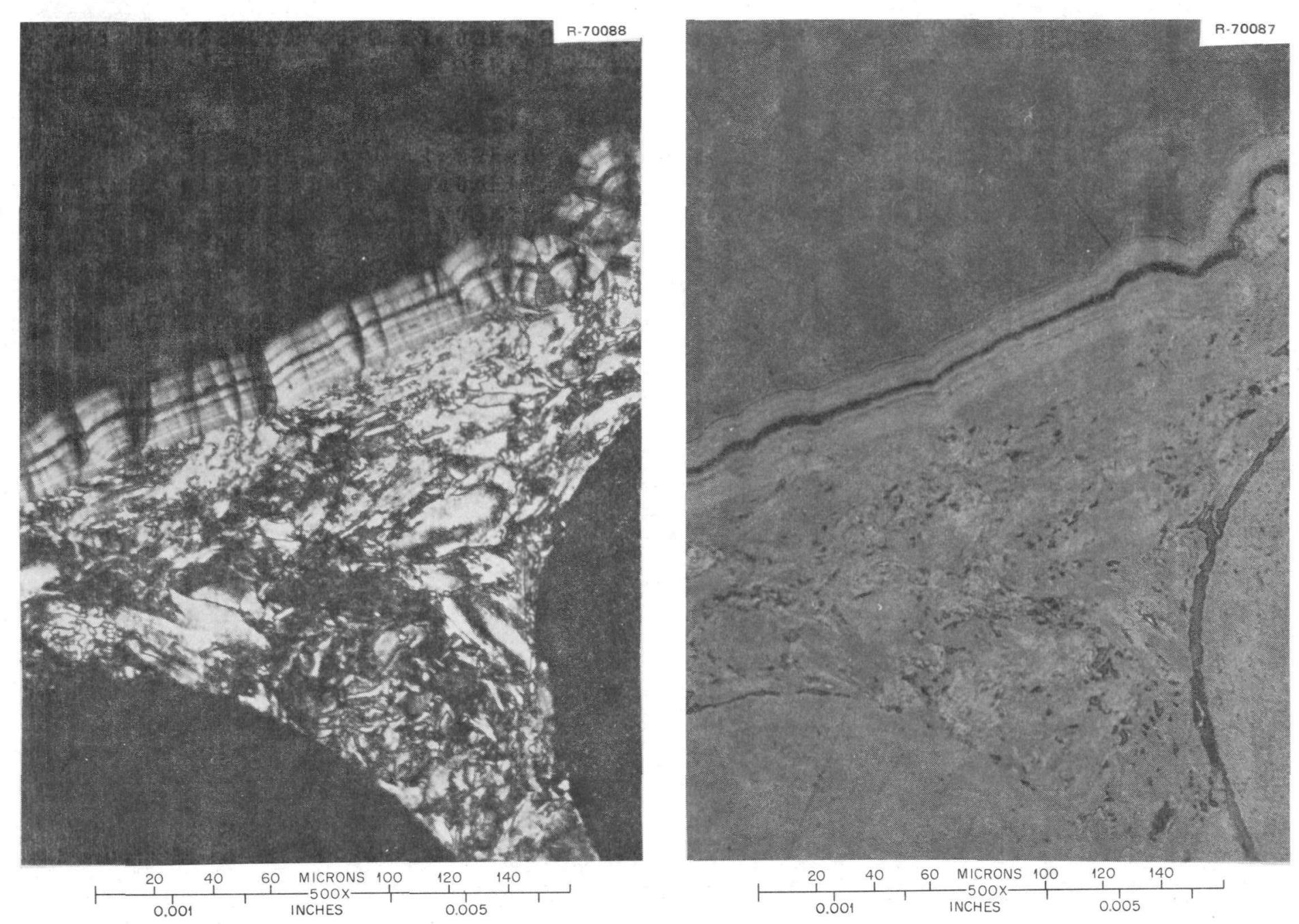

Fig. 6.2-26. Graphite matrix and particle pyrocarbon at inside diameter of compact 29 viewed. with polarized (left) and normal (right) light. Magnification 500x. 


\subsection{Particle Coating Failure Fraction}

Table 6.3-1 presents the results obtained for the fraction of particles that had coating failures in FO3-OI fuel. For comparison, the failure fractions previously reported ${ }^{2}$ for fuel element Ell-07 and Peach Bottom archive fuel are tabulated. The failure fraction was determined by the hot-chlorine leaching method described in ref. 2 and was derived on the basis of both the thorium and the uranium that were leached from the sample. The calculated and measured Th/U ratios are also reported in Table 6.3-1. The calculated Th/U ratio was determined from data given in ref. 8 . As may be noted, the failure fraction computed from the uranium leached from the sample is often significantly higher than the result based on thorium. The low result based on thorium is normally associated with a low value for the measured Th/U ratio. This effect is thought to be due to the fact that the volatility of thorium chloride is lower than that of uranium chloride, which results in incomplete collection of the thorium chloride vaporized from the sample. It should be noted that the high value obtained for the failure fraction on compact 3 was measured after this compact had been shipped to GAC for fission gas release measurements and then returned to ORNI. It is possible that some changes in the compact may have occurred during this period and later influenced the hot-chlorine leaching procedure, resulting in the high estimate of the failure fraction.

\section{Table 6.3-1. Fraction of particles that had failed coatings in Peach Bottom fuel ${ }^{a}$}

\begin{tabular}{|c|c|c|c|c|c|}
\hline \multirow[b]{2}{*}{ Fuel element } & \multirow[b]{2}{*}{ Compact } & \multicolumn{2}{|c|}{$\mathrm{Th} / \mathrm{U}$ ratio } & \multicolumn{2}{|c|}{ Failed particle $\%$ based on } \\
\hline & & Calc.b & Meas. & Th & $\mathrm{U}$ \\
\hline E11-07 & $\begin{array}{r}2 \\
13 \\
16 \\
28\end{array}$ & $\begin{array}{l}7.11 \\
7.82 \\
7.78 \\
6.94\end{array}$ & $\begin{array}{l}7.64 \\
4.83 \\
9.58 \\
3.68\end{array}$ & $\begin{array}{l}0.68 \\
0.25 \\
0.22 \\
0.33\end{array}$ & $\begin{array}{l}0.64 \\
0.41 \\
0.18 \\
0.63\end{array}$ \\
\hline $\mathrm{FO3-O1}$ & $\begin{array}{r}2^{\prime} \\
3 \\
13 \\
19 \\
28\end{array}$ & $\begin{array}{l}6.51 \\
6.83 \\
8.17 \\
7.86 \\
6.46\end{array}$ & $\begin{array}{l}3.54 \\
8.73 \\
6.80 \\
3.43 \\
5.43\end{array}$ & $\begin{array}{l}0.17 \\
6.12 \\
1.55 \\
0.35 \\
0.27\end{array}$ & $\begin{array}{l}0.31 \\
4.81 \\
1.87 \\
0.79 \\
0.33\end{array}$ \\
\hline Archive (av o & 4) & 5.50 & 5.47 & 0.28 & $0.28^{c}$ \\
\hline
\end{tabular}

\footnotetext{
Determined by hot-chlorine leaching method described in ref. 2.

$\mathrm{b}$ Based on data given in ref. 8 .

$c_{0.18 \%}$ due to matrix contamination.
} 
7. RFFERENCES

L. . . J ", R. P. Wichner, W. J. Martin, I. I. Fairchild, R. J. Kedl, and II. - le Iordwall, Postirradiation Examination of Peach Bottom HTGR Driver Fuel Element EO6-01, ORNL-5126 (March 1976).

2. R. P. Wichner, F. F. Dyer, W. J. Martin, and I. C. Bate, Distribution of Fission Products in Peach Bottom FTGR Fuel Element Ell-O7, ORNL5214 (April 1977).

3. R. P. Wichner, F. F. Dyer, and W. J. Martin, Distribution of Fission Products in Peach Bottom HTGR Fuel Element EI4-Ol, ORNI/TM-5730 (August 1977).

4. F. F. Dyer, R. P. Wichner, W. J. Martin, and H. J. de Iordwall, Distribution of Radionuclides in the Peach Bottom HTGR Primary Circuit During Core 2 Operation, ORNL-5188 (Apri1 1977).

5. Peach Bottom Atomic Power Station, Final Hazards Summary Report, Part C, vol. 2, NP-9115 (March 1964).

6. Proposed Facility Change and Technical Specifications Change No. 13 to the Final Hazard.s Summary Report (January 1970).

7. R. F. Turner, R. D. Burnette, and W. J. Scheffel, HTGR Fuel Performance in the Peach Bottom Reactor, GA-Al2675 (July 9, 1973).

8. Internal correspondence, GAC, Frances McCord to C. F. Wallroth, "Peach Bottom Core 2 Driver Element FO3-OI Irradiation Sumary," Aug. 8, 1975.

9. Letter, C. M. Miller (GAC) to W. J. Martin (ORNL), dated Jan. 22, 1974, Attachment 3 .

10. G. Buzzelli and R. H. Smith, Spectrophotometric Determination of Fission Zirconium in Nuclear Fuels, GAMD-10072 (February 1973 ).

11. C. F. Wallroth et al., Postirradiation Examination and Evaluation of Peach Bottom Molded Test Element FTE-18, GA-Al3699 (June 1976).

12. T. B. Lindemer and R. I. Pearson, Kernel Migration in HTGR Fuels from the Th-U-C-O-N System, ORNL/TM-5207 (April 1976). 
13. E. L. Long, Metals and Ceramics Division, ORVL, personal communication, March 1976.

14. M. J. Kania, Metals and Ceramics Division, ORVI, personal communication, November 1976. 
$\bullet$

- APPEIDIXES 


\subsection{Appendix A: ${ }^{*}$ Measured Axial Distribution of Gamma-Emitters in the sleeve, Spine, and Bottom Connector in Planes 1 and 2}

Tables A-I through A-18 list measured nuclide inventories along the axes of two planes of the sleeve, spine, and bottom connector in terms of curies per 3-in. segment. The listed "error" is the standard deviation in percent determined from the counting statistics. The designations (*****), which occasionally appear in the "error" column, signify that an upper-limit value appears in the inventory column (see sect. 4.2-2). 
Table A-1. Axial distribution of ${ }^{60} \mathrm{Co}$ in the sleeve of element FO3-01 (corrected to October 31, 1974)

\begin{tabular}{|c|c|c|c|c|c|}
\hline \multirow[b]{2}{*}{ Tocation } & \multirow[b]{2}{*}{$\begin{array}{l}\text { Distance } \\
\text { (in.) }\end{array}$} & \multicolumn{2}{|c|}{ Plane 1} & \multicolumn{2}{|c|}{ Plane 2} \\
\hline & & $\begin{array}{l}\text { Inventory } \\
(\mathrm{Ci} / 3 \text { in.) }\end{array}$ & $\begin{array}{c}\text { Error } \\
(\%)\end{array}$ & $\begin{array}{l}\text { Inventory } \\
(\mathrm{Ci} / 3 \mathrm{in.})\end{array}$ & $\begin{array}{c}\text { Error } \\
(\%)\end{array}$ \\
\hline 1 & 0.25 & $7.19 k-05$ & 10.32 & $1.85 E-04$ & $5 \cdot 43$ \\
\hline 2 & 0.49 & 4. $02 E-05$ & $12 \cdot 43$ & $4 \cdot 15 E-05$ & $11 \cdot 74$ \\
\hline 3 & 0.74 & $2.84 \varepsilon-05$ & 13.55 & $1.98 E-05$ & 17.55 \\
\hline 4 & 0.99 & $2.33 E-05$ & 14.11 & $2.83 E-05$ & 13.44 \\
\hline 5 & 1.23 & $2.765-05$ & 13.39 & $4.57 E-05$ & 10.97 \\
\hline 6 & 1.48 & $1.52 k-05$ & 24.00 & $8 \cdot 79 E-05$ & 6.90 \\
\hline 7 & 1.72 & $2.57 t-05$ & 13.74 & 8. $13 E-05$ & $7 \cdot 62$ \\
\hline 8 & 1.97 & $2.85 t-05$ & 14.18 & $9 \cdot 29 \mathrm{E}-05$ & 6.68 \\
\hline 9 & $2 \cdot 22$ & $2.64 t-05$ & 14.24 & $6 \cdot 46 t-05$ & 7.86 \\
\hline 10 & $2 \cdot 46$ & $2 \cdot 21 上-05$ & 17.45 & $3.23 k-05$ & $12 \cdot 4 !$ \\
\hline 11 & $2 \cdot 71$ & $2 \cdot 19 E-05$ & 15.89 & 3. $18 E-05$ & 12.07 \\
\hline 12 & $2 \cdot 95$ & $3.61 \mathrm{E}-05$ & $10 \cdot 11$ & $3.01 \mathrm{E}-05$ & 13.25 \\
\hline 13 & $3 \cdot 20$ & $2.42 t-05$ & 13.98 & $1.63 E-05$ & $25 \cdot 62$ \\
\hline 14 & 3.44 & $1.98 E-05$ & 19.50 & $2.77 \varepsilon-05$ & $14 \cdot 14$ \\
\hline 15 & 3.69 & $2 \cdot 70 \mathrm{E}-05$ & $12 \cdot 21$ & $2.88 E-05$ & 13.18 \\
\hline 16 & 3.94 & $2.46 t-05$ & 12.97 & $2 \cdot 76 \mathrm{E}-05$ & 12.88 \\
\hline 17 & 4.18 & $1.30 t-05$ & $30 \cdot 63$ & $3.03 \mathrm{E}-05$ & 14.84 \\
\hline 18 & 4.43 & $3.05 t-05$ & $13 \cdot 15$ & $2.07 t-05$ & 19.98 \\
\hline 19 & 4.67 & $2 \cdot 47 E-05$ & 12.65 & $2 \cdot 72 k-05$ & $15 \cdot 71$ \\
\hline 20 & $4 \cdot 92$ & $2 \cdot 56 t-05$ & $13 \cdot 37$ & 2. $77 E-05$ & $16 \cdot 20$ \\
\hline 21 & $5 \cdot 17$ & $2.68 \mathrm{E}-05$ & 15.47 & $3.23 k-05$ & 13.44 \\
\hline 22 & $5 \cdot 41$ & $2 \cdot 58 k-05$ & $20 \cdot 23$ & $3 \cdot 31 E-05$ & $15 \cdot 11$ \\
\hline 23 & $5 \cdot 66$ & $3.57 \mathrm{E}-05$ & $27 \cdot 32$ & $2.15 E-05$ & 36.06 \\
\hline 24 & 5.90 & 5. $14 t-05$ & 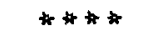 & $0.011-05$ & $17 \cdot 13$ \\
\hline 25 & 6.15 & $4.69 \mathrm{E}-05$ & 28.77 & $3.37 E-05$ & $21 \cdot 28$ \\
\hline 26 & 6.40 & $3.25 t-05$ & 15.87 & $2.23 k-05$ & 17.92 \\
\hline 27 & 6.64 & $2.82 t-05$ & $14 \cdot 17$ & $1.66 \mathrm{E}-05$ & 26.68 \\
\hline 28 & 6.89 & 3. $72 \mathrm{E}-05$ & 11.57 & $2.21 E-05$ & 19.04 \\
\hline 29 & $7 \cdot 13$ & 3.31 t -05 & $14 \cdot 74$ & $3.30 \mathrm{k}-05$ & $13 \cdot 63$ \\
\hline 30 & $7 \cdot 38$ & 2. $72 k-05$ & $18 \cdot 68$ & $2.87 k-05$ & $15 \cdot 81$ \\
\hline 31 & 7. 62 & 3. $03 k-05$ & 18.06 & $3.665-05$ & $12 \cdot 11$ \\
\hline 32 & 7.87 & $2.60 \mathrm{E}-05$ & $21 \cdot 74$ & $1.97 \mathrm{k}-05$ & 23.84 \\
\hline 33 & $8 \cdot 12$ & $4 \cdot 165-05$ & 14.31 & $3.47 k-05$ & 13.40 \\
\hline 34 & 8.36 & $3.00 \mathrm{~b}-0 \mathrm{~s}$ & 28.75 & $3.45 k-05$ & 18.21 \\
\hline 35 & 8.61 & $3.97 b-05$ & $\# *$ & $4.065-05$ & $27 \cdot 26$ \\
\hline 36 & 8.85 & $8.91 k-05$ & $* * * *$ & $6 \cdot 19 上-05$ & 37.89 \\
\hline 37 & 9.10 & $1.35 k-04$ & 37.33 & 7.05k-05 & $\# * *$ \\
\hline 38 & $9 \cdot 35$ & $7 \cdot 63 \mathrm{~L}-05$ & $29 \cdot 12$ & $2.68 \mathrm{t}-05$ & $* * *$ \\
\hline 39 & $9 \cdot 59$ & $5.65 t-05$ & 20.29 & $2 \cdot 38 t-05$ & $\# * *$ \\
\hline 40 & $9 \cdot 84$ & $2 \cdot 81 k-05$ & $* * * *$ & $5.10 \mathrm{E}-05$ & $21 \cdot 11$ \\
\hline 41 & 10.08 & $3.95 k-05$ & 33.31 & $2 \cdot 74 E-05$ & \\
\hline 42 & 10.33 & $4.74 \mathrm{k}-05$ & $25 \cdot 79$ & $3 \cdot 77 E-05$ & $28 \cdot 17$ \\
\hline 43 & 10.58 & 4. $05 t-05$ & 34.37 & $2 \cdot 84 t-05$ & $\# * *$ \\
\hline 44 & 10.82 & $5 \cdot 11 k-05$ & 24.56 & 2. $92 k-05$ & $31 \cdot 20$ \\
\hline 45 & 11.07 & $5.63 k-05$ & 22.97 & $3.52 t-05$ & 30.06 \\
\hline 46 & 11.31 & $3.46 \mathrm{k}-05$ & 35.78 & $3.07 t-05$ & $* * *$ \\
\hline 47 & 11.56 & 3. $77 \mathrm{E}-05$ & 31.76 & 3. $77 t-05$ & 33.26 \\
\hline 48 & 11.81 & $6.83 k-05$ & 30.00 & $4.15 E-05$ & $* * *$ \\
\hline 49 & 12.05 & $5 \cdot 14 E-05$ & $* * * *$ & $6.14 E-05$ & $* * *$ \\
\hline 50 & 12.30 & $5.00 t-05$ & $\# * * *$ & $5.91 E-05$ & 27.54 \\
\hline 51 & $12 \cdot 54$ & 4. $43 t-05$ & 36.51 & 3. $16 \mathrm{t}-05$ & **** \\
\hline 52 & 12.79 & 4. $98 \mathrm{k}-05$ & $* * *$ & $3 \cdot 52 E-05$ & 38.69 \\
\hline
\end{tabular}


Table A-I (continued)

\begin{tabular}{|c|c|c|c|c|c|}
\hline \multirow[b]{2}{*}{ Location } & \multirow[b]{2}{*}{$\begin{array}{c}\text { Distance } \\
\text { (in.) }\end{array}$} & \multicolumn{2}{|c|}{ Plane 1} & \multicolumn{2}{|c|}{ Plane 2} \\
\hline & & $\begin{array}{l}\text { Inventory } \\
(\mathrm{Ci} / 3 \mathrm{in.})\end{array}$ & $\begin{array}{c}\text { Error } \\
(\%)\end{array}$ & $\begin{array}{l}\text { Inventory } \\
(\mathrm{Ci} / 3 \text { in.) }\end{array}$ & $\begin{array}{c}\text { Error } \\
(\%)\end{array}$ \\
\hline 53 & 13.03 & $5.56 z-05$ & $* * * *$ & 3. $48 E-05$ & $* * * *$ \\
\hline 54 & 13.28 & $5.162-05$ & $\star * *$ & $3.68 t-05$ & $* * *$ \\
\hline 55 & 13.53 & $5.03 k-05$ & $\# * *$ & $5.35 t-05$ & 29.66 \\
\hline 56 & 13.77 & $5.98 E-05$ & $* * * *$ & $3.96 E-05$ & $\star \star * \star$ \\
\hline 57 & 14.02 & $5 \cdot 44 E-05$ & $* * * *$ & 4. $17 k-05$ & $* * * *$ \\
\hline 58 & 14.26 & $9.94 E-05$ & $21 \cdot 17$ & $5.88 t-05$ & $30 \cdot 41$ \\
\hline 59 & 14.51 & $9.33 k-05$ & 27.55 & 4. $27 t-05$ & $\# \star \star \star *$ \\
\hline 60 & 14.76 & $7.26 L-05$ & $\star *$ & $7.04 E-05$ & 38.04 \\
\hline 61 & 15.00 & $8.85 E-05$ & $* * *$ & $8.10 E-05$ & $\# \# \#$ \\
\hline 62 & $15 \cdot 25$ & $7.93 k-05$ & $* * * *$ & 7. $15 t-05$ & 39.02 \\
\hline 63 & 15.49 & $0.82 i-05$ & $\# * * *$ & $6.59 t-05$ & 34.82 \\
\hline 64 & 15.74 & 1. $04 k-04$ & $33 \cdot 38$ & $6.83 \mathrm{E}-05$ & $\# * *$ \\
\hline 65 & 15.99 & $1.05 \mathrm{~b}-04$ & $38 \cdot 10$ & 1. $112-04$ & $28 \cdot 31$ \\
\hline 66 & 16.23 & $9.45 \mathrm{E}-05$ & $* * *$ & 7. $64 t-05$ & $* *$ \\
\hline 67 & 10.48 & $1.07 t-04$ & $\star * *$ & $8.35 t-05$ & $* * * *$ \\
\hline 68 & 10.72 & 1. $19 t-04$ & $* * *$ & $8.55 z-05$ & $* * * *$ \\
\hline 69 & 16.97 & $1.27 \mathrm{E}-04$ & $* * * *$ & $9 \cdot 24 t-05$ & $4 * 4$ \\
\hline 70 & 17.22 & $1.79 k-04$ & $* * * *$ & $1.03 E-04$ & $* * * *$ \\
\hline 71 & 17.40 & $2.015-04$ & $* * *$ & 1. $10 \mathrm{E}-04$ & $* * *$ \\
\hline 72 & 17.71 & $1.80 E-04$ & $* * *$ & $1.53 E-04$ & $* * *$ \\
\hline 73 & 17.95 & $2.77 \mathrm{k}-04$ & $* * *$ & $2 \cdot 15 \mathrm{E}-04$ & $\forall *$ \\
\hline 74 & 18.20 & $2.90 z-04$ & $* * *$ & 3. $73 t-04$ & $26 \cdot 56$ \\
\hline 75 & $18 \cdot 44$ & $2.06 E-04$ & $\star * * *$ & 2. $31 \mathrm{E}-04$ & $* \star \star \star$ \\
\hline 76 & 18.69 & $2.49 E-04$ & $* * * *$ & 2. $49 \mathrm{E}-04$ & $* * *$ \\
\hline 77 & 18.94 & $2.66 z-04$ & $* * * *$ & 2. $18 E-04$ & $\star * *$ \\
\hline 78 & 19.18 & 2. $03 t-04$ & $* * * *$ & 2. $15 t-04$ & $* * * *$ \\
\hline 79 & 19.43 & $2.70 k-04$ & $* * *$ & 2. $66 \mathrm{~L}-04$ & $* * * *$ \\
\hline 80 & 19.67 & 2. $70 E-04$ & $* * * *$ & $3.16 t-04$ & $* * *$ \\
\hline 51 & 19.92 & 3. 11 E- 04 & $* * *$ & 3. $19 \mathrm{E}-04$ & $* * *$ \\
\hline 82 & $20 \cdot 17$ & $2.75 \mathrm{E}-04$ & $* * * *$ & $3.21 E-04$ & $* * * *$ \\
\hline 83 & 20.41 & $3.50 z-04$ & $\star * * *$ & $3.59 \mathrm{E}-04$ & $* * *$ \\
\hline 84 & 20.66 & $4.29 E-04$ & 39.70 & $3.88 k-04$ & $* * * *$ \\
\hline 85 & 20.90 & $3.78 E-04$ & $* * *$ & 4. $21 \mathrm{E}-04$ & $* * *$ \\
\hline 86 & $21 \cdot 15$ & 4. $75 E-04$ & **** & 6. $68 E-04$ & $38 \cdot 21$ \\
\hline 87 & $21 \cdot 40$ & 4. $03 E-04$ & $* * * *$ & $6.40 \mathrm{E}-04$ & $* * * *$ \\
\hline 88 & $21 \cdot 64$ & $3.53 E-04$ & $* * *$ & $6.97 t-04$ & $* * * *$ \\
\hline 89 & 21.89 & 4. $35 \mathrm{E}-04$ & $* * *$ & 7. $60 t-04$ & $* * *$ \\
\hline 90 & $22 \cdot 13$ & 4. 72 t -04 & **** & 8. $62 E-04$ & $* * * *$ \\
\hline 91 & $22 \cdot 38$ & $5.31 E-04$ & $* * * *$ & 8. $67 t-04$ & $* * * *$ \\
\hline 92 & $22 \cdot 62$ & $0.13 E-04$ & $* * * *$ & $9.62 \mathrm{E}-04$ & $* * *$ \\
\hline 93 & 22.87 & $6.91 E-04$ & $* * *$ & 1. $22 E-03$ & $* * * *$ \\
\hline 94 & $23 \cdot 12$ & 8. $53 E-04$ & $\# * * *$ & 1. $36 E-03$ & **** \\
\hline 95 & 23.36 & $1.07 \mathrm{E}-03$ & $* * * *$ & 1. $31 E-03$ & $* * *$ \\
\hline 96 & 23.61 & $1.11 \mathrm{E}-03$ & $* * *$ & 1. $33 \mathrm{E}-03$ & $* * * *$ \\
\hline 97 & 23.85 & 1. $23 E-03$ & $* * * *$ & 1. $46 E-03$ & $* * *$ \\
\hline 98 & $24 \cdot 10$ & 1. $53 \mathrm{E}-03$ & $* * * *$ & $1.69 \mathrm{E}-03$ & $* * *$ \\
\hline 99 & $24 \cdot 35$ & 1. $65 E-03$ & $* * * *$ & 1.99E-03 & $* * * *$ \\
\hline 100 & 24.59 & $1.49 t-03$ & $* * * *$ & 1. $80 E-03$ & $* * *$ \\
\hline 101 & $24 \cdot 84$ & $1.74 E-03$ & $* * * *$ & $1.78 t-03$ & $* * *$ \\
\hline 102 & $25 \cdot 18$ & $2.19 t-03$ & 33.52 & $1.01 E-03$ & $* * * *$ \\
\hline 103 & 25.33 & 1. $66 \mathrm{E}-03$ & *** & $1.81 k-03$ & $* * *$ \\
\hline 104 & $25 \cdot 58$ & 1. $46 t-03$ & **** & $1.92 k-03$ & $* * *$ \\
\hline
\end{tabular}


Table A-I (continued)

\begin{tabular}{|c|c|c|c|c|c|}
\hline \multirow[b]{2}{*}{ Location } & \multirow[b]{2}{*}{$\begin{array}{l}\text { Distance } \\
\text { (in.) }\end{array}$} & \multicolumn{2}{|c|}{ Plane 1} & \multicolumn{2}{|c|}{ Plane 2} \\
\hline & & $\begin{array}{l}\text { Inventory } \\
\text { (ci/3 in.) }\end{array}$ & $\begin{array}{c}\text { Error } \\
(\%)\end{array}$ & $\begin{array}{l}\text { Inventory } \\
(\mathrm{Ci} / 3 \mathrm{in.})\end{array}$ & $\begin{array}{l}\text { Error } \\
(\%)\end{array}$ \\
\hline 105 & 25.82 & 1.70 t- 03 & $* * * *$ & $2.01 k-03$ & $* * *$ \\
\hline 106 & $26 \cdot 07$ & $1.55 z-03$ & $\# * * *$ & $1.89 k-03$ & $\# * * *$ \\
\hline 107 & $26 \cdot 31$ & $1.54 t-03$ & 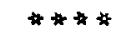 & $1.90 \mathrm{E}-03$ & $t * t$ \\
\hline 108 & $26 \cdot 56$ & $1.67 t-03$ & $* * * *$ & $1.08 E-03$ & $\star * * *$ \\
\hline 109 & 26.81 & 1. $66 \mathrm{k}-03$ & $* * *$ & 1. $75 i-03$ & $* * * *$ \\
\hline 110 & 27.05 & $1.60 \mathrm{t}-03$ & $* * * *$ & $2 \cdot 01 E-03$ & $* * * *$ \\
\hline 111 & $27 \cdot 30$ & $1.57 \mathrm{t}-03$ & $* * *$ & $1.94 k-03$ & $t+4 x$ \\
\hline 112 & $27 \cdot 54$ & $1.43 t-03$ & 34.73 & $1.53 E-03$ & $* * *$ \\
\hline 113 & 27.79 & $1.02 t-03$ & $* * * *$ & 1. $4: 1=-03$ & $\Rightarrow \neq *$ \\
\hline 114 & 28.03 & $1.09 \mathrm{~L}-03$ & $* * *$ & $1.88 L-03$ & $31 \cdot 48$ \\
\hline 115 & $28 \cdot 28$ & 1.0OE-03 & $* * * *$ & $1 \cdot 57 \mathrm{~L}-03$ & $* * x^{2}$ \\
\hline 116 & $28 \cdot 53$ & $8.98 k-04$ & $* * * *$ & $1.70 E-03$ & $* * * *$ \\
\hline 117 & $28 \cdot 77$ & $1.25 t-03$ & $* * * *$ & 1. $82 t-03$ & 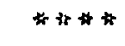 \\
\hline 118 & 29.02 & $2.11 k-03$ & 24.82 & 1. $67 \mathrm{z}-03$ & $4 * *$ \\
\hline 119 & $29 \cdot 26$ & $1.17 E-03$ & $\# * * *$ & 1. $75 \mathrm{t}-03$ & $4 * t *$ \\
\hline 120 & $29 \cdot 51$ & 1. $18 t-03$ & $* * * *$ & 1. $76 t-03$ & $* * * 4$ \\
\hline 121 & $29 \cdot 76$ & 1. $22 E-03$ & $* * * *$ & 1. $66 E-03$ & $* * * *$ \\
\hline 122 & $30 \cdot 19$ & $9.35 E-04$ & $* * *$ & 8. $78 E-04$ & $34 \cdot 51$ \\
\hline 123 & $30 \cdot 43$ & $1.84 E-03$ & $* * * *$ & 1. $38 z-03$ & $s_{z} * * *$ \\
\hline 124 & 30.68 & 1. $57 \mathrm{E}-03$ & $* * * *$ & 1. $39 E-03$ & $* * * *$ \\
\hline 125 & 30.92 & 1. $44 \mathrm{E}-03$ & $* * * *$ & $1.512-03$ & $* * * *$ \\
\hline 126 & $31 \cdot 17$ & 1. $\in 7 E-03$ & **** & 1. $65 E-03$ & $* * * *$ \\
\hline 127 & $31 \cdot 42$ & $1.61 \mathrm{~L}-03$ & $* * * *$ & 1. $822-03$ & $* * *$ \\
\hline 128 & $31 \cdot 66$ & $1.80 \mathrm{E}-03$ & $* *$ & $2.012-03$ & $* * *$ \\
\hline 129 & 31.91 & $1.94 t-03$ & $* * * *$ & $2.19 t-03$ & 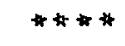 \\
\hline 130 & $32 \cdot 15$ & $1.89 E-03$ & $* * *$ & 2. $10 k-03$ & $* * *$ \\
\hline 131 & $32 \cdot 40$ & $2.27 t-03$ & $* * *$ & $2.31 z-03$ & $* 4 * t$ \\
\hline 132 & 32.65 & $2.44 \mathrm{~L}-03$ & $* * * *$ & $2.42 z-03$ & $* * * *$ \\
\hline 133 & 32.89 & $2.80 \mathrm{k}-03$ & $* * * *$ & $2.71 t-03$ & $* * * *$ \\
\hline 134 & $33 \cdot 14$ & 3. $42 E-03$ & $* * * *$ & $3.09 z-03$ & 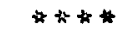 \\
\hline 135 & $33 \cdot 38$ & $3 \cdot 11 k-03$ & $* * *$ & $2.68 t-03$ & $\neq \dot{*} * *$ \\
\hline 136 & 33.63 & $3.14 E-03$ & $* * * *$ & $2.48 \mathrm{z}-03$ & 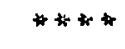 \\
\hline 137 & 33.88 & $2.97 E-03$ & $* * * *$ & $2.35 i-03$ & $\# * * *$ \\
\hline 138 & 34.12 & 3. $12 \mathrm{~L}-03$ & $* * * *$ & $2.62 i-03$ & $\star * * *$ \\
\hline 139 & $34 \cdot 37$ & $3.03 E-03$ & $* \star * *$ & $2 \cdot 54 k-03$ & $t r * t *$ \\
\hline 140 & $34 \cdot 61$ & $2.93 L-03$ & $* * * *$ & $2.73 E-03$ & $* * * *$ \\
\hline 141 & 34.86 & $2.89 z-03$ & $* * * *$ & $2.82 E-03$ & $\hbar * * t$ \\
\hline 142 & $35 \cdot 11$ & $3.00 \mathrm{t}-03$ & $* * * *$ & 2. $78 z-03$ & $* * *$ \\
\hline 143 & $35 \cdot 35$ & 2. $71 \mathrm{t}-03$ & $* * * *$ & $2.32 t-03$ & $* * * *$ \\
\hline 144 & $35 \cdot 60$ & 2. $69 \mathrm{t}-03$ & $* * * *$ & $3.235-03$ & 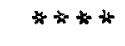 \\
\hline 145 & $35 \cdot 84$ & $2.75 t-03$ & $* * *$ & $3.202-03$ & $\star * * *$ \\
\hline 146 & 36.09 & $2.86 t-03$ & **** & $3.58 z-03$ & $* * * *$ \\
\hline 147 & $36 \cdot 33$ & $2.85 t-03$ & $* * *$ & $3 \cdot 24 \mathrm{E}-03$ & $* * *$ \\
\hline 148 & $36 \cdot 58$ & $2 \cdot 41 E-03$ & $* * * *$ & 2. $78 z-03$ & $38 \cdot 27$ \\
\hline 149 & $36 \cdot 83$ & 2. $30 \mathrm{E}-03$ & $* * * *$ & $2 \cdot 57 t-03$ & $32 \cdot 72$ \\
\hline 150 & 37.07 & $2.32 E-03$ & $* * * *$ & $2.07 t-03$ & 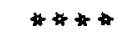 \\
\hline 151 & $37 \cdot 32$ & $2.27 E-03$ & $* * * *$ & 1. $92 z-03$ & $* * *$ \\
\hline 152 & $37 \cdot 56$ & $2.25 t-03$ & **** & $1.93 E-03$ & $t * * *$ \\
\hline 153 & 37.81 & $2.13 t-03$ & $* * * *$ & $1.99 t-03$ & $* * * *$ \\
\hline 154 & 38.06 & 2. $16 \mathrm{k}-03$ & $* * * *$ & 3. 51 L- 03 & 23.83 \\
\hline 155 & $38 \cdot 30$ & $2.18 E-03$ & $* * * *$ & $1.93 L-03$ & $* * * *$ \\
\hline 156 & $38 \cdot 55$ & $2.10 E-03$ & **** & $2 \cdot 33 E-03$ & $38 \cdot 19$ \\
\hline
\end{tabular}


Table A-1 (continued)

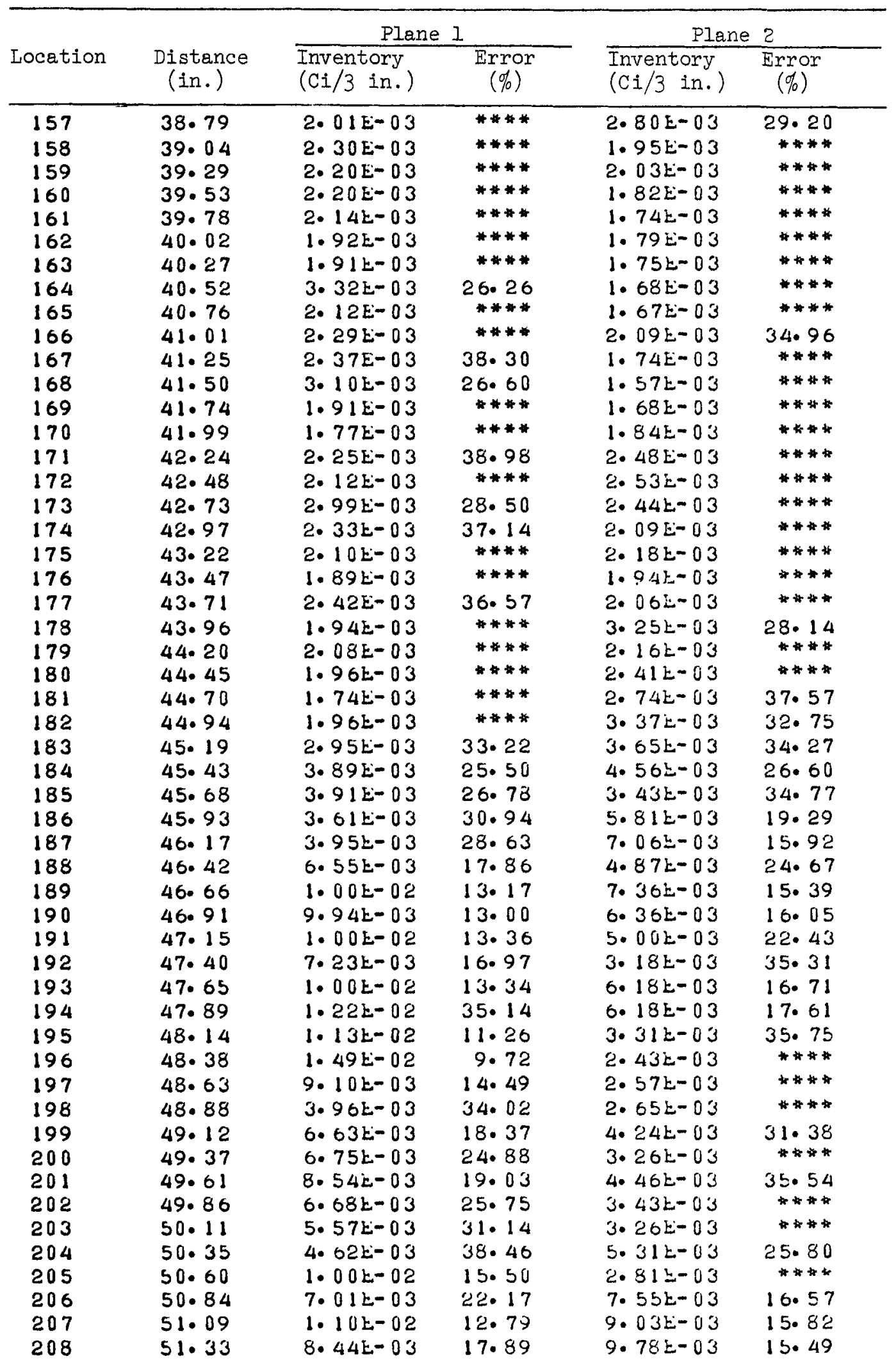


Table A-I (continued)

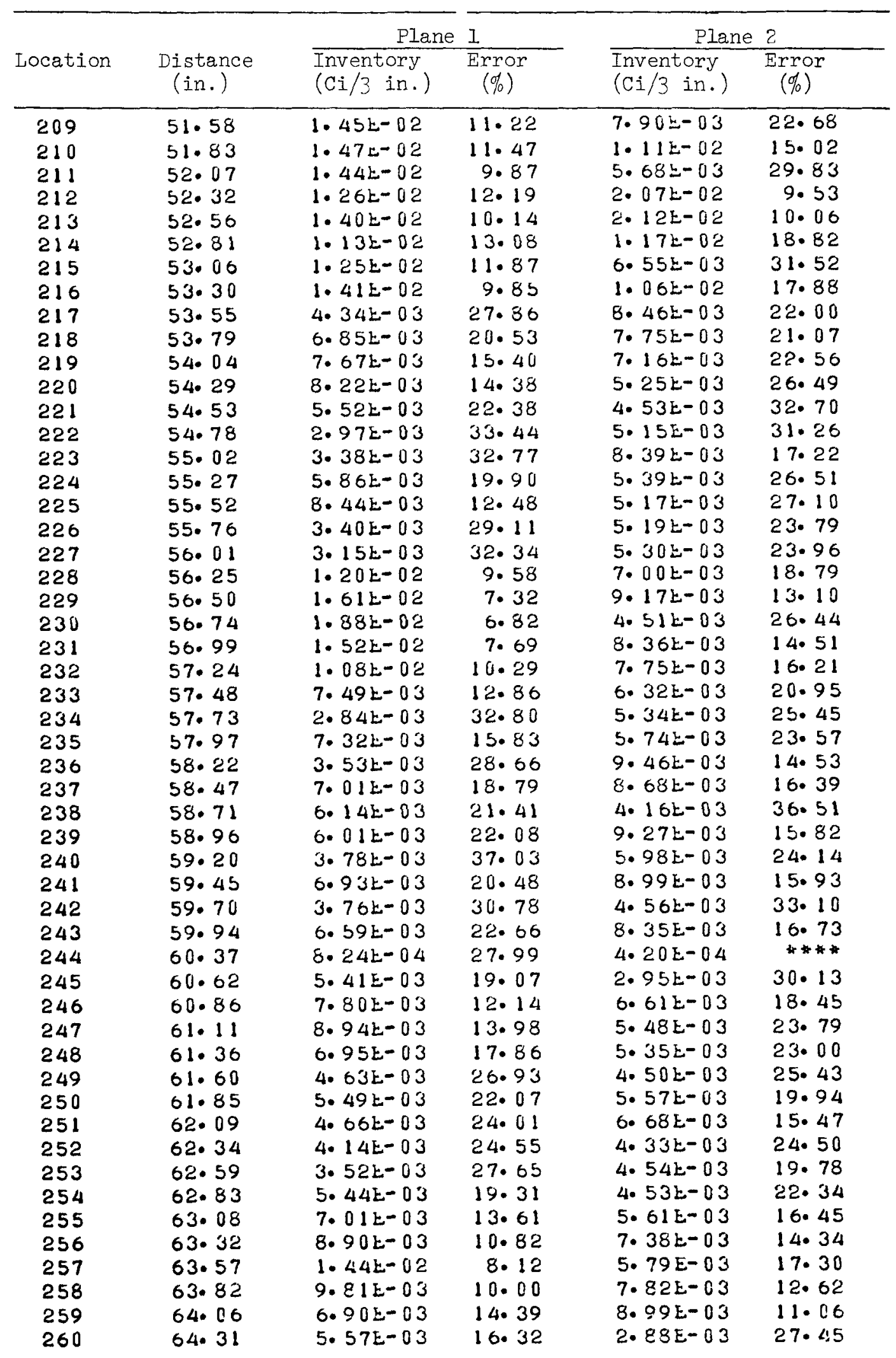


Table A-1 (continued)

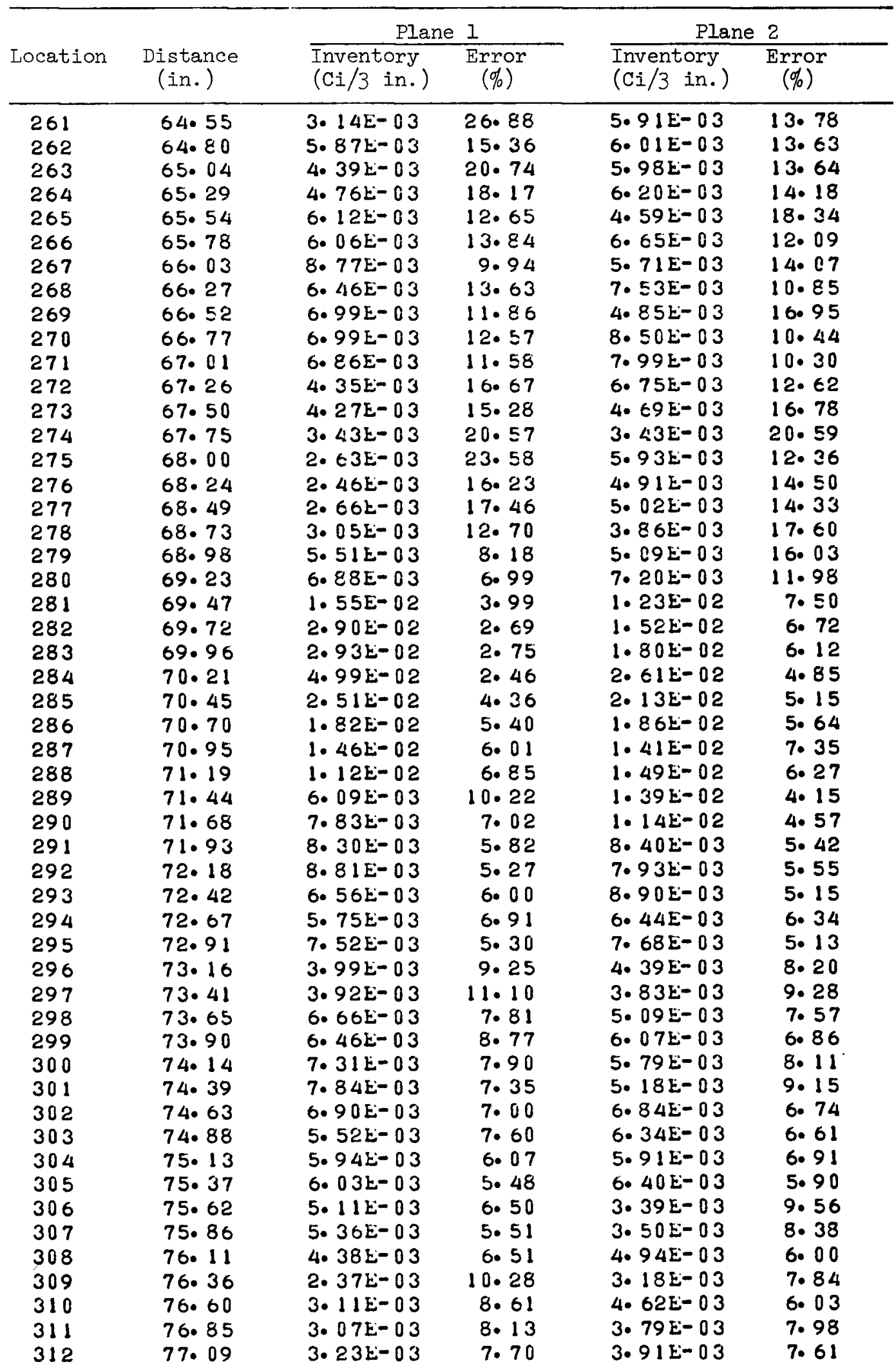


Table A-1 (continued)

\begin{tabular}{|c|c|c|c|c|c|}
\hline \multirow[b]{2}{*}{ Location } & \multirow[b]{2}{*}{$\begin{array}{c}\text { Distance } \\
(\text { in. })\end{array}$} & \multicolumn{2}{|c|}{ Plane 1} & \multicolumn{2}{|c|}{ Plane 2} \\
\hline & & $\begin{array}{l}\text { Inventory } \\
\text { (Ci/3 in.) }\end{array}$ & $\begin{array}{c}\text { Error } \\
(\%)\end{array}$ & $\begin{array}{l}\text { Inventory } \\
\text { ( } \mathrm{Ci} / 3 \text { in.) }\end{array}$ & $\begin{array}{c}\text { Error } \\
(\%)\end{array}$ \\
\hline 313 & $77 \cdot 34$ & $2.92 E-03$ & 7.97 & 4. $75 E-03$ & $6 \cdot 41$ \\
\hline 314 & 77.59 & $1.95 \mathrm{t}-03$ & 11.66 & $3.46 \mathrm{t}-03$ & 8.49 \\
\hline 315 & 77.83 & $2 \cdot 68 E-03$ & $8 \cdot 10$ & $3.11 \mathrm{E}-03$ & $8 \cdot 40$ \\
\hline 316 & 78.08 & $2 \cdot 73 \mathrm{k}-03$ & 5.08 & $2.70 \mathrm{E}-03$ & 8.23 \\
\hline 317 & $78 \cdot 32$ & $3.04 E-03$ & $4 \cdot 49$ & $3.84 E-03$ & 6. 14 \\
\hline 318 & $78 \cdot 57$ & $2.83 E-03$ & 4.65 & $3.01 \mathrm{E}-03$ & 4. 17 \\
\hline 319 & $78 \cdot 82$ & 3. $53 E-03$ & 3.73 & 3. $38 E-03$ & 3. 79 \\
\hline 320 & 79.06 & 4. $30 \mathrm{E}-03$ & 3.21 & $5 \cdot 16 \mathrm{E}-03$ & 2.86 \\
\hline 321 & $79 \cdot 31$ & 4. $37 E-03$ & 3.08 & $5.59 \mathrm{E}-03$ & $2 \cdot 76$ \\
\hline 322 & $79 \cdot 55$ & $6.17 E-03$ & $2 \cdot 31$ & $6.04 \mathrm{E}-03$ & 2. 56 \\
\hline 323 & 79.80 & $6.47 E-03$ & $2 \cdot 12$ & $4.91 \mathrm{E}-03$ & 2. 75 \\
\hline 324 & 80.04 & $6 \cdot 25 t-03$ & 2.06 & 4. $45 E-03$ & 2. 71 \\
\hline 325 & 80.29 & $5.80 \mathrm{E}-03$ & $2 \cdot 10$ & 4. $58 \mathrm{E}-03$ & 2.54 \\
\hline 326 & 80.54 & 5. $14 E-03$ & $2 \cdot 27$ & 5. $66 \mathrm{E}-03$ & 2.09 \\
\hline 327 & $80 \cdot 78$ & $5.21 E-03$ & $2 \cdot 14$ & 5. $42 E-03$ & 2.11 \\
\hline 328 & 81.03 & 4. $79 t-03$ & $2 \cdot 26$ & $4.86 t-03$ & $2 \cdot 18$ \\
\hline 329 & $81 \cdot 27$ & 4. $51 E-03$ & 2.35 & $4.83 E-03$ & 2.17 \\
\hline 330 & $81 \cdot 52$ & 3. $98 \mathrm{E}-03$ & $2 \cdot 45$ & 5. $14 t-03$ & 2.07 \\
\hline 331 & $81 \cdot 77$ & $3.95 E-03$ & 2.41 & 4. $77 t-03$ & $2 \cdot 13$ \\
\hline 332 & 82.01 & 4. $15 E-03$ & 2.38 & $4 \cdot 13 t-03$ & 2. 31 \\
\hline 333 & $82 \cdot 26$ & $3.92 E-03$ & 2.40 & 3. $34 t-03$ & 2. 53 \\
\hline 334 & 82.50 & $3.75 E-03$ & $2 \cdot 49$ & $2.11 \mathrm{E}-03$ & 3. 48 \\
\hline 335 & $82 \cdot 75$ & $3.79 \mathrm{E}-03$ & $2 \cdot 44$ & 2. $45 E-03$ & 3. 27 \\
\hline 336 & 83.00 & 3. $25 E-03$ & 2. 54 & 2. $59 \mathrm{E}-03$ & 2.91 \\
\hline 337 & $83 \cdot 24$ & $2 \cdot 14 E-03$ & 3.16 & 2. $07 E-03$ & 3. 47 \\
\hline 338 & 83.49 & 1. $79 k-03$ & 3.35 & $2.03 E-03$ & 3.26 \\
\hline 339 & 83.73 & 1. $33 E-03$ & $4 \cdot 12$ & $1.88 E-03$ & 3.16 \\
\hline 340 & 83.95 & $1 \cdot 43 \mathrm{E}-03$ & 3.75 & 1. $48 \mathrm{E}-03$ & 3.63 \\
\hline 341 & $84 \cdot 22$ & $1.43 \mathrm{E}-03$ & 2.08 & 1. $72 E-03$ & 1.78 \\
\hline 342 & $84 \cdot 47$ & $1.51 \mathrm{E}-03$ & 1.91 & 1. $70 E-03$ & 1.73 \\
\hline 343 & 84.72 & $1.84 E-03$ & 1.70 & 1. $70 \mathrm{E}-03$ & $1 \cdot 72$ \\
\hline 344 & 84.96 & $2.32 E-03$ & 1.48 & $2.25 t-03$ & 1.44 \\
\hline 345 & 85.21 & $1.51 k-03$ & 2.02 & $1.94 E-03$ & 1.56 \\
\hline 346 & $85 \cdot 45$ & 1.02z-03 & $2 \cdot 31$ & $9.80 t-04$ & 2. 22 \\
\hline 347 & 85.70 & $9.45 z-04$ & $2 \cdot 33$ & $6.20 E-04$ & 2.97 \\
\hline 348 & 85.95 & $8.28 E-04$ & $2 \cdot 47$ & $5.84 z-04$ & 2.94 \\
\hline 349 & $80 \cdot 19$ & $6 \cdot 26 E-04$ & 2.86 & 5. $73 z-04$ & 2.91 \\
\hline 350 & $86 \cdot 44$ & 5. $12 \mathrm{E}-04$ & 3.22 & $5.55 z-04$ & 2.99 \\
\hline 351 & 86.68 & 4. $77 \mathrm{E}-04$ & 3.23 & $5.99 k-04$ & 2.74 \\
\hline 352 & 86.93 & $5.04 \mathrm{E}-04$ & 3.15 & $5 \cdot 45 \pm-04$ & 2.98 \\
\hline 353 & $87 \cdot 18$ & 3. $45 t-04$ & 4.01 & $5.37 t-04$ & 3.00 \\
\hline 354 & $87 \cdot 42$ & $3.65 t-04$ & 3.57 & $5 \cdot 56 z-04$ & $2 \cdot 77$ \\
\hline 355 & 87.67 & $3 \cdot 26 t-04$ & 3.81 & 5. 0こE- 04 & 2.93 \\
\hline 356 & 87.91 & $3.04 t-04$ & 3.85 & 4. $71 \mathrm{E}-04$ & 2.96 \\
\hline 357 & $88 \cdot 16$ & $2.62 t-04$ & $4 \cdot 48$ & $4.65 z-04$ & 2.97 \\
\hline 358 & $88 \cdot 41$ & $1.94 \mathrm{E}-04$ & $5 \cdot 16$ & $3.01 z-04$ & 3.90 \\
\hline 359 & 88.65 & 1. $54 t-04$ & 6.29 & $2.172-04$ & 4.61 \\
\hline 360 & 88.90 & $1 \cdot 27 \mathrm{~L}-04$ & $7 \cdot 15$ & $1.65 E-04$ & 5.93 \\
\hline 361 & $89 \cdot 14$ & 1. $38 E-04$ & $6 \cdot 45$ & 1. $57 \mathrm{E}-04$ & 5.63 \\
\hline 362 & $89 \cdot 39$ & 1. $42 t-04$ & 0.08 & $1.86=-04$ & 5. 47 \\
\hline 363 & 89.63 & $1.17 \mathrm{E}-04$ & $7 \cdot 72$ & 1. $74 t-04$ & 5.91 \\
\hline 364 & 89.88 & 1. $32 t-04$ & $6 \cdot 73$ & $1.94 \mathrm{t}-04$ & $5 \cdot 34$ \\
\hline
\end{tabular}


Table A-2. Axial distribution of ${ }^{60} \mathrm{CO}$ in the spine of element F03-01 (corrected to october 31, 1974)

\begin{tabular}{|c|c|c|c|c|c|}
\hline \multirow[b]{2}{*}{ Location } & \multirow[b]{2}{*}{$\begin{array}{c}\text { Distance } \\
\text { (in.) }\end{array}$} & \multicolumn{2}{|c|}{ Plane 1} & \multicolumn{2}{|c|}{ Plane 2} \\
\hline & & $\begin{array}{l}\text { Inventory } \\
\text { ( } \mathrm{Ci} / 3 \text { in.) }\end{array}$ & $\begin{array}{c}\text { Error } \\
(\%)\end{array}$ & $\begin{array}{l}\text { Inventory } \\
(\mathrm{Ci} / 3 \text { in.) }\end{array}$ & $\begin{array}{l}\text { Error } \\
(\%)\end{array}$ \\
\hline 1 & 0.25 & 1. $03 E-04$ & 11.86 & $6.67 \mathrm{E}-05$ & $14 \cdot 36$ \\
\hline 2 & 0.49 & $7.80 E-05$ & $14 \cdot 36$ & $9.16 \mathrm{E}-05$ & 12.02 \\
\hline 3 & 0.74 & $9.52 E-05$ & $11 \cdot 54$ & 4. $68 E-05$ & $25 \cdot 14$ \\
\hline 4 & 0.99 & $1.11 \mathrm{E}-04$ & 11.56 & $5.97 E-05$ & $20 \cdot 44$ \\
\hline 5 & 1.23 & 1. $13 E-04$ & $12 \cdot 60$ & 1. $14 \mathrm{E}-04$ & $11 \cdot 36$ \\
\hline 6 & 1.48 & 1. $54 E-04$ & 10.13 & 1. $19 \mathrm{E}-04$ & 11.83 \\
\hline 7 & 1.72 & 1. $38 E-04$ & 9.00 & 1. $43 E-04$ & $10 \cdot 65$ \\
\hline 8 & 1.97 & $1.88 E-04$ & 10.36 & $7.86 \mathrm{E}-05$ & $22 \cdot 53$ \\
\hline 9 & 2.22 & 1. $65 \mathrm{E}-04$ & $12 \cdot 53$ & 1. $82 \mathrm{E}-04$ & 10.02 \\
\hline 10 & $2 \cdot 46$ & 2. $04 E-04$ & 10.96 & $1.95 E-04$ & 10.88 \\
\hline 11 & 2.71 & 2. $42 \xi-04$ & $10 \cdot 30$ & $2.36 t-04$ & $9 \cdot 20$ \\
\hline 12 & 2.95 & 2. $06 \mathrm{E}-04$ & $13 \cdot 34$ & $2.21 E-04$ & $10 \cdot 72$ \\
\hline 13 & $3 \cdot 20$ & 3. $00 \mathrm{E}-04$ & $10 \cdot 21$ & 2. $59 E-04$ & $9 \cdot 84$ \\
\hline 14 & 3.44 & 2. $32 \mathrm{E}-04$ & $14 \cdot 43$ & $3 \cdot 30 \mathrm{E}-04$ & $7 \cdot 69$ \\
\hline 15 & 3.69 & $3.93 E-04$ & $9 \cdot 65$ & 3. $50 \mathrm{E}-04$ & $8 \cdot 27$ \\
\hline 16 & 3.94 & 1. $25 E-04$ & 29.53 & 2. $84 E-04$ & 10.92 \\
\hline 17 & $4 \cdot 18$ & 4. $54 E-04$ & 10.83 & $3.11 \mathrm{E}-04$ & 10.62 \\
\hline 18 & $4 \cdot 43$ & $2.02 \mathrm{E}-04$ & $23 \cdot 75$ & $2.83 \mathrm{E}-04$ & 12.56 \\
\hline 19 & $4 \cdot 67$ & 5. $29 E-04$ & 11.00 & $4 \cdot 95 E-04$ & 8.08 \\
\hline 20 & 4.92 & $4 \cdot 32 t-04$ & $14 \cdot 60$ & 2. $13 E-04$ & 18.82 \\
\hline 21 & $5 \cdot 17$ & $2.91 E-04$ & 19.96 & $4 \cdot 26 \mathrm{E}-04$ & 10.94 \\
\hline 22 & $5 \cdot 41$ & $2.70 \mathrm{E}-04$ & 20.02 & 5. $52 E-04$ & 13.59 \\
\hline 23 & $5 \cdot 66$ & 1. $15 \mathrm{E}-04$ & $38 \cdot 44$ & 4. $98 \mathrm{E}-04$ & $15 \cdot 46$ \\
\hline 24 & 5.90 & $6.87 E-04$ & $15 \cdot 42$ & $2.65 E-04$ & $28 \cdot 75$ \\
\hline 25 & $6 \cdot 15$ & 3. $75 \mathrm{E}-04$ & $27 \cdot 39$ & $5.98 E-04$ & $13 \cdot 24$ \\
\hline 26 & 6.40 & 6. $46 E-04$ & $15 \cdot 17$ & $5.91 E-04$ & 13.08 \\
\hline 27 & 6.64 & $5 \cdot 92 t-04$ & 16.62 & $5.09 E-04$ & 16.04 \\
\hline 28 & 6.89 & 4. $48 E-04$ & 23.26 & $6.82 E-04$ & 12.25 \\
\hline 29 & $7 \cdot 13$ & $6 \cdot 57 \mathrm{E}-04$ & $17 \cdot 59$ & $6.83 E-04$ & $12 \cdot 85$ \\
\hline 30 & 7. 38 & 5. $44 \mathrm{E}-04$ & $21 \cdot 64$ & $5 \cdot 77 \mathrm{E}-04$ & $14 \cdot 27$ \\
\hline 31 & 7. 62 & $5.86 E-04$ & 17.31 & $5.91 \mathrm{E}-04$ & 15.95 \\
\hline 32 & $7 \cdot 87$ & $7 \cdot 24 E-04$ & $15 \cdot 22$ & $5 \cdot 78 E-04$ & $15 \cdot 42$ \\
\hline 33 & $8 \cdot 12$ & 5. $65 E-04$ & $20 \cdot 26$ & $4.76 E-04$ & 19.90 \\
\hline 34 & $8 \cdot 36$ & $4 \cdot 51 E-04$ & 23.33 & 5. $47 E-04$ & $20 \cdot 30$ \\
\hline 35 & 8.61 & $6.92 E-04$ & $17 \cdot 59$ & $5.85 E-04$ & 14.92 \\
\hline 36 & 8.85 & $5 \cdot 50 E-04$ & 19.05 & $5 \cdot 74 E-04$ & $17 \cdot 28$ \\
\hline 37 & $9 \cdot 10$ & $6.56 \mathrm{E}-04$ & $17 \cdot 42$ & $6 \cdot 18 \mathrm{E}-04$ & $15 \cdot 29$ \\
\hline 38 & 9.35 & 7. $62 \mathrm{E}-04$ & $14 \cdot 16$ & $5.35 E-04$ & $21 \cdot 08$ \\
\hline 39 & 9.59 & $7.34 E-04$ & $16 \cdot 26$ & $6.44 E-04$ & $16 \cdot 22$ \\
\hline 40 & $9 \cdot 84$ & $6 \cdot 12 \mathrm{E}-04$ & $22 \cdot 16$ & 4. $53 E-04$ & $24 \cdot 26$ \\
\hline 41 & 10.08 & $7 \cdot 71 \mathrm{E}-04$ & $21 \cdot 68$ & $7.50 \mathrm{E}-04$ & $14 \cdot 20$ \\
\hline 42 & 10.33 & $8.55 E-04$ & $15 \cdot 18$ & 4. $59 E-04$ & $22 \cdot 27$ \\
\hline 43 & $10 \cdot 58$ & $9.53 E-04$ & $11 \cdot 61$ & 5. $48 E-04$ & 19.88 \\
\hline 44 & 10.82 & $9.13 \mathrm{E}-04$ & 12.07 & $7 \cdot 53 E-04$ & $14 \cdot 62$ \\
\hline 45 & 11.07 & 7. $36 t-04$ & 14.58 & $7 \cdot 19 \mathrm{E}-04$ & $15 \cdot 35$ \\
\hline 46 & $11 \cdot 31$ & 9. $30 \mathrm{E}-04$ & $12 \cdot 51$ & $6.40 E-04$ & $21 \cdot 73$ \\
\hline 47 & 11.56 & $5.89 E-04$ & $17 \cdot 32$ & $8.34 \mathrm{E}-04$ & $15 \cdot 24$ \\
\hline 48 & 11.81 & 6. $51 E-04$ & 16.01 & 7. $00 \mathrm{E}-04$ & $17 \cdot 73$ \\
\hline 49 & $12 \cdot 05$ & 8. $17 \mathrm{E}-04$ & $12 \cdot 08$ & 4. $49 \mathrm{E}-04$ & $31 \cdot 63$ \\
\hline 50 & 12.30 & 5. $12 E-04$ & 19.71 & $4 \cdot 82 E-04$ & $29 \cdot 11$ \\
\hline 51 & $12 \cdot 54$ & $6 \cdot 74 E-04$ & 14.93 & $7.97 \mathrm{E}-04$ & 17.88 \\
\hline 52 & $12 \cdot 79$ & 3. $68 E-04$ & $25 \cdot 46$ & $4.94 E-04$ & 30.91 \\
\hline
\end{tabular}


Table A-2 (continued)

\begin{tabular}{|c|c|c|c|c|c|}
\hline \multirow[b]{2}{*}{ Location } & \multirow[b]{2}{*}{$\begin{array}{l}\text { Distance } \\
\text { (in.) }\end{array}$} & \multicolumn{2}{|c|}{ Plane I } & \multicolumn{2}{|c|}{ Plane 2} \\
\hline & & $\begin{array}{l}\text { Inventory } \\
(\mathrm{Ci} / 3 \text { in.) }\end{array}$ & $\begin{array}{c}\text { Error } \\
(\%)\end{array}$ & $\begin{array}{l}\text { Inventory } \\
(\mathrm{Ci} / 3 \text { in.) }\end{array}$ & $\begin{array}{c}\text { Error } \\
(\%)\end{array}$ \\
\hline $\begin{array}{l}53 \\
54 \\
55 \\
56 \\
57 \\
58 \\
59 \\
60 \\
61 \\
62 \\
63 \\
64 \\
65 \\
66 \\
67 \\
68 \\
69 \\
70 \\
71 \\
72 \\
73 \\
74 \\
75 \\
76 \\
77 \\
78 \\
79 \\
80 \\
81 \\
82 \\
83 \\
84 \\
85 \\
86 \\
87 \\
88 \\
89 \\
90 \\
91 \\
92 \\
93 \\
94 \\
95 \\
96 \\
97 \\
98 \\
99 \\
100 \\
101 \\
102 \\
103 \\
104\end{array}$ & $\begin{array}{l}13.03 \\
13.28 \\
13.53 \\
13.77 \\
14002 \\
14.26 \\
14.51 \\
14.76 \\
15000 \\
15.25 \\
15.49 \\
15.74 \\
15.99 \\
16.23 \\
16048 \\
16072 \\
16.97 \\
17.22 \\
17.46 \\
17.71 \\
17.95 \\
18.20 \\
18.44 \\
18.69 \\
18.94 \\
19.18 \\
19.43 \\
19.67 \\
19.92 \\
20.17 \\
20.41 \\
20.66 \\
20.90 \\
21.15 \\
21.40 \\
21.64 \\
21.89 \\
22013 \\
22.38 \\
22.62 \\
22.87 \\
23.12 \\
23.36 \\
23.61 \\
23.85 \\
24.10 \\
24.35 \\
24.59 \\
24.84 \\
25.08 \\
25.33 \\
25.58\end{array}$ & 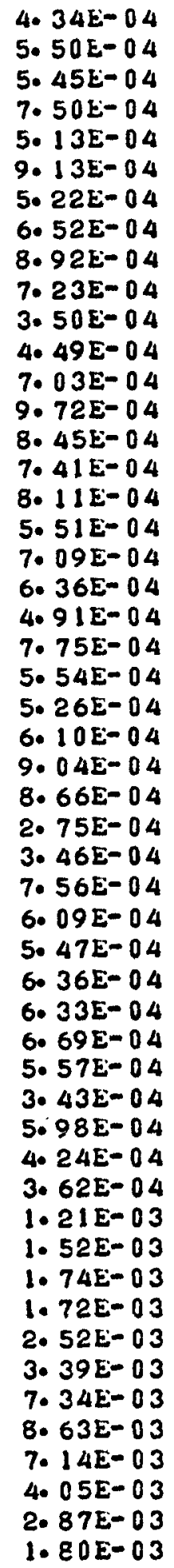 & $\begin{array}{l}21.90 \\
19.04 \\
17.46 \\
13.76 \\
20.41 \\
12.44 \\
22.42 \\
18.28 \\
14.87 \\
15.65 \\
27.50 \\
22.61 \\
15.50 \\
13.06 \\
14.32 \\
16.68 \\
14.86 \\
18.43 \\
15.12 \\
15.92 \\
22.23 \\
15.39 \\
24.52 \\
21.53 \\
21.66 \\
13.69 \\
13.01 \\
37.93 \\
32.21 \\
14.38 \\
19.25 \\
22.59 \\
21.21 \\
20.18 \\
19.57 \\
25.49 \\
35.36 \\
24.96 \\
33.98 \\
39.84 \\
14.36 \\
12.27 \\
12.60 \\
15.40 \\
11.66 \\
12.73 \\
6.79 \\
6.69 \\
7.31 \\
10.57 \\
14.12 \\
20.43\end{array}$ & 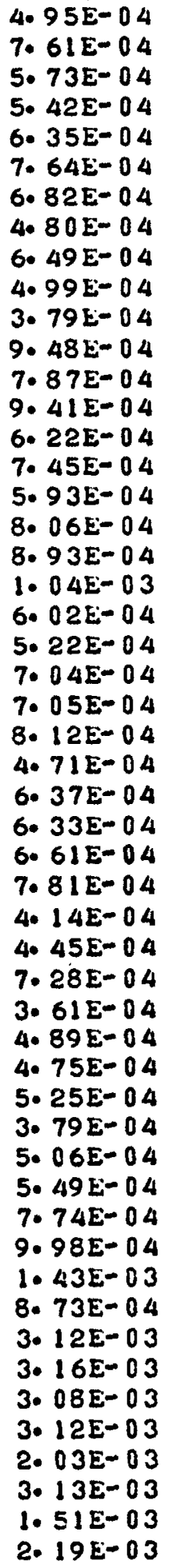 & 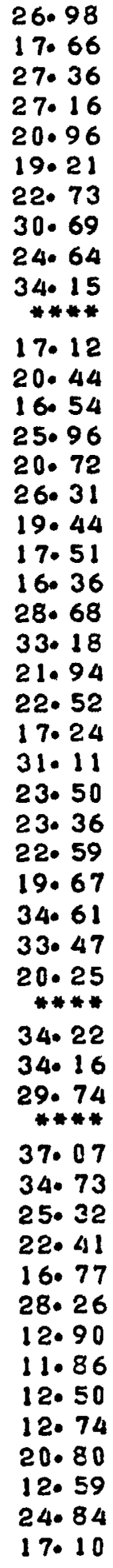 \\
\hline
\end{tabular}


Table A-2 (continued)

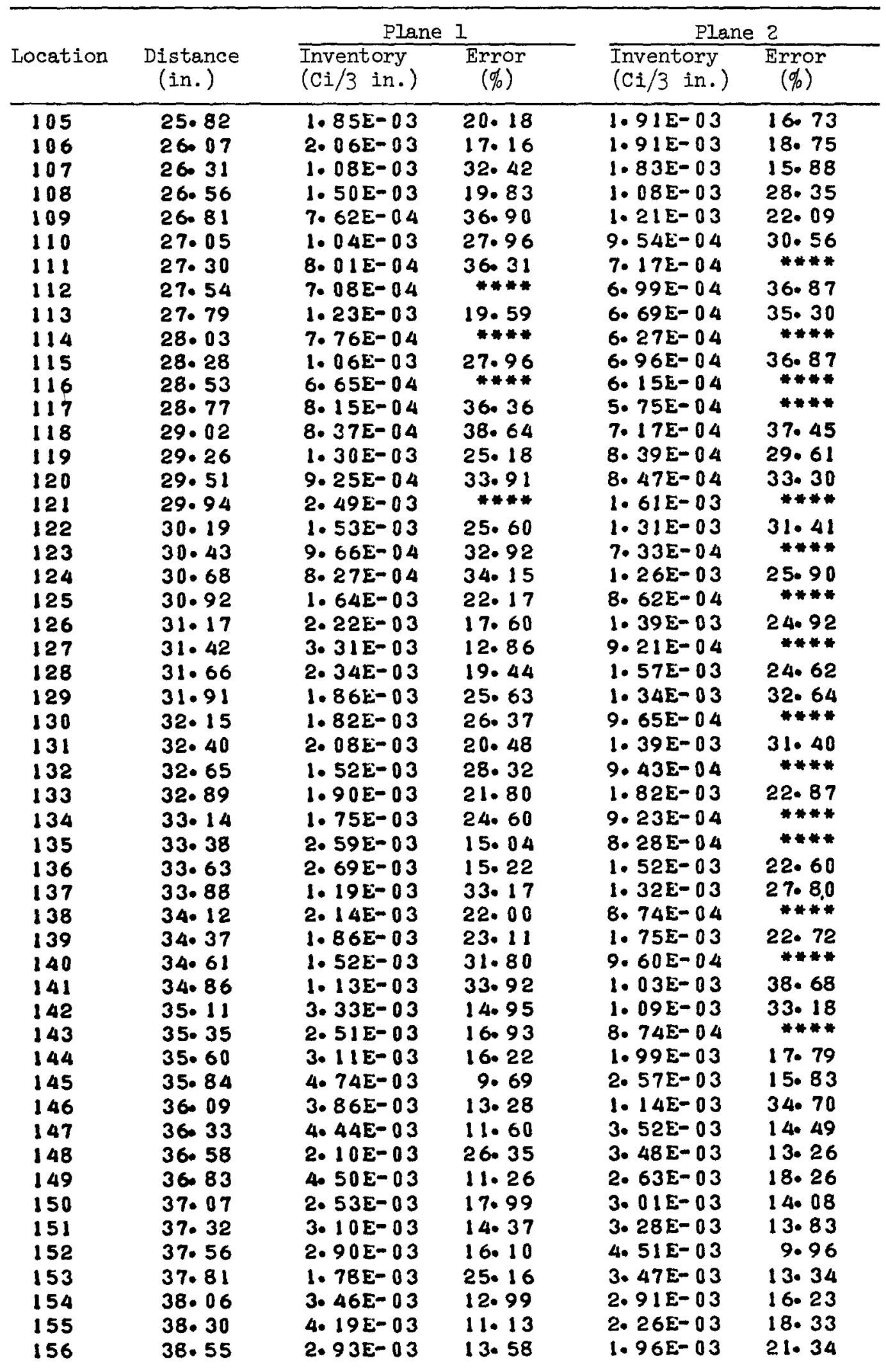


Table A-2 (continuela)

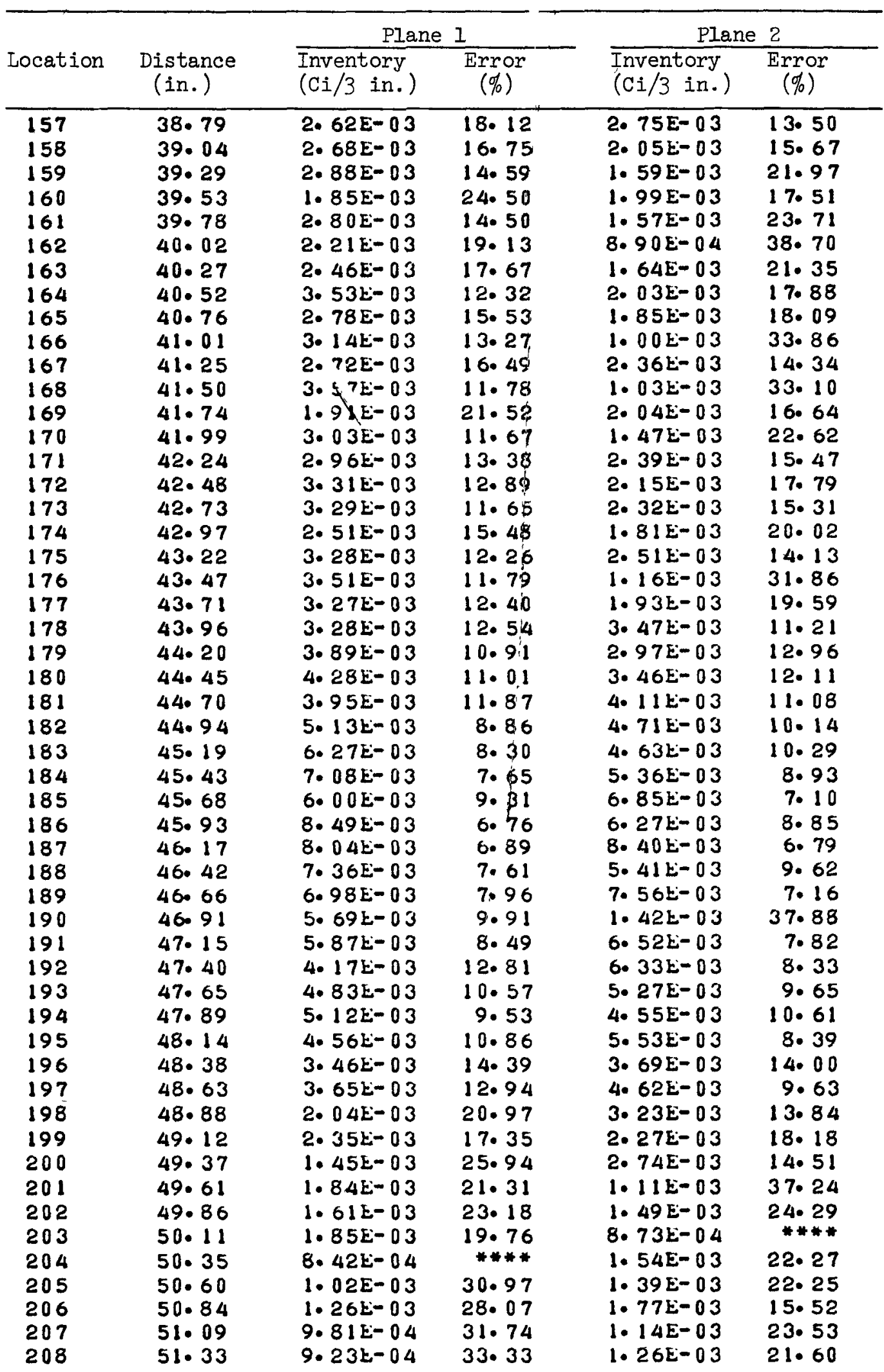


Table A-2 (continued)

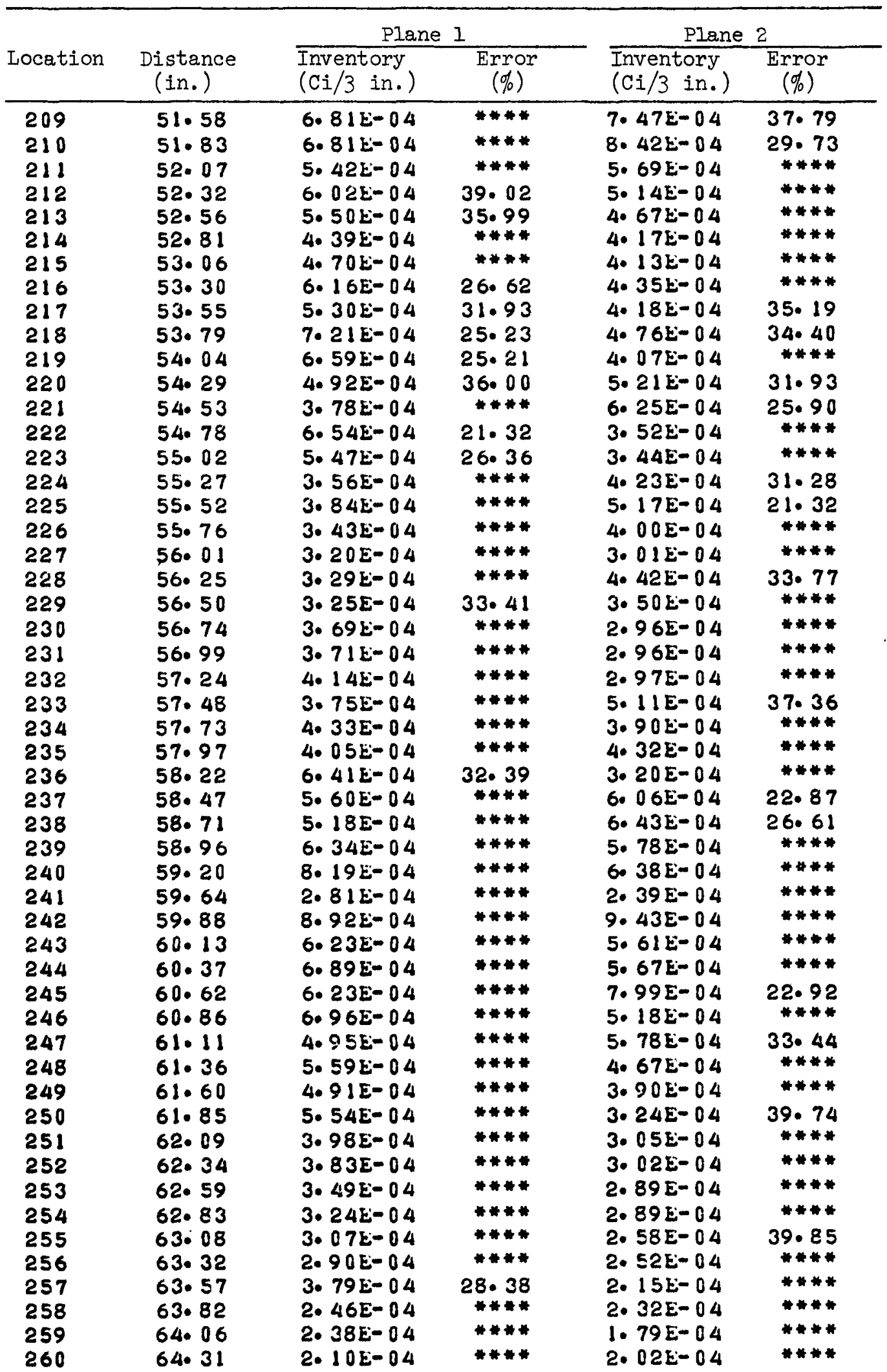


Table A-2 (continued)

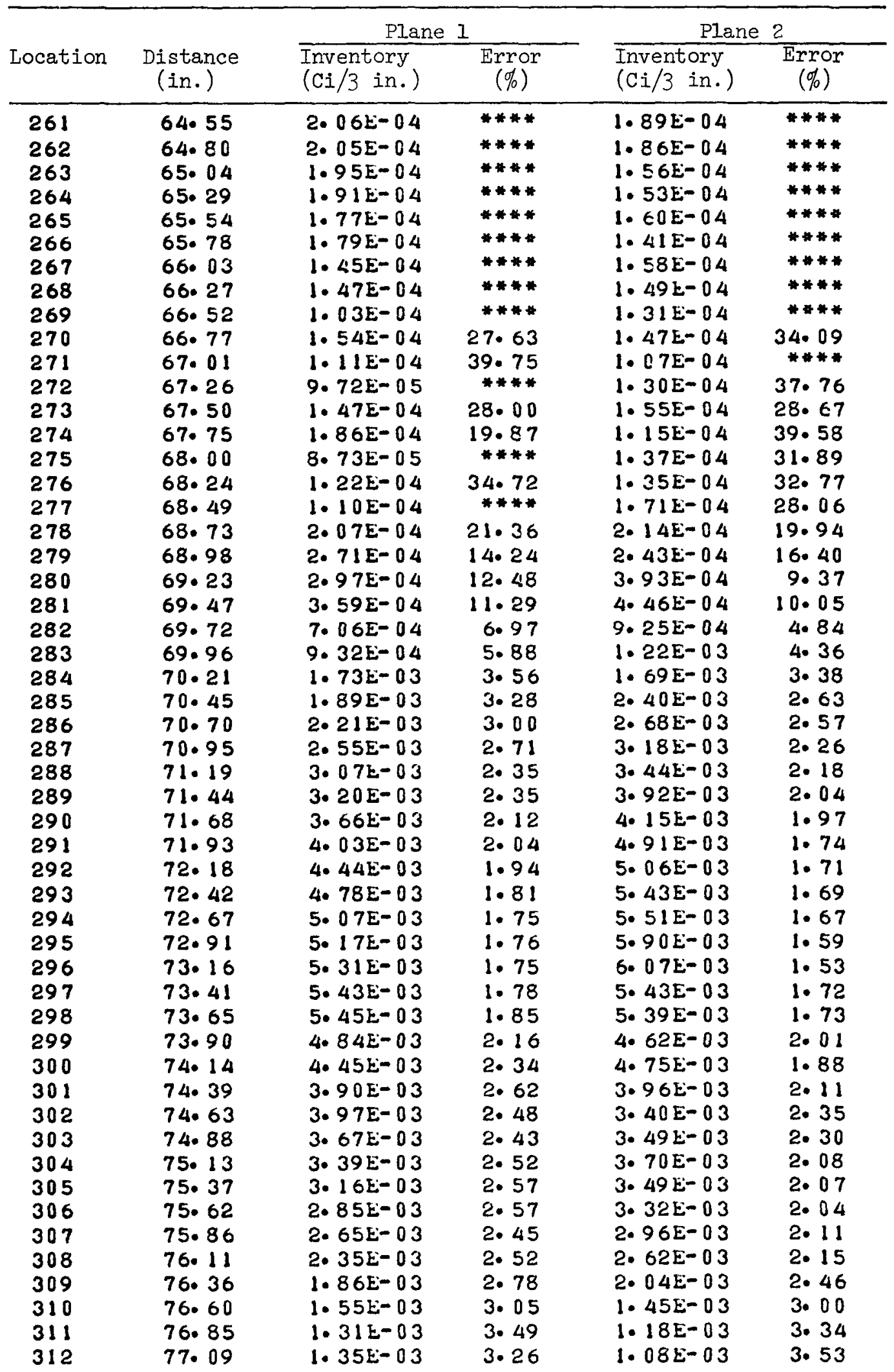


Table A-2 (continued)

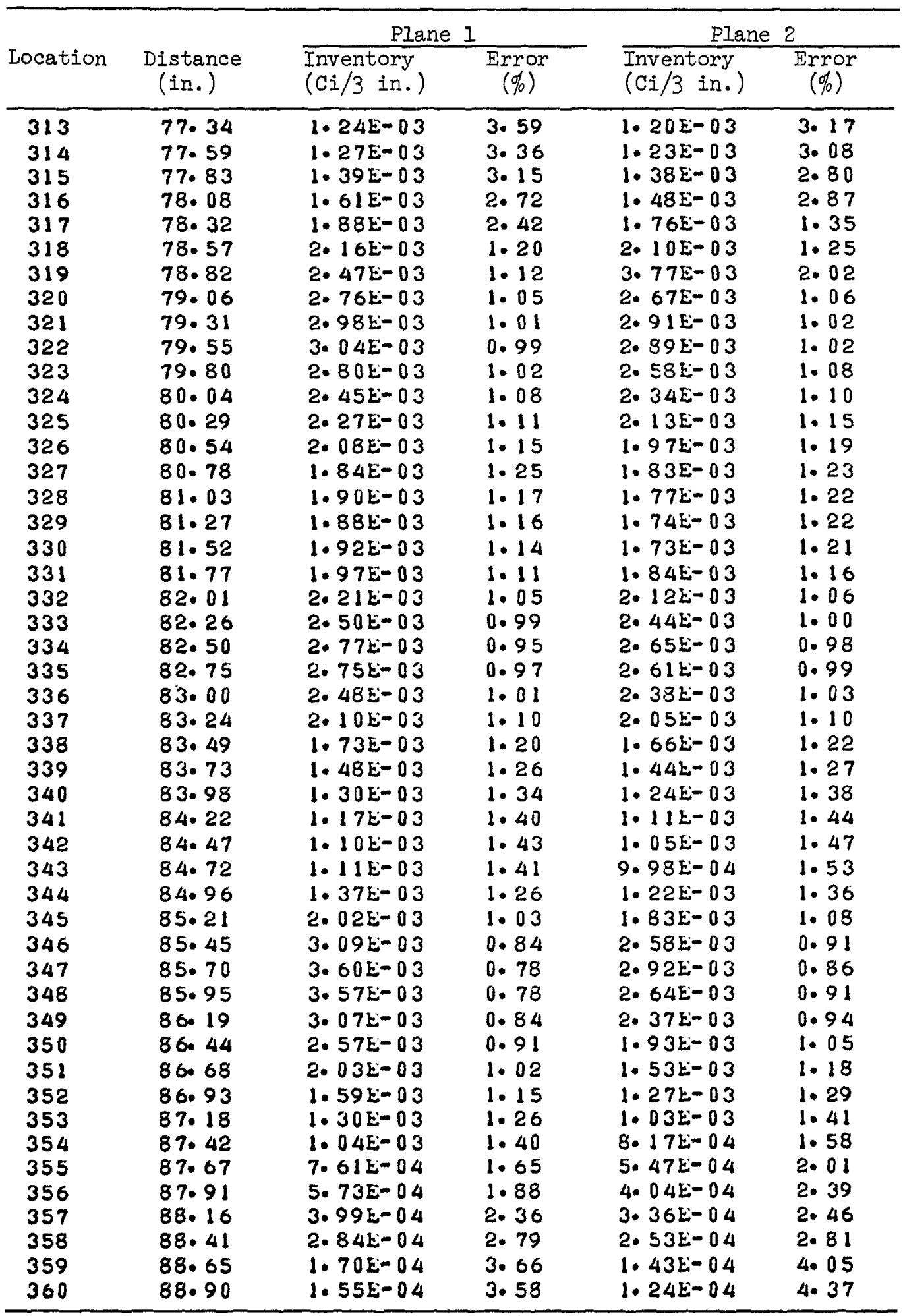


Table A-3. Axial distribution of ${ }^{110 \mathrm{~m}} \mathrm{Ag}$ in the sleeve of element FO3-01 (corrected to October 3I, 1974)

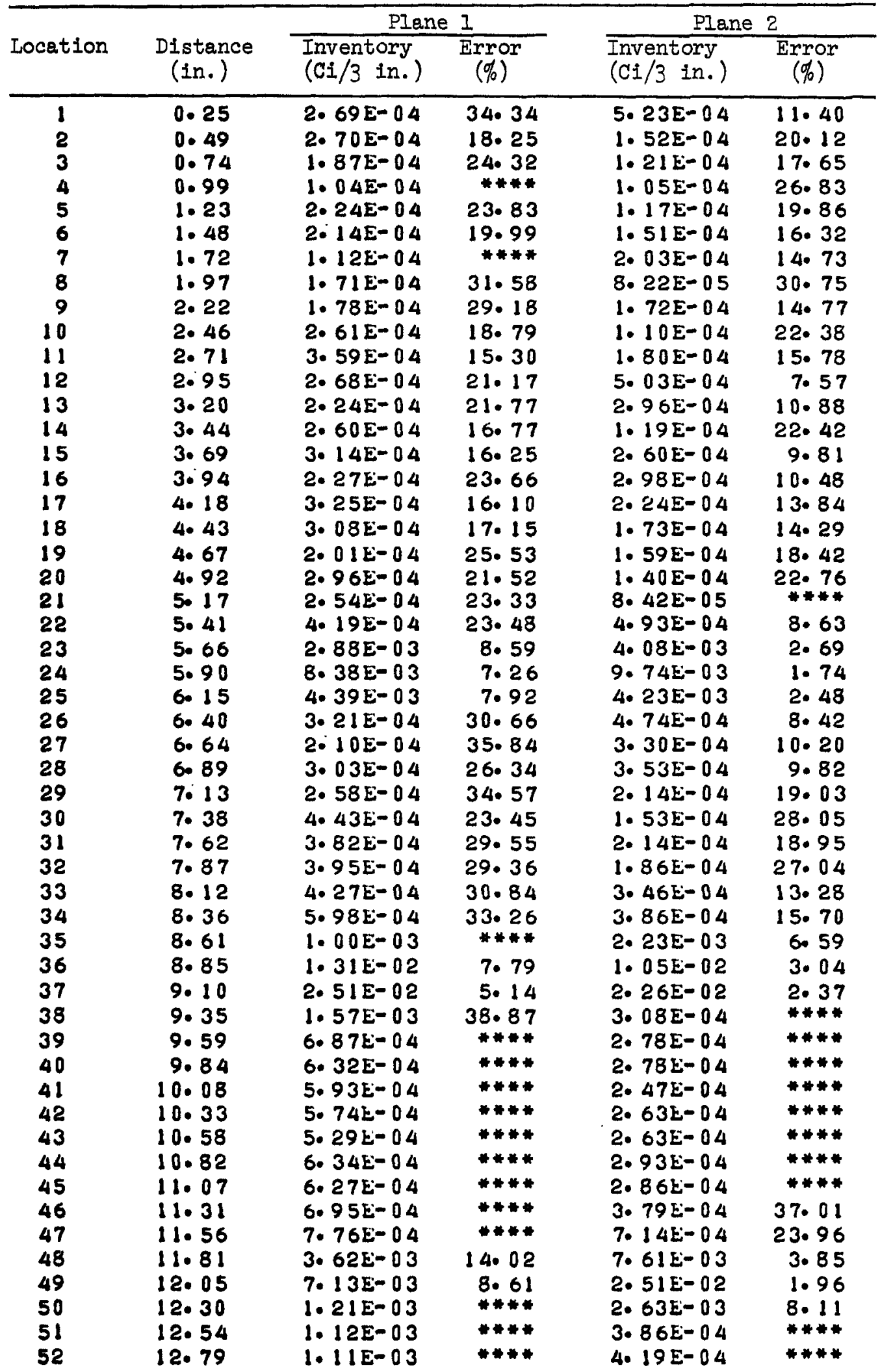


Table A-3 (continued)

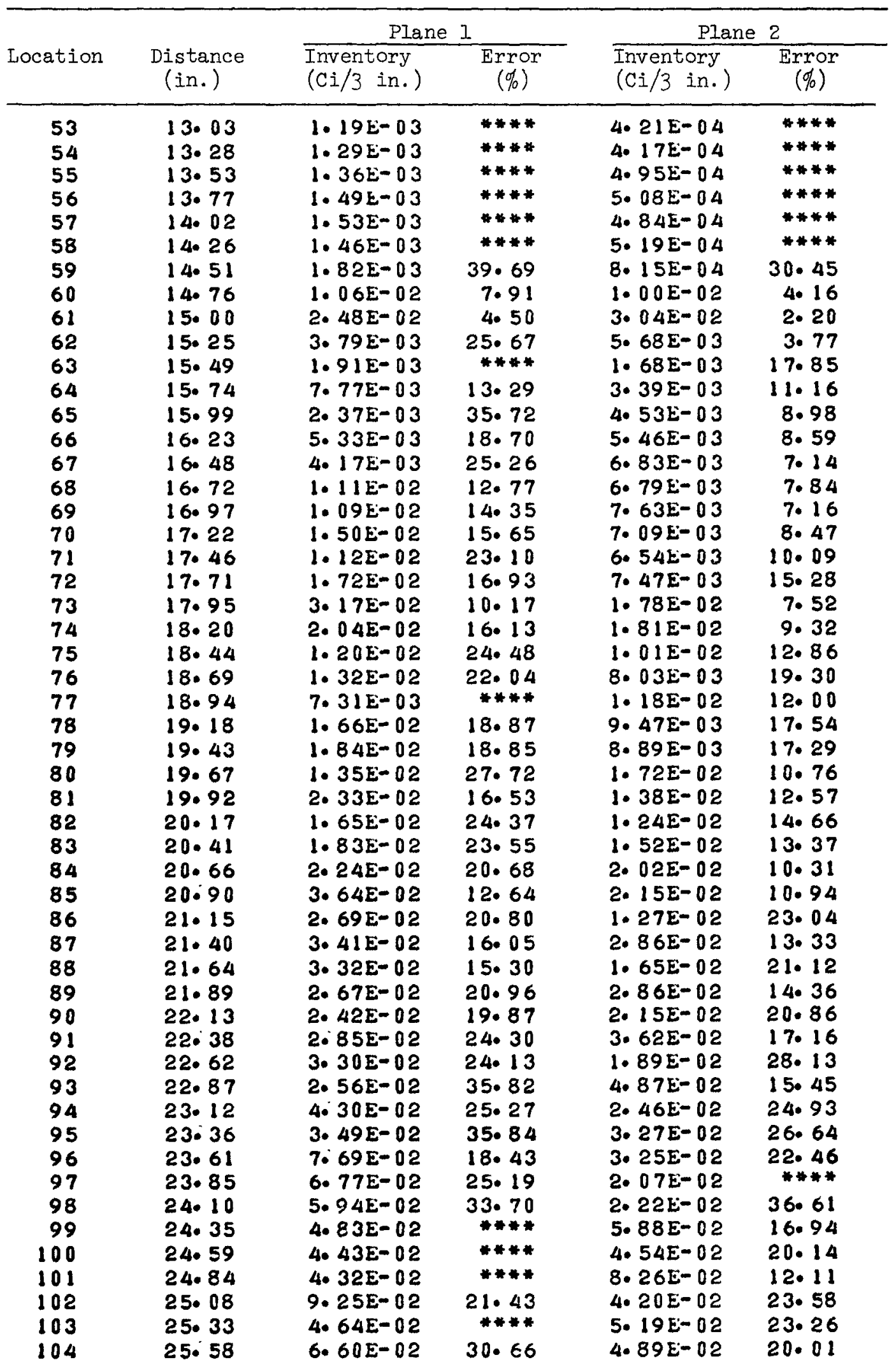


Table A-3 (continued)

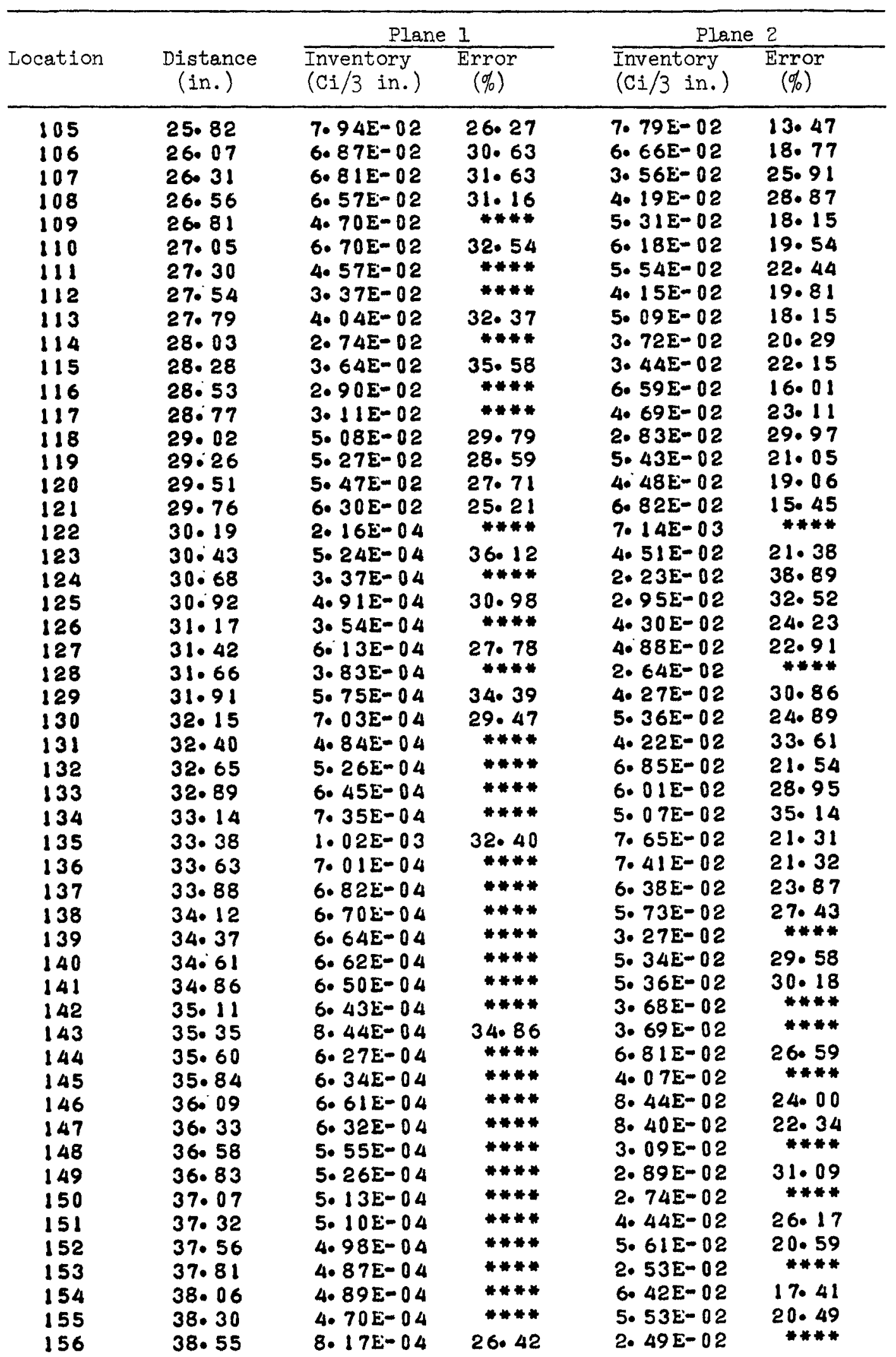


Table A-3 (continued)

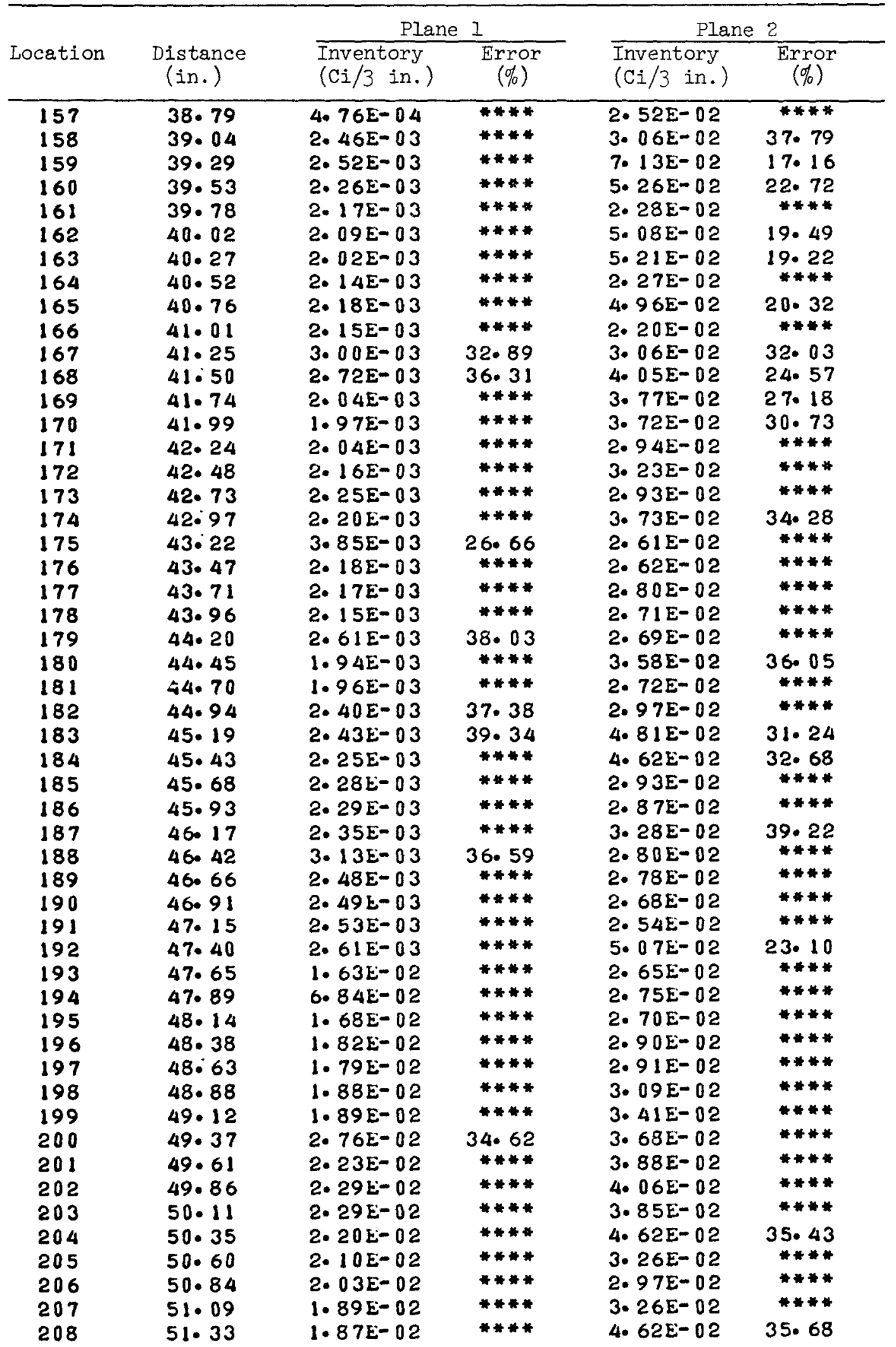


Table A-3 (continued)

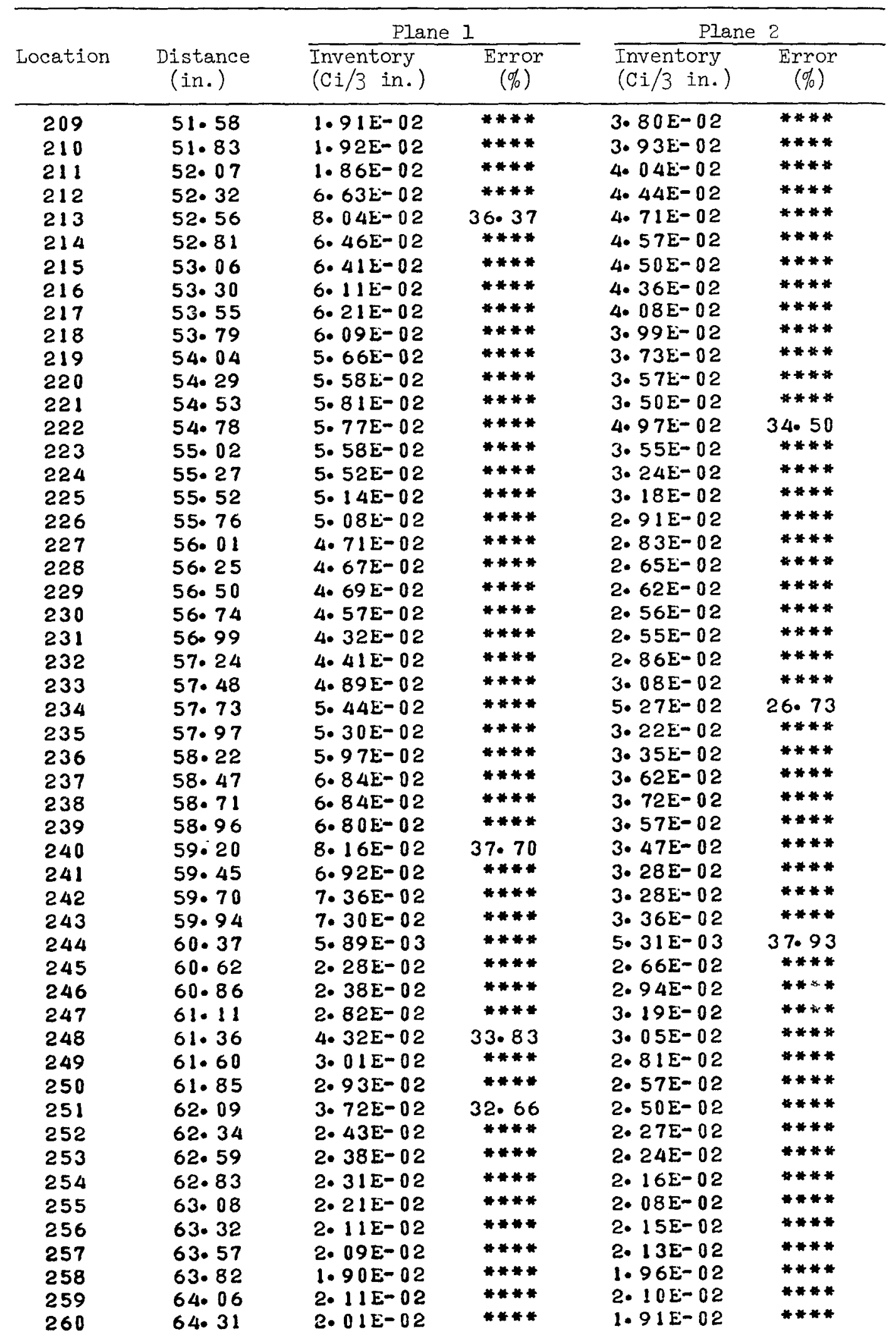


Table A-3 (continued)

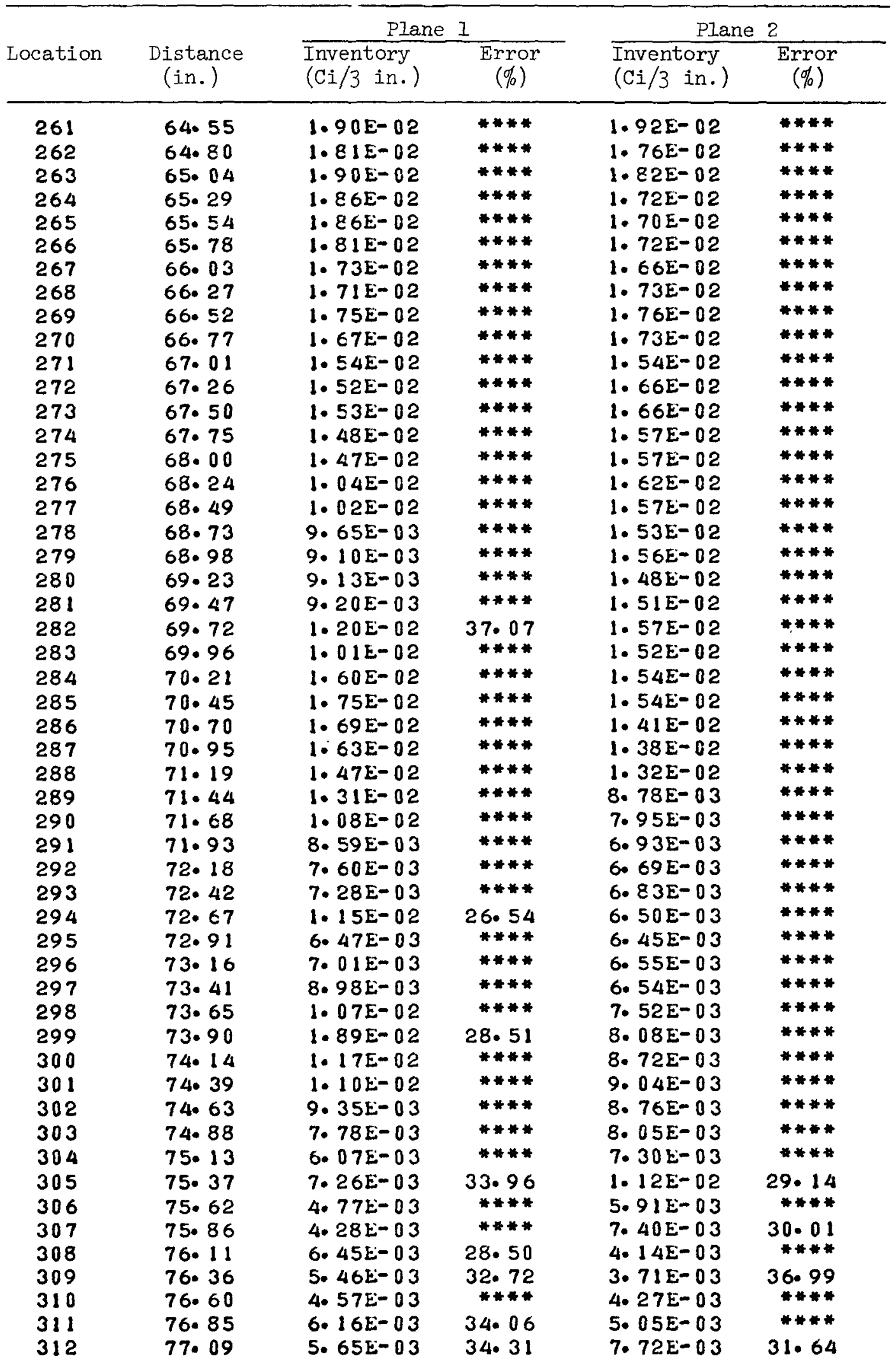




\begin{tabular}{|c|c|c|c|c|c|}
\hline \multirow[b]{2}{*}{ Location } & \multirow[b]{2}{*}{$\begin{array}{l}\text { Distance } \\
\text { (in.) }\end{array}$} & \multicolumn{2}{|c|}{ Plane 1} & \multicolumn{2}{|c|}{ Plane 2} \\
\hline & & $\begin{array}{l}\text { Inventory } \\
\text { (Ci/3 in.) }\end{array}$ & $\begin{array}{c}\text { Error } \\
(\%)\end{array}$ & $\begin{array}{l}\text { Inventory } \\
\text { (Ci/3 in.) }\end{array}$ & $\begin{array}{c}\text { Error } \\
(\%)\end{array}$ \\
\hline 313 & 77.34 & $5.53 \mathrm{E}-03$ & 31.79 & $5.04 \mathrm{E}-03$ & \#***4 \\
\hline 314 & 77.59 & $3.33 E-03$ & $* * * *$ & 4. $43 E-03$ & ***** \\
\hline 315 & 77.83 & 3. $18 \mathrm{E}-03$ & $* * * *$ & 4. $13 \mathrm{E}-03$ & **** \\
\hline 316 & 78.08 & $8.30 E-03$ & 14.25 & $3.31 \mathrm{E}-03$ & $* * * *$ \\
\hline 317 & 78.32 & 3. $90 \mathrm{E}-03$ & 27.48 & 2. $94 E-03$ & $* * * *$ \\
\hline 318 & 78.57 & $3.47 \mathrm{E}-03$ & 29.57 & 2. $03 E-03$ & $* * * *$ \\
\hline 319 & 78.82 & $3.57 \mathrm{E}-03$ & $27 \cdot 32$ & $1.84 E-03$ & $35 \cdot 76$ \\
\hline 320 & 79.06 & $1.85 E-03$ & $* * * *$ & $1.97 E-03$ & $* * * *$ \\
\hline 321 & 79.31 & $4.07 E-03$ & 21.23 & 4. $98 E-03$ & 18.22 \\
\hline 322 & 79.55 & $3.07 \mathrm{E}-03$ & $25 \cdot 34$ & 3. $44 E-03$ & 27.13 \\
\hline 323 & 79.80 & $2.05 E-03$ & 32.25 & 2. $29 \mathrm{E}-03$ & $35 \cdot 70$ \\
\hline 324 & 80.04 & $1.33 E-03$ & $* * * *$ & $2.84 E-03$ & 23.87 \\
\hline 325 & 80.29 & $3.05 E-03$ & 18.56 & $2.74 E-03$ & 22.21 \\
\hline 326 & 80.54 & $1.16 \mathrm{E}-03$ & $\# * * *$ & 2. $59 E-03$ & 20.96 \\
\hline 327 & 80.78 & $2.06 \mathrm{E}-03$ & 25.00 & 2. $42 E-03$ & 19.82 \\
\hline 328 & 81.03 & $2.43 E-03$ & 20.02 & $1.16 E-03$ & 29.59 \\
\hline 329 & 81.27 & 8. $57 E-04$ & 37.95 & $1.08 E-03$ & 31.06 \\
\hline 330 & 81.52 & $1.52 E-03$ & 28.98 & $1.43 E-03$ & 23.60 \\
\hline 331 & 81.77 & $1.34 E-03$ & $32 \cdot 62$ & $2.54 E-03$ & $15 \cdot 96$ \\
\hline 332 & 82.01 & $8.81 E-04$ & $* * *$ & 2. $50 \mathrm{E}-03$ & $15 \cdot 58$ \\
\hline 333 & 82.26 & $1.61 E-03$ & $26 \cdot 14$ & $2 \cdot 12 E-03$ & 17.57 \\
\hline 334 & 82.50 & $1.68 E-03$ & $21 \cdot 74$ & $2.98 E-03$ & 11.64 \\
\hline 335 & 82.75 & 2. $76 \mathrm{E}-03$ & 13. 74 & 2. $27 E-03$ & 18.62 \\
\hline 336 & 83.00 & 2. $90 \mathrm{E}-03$ & 11.30 & $1.06 \mathrm{E}-03$ & 26.93 \\
\hline 337 & 83.24 & 2. $97 k-03$ & 9.79 & $1.97 E-03$ & 15.15 \\
\hline 338 & 83.49 & $2.51 E-03$ & 10.42 & 2. $60 \mathrm{E}-03$ & $10 \cdot 77$ \\
\hline 339 & 83.73 & $3.40 \mathrm{E}-03$ & 7.54 & $1.43 E-03$ & 14.93 \\
\hline 340 & 83.98 & 3. $58 \mathrm{E}-03$ & $7 \cdot 34$ & $1.74 E-03$ & 11.87 \\
\hline 341 & 84.22 & $2.56 \mathrm{E}-03$ & 5.57 & $1.74 E-03$ & 7.14 \\
\hline 342 & 84.47 & $2 \cdot 71 k-03$ & 4.99 & $1.81 E-03$ & 6.56 \\
\hline 343 & $84 \cdot 72$ & $2.66 \mathrm{E}-03$ & $4 \cdot 99$ & $1.96 E-03$ & 5.96 \\
\hline 344 & 84.96 & $2.90 \mathrm{k}-03$ & 4.68 & $2 \cdot 22 E-03$ & $5 \cdot 26$ \\
\hline 345 & 85.21 & $3.18 E-03$ & $4 \cdot 12$ & $2.09 E-03$ & $5 \cdot 35$ \\
\hline 346 & 85.45 & 3. $55 \mathrm{E}-03$ & 3.43 & 3. $29 E-03$ & 3. 47 \\
\hline 347 & 85.70 & $3.24 k-03$ & 3.76 & $3.37 E-03$ & 3.27 \\
\hline 348 & 85.95 & $2.71 k-03$ & 3.90 & $3.21 E-03$ & 3.23 \\
\hline 349 & 86.19 & $2.94 \mathrm{E}-03$ & 3.44 & $3.04 E-03$ & 3.20 \\
\hline 350 & 86.44 & $2.80 E-03$ & 3.45 & $3.08 E-03$ & 3.09 \\
\hline 351 & 86.68 & $2.80 E-03$ & 3.39 & $3 \cdot 12 E-03$ & 2.96 \\
\hline 352 & 86.93 & $2.93 E-03$ & 3.24 & $2.94 \mathrm{E}-03$ & 3.05 \\
\hline 353 & 87.18 & $2.38 \mathrm{E}-03$ & 3.73 & $3 \cdot 16 E-03$ & 2.82 \\
\hline 354 & 87.42 & $2.29 E-03$ & 3.75 & $2.88 E-03$ & 3.01 \\
\hline 355 & 87.67 & $2.41 E-03$ & 3. 32 & $2.65 E-03$ & 3.06 \\
\hline 356 & 87.91 & $2.25 E-03$ & $3 \cdot 52$ & $2.57 \mathrm{E}-03$ & 3. 16 \\
\hline 357 & $88 \cdot 16$ & $2.30 \mathrm{E}-03$ & 3.49 & $2 \cdot 46 E-03$ & 3.20 \\
\hline 358 & 88.41 & $2.89 k-03$ & 2.97 & $2.66 E-03$ & 3.00 \\
\hline 359 & 88.65 & $3.58 \mathrm{E}-03$ & $2 \cdot 57$ & $3.03 E-03$ & $2 \cdot 73$ \\
\hline 360 & 88.90 & $4.16 \mathrm{E}-03$ & 2.24 & $3.28 E-03$ & 2.59 \\
\hline 361 & 89.14 & $4.27 E-03$ & $2 \cdot 18$ & 3. $42 \mathrm{E}-03$ & 2. 52 \\
\hline 362 & 89.39 & $4.31 E-03$ & $2 \cdot 14$ & $4 \cdot 25 E-03$ & 2.20 \\
\hline 363 & 89.63 & $4.26 \mathrm{E}-03$ & $2 \cdot 21$ & $4.49 E-03$ & $2 \cdot 11$ \\
\hline 364 & 89.88 & $4.32 \mathrm{E}-03$ & $2 \cdot 19$ & 4. $73 \mathrm{E}-03$ & 2.11 \\
\hline
\end{tabular}


Table A-4. Axial distribution of ${ }^{110 \mathrm{~m}} \mathrm{Ag}$ in the spine of element FO3-01

(corrected to October 31, 1974)

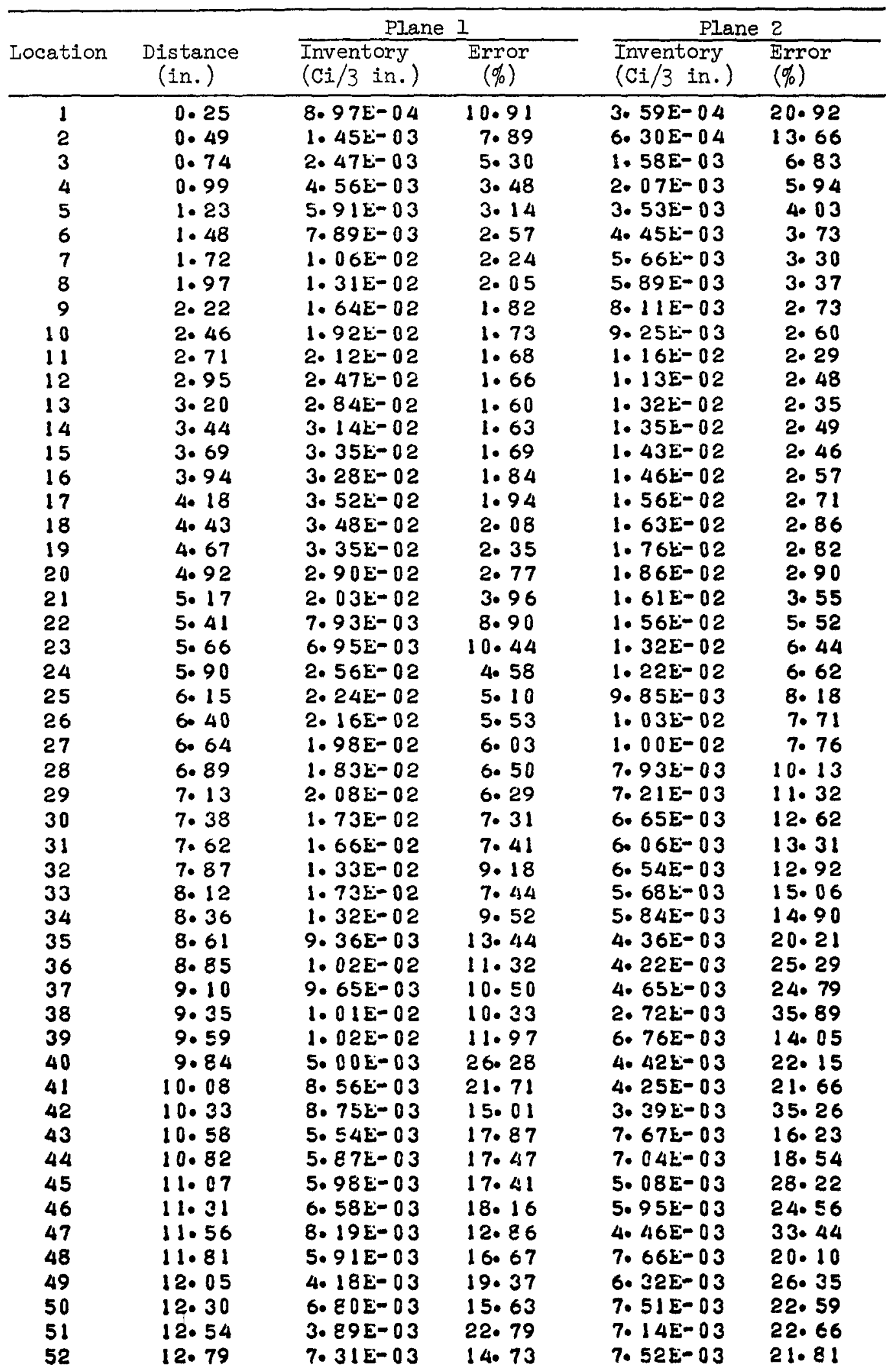


Table A-4 (continued)

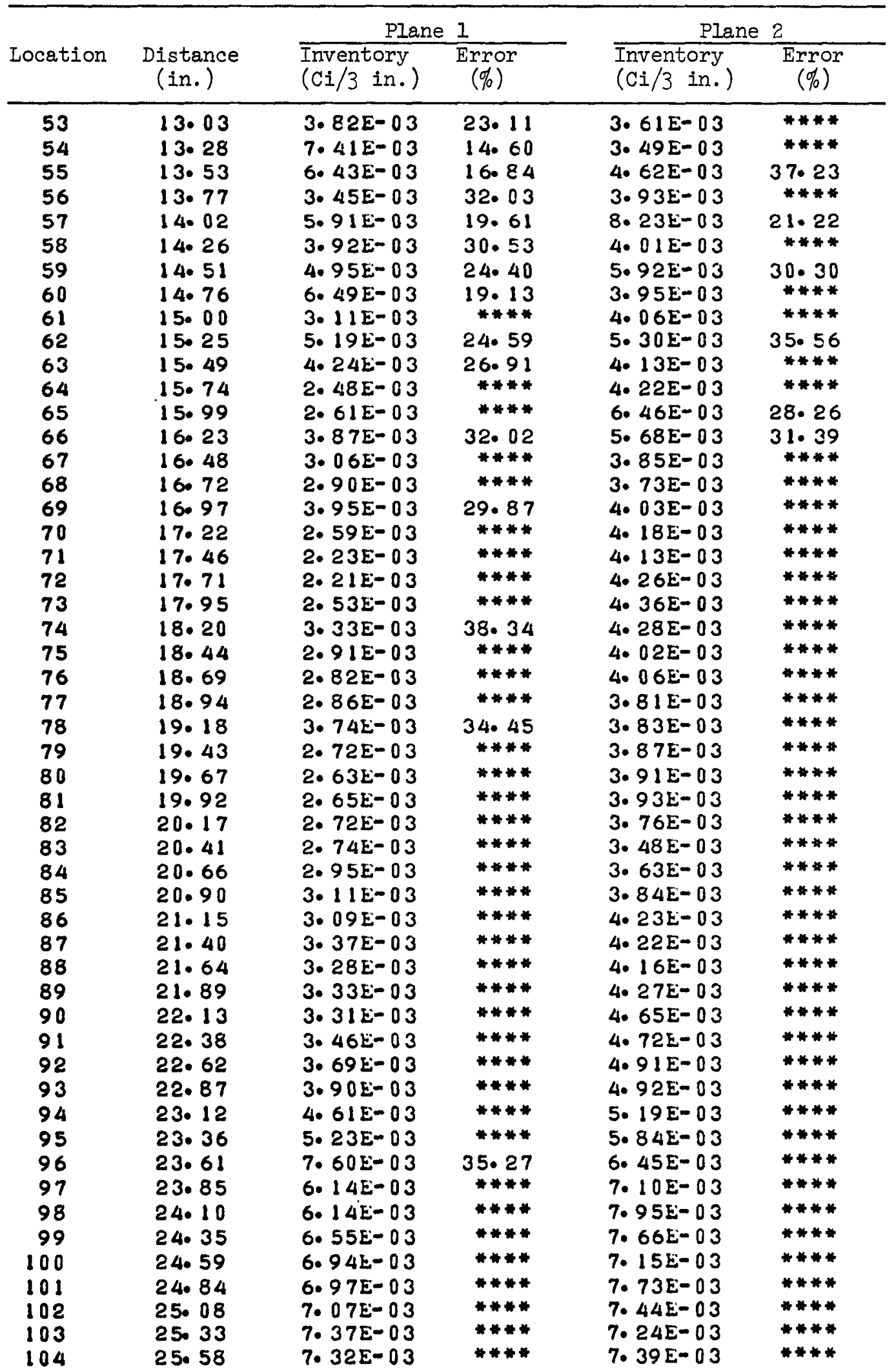


Table A-4 (continued)

\begin{tabular}{|c|c|c|c|c|c|}
\hline \multirow[b]{2}{*}{ Location } & \multirow[b]{2}{*}{$\begin{array}{c}\text { Distance } \\
\text { (in.) }\end{array}$} & \multicolumn{2}{|c|}{ Plane 1} & \multicolumn{2}{|c|}{ Plane 2} \\
\hline & & $\begin{array}{l}\text { Inventory } \\
(\mathrm{Ci} / 3 \text { in.) }\end{array}$ & $\begin{array}{c}\text { Error } \\
(\%)\end{array}$ & $\begin{array}{l}\text { Inventory } \\
(\mathrm{Ci} / 3 \mathrm{in.})\end{array}$ & $\begin{array}{c}\text { Error } \\
(\%)\end{array}$ \\
\hline 105 & $25 \cdot 82$ & $7 \cdot 53 \mathrm{E}-03$ & $* * * *$ & $7.92 E-03$ & $* * * *$ \\
\hline 106 & $26 \cdot 07$ & $7 \cdot 21 E-03$ & $* * * *$ & 7. $40 E-03$ & $* * * *$ \\
\hline 107 & $26 \cdot 31$ & $7.53 E-03$ & $* * * *$ & 7. $30 \mathrm{E}-03$ & $* * * *$ \\
\hline 108 & $26 \cdot 56$ & $6.88 E-03$ & $* * * *$ & 7. $30 \mathrm{E}-03$ & $* * * *$ \\
\hline 109 & 26.81 & 7. $00 \mathrm{E}-03$ & **** & 7. $48 E-03$ & $* * * *$ \\
\hline 110 & 27.05 & $6.96 E-03$ & **** & 7. $09 \mathrm{E}-03$ & $* * * *$ \\
\hline 111 & 27.30 & $6.82 E-03$ & $* * * *$ & $6.83 \mathrm{E}-03$ & $* * * *$ \\
\hline 112 & $27 \cdot 54$ & $7 \cdot 28 E-03$ & $* * * *$ & $6.45 E-03$ & $* * * *$ \\
\hline 113 & $27 \cdot 79$ & $7 \cdot 42 E-03$ & **** & $6 \cdot 46 E-03$ & $* * * *$ \\
\hline 114 & $28 \cdot 03$ & 7. $18 \mathrm{E}-03$ & $* * * *$ & 6. $36 E-03$ & $* * * *$ \\
\hline 115 & $28 \cdot 28$ & 7. $17 \mathrm{E}-03$ & **** & 6. $42 E-03$ & $* * * *$ \\
\hline 116 & $28 \cdot 53$ & $7.06 E-03$ & $* * * *$ & $6 \cdot 16 E-03$ & $* * * *$ \\
\hline 117 & $28 \cdot 77$ & 7. $35 E-03$ & $* * * *$ & 6. $70 \mathrm{E}-03$ & $* * * *$ \\
\hline 118 & 29.02 & 7. $70 €-03$ & $* * * *$ & $6.90 E-03$ & $* * * *$ \\
\hline 119 & $29 \cdot 26$ & 8. $56 \mathrm{E}-03$ & **** & 7. $00 E-03$ & $* * * *$ \\
\hline 120 & $29 \cdot 51$ & $8 \cdot 27 E-03$ & $* * * *$ & 7. $66 \mathrm{E}-03$ & $* * * *$ \\
\hline 121 & 29.94 & 3. $03 E-02$ & $* * * *$ & $2.01 E-02$ & $* * * *$ \\
\hline 122 & $30 \cdot 19$ & $9.84 E-03$ & $* * * *$ & $1.06 E-02$ & $* * * *$ \\
\hline 123 & $30 \cdot 43$ & $7 \cdot 17 \mathrm{E}-03$ & **** & $9.30 E-03$ & $* * * *$ \\
\hline 124 & $30 \cdot 68$ & $6.32 E-03$ & **** & $9 \cdot 25 E-03$ & $* * * *$ \\
\hline 125 & 30.92 & $6.93 E-03$ & $* * * *$ & $9.65 E-03$ & $* * * *$ \\
\hline 126 & $31 \cdot 17$ & $8.03 E-03$ & $* * * *$ & $1.01 \mathrm{E}-02$ & $* * * *$ \\
\hline 127 & $31 \cdot 42$ & $9 \cdot 63 \mathrm{E}-03$ & $* * * *$ & 1. $03 E-02$ & $* * * *$ \\
\hline 128 & 31.66 & 1. $02 E-02$ & $* * * *$ & 1. $12 E-02$ & $* * * *$ \\
\hline 129 & 31.91 & 1. $08 t-02$ & **** & $1.15 \mathrm{E}-02$ & $* * * *$ \\
\hline 130 & $32 \cdot 15$ & 1. $13 E-02$ & $* * * *$ & 1. $15 \mathrm{E}-02$ & $* * * *$ \\
\hline 131 & $32 \cdot 40$ & 1. $09 \mathrm{E}-02$ & $* * * *$ & 1. $06 \mathrm{E}-02$ & $* * * *$ \\
\hline 132 & $32 \cdot 65$ & $1.08 E-02$ & $* * * *$ & 1. $07 \mathrm{E}-02$ & **** \\
\hline 133 & $32 \cdot 89$ & $1.17 \mathrm{E}-02$ & $* * * *$ & $1.01 \mathrm{E}-02$ & **** \\
\hline 134 & $33 \cdot 14$ & 1. $03 E-02$ & $* * * *$ & $9 \cdot 77 \mathrm{E}-03$ & $* * * *$ \\
\hline 135 & $33 \cdot 38$ & 1. $06 E-02$ & $* * * *$ & $1.00 E-02$ & $* * * *$ \\
\hline 136 & 33.63 & $1.06 \mathrm{E}-02$ & $* * * *$ & $9.86 E-03$ & $* * * *$ \\
\hline 137 & 33.88 & $1.05 E-02$ & $* * * *$ & $9.98 E-03$ & $* * * *$ \\
\hline 138 & $34 \cdot 12$ & $1.07 E-02$ & $* * * *$ & $9.83 E-03$ & $* * * *$ \\
\hline 139 & $34 \cdot 37$ & $1.03 E-02$ & $* * * *$ & $9.89 E-03$ & $* * * *$ \\
\hline 140 & $34 \cdot 61$ & $1.05 E-02$ & **** & $9 \cdot 77 \mathrm{E}-03$ & **** \\
\hline 141 & 34.86 & $1 \cdot 10 \mathrm{E}-02$ & $* * * *$ & $9.43 E-03$ & $* * * *$ \\
\hline 142 & $35 \cdot 11$ & $1.01 \mathrm{E}-02$ & $* * * *$ & $9.63 E-03$ & $* * * *$ \\
\hline 143 & $35 \cdot 35$ & $1.07 \mathrm{E}-02$ & **** & $9.66 \mathrm{E}-03$ & $* * * *$ \\
\hline 144 & 35.60 & 1. $10 \mathrm{E}-02$ & $* * * *$ & 1. $00 E-02$ & $* * * *$ \\
\hline 145 & $35 \cdot 84$ & $1.07 \mathrm{E}-02$ & $* * * *$ & $9.69 E-03$ & $* * * *$ \\
\hline 146 & 36009 & 1. $09 E-02$ & $* * * *$ & $9.96 E-03$ & $* * * *$ \\
\hline 147 & $36 \cdot 33$ & 1. $05 \mathrm{E}-02$ & $* * * *$ & $1.00 E-02$ & $* * * *$ \\
\hline 148 & $36 \cdot 58$ & 1. $09 \mathrm{E}-02$ & $* * * *$ & 1.00E-02 & $* * * *$ \\
\hline 149 & 36.83 & $9.86 \mathrm{E}-03$ & $* * * *$ & $9 \cdot 35 E-03$ & $* * * *$ \\
\hline 150 & $37 \cdot 07$ & $9.56 \mathrm{E}-03$ & $* * * *$ & $9.27 E-03$ & $* * * *$ \\
\hline 151 & $37 \cdot 32$ & $9.33 E-03$ & **** & 8. $73 E-03$ & **** \\
\hline 152 & $37 \cdot 56$ & 1.00E-02 & $* * * *$ & $9 \cdot 22 E-03$ & **** \\
\hline 153 & 37.81 & $1.00 E-02$ & $* * * *$ & $8.61 E-03$ & $* * * *$ \\
\hline 154 & 38.06 & 1.02E-02 & $* * * *$ & $8.81 E-03$ & $* * * *$ \\
\hline 155 & $38 \cdot 30$ & 9. $00 \mathrm{E}-03$ & **** & 8. $22 E-03$ & $* * * *$ \\
\hline 156 & $38 \cdot 55$ & $9.10 E-03$ & $* * * *$ & 8. $26 E-03$ & $* * * *$ \\
\hline
\end{tabular}


Table A-4 (continued)

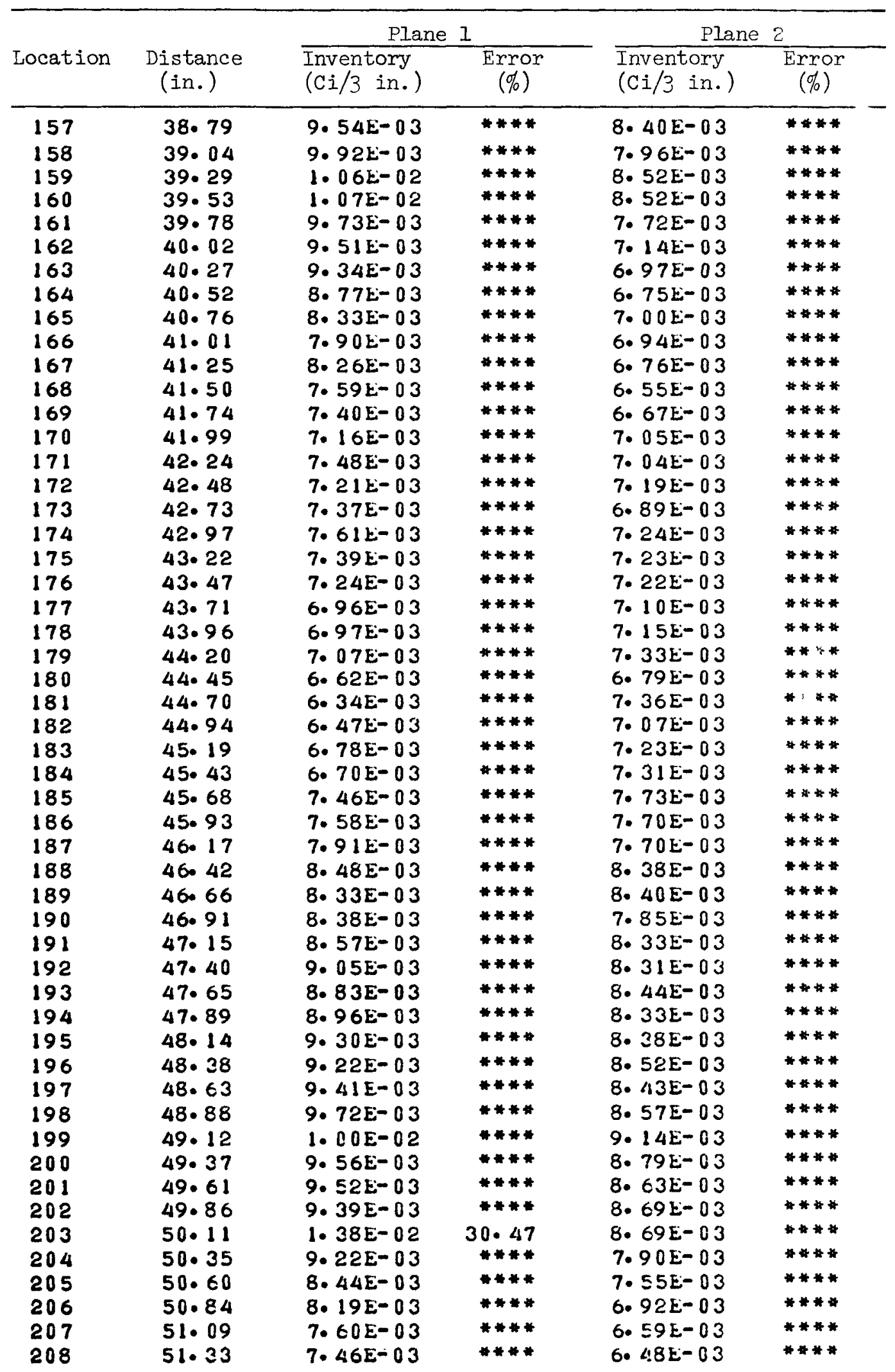


Table A-4 (continued)

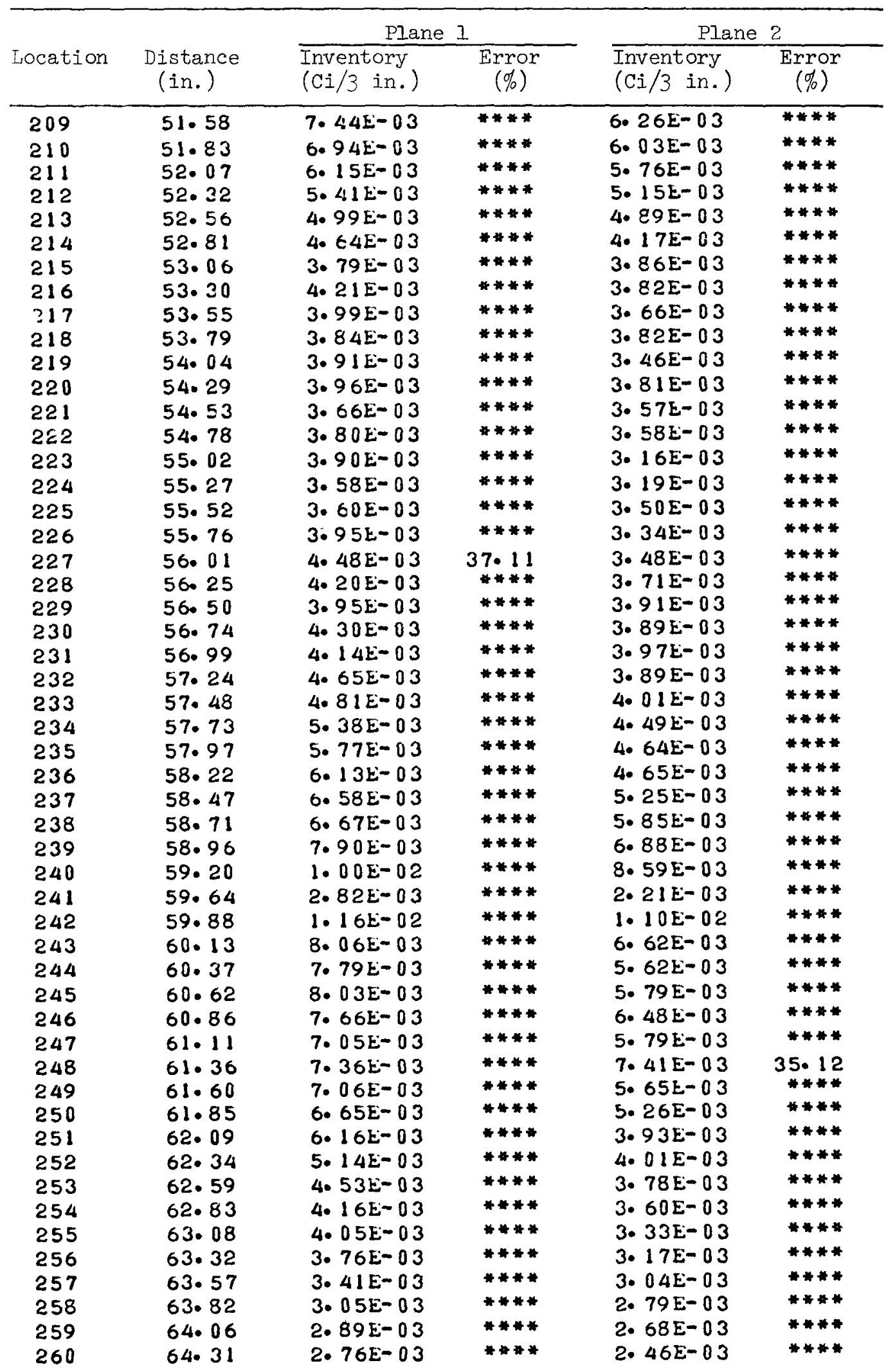


Table A-4 (continued)

\begin{tabular}{|c|c|c|c|c|c|}
\hline \multirow[b]{2}{*}{ Location } & \multirow[b]{2}{*}{$\begin{array}{c}\text { Distance } \\
\text { (in.) }\end{array}$} & \multicolumn{2}{|c|}{ Plane 1} & \multicolumn{2}{|c|}{ Plane 2} \\
\hline & & $\begin{array}{l}\text { Inventory } \\
(\mathrm{Ci} / 3 \text { in.) }\end{array}$ & $\begin{array}{c}\text { Error } \\
(\%)\end{array}$ & $\begin{array}{l}\text { Inventory } \\
(\mathrm{Ci} / 3 \mathrm{in.})\end{array}$ & $\begin{array}{c}\text { Error } \\
(\%)\end{array}$ \\
\hline 261 & $64 \cdot 55$ & $2.53 E-03$ & ***** & $2 \cdot 46 E-03$ & $* * * *$ \\
\hline 262 & $64 \cdot 80$ & $2.53 E-03$ & $* * * *$ & 2. $35 E-03$ & $* * * *$ \\
\hline 263 & 65.04 & 2. $49 E-03$ & $* * * *$ & 2. $31 E-03$ & $* * * *$ \\
\hline 264 & $65 \cdot 29$ & 2. $44 E-03$ & $* * * *$ & $2.20 E-03$ & $* * * *$ \\
\hline 265 & $65 \cdot 54$ & $2.29 E-03$ & $* * * *$ & 2. $15 \mathrm{E}-03$ & $* * *$ \\
\hline 266 & $65 \cdot 78$ & 2. $08 E-03$ & $* * * *$ & 2. $04 \mathrm{E}-03$ & **** \\
\hline 267 & 66.03 & 2. $04 \mathrm{E}-03$ & **** & 1. $92 E-03$ & **** \\
\hline 268 & $66 \cdot 27$ & $1.80 E-03$ & $* * * *$ & 1. $80 E-03$ & $* * * *$ \\
\hline 269 & $66 \cdot 52$ & $1 \cdot 24 E-03$ & $* * * *$ & 1. $77 E-03$ & $* * * *$ \\
\hline 270 & 66.77 & 1. $13 \mathrm{E}-03$ & $* * * *$ & $1.30 \mathrm{E}-03$ & $* * * *$ \\
\hline 271 & 67.01 & $1.08 \mathrm{E}-03$ & $* * * *$ & 1. $21 \mathrm{E}-03$ & $* * * *$ \\
\hline 272 & $67 \cdot 26$ & 1. $06 E-03$ & **** & 1. $19 E-03$ & **** \\
\hline 273 & $67 \cdot 50$ & $1.00 E-03$ & $* * * *$ & 1. $16 E-03$ & $* * * *$ \\
\hline 274 & $67 \cdot 75$ & $9.69 E-04$ & $* * * *$ & $1.11 \mathrm{E}-03$ & $* * * *$ \\
\hline 275 & 68.00 & $9.93 E-04$ & $* * * *$ & 1. $10 \mathrm{E}-03$ & **** \\
\hline 276 & $68 \cdot 24$ & 1. $07 k-03$ & $* * * *$ & $1.06 \mathrm{E}-03$ & $* * * *$ \\
\hline 277 & $68 \cdot 49$ & 1. $14 \mathrm{E}-03$ & $* * * *$ & 1. $19 E-03$ & $* * * *$ \\
\hline 278 & $68 \cdot 73$ & $1.01 E-03$ & $* * * *$ & $1.07 \mathrm{E}-03$ & $* * * *$ \\
\hline 279 & 68.98 & 8. $72 E-04$ & $* * * *$ & $9.07 \pm-04$ & $* * * *$ \\
\hline 280 & $69 \cdot 23$ & 8. $08 E-04$ & $* * * *$ & 8. $34 E-04$ & $* * * *$ \\
\hline 281 & $69 \cdot 47$ & 8. $44 t-04$ & $* * * *$ & $8.45 E-04$ & $* * * *$ \\
\hline 282 & 69.72 & $9.28 E-04$ & $* * * *$ & 8. $73 E-04$ & $* * * *$ \\
\hline 283 & 69.96 & $9.35 k-04$ & \#*** & 8. $16 E-04$ & $* * * *$ \\
\hline 284 & 70.21 & $8.86 k-04$ & $* * * *$ & 7. $84 E-04$ & $* * * *$ \\
\hline 285 & $70 \cdot 45$ & $8.55 E-04$ & $* * * *$ & 7. $69 E-04$ & $* * * *$ \\
\hline 286 & 70.70 & 8. $46 \mathrm{E}-04$ & $* * *$ & 7. $67 E-04$ & $* * * *$ \\
\hline 287 & 70.95 & 8. $37 \mathrm{E}-04$ & $* * *$ & 7. $57 \mathrm{E}-04$ & $* * * *$ \\
\hline 288 & $71 \cdot 19$ & 8. $13 k-04$ & **** & 7. $74 \mathrm{E}-04$ & \#*** \\
\hline 289 & $71 \cdot 44$ & 7. $95 E-04$ & $* * * *$ & 7. $69 \mathrm{E}-04$ & $* * * *$ \\
\hline 290 & $71 \cdot 68$ & $7 \cdot 94 E-04$ & $* * *$ & $7.81 E-04$ & $* * * *$ \\
\hline 291 & 71.93 & 7. $95 \mathrm{E}-04$ & **** & $7.85 t-04$ & $* * * *$ \\
\hline 292 & $72 \cdot 18$ & $8.20 E-04$ & $* * * *$ & $7.94 E-04$ & $* * * *$ \\
\hline 293 & $72 \cdot 42$ & 8. $09 E-04$ & $* * * *$ & 8. $07 k-04$ & $* * * *$ \\
\hline 294 & $72 \cdot 67$ & 8. $09 E-04$ & $* * * *$ & 8. $10 \mathrm{E}-04$ & $* * * *$ \\
\hline 295 & 72.91 & 8. $02 E-04$ & $* * * *$ & 8. $21 E-04$ & $* * * *$ \\
\hline 296 & $73 \cdot 16$ & 8. $13 E-04$ & $* * * *$ & $7.83 E-04$ & $* * * *$ \\
\hline 297 & 73.41 & $8.61 E-04$ & $* * * *$ & $8.07 t-04$ & $* * * *$ \\
\hline 298 & $73 \cdot 65$ & $1.02 z-03$ & $* * * *$ & 8. $52 \mathrm{E}-04$ & $* * * *$ \\
\hline 299 & 73.90 & $1.22 E-03$ & $* * * *$ & $8.87 t-04$ & $* * * *$ \\
\hline 300 & $74 \cdot 14$ & $1.28 \mathrm{E}-03$ & $* * *$ & $9.09 E-04$ & $* * * *$ \\
\hline 301 & $74 \cdot 39$ & 1. $35 E-03$ & $* * * *$ & 8. $74 \mathrm{E}-04$ & $* * * *$ \\
\hline 302 & $74 \cdot 63$ & $1.24 \mathrm{~L}-03$ & $* * * *$ & 8. $69 E-04$ & $* * * *$ \\
\hline 303 & $74 \cdot 88$ & 1. $06 \mathrm{E}-03$ & $* * * *$ & 8. $72 E-04$ & $* * * *$ \\
\hline 304 & $75 \cdot 13$ & $1.05 \mathrm{E}-03$ & $* * * *$ & $7.95 E-04$ & $* * * *$ \\
\hline 305 & $75 \cdot 37$ & $9.24 E-04$ & **** & 6. $62 k-04$ & $* * * *$ \\
\hline 306 & $75 \cdot 62$ & $8.08 \mathrm{E}-04$ & $* * * *$ & $5.94 E-04$ & *** \\
\hline 307 & $75 \cdot 86$ & 6. $63 E-04$ & $* * * *$ & 5. $30 \mathrm{E}-04$ & $* * * *$ \\
\hline 308 & $76 \cdot 11$ & $5.93 \mathrm{k}-04$ & $* * * *$ & 4. $61 E-04$ & $* * * *$ \\
\hline 309 & $76 \cdot 36$ & 5. $42 E-04$ & $* * * *$ & 4. $31 E-04$ & $* * *$ \\
\hline 310 & $76 \cdot 60$ & 5. $41 \mathrm{E}-04$ & $* * * *$ & 4. $19 \mathrm{E}-04$ & $* * * *$ \\
\hline 311 & $76 \cdot 85$ & 5. $52 E-04$ & $* * * *$ & $3.99 E-04$ & $* * * *$ \\
\hline 312 & 77.09 & 5. $53 E-04$ & $* * * *$ & $3.87 \mathrm{E}-04$ & $* \# *$ \\
\hline
\end{tabular}


Table A-4 (continued)

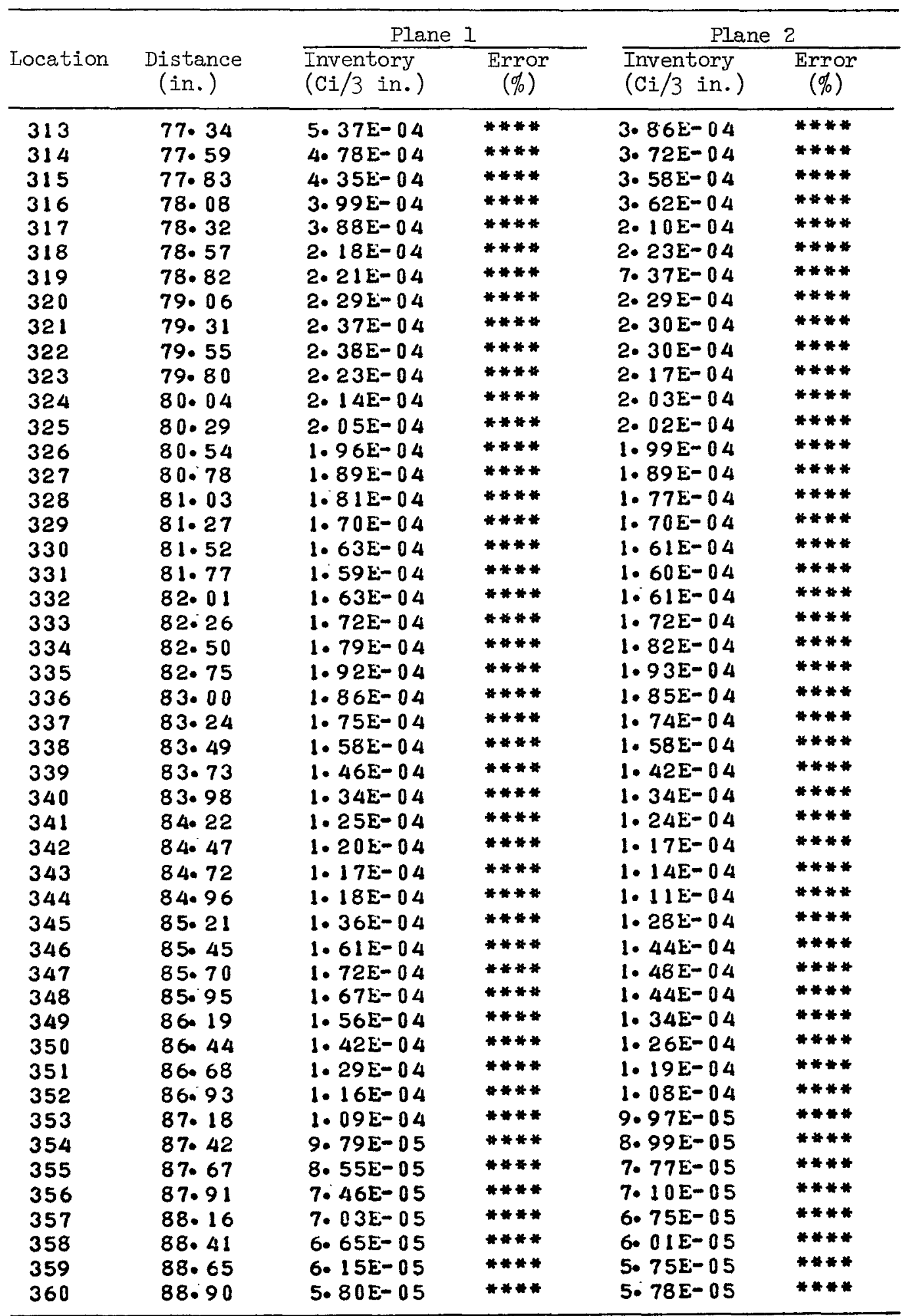


Table A-5. Axial distribution of ${ }^{134} \mathrm{Cs}$ in the sleeve of element FO3-01 (corrected to October 31, 1974)

\begin{tabular}{|c|c|c|c|c|c|}
\hline \multirow{2}{*}{ Location } & \multirow[b]{2}{*}{$\begin{array}{l}\text { Distance } \\
\text { (in.) }\end{array}$} & \multicolumn{2}{|c|}{ Plane 1} & \multicolumn{2}{|c|}{ Plane 2} \\
\hline & & $\begin{array}{l}\text { Inventory } \\
(\mathrm{Ci} / 3 \mathrm{in.})\end{array}$ & $\begin{array}{c}\text { Error } \\
(\%)\end{array}$ & $\begin{array}{l}\text { Inventory } \\
(\mathrm{Ci} / 3 \mathrm{in.})\end{array}$ & $\begin{array}{c}\text { Error } \\
(\%)\end{array}$ \\
\hline 1 & 0.25 & $8.18 E-03$ & 0.66 & $1.20 E-02$ & 0.55 \\
\hline 2 & 0.49 & $1.48 E-03$ & $1 \cdot 62$ & $2.26 E-03$ & $1 \cdot 25$ \\
\hline 3 & 0.74 & $1.08 \mathrm{E}-03$ & 1.85 & 1. $59 \mathrm{E}-03$ & 1.48 \\
\hline 4 & 0.99 & $1.62 \mathrm{E}-03$ & 1.44 & $1.84 E-03$ & 1. 36 \\
\hline 5 & 1.23 & $2.14 E-03$ & $1 \cdot 26$ & $2 \cdot 44 E-03$ & 1. 18 \\
\hline 6 & 1.48 & 2. $34 E-03$ & $1 \cdot 22$ & $2.88 \mathrm{E}-03$ & 1. 08 \\
\hline 7 & 1. 72 & $2.35 \mathrm{E}-03$ & $1 \cdot 22$ & $2.99 \mathrm{E}-03$ & 1.07 \\
\hline 8 & 1.97 & $2.73 E-03$ & $1 \cdot 13$ & $2.84 E-03$ & 1. 10 \\
\hline 9 & 2.22 & $2 \cdot 37 E-03$ & 1.21 & 2. $59 \mathrm{E}-03$ & 1.16 \\
\hline 10 & 2.46 & 2. $14 E-03$ & $1 \cdot 28$ & 2. $49 \mathrm{E}-03$ & $1 \cdot 18$ \\
\hline 11 & 2.71 & $2.94 E-03$ & 1.07 & $3.41 \mathrm{E}-03$ & 0.99 \\
\hline 12 & 2.95 & 5. $02 E-03$ & 0.83 & 5. $28 E-03$ & 0.81 \\
\hline 13 & 3.20 & $2.79 E-03$ & $1 \cdot 12$ & $2 \cdot 93 E-03$ & 1.08 \\
\hline 14 & 3.44 & $1.81 E-03$ & $1 \cdot 39$ & $1.88 \mathrm{E}-03$ & 1. 36 \\
\hline 15 & $3 \cdot 69$ & $1.90 E-03$ & $1 \cdot 35$ & 2. $13 E-03$ & 1. 27 \\
\hline 16 & 3.94 & $2.11 \mathrm{E}-03$ & $1 \cdot 28$ & 2. $28 E-03$ & 1.24 \\
\hline 17 & $4 \cdot 18$ & $2 \cdot 46 E-03$ & $1 \cdot 20$ & 2. $46 \mathrm{E}-03$ & 1.20 \\
\hline 18 & $4 \cdot 43$ & $2.82 E-03$ & $1 \cdot 12$ & 2. $70 E-03$ & 1.16 \\
\hline 19 & $4 \cdot 67$ & $3 \cdot 51 E-03$ & 1.02 & 3. $33 E-03$ & 1.04 \\
\hline 20 & 4.92 & 4. $03 E-03$ & 0.97 & 3. $63 E-03$ & 1.01 \\
\hline 21 & 5. 17 & 4. $48 E-03$ & 0.91 & 4. $07 E-03$ & 0.96 \\
\hline 22 & $5 \cdot 41$ & 8. 08E-03 & 0.69 & $7 \cdot 22 E-03$ & 0.73 \\
\hline 23 & $5 \cdot 66$ & 3. $58 E-02$ & 0.37 & 2. $16 \mathrm{E}-02$ & 0.44 \\
\hline 24 & 5.90 & $5.80 E-02$ & 0.42 & $3.35 E-02$ & 0.37 \\
\hline 25 & 6.15 & 4. $76 E-02$ & 0.35 & 1. $74 \mathrm{E}-02$ & 0.49 \\
\hline 26 & 6.40 & 1. 02E-02 & 0.62 & 3. $79 \mathrm{E}-03$ & 1.03 \\
\hline 27 & 6.64 & $6.27 E-03$ & 0.78 & 2. $98 E-03$ & $1 \cdot 15$ \\
\hline 28 & 6.89 & 7. $55 \mathrm{E}-03$ & 0.71 & 4. $03 E-03$ & 0.97 \\
\hline 29 & 7. 13 & $9.19 \mathrm{E}-03$ & 0.65 & 5. $33 \mathrm{E}-03$ & 0.85 \\
\hline 30 & 7. 38 & $1.09 E-02$ & $0 \cdot \in 0$ & $6.41 E-03$ & 0.78 \\
\hline 31 & 7. 62 & 1. $23 E-02$ & 0.57 & $6.77 E-03$ & 0.77 \\
\hline 32 & 7.87 & 1. $25 E-02$ & 0.57 & 7. $09 \mathrm{E}-03$ & 0.76 \\
\hline 33 & $8 \cdot 12$ & 1. $43 \mathrm{E}-02$ & 0.55 & $8 \cdot 13 E-03$ & 0.71 \\
\hline 34 & $8 \cdot 36$ & 2. $42 E-02$ & 0.45 & 1. $42 E-02$ & 0.56 \\
\hline 35 & $8 \cdot 61$ & 5. $01 E-02$ & 0.44 & $3.67 \mathrm{E}-02$ & 0.39 \\
\hline 36 & 8.85 & $1.66 E-0 !$ & 0.36 & $7.10 \mathrm{E}-02$ & 0.34 \\
\hline 37 & 9.10 & $2.06 \mathrm{E}-01$ & 0.34 & $1.15 E-01$ & 0.41 \\
\hline 38 & 9.35 & $1.04 E-01$ & 0.43 & $2.77 \mathrm{E}-02$ & 0.78 \\
\hline 39 & $9 \cdot 59$ & 3. $45 E-02$ & 0.71 & $1.21 \mathrm{E}-02$ & $1 \cdot 19$ \\
\hline 40 & 9.84 & $2 \cdot 68 \mathrm{E}-02$ & 0.79 & 1. $22 E-02$ & 1.20 \\
\hline 41 & 10.08 & $2 \cdot 26 E-02$ & 0.87 & $1.17 \mathrm{E}-02$ & $1 \cdot 23$ \\
\hline 42 & $10 \cdot 33$ & 2. $09 \mathrm{E}-02$ & 0.91 & $1 \cdot 24 E-02$ & 1.19 \\
\hline 43 & 10.58 & $2 \cdot 13 E-02$ & 0.90 & 1. $28 E-02$ & $1 \cdot 17$ \\
\hline 44 & 10.82 & $2 \cdot 26 E-02$ & 0.87 & 1. $48 E-02$ & 1.09 \\
\hline 45 & 11.07 & $2 \cdot 28 E-02$ & 0.92 & 1. $68 \mathrm{E}-02$ & 1.03 \\
\hline 46 & $11 \cdot 31$ & $2.74 E-02$ & 0.81 & 1. $97 \mathrm{E}-02$ & 0.95 \\
\hline 47 & $11 \cdot 56$ & $3.50 \mathrm{E}-02$ & 0.72 & 2. $18 \mathrm{E}-02$ & 0.90 \\
\hline 48 & $11 \cdot 81$ & 5. $24 E-02$ & 0.59 & $2.80 E-02$ & 0.82 \\
\hline 49 & 12.05 & 7. $37 E-02$ & 0.51 & $3.90 E-C 2$ & 0.72 \\
\hline 50 & $12 \cdot 30$ & 7. $46 E-02$ & 0.51 & 3. $34 \mathrm{E}-02$ & 0.75 \\
\hline 51 & $12: 54$ & 6. $18 E-02$ & 0.56 & $2.86 E-02$ & 0.81 \\
\hline 52 & $12 \cdot 79$ & $6.45 E-02$ & 0.55 & 3. $19 E-02$ & 0.76 \\
\hline
\end{tabular}




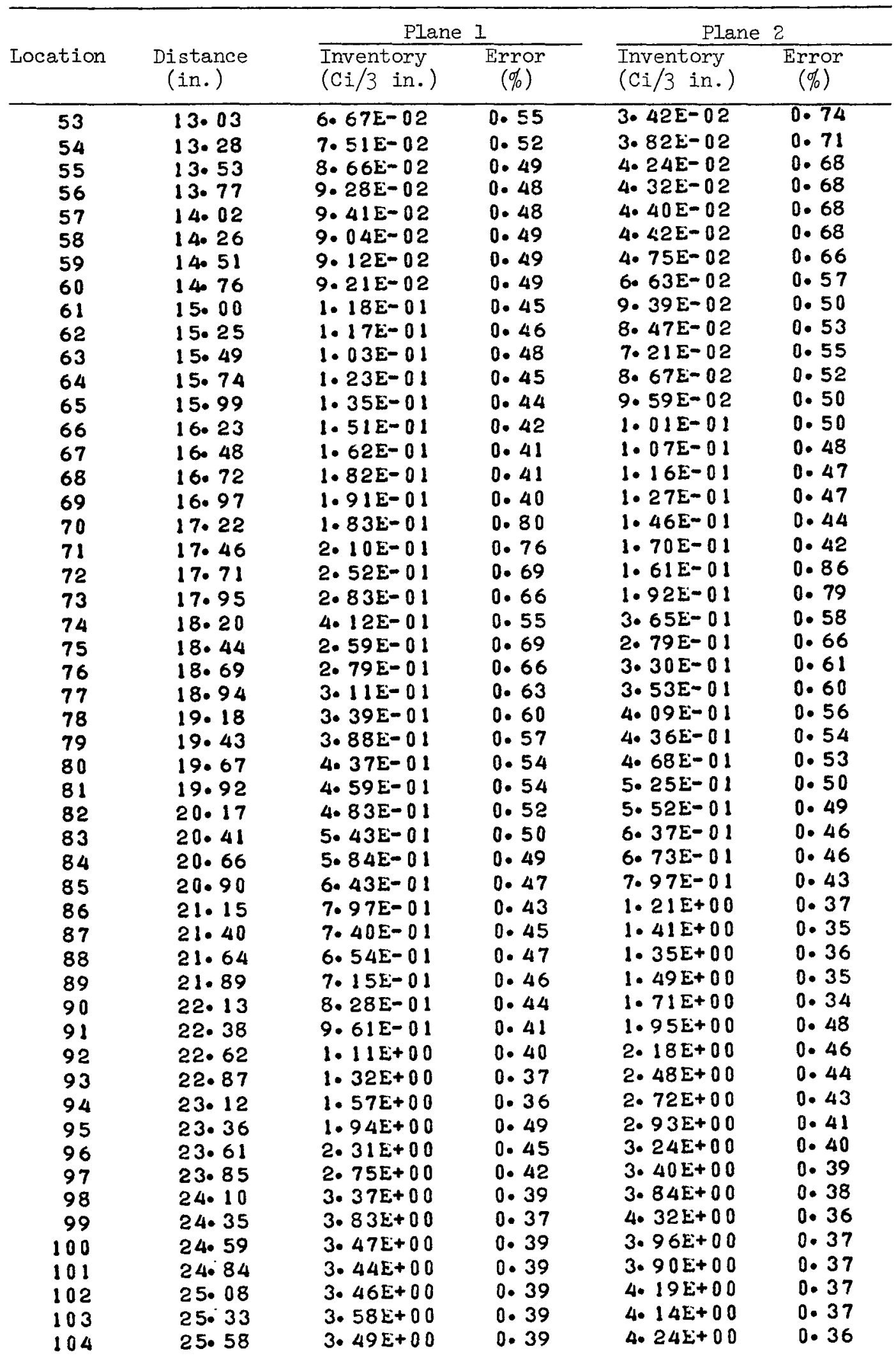


181

Table A-5 (continued)

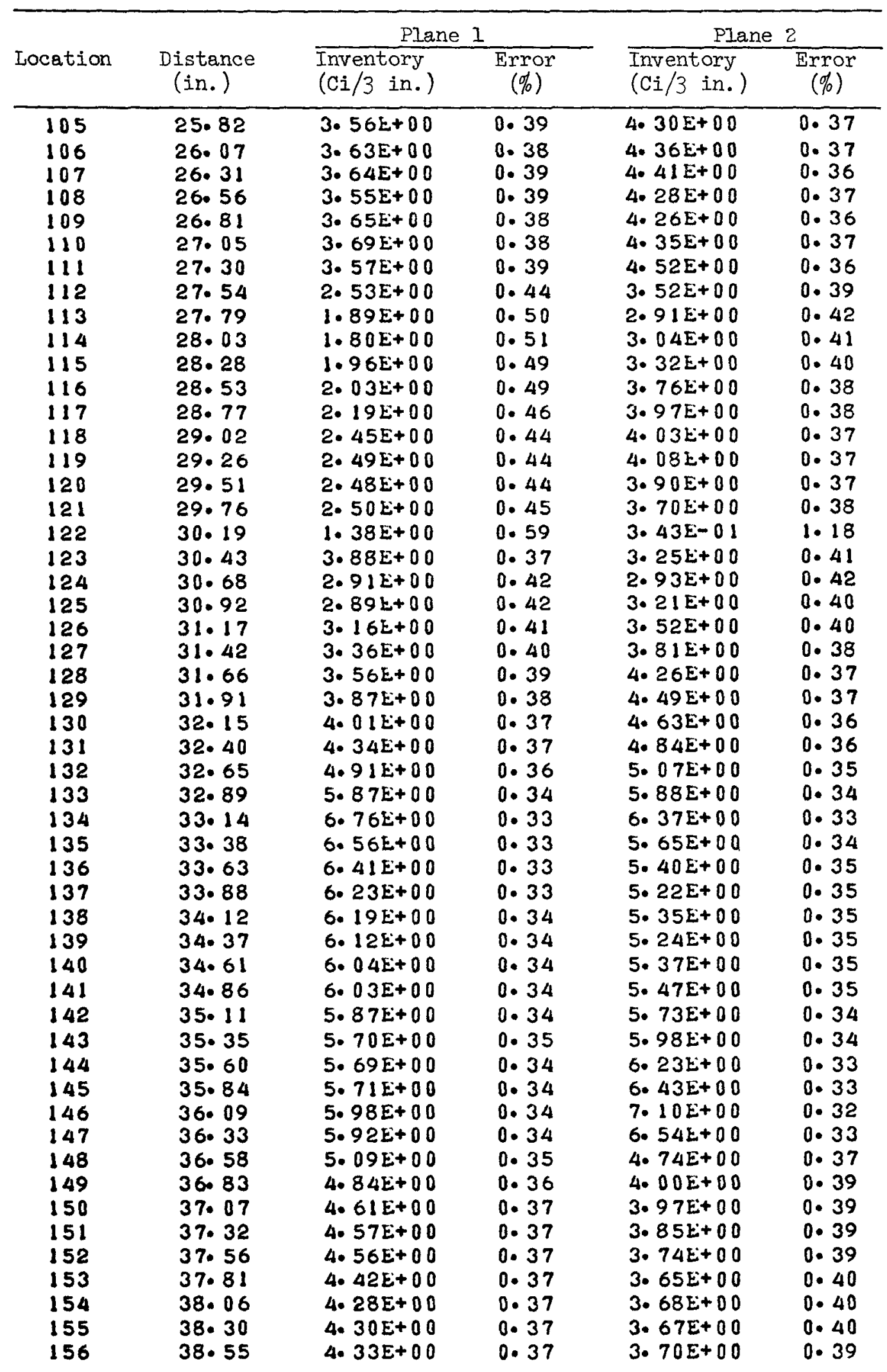


Table A-5 (continued)

\begin{tabular}{|c|c|c|c|c|c|}
\hline \multirow[b]{2}{*}{ Location } & \multirow[b]{2}{*}{$\begin{array}{l}\text { Distance } \\
\text { (in.) }\end{array}$} & \multicolumn{2}{|c|}{ Plane I } & \multicolumn{2}{|c|}{ Plane 2} \\
\hline & & $\begin{array}{l}\text { Inventory } \\
\text { (Ci/3 in.) }\end{array}$ & $\underset{(\%)}{\operatorname{Error}}$ & $\begin{array}{l}\text { Inventory } \\
\text { ( } \mathrm{Ci} / 3 \text { in.) }\end{array}$ & $\begin{array}{c}\text { Error } \\
(\%)\end{array}$ \\
\hline $\begin{array}{l}157 \\
158 \\
159 \\
160 \\
161 \\
162 \\
163 \\
164 \\
165 \\
166 \\
167 \\
168 \\
169 \\
170 \\
171 \\
172 \\
173 \\
174 \\
175 \\
176 \\
177 \\
178 \\
179 \\
180 \\
181 \\
182 \\
183 \\
184 \\
185 \\
186 \\
187 \\
188 \\
189 \\
190 \\
191 \\
192 \\
193 \\
194 \\
195 \\
196 \\
197 \\
198 \\
199 \\
200 \\
201 \\
202 \\
203 \\
204 \\
205 \\
206 \\
207 \\
208\end{array}$ & 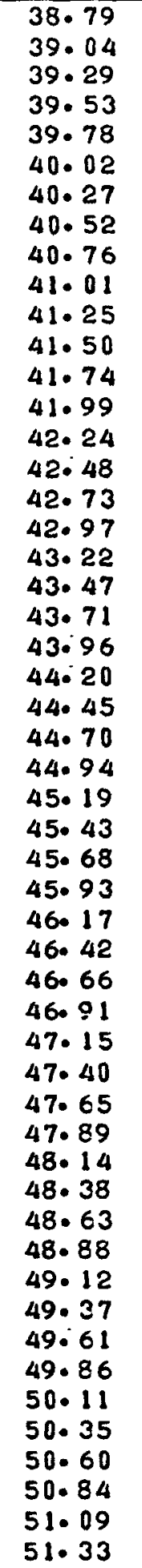 & 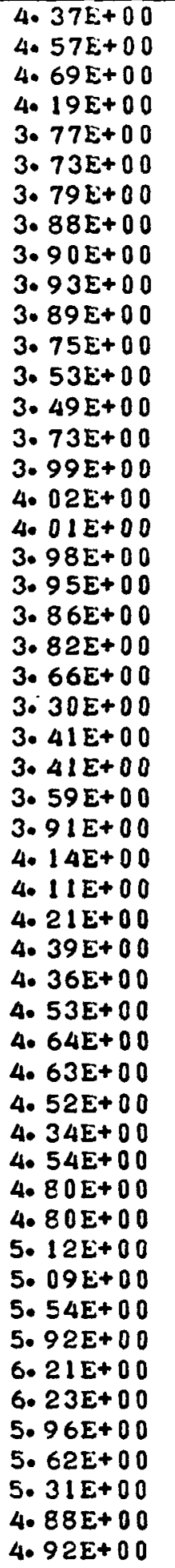 & $\begin{array}{l}0.37 \\
0.36 \\
0.36 \\
0.37 \\
0.39 \\
0.39 \\
0.39 \\
0.38 \\
0.38 \\
0.39 \\
0.38 \\
0.39 \\
0.40 \\
0.40 \\
0.39 \\
0.38 \\
0.38 \\
0.39 \\
0.38 \\
0.39 \\
0.39 \\
0.39 \\
0.39 \\
0.41 \\
0.41 \\
0.41 \\
0.40 \\
0.40 \\
0.38 \\
0.38 \\
0.38 \\
0.37 \\
0.37 \\
0.37 \\
0.37 \\
0.37 \\
0.38 \\
1.60 \\
0.37 \\
0.36 \\
0.37 \\
0.36 \\
0.36 \\
0.35 \\
0.34 \\
0.34 \\
0.34 \\
0.35 \\
0.35 \\
0.36 \\
0.37 \\
0.37\end{array}$ & 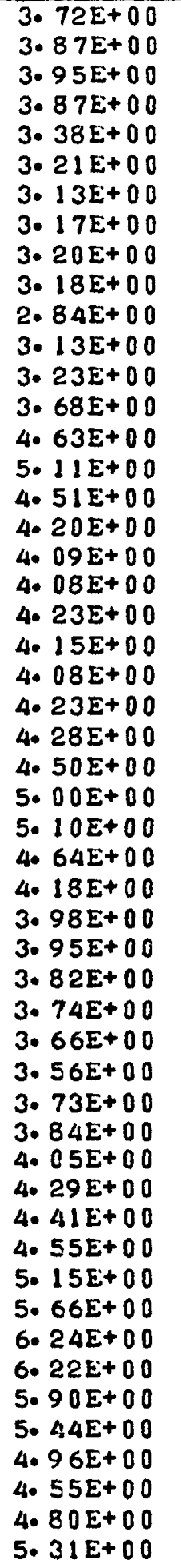 & $\begin{array}{l}0.39 \\
0.39 \\
0.39 \\
0.33 \\
0.40 \\
0.41 \\
0.41 \\
0.42 \\
0.42 \\
0.41 \\
0.44 \\
0.42 \\
0.41 \\
0.40 \\
0.36 \\
0.35 \\
0.37 \\
0.38 \\
0.38 \\
0.38 \\
0.38 \\
0.38 \\
0.38 \\
0.38 \\
0.37 \\
0.37 \\
0.35 \\
0.36 \\
0.37 \\
0.38 \\
0.39 \\
0.39 \\
0.39 \\
0.39 \\
0.49 \\
0.40 \\
0.40 \\
0.40 \\
0.38 \\
0.38 \\
0.38 \\
0.37 \\
0.37 \\
0.36 \\
0.35 \\
0.35 \\
0.34 \\
0.35 \\
0.35 \\
0.36 \\
0.37 \\
0.36 \\
0.36\end{array}$ \\
\hline
\end{tabular}


Table A-5 (continued)

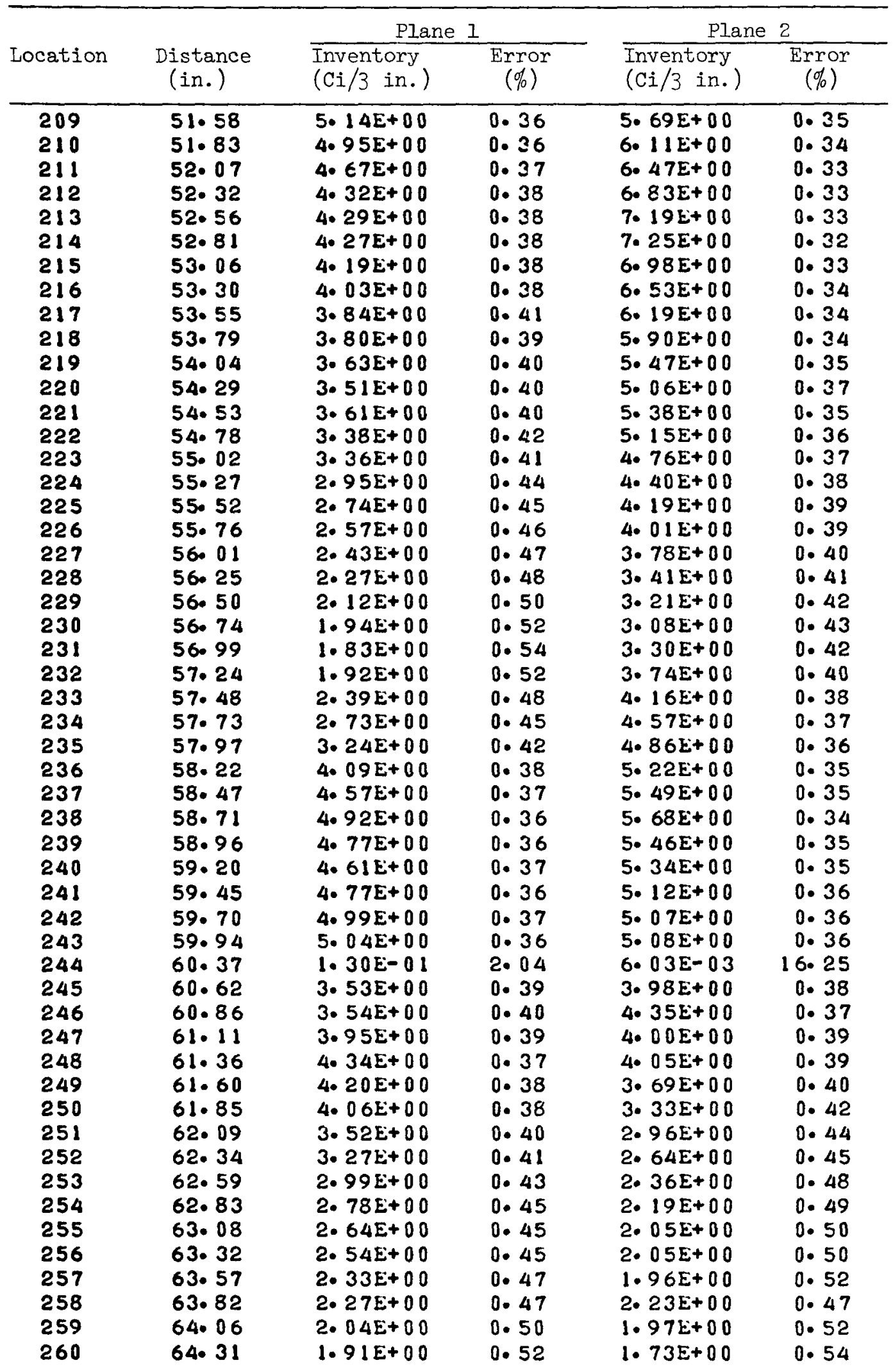


184

Table A-5 (continued)

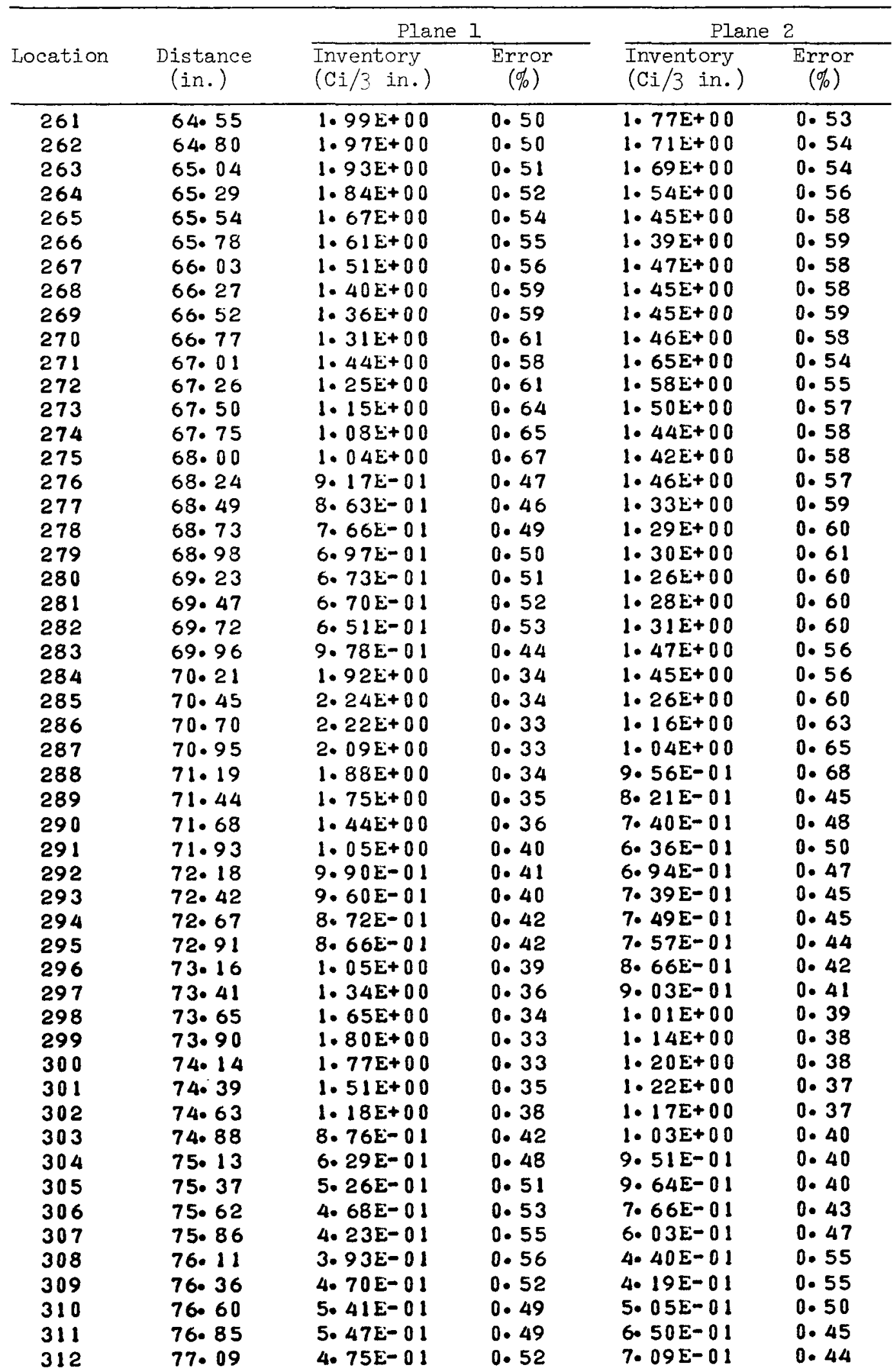


Table A-5 (continued)

\begin{tabular}{|c|c|c|c|c|c|}
\hline \multirow{2}{*}{ Location } & \multirow[b]{2}{*}{$\begin{array}{l}\text { Distance } \\
\text { (in.) }\end{array}$} & \multicolumn{2}{|c|}{ Plane 1} & \multicolumn{2}{|c|}{ Plane 2} \\
\hline & & $\begin{array}{l}\text { Inventory } \\
\text { (Ci/3 in.) }\end{array}$ & $\begin{array}{c}\text { Error } \\
(\%)\end{array}$ & $\begin{array}{l}\text { Inventory } \\
\text { (Ci/3 in.) }\end{array}$ & $\underset{(\%)}{\operatorname{Error}}$ \\
\hline 313 & $77 \cdot 34$ & $3.84 E-01$ & 0.56 & $6.59 E-01$ & 0.45 \\
\hline 314 & 77.59 & 3. $18 \mathrm{E}-01$ & 0.65 & 5. $58 E-01$ & 0.48 \\
\hline 315 & 77.83 & $2.85 E-01$ & 0.64 & 4. $22 E-01$ & 0.54 \\
\hline 316 & 78.08 & $2.74 E-01$ & 0.38 & 3. $16 E-01$ & 0.61 \\
\hline 317 & 78.32 & 2. $57 E-01$ & 0.37 & 2. $50 \mathrm{E}-01$ & 0.68 \\
\hline 318 & $78 \cdot 57$ & 2. $47 E-01$ & 0.37 & $2.26 \mathrm{E}-01$ & 0.39 \\
\hline 319 & 78.82 & 2. $31 E-01$ & 0.38 & 2. $09 \mathrm{E}-01$ & 0.39 \\
\hline 320 & 79.06 & $1.97 \mathrm{E}-01$ & 0.39 & 2. $00 \mathrm{E}-01$ & 0.39 \\
\hline 321 & 79.31 & 2. $09 \mathrm{E}-01$ & 0.39 & $2.16 \mathrm{E}-01$ & 0.39 \\
\hline 322 & 79.55 & $1.66 E-01$ & 0.41 & $2.22 \mathrm{E}-01$ & 0.37 \\
\hline 323 & 79.80 & $9.50 E-02$ & 0.52 & $1.82 \mathrm{E}-01$ & 0.40 \\
\hline 324 & 80.04 & $8.05 E-02$ & 0.56 & $1.47 E-01$ & 0.42 \\
\hline 325 & 80.29 & $7.71 E-02$ & 0.57 & $1.17 E-01$ & 0.46 \\
\hline 326 & 80.54 & 7. $38 \mathrm{E}-02$ & 0.56 & $9.25 E-02$ & 0.50 \\
\hline 327 & $80 \cdot 78$ & $7.09 E-02$ & 0.57 & $6.92 E-02$ & 0.57 \\
\hline 328 & 81.03 & $7.77 E-02$ & 0.54 & 5. $99 E-02$ & 0.60 \\
\hline 329 & 81.27 & $7.85 E-02$ & 0.53 & $6.13 E-02$ & 0.59 \\
\hline 330 & 81.52 & $8.06 E-02$ & 0.52 & $5.81 E-02$ & 0.63 \\
\hline 331 & 81.77 & 7. $51 \mathrm{E}-02$ & 0.53 & 5. $41 E-02$ & 0.61 \\
\hline 332 & 82.01 & 6. $39 E-02$ & 0.57 & $4.93 E-02$ & 0.64 \\
\hline 333 & 82.26 & $6.05 E-02$ & 0.59 & $5 \cdot 31 E-02$ & 0.62 \\
\hline 334 & 82.50 & $8.89 E-02$ & 0.49 & 8. $62 \mathrm{E}-02$ & 0.49 \\
\hline 335 & 82.75 & 6. $29 E-02$ & 0.57 & $8.98 E-02$ & 0.48 \\
\hline 336 & 83.00 & 4. $11 E-02$ & 0.70 & 6. $15 E-02$ & 0.57 \\
\hline 337 & 83.24 & 3. $49 E-02$ & 0.74 & 5. $14 \mathrm{E}-02$ & 0.61 \\
\hline 338 & 83.49 & $2.80 E-02$ & 0.81 & 3. $63 E-02$ & 0.72 \\
\hline 339 & 83.73 & $2 \cdot 33 E-02$ & 0.89 & 2. $22 E-02$ & 0.91 \\
\hline 340 & 83.98 & 2. $42 E-02$ & 0.86 & 1. $46 \mathrm{E}-02$ & 1.12 \\
\hline 341 & $84 \cdot 22$ & $2.07 E-02$ & 0.52 & $1 \cdot 26 E-02$ & 0.65 \\
\hline 342 & 84.47 & $1.71 E-02$ & 0.55 & $9.69 \mathrm{E}-03$ & 0.79 \\
\hline 343 & 84.72 & 1. $54 E-02$ & 0.58 & $8.24 E-03$ & 0.79 \\
\hline 344 & 84096 & $1 \cdot 38 E-02$ & 0.61 & $7.68 \mathrm{E}-03$ & 0.81 \\
\hline 345 & 85.21 & 1. $43 E-02$ & 0.59 & $8 \cdot 36 E-03$ & 0.77 \\
\hline 346 & 85.45 & $1.54 E-02$ & 0.55 & $9.97 E-03$ & 0.69 \\
\hline 347 & 85.70 & $1.34 \mathrm{E}-02$ & 0.59 & $9 \cdot 72 E-03$ & 0.69 \\
\hline 348 & 85.95 & $1.17 E-02$ & 0.63 & 8. $09 E-03$ & 0.75 \\
\hline 349 & 86.19 & 1. $08 \mathrm{E}-02$ & 0.64 & $6.86 E-03$ & 0.81 \\
\hline 350 & $86 \cdot 44$ & $1.04 E-02$ & 0.66 & $5.88 \mathrm{E}-03$ & 0.86 \\
\hline 351 & 86.68 & 1. $04 E-02$ & 0.64 & 5. $09 \mathrm{E}-03$ & 0.93 \\
\hline 352 & 86.93 & 1. $15 E-02$ & 0.62 & 4. $78 \mathrm{E}-\mathrm{C3}$ & 0.96 \\
\hline 353 & 87.18 & $1 \cdot 10 E-02$ & 0.62 & $5.01 E-03$ & 0.92 \\
\hline 354 & $87 \cdot 42$ & $9.92 E-C 3$ & 0.64 & $5.00 E-03$ & 0.92 \\
\hline 355 & 87.67 & $9.06 E-03$ & $0 \cdot 68$ & 4. $81 E-03$ & 0.93 \\
\hline 356 & 87.91 & $8 \cdot t 4 E-03$ & 0.69 & 4. $38 E-03$ & 0.97 \\
\hline 357 & $88 \cdot 16$ & $8 \cdot 04 E-03$ & 0.71 & 4. $44 E-03$ & 0.96 \\
\hline 358 & 88.41 & 9. $C 9 L-03$ & 0.67 & 5. $80 E-03$ & 0.82 \\
\hline 359 & $88 \cdot 65$ & $9.26 E-03$ & 0.66 & $6.95 \mathrm{E}-03$ & 0.75 \\
\hline 360 & 88.90 & $7.98 E-03$ & 0.71 & 6. $70 \mathrm{E}-03$ & 0.77 \\
\hline 361 & 89.14 & $6.95 \mathrm{E}-03$ & 0.75 & $6.28 E-03$ & 0.79 \\
\hline 362 & 89.39 & 6. $68 \mathrm{E}-03$ & 0.77 & 7. $05 E-03$ & 0.76 \\
\hline 363 & 89.63 & $6 \cdot E 5 E-03$ & 0.77 & 7. $28 E-03$ & 0.75 \\
\hline 364 & 89.88 & $6.64 E-03$ & 0.77 & 7. $20 E-03$ & 0.75 \\
\hline
\end{tabular}


Table A-6. Axial distribution of ${ }^{134} \mathrm{Cs}$ in the spine of element F03-01 (corrected to October 31, 1974)

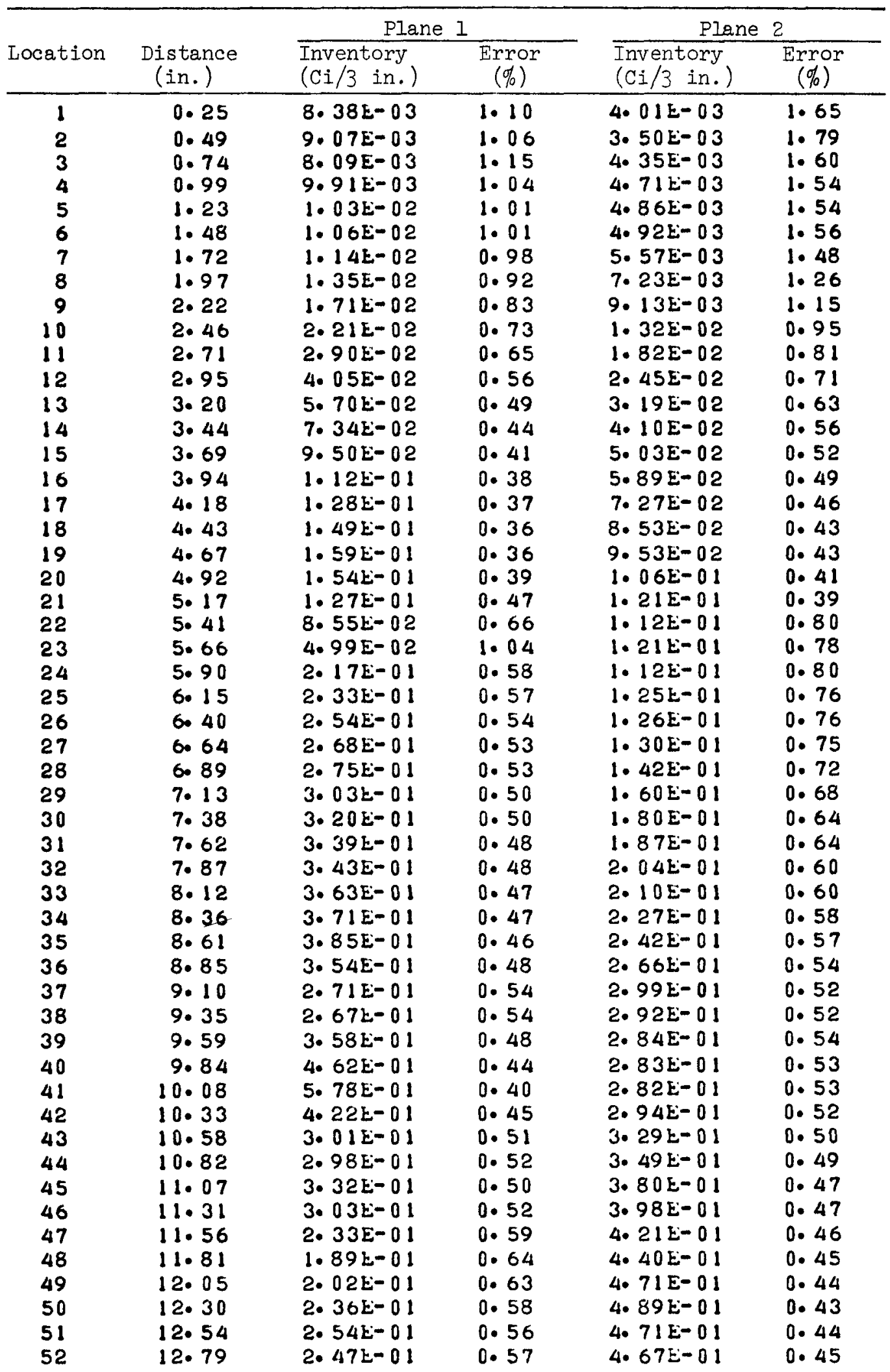


Table A-6 (continued)

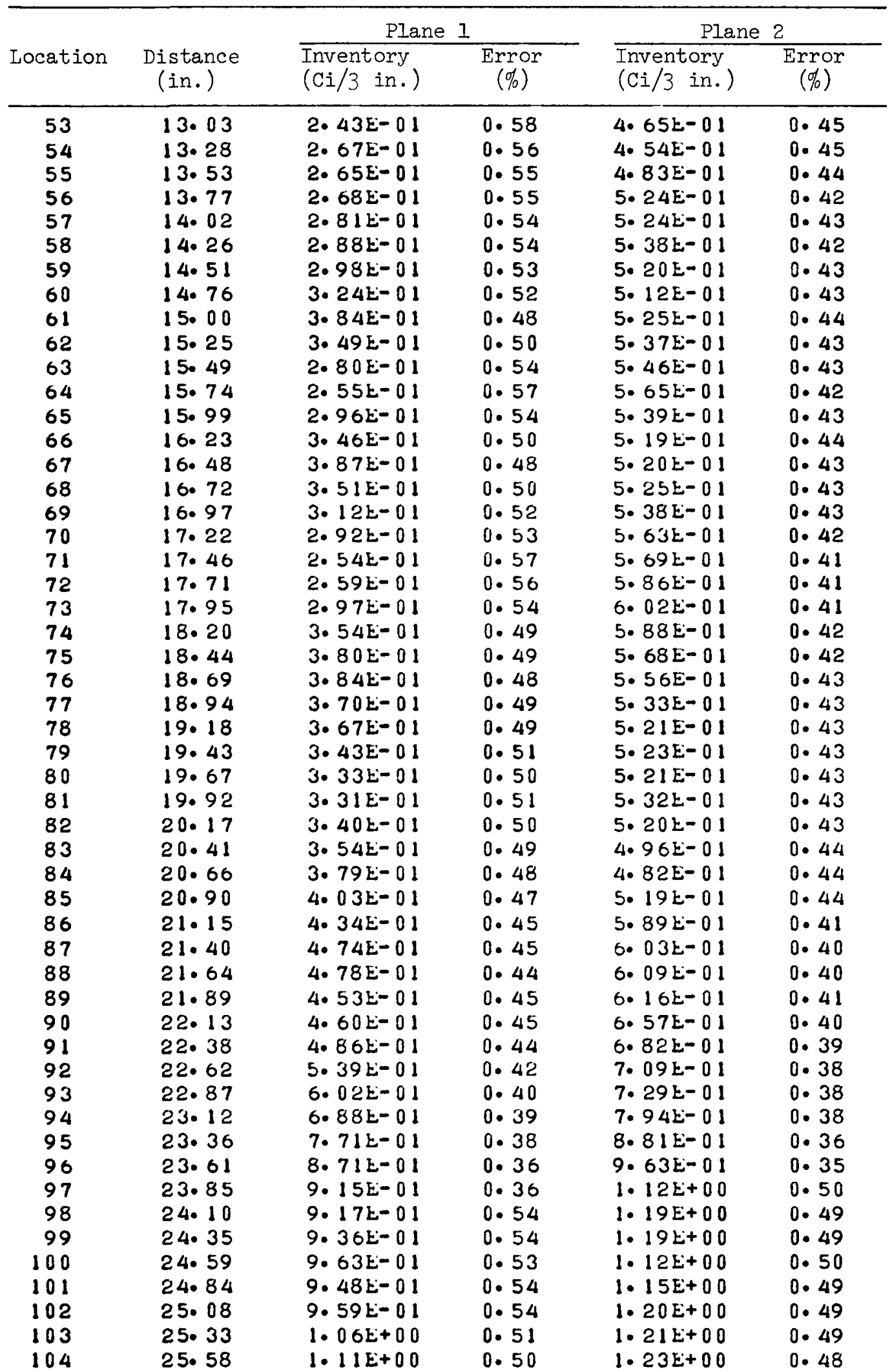


Table A-6 (continued)

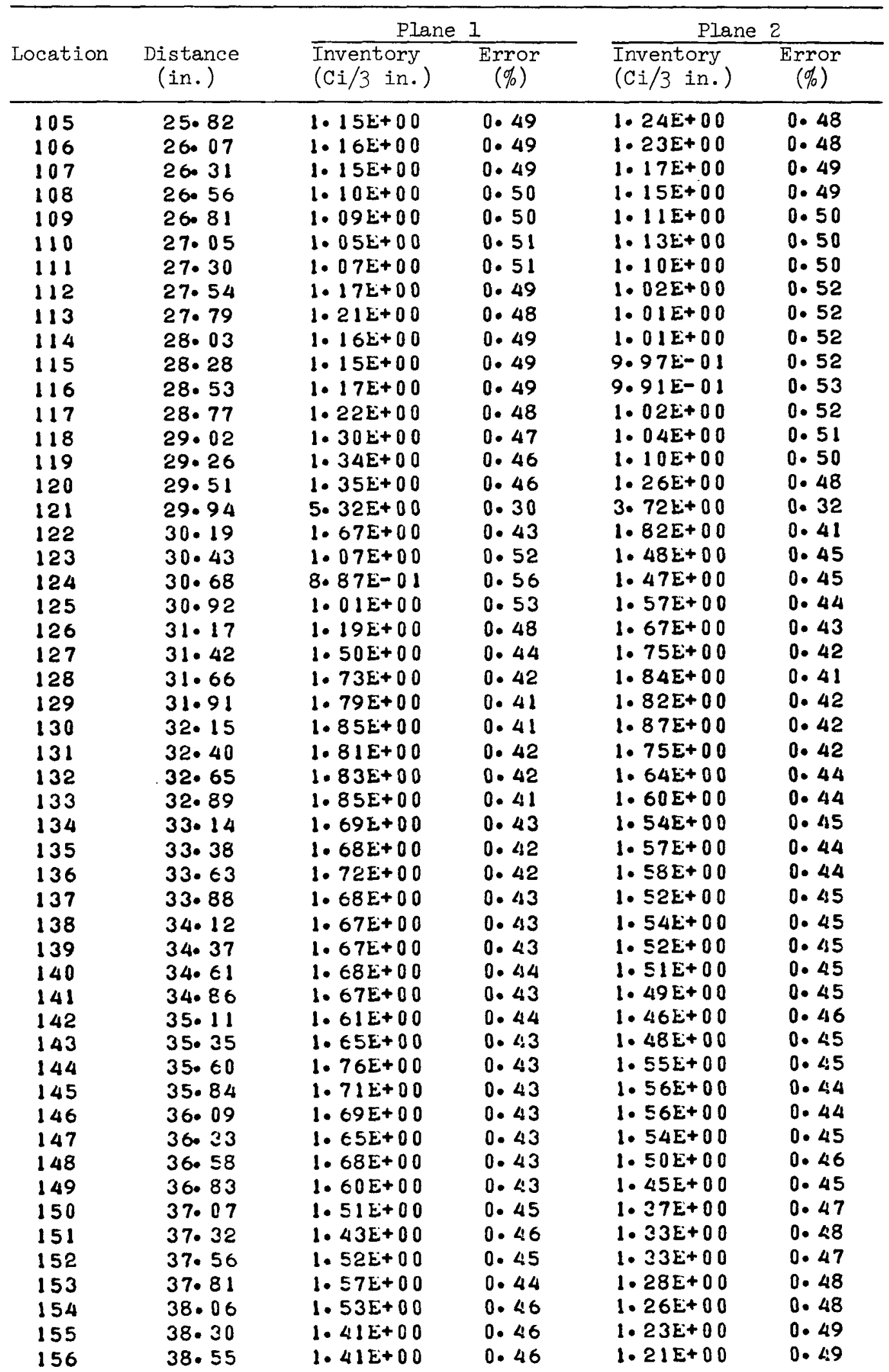


Table A-6 (continued)

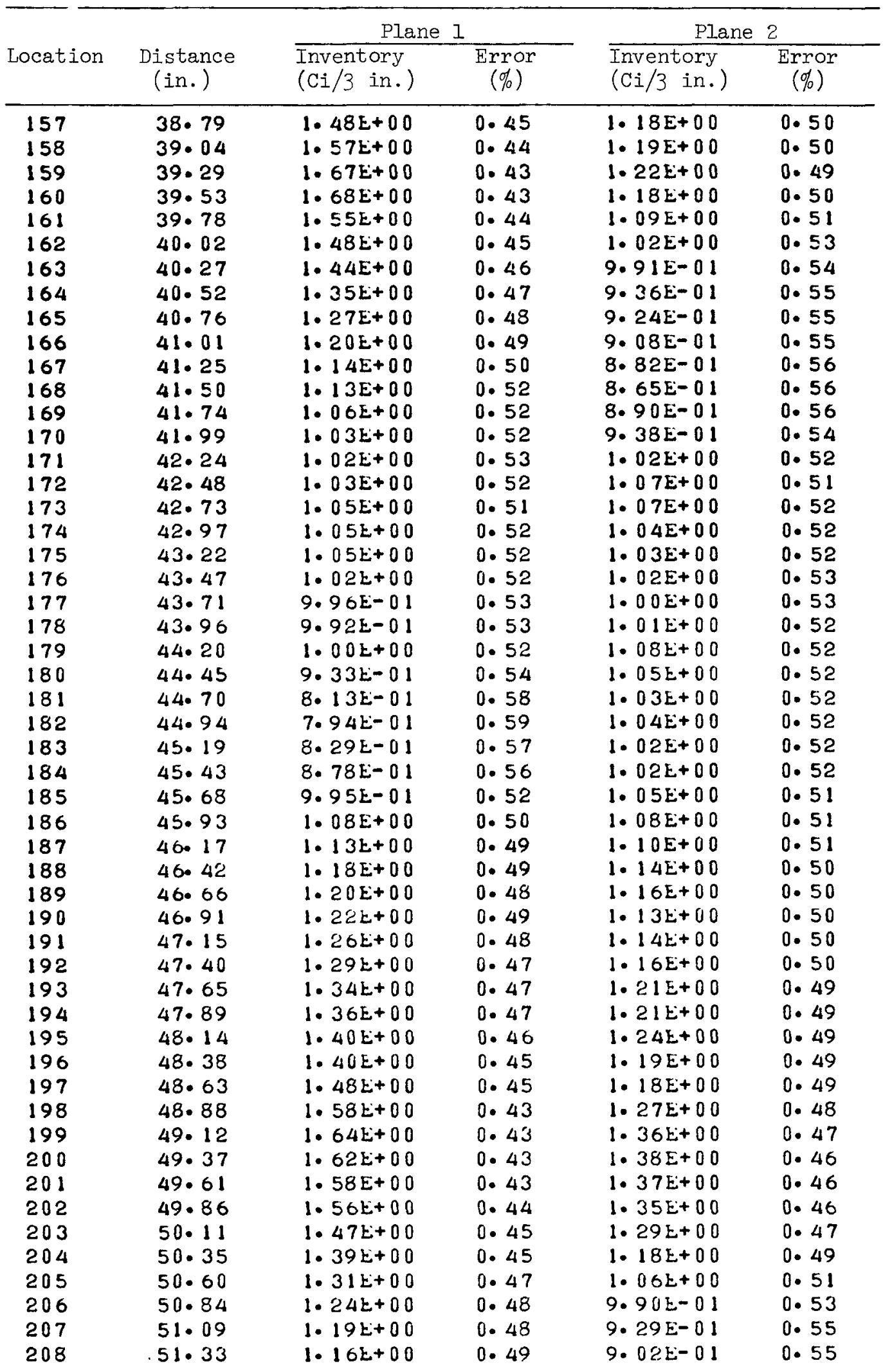


Table A-6 (continued)

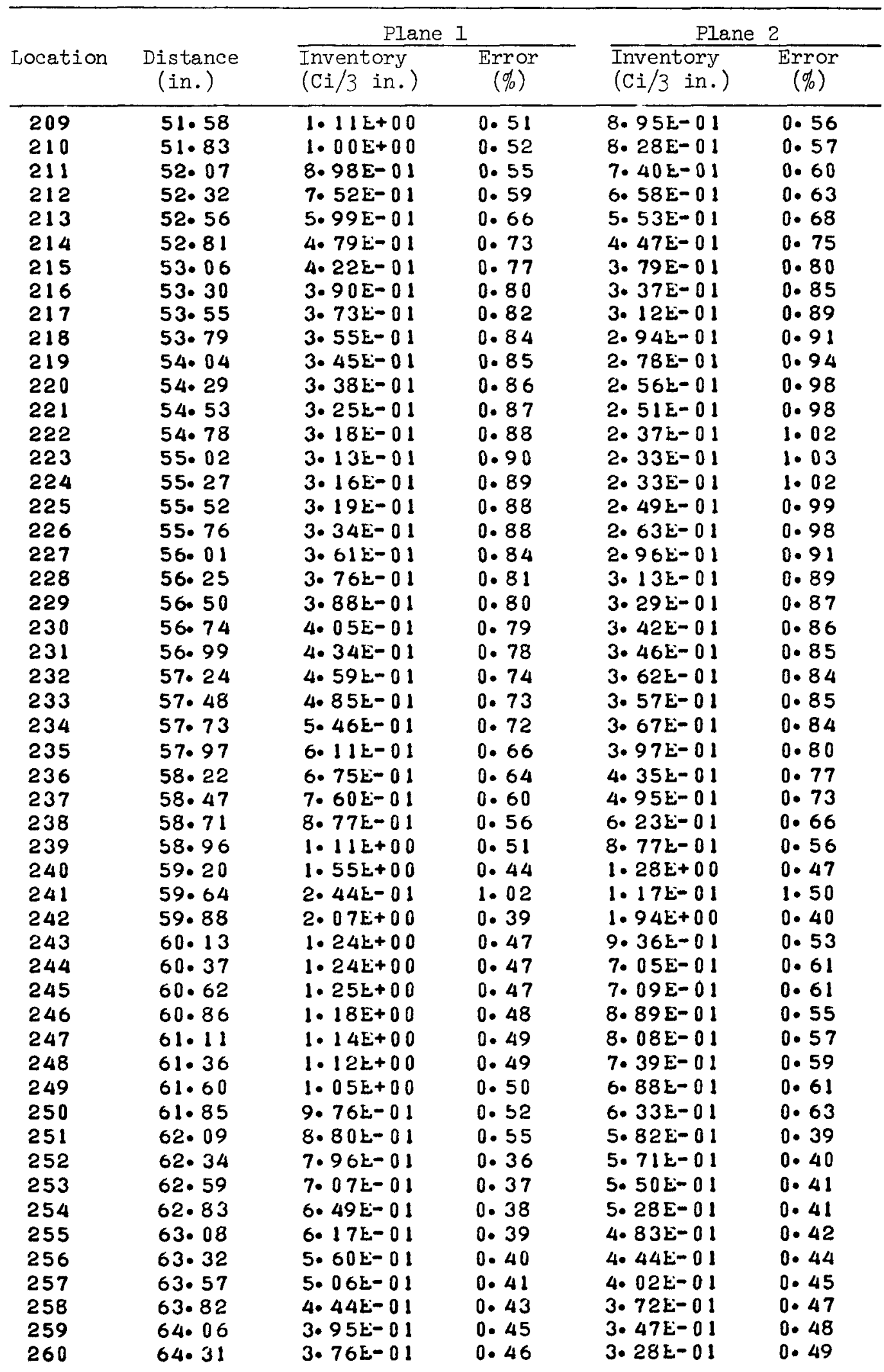




\begin{tabular}{|c|c|c|c|c|c|}
\hline \multirow[b]{2}{*}{ Location } & \multirow[b]{2}{*}{$\begin{array}{l}\text { Distance } \\
\text { (in.) }\end{array}$} & \multicolumn{2}{|c|}{ Plane 1} & \multicolumn{2}{|c|}{ Plane 2} \\
\hline & & $\begin{array}{l}\text { Inventory } \\
(\mathrm{Ci} / 3 \text { in. })\end{array}$ & $\begin{array}{c}\text { Error } \\
(\%)\end{array}$ & $\begin{array}{l}\text { Inventory } \\
\text { ( } \mathrm{C} / \mathrm{3} \text { in.) }\end{array}$ & $\begin{array}{c}\text { Error } \\
(\%)\end{array}$ \\
\hline $\begin{array}{l}261 \\
262 \\
263 \\
264 \\
265 \\
266 \\
267 \\
268 \\
269 \\
270 \\
271 \\
272 \\
273 \\
274 \\
275 \\
276 \\
277 \\
278 \\
279 \\
280 \\
281 \\
282 \\
283 \\
284 \\
285 \\
286 \\
287 \\
288 \\
289 \\
290 \\
291 \\
292 \\
293 \\
294 \\
295 \\
296 \\
297 \\
298 \\
299 \\
300 \\
301 \\
302 \\
303 \\
304 \\
305 \\
306 \\
307 \\
308 \\
309 \\
310 \\
311 \\
312\end{array}$ & 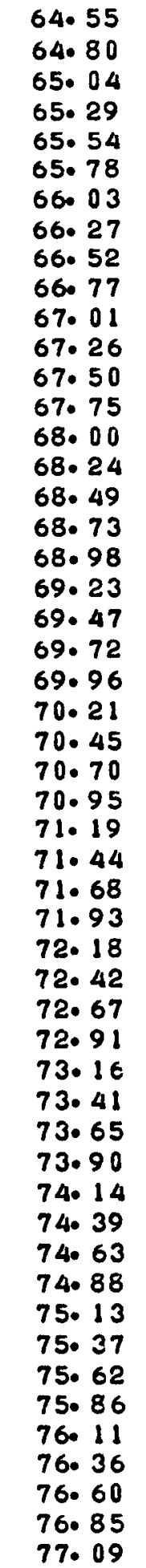 & 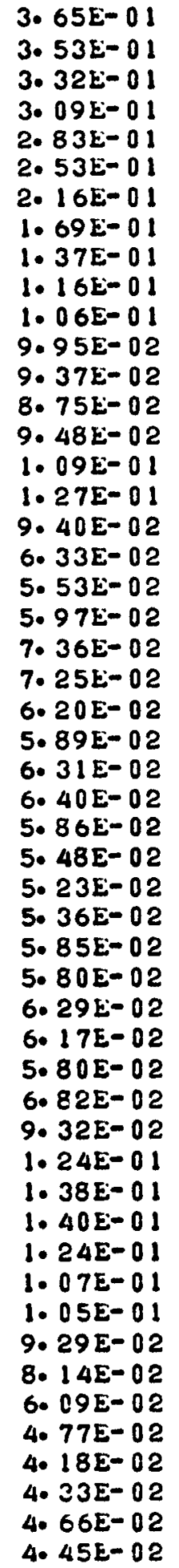 & $\begin{array}{l}0.47 \\
0.47 \\
0.48 \\
0.50 \\
0.51 \\
0.54 \\
0.58 \\
0.65 \\
0.39 \\
0.41 \\
0.42 \\
0.43 \\
0.44 \\
0.46 \\
0.44 \\
0.41 \\
0.39 \\
0.44 \\
0.51 \\
0.54 \\
0.53 \\
0.48 \\
0.49 \\
0.52 \\
0.53 \\
0.50 \\
0.50 \\
0.52 \\
0.53 \\
0.55 \\
0.55 \\
0.51 \\
0.51 \\
0.49 \\
0.49 \\
0.51 \\
0.48 \\
0.43 \\
0.39 \\
0.38 \\
0.38 \\
0.39 \\
0.42 \\
0.41 \\
0.42 \\
0.43 \\
0.49 \\
0.53 \\
0.56 \\
0.56 \\
0.54 \\
0.54\end{array}$ & 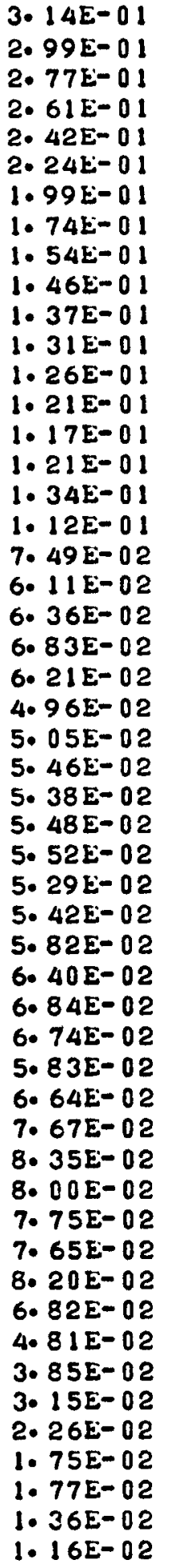 & $\begin{array}{l}0.50 \\
0.51 \\
0.52 \\
0.54 \\
0.55 \\
0.57 \\
0.61 \\
0.64 \\
0.67 \\
0.37 \\
0.38 \\
0.38 \\
0.38 \\
0.39 \\
0.39 \\
0.39 \\
0.37 \\
0.41 \\
0.47 \\
0.51 \\
0.50 \\
0.49 \\
0.51 \\
0.55 \\
0.54 \\
0.52 \\
0.52 \\
0.52 \\
0.51 \\
0.53 \\
0.52 \\
0.49 \\
0.48 \\
0.45 \\
0.46 \\
0.49 \\
0.47 \\
0.45 \\
0.44 \\
0.44 \\
0.45 \\
0.45 \\
0.44 \\
0.47 \\
0.53 \\
0.58 \\
0.63 \\
0.73 \\
0.83 \\
0.82 \\
0.94 \\
1.02\end{array}$ \\
\hline
\end{tabular}


Table A-6 (continued)

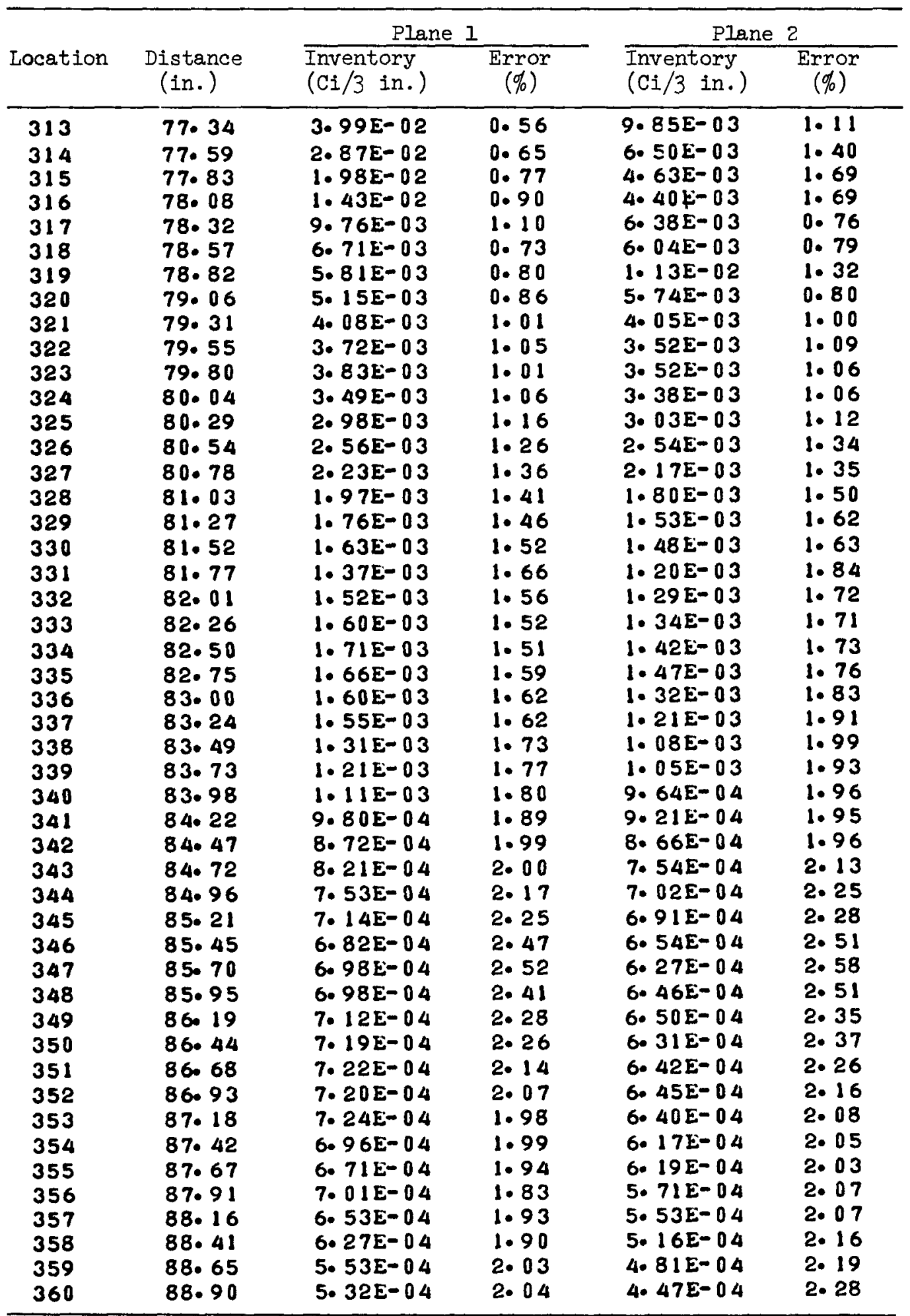


Table A-7. Axial distribution of ${ }^{137} \mathrm{Cs}$ in the sleeve of element F03-01

(corrected to October 31, 1974)

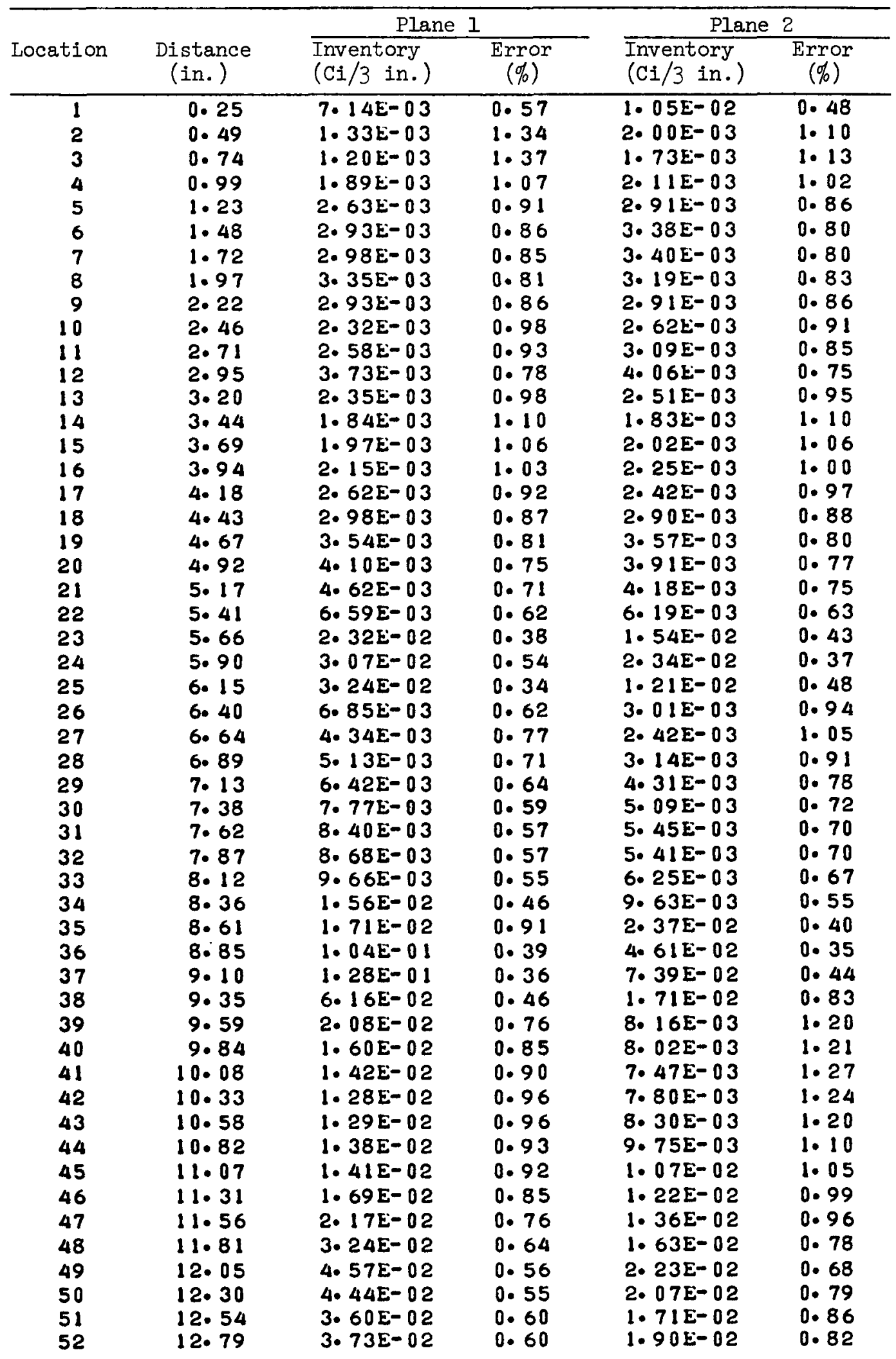


Table A-7 (continued)

\begin{tabular}{|c|c|c|c|c|c|}
\hline \multirow[b]{2}{*}{ Location } & \multirow[b]{2}{*}{$\begin{array}{l}\text { Distance } \\
\text { (in.) }\end{array}$} & \multicolumn{2}{|c|}{ Plane 1} & \multicolumn{2}{|c|}{ Plane 2} \\
\hline & & $\begin{array}{l}\text { Inventory } \\
(\mathrm{Ci} / 3 \text { in. })\end{array}$ & $\begin{array}{c}\text { Error } \\
(\%)\end{array}$ & $\begin{array}{l}\text { Inventory } \\
(\mathrm{Ci} / 3 \mathrm{in.})\end{array}$ & $\begin{array}{c}\text { Error } \\
(\%)\end{array}$ \\
\hline 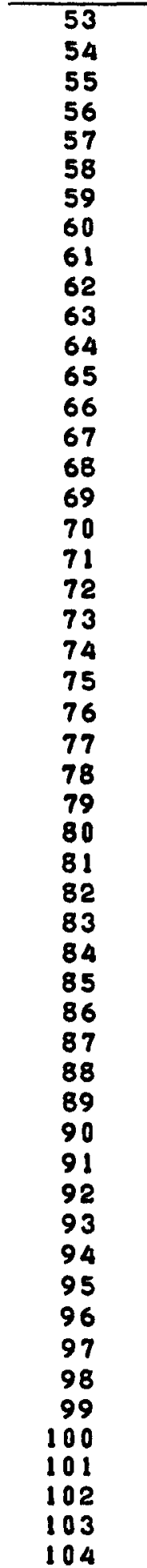 & 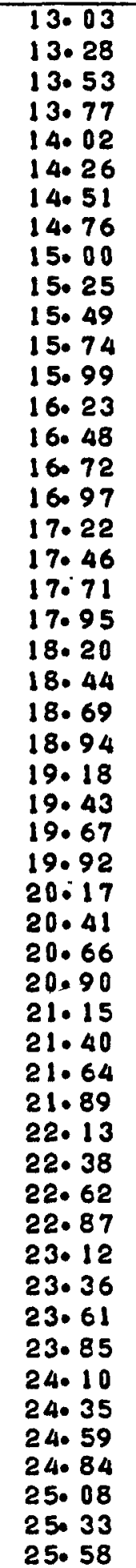 & 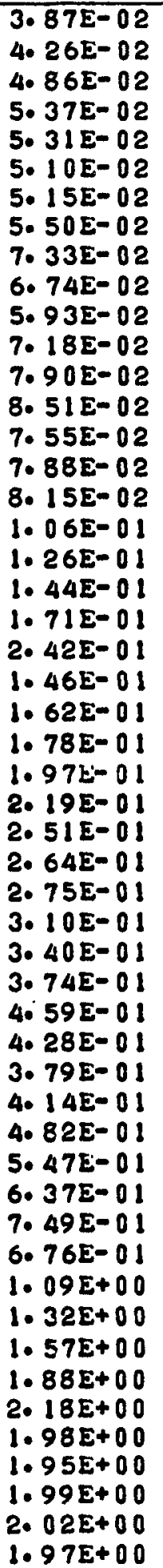 & 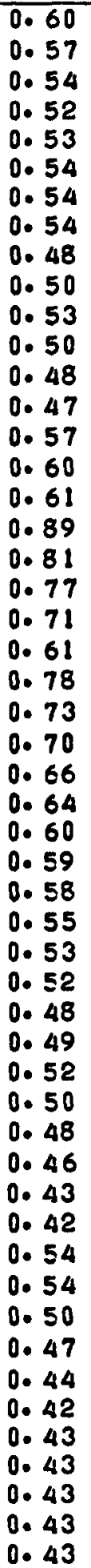 & 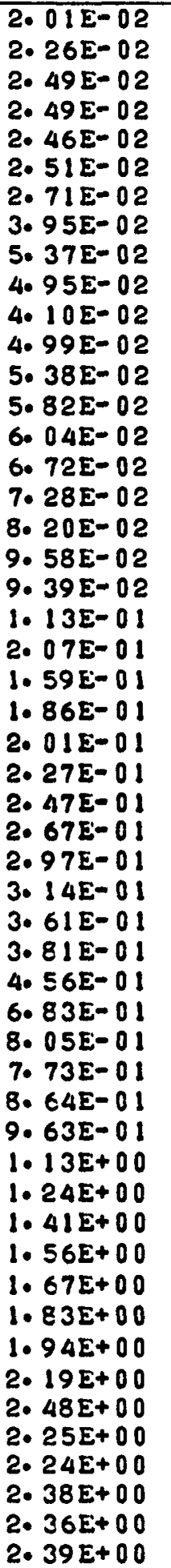 & $\begin{array}{l}0.80 \\
0.77 \\
0.74 \\
0.74 \\
0.75 \\
0.75 \\
0.74 \\
0.63 \\
0.48 \\
0.57 \\
0.63 \\
0.58 \\
0.56 \\
0.55 \\
0.55 \\
0.53 \\
0.52 \\
0.50 \\
0.48 \\
0.95 \\
0.87 \\
0.64 \\
0.74 \\
0.68 \\
0.66 \\
0.62 \\
0.60 \\
0.58 \\
0.56 \\
0.54 \\
0.52 \\
0.50 \\
0.48 \\
0.41 \\
0.39 \\
0.40 \\
0.39 \\
0.38 \\
0.53 \\
0.51 \\
0.49 \\
0.47 \\
0.46 \\
0.44 \\
0.44 \\
0.41 \\
0.40 \\
0.41 \\
0.42 \\
0.41 \\
0.40\end{array}$ \\
\hline
\end{tabular}


Table A-7 (continued)

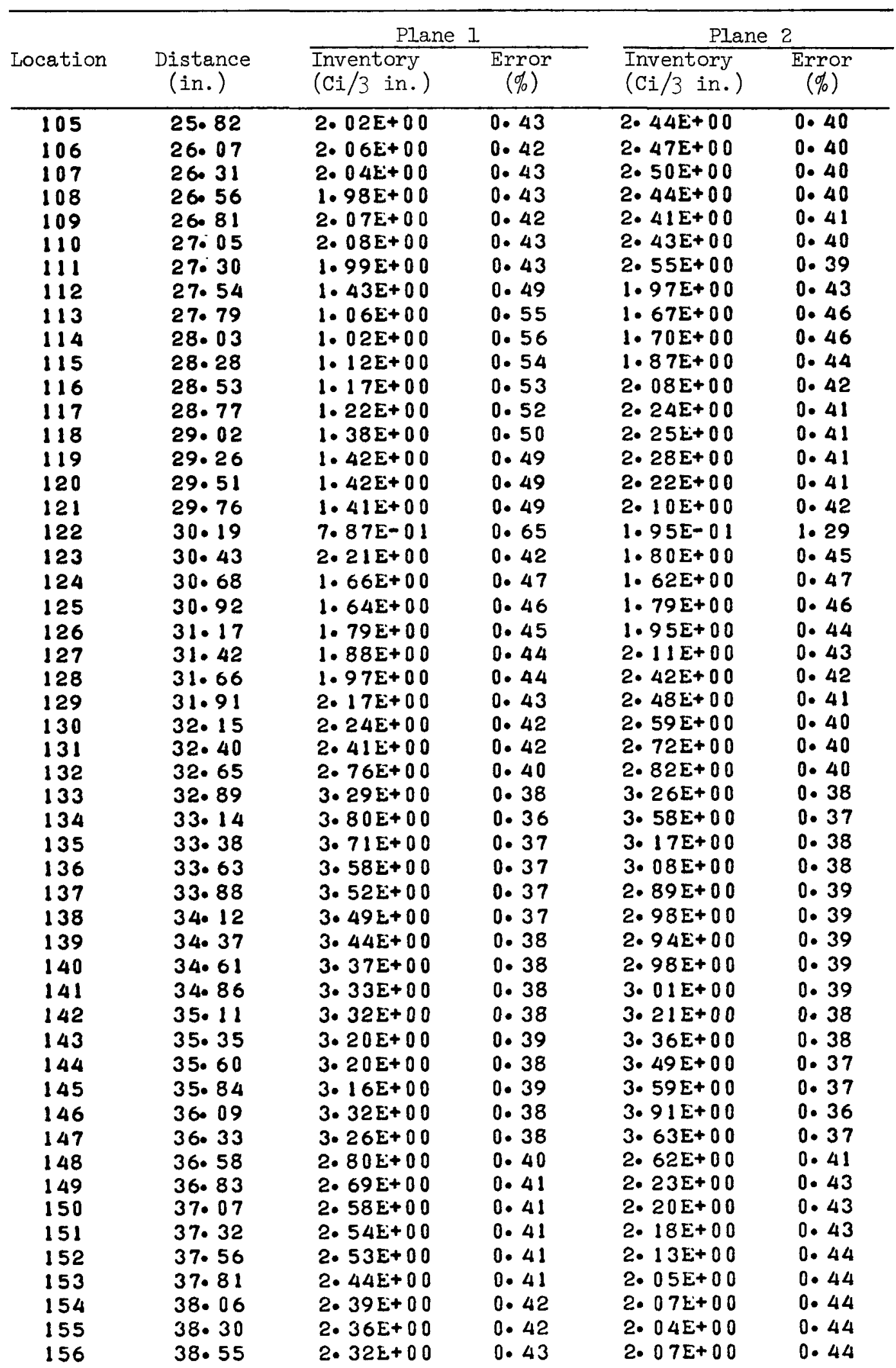




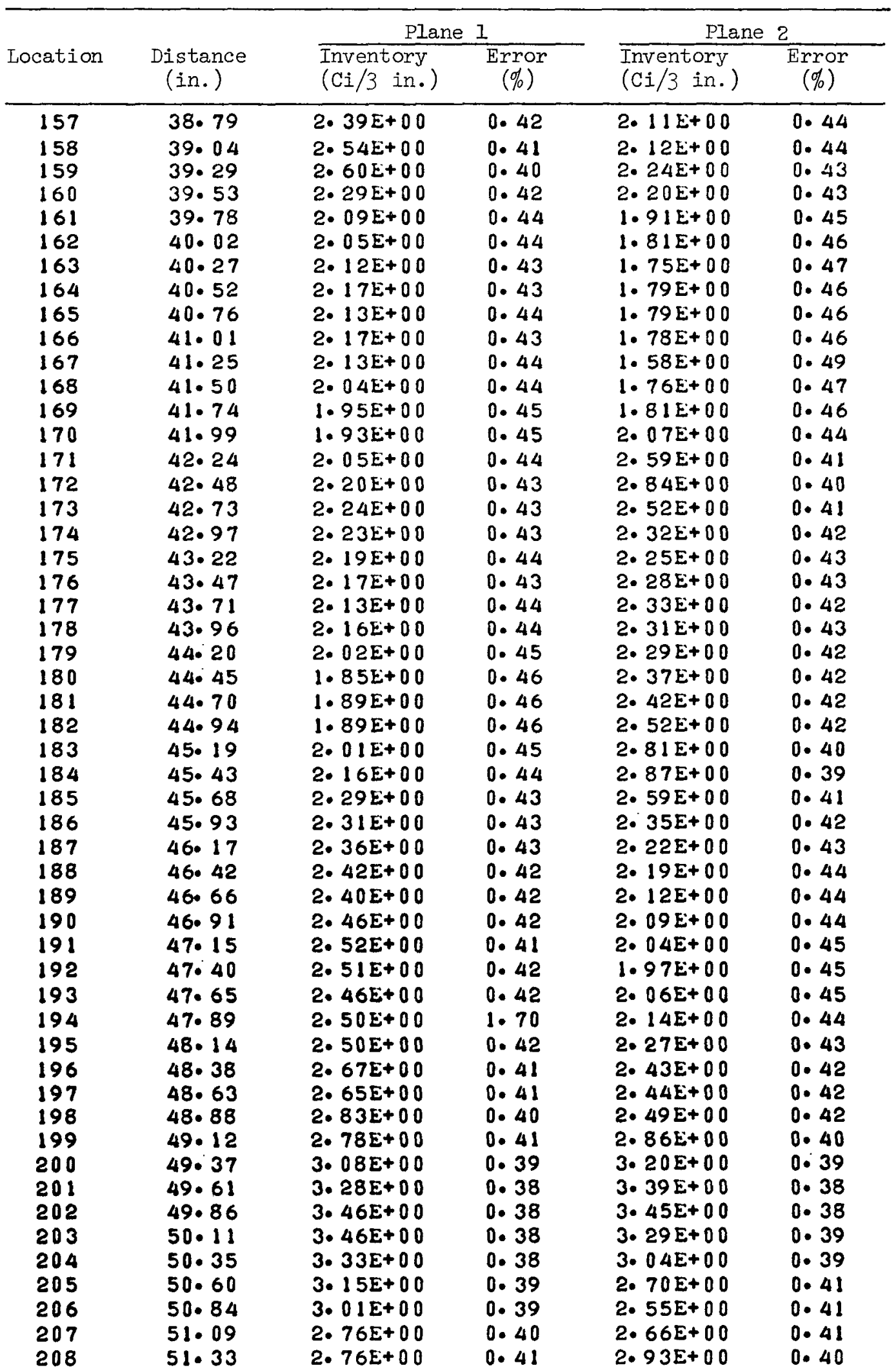


Table A-7 (continued)

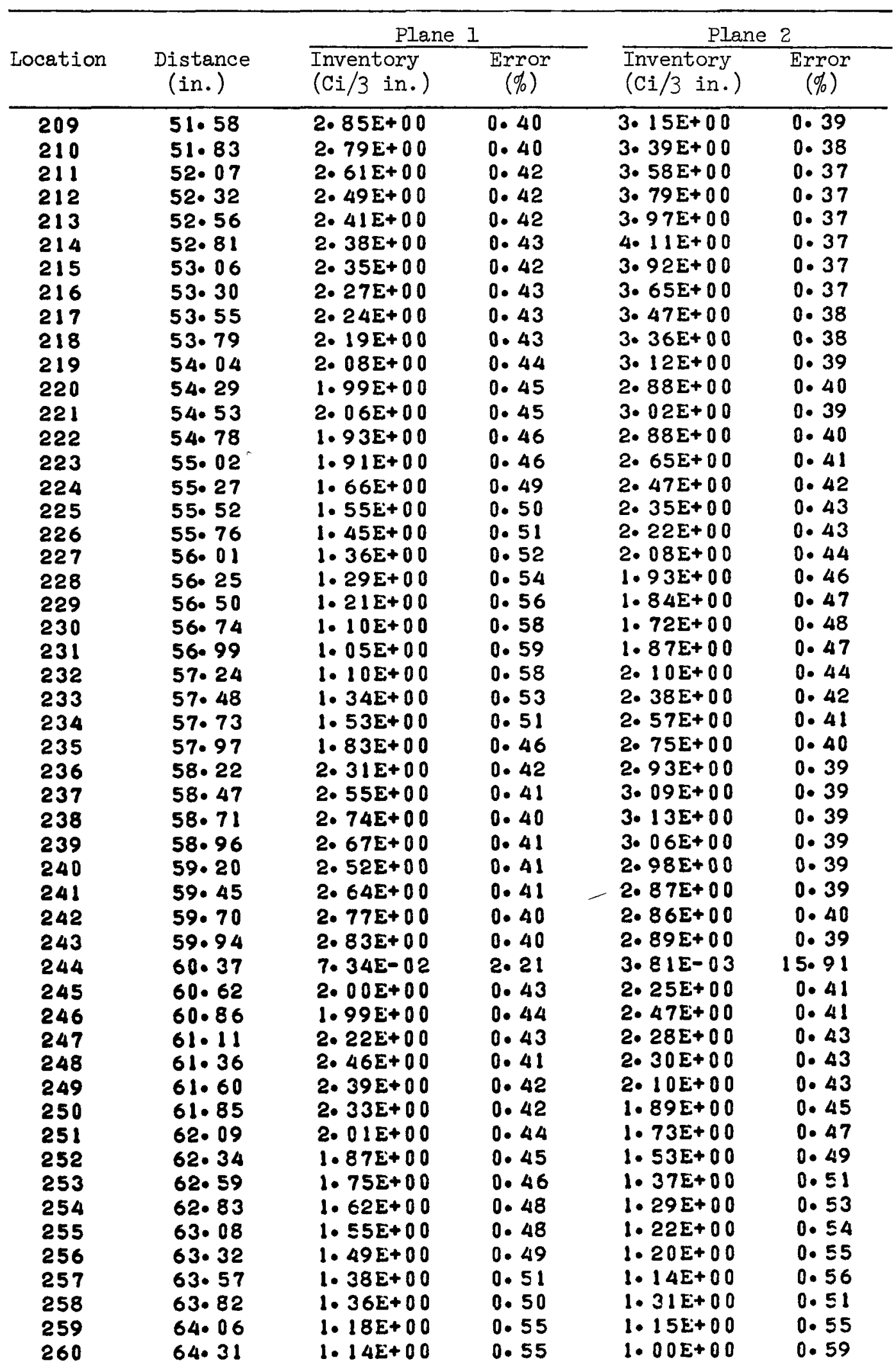


Table A-7 (continued)

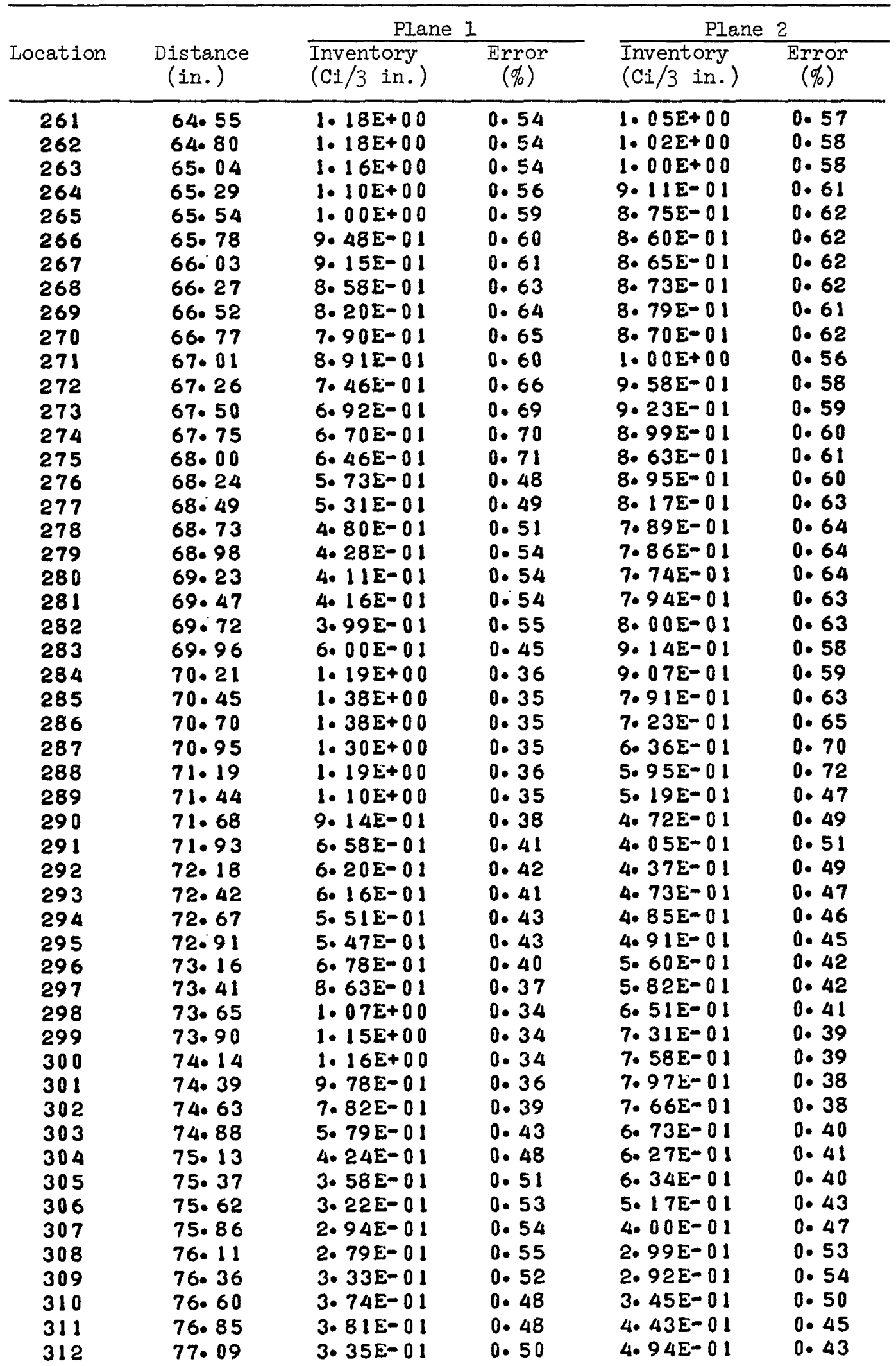


Table A-7 (continued)

\begin{tabular}{|c|c|c|c|c|c|}
\hline \multirow[b]{2}{*}{ Location } & \multirow[b]{2}{*}{$\begin{array}{l}\text { Distance } \\
\text { (in.) }\end{array}$} & \multicolumn{2}{|c|}{ Plane 1} & \multicolumn{2}{|c|}{ Plane 2} \\
\hline & & $\begin{array}{l}\text { Inventory } \\
(\mathrm{Ci} / 3 \text { in. })\end{array}$ & $\begin{array}{c}\text { Error } \\
(\%)\end{array}$ & $\begin{array}{l}\text { Inventory } \\
\text { ( } \mathrm{C} i / 3 \text { in.) }\end{array}$ & $\begin{array}{c}\text { Error } \\
(\%)\end{array}$ \\
\hline $\begin{array}{l}313 \\
314 \\
315 \\
316 \\
317 \\
318 \\
319 \\
320 \\
321 \\
322 \\
323 \\
324 \\
325 \\
326 \\
327 \\
328 \\
329 \\
330 \\
331 \\
332 \\
333 \\
334 \\
335 \\
336 \\
337 \\
338 \\
339 \\
340 \\
341 \\
342 \\
343 \\
344 \\
345 \\
346 \\
347 \\
348 \\
349 \\
350 \\
351 \\
352 \\
353 \\
354 \\
355 \\
356 \\
357 \\
358 \\
359 \\
360 \\
361 \\
362 \\
363 \\
364\end{array}$ & 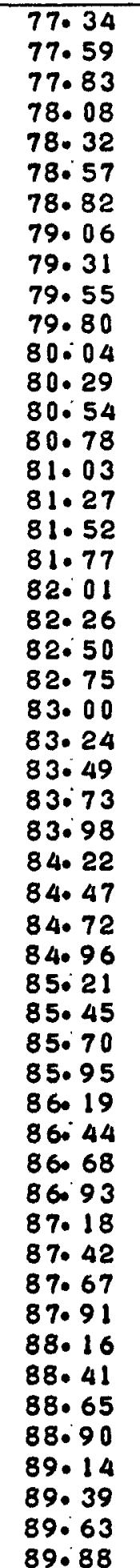 & 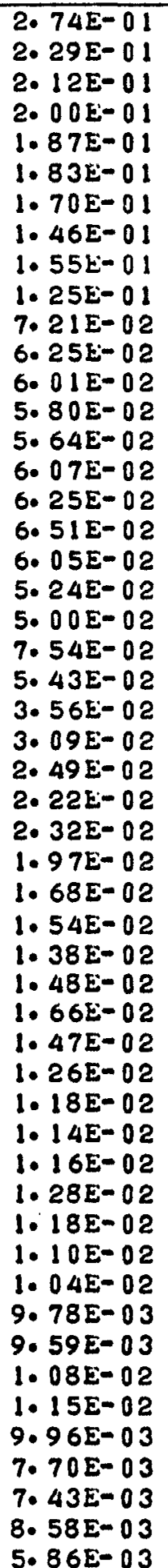 & $\begin{array}{l}0.55 \\
0.60 \\
0.61 \\
0.36 \\
0.36 \\
0.36 \\
0.36 \\
0.38 \\
0.36 \\
0.39 \\
0.50 \\
0.52 \\
0.52 \\
0.52 \\
0.52 \\
0.50 \\
0.48 \\
0.47 \\
0.48 \\
0.51 \\
0.53 \\
0.43 \\
0.50 \\
0.61 \\
0.64 \\
0.70 \\
0.74 \\
0.71 \\
0.43 \\
0.45 \\
0.47 \\
0.49 \\
0.46 \\
0.43 \\
0.45 \\
0.48 \\
0.49 \\
0.50 \\
0.49 \\
0.47 \\
0.48 \\
0.49 \\
0.50 \\
0.52 \\
0.51 \\
0.49 \\
0.47 \\
0.55 \\
0.52 \\
0.53 \\
0.54 \\
0.79\end{array}$ & 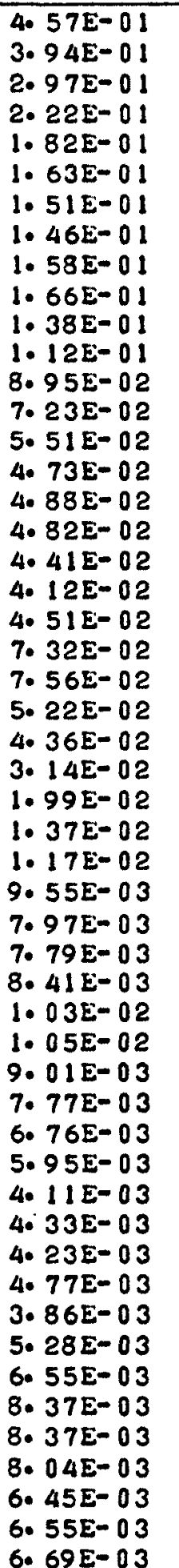 & $\begin{array}{l}0.44 \\
0.47 \\
0.53 \\
0.60 \\
0.65 \\
0.37 \\
0.38 \\
0.37 \\
0.36 \\
0.35 \\
0.38 \\
0.40 \\
0.43 \\
0.46 \\
0.52 \\
0.56 \\
0.54 \\
0.54 \\
0.56 \\
0.57 \\
0.55 \\
0.43 \\
0.42 \\
0.50 \\
0.54 \\
0.63 \\
0.78 \\
0.94 \\
0.56 \\
0.61 \\
0.66 \\
0.65 \\
0.62 \\
0.54 \\
0.53 \\
0.57 \\
0.61 \\
0.64 \\
0.68 \\
0.95 \\
0.91 \\
0.93 \\
0.66 \\
0.95 \\
0.70 \\
0.62 \\
0.55 \\
0.55 \\
0.55 \\
0.73 \\
0.73 \\
0.72\end{array}$ \\
\hline
\end{tabular}


Table A-8. Axial distribution of ${ }^{137} \mathrm{Cs}$ in the spine of element FO3-OI

(corrected to October 31, 1974)

\begin{tabular}{|c|c|c|c|c|c|}
\hline \multirow[b]{2}{*}{ Location } & \multirow[b]{2}{*}{$\begin{array}{c}\text { Distance } \\
\text { (in.) }\end{array}$} & \multicolumn{2}{|c|}{ Plane 1} & \multicolumn{2}{|c|}{ Plane 2} \\
\hline & & $\begin{array}{l}\text { Inventory } \\
(\mathrm{Ci} / 3 \text { in.) }\end{array}$ & $\begin{array}{c}\text { Error } \\
(\%)\end{array}$ & $\begin{array}{l}\text { Inventory } \\
\text { (Ci/3 in.) }\end{array}$ & $\begin{array}{c}\text { Error } \\
(\%)\end{array}$ \\
\hline 1 & 0.25 & $6 \cdot 40 E-03$ & 1.02 & $2 \cdot 35 \mathrm{E}-03$ & 1.88 \\
\hline 2 & 0.49 & $6.26 \mathrm{E}-03$ & 1.06 & $2.17 \mathrm{E}-03$ & $1 \cdot 98$ \\
\hline 3 & 0.74 & $6 \cdot 13 k-03$ & 1.08 & 2. $47 \mathrm{E}-03$ & 1.97 \\
\hline 4 & 0.99 & 5. $26 E-03$ & 1.42 & $2.79 \mathrm{E}-03$ & 1.40 \\
\hline 5 & 1.23 & $6.68 E-03$ & 0.91 & $3.21 \mathrm{E}-03$ & $1 \cdot 31$ \\
\hline 6 & 1.48 & $6.87 t-03$ & 0.90 & $3 \cdot 14 k-03$ & $1 \cdot 33$ \\
\hline 7 & 1.72 & $7.27 \mathrm{E}-03$ & 0.88 & $3.40 E-03$ & $1 \cdot 28$ \\
\hline 8 & 1.97 & $8 \cdot 54 \mathrm{E}-03$ & 0.82 & 4. $08 E-03$ & 1. 18 \\
\hline 9 & $2 \cdot 22$ & 1.07E-02 & 0.74 & $6 \cdot 12 E-03$ & 0.97 \\
\hline 10 & 2.46 & 1. $39 \mathrm{E}-02$ & 0.66 & $8.30 \mathrm{E}-03$ & 0.84 \\
\hline 11 & $2 \cdot 71$ & 1. $82 \mathrm{E}-02$ & 0.58 & 1. $17 \mathrm{E}-02$ & 0.71 \\
\hline 12 & 2.95 & 2. $44 \mathrm{E}-02$ & 0.51 & $1.84 \mathrm{E}-02$ & 0.68 \\
\hline 13 & 3.20 & $4 \cdot 24 \mathrm{E}-02$ & 0.46 & 2. $27 E-02$ & 0.62 \\
\hline 14 & $3 \cdot 44$ & 5. $38 \mathrm{E}-02$ & 0.43 & $2.85 E-02$ & 0.57 \\
\hline 15 & 3.69 & $6.69 E-02$ & 0.40 & $3.40 \mathrm{E}-02$ & 0.52 \\
\hline 16 & 3.94 & 7. $79 \mathrm{E}-02$ & 0.38 & $3.97 \mathrm{E}-02$ & 0.50 \\
\hline 17 & $4 \cdot 18$ & 8. $69 \mathrm{E}-02$ & 0.37 & $4.84 E-02$ & 0.46 \\
\hline 18 & $4 \cdot 43$ & $1.00 \mathrm{E}-01$ & $0 \cdot 36$ & $5.60 E-02$ & 0.44 \\
\hline 19 & $4 \cdot 67$ & $1.05 E-01$ & 0.37 & $6 \cdot 30 \mathrm{E}-02$ & 0.42 \\
\hline 20 & 4.92 & $1.01 E-01$ & 0.39 & $6.88 E-02$ & 0.42 \\
\hline 21 & 5. 17 & 8. $43 E-02$ & 0.48 & $7 \cdot 77 \mathrm{E}-02$ & 0.40 \\
\hline 22 & $5 \cdot 41$ & $5 \cdot 26 E-02$ & 0.72 & $7 \cdot 21 E-02$ & 0.82 \\
\hline 23 & $5 \cdot 66$ & $3 \cdot 15 \mathrm{E}-02$ & 1.08 & $8.06 \mathrm{E}-02$ & 0.79 \\
\hline 24 & 5.90 & $1.39 \mathrm{E}-01$ & 0.60 & 7. $25 \mathrm{E}-02$ & 0.82 \\
\hline 25 & 6.15 & 1. $45 E-01$ & 0.59 & 7. $79 \mathrm{E}-02$ & 0.79 \\
\hline 26 & $6 \cdot 40$ & $1.58 \mathrm{E}-01$ & 0.57 & 8. $06 \mathrm{E}-02$ & 0.78 \\
\hline 27 & 6.64 & $1.67 \mathrm{E}-01$ & 0.56 & 8. 15E-02 & 0.78 \\
\hline 28 & 6.89 & $1.73 E-01$ & 0.55 & $9 \cdot 24 E-02$ & 0.72 \\
\hline 29 & 7. 13 & $1.90 E-01$ & 0.52 & $9.95 \mathrm{k}-02$ & 0.71 \\
\hline 30 & 7. 38 & $1.97 \mathrm{E}-01$ & 0.52 & $1.09 E-01$ & 0.68 \\
\hline 31 & $7 \cdot 62$ & $2.07 E-01$ & 0.51 & $1 \cdot 16 E-01$ & 0.66 \\
\hline 32 & $7 \cdot 87$ & 2. $08 E-01$ & 0.52 & $1.25 E-01$ & 0.64 \\
\hline 33 & $8 \cdot 12$ & 2. $18 \mathrm{E}-01$ & 0.50 & 1. $28 E-01$ & 0.63 \\
\hline 34 & $8 \cdot 36$ & $2.25 \mathrm{E}-01$ & 0.50 & 1. $42 E-01$ & 0.60 \\
\hline 35 & 8.61 & $2.31 \mathrm{E}-01$ & 0.50 & $1 \cdot 45 E-01$ & 0.60 \\
\hline 36 & 8.85 & 2. $14 \mathrm{E}-01$ & 0.51 & $1.59 \mathrm{E}-01$ & 0.58 \\
\hline 37 & 9.10 & $1.02 E-01$ & 0.58 & $1.77 \mathrm{E}-01$ & 0.55 \\
\hline 38 & 9.35 & $1.62 E-01$ & 0.57 & $1.73 \mathrm{E}-01$ & 0.56 \\
\hline 39 & 9.59 & $2.13 \mathrm{E}-01$ & 0.51 & 1. $72 E-01$ & 0.56 \\
\hline 40 & 9.84 & 2. $79 \mathrm{E}-0 \mathrm{l}$ & 0.46 & 1. $72 E-01$ & 0.56 \\
\hline 41 & 10.08 & 3. $39 \varepsilon-01$ & 0.43 & 1. $69 \mathrm{E}-01$ & 0.56 \\
\hline 42 & $10 \cdot 33$ & 2. $53 \mathrm{E}-01$ & 0.48 & $1.78 \mathrm{E}-01$ & 0.56 \\
\hline 43 & $10 \cdot 58$ & $1.81 \mathrm{E}-01$ & 0.55 & $2.00 E-01$ & 0.53 \\
\hline 44 & 10.82 & $1.79 E-0 i$ & 0.55 & $2.07 \mathrm{E}-01$ & 0.52 \\
\hline 45 & 11.07 & 2. $00 E-01$ & 0.53 & $2 \cdot 26 \mathrm{E}-01$ & 0.50 \\
\hline 46 & $11 \cdot 31$ & $1.81 \mathrm{E}-01$ & 0.56 & $2.36 \mathrm{E}-01$ & 0.50 \\
\hline 47 & 11.56 & 1. $37 \mathrm{E}-01$ & 0.62 & $2.51 E-01$ & 0.49 \\
\hline 48 & 11.81 & $1 \cdot 11 \mathrm{E}-01$ & 0.69 & 2. $63 E-01$ & 0.48 \\
\hline 49 & 12.05 & $1 \cdot 22 E-01$ & 0.66 & $2.85 t-01$ & 0.47 \\
\hline 50 & $12 \cdot 30$ & 1. $40 \mathrm{E}-01$ & 0.63 & $2.89 E-01$ & 0.46 \\
\hline 51 & $12 \cdot 54$ & $1.49 E-01$ & 0.61 & $2.77 E-01$ & 0.47 \\
\hline 52 & $12 \cdot 79$ & $1.47 \mathrm{E}-01$ & 0.61 & $2.75 E-01$ & 0.47 \\
\hline
\end{tabular}




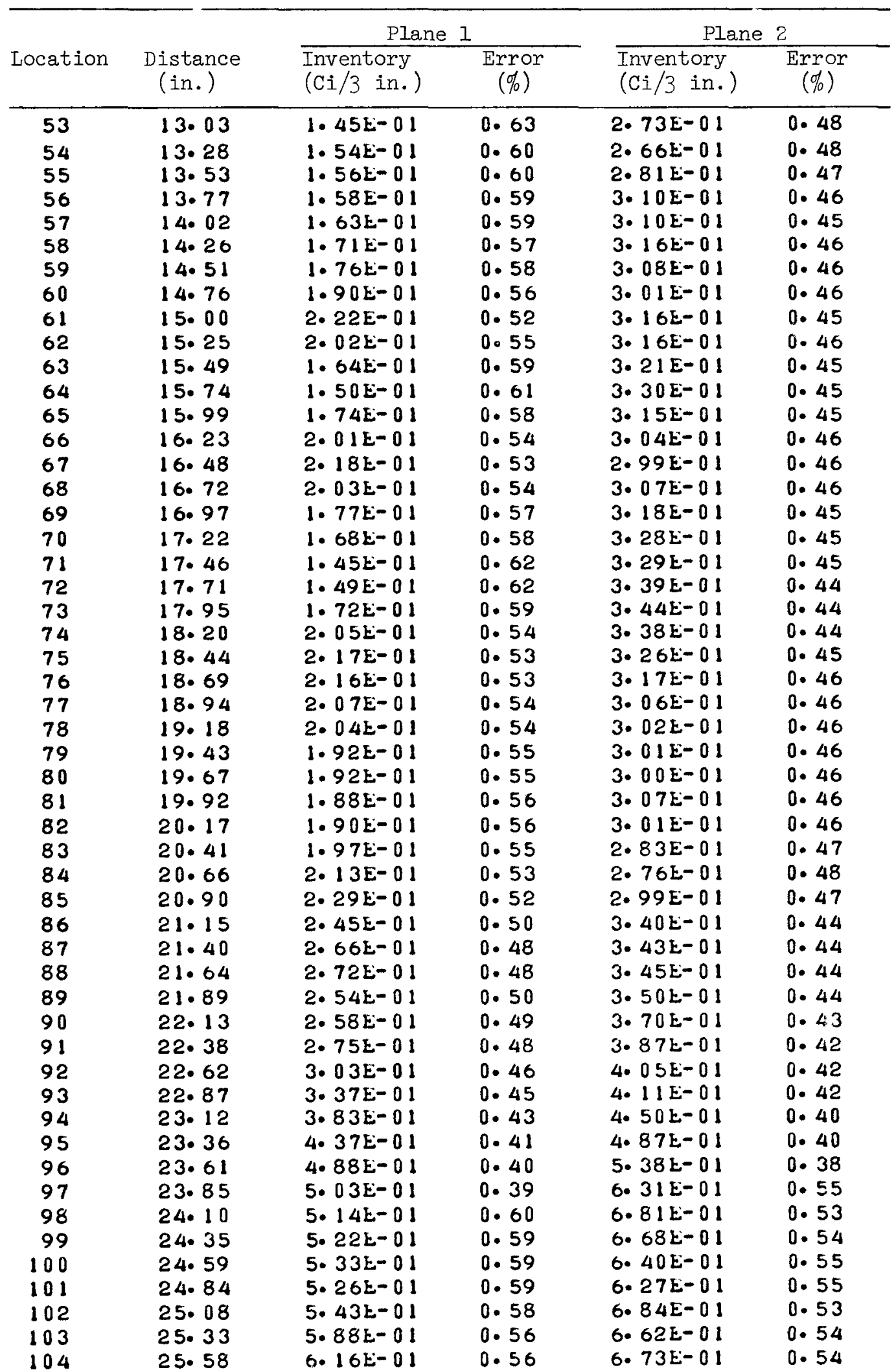


Table A-8 (continued)

\begin{tabular}{|c|c|c|c|c|c|}
\hline \multirow{2}{*}{ Location } & \multirow[b]{2}{*}{$\begin{array}{l}\text { Distance } \\
\text { (in.) }\end{array}$} & \multicolumn{2}{|c|}{ Plane $I$} & \multicolumn{2}{|c|}{ Plane 2} \\
\hline & & $\begin{array}{l}\text { Inventory } \\
\text { ( } \mathrm{Ci} / 3 \mathrm{in.} \text { ) }\end{array}$ & $\begin{array}{c}\text { Error } \\
(\%)\end{array}$ & $\begin{array}{l}\text { Inventory } \\
\text { ( } \mathrm{Ci} / 3 \text { in.) }\end{array}$ & $\begin{array}{c}\text { Error } \\
(\%)\end{array}$ \\
\hline 105 & 25.82 & $6.34 \mathrm{E}-01$ & 0.55 & $0.92 \mathrm{E}-01$ & 0.53 \\
\hline 106 & 26.07 & $6.51 \mathrm{~L}-01$ & 0.54 & $6.87 E-01$ & 0.53 \\
\hline 107 & 26.31 & $6.38 E-01$ & 0.55 & 6. $54 E-01$ & 0.54 \\
\hline 108 & 26.56 & $6 \cdot 18 t-01$ & 0.55 & $6.40 E-01$ & 0.55 \\
\hline 109 & 26.81 & $6.09 E-01$ & 0.55 & $0.22 E-01$ & 0.55 \\
\hline 110 & 27.05 & $5.83 E-01$ & 0.57 & 6. $34 \mathrm{E}-01$ & 0.54 \\
\hline 111 & $27 \cdot 30$ & $5.99 k-01$ & 0.56 & $6.22 E-01$ & 0.55 \\
\hline 112 & $27 \cdot 54$ & $6.46 E-01$ & 0.54 & $5.65 E-01$ & 0.58 \\
\hline 113 & 27.79 & $6.74 E-01$ & 0.53 & $5.57 \mathrm{E}-01$ & 0.58 \\
\hline 114 & 28.03 & $6.38 E-01$ & 0.54 & 5. $59 k-01$ & 0.58 \\
\hline 115 & 28.28 & $6.35 t-01$ & 0.55 & $5 \cdot 43 E-01$ & 0.58 \\
\hline 116 & 28.53 & $6.48 t-01$ & 0.54 & 5. $43 \mathrm{E}-01$ & 0.58 \\
\hline 117 & 28.77 & $6.90 \mathrm{E}-01$ & 0.53 & $5 \cdot 58 \varepsilon-01$ & 0.57 \\
\hline 118 & 29.02 & $7.05 t-01$ & 0.52 & $5 \cdot 77 \mathrm{E}-01$ & 0.57 \\
\hline 119 & 29.26 & $7.37 k-01$ & 0.51 & $0.04 E-01$ & 0.56 \\
\hline 120 & 29.51 & $7.64 t-01$ & 0.51 & $6.99 E-01$ & 0.53 \\
\hline 121 & 29.94 & $2.97 E+00$ & 0.32 & $2.06 \mathrm{E}+00$ & 0.35 \\
\hline 122 & $30 \cdot 19$ & $9.35 t-01$ & 0.47 & $1.01 \mathrm{E}+00$ & 0.46 \\
\hline 123 & 30.43 & $5.92 k-01$ & 0.57 & $8.35 E-01$ & 0.49 \\
\hline 124 & 30.68 & $5.02 E-01$ & 0.61 & $8.15 E-01$ & 0.50 \\
\hline 125 & 30.92 & $5.57 E-01$ & 0.58 & $8.71 E-01$ & 0.48 \\
\hline 126 & $31 \cdot 17$ & $6.67 E-01$ & 0.54 & $9.29 E-01$ & 0.47 \\
\hline 127 & 31.42 & $8.21 E-01$ & 0.49 & $9.65 \mathrm{k}-01$ & 0.46 \\
\hline 128 & 31.66 & $9.53 \mathrm{E}-01$ & 0.47 & $1.02 E+00$ & 0.46 \\
\hline 129 & 31.91 & $9.86 \mathrm{E}-01$ & 0.46 & $1.01 E+00$ & 0.46 \\
\hline 130 & $32 \cdot 15$ & $1.01 \mathrm{E}+00$ & 0.46 & $1.02 E+00$ & 0.46 \\
\hline 131 & 32.40 & $9.82 k-01$ & 0.48 & $9.84 \mathrm{E}-01$ & 0.46 \\
\hline 132 & 32.65 & $1.00 E+00$ & 0.46 & $9.10 E-01$ & 0.48 \\
\hline 133 & $32 \cdot 89$ & $1.04 \mathrm{E}+00$ & 0.45 & $8.83 E-01$ & 0.49 \\
\hline 134 & $33 \cdot 14$ & $9.37 t-01$ & 0.47 & $8.62 E-01$ & 0.49 \\
\hline 135 & $33 \cdot 38$ & $9.38 \mathrm{E}-01$ & 0.47 & $8.68 E-01$ & 0.49 \\
\hline 136 & 33.63 & $9.46 \mathrm{E}-01$ & 0.48 & $8.60 \mathrm{E}-0 \mathrm{I}$ & 0.49 \\
\hline 137 & 33.88 & $9.28 \mathrm{E}-01$ & 0.48 & $8.43 E-01$ & 0.49 \\
\hline 138 & $34 \cdot 12$ & $9.30 \mathrm{E}-01$ & 0.48 & $8.53 E-01$ & 0.49 \\
\hline 139 & $34 \cdot 37$ & $9.33 \mathrm{E}-01$ & 0.47 & $8 \cdot 31 \mathrm{E}-01$ & 0.50 \\
\hline 140 & 34.61 & $9.25 E-01$ & 0.48 & $8.39 E-01$ & 0.49 \\
\hline 141 & 34.86 & $9.20 E-01$ & 0.48 & $8.20 \mathrm{E}-01$ & 0.50 \\
\hline 142 & 35.11 & $8.90 E-01$ & 0.49 & $8.02 E-01$ & 0.51 \\
\hline 143 & $35 \cdot 35$ & $9.17 t-01$ & 0.48 & $8 \cdot 13 E-01$ & 0.50 \\
\hline 144 & 35.60 & $9.55 E-01$ & 0.47 & $8.69 \mathrm{E}-01$ & 0.49 \\
\hline 145 & 35.84 & $9.47 \mathrm{E}-01$ & 0.47 & $8.49 \mathrm{E}-01$ & 0.50 \\
\hline 146 & 36.09 & $9.35 E-01$ & 0.47 & $8.53 E-01$ & 0.49 \\
\hline 147 & $36 \cdot 33$ & $9.17 E-01$ & 0.48 & 8. $51 t-0 \mid$ & 0.50 \\
\hline 148 & 36.58 & $9.25 E-01$ & 0.48 & $8 \cdot 33 \mathrm{k}-01$ & 0.50 \\
\hline 149 & 36.83 & $8.69 \mathrm{E}-01$ & 0.49 & 7. $88 \mathrm{E}-01$ & 0.51 \\
\hline 150 & 37.07 & $8.15 E-01$ & 0.50 & $7 \cdot 53 E-01$ & 0.52 \\
\hline 151 & $37 \cdot 32$ & $7.88 E-01$ & 0.51 & $7 \cdot 24 \mathrm{E}-01$ & 0.53 \\
\hline 152 & 37.56 & $8.17 E-01$ & 0.50 & $7.29 E-01$ & 0.52 \\
\hline 153 & 37.81 & $8.60 E-01$ & 0.49 & 7. $13 \mathrm{E}-01$ & 0.53 \\
\hline 154 & 38.06 & $8.58 E-01$ & 0.49 & $6.88 E-01$ & 0.54 \\
\hline 155 & $38 \cdot 30$ & $7.64 E-01$ & 0.51 & $6.64 t-01$ & 0.55 \\
\hline 156 & 38.55 & $7.60 k-01$ & 0.52 & $6.63 E-01$ & 0.55 \\
\hline
\end{tabular}




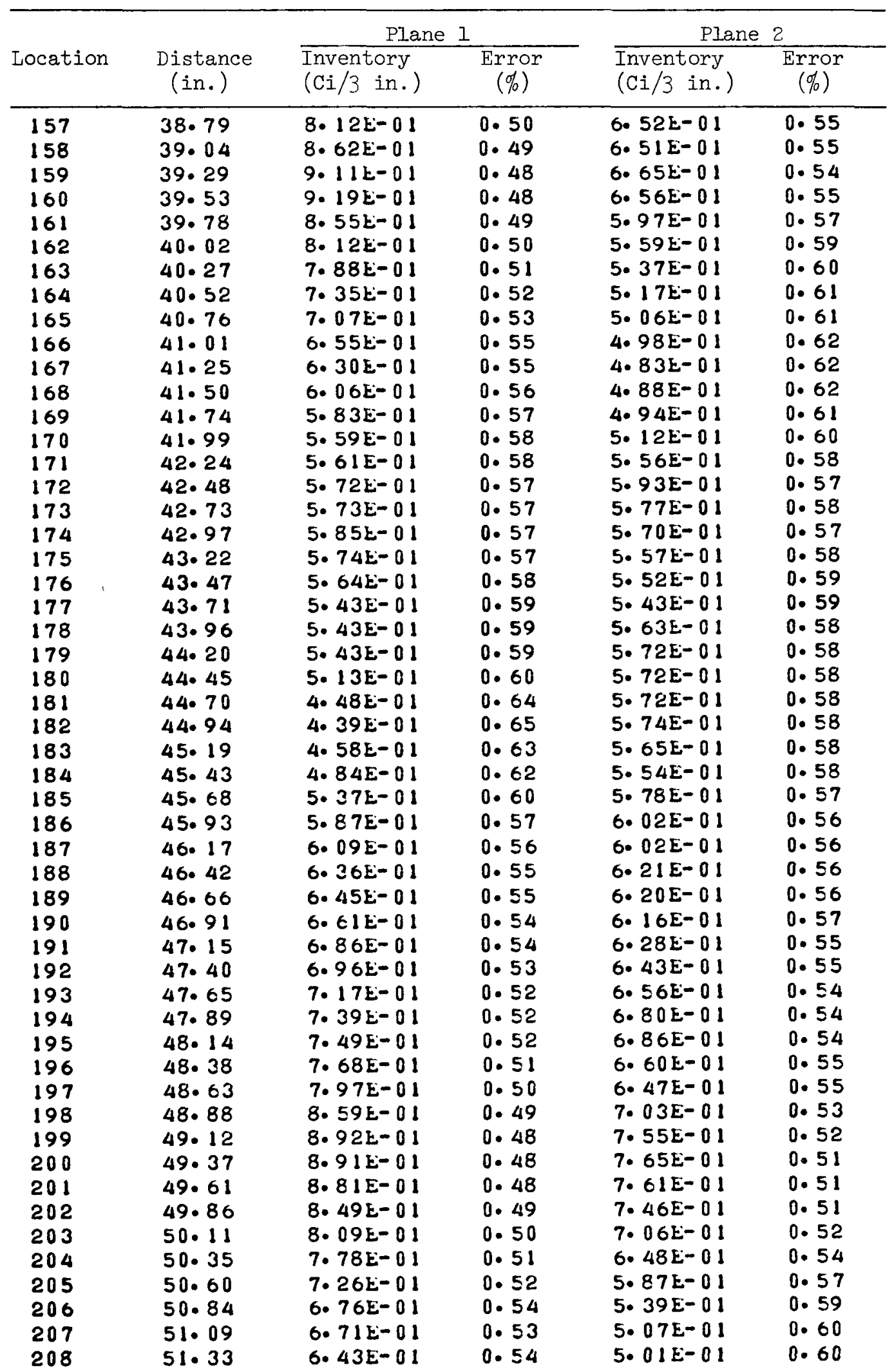


Table A-8 (continued)

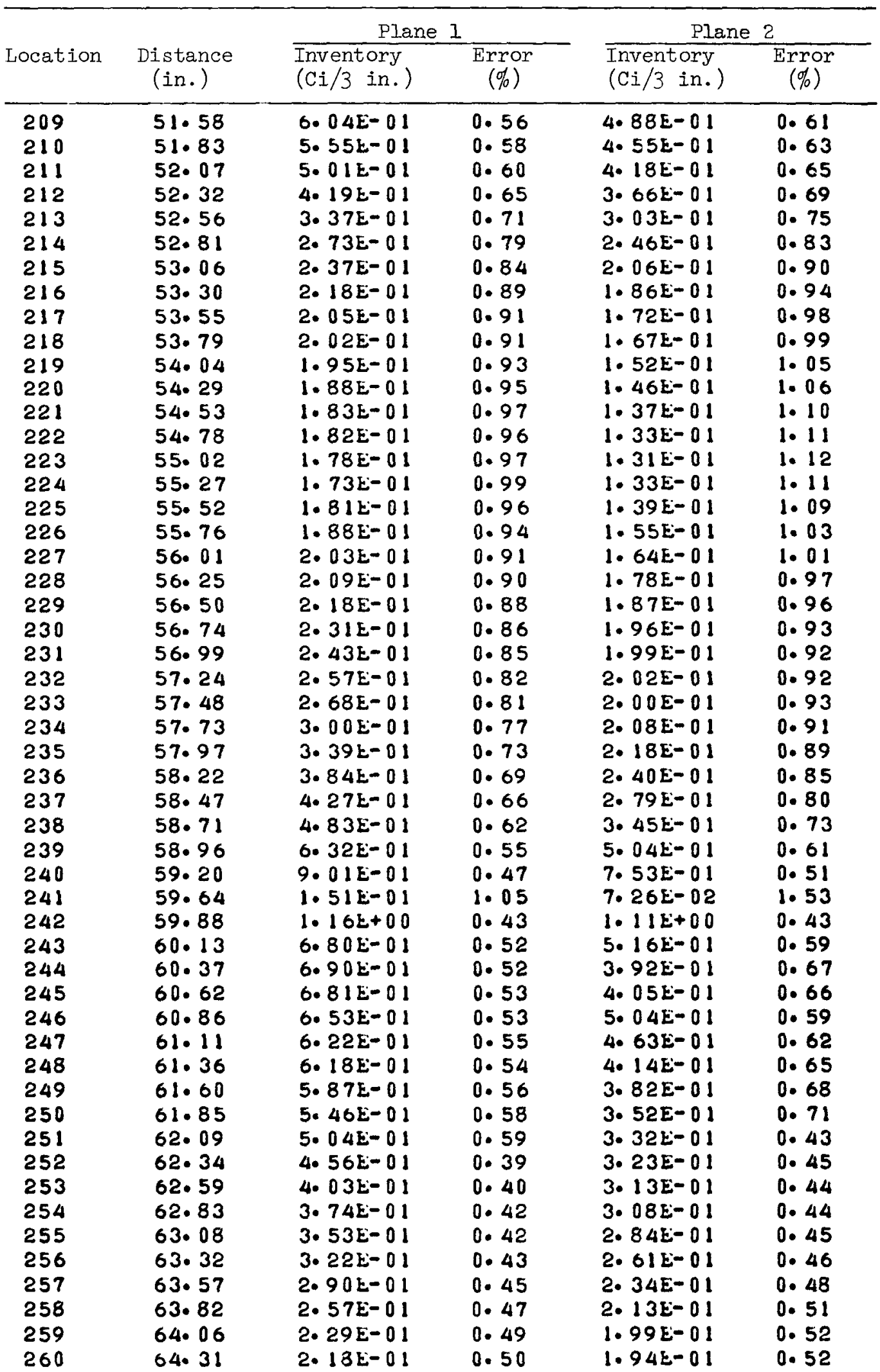


Table A-8 (continued)

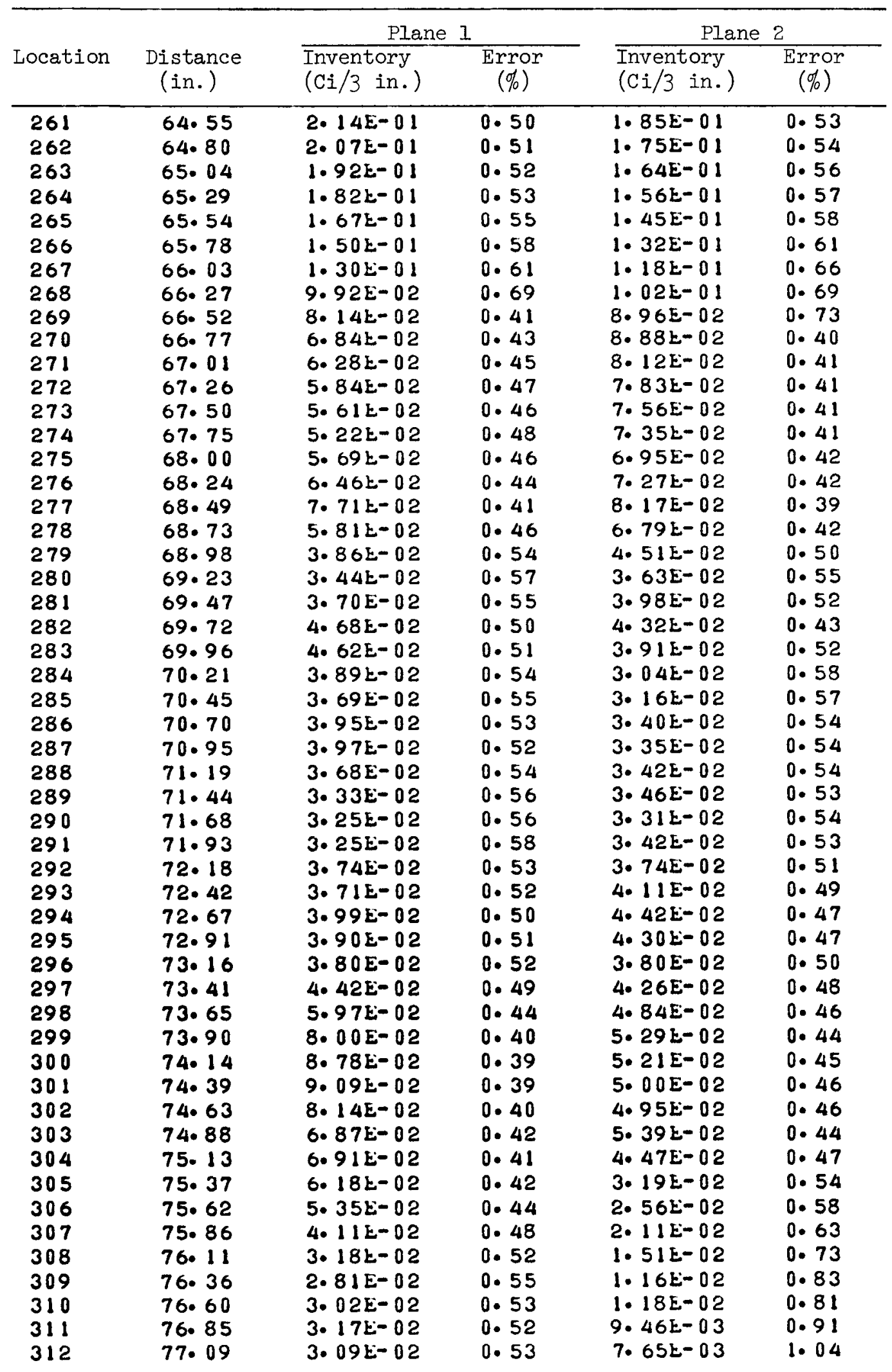


206

Table A-8 (continued)

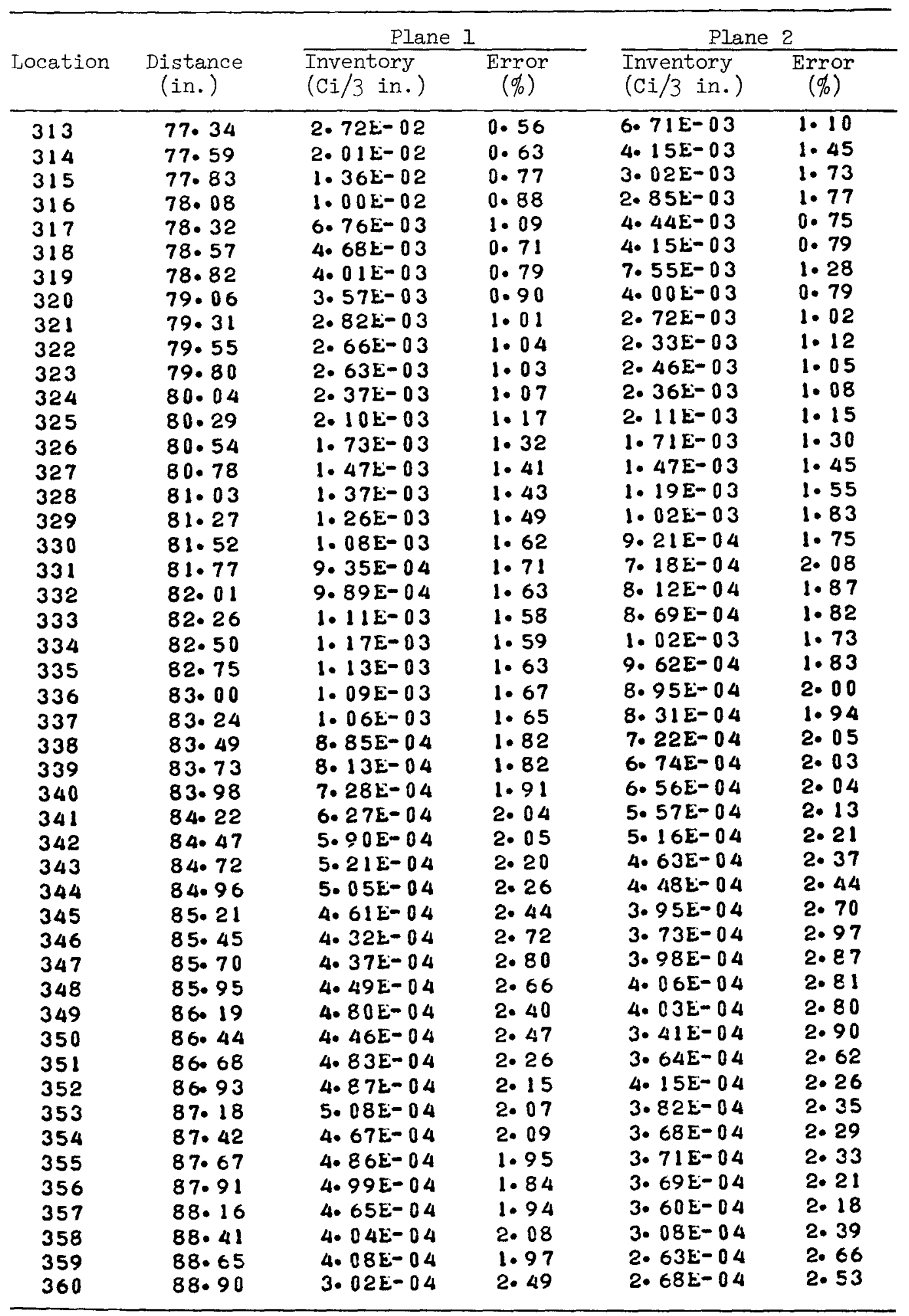


Table A-9. Axial distribution of ${ }^{144} \mathrm{Ce}$ in the sleeve of element FO3-O1 (corrected to October 31, 1974)

\begin{tabular}{|c|c|c|c|c|c|}
\hline \multirow{2}{*}{ Location } & \multirow[b]{2}{*}{$\begin{array}{l}\text { Distance } \\
\text { (in.) }\end{array}$} & \multicolumn{2}{|c|}{ Plane 1} & \multicolumn{2}{|c|}{ Plane 2} \\
\hline & & $\begin{array}{l}\text { Inventory } \\
(\mathrm{Ci} / 3 \text { in. })\end{array}$ & $\begin{array}{c}\text { Error } \\
(\%)\end{array}$ & $\begin{array}{l}\text { Inventory } \\
\text { ( } \mathrm{Ci} / 3 \text { in.) }\end{array}$ & $\begin{array}{c}\text { Error } \\
(\%)\end{array}$ \\
\hline 1 & 0.25 & $5.27 \mathrm{E}-02$ & 1.00 & $9.07 \mathrm{E}-02$ & $0 . \overline{69}$ \\
\hline 2 & 0.49 & $6.41 E-03$ & 5.08 & $9.75 \mathrm{E}-03$ & 3.66 \\
\hline 3 & 0.74 & $4.86 E-03$ & 6.73 & $7.91 E-03$ & 4.24 \\
\hline 4 & 0.99 & $8.86 \mathrm{E}-03$ & 4.08 & $8.88 E-03$ & 4.00 \\
\hline 5 & 1.23 & $1.26 E-02$ & 3.03 & $1.18 E-02$ & 3. 49 \\
\hline 6 & 1.48 & 1. $32 \mathrm{E}-02$ & 2.87 & 1. $62 \mathrm{E}-02$ & 2. 49 \\
\hline 7 & 1.72 & 1. $53 E-02$ & 2.81 & $1.70 E-02$ & 2.41 \\
\hline 8 & 1.97 & $1.53 \mathrm{E}-02$ & 2.70 & $1.43 E-02$ & 3. 32 \\
\hline 9 & $2 \cdot 22$ & $1.22 E-02$ & 3.21 & $1.31 E-02$ & 3.10 \\
\hline 10 & 2.46 & $8.95 E-03$ & 4. 51 & $9.18 E-03$ & 4.08 \\
\hline 11 & 2.71 & $7.25 E-03$ & 5. 43 & $1.08 E-02$ & 3.90 \\
\hline 12 & 2.95 & $6.21 E-03$ & $6 \cdot 33$ & $6.45 E-03$ & $6 \cdot 18$ \\
\hline 13 & 3.20 & $7.46 E-03$ & $5 \cdot 71$ & $1.98 E-03$ & 24.49 \\
\hline 14 & 3.44 & $6.69 E-03$ & $5 \cdot 76$ & 5. $14 E-03$ & 7. 47 \\
\hline 15 & 3.69 & $5.69 E-03$ & 6.87 & 5. $52 \mathrm{E}-03$ & 7. 50 \\
\hline 16 & 3.94 & $5 \cdot 72 E-03$ & 7.04 & $6.45 E-03$ & $6 \cdot 31$ \\
\hline 17 & $4 \cdot 18$ & $6.26 \mathrm{E}-03$ & 6.68 & $8 \cdot 13 E-03$ & 5.43 \\
\hline 18 & 4. 43 & $6.70 \mathrm{E}-03$ & $7 \cdot 13$ & $8.45 E-03$ & 5.14 \\
\hline 19 & 4. 67 & 1. $11 \mathrm{E}-02$ & 4.27 & $1.05 E-02$ & 4.49 \\
\hline 20 & 4.92 & $1.14 \mathrm{E}-02$ & $4 \cdot 33$ & $1.16 \mathrm{E}-02$ & 4.21 \\
\hline 21 & 5. 17 & 1. $29 E-02$ & 4.02 & 1. $15 E-02$ & $4 \cdot 42$ \\
\hline 22 & 5.41 & $1.36 \mathrm{E}-02$ & 5.04 & $1.19 \mathrm{E}-02$ & $4 \cdot 58$ \\
\hline 23 & 5. 66 & $1.08 E-02$ & 8.66 & $1.51 E-02$ & 453 \\
\hline 24 & 5.90 & $7.42 \mathrm{E}-03$ & 18.35 & $9.11 \mathrm{E}-03$ & $8 \cdot 14$ \\
\hline 25 & 6.15 & $6.88 \mathrm{E}-03$ & 15.93 & $6.90 \mathrm{E}-03$ & 9.19 \\
\hline 26 & $6 \cdot 40$ & $7.98 E-03$ & 9.33 & $6.20 E-03$ & $8 \cdot 37$ \\
\hline 27 & 6.64 & $6.06 E-03$ & 11.74 & 3. $75 \mathrm{E}-03$ & 13.00 \\
\hline 28 & 6.89 & $2.92 E-03$ & 18.04 & $4.24 \mathrm{E}-03$ & 12.55 \\
\hline 29 & 7. 13 & 4. $88 k-03$ & 11.93 & $7.70 E-03$ & 7. 70 \\
\hline 30 & 7.38 & $7.51 \mathrm{E}-03$ & 8.22 & $1.09 \mathrm{E}-02$ & $5 \cdot 65$ \\
\hline 31 & 7.62 & $8.56 \mathrm{E}-03$ & 7.90 & $1.12 E-02$ & 5.99 \\
\hline 32 & 7.87 & $6.21 E-03$ & 10.55 & $9.26 \mathrm{E}-03$ & 7.06 \\
\hline 33 & $8 \cdot 12$ & $1.04 \mathrm{E}-02$ & $8 \cdot 62$ & $9.30 E-03$ & 8.02 \\
\hline 34 & $8 \cdot 36$ & $1.13 E-02$ & 9.12 & $7.95 \mathrm{E}-03$ & 8.87 \\
\hline 35 & 8.61 & $1.20 \mathrm{E}-02$ & 13.01 & $5.21 E-03$ & 17.00 \\
\hline 36 & 8.85 & $2.45 \mathrm{E}-02$ & $16 \cdot 17$ & $1.18 k-02$ & 13.51 \\
\hline 37 & 9.10 & $2.27 E-02$ & 19.01 & 1. $44 \mathrm{E}-02$ & $22 \cdot 94$ \\
\hline 38 & $9 \cdot 35$ & $1.91 \mathrm{E}-02$ & $17 \cdot 24$ & 4. $24 \mathrm{E}-03$ & 38.35 \\
\hline 39 & 9.59 & $7.11 \mathrm{E}-03$ & $36 \cdot 71$ & 4. $74 \mathrm{k}-03$ & **** \\
\hline 40 & 9.84 & 1. 19 L- 02 & $21 \cdot 12$ & $1.04 \mathrm{E}-02$ & $22 \cdot 17$ \\
\hline 41 & 10.08 & $9.90 E-03$ & $25 \cdot 50$ & $5.89 E-03$ & 39.97 \\
\hline 42 & 10.33 & 5. $40 \mathrm{E}-03$ & $* * * *$ & $4.94 \mathrm{E}-03$ & **** \\
\hline 43 & 10.58 & $1.16 \mathrm{E}-02$ & $22 \cdot 12$ & $5.05 E-03$ & $* * * *$ \\
\hline 44 & 10.82 & $1.42 E-02$ & 18.61 & 1. $41 E-02$ & 17.95 \\
\hline 45 & 11.07 & 1. $52 E-02$ & 17.81 & $8.68 \mathrm{E}-03$ & 30.26 \\
\hline 46 & 11.31 & $1.97 \mathrm{E}-02$ & $14 \cdot 42$ & 1. $40 E-02$ & 19.50 \\
\hline 47 & 11.56 & $1.91 \mathrm{E}-02$ & $15 \cdot 68$ & $5.83 E-03$ & $34 \cdot 78$ \\
\hline 48 & 11.81 & $1.09 E-02$ & 21.50 & $6.19 E-03$ & *** \\
\hline 49 & 12.05 & $1.97 E-02$ & $18 \cdot 17$ & $1.92 E-02$ & 16.86 \\
\hline 50 & 12.30 & $1.92 \mathrm{E}-02$ & 18.87 & 1. $20 E-02$ & $22 \cdot 73$ \\
\hline 51 & 12.54 & 2. $39 E-02$ & 15.02 & $1.93 \mathrm{E}-02$ & 12.83 \\
\hline 52 & 12.79 & 8. $37 E-03$ & $31 \cdot 82$ & $1.62 \mathrm{E}-02$ & 15.85 \\
\hline
\end{tabular}




\begin{tabular}{|c|c|c|c|c|c|}
\hline \multirow[b]{2}{*}{ Location } & \multirow[b]{2}{*}{$\begin{array}{l}\text { Distance } \\
\text { (in.) }\end{array}$} & \multicolumn{2}{|c|}{ Plane 1} & \multicolumn{2}{|c|}{ Plane 2} \\
\hline & & $\begin{array}{l}\text { Inventory } \\
\text { (Ci/3 in.) }\end{array}$ & $\begin{array}{c}\text { Error } \\
(\%)\end{array}$ & $\begin{array}{l}\text { Inventory } \\
\text { (Ci/3 in.) }\end{array}$ & $\begin{array}{c}\text { Error } \\
(\%)\end{array}$ \\
\hline 53 & 13.03 & 2. $09 E-02$ & $18 \cdot 36$ & 1. $20 E-02$ & 20.63 \\
\hline 54 & 13.28 & $3.31 E-02$ & 12.04 & $1.57 E-02$ & $17 \cdot 42$ \\
\hline 55 & $13 \cdot 53$ & $2.95 \mathrm{E}-02$ & $14 \cdot 17$ & 2. $53 \mathrm{E}-02$ & 14.71 \\
\hline 56 & 13.77 & $2 \cdot 71 \mathrm{E}-02$ & 16.04 & $1.81 E-02$ & 21.17 \\
\hline 57 & 14.02 & $2.59 E-02$ & 17.25 & $8.07 E-03$ & \\
\hline 58 & 14.26 & $2.83 \mathrm{E}-02$ & 15.92 & $2.85 E-02$ & 14.13 \\
\hline 59 & 14.51 & $2.05 \mathrm{E}-02$ & $22 \cdot 55$ & $2 \cdot 16 \mathrm{E}-02$ & 19.35 \\
\hline 60 & $14 \cdot 76$ & 2. $79 E-02$ & $17 \cdot 30$ & $1.45 E-02$ & 28.82 \\
\hline 61 & 15.00 & $2 \cdot 29 E-02$ & $22 \cdot 82$ & $1.29 E-02$ & $27 \cdot 52$ \\
\hline 62 & $15 \cdot 25$ & $3.76 \mathrm{E}-02$ & 14.00 & $1.01 E-02$ & **** \\
\hline 63 & 15. 49 & $3.36 \mathrm{E}-02$ & $15 \cdot 72$ & $1.68 E-02$ & $22 \cdot 38$ \\
\hline 64 & $15 \cdot 74$ & $2.48 E-02$ & $22 \cdot 68$ & 3. $15 E-02$ & 16061 \\
\hline 55 & 15.99 & $3 \cdot 33 E-02$ & 17.64 & 2. $12 E-02$ & 25.58 \\
\hline 66 & $16 \cdot 23$ & $2 \cdot 36 E-02$ & $26 \cdot 16$ & $1.15 E-02$ & **** \\
\hline 67 & $16 \cdot 48$ & 3. $94 \mathrm{E}-02$ & 16.40 & $1.20 E-02$ & $* * * *$ \\
\hline 68 & $16 \cdot 72$ & 3. $67 \mathrm{E}-02$ & 18.53 & 4. $11 E-02$ & 14.88 \\
\hline 69 & $16 \cdot 97$ & 4. $06 E-02$ & 17.57 & 5. $17 \mathrm{E}-02$ & 12.34 \\
\hline 70 & $17 \cdot 22$ & $5 \cdot 42 E-02$ & 29.85 & $1.39 E-02$ & $* * * *$ \\
\hline 71 & $17 \cdot 46$ & 4. $57 \mathrm{E}-02$ & 37.10 & 1. $49 E-02$ & **** \\
\hline 72 & $17 \cdot 7 !$ & 3. $79 \mathrm{E}-02$ & $* * * *$ & $3 \cdot 43 E-02$ & **** \\
\hline 73 & 17.95 & $1.03 E-01$ & 17.91 & $5 \cdot 62 E-02$ & 31.25 \\
\hline 74 & $18 \cdot 20$ & 4. $30 \mathrm{E}-02$ & $* * * *$ & $7.67 E-02$ & 25.50 \\
\hline 75 & $18 \cdot 44$ & $5 \cdot 69 E-02$ & $33 \cdot 14$ & $6.91 E-02$ & $27 \cdot 47$ \\
\hline 76 & 18.69 & $6 \cdot 42 E-02$ & $30 \cdot 31$ & 4. $07 E-02$ & $* * * *$ \\
\hline 77 & 18.94 & $6.06 E-02$ & 33.09 & 6. $35 E-02$ & $32 \cdot 18$ \\
\hline 78 & $19 \cdot 18$ & $4.38 E-02$ & **** & 7. $26 \mathrm{E}-02$ & 29.21 \\
\hline 79 & $19 \cdot 43$ & $7 \cdot 96 \mathrm{E}-02$ & 26.94 & $8.03 E-02$ & 27.21 \\
\hline 80 & 19.67 & $1 \cdot 15 E-01$ & 19.20 & $1.04 E-01$ & 21.54 \\
\hline 81 & 19.92 & 4. $85 E-02$ & $* * *$ & $6.31 \mathrm{E}-02$ & 37.33 \\
\hline 82 & $20 \cdot 17$ & $7 \cdot 52 E-02$ & $31 \cdot 26$ & $5.00 E-02$ & ***** \\
\hline 83 & $20 \cdot 41$ & $8.85 E-02$ & $27 \cdot 74$ & $1.05 E-01$ & 24.20 \\
\hline 84 & $20 \cdot 66$ & $1.35 E-01$ & $18 \cdot 78$ & $9 \cdot 77 E-02$ & 27.04 \\
\hline 85 & 20.90 & $9.00 E-02$ & 29.63 & $9.10 E-02$ & $31 \cdot 14$ \\
\hline 86 & $21 \cdot 15$ & $6.10 E-02$ & **** & $7.07 E-02$ & **** \\
\hline 87 & $21 \cdot 40$ & $1.21 E-01$ & 23.43 & $7.37 E-02$ & $* * *$ \\
\hline 88 & $21 \cdot 64$ & $7.84 E-02$ & 36.03 & 7. $67 E-02$ & $* * *$ \\
\hline 89 & 21.89 & $6.27 E-02$ & $* * * *$ & $2.01 E-01$ & 18.94 \\
\hline 90 & $22 \cdot 13$ & 6. $69 E-02$ & $* * * *$ & 8. $39 E-02$ & $* * * *$ \\
\hline 91 & $22 \cdot 38$ & $1 \cdot 18 E-01$ & $28 \cdot 29$ & 2. $24 \mathrm{E}-01$ & 31.21 \\
\hline 92 & $22 \cdot 62$ & $7 \cdot 66 E-02$ & *** & $1.51 E-01$ & *** \\
\hline 93 & $22: 87$ & 8. $27 E-02$ & $* * * *$ & 2. $59 \mathrm{E}-01$ & $30 \cdot 10$ \\
\hline 94 & $23 \cdot 12$ & $1.95 E-01$ & 21.87 & $1.73 E-01$ & **** \\
\hline 95 & $23 \cdot 36$ & $1.54 E-01$ & $* * * *$ & $1.81 E-01$ & $* * * *$ \\
\hline 96 & $23 \cdot 61$ & $1.65 E-01$ & $* * * *$ & 2. $28 E-01$ & 38.85 \\
\hline 97 & 23.85 & $1.78 E-01$ & $* * * *$ & 2. $41 E-01$ & 38.03 \\
\hline 98 & $24 \cdot 10$ & 2. $53 E-01$ & 36.09 & $2.07 E-01$ & $* * * *$ \\
\hline 99 & $24 \cdot 35$ & $2.06 E-01$ & $6 *$ & $4.89 E-01$ & 21.05 \\
\hline 100 & $24 \cdot 59$ & 4. $77 E-01$ & 19.53 & 2. $\mid 3 E-01$ & $* * *$ \\
\hline 101 & $24 \cdot 84$ & 4. $44 E-01$ & 21.05 & 3. $29 E-01$ & 30.30 \\
\hline 102 & $25 \cdot 08$ & 2. $48 E-01$ & 37.99 & 3. $78 E-01$ & $27 \cdot 15$ \\
\hline 103 & $25 \cdot 33$ & 2. $53 E-01$ & $37 \cdot 70$ & $2 \cdot 18 E-01$ & $* * * *$ \\
\hline 104 & $25 \cdot 58$ & 3. $70 E-01$ & $25 \cdot 61$ & 4. $45 E-01$ & 23.28 \\
\hline
\end{tabular}


Table A-9 (continued)

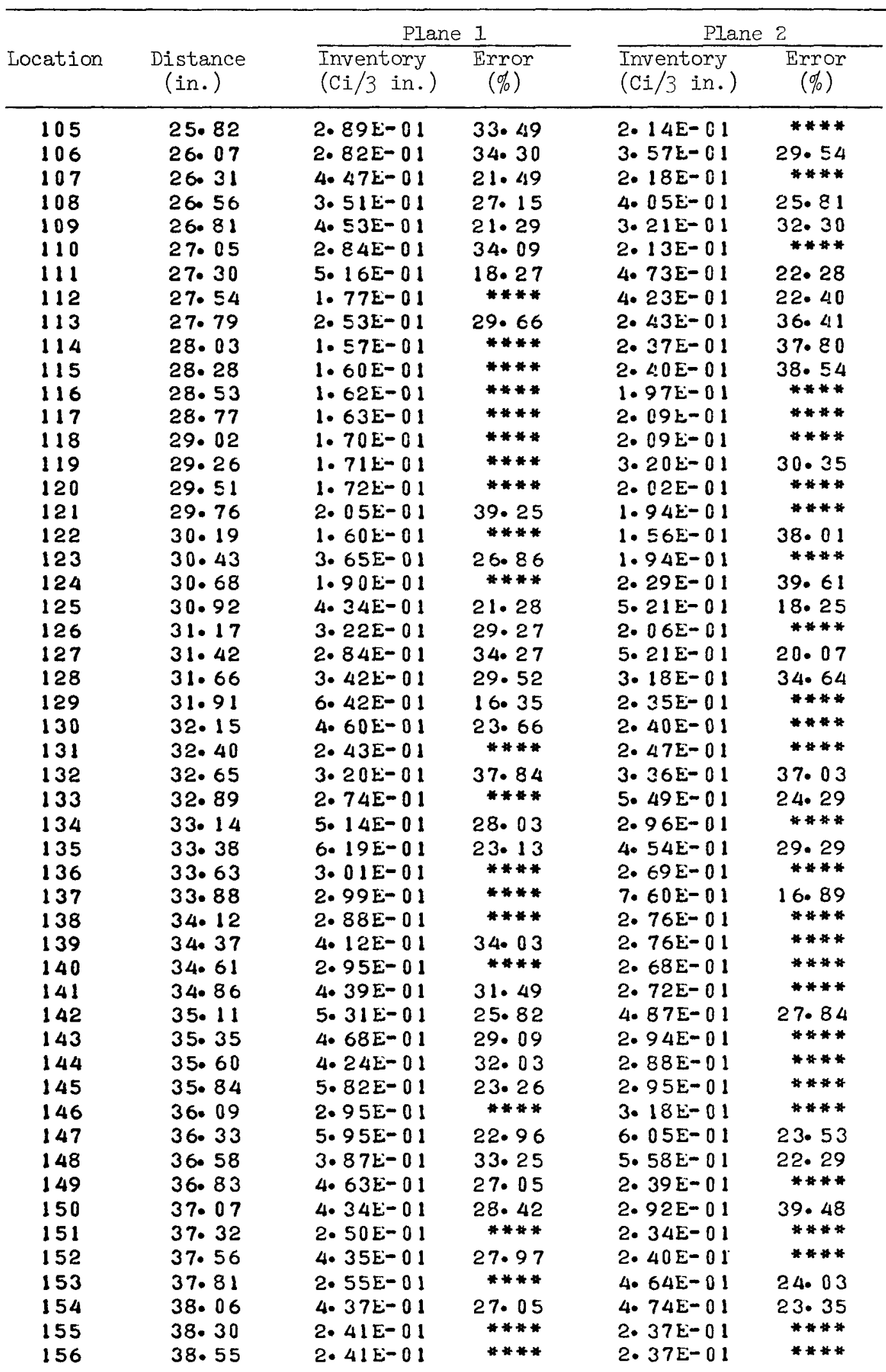




\begin{tabular}{|c|c|c|c|c|c|}
\hline \multirow[b]{2}{*}{ Location } & \multirow[b]{2}{*}{$\begin{array}{c}\text { Distance } \\
\text { (in.) }\end{array}$} & \multicolumn{2}{|c|}{ Plane 1} & \multicolumn{2}{|c|}{ Plane 2} \\
\hline & & $\begin{array}{l}\text { Inventory } \\
(\mathrm{Ci} / 3 \mathrm{in.})\end{array}$ & $\begin{array}{c}\text { Error } \\
(\%)\end{array}$ & $\begin{array}{l}\text { Inventory } \\
(\mathrm{Ci} / 3 \text { in. })\end{array}$ & $\begin{array}{c}\text { Error } \\
(\%)\end{array}$ \\
\hline 157 & $38 \cdot 79$ & $3.71 E-01$ & $31 \cdot 70$ & $2.37 E-01$ & $* * * *$ \\
\hline 158 & 39.04 & $2 \cdot 57 E-01$ & $* * *$ & 3. $48 E-01$ & $32 \cdot 37$ \\
\hline 159 & 39.29 & 4. $56 \mathrm{E}-01$ & $26 \cdot 53$ & $3 \cdot 13 \mathrm{E}-01$ & $36 \cdot 43$ \\
\hline 160 & 39.53 & $3.57 \mathrm{E}-0 \mathrm{l}$ & $32 \cdot 29$ & 4. $31 E-01$ & $26 \cdot 05$ \\
\hline 161 & 39.78 & $2.94 E-01$ & 37.92 & $2.21 \mathrm{E}-01$ & $* * * *$ \\
\hline 162 & 40.02 & $3.86 \mathrm{E}-01$ & $28 \cdot 50$ & $2 \cdot 24 E-01$ & $* * * *$ \\
\hline 163 & $40 \cdot 27$ & 4. $18 E-01$ & $26 \cdot 63$ & 3. $57 E-01$ & $29 \cdot 22$ \\
\hline 164 & $40 \cdot 52$ & $4.06 E-01$ & $27 \cdot 62$ & 4. $97 \mathrm{E}-01$ & 20.92 \\
\hline 165 & $40 \cdot 76$ & $2 \cdot 31 E-01$ & $* * * *$ & 2. $22 E-01$ & $* * * *$ \\
\hline 166 & 41.01 & $2 \cdot 31 \mathrm{E}-01$ & $* * * *$ & 2. $15 E-01$ & $* * * *$ \\
\hline 167 & $41 \cdot 25$ & 2. $39 \mathrm{E}-01$ & **** & $2 \cdot 23 \mathrm{E}-01$ & **** \\
\hline 168 & $41 \cdot 50$ & $3.35 E-01$ & 33.00 & 2. $24 \mathrm{E}-01$ & $* * * *$ \\
\hline 169 & $41 \cdot 74$ & $3.09 \mathrm{E}-01$ & $35 \cdot 23$ & $2.82 \mathrm{E}-01$ & $37 \cdot 53$ \\
\hline 170 & 41.99 & $2 \cdot 31 E-01$ & $* * * *$ & $2.97 \mathrm{E}-01$ & $37 \cdot 50$ \\
\hline 171 & $42 \cdot 24$ & 2. $97 E-01$ & 37.45 & $5.04 E-01$ & $24 \cdot 05$ \\
\hline 172 & $42 \cdot 48$ & 4. $83 E-01$ & $23 \cdot 60$ & 2. $69 \mathrm{E}-01$ & \#** \\
\hline 173 & $42 \cdot 73$ & 3. $24 t-01$ & $35 \cdot 76$ & 5. $02 E-01$ & $24 \cdot 07$ \\
\hline 174 & $42 \cdot 97$ & 3. $22 E-01$ & $36 \cdot 03$ & 2. $43 E-01$ & **** \\
\hline 175 & $43 \cdot 22$ & $4.90 \mathrm{E}-01$ & $23 \cdot 56$ & 2. $39 E-01$ & $* * * *$ \\
\hline 176 & $43 \cdot 47$ & 3. $34 E-01$ & $34 \cdot 38$ & 2. $50 \mathrm{E}-01$ & $* * *$ \\
\hline 177 & 43.71 & 3. $03 E-01$ & $37 \cdot 63$ & 5. $18 E-01$ & 22. 77 \\
\hline 178 & 43.96 & 2. $43 E-01$ & $* * * *$ & 2. $42 E-01$ & **** \\
\hline 179 & $44 \cdot 20$ & 2. $40 E-01$ & $* * * *$ & 2. $41 \mathrm{E}-01$ & $* * * *$ \\
\hline 180 & $44 \cdot 45$ & 2. $25 E-01$ & **** & $5.99 E-01$ & 19.88 \\
\hline 181 & $44 \cdot 70$ & $2 \cdot 25 \mathrm{E}-01$ & $* * * *$ & 2. $56 E-01$ & $* * * *$ \\
\hline 182 & $44 \cdot 94$ & 5. $02 E-01$ & $21 \cdot 74$ & 3. $43 E-01$ & $35 \cdot 47$ \\
\hline 183 & $45 \cdot 19$ & $4.85 E-01$ & $22 \cdot 99$ & 2. $62 E-01$ & $* * * *$ \\
\hline 184 & $45 \cdot 43$ & 4. $79 \mathrm{E}-01$ & 23.97 & 2. $74 E-01$ & $* * * *$ \\
\hline 185 & $45 \cdot 68$ & 2. $42 E-01$ & $* * * *$ & 2. $53 E-01$ & $t * * *$ \\
\hline 186 & $45 \cdot 93$ & 2. $51 \mathrm{E}-01$ & $* * * *$ & 3. $49 \mathrm{E}-01$ & $34 \cdot 18$ \\
\hline 187 & 46.17 & 5. $29 \mathrm{E}-01$ & $22 \cdot 45$ & 5. $56 E-01$ & $21 \cdot 16$ \\
\hline 188 & $46 \cdot 42$ & 4. $77 \mathrm{E}-01$ & $25 \cdot 44$ & $2.41 E-01$ & $* * *$ \\
\hline 189 & $46 \cdot 66$ & 2. $49 \mathrm{E}-01$ & $* * * *$ & 2. $48 \mathrm{t}-01$ & $* * * *$ \\
\hline 190 & 46.91 & 2. $51 E-01$ & $* * * *$ & 2. $47 E-01$ & $* * * *$ \\
\hline 191 & $47 \cdot 15$ & 5. $40 E-01$ & 22.86 & 4. $54 E-01$ & $25 \cdot 33$ \\
\hline 192 & $47 \cdot 40$ & $2 \cdot 65 \mathrm{E}-0 \mathrm{I}$ & **** & 2. $42 \mathrm{E}-01$ & $* * * *$ \\
\hline 193 & $47 \cdot 65$ & $6.60 \mathrm{k}-01$ & $18 \cdot 70$ & 2. $37 \mathrm{t}-01$ & $* * * *$ \\
\hline 194 & $47 \cdot 89$ & $1 \cdot 11 \mathrm{E}+00$ & $* * * *$ & 3. $23 E-01$ & $36 \cdot 28$ \\
\hline 195 & $48 \cdot 14$ & 4. $37 E-01$ & $28 \cdot 47$ & 4. $07 E-01$ & $29 \cdot 32$ \\
\hline 196 & $48 \cdot 38$ & $5 \cdot 28 E-01$ & $24 \cdot 13$ & $3.82 \mathrm{E}-01$ & $31 \cdot 89$ \\
\hline 197 & $48 \cdot 63$ & 2. $62 \mathrm{E}-01$ & **** & 2. $53 E-01$ & $* * * *$ \\
\hline 198 & $48 \cdot 88$ & 4. $63 \mathrm{E}-01$ & $28 \cdot 18$ & 2. $59 \mathrm{E}-01$ & $* * * *$ \\
\hline 199 & $49 \cdot 12$ & $3.98 \mathrm{E}-01$ & 32.91 & 8. $28 E-01$ & $15 \cdot 82$ \\
\hline 200 & $49 \cdot 37$ & 4. $11 \mathrm{E}-01$ & $33 \cdot 13$ & 4. $23 E-01$ & $32 \cdot 68$ \\
\hline 201 & 49.61 & $2.89 \varepsilon-01$ & $* * * *$ & $4.88 E-01$ & $29 \cdot 26$ \\
\hline 202 & 49.86 & $2.96 \mathrm{E}-01$ & $* * * *$ & 5. $66 E-01$ & $25 \cdot 37$ \\
\hline 203 & $50 \cdot 11$ & 3. $07 E-01$ & **** & $2.88 E-01$ & $* * * *$ \\
\hline 204 & $50 \cdot 35$ & $3.00 \mathrm{E}-01$ & $* * * *$ & $4.97 E-01$ & $27 \cdot 25$ \\
\hline 205 & $50 \cdot 60$ & 4. $52 \mathrm{E}-01$ & $30 \cdot 39$ & 4. $76 \mathrm{E}-01$ & $27 \cdot 08$ \\
\hline 206 & $50 \cdot 84$ & $3.81 E-01$ & $35 \cdot 33$ & 4. $26 \mathrm{E}-01$ & $29 \cdot 49$ \\
\hline $\begin{array}{l}207 \\
208\end{array}$ & $\begin{array}{l}51 \cdot 09 \\
51 \cdot 33\end{array}$ & $\begin{array}{l}\text { 4. } 07 \mathrm{E}-01 \\
\text { 4. } 60 \mathrm{E}-01\end{array}$ & $\begin{array}{l}32.00 \\
28.24\end{array}$ & $\begin{array}{l}\text { 3. } 69 \mathrm{E}-01 \\
2.74 E-01\end{array}$ & $\begin{array}{r}34.81 \\
* * * *\end{array}$ \\
\hline
\end{tabular}


Table A-9 (continued)

\begin{tabular}{|c|c|c|c|c|c|}
\hline \multirow[b]{2}{*}{ Location } & \multirow[b]{2}{*}{$\begin{array}{l}\text { Distance } \\
\text { (in.) }\end{array}$} & \multicolumn{2}{|c|}{ Plane 1} & \multicolumn{2}{|c|}{ Plane 2} \\
\hline & & $\begin{array}{l}\text { Inventory } \\
\text { ( } \mathrm{Ci} / 3 \text { in.) }\end{array}$ & $\begin{array}{l}\text { Error } \\
(\%)\end{array}$ & $\begin{array}{l}\text { Inventory } \\
\text { ( } \mathrm{Ci} / 3 \text { in. })\end{array}$ & $\begin{array}{l}\text { Error } \\
(\%)\end{array}$ \\
\hline 209 & 51.58 & $4 \cdot 38 \mathrm{E}-01$ & 30.25 & $5.29 \mathrm{E}-01$ & 26.03 \\
\hline 210 & 51.83 & 4. $17 E-01$ & $31 \cdot 14$ & $0.82 E-01$ & 20.82 \\
\hline 211 & 52.07 & $2.69 k-01$ & $* * *$ & 4. $40 \mathrm{E}-01$ & $33 \cdot 31$ \\
\hline 212 & 52.32 & $2.54 \mathrm{E}-01$ & $* * * *$ & 3. $20 \mathrm{E}-0 \mathrm{i}$ & $* * * *$ \\
\hline 213 & 52.56 & $6.25 E-01$ & $19 \cdot 38$ & $4.85 E-0 i$ & $31 \cdot 77$ \\
\hline 214 & 52.81 & $3.47 E-01$ & 34.83 & $5 \cdot 29 \mathrm{E}-0 \mathrm{i}$ & $29 \cdot 28$ \\
\hline 215 & 53.06 & 2. $55 t-01$ & \#*** & $4.86 t-01$ & $31 \cdot 32$ \\
\hline 216 & 53.30 & 3. $29 t-01$ & 35.65 & $3.00 \mathrm{E}-01$ & $\# * * *$ \\
\hline 217 & 53.55 & $2.38 t-01$ & $* * *$ & $2.93 E-01$ & **** \\
\hline 218 & 53.79 & $4.90 k-01$ & $23 \cdot 32$ & $2.85 E-01$ & **** \\
\hline 219 & 54.04 & $2.38 E-01$ & $* * * *$ & $2.84 \mathrm{E}-0 \mathrm{l}$ & $* * * *$ \\
\hline 220 & 54.29 & $2.34 \mathrm{E}-01$ & **** & $3.81 \mathrm{E}-01$ & 33.95 \\
\hline 221 & 54.53 & $2.27 t-01$ & **** & 2. $78 \mathrm{E}-01$ & $* * * *$ \\
\hline 222 & 54.78 & $3.605-01$ & 30.43 & 5. $53 E-01$ & $23 \cdot 54$ \\
\hline 223 & 55.02 & $2.85 \mathrm{k}-01$ & 37.26 & 2. $59 E-01$ & $* * * *$ \\
\hline 224 & 55.27 & $3.91 E-01$ & 26.66 & $5.36 \mathrm{E}-01$ & $22 \cdot 48$ \\
\hline 225 & $55 \cdot 52$ & 3. $31 E-01$ & $30 \cdot 30$ & 2. $50 \mathrm{E}-01$ & **** \\
\hline 226 & $55 \cdot 76$ & 3. $98 k-01$ & $24 \cdot 53$ & 3. $51 k-01$ & $32 \cdot 53$ \\
\hline 227 & 56.01 & $1.96 E-01$ & $* * *$ & $2 \cdot 36 \mathrm{E}-01$ & \#*** \\
\hline 228 & 56.25 & $1.99 \mathrm{E}-01$ & $* * * *$ & $2 \cdot 20 E-01$ & $* * * *$ \\
\hline 229 & 56.50 & 2. $41 E-01$ & 37.92 & $3.93 E-01$ & $26 \cdot 55$ \\
\hline 230 & $56 \cdot 74$ & $1.89 E-01$ & $* * * *$ & 2. $68 E-01$ & $38 \cdot 68$ \\
\hline 231 & 56.99 & $1.87 \mathrm{E}-01$ & **** & 2. $24 E-01$ & $* * * *$ \\
\hline 232 & $57 \cdot 24$ & $1.83 \mathrm{E}-01$ & $* * * *$ & $3.89 E-01$ & $28 \cdot 35$ \\
\hline 233 & $57 \cdot 48$ & $1.99 k-01$ & $* * * *$ & 2. $35 E-01$ & $\star * * *$ \\
\hline 234 & $57 \cdot 73$ & $2.51 \mathrm{k}-01$ & $39 \cdot 32$ & 3. $07 \mathrm{E}-01$ & 37.81 \\
\hline 235 & 57.97 & 2. $09 \mathrm{E}-01$ & $* * * *$ & 2. $57 E-01$ & $* * * *$ \\
\hline 236 & $58 \cdot 22$ & 2. $26 E-01$ & $* * * *$ & $3.97 \mathrm{E}-01$ & $31 \cdot 49$ \\
\hline 237 & $58 \cdot 47$ & $2.40 E-01$ & $* * * *$ & 2. $73 \mathrm{E}-01$ & $* * * *$ \\
\hline 238 & 58.71 & 2. $57 \mathrm{k}-01$ & **** & 2. $66 \mathrm{E}-01$ & $* * * *$ \\
\hline 239 & 58.96 & 2. $53 \mathrm{E}-01$ & $* * * *$ & $2.71 E-01$ & $* * * *$ \\
\hline 240 & $59 \cdot 20$ & 4. $14 E-01$ & $28 \cdot 26$ & $2.67 E-01$ & $* * * *$ \\
\hline 241 & $59 \cdot 45$ & $3.65 E-01$ & 33.10 & $2.61 \mathrm{E}-01$ & $* * * *$ \\
\hline 242 & 59.70 & $2.57 \mathrm{E}-01$ & $* * *$ & 4. $39 \mathrm{E}-01$ & $27 \cdot 72$ \\
\hline 243 & 59.94 & 4. $80 E-01$ & 25.93 & $3.65 E-01$ & $33 \cdot 34$ \\
\hline 244 & 60.37 & $1.60 E-01$ & $28 \cdot 66$ & $6.38 E-02$ & **** \\
\hline 245 & 60.62 & $1.89 E-B 1$ & $* * * *$ & $3.37 \mathrm{E}-01$ & 28.85 \\
\hline 246 & 60.86 & $1.91 \mathrm{E}-01$ & $* * * *$ & 4. $06 E-01$ & $25 \cdot 92$ \\
\hline 247 & $61 \cdot 11$ & 2. $72 \mathrm{E}-01$ & 37.65 & 2. $32 E-01$ & $* * *$ \\
\hline 248 & $61 \cdot 36$ & $2.27 E-01$ & $* * * *$ & $2.90 \mathrm{E}-01$ & $37 \cdot 23$ \\
\hline 249 & $61 \cdot 60$ & 3. $31 E-01$ & $32 \cdot 18$ & 4. $63 E-01$ & $22 \cdot 39$ \\
\hline 250 & $61 \cdot 85$ & $2.22 \mathrm{E}-01$ & $* * * *$ & 2. $05 \mathrm{E}-01$ & **** \\
\hline 251 & 62.09 & $2.02 E-01$ & $* * * *$ & 4. $85 E-01$ & $19 \cdot 73$ \\
\hline 252 & $62 \cdot 34$ & 2. $75 E-01$ & $34 \cdot 58$ & 4. $83 E-01$ & 18.92 \\
\hline 253 & $62 \cdot 59$ & $2.84 E-01$ & 32.26 & 2. $49 E-01$ & 35.50 \\
\hline 254 & 62.83 & $1.90 E-01$ & $* * * *$ & 1. $77 \mathrm{E}-01$ & $* * * *$ \\
\hline 255 & 63.08 & $2.31 \mathrm{E}-01$ & $37 \cdot 59$ & $1.74 E-01$ & **** \\
\hline 256 & 63.32 & 1. $75 \mathrm{E}-01$ & $* * * *$ & $2.83 E-01$ & 29.87 \\
\hline 257 & 63.57 & $1.77 \mathrm{~b}-01$ & **** & 1. $77 \mathrm{E}-01$ & $\# * * *$ \\
\hline 258 & 63.82 & $3.54 \mathrm{E}-01$ & 22.74 & 2. $57 \mathrm{E}-01$ & $32 \cdot 28$ \\
\hline 259 & 64.06 & $1.64 E-01$ & $* * * *$ & 1. $74 \mathrm{E}-01$ & $* * * *$ \\
\hline 260 & $64 \cdot 31$ & $2 \cdot 14 E-01$ & $36 \cdot 65$ & $1.62 E-01$ & $* * * *$ \\
\hline
\end{tabular}


Table A-9 (continued)

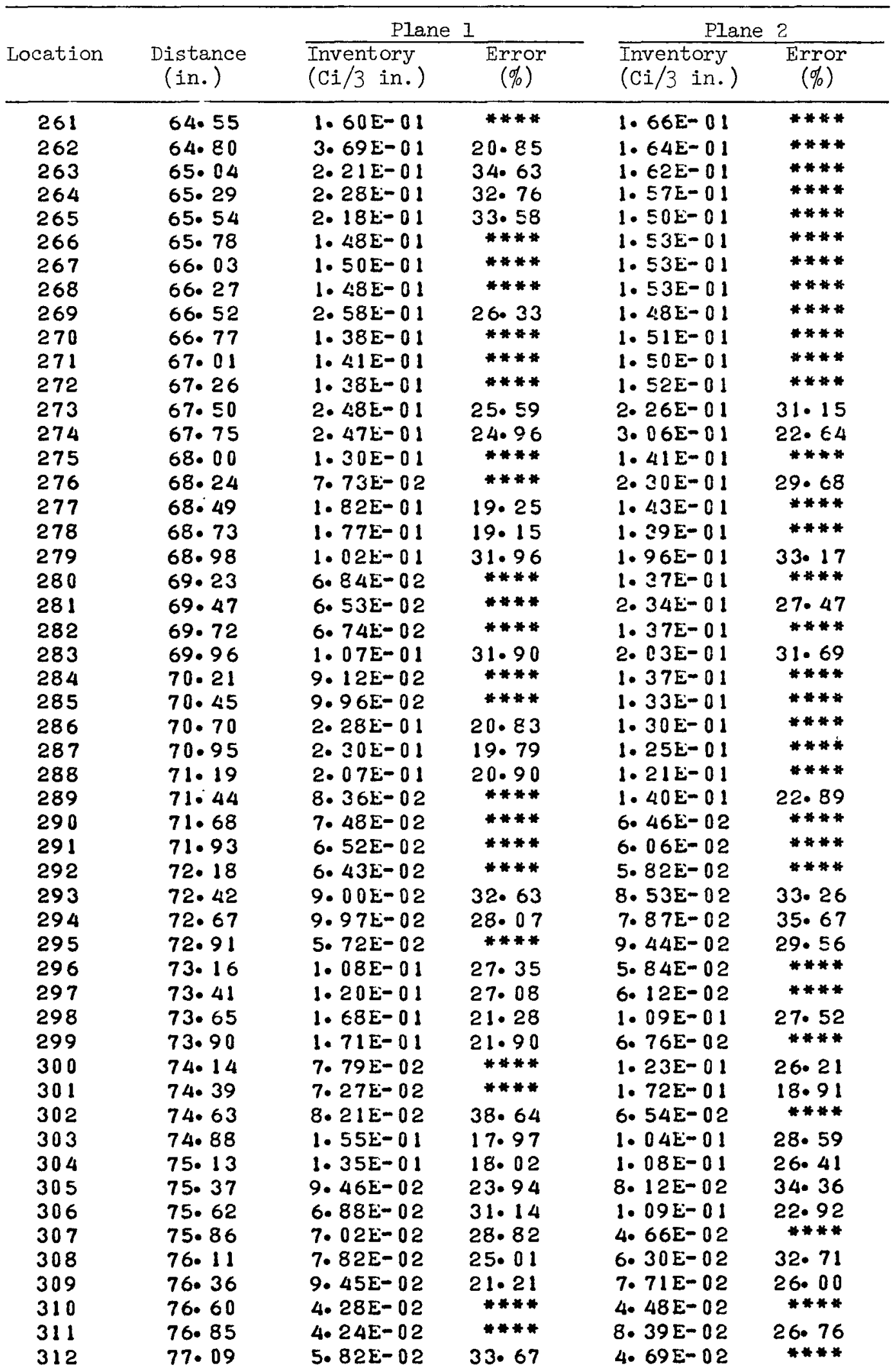


Table A-9 (continued)

\begin{tabular}{|c|c|c|c|c|c|}
\hline \multirow[b]{2}{*}{ Location } & \multirow[b]{2}{*}{$\begin{array}{l}\text { Distance } \\
\text { (in.) }\end{array}$} & \multicolumn{2}{|c|}{ Plane 1} & \multicolumn{2}{|c|}{ Plane 2} \\
\hline & & $\begin{array}{l}\text { Inventory } \\
\text { ( } \mathrm{Ci} / 3 \text { in.) }\end{array}$ & $\begin{array}{c}\text { Error } \\
(\%)\end{array}$ & $\begin{array}{l}\text { Inventory } \\
\text { ( } \mathrm{C} / \mathrm{3} \text { in.) }\end{array}$ & $\begin{array}{c}\text { Error } \\
(\%)\end{array}$ \\
\hline 313 & $77 \cdot 34$ & $3.89 k-02$ & $* * *$ & 4. $72 E-02$ & $* * * *$ \\
\hline $\begin{array}{l}314 \\
315\end{array}$ & $\begin{array}{l}77.59 \\
77.83\end{array}$ & $\begin{array}{l}\text { 6. } 12 E-02 \\
4.36 E-02\end{array}$ & $\begin{array}{l}27 \cdot 98 \\
37 \cdot 25\end{array}$ & $\begin{array}{l}6.08 E-02 \\
5.94 E-02\end{array}$ & $\begin{array}{l}34 \cdot 08 \\
31 \cdot 43\end{array}$ \\
\hline 316 & 78.08 & $6.08 E-02$ & $13 \cdot 89$ & $3.60 \mathrm{E}-02$ & **** \\
\hline 317 & $78 \cdot 32$ & 5. $77 \mathrm{E}-02$ & 13.73 & $4.91 \mathrm{E}-02$ & 32.01 \\
\hline 318 & 78.57 & 4. $66 \mathrm{E}-02$ & $16 \cdot 45$ & $6.19 \mathrm{E}-02$ & 12.23 \\
\hline 319 & 78.82 & 4. $09 \mathrm{E}-02$ & $14 \cdot 36$ & 4. $55 \mathrm{E}-02$ & $15 \cdot 92$ \\
\hline 320 & 79.06 & 1. $40 E-02$ & *** & $5.41 \mathrm{E}-02$ & 12.96 \\
\hline 321 & 79.31 & 1. $38 E-02$ & $* * *$ & $3.89 \mathrm{E}-02$ & 17.83 \\
\hline 322 & 79.55 & $3.28 \mathrm{E}-02$ & $18 \cdot 67$ & 1. $39 E-02$ & $* * * *$ \\
\hline 323 & 79.80 & 2. $52 \mathrm{E}-02$ & $21 \cdot 47$ & 3. $42 E-02$ & $13 \cdot 34$ \\
\hline 324 & 80.04 & 3. $01 E-02$ & 16.85 & 2. $35 \mathrm{E}-02$ & $24 \cdot 11$ \\
\hline 325 & 80.29 & $2.50 \mathrm{E}-02$ & $19 \cdot 38$ & $2.61 \mathrm{E}-02$ & 19.93 \\
\hline 326 & 80.54 & $9.62 E-03$ & $* * *$ & $1.38 \mathrm{E}-02$ & 35.06 \\
\hline 327 & 80.78 & 3. $62 \mathrm{E}-02$ & 9.53 & $9.15 t-03$ & $* * * *$ \\
\hline 328 & 81.03 & $4 \cdot 28 E-02$ & $8 \cdot 40$ & $9.19 E-03$ & 32.81 \\
\hline 329 & 81.27 & $3.38 \mathrm{E}-02$ & 9.74 & 1. $43 t-02$ & $24 \cdot 38$ \\
\hline 330 & 81.52 & $4.06 \mathrm{E}-02$ & $8 \cdot 40$ & 1. $13 \mathrm{k}-02$ & 25.06 \\
\hline 331 & 81.77 & $3.21 E-02$ & 9.62 & $9.83 E-03$ & 27.84 \\
\hline 332 & 82.01 & $3.42 E-02$ & 9.08 & $9.63 E-03$ & 27.45 \\
\hline 333 & 82.26 & $2.64 E-02$ & 10.91 & 1. $58 \mathrm{E}-02$ & 17.59 \\
\hline 334 & 82.50 & $3.46 \mathrm{E}-02$ & 9.75 & 1. $21 \mathrm{E}-02$ & 22.63 \\
\hline 335 & 82.75 & 3. $28 \mathrm{E}-02$ & 9.05 & 2. $16 E-02$ & 17.74 \\
\hline 336 & 83.00 & 3. $44 E-02$ & 9.05 & $1.30 E-02$ & 19.35 \\
\hline 337 & 83.24 & $2.72 \mathrm{E}-02$ & 8.81 & 1. $47 \mathrm{E}-02$ & $16 \cdot 13$ \\
\hline 338 & 83.49 & $2.45 \mathrm{E}-02$ & 9.16 & $9.71 E-03$ & $22 \cdot 59$ \\
\hline 339 & 83.73 & 5. $11 E-02$ & $4 \cdot 52$ & $1.01 \mathrm{E}-02$ & 20.96 \\
\hline 340 & 83.98 & $1.01 E-01$ & $2 \cdot 51$ & $1.418-02$ & 13.93 \\
\hline 341 & $84 \cdot 22$ & $2.77 \mathrm{E}-02$ & 4.11 & 1. $75 E-02$ & 5.80 \\
\hline 342 & $84 \cdot 47$ & $2.65 E-02$ & 3.86 & $1.57 \mathrm{E}-02$ & 5.81 \\
\hline 343 & $84 \cdot 72$ & $2.41 \mathrm{E}-02$ & 4.04 & 1. $33 E-02$ & 6.21 \\
\hline 344 & 84.96 & $2.43 E-02$ & 3.86 & $1 \cdot 45 E-02$ & 6.05 \\
\hline 345 & $85 \cdot 21$ & $2.76 E-02$ & $3 \cdot 45$ & 1. $79 E-02$ & $5 \cdot 62$ \\
\hline 346 & 85.45 & $2 \cdot 75 \mathrm{E}-02$ & 3. 38 & 1. $33 E-02$ & 6.00 \\
\hline 347 & 85.70 & $2.58 E-02$ & 3.47 & $1.47 \mathrm{E}-02$ & 6.32 \\
\hline 348 & 85.95 & $2.53 E-02$ & 3.38 & $1.82 \mathrm{E}-02$ & 4. 32 \\
\hline 349 & 86.19 & $2.25 E-02$ & 3.45 & $1.86 b-02$ & 4. 21 \\
\hline 350 & 86044 & $2 \cdot 15 \mathrm{E}-02$ & 3.51 & $1.60 \mathrm{E}-02$ & 4.89 \\
\hline 351 & 86.68 & 3. $41 E-02$ & 2.23 & $1 \cdot 33 \mathrm{E}-02$ & 4.91 \\
\hline 352 & 86.93 & 5. $58 \mathrm{E}-02$ & 1.47 & 1. $69 \mathrm{E}-02$ & 3.81 \\
\hline 353 & 87.18 & $1.70 \mathrm{E}-02$ & 4. 09 & 1. $76 \mathrm{E}-02$ & 3.75 \\
\hline 354 & 87.42 & 1. $60 \mathrm{E}-02$ & 4.01 & $1.93 \mathrm{E}-02$ & 3.20 \\
\hline 355 & 87.67 & 1. $89 \mathrm{E}-02$ & $3 \cdot 48$ & 1. $99 E-02$ & 3. 57 \\
\hline 356 & 87.91 & $1.87 E-02$ & 3.42 & $1.77 \mathrm{E}-02$ & 3.40 \\
\hline 357 & $88 \cdot 16$ & $2.16 \mathrm{E}-02$ & 2.89 & $1.60 \mathrm{E}-02$ & 3. 70 \\
\hline 358 & 88.41 & $2.29 E-02$ & 2.61 & $1.55 \mathrm{E}-02$ & 3.61 \\
\hline 359 & 88.65 & 2. $21 \mathrm{E}-02$ & 2. 78 & $1.63 E-02$ & 3.47 \\
\hline 360 & 88.90 & $1.84 \mathrm{E}-02$ & 3.06 & 2. $00 \mathrm{E}-02$ & 2.90 \\
\hline 361 & 89.14 & $1.69 \mathrm{E}-02$ & 3.21 & 2. $03 E-02$ & 2.82 \\
\hline 362 & 89.39 & $2.16 \mathrm{E}-02$ & $2 \cdot 64$ & $2.47 t-02$ & 2.40 \\
\hline 363 & 89.63 & $2.15 \mathrm{E}-02$ & $2 \cdot 67$ & $2.69 \mathrm{E}-02$ & $2 \cdot 51$ \\
\hline 364 & 89.88 & $2.26 E-02$ & 2.84 & $2.67 E-02$ & 2.27 \\
\hline
\end{tabular}


Table A-10. Axial distribution of ${ }^{144} \mathrm{Ce}$ in the spine of element F03-01

(corrected to October 31, 1974)

\begin{tabular}{|c|c|c|c|c|c|}
\hline \multirow[b]{2}{*}{ Location } & \multirow[b]{2}{*}{$\begin{array}{c}\text { Distance } \\
\text { (in.) }\end{array}$} & \multicolumn{2}{|c|}{ Plane 1} & \multicolumn{2}{|c|}{ Plane 2} \\
\hline & & $\begin{array}{l}\text { Inventory } \\
(\mathrm{C} i / 3 \text { in.) }\end{array}$ & $\begin{array}{c}\text { Error } \\
(\%)\end{array}$ & $\begin{array}{l}\text { Inventory } \\
\text { (Ci/3 in.) }\end{array}$ & $\begin{array}{c}\text { Error } \\
(\%)\end{array}$ \\
\hline 1 & 0.25 & $1.33 \mathrm{E}-02$ & $6 \cdot 45$ & $2.07 E-03$ & $* * * *$ \\
\hline 2 & 0.49 & $2.21 E-03$ & $* * *$ & $2.12 E-03$ & $* * * *$ \\
\hline 3 & 0.74 & $2 \cdot 28 E-03$ & $* * * *$ & $2 \cdot 24 E-03$ & $* * *$ \\
\hline 4 & 0.99 & $3.59 E-03$ & 30.94 & 2. $31 E-03$ & $* * * *$ \\
\hline 5 & $1 \cdot 23$ & 2. $48 \mathrm{E}-03$ & $* * * *$ & $2 \cdot 31 E-03$ & **** \\
\hline 6 & 1.48 & 2. $48 E-03$ & **** * & 4. $18 \mathrm{E}-03$ & $28 \cdot 21$ \\
\hline 7 & 1.72 & $2.71 E-03$ & $* * *$ & $3 \cdot 54 E-03$ & $35 \cdot 20$ \\
\hline 8 & 1.97 & $2.89 \mathrm{E}-03$ & $* * * *$ & $3.91 \mathrm{E}-03$ & 33.75 \\
\hline 9 & $2 \cdot 22$ & $3.82 E-03$ & 37.94 & $2.91 \mathrm{E}-03$ & $* * *$ \\
\hline 10 & 2.46 & 3. $38 E-03$ & $* * * *$ & 3. $13 E-03$ & $* * * *$ \\
\hline 11 & 2.71 & 5. $19 \mathrm{E}-03$ & $33 \cdot 18$ & $3.41 E-03$ & $* * * *$ \\
\hline 12 & 2.95 & $3.97 \mathrm{E}-03$ & $* * * *$ & $7 \cdot 16 E-03$ & $25 \cdot 48$ \\
\hline 13 & 3. 20 & $9.22 E-03$ & $23 \cdot 60$ & $7 \cdot 46 \mathrm{E}-03$ & 26.54 \\
\hline 14 & 3. 44 & $8.77 E-03$ & 27.92 & $7.82 E-03$ & $27 \cdot 45$ \\
\hline 15 & 3. 69 & $1 \cdot 41 E-02$ & $19 \cdot 46$ & $1.19 \mathrm{E}-02$ & 19.51 \\
\hline 16 & 3.94 & 6. $43 E-03$ & $* * * *$ & 1. $00 \mathrm{E}-02$ & $25 \cdot 11$ \\
\hline 17 & 4. 18 & 1. $12 E-02$ & $29 \cdot 34$ & $7.30 E-03$ & 38.00 \\
\hline 18 & 4.43 & $1.85 \mathrm{E}-02$ & 19.41 & 1. $33 E-02$ & $22 \cdot 47$ \\
\hline 19 & 4.67 & $7 \cdot 98 E-03$ & $* * * *$ & 6. $59 \mathrm{E}-03$ & $* * * *$ \\
\hline 20 & 4.92 & $1.98 E-02$ & 21.03 & 7. $02 E-03$ & $* * * *$ \\
\hline 21 & 5.17 & $1.88 \mathrm{E}-02$ & 23.73 & $1.41 E-02$ & 25.86 \\
\hline 22 & 5.41 & $1.04 E-02$ & $* * * *$ & 1. $64 \mathrm{E}-02$ & $* * * *$ \\
\hline 23 & 5. 66 & $1.08 E-02$ & $* * * *$ & 2. $75 E-02$ & 29.11 \\
\hline 24 & 5.90 & $1.93 E-02$ & **** & 2. $78 \mathrm{E}-02$ & $27 \cdot 76$ \\
\hline 25 & 6.15 & 3. $35 \mathrm{E}-02$ & 29.31 & 3. $30 \mathrm{E}-02$ & $24 \cdot 21$ \\
\hline 26 & $6 \cdot 40$ & 2. $17 E-02$ & **** & 1. $70 E-02$ & $* * * *$ \\
\hline 27 & 6.64 & 2. $22 E-02$ & **** * * & 1. $79 \mathrm{E}-02$ & $* * * *$ \\
\hline 28 & 6.89 & 5. $29 E-02$ & 20.23 & $1.85 E-02$ & $* * * *$ \\
\hline 29 & 7. 13 & $3.21 E-02$ & 34.88 & $1.94 \mathrm{E}-02$ & $* * * *$ \\
\hline 30 & 7. 38 & $2.47 \mathrm{E}-02$ & $* * *$ & $2.01 E-02$ & $* * * *$ \\
\hline 31 & 7. 62 & 3. $32 E-02$ & $35 \cdot 75$ & 4. $67 \mathrm{E}-02$ & $20 \cdot 68$ \\
\hline 32 & 7.87 & 2. $58 \mathrm{E}-02$ & $* * * *$ & $2 \cdot 14 E-02$ & **** \\
\hline 33 & 8. 12 & $2.56 E-02$ & $* * * *$ & 2. $20 \mathrm{E}-02$ & $* * * *$ \\
\hline 34 & 8.36 & $2.71 \mathrm{E}-02$ & $* * * *$ & 3. $09 \mathrm{E}-02$ & $34 \cdot 42$ \\
\hline 35 & 8.61 & 4. $11 E-02$ & 31.66 & 2. $35 E-02$ & $* * * *$ \\
\hline 36 & 8.85 & 4. $36 \mathrm{E}-02$ & 29.27 & 2. $44 \mathrm{E}-02$ & $* * * *$ \\
\hline 37 & 9.10 & 5. $19 \mathrm{E}-02$ & $22 \cdot 71$ & 3. $93 \mathrm{E}-02$ & $30 \cdot 34$ \\
\hline 38 & 9.35 & $3.36 E-02$ & $35 \cdot 36$ & 2. $53 \mathrm{E}-02$ & $* * *$ \\
\hline 39 & 9.59 & 3. $45 E-02$ & 37.96 & 2. $55 E-02$ & $* * * *$ \\
\hline 40 & 9.84 & $5.96 E-02$ & 24.30 & $2.55 E-02$ & $* * * *$ \\
\hline 41 & 10.08 & 5. $68 \mathrm{E}-02$ & 27.74 & $2.55 E-02$ & $* * * *$ \\
\hline 42 & $10 \cdot 33$ & 4. $12 E-02$ & $34 \cdot 45$ & 3. $27 E-02$ & $37 \cdot 58$ \\
\hline 43 & 10.58 & $2.76 \mathrm{E}-02$ & $* * * *$ & 2. $77 \mathrm{E}-02$ & $* * * *$ \\
\hline 44 & 10.82 & $7.28 \mathrm{E}-02$ & 17.84 & 3. $71 \mathrm{E}-02$ & $36 \cdot 14$ \\
\hline 45 & 11.07 & $2.89 \mathrm{E}-02$ & $* * * *$ & 4. $15 E-02$ & 33.58 \\
\hline 46 & $11 \cdot 31$ & $2.84 E-02$ & **** * & $4.20 E-02$ & $34 \cdot 15$ \\
\hline 47 & 11.56 & $3.87 \mathrm{E}-02$ & $32 \cdot 19$ & $3.15 E-02$ & $* * *$ \\
\hline 48 & 11.81 & 2. $46 \mathrm{E}-02$ & $* * * *$ & $5.93 E-02$ & $25 \cdot 58$ \\
\hline 49 & $12 \cdot 05$ & 2. $62 E-02$ & $* * * *$ & $6.10 E-02$ & $25 \cdot 68$ \\
\hline 50 & 12.30 & 4. $35 E-02$ & 29.51 & 3. $37 \mathrm{E}-02$ & $* * * *$ \\
\hline 51 & 12.54 & 4. $35 E-02$ & 30.17 & 3. $36 E-02$ & $* * * *$ \\
\hline 52 & 12.79 & $2.82 E-02$ & $* * * *$ & $5.66 \mathrm{E}-02$ & 28.01 \\
\hline
\end{tabular}


Table A-10 (continued)

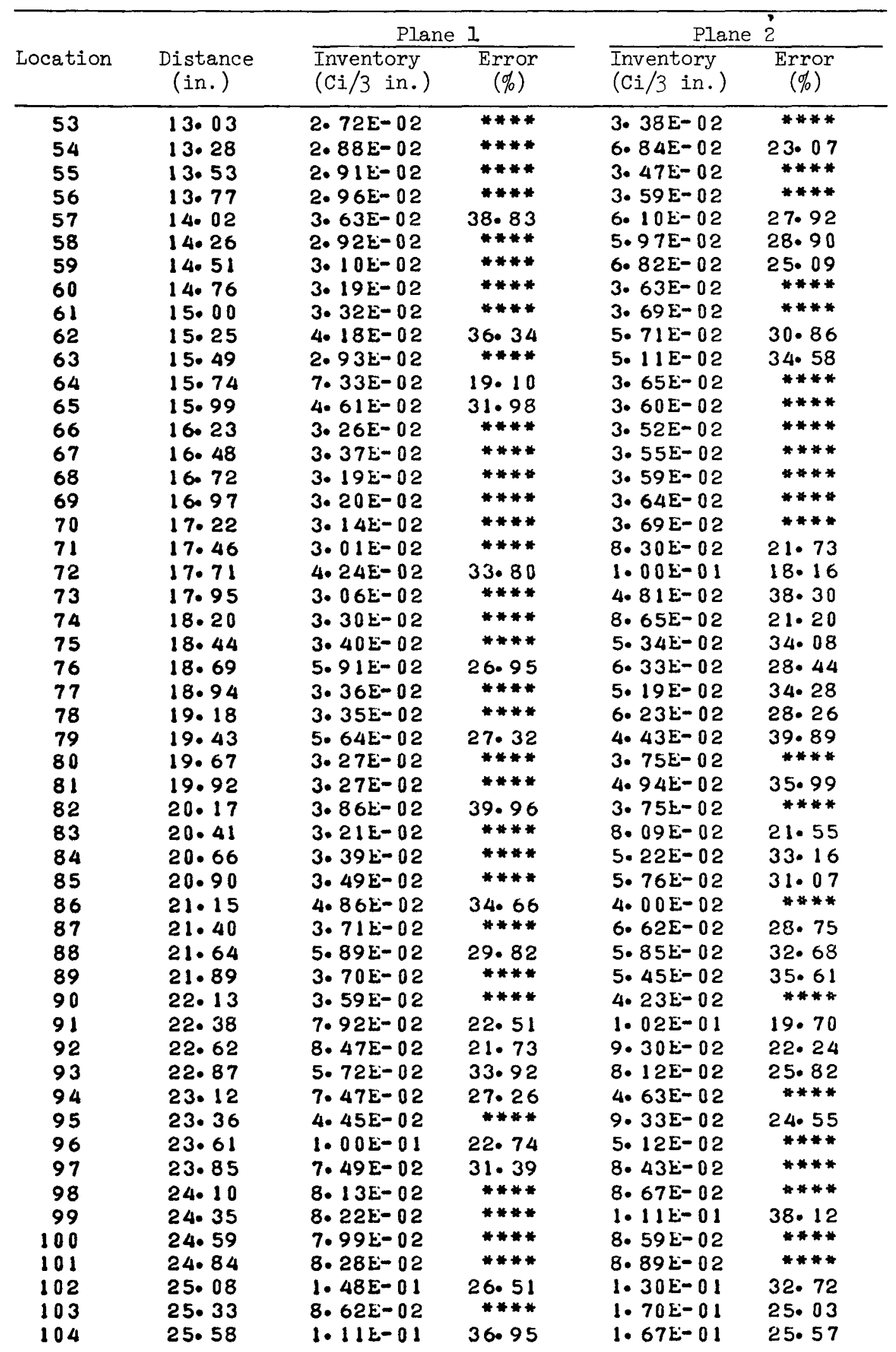


Table A-10 (continued)

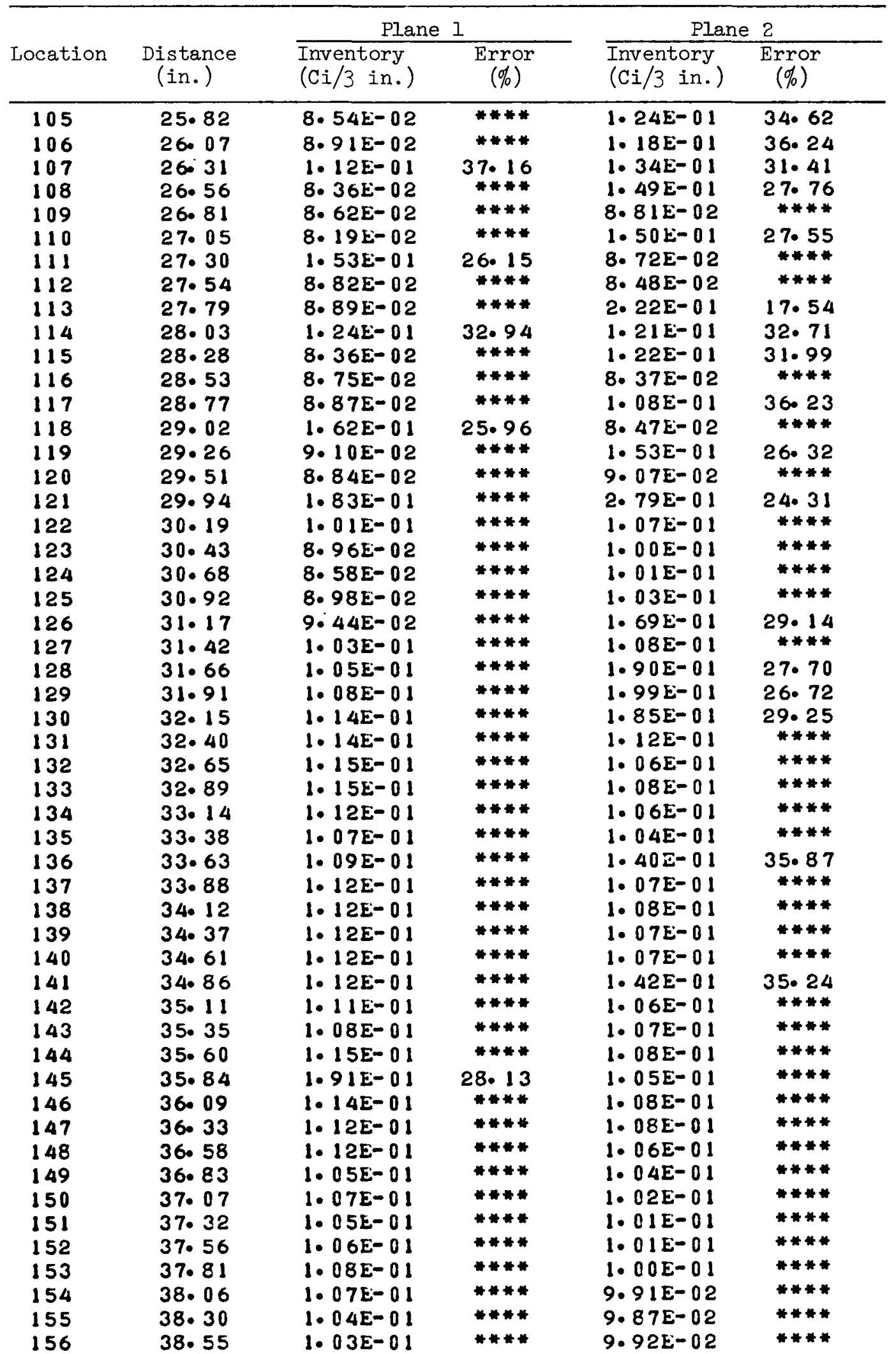


Table A-10 (continued)

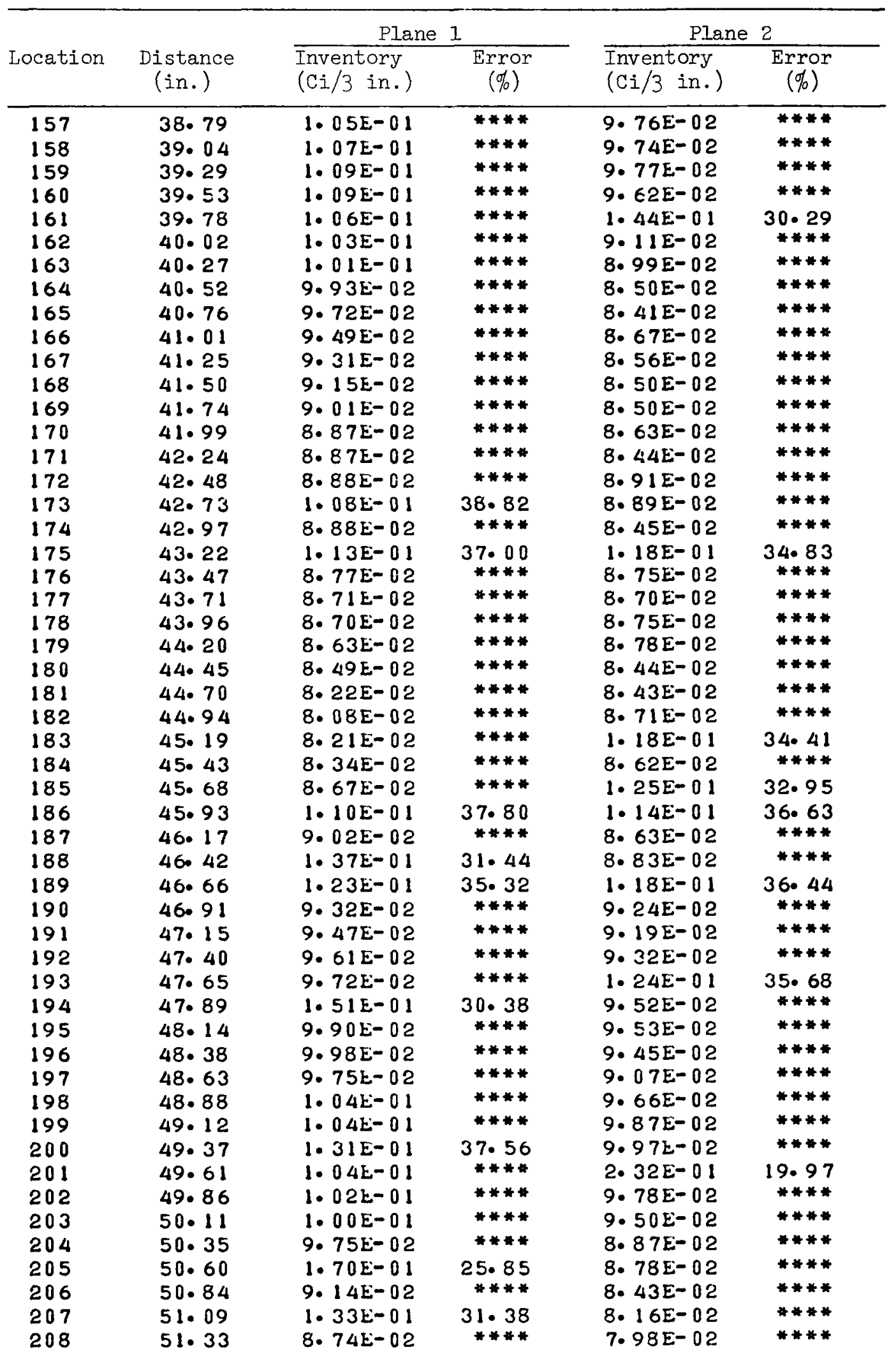


Table A-10 (continued)

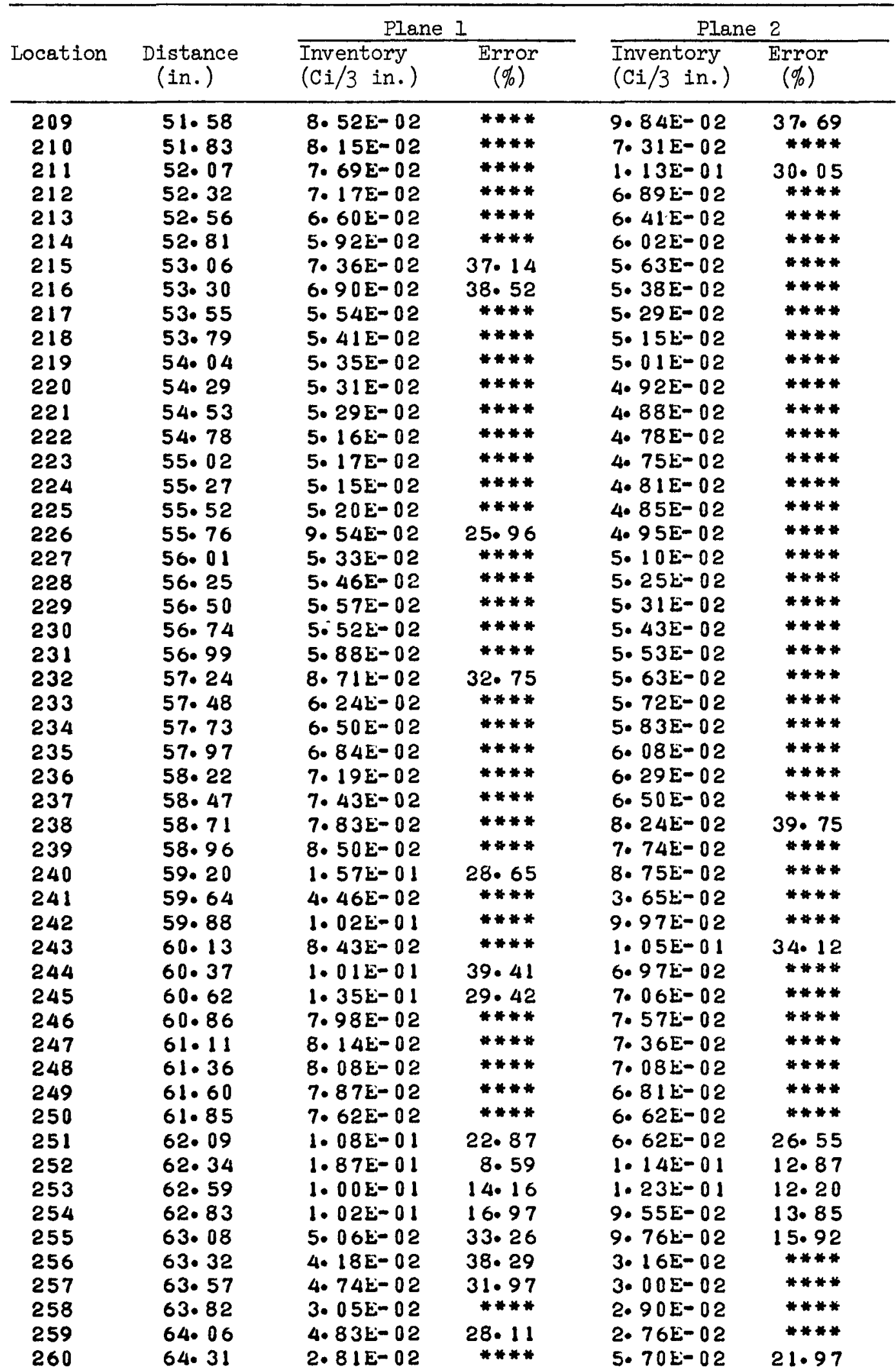


Table A-10 (continued)

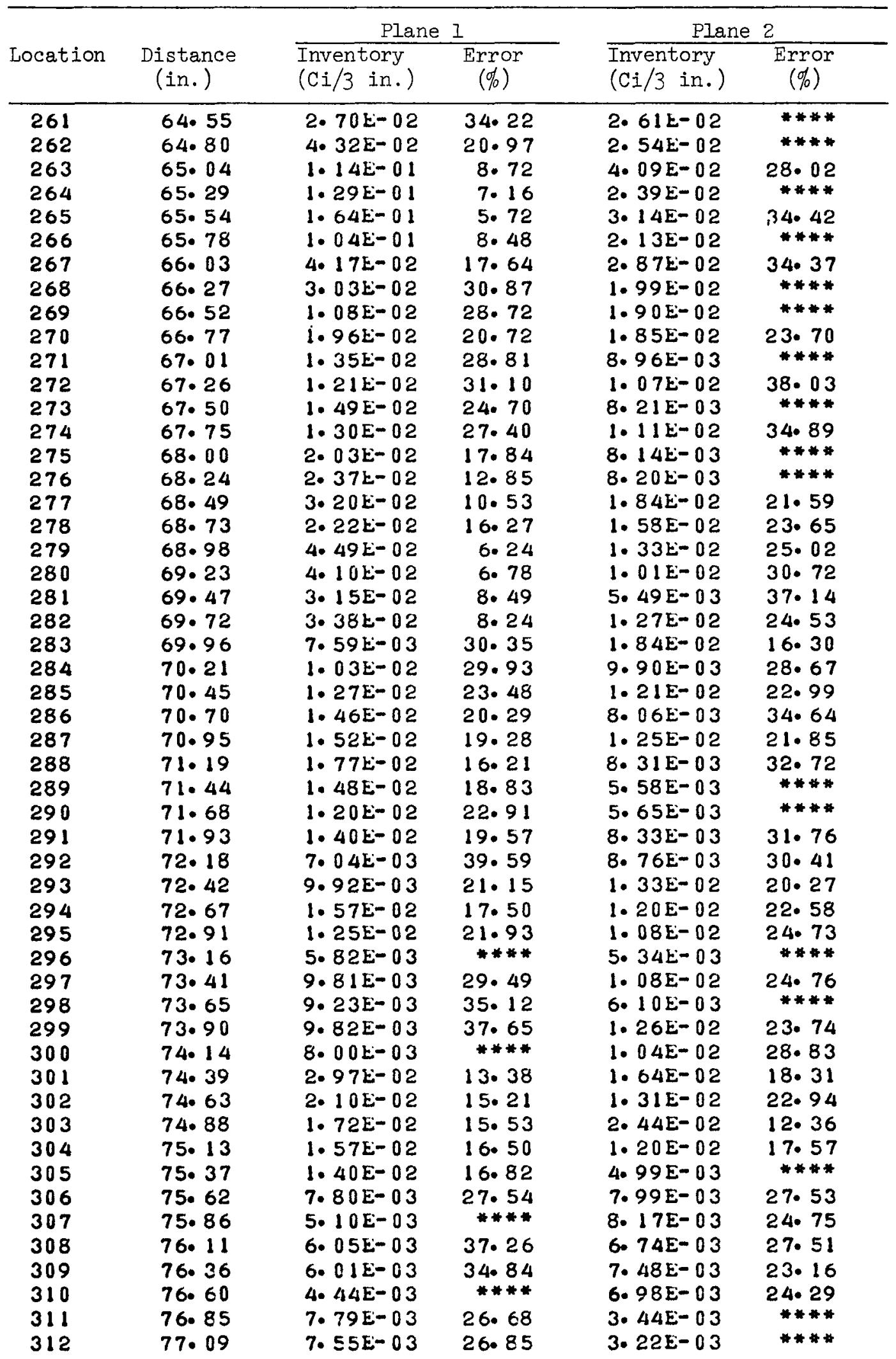


Table A-10 (continued)

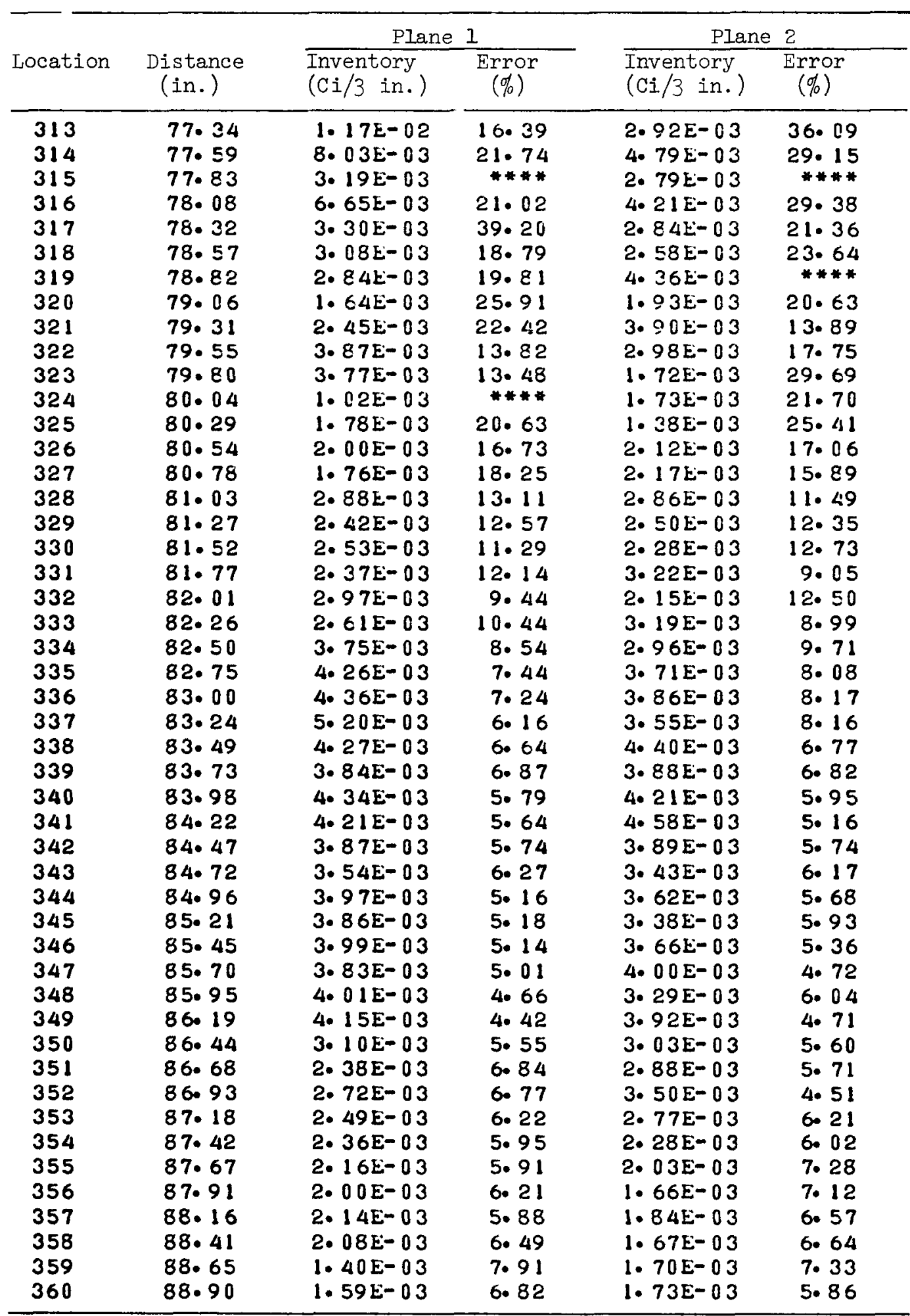


Table A-11. Axial distribution of ${ }^{154}$ Eu in the sleeve of element F03-01 (corrected to October 31, 1974)

\begin{tabular}{|c|c|c|c|c|c|}
\hline \multirow[b]{2}{*}{ Location } & \multirow[b]{2}{*}{$\begin{array}{l}\text { Distance } \\
\text { (in.) }\end{array}$} & \multicolumn{2}{|c|}{ Plane 1} & \multicolumn{2}{|c|}{ Plane 2} \\
\hline & & $\begin{array}{l}\text { Inventory } \\
(\mathrm{Ci} / 3 \text { in.) }\end{array}$ & $\begin{array}{c}\text { Error } \\
(\%)\end{array}$ & $\begin{array}{l}\text { Inventory } \\
(\mathrm{Ci} / 3 \mathrm{in} .)\end{array}$ & $\begin{array}{c}\text { Error } \\
(\%)\end{array}$ \\
\hline 1 & 0.25 & 2. $40 E-04$ & 8.02 & $3.54 E-04$ & 7.02 \\
\hline 2 & 0.49 & $6 \cdot 47 E-05$ & $16 \cdot 34$ & $1.09 E-04$ & 11.67 \\
\hline 3 & 0.74 & $3.44 E-05$ & $23 \cdot 77$ & $5.92 E-05$ & 15.90 \\
\hline 4 & 0.99 & $4 \cdot 45 \mathrm{E}-05$ & $15 \cdot 41$ & $4 \cdot 43 E-05$ & $16 \cdot 26$ \\
\hline 5 & 1.23 & $3 \cdot 19 E-05$ & $24 \cdot 53$ & $5 \cdot 66 E-05$ & $16 \cdot 05$ \\
\hline 6 & 1.48 & 4. $68 E-05$ & 17.79 & $6 \cdot 46 \mathrm{E}-05$ & 14.68 \\
\hline 7 & 1.72 & $3 \cdot 55 \mathrm{E}-0.5$ & $22 \cdot 70$ & $6 \cdot 29 E-05$ & 17.70 \\
\hline 8 & 1.97 & $5 \cdot 61 E-05$ & $15 \cdot 23$ & $3.50 E-05$ & 30.95 \\
\hline 9 & $2 \cdot 22$ & $5.22 E-05$ & $16 \cdot 55$ & $6 \cdot 70 E-05$ & $15 \cdot 46$ \\
\hline 10 & $2 \cdot 46$ & $4 \cdot 32 E-05$ & 20.91 & 4. $39 E-05$ & $23 \cdot 82$ \\
\hline 11 & 2.71 & $3.71 E-05$ & $22 \cdot 87$ & 4. $16 \mathrm{E}-05$ & 19.60 \\
\hline 12 & 2.95 & $3.90 \mathrm{E}-05$ & 19.89 & $3 \cdot 46 E-05$ & 27.93 \\
\hline 13 & $3 \cdot 20$ & $3.83 E-05$ & $18 \cdot 10$ & $4.94 E-05$ & $18 \cdot 49$ \\
\hline 14 & $3 \cdot 44$ & $2 \cdot 33 E-05$ & 30.35 & $3 \cdot 14 E-05$ & 22.96 \\
\hline 15 & 3.69 & $2 \cdot 52 E-05$ & $31 \cdot 30$ & $2 \cdot 36 E-05$ & $35 \cdot 67$ \\
\hline 16 & 3.94 & $1.90 \mathrm{E}-05$ & $* * * *$ & 2. $93 E-05$ & 28.84 \\
\hline 17 & $4 \cdot 18$ & $2.25 E-05$ & $36 \cdot 10$ & $3.50 E-05$ & $22 \cdot 43$ \\
\hline 18 & $4 \cdot 43$ & $3.87 E-05$ & 19.17 & 2. $80 E-05$ & 32.45 \\
\hline 19 & $4 \cdot 67$ & $3.44 E-05$ & $25 \cdot 78$ & $1.93 E-05$ & $* * * *$ \\
\hline 20 & 4.92 & $5.54 \mathrm{E}-05$ & 17.96 & $5 \cdot 29 E-05$ & 18.03 \\
\hline 21 & 5. 17 & $3.64 E-05$ & 29.77 & $2 \cdot 25 E-05$ & $* * * *$ \\
\hline 22 & $5 \cdot 41$ & 5. $64 E-05$ & $22 \cdot 62$ & $3.20 E-05$ & $38 \cdot 76$ \\
\hline 23 & 5.66 & $6.56 E-05$ & $* * * *$ & $4.66 \mathrm{E}-05$ & $* * * *$ \\
\hline 24 & 5.90 & 1. $53 E-04$ & $* * * *$ & $6 \cdot 75 E-05$ & **** \\
\hline 25 & 6.15 & $8.50 E-05$ & $* * * *$ & $4.60 E-05$ & **** \\
\hline 26 & 6040 & $5.07 E-05$ & $22 \cdot 81$ & $2 \cdot 25 E-05$ & $* * * *$ \\
\hline 27 & 6.64 & 4. $78 E-05$ & 20.85 & $1.99 E-05$ & $* * * *$ \\
\hline 28 & 6.89 & 4. $13 E-05$ & $24 \cdot 33$ & 2. $19 E-05$ & $* * * *$ \\
\hline 29 & $7 \cdot 13$ & 4. $38 E-05$ & 28.03 & $5.85 E-05$ & $17 \cdot 39$ \\
\hline 30 & $7 \cdot 38$ & $5 \cdot 20 E-05$ & $23 \cdot 13$ & $2.84 E-05$ & $* * * *$ \\
\hline 31 & $7 \cdot 62$ & $7.46 E-05$ & 19.21 & $3 \cdot 22 E-05$ & $38 \cdot 27$ \\
\hline 32 & $7 \cdot 87$ & $3 \cdot 32 E-05$ & $* * * *$ & 3. $59 \mathrm{E}-05$ & $28 \cdot 71$ \\
\hline 33 & $8 \cdot 12$ & $7.04 E-05$ & 20.84 & $2.69 E-05$ & $* * * *$ \\
\hline 34 & $8 \cdot 36$ & $6.87 E-05$ & 34.09 & 3. $74 \mathrm{E}-05$ & **** \\
\hline 35 & 8.61 & 1. $57 E-04$ & 32.95 & $7.30 E-05$ & **** \\
\hline 36 & 8.85 & $2.75 E-04$ & $* * * *$ & 1. $56 E-04$ & $* * * *$ \\
\hline 37 & 9.10 & 3. $17 E-04$ & $* * * *$ & 2. $17 E-04$ & $\# * * *$ \\
\hline 38 & 9.35 & $1.45 E-04$ & $* * * *$ & $7 \cdot 11 E-05$ & $* * * *$ \\
\hline 39 & 9.59 & $6.59 E-05$ & **** & 4. $38 E-05$ & $* * * *$ \\
\hline 40 & 9.84 & $6.87 E-05$ & **** & $5 \cdot 36 E-05$ & **** \\
\hline 41 & 10.08 & $6.06 E-05$ & **** & $6 \cdot 33 E-05$ & $* * * *$ \\
\hline 42 & 10.33 & $7.07 E-05$ & *** * * & $5.96 E-05$ & $* * * *$ \\
\hline 43 & 10.58 & $6.60 E-05$ & **** & $4 \cdot 42 E-05$ & **** \\
\hline 44 & 10.82 & 7. $37 \mathrm{E}-05$ & $* * *$ & $6 \cdot 16 E-05$ & $* * * *$ \\
\hline 45 & 11.07 & $9.02 E-05$ & $31 \cdot 10$ & 6. $34 t-05$ & $* * * *$ \\
\hline 46 & $11 \cdot 31$ & $6.63 E-05$ & **** & $6.91 k-05$ & $* * * *$ \\
\hline 47 & 11.56 & $7.40 E-05$ & $* * * *$ & $7.91 \mathrm{E}-05$ & $* * * *$ \\
\hline 48 & 11.81 & 1. $19 \mathrm{E}-04$ & $* * *$ & $1.07 \mathrm{E}-04$ & $* * * *$ \\
\hline 49 & $12 \cdot 05$ & $1.51 E-04$ & $* * * *$ & $1.73 E-04$ & $* * * *$ \\
\hline 50 & 12.30 & 1. $71 E-04$ & 29.97 & $1.20 E-04$ & $34 \cdot 25$ \\
\hline 51 & $12 \cdot 54$ & $1.25 E-04$ & 36.06 & $9 \cdot 34 E-05$ & **** \\
\hline 52 & 12.79 & $1.24 E-04$ & $* * * *$ & $1.07 t-04$ & $34 \cdot 52$ \\
\hline
\end{tabular}


Table A-11 (continued)

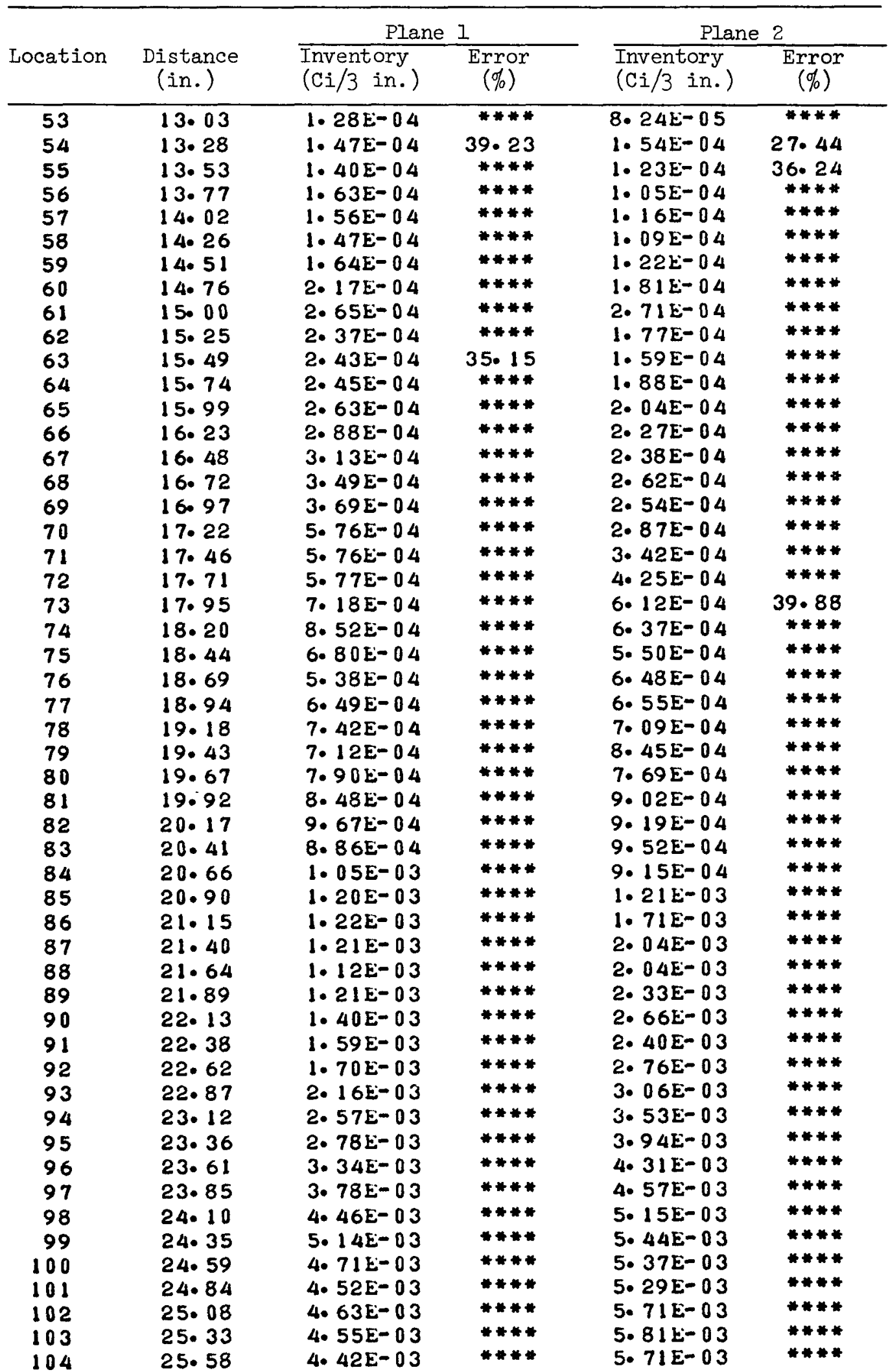


Table A-II (continued)

\begin{tabular}{|c|c|c|c|c|c|}
\hline \multirow[b]{2}{*}{ Location } & \multirow[b]{2}{*}{$\begin{array}{c}\text { Distance } \\
\text { (in.) }\end{array}$} & \multicolumn{2}{|c|}{ Plane 1} & \multicolumn{2}{|c|}{ Plane 2} \\
\hline & & $\begin{array}{l}\text { Inventory } \\
\text { (Ci/3 in.) }\end{array}$ & $\begin{array}{c}\text { Error } \\
(\%)\end{array}$ & $\begin{array}{l}\text { Inventory } \\
\text { (ci/3 in.) }\end{array}$ & $\begin{array}{c}\text { Error } \\
(\%)\end{array}$ \\
\hline $\begin{array}{l}105 \\
106 \\
107 \\
108 \\
109 \\
110 \\
111 \\
112 \\
113 \\
114 \\
115 \\
116 \\
117 \\
118 \\
119 \\
120 \\
121 \\
122 \\
123 \\
124 \\
125 \\
126 \\
127 \\
128 \\
129 \\
130 \\
131 \\
132 \\
133 \\
134 \\
135 \\
136 \\
137 \\
138 \\
139 \\
140 \\
141 \\
142 \\
143 \\
144 \\
145 \\
146 \\
147 \\
148 \\
149 \\
150 \\
151 \\
152 \\
153 \\
154 \\
155 \\
156\end{array}$ & $\begin{array}{l}25 \cdot 82 \\
26 \cdot 07 \\
26 \cdot 31 \\
26 \cdot 56 \\
26 \cdot 81 \\
27 \cdot 05 \\
27 \cdot 30 \\
27 \cdot 54 \\
27 \cdot 79 \\
28 \cdot 03 \\
28 \cdot 28 \\
28 \cdot 53 \\
28 \cdot 77 \\
29 \cdot 02 \\
29 \cdot 26 \\
29 \cdot 51 \\
29 \cdot 76 \\
30 \cdot 19 \\
30 \cdot 43 \\
30 \cdot 68 \\
30 \cdot 92 \\
31 \cdot 17 \\
31 \cdot 42 \\
31 \cdot 66 \\
31 \cdot 91 \\
32 \cdot 15 \\
32 \cdot 40 \\
32 \cdot 65 \\
32 \cdot 89 \\
33 \cdot 14 \\
33 \cdot 38 \\
33 \cdot 63 \\
33 \cdot 88 \\
34 \cdot 12 \\
34 \cdot 37 \\
34 \cdot 61 \\
34 \cdot 86 \\
35 \cdot 11 \\
35 \cdot 35 \\
35 \cdot 60 \\
35 \cdot 84 \\
36 \cdot 09 \\
36 \cdot 33 \\
36 \cdot 58 \\
36 \cdot 83 \\
37 \cdot 07 \\
37 \cdot 32 \\
37 \cdot 56 \\
37 \cdot 81 \\
38 \cdot 06 \\
38 \cdot 30 \\
38 \cdot 55\end{array}$ & 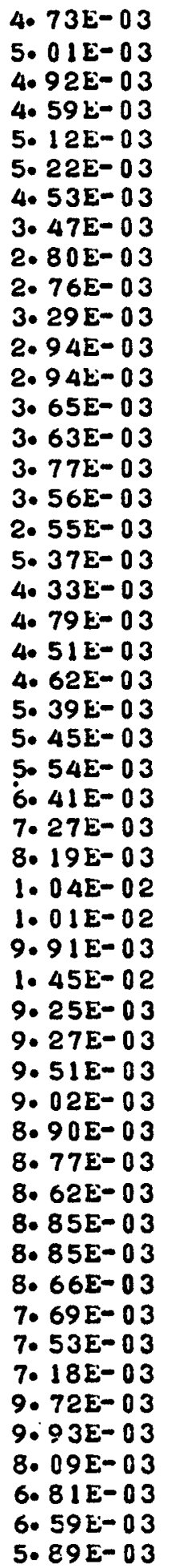 & 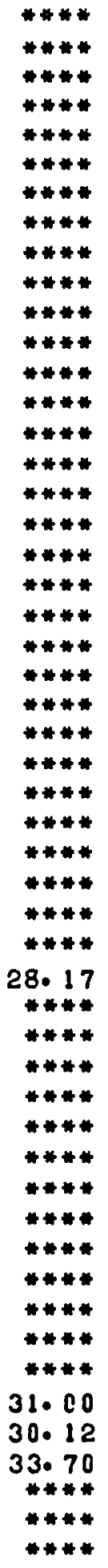 & 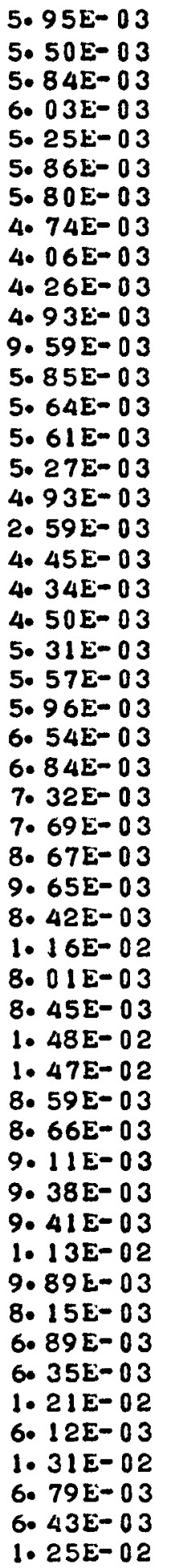 & 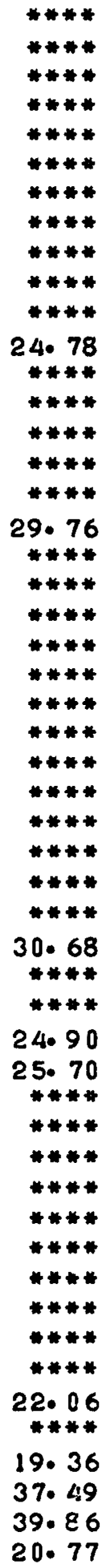 \\
\hline
\end{tabular}


Table A-11 (continued)

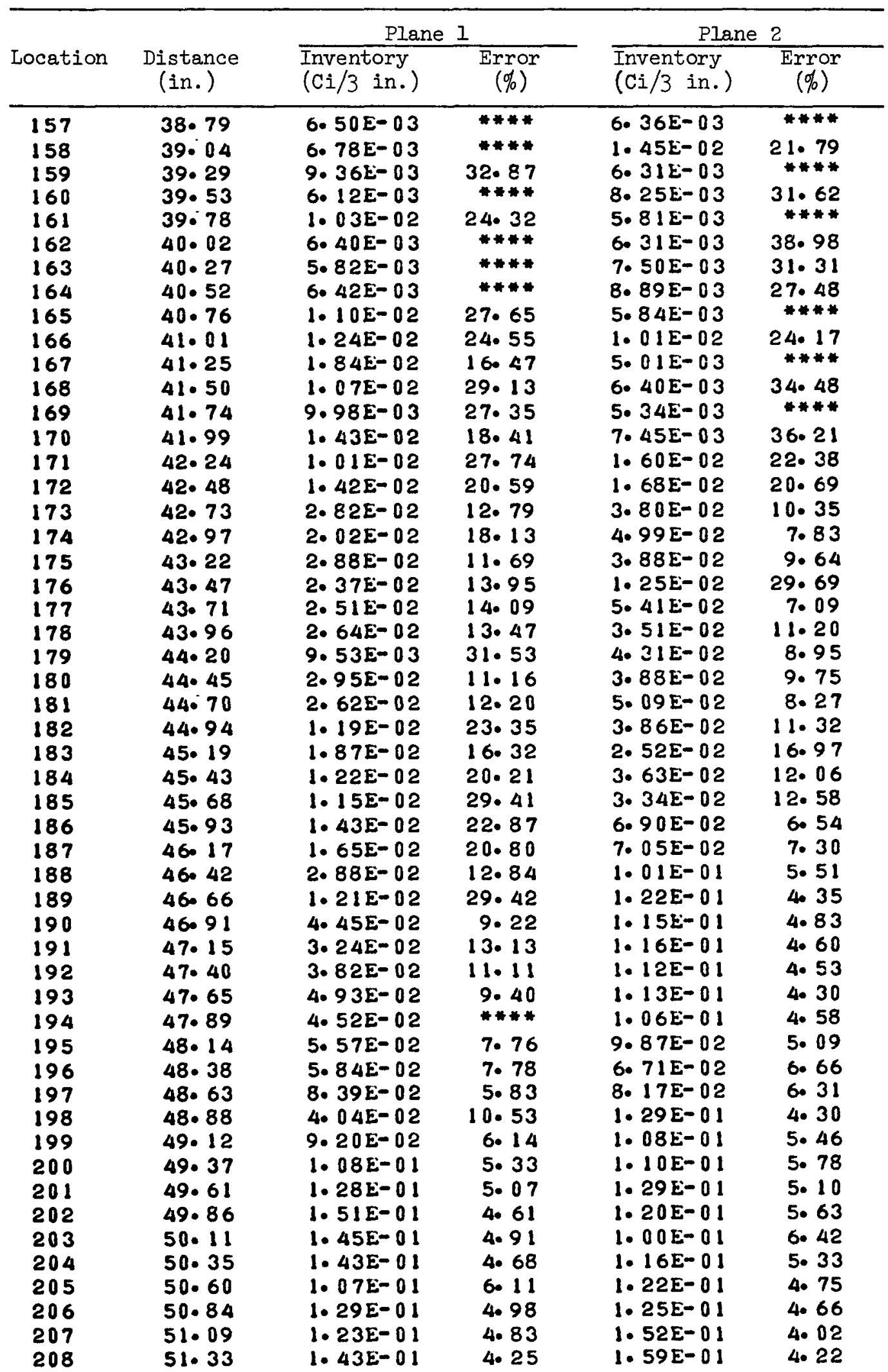


Table A-II (continued)

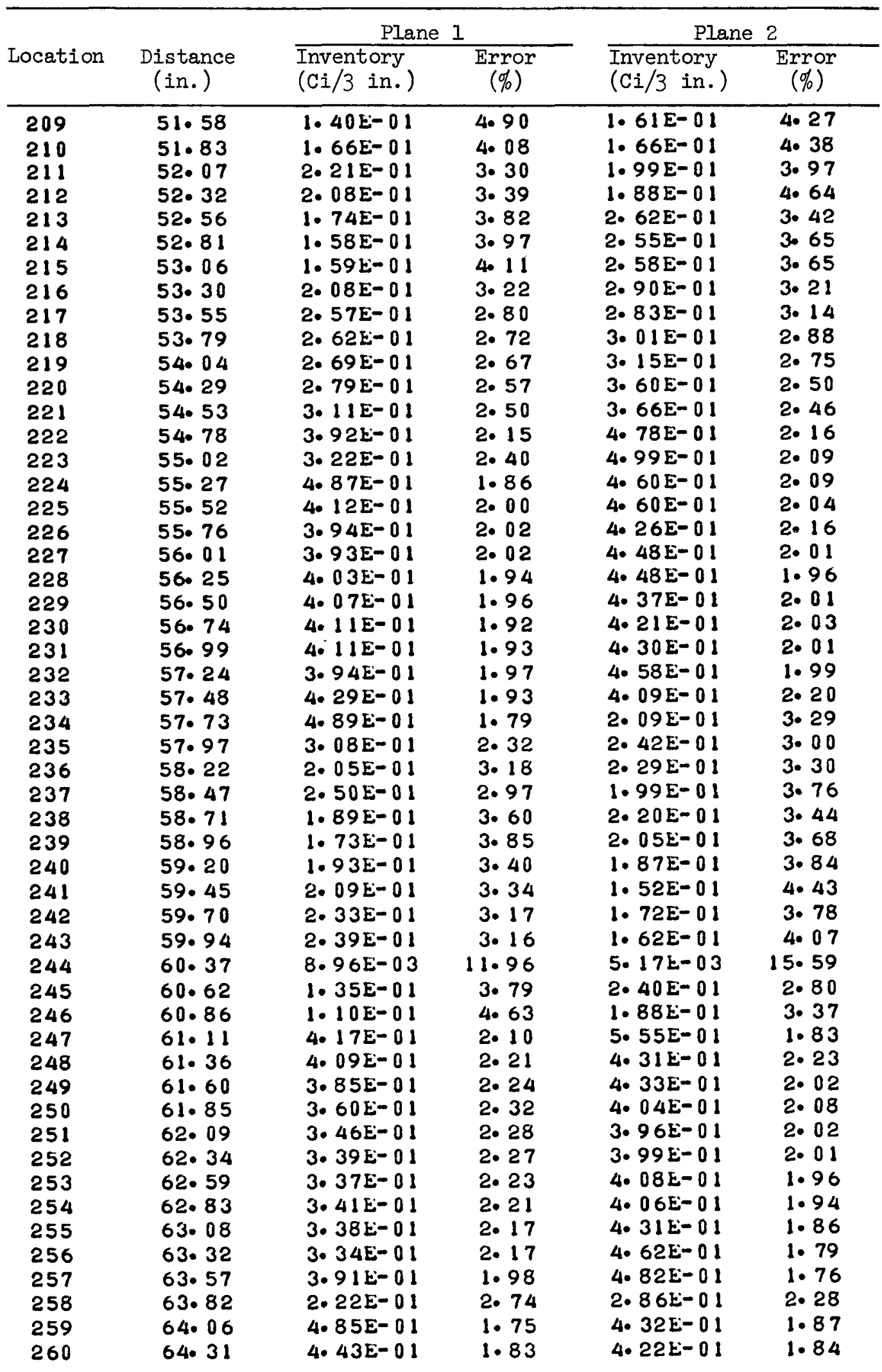


Table A-II (continued)

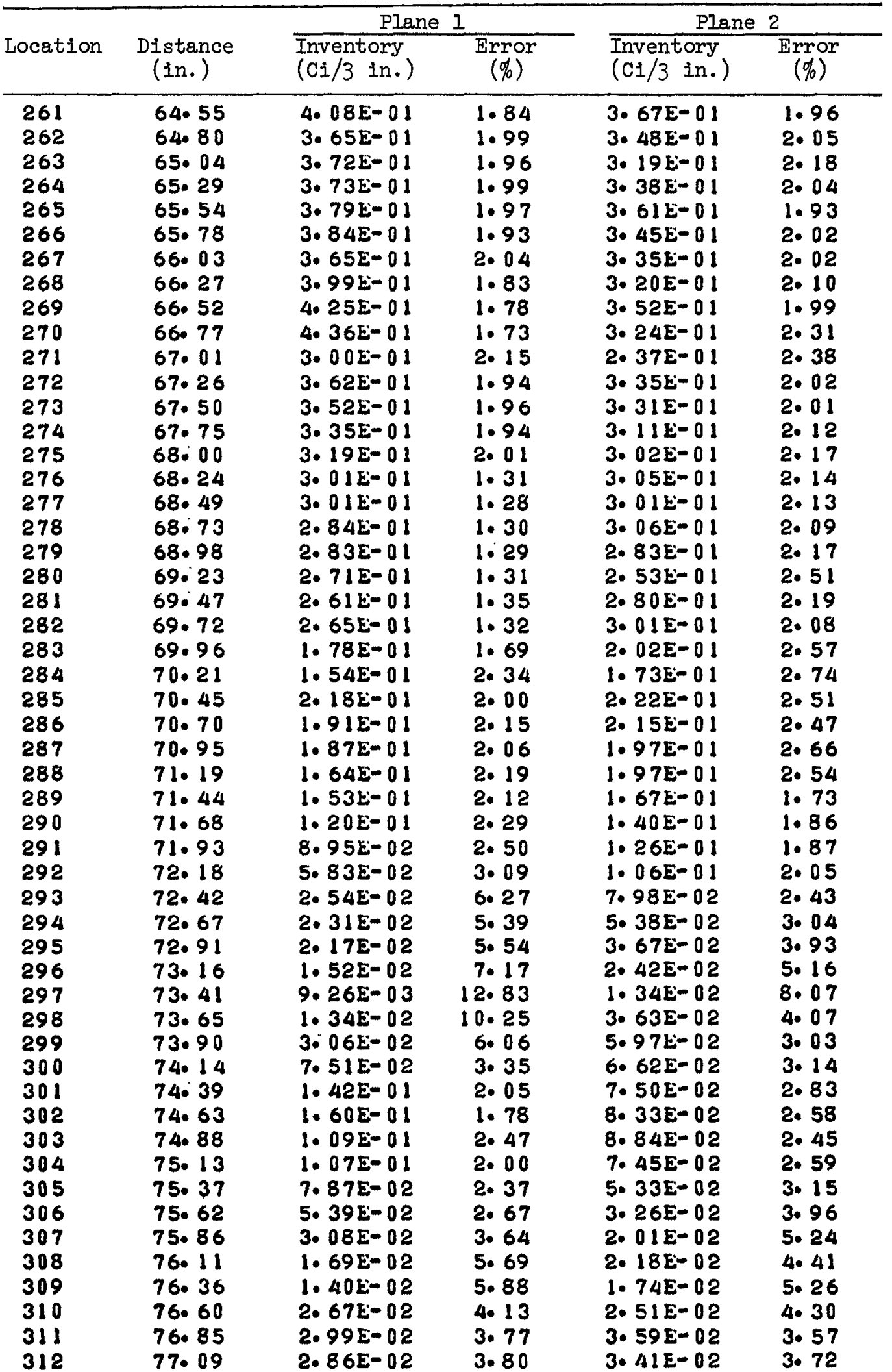


Table A-II (continued)

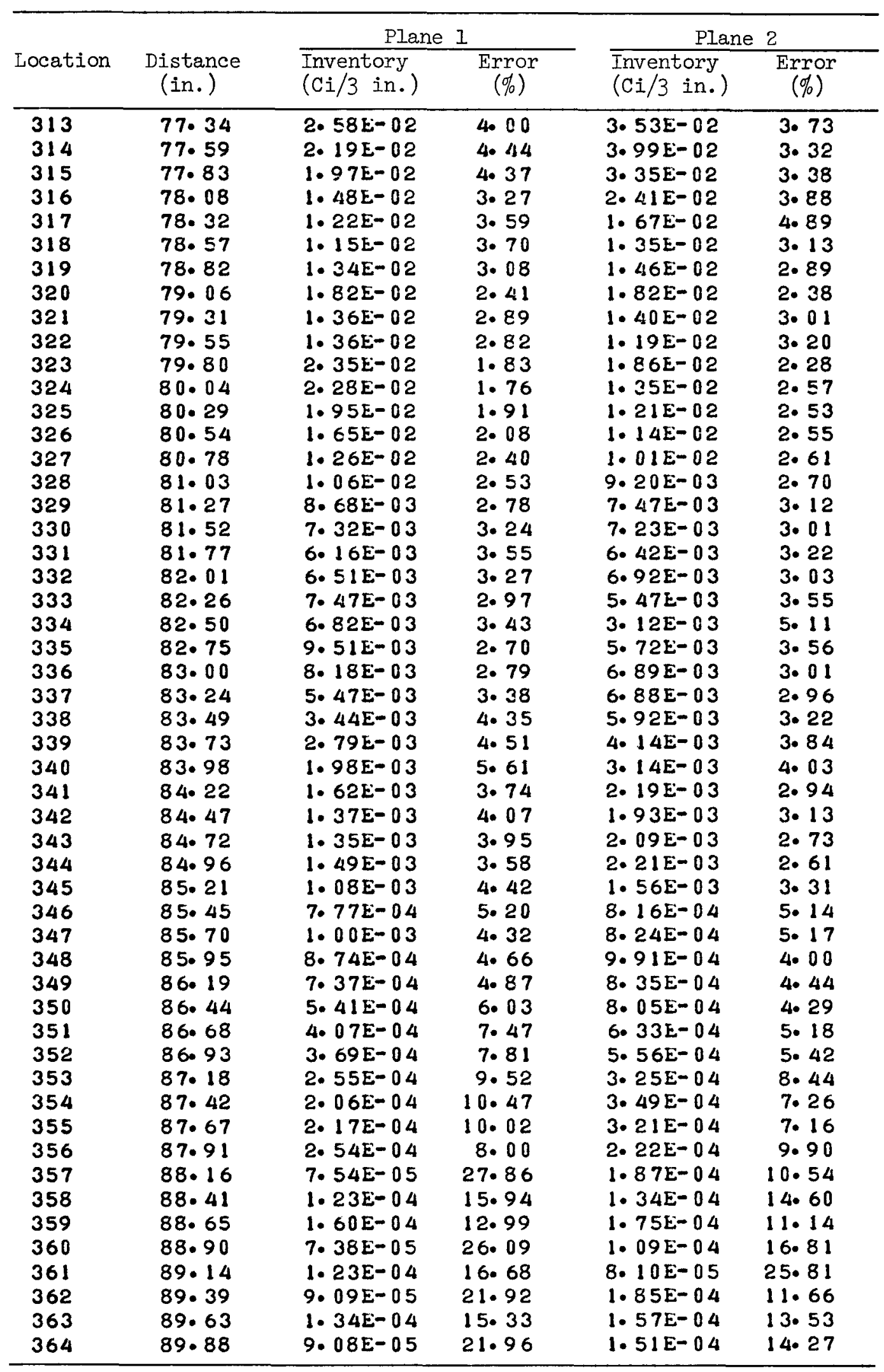


Table A-12. Axial distribution of ${ }^{154} \mathrm{Eu}$ in the spine of element FO3-01 (corrected to October 31, 1974)

\begin{tabular}{|c|c|c|c|c|c|}
\hline \multirow[b]{2}{*}{ Location } & \multirow[b]{2}{*}{$\begin{array}{c}\text { Distance } \\
\text { (in.) }\end{array}$} & \multicolumn{2}{|c|}{ Plane I } & \multicolumn{2}{|c|}{ Plane 2} \\
\hline & & $\begin{array}{l}\text { Inventory } \\
\text { (Ci/3 in.) }\end{array}$ & $\begin{array}{c}\text { Error } \\
(\%)\end{array}$ & $\begin{array}{l}\text { Inventory } \\
(\mathrm{Ci} / 3 \text { in.) }\end{array}$ & $\begin{array}{c}\text { Error } \\
(\%)\end{array}$ \\
\hline 1 & 0.25 & $2.05 E-04$ & 13.82 & 2. $68 \mathrm{E}-04$ & 11.93 \\
\hline 2 & $0 \cdot 49$ & $2 \cdot 21 E-04$ & $16 \cdot 43$ & 2. $74 E-04$ & 13.17 \\
\hline 3 & 0.74 & 2. $44 E-04$ & 14.23 & $1.21 E-04$ & $29 \cdot 64$ \\
\hline 4 & 0.99 & 2. $22 E-04$ & $16 \cdot 55$ & 2. $65 E-04$ & $14 \cdot 29$ \\
\hline 5 & 1.23 & 2. $52 E-04$ & 16.14 & 2. $79 E-04$ & 13.20 \\
\hline 6 & 1.48 & 2. $31 \mathrm{E}-04$ & 19.45 & 3. $53 E-04$ & 11.90 \\
\hline 7 & $1 \cdot 72$ & 2. $69 \mathrm{E}-04$ & $17 \cdot 61$ & 2. $74 \mathrm{E}-04$ & $15 \cdot 51$ \\
\hline 8 & 1.97 & 2. $35 E-04$ & 20.87 & $2.87 E-04$ & 15.09 \\
\hline 9 & $2 \cdot 22$ & 3. $49 E-04$ & 14.97 & 2. $08 E-04$ & $20 \cdot 62$ \\
\hline 10 & $2 \cdot 46$ & 3. $28 E-04$ & $17 \cdot 12$ & 3. $24 E-04$ & $15 \cdot 78$ \\
\hline 11 & 2.71 & 2. $76 E-04$ & 24.07 & $3.47 E-04$ & 16.08 \\
\hline 12 & 2.95 & $1.84 E-04$ & 39.83 & 3. $06 E-04$ & $19 \cdot 60$ \\
\hline 13 & 3.20 & 1. $93 E-04$ & $* * * *$ & $3.81 E-04$ & 15.91 \\
\hline 14 & 3. 44 & $2 \cdot 86 E-04$ & $34 \cdot 68$ & 3. $79 E-04$ & 17.02 \\
\hline 15 & 3.69 & 3. $11 E-04$ & $33 \cdot 78$ & 2. $77 \mathrm{E}-04$ & $26 \cdot 34$ \\
\hline 16 & 3.94 & 4. $37 E-04$ & $27 \cdot 19$ & 1. $79 E-04$ & $* * * *$ \\
\hline 17 & 4. 18 & $2.86 E-04$ & $* * * *$ & 2. $06 E-04$ & $33 \cdot 18$ \\
\hline 18 & $4 \cdot 43$ & 6. $60 E-04$ & $21 \cdot 74$ & $2.75 E-04$ & 34.81 \\
\hline 19 & $4 \cdot 67$ & 3. $56 E-04$ & $* * * *$ & 2. $78 E-04$ & 36.96 \\
\hline 20 & $4 \cdot 92$ & 3. $50 z-04$ & $* * * *$ & $3.45 E-04$ & 33.15 \\
\hline 21 & $5 \cdot 17$ & 3. $77 E-04$ & $* * * *$ & 4. $65 E-04$ & $28 \cdot 13$ \\
\hline 22 & 5. 41 & $3.14 E-04$ & $* * * *$ & 5. $16 E-04$ & 31.97 \\
\hline 23 & $5 \cdot 66$ & $2.88 E-04$ & $* * * *$ & 4. $03 E-04$ & $* * *$ \\
\hline 24 & 5.90 & 5. $17 E-04$ & $* * * *$ & $3.90 \mathrm{E}-04$ & $\# * * *$ \\
\hline 25 & $6 \cdot 15$ & $4 \cdot 77 E-04$ & $* * * *$ & $4.06 E-04$ & **** * \\
\hline 26 & 6. 40 & 5. $28 E-04$ & $* * * *$ & 4. $14 E-04$ & $* * * *$ \\
\hline 27 & 6.64 & $5.47 E-04$ & **** & $3.78 E-04$ & $* * * *$ \\
\hline 28 & 6.89 & $5.87 \mathrm{E}-04$ & $* * * *$ & 3. $50 \mathrm{E}-04$ & $* * * *$ \\
\hline 29 & $7 \cdot 13$ & $5.96 E-04$ & $* * * *$ & 4. $13 E-04$ & $* * * *$ \\
\hline 30 & 7.38 & $6.27 E-04$ & $* * * *$ & $3.96 E-04$ & $* * * *$ \\
\hline 31 & 7.62 & $6.16 E-04$ & $* * * *$ & 3. $76 E-04$ & $* * * *$ \\
\hline 32 & 7.87 & 5. $70 \mathrm{E}-04$ & $* * * *$ & $4.00 E-04$ & $* * * *$ \\
\hline 33 & $8 \cdot 12$ & $6.43 E-04$ & **** & $4 \cdot 38 E-04$ & $* * * *$ \\
\hline 34 & $8 \cdot 36$ & $5 \cdot 92 \mathrm{E}-04$ & $* * * *$ & $4.80 \mathrm{E}-04$ & $* * * *$ \\
\hline 35 & 8.61 & 6. $44 \mathrm{E}-04$ & $* * * *$ & $6.67 E-04$ & $28 \cdot 77$ \\
\hline 36 & 8.85 & $6.34 E-04$ & $\# * * *$ & $5.29 \mathrm{E}-04$ & $* * * *$ \\
\hline 37 & 9.10 & 5. $69 E-04$ & **** & $5.41 E-04$ & $* * * *$ \\
\hline 38 & 9.35 & $6.01 E-04$ & 38.88 & $9.40 \mathrm{E}-04$ & $23 \cdot 56$ \\
\hline 39 & 9.59 & 5. $76 \mathrm{E}-04$ & $* * * *$ & $6.03 E-04$ & 37.14 \\
\hline 40 & 9.84 & $7 \cdot 28 E-04$ & $* * * *$ & $5.08 E-04$ & $* * *$ \\
\hline 41 & 10.08 & $8.70 E-04$ & $* * * *$ & $4 \cdot 74 E-04$ & **** \\
\hline 42 & 10.33 & 7. $18 E-04$ & $* * * *$ & $5 \cdot 32 E-04$ & $* * * *$ \\
\hline 43 & 10.58 & $5.60 \mathrm{E}-04$ & $* * * *$ & $6.05 E-04$ & $\# * * *$ \\
\hline 44 & 10.82 & $5.67 \mathrm{E}-04$ & $* * * *$ & $5.67 E-04$ & $* * * *$ \\
\hline 45 & 11.07 & 7. $32 E-04$ & 36.91 & 8. $54 E-04$ & $32 \cdot 75$ \\
\hline 46 & 11.31 & $5.51 E-04$ & $* * * *$ & $6.92 E-04$ & $* * * *$ \\
\hline 47 & 11.56 & $4.88 \mathrm{E}-04$ & $* * * *$ & $1.16 E-03$ & $25 \cdot 49$ \\
\hline 48 & 11.81 & $5.85 E-04$ & $35 \cdot 33$ & $6.95 \mathrm{E}-04$ & $* * * *$ \\
\hline 49 & 12.05 & 4. $59 E-04$ & **** & 7. $19 \mathrm{E}-04$ & $* * * *$ \\
\hline 50 & 12.30 & $4.88 \mathrm{E}-04$ & $* * * *$ & 8. $19 E-04$ & $* * * *$ \\
\hline 51 & $12 \cdot 54$ & $5.60 \mathrm{E}-04$ & 38.99 & $7.68 E-04$ & $* * * *$ \\
\hline 52 & $12 \cdot 79$ & 5. $43 k-04$ & $* * * *$ & $7.95 \mathrm{E}-04$ & $* * * *$ \\
\hline
\end{tabular}


Table A-12 (continued)

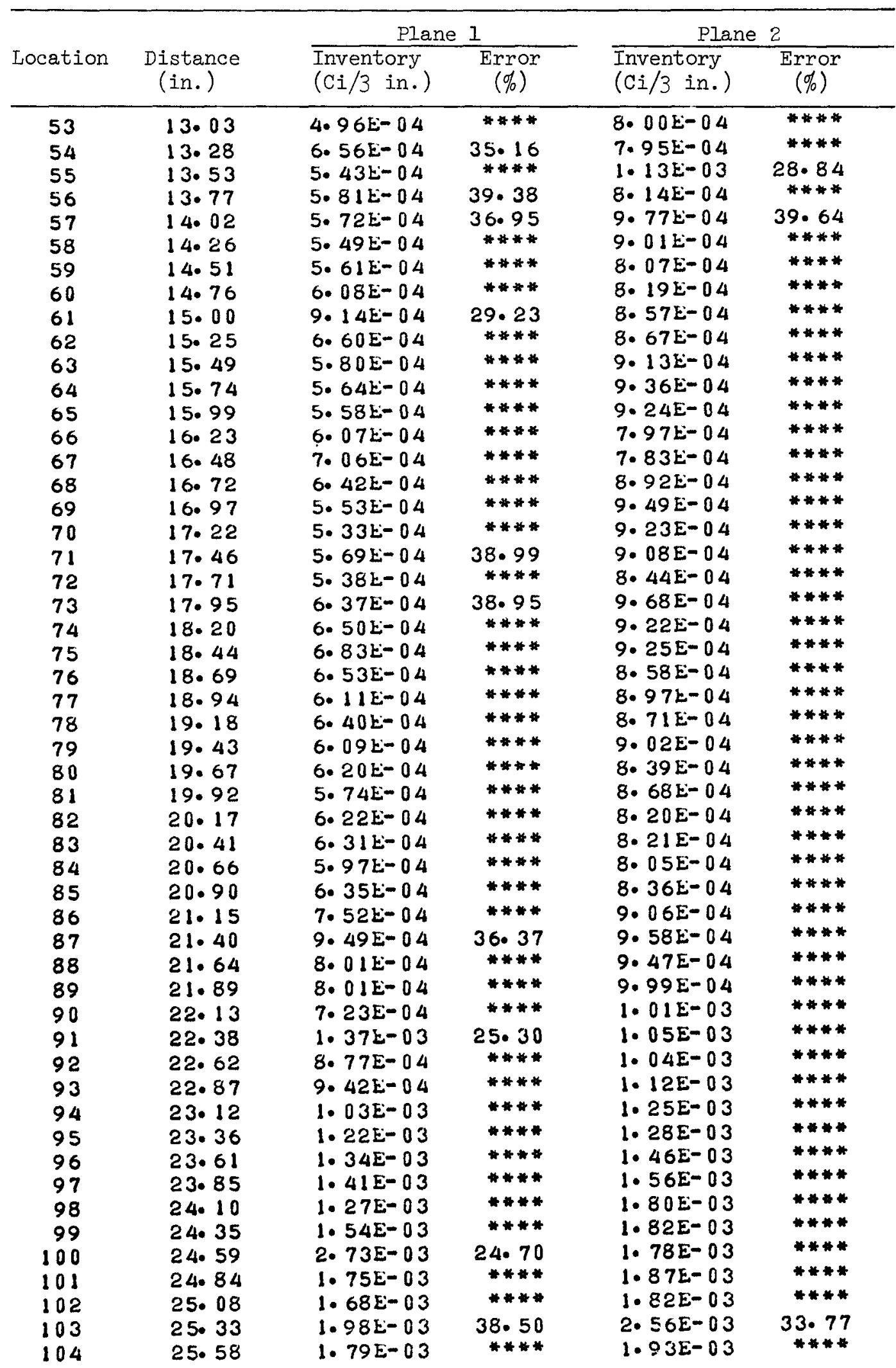


Table A-12 (continued)

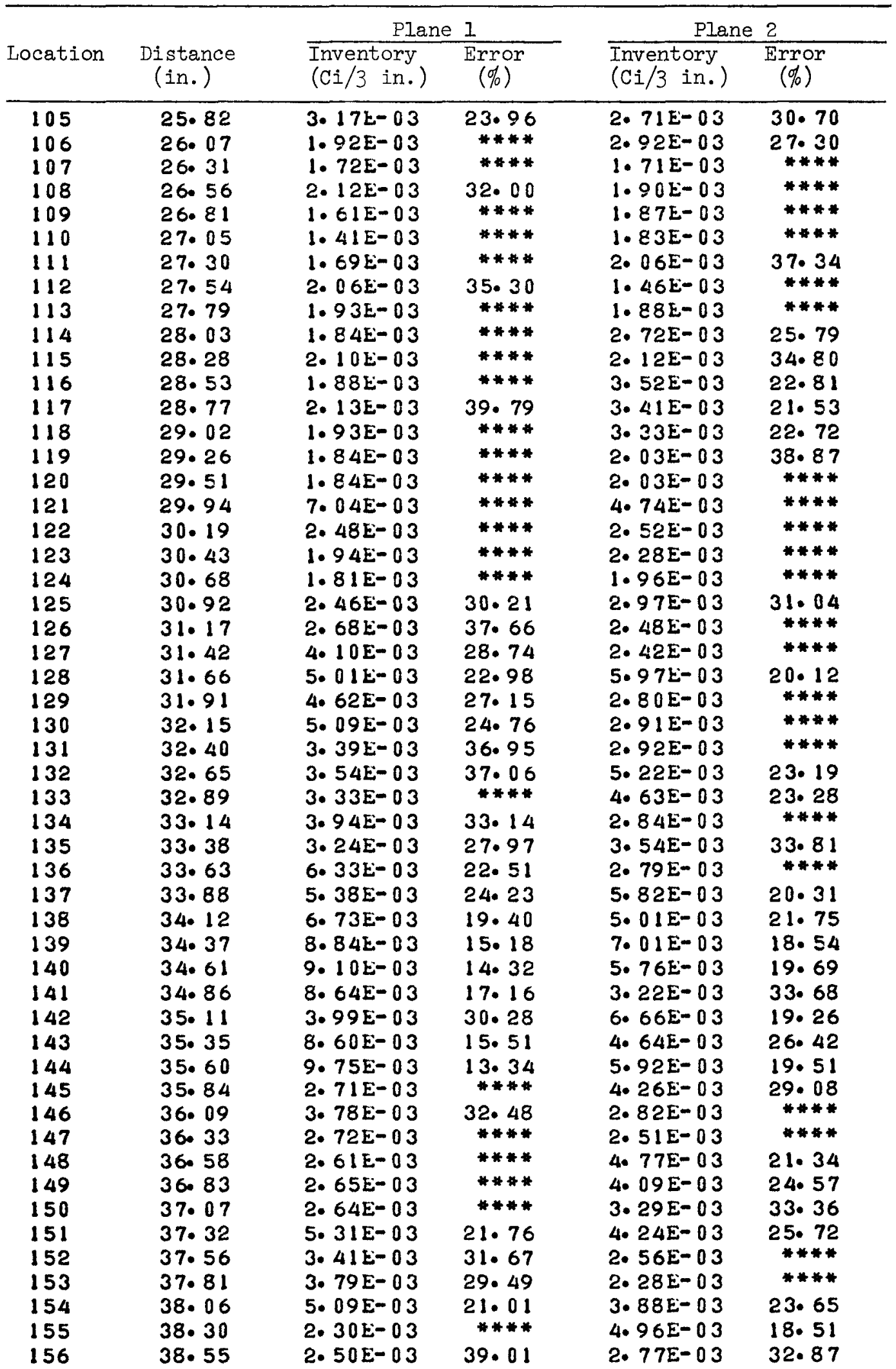


Table A-12 (continued)

\begin{tabular}{|c|c|c|c|c|c|}
\hline \multirow[b]{2}{*}{ Location } & \multirow[b]{2}{*}{$\begin{array}{l}\text { Distance } \\
\text { (in.) }\end{array}$} & \multicolumn{2}{|c|}{ Plane 1} & \multicolumn{2}{|c|}{ Plane 2} \\
\hline & & $\begin{array}{l}\text { Inventory } \\
(\mathrm{Ci} / 3 \text { in. })\end{array}$ & $\begin{array}{c}\text { Error } \\
(\%)\end{array}$ & $\begin{array}{l}\text { Inventory } \\
\text { ( } \mathrm{Ci} / 3 \text { in.) }\end{array}$ & $\begin{array}{l}\text { Error } \\
(\%)\end{array}$ \\
\hline $\begin{array}{l}157 \\
158 \\
159 \\
160 \\
161 \\
162 \\
163 \\
164 \\
165 \\
166 \\
167 \\
168 \\
169 \\
170 \\
171 \\
172 \\
173 \\
174 \\
175 \\
176 \\
177 \\
178 \\
179 \\
180 \\
181 \\
182 \\
183 \\
184 \\
185 \\
186 \\
187 \\
188 \\
189 \\
190 \\
191 \\
192 \\
193 \\
194 \\
195 \\
196 \\
197 \\
198 \\
199 \\
200 \\
201 \\
202 \\
203 \\
204 \\
205 \\
206 \\
207 \\
208\end{array}$ & $\begin{array}{l}38.79 \\
39.04 \\
39.29 \\
39.53 \\
39.78 \\
40.02 \\
40.27 \\
40.52 \\
40.76 \\
41 \cdot 01 \\
41.25 \\
41.50 \\
41.74 \\
41.99 \\
42.24 \\
42.48 \\
42.73 \\
42.97 \\
43.22 \\
43.47 \\
43.71 \\
43.96 \\
44.20 \\
44.45 \\
44070 \\
44.94 \\
45.19 \\
45.43 \\
45.68 \\
45.93 \\
46.17 \\
46.42 \\
46.66 \\
46.91 \\
47.15 \\
47.40 \\
47.65 \\
47.89 \\
48 \cdot 14 \\
48.38 \\
48.63 \\
48.88 \\
49.12 \\
49.37 \\
49.61 \\
49.86 \\
50.11 \\
50.35 \\
50.60 \\
50.84 \\
51 \cdot 09 \\
51.33\end{array}$ & $\begin{array}{l}2.99 E-03 \\
4.23 E-03 \\
3.91 E-03 \\
8.48 E-03 \\
6.67 E-03 \\
8.32 E-03 \\
7.07 E-03 \\
1.09 E-02 \\
5.76 E-03 \\
1.12 E-02 \\
1.19 E-02 \\
1.39 E-02 \\
1.45 E-02 \\
9.30 E-03 \\
9.03 E-03 \\
6.42 E-03 \\
1.04 E-02 \\
8.06 E-03 \\
9.78 E-03 \\
6.45 E-03 \\
9.57 E-03 \\
8.53 E-03 \\
8.14 E-03 \\
6.83 E-03 \\
6.79 E-03 \\
4.93 E-03 \\
7.70 E-03 \\
8.08 E-03 \\
7.08 E-03 \\
6.88 E-03 \\
9.07 E-03 \\
8.87 E-03 \\
1.54 E-02 \\
1.12 E-02 \\
1.08 E-02 \\
1.58 E-02 \\
1.92 E-02 \\
1.98 E-02 \\
2.35 E-02 \\
2.06 E-02 \\
1.98 E-02 \\
1.45 E-02 \\
1.59 E-02 \\
1.74 E-02 \\
2.15 E-02 \\
2.31 E-02 \\
2.19 E-02 \\
1.72 E-02 \\
1.68 E-02 \\
1.89 E-02 \\
1.85 E-02 \\
2.26 E-02\end{array}$ & $\begin{array}{r}38.42 \\
27.56 \\
30.31 \\
15.98 \\
17.34 \\
15.73 \\
18.68 \\
13.00 \\
23.85 \\
12.49 \\
11.17 \\
8.84 \\
8.52 \\
12.03 \\
12.58 \\
18.29 \\
9.95 \\
13.75 \\
11.41 \\
19.07 \\
12.47 \\
12.91 \\
13.57 \\
17.60 \\
14.40 \\
19.80 \\
13.12 \\
13.16 \\
15.53 \\
17.34 \\
12.11 \\
14.40 \\
8.83 \\
11.21 \\
13.57 \\
9.82 \\
8.27 \\
7.77 \\
6.95 \\
7.97 \\
8.46 \\
10.62 \\
9.96 \\
9.43 \\
7.83 \\
7.50 \\
7.26 \\
10.04 \\
9.13 \\
7.21 \\
7.66 \\
6.23\end{array}$ & 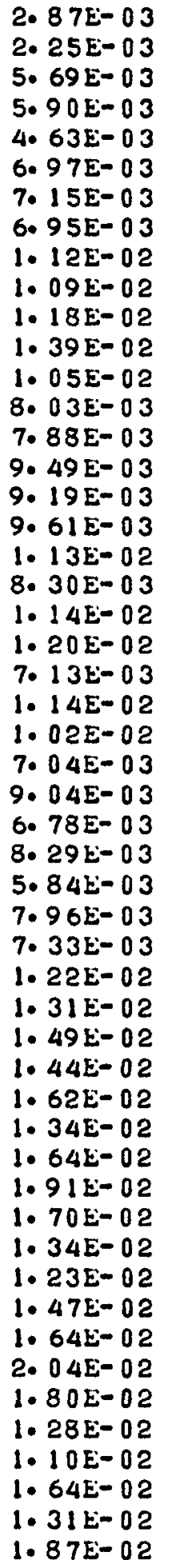 & $\begin{array}{r}32.40 \\
1 * * * \\
19.15 \\
15.76 \\
22.78 \\
14.98 \\
15.09 \\
16.51 \\
10.42 \\
11.86 \\
10.21 \\
8.31 \\
10.64 \\
14.03 \\
13.53 \\
11.84 \\
10.77 \\
11.20 \\
9.54 \\
14.18 \\
11.10 \\
10.30 \\
16.71 \\
10.17 \\
10.40 \\
14.42 \\
11.11 \\
16.33 \\
13.25 \\
19.96 \\
15.62 \\
16.13 \\
10.75 \\
10.76 \\
9.55 \\
9.44 \\
8.42 \\
11.39 \\
9.42 \\
7.85 \\
8.71 \\
10.20 \\
11.85 \\
10.01 \\
9.44 \\
7.66 \\
7.98 \\
11.69 \\
11.75 \\
7.40 \\
9.47 \\
7.18\end{array}$ \\
\hline
\end{tabular}


Table A-12 (continued)

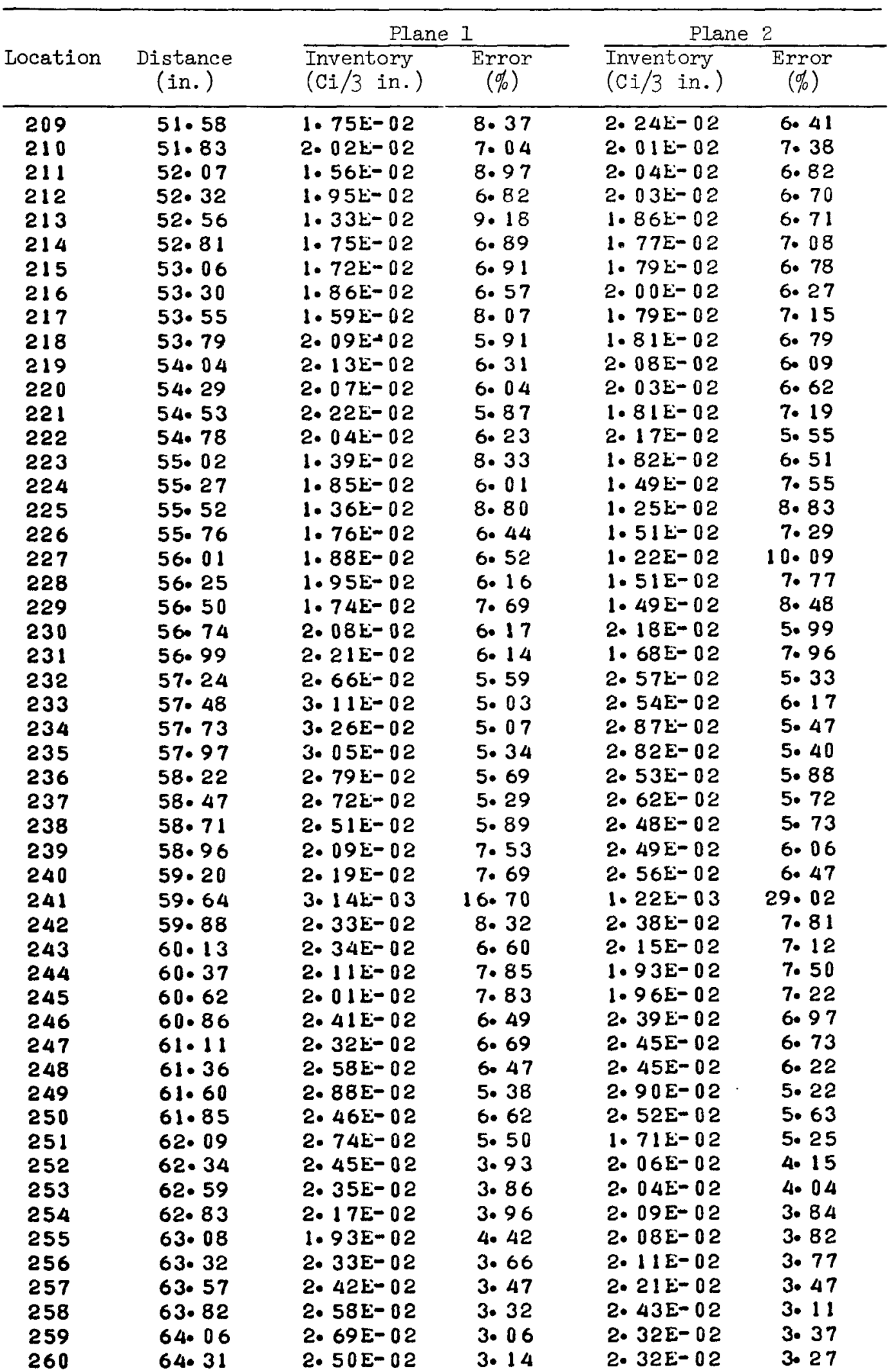


Table A-12 (continued)

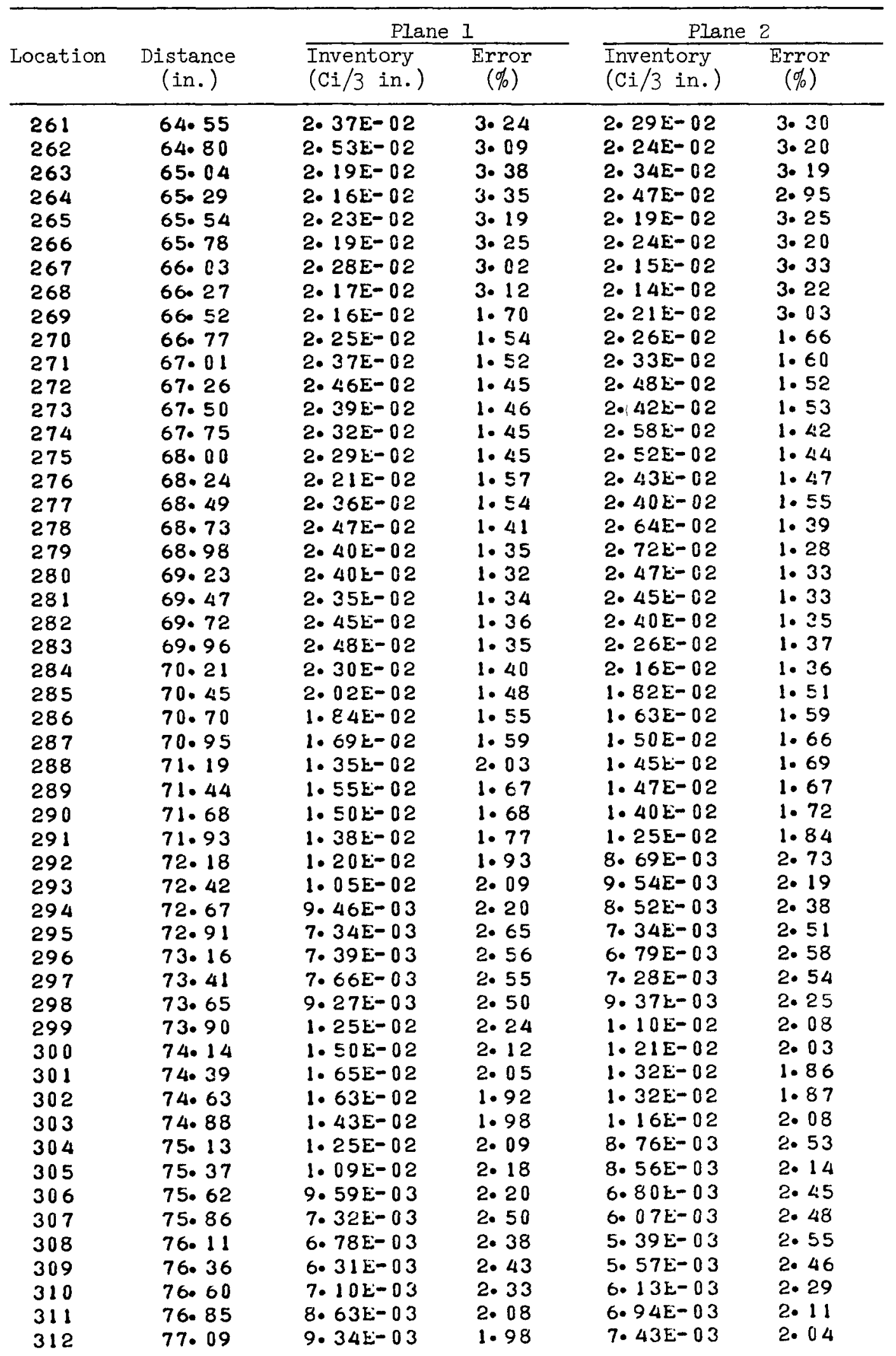


Table A-12 (continued)

\begin{tabular}{|c|c|c|c|c|c|}
\hline \multirow[b]{2}{*}{ Location } & \multirow[b]{2}{*}{$\begin{array}{c}\text { Distance } \\
\text { (in.) }\end{array}$} & \multicolumn{2}{|c|}{ Plane 1} & \multicolumn{2}{|c|}{ Plane 2} \\
\hline & & $\begin{array}{l}\text { Inventory } \\
\text { (Ci/3 in.) }\end{array}$ & $\begin{array}{c}\text { Error } \\
(\%)\end{array}$ & $\begin{array}{l}\text { Inventory } \\
\text { (Ci/3 in.) }\end{array}$ & $\underset{(\%)}{\text { Error }}$ \\
\hline 313 & $77 \cdot 34$ & $9.85 \mathrm{E}-03$ & 1.86 & $7.27 \mathrm{E}-03$ & $2 \cdot 12$ \\
\hline 314 & 77.59 & $8.81 E-03$ & 1.98 & $7.03 E-03$ & $2 \cdot 11$ \\
\hline 315 & 77.83 & 7. $61 \mathrm{E}-03$ & 2.04 & $6.64 \mathrm{E}-03$ & 2.08 \\
\hline 316 & 78.08 & $6.50 E-03$ & $2 \cdot 18$ & 5. $65 k-03$ & $2 \cdot 30$ \\
\hline 317 & $78 \cdot 32$ & 5. $49 \mathrm{E}-03$ & 2.40 & $6.89 E-03$ & $1 \cdot 12$ \\
\hline 318 & $78 \cdot 57$ & $6.03 E-03$ & 1.20 & $6.40 E-03$ & $1 \cdot 19$ \\
\hline 319 & $78 \cdot 82$ & $6.03 E-03$ & 1.20 & $6.53 E-03$ & 3. 71 \\
\hline 320 & 79.06 & $6.98 E-03$ & 1.10 & $6.69 \mathrm{E}-03$ & 1. 12 \\
\hline 321 & $79 \cdot 31$ & $7.90 E-03$ & 1.03 & 7. $52 E-03$ & 1.04 \\
\hline 322 & $79 \cdot 55$ & $7.73 E-03$ & 1.05 & $5 \cdot 19 k-03$ & $1 \cdot 63$ \\
\hline 323 & 79.80 & $7.44 E-03$ & 1.03 & $7.18 E-03$ & 1.05 \\
\hline 324 & 80.04 & $7 \cdot 26 \mathrm{E}-03$ & 1.04 & 7. $00 \mathrm{E}-03$ & 1.07 \\
\hline 325 & $80 \cdot 29$ & $7.25 E-03$ & 1.04 & $7.29 \mathrm{E}-03$ & 1.03 \\
\hline 326 & 80.54 & $7 \cdot 17 E-03$ & 1.03 & $7 \cdot 27 E-03$ & 1.01 \\
\hline 327 & .0 .78 & $6.88 E-03$ & 1.03 & $6.82 \mathrm{E}-03$ & 1.04 \\
\hline 328 & 81.03 & $6.01 \mathrm{E}-03$ & 1.09 & $5.99 E-03$ & 1.09 \\
\hline 329 & $81 \cdot 27$ & $4.96 E-03$ & 1.21 & $5.08 \mathrm{E}-03$ & $1 \cdot 18$ \\
\hline 330 & $81 \cdot 52$ & $4 \cdot 42 E-03$ & 1.26 & 4. $43 E-03$ & 1.26 \\
\hline 331 & $81 \cdot 77$ & $3.79 \mathrm{E}-03$ & $1 \cdot 36$ & $3.84 E-03$ & $1 \cdot 34$ \\
\hline-32 & 82.01 & $3.49 E-03$ & 1.42 & $3.30 \mathrm{E}-03$ & 1.47 \\
\hline 333 & $82 \cdot 26$ & $3.68 \mathrm{E}-03$ & $1 \cdot 38$ & $3.64 E-03$ & $1 \cdot 38$ \\
\hline 334 & 82.50 & 4. $53 E-03$ & 1.26 & $4 \cdot 13 E-03$ & 1. 34 \\
\hline 335 & 82.75 & 5. $45 \mathrm{E}-03$ & $1 \cdot 15$ & $5.08 \mathrm{E}-03$ & $1 \cdot 19$ \\
\hline 336 & 83.00 & $5 \cdot 54 \mathrm{k}-03$ & 1.04 & $5.37 E-03$ & 1.15 \\
\hline 337 & 83.24 & $3 \cdot 33 \mathrm{E}-03$ & 2.03 & $5.02 E-03$ & $1 \cdot 18$ \\
\hline 338 & 83.49 & $4.62 \mathrm{E}-03$ & $1 \cdot 21$ & 4. $43 E-03$ & 1.24 \\
\hline 339 & 83.73 & $3.89 E-03$ & $1 \cdot 31$ & 3. $74 \mathrm{E}-03$ & 1. 32 \\
\hline 340 & 83.98 & $3.32 \mathrm{E}-03$ & 1.39 & $3.05 E-03$ & 1. 48 \\
\hline 341 & $84 \cdot 22$ & $2.81 \mathrm{E}-03$ & 1.50 & 2. $56 E-03$ & 1.61 \\
\hline 342 & $84 \cdot 47$ & $2.46 E-03$ & 1. 59 & 2. $26 E-03$ & 1.65 \\
\hline 343 & $84 \cdot 72$ & $2 \cdot 24 E-03$ & 1.67 & $1.98 E-03$ & $1 \cdot 77$ \\
\hline 344 & 84.96 & $1.92 E-03$ & 1.81 & $1.84 \mathrm{E}-03$ & 1.86 \\
\hline 345 & $85 \cdot 21$ & $1.29 E-03$ & 2.75 & $1.59 k-03$ & 2.04 \\
\hline 346 & $85 \cdot 45$ & $1.35 E-03$ & 2.43 & $1.33 E-03$ & $2 \cdot 35$ \\
\hline 347 & $85 \cdot 70$ & $1.18 \mathrm{E}-03$ & 2. 55 & $1.05 E-03$ & 2.73 \\
\hline 348 & 85.95 & $9.62 E-04$ & 2.97 & $9.76 E-04$ & 2. 77 \\
\hline 349 & $86 \cdot 19$ & $1.01 E-03$ & 2.80 & $8.76 E-04$ & 2.93 \\
\hline 350 & 86.44 & $8.96 E-04$ & 2.96 & $9.32 k-04$ & 2.80 \\
\hline 351 & 86.68 & $9.02 E-04$ & 2.87 & $7.90 E-04$ & 3.14 \\
\hline 352 & 86.93 & $8.14 \mathrm{E}-04$ & 2.96 & $7 \cdot 33 E-04$ & 3.15 \\
\hline 353 & $87 \cdot 18$ & $6.96 E-04$ & $3 \cdot 17$ & $6.05 E-04$ & 3.42 \\
\hline 354 & 87.42 & $5 \cdot 42 E-04$ & 3.63 & 5. $39 E-04$ & 3.63 \\
\hline 355 & 87.67 & $5.43 E-04$ & $3 \cdot 59$ & 4. $15 \mathrm{E}-04$ & $4 \cdot 22$ \\
\hline 356 & 87.91 & $4.84 t-04$ & 3.81 & 4. $79 \mathrm{E}-04$ & 3.51 \\
\hline 357 & $88 \cdot 16$ & 4. $77 E-84$ & 3.59 & 4. $32 E-04$ & 3.76 \\
\hline 358 & 88.41 & 4. $21 E-04$ & 3.95 & $3.71 E-04$ & $4 \cdot 17$ \\
\hline 359 & 88.65 & $3.48 E-04$ & $4 \cdot 26$ & 3. $56 \mathrm{E}-04$ & 3.92 \\
\hline 360 & $88 \cdot 90$ & $2.98 k-04$ & 4.46 & $3.05 E-04$ & 4. 51 \\
\hline
\end{tabular}


Table A-13. Axial distribution of ${ }^{60} \mathrm{Co}$ in bottom connector of element FO3-OI

(corrected to October 31, 1974)

\begin{tabular}{|c|c|c|c|c|c|}
\hline \multirow[b]{2}{*}{ Location } & \multirow[b]{2}{*}{$\begin{array}{l}\text { Distance } \\
\text { (in.) }\end{array}$} & \multicolumn{2}{|c|}{ Plane 1} & \multicolumn{2}{|c|}{ Plane 2} \\
\hline & & $\begin{array}{l}\text { Inventory } \\
\text { ( } \mathrm{Ci} / 3 \text { in.) }\end{array}$ & $\begin{array}{c}\text { Error } \\
(\%)\end{array}$ & $\begin{array}{l}\text { Inventory } \\
\text { (Ci/3 in.) }\end{array}$ & $\begin{array}{c}\text { Error } \\
(\%)\end{array}$ \\
\hline 1 & 0.12 & $2.57 \mathrm{k}-05$ & 12.1 & 8. $66 \mathrm{E}-05$ & $6 \cdot 8$ \\
\hline 2 & 0.37 & 3. $44 \mathrm{E}-05$ & $10 \cdot 2$ & 1. $28 E-05$ & $31 \cdot 0$ \\
\hline 3 & 0.61 & 5. $19 \mathrm{E}-05$ & 8.2 & 2. $08 k-05$ & 18.1 \\
\hline 4 & 0.86 & $6.31 E-05$ & 7.5 & $2.51 E-05$ & 15.8 \\
\hline 5 & 1.11 & $5.96 \mathrm{E}-05$ & $7 \cdot 4$ & $2.81 E-05$ & $15 \cdot 3$ \\
\hline 6 & 1.35 & 5. $01 E-05$ & 11.0 & 2. $54 E-05$ & $17 \cdot 5$ \\
\hline 7 & 1.60 & 7. $68 \mathrm{E}-05$ & $7 \cdot 4$ & 4. $04 E-05$ & 12.0 \\
\hline 8 & 1.84 & $8.95 E-05$ & $6 \cdot 3$ & $1.97 \mathrm{E}-05$ & $27 \cdot 1$ \\
\hline 9 & 2.09 & $9.53 E-05$ & 6.4 & $4.10 E-05$ & $12 \cdot 4$ \\
\hline 10 & 2.34 & $1.13 \mathrm{E}-04$ & $5 \cdot 4$ & 3. $93 E-05$ & $12 \cdot 8$ \\
\hline 11 & $2 \cdot 58$ & $1.02 \mathrm{E}-04$ & $6 \cdot 1$ & $2.70 E-05$ & $16 \cdot 4$ \\
\hline 12 & 2.83 & $1.09 E-04$ & 6.1 & 3. $18 E-05$ & 14.1 \\
\hline 13 & 3.07 & $8.96 \mathrm{E}-05$ & $6 \cdot 8$ & 3. $11 E-05$ & $13 \cdot 2$ \\
\hline 14 & $3 \cdot 32$ & $5.50 \mathrm{E}-05$ & $10 \cdot 4$ & $2.03 E-05$ & $21 \cdot 3$ \\
\hline 15 & 3.57 & $7.25 E-05$ & 6.9 & 2. $26 E-05$ & 16.5 \\
\hline 16 & 3.81 & 7. $67 \mathrm{E}-05$ & $6 \cdot 5$ & $2 \cdot 46 E-05$ & $14 \cdot 3$ \\
\hline 17 & 4.06 & $5 \cdot 21 E-05$ & 9.0 & $1.90 E-05$ & 18.1 \\
\hline 18 & $4 \cdot 30$ & $5.41 E-05$ & 8.0 & 1. $35 E-05$ & $25 \cdot 2$ \\
\hline 19 & 4. 55 & $4.86 k-05$ & $8 \cdot 3$ & $1.04 E-05$ & 24.0 \\
\hline 20 & 4.80 & $2.96 E-05$ & 12.8 & $1.35 E-05$ & 23.9 \\
\hline 21 & 5.04 & $1.87 E-05$ & 20.5 & $9.94 E-06$ & 27.3 \\
\hline 22 & $5 \cdot 29$ & $2.94 \mathrm{E}-05$ & 11.0 & $1.52 E-05$ & $21 \cdot 4$ \\
\hline 23 & 5.53 & $2.95 E-05$ & $11 \cdot 0$ & $1.26 \mathrm{k}-05$ & $26 \cdot 7$ \\
\hline 24 & $5 \cdot 78$ & $2.88 E-05$ & 12.9 & 1. $53 \mathrm{E}-05$ & $22 \cdot 8$ \\
\hline 25 & 6.02 & $3.07 E-05$ & 10.8 & 1. $22 k-05$ & 30.5 \\
\hline 26 & 6.27 & $1.08 t-05$ & $36 \cdot 4$ & $3 \cdot 15 E-05$ & $13 \cdot 5$ \\
\hline 27 & 6.52 & $3.77 \mathrm{E}-05$ & 10.5 & 3. $49 t-05$ & 13.4 \\
\hline 28 & $6 \cdot 76$ & $4.50 E-05$ & 9.4 & 3. $41 \mathrm{E}-05$ & 14.9 \\
\hline 29 & 7.01 & $6.37 t-05$ & $7 \cdot 8$ & 5. $93 E-05$ & 10.6 \\
\hline 30 & 7.25 & 7. $16 \mathrm{E}-05$ & 7.5 & $6.65 k-05$ & 9.9 \\
\hline 31 & 7.50 & $7.91 t-05$ & $8 \cdot 3$ & $8 \cdot 28 E-05$ & $9 \cdot 9$ \\
\hline 32 & $7 \cdot 75$ & $9.29 E-05$ & $7 \cdot 2$ & $8 \cdot 78 t-05$ & 9.6 \\
\hline 33 & 7.99 & 1. $31 \mathrm{E}-04$ & 5.8 & $8.04 E-05$ & $11 \cdot 6$ \\
\hline 34 & $8 \cdot 24$ & $1.63 \mathrm{E}-04$ & $5 \cdot 4$ & $1.41 E-04$ & $8 \cdot 5$ \\
\hline 35 & $8 \cdot 48$ & $1.90 E-04$ & 4.9 & 2. $19 E-04$ & $7 \cdot 5$ \\
\hline 36 & $8 \cdot 73$ & $1.84 \mathrm{E}-04$ & $5 \cdot 4$ & $2.47 E-04$ & $9 \cdot 5$ \\
\hline 37 & 8.98 & $2.35 \mathrm{E}-04$ & 4.6 & $3.67 \mathrm{E}-04$ & 8.9 \\
\hline 38 & 9.22 & $3.55 E-04$ & 3.9 & 3. $23 E-04$ & 12.6 \\
\hline 39 & 9.47 & $5 \cdot 13 E-04$ & 3.4 & 3. $60 E-04$ & $13 \cdot 2$ \\
\hline 40 & 9.71 & 2. $03 E-04$ & $10 \cdot 6$ & 3. $45 k-04$ & $22 \cdot 6$ \\
\hline 41 & 9.96 & $6.56 E-04$ & $5 \cdot 8$ & 8. $52 E-04$ & $13 \cdot 1$ \\
\hline 42 & 10.20 & $6.09 E-04$ & 6.8 & 1. $76 \mathrm{E}-02$ & 9.7 \\
\hline 43 & 10.45 & $6.20 \mathrm{E}-04$ & $7 \cdot 9$ & $2 \cdot 22 E+00$ & 0.9 \\
\hline 44 & 10.70 & $1.11 E-03$ & 8.1 & 1. $56 E-03$ & $7 \cdot 3$ \\
\hline 45 & 10.94 & $5.83 \mathrm{k}-03$ & 6.5 & $1 \cdot 19 L-03$ & 7.0 \\
\hline 46 & 11.19 & $3.09 \mathrm{E}-04$ & $19 \cdot 7$ & $1 \cdot 33 E-03$ & $5 \cdot 1$ \\
\hline 47 & 11.43 & 2. $01 E-03$ & $4 \cdot 4$ & $2.08 E-03$ & $3 \cdot 3$ \\
\hline 48 & 11.68 & $1.81 \mathrm{E}-03$ & $3 \cdot 5$ & 1. $63 E-03$ & 3.8 \\
\hline 49 & 11.93 & $1.85 E-03$ & $3 \cdot 5$ & $1.21 E-03$ & $4 \cdot 1$ \\
\hline
\end{tabular}


Table A-13 (continued)

\begin{tabular}{|c|c|c|c|c|c|}
\hline \multirow[b]{2}{*}{ Location } & \multirow[b]{2}{*}{$\begin{array}{l}\text { Distance } \\
\text { (in.) }\end{array}$} & \multicolumn{2}{|c|}{ Plane I } & \multicolumn{2}{|c|}{ Plane 2} \\
\hline & & $\begin{array}{l}\text { Inventory } \\
\text { ( } \mathrm{Ci} / 3 \text { in.) }\end{array}$ & $\begin{array}{c}\text { Error } \\
(\%)\end{array}$ & $\begin{array}{l}\text { Inventory } \\
\text { ( } \mathrm{Ci} / 3 \text { in.) }\end{array}$ & $\begin{array}{c}\text { Error } \\
(\%)\end{array}$ \\
\hline 50 & $12 \cdot 17$ & $3.39 E-03$ & $2 \cdot 3$ & $1.20 \mathrm{E}-03$ & $4 \cdot 3$ \\
\hline 51 & $12 \cdot 42$ & $2.76 \mathrm{E}-03$ & $2 \cdot 6$ & $1.71 E-03$ & 1.9 \\
\hline 52 & 12.66 & $2.76 \mathrm{E}-03$ & $1 \cdot 4$ & $1.85 \mathrm{E}-03$ & $1 \cdot 7$ \\
\hline 53 & 12.91 & 2. $48 k-03$ & $1 \cdot 4$ & $1.83 \mathrm{E}-03$ & 1.6 \\
\hline 54 & $13 \cdot 16$ & 2. $42 E-03$ & $1 \cdot 4$ & $1.90 \mathrm{E}-03$ & 1.6 \\
\hline 55 & $13 \cdot 40$ & $2.37 E-03$ & 1.4 & $1.89 E-03$ & $1 \cdot 6$ \\
\hline 56 & 13.65 & 2. $55 \mathrm{E}-03$ & $1 \cdot 3$ & $2.01 E-03$ & 1.5 \\
\hline 57 & 13.89 & $2.50 E-03$ & $1 \cdot 3$ & $1.99 \mathrm{E}-03$ & 1.5 \\
\hline 58 & 14.14 & 2. $37 E-03$ & $1 \cdot 3$ & $1.80 \mathrm{E}-03$ & 1.6 \\
\hline 59 & 14.39 & $2.41 \mathrm{E}-03$ & $1 \cdot 3$ & $1.81 E-03$ & 1.5 \\
\hline 60 & 14.63 & $2.29 \mathrm{E}-03$ & $1 \cdot 3$ & $1.84 E-03$ & $1 \cdot 5$ \\
\hline 61 & 14.88 & $2.20 \mathrm{E}-03$ & $1 \cdot 3$ & $2.10 \mathrm{E}-03$ & 1.4 \\
\hline 62 & $15 \cdot 12$ & $2.21 E-03$ & $1 \cdot 3$ & $2.05 E-03$ & 1.4 \\
\hline 63 & $15 \cdot 37$ & 2. $28 \mathrm{E}-03$ & $1 \cdot 3$ & $2.05 \mathrm{E}-03$ & 1.4 \\
\hline 64 & $15 \cdot 61$ & 2. $30 \mathrm{E}-03$ & $1 \cdot 3$ & $2.04 \mathrm{E}-03$ & 1.4 \\
\hline 65 & 15.86 & $2.30 \mathrm{E}-03$ & $1 \cdot 3$ & $2.28 \mathrm{E}-03$ & $1 \cdot 3$ \\
\hline 66 & 16.11 & $2.17 E-03$ & $1 \cdot 3$ & $2.07 E-03$ & $1 \cdot 4$ \\
\hline 67 & $16 \cdot 35$ & $2.20 \mathrm{E}-03$ & $1 \cdot 3$ & $2.04 E-03$ & 1.4 \\
\hline 68 & $16 \cdot 60$ & $2.33 \mathrm{E}-03$ & $1 \cdot 3$ & $2 \cdot 12 E-03$ & 1.4 \\
\hline 69 & 16.84 & $2.27 \mathrm{E}-03$ & $1 \cdot 3$ & $2.23 \mathrm{E}-03$ & $1 \cdot 3$ \\
\hline 70 & 17.09 & $2.35 \mathrm{E}-03$ & $1 \cdot 2$ & 2. $15 E-03$ & $1 \cdot 3$ \\
\hline 71 & $17 \cdot 34$ & $2.37 E-03$ & $1 \cdot 3$ & $2.41 E-03$ & $1 \cdot 3$ \\
\hline 72 & $17 \cdot 58$ & 2. $45 E-03$ & $1 \cdot 2$ & $2.19 E-03$ & 1.4 \\
\hline 73 & 17.83 & 2. $42 E-03$ & $1 \cdot 2$ & 2. $45 E-03$ & $1 \cdot 3$ \\
\hline 74 & 18.07 & $2.37 k-03$ & $1 \cdot 3$ & $2 \cdot 33 E-03$ & $1 \cdot 3$ \\
\hline 75 & $18 \cdot 32$ & $2.47 E-03$ & $1 \cdot 2$ & $2.51 E-03$ & $1 \cdot 3$ \\
\hline 76 & $18 \cdot 57$ & 2. $46 E-03$ & $1 \cdot 2$ & 2. $32 E-03$ & 1.4 \\
\hline 77 & 18.81 & $2.57 \mathrm{E}-03$ & $1 \cdot 2$ & $2.34 E-03$ & $1 \cdot 4$ \\
\hline 78 & 19.06 & $2.65 E-03$ & $1 \cdot 2$ & 2. $24 E-03$ & $1 \cdot 4$ \\
\hline 79 & $19 \cdot 30$ & $2.83 E-03$ & $1 \cdot 1$ & $2.05 E-03$ & 1.4 \\
\hline 80 & 19.55 & $2.87 E-03$ & $1 \cdot 1$ & $1.68 \mathrm{E}-03$ & 1.5 \\
\hline 81 & 19.79 & $2.71 \mathrm{E}-03$ & $1 \cdot 2$ & $1.71 \mathrm{E}-03$ & 1.5 \\
\hline 82 & 20.04 & $2.61 E-03$ & $1 \cdot 2$ & $1.71 E-03$ & 1.5 \\
\hline 83 & 20.29 & 2. $41 E-03$ & $1 \cdot 3$ & 1. $70 \mathrm{E}-03$ & 1.5 \\
\hline 84 & 20.53 & $2.16 \mathrm{E}-03$ & 1.3 & $1.61 E-03$ & 1.5 \\
\hline 85 & $20 \cdot 78$ & $1.90 E-03$ & $1 \cdot 4$ & $1.69 E-03$ & 1.5 \\
\hline 86 & 21.02 & $1.91 k-03$ & $1 \cdot 4$ & $1.72 E-03$ & 1.5 \\
\hline 87 & $21 \cdot 27$ & $1.90 \mathrm{E}-03$ & 1.4 & $1.63 E-03$ & 1.6 \\
\hline 88 & 21.52 & $1.91 \mathrm{E}-03$ & 1.4 & 1. $62 E-03$ & 1.6 \\
\hline 89 & $21 \cdot 76$ & $1.85 k-03$ & $1 \cdot 4$ & $1.40 E-03$ & 1.9 \\
\hline 90 & 22.01 & $1.88 E-03$ & 1.4 & $6.32 E-05$ & $* * * *$ \\
\hline 91 & $22 \cdot 25$ & $1.89 E-03$ & 1.4 & $7.81 E-04$ & $2 \cdot 3$ \\
\hline 92 & $22 \cdot 50$ & $1.83 k-03$ & $1 \cdot 4$ & $8.25 E-04$ & $2 \cdot 0$ \\
\hline 93 & $22 \cdot 75$ & $1.87 \mathrm{E}-03$ & $1 \cdot 4$ & $6.46 E-04$ & 3.0 \\
\hline 94 & 22.99 & $1.75 \mathrm{E}-03$ & 1.6 & $6.08 E-04$ & 3.0 \\
\hline 95 & $23 \cdot 24$ & $1.32 E-03$ & 2. 4 & $2.97 E-04$ & $4 \cdot 2$ \\
\hline 96 & 23.48 & $6.86 E-04$ & $4 \cdot 4$ & $9.49 E-06$ & $* * *$ \\
\hline 97 & 23.73 & $9.03 E-04$ & 2.6 & 4. $07 E-06$ & $* * * *$ \\
\hline 98 & 23.98 & $7.95 E-04$ & $2 \cdot 5$ & $3.10 E-06$ & $* * * *$ \\
\hline
\end{tabular}


Table A-14. Axial distribution of ${ }^{110 \mathrm{~m}} \mathrm{Ag}$ in bottom connector of element $\mathrm{FO}-\mathrm{OI}$

(corrected to october 31, 1974)

\begin{tabular}{|c|c|c|c|c|c|}
\hline \multirow[b]{2}{*}{ Location } & \multirow[b]{2}{*}{$\begin{array}{c}\text { Distance } \\
\text { (in.) }\end{array}$} & \multicolumn{2}{|c|}{ Plane 1} & \multicolumn{2}{|c|}{ Plane 2} \\
\hline & & $\begin{array}{l}\text { Inventory } \\
\text { ( } \mathrm{Ci} / 3 \text { in.) }\end{array}$ & $\begin{array}{c}\text { Error } \\
(\%)\end{array}$ & $\begin{array}{l}\text { Inventory } \\
\text { (Ci/3 in.) }\end{array}$ & $\begin{array}{c}\text { Error } \\
(\%)\end{array}$ \\
\hline 1 & 0.12 & $2.98 k-05$ & $* * * *$ & $4.67 \mathrm{E}-05$ & $* * * *$ \\
\hline 2 & 0.37 & 3. $13 E-05$ & $* * * *$ & 4. $15 E-05$ & $* * * *$ \\
\hline 3 & 0.61 & 3. $72 E-05$ & $* * * *$ & 4. $48 \mathrm{E}-05$ & $* * *$ \\
\hline 4 & 0.86 & $4 \cdot 27 E-05$ & $* * * *$ & $5.04 E-05$ & $* * * *$ \\
\hline 5 & $1 \cdot 11$ & 3. $94 \mathrm{E}-05$ & $* * * *$ & 5. $47 E-05$ & $* * * *$ \\
\hline 6 & 1.35 & $4 \cdot 60 E-05$ & **** & 5. $53 \mathrm{E}-05$ & $* * * *$ \\
\hline 7 & 1.60 & $5.20 E-05$ & $* * *$ & $6.05 E-05$ & $* * * *$ \\
\hline 8 & 1.84 & 5. $30 E-05$ & **** & $6.29 E-05$ & $* * * *$ \\
\hline 9 & 2.09 & 5. $97 E-05$ & **** & $6.67 E-05$ & $* * *$ \\
\hline 10 & $2 \cdot 34$ & $6.08 E-05$ & **** & $6.24 E-05$ & $* * * *$ \\
\hline 11 & 2.58 & $6.11 E-05$ & $* * * *$ & $6.74 E-05$ & $* * * *$ \\
\hline 12 & 2.83 & $6 \cdot 16 E-05$ & **** & $6.28 E-05$ & $* * * *$ \\
\hline 13 & 3.07 & $6.27 E-05$ & **** & 6. $07 E-05$ & $* * * *$ \\
\hline 14 & 3. 32 & $6 \cdot 17 E-05$ & $* * * *$ & $5.91 E-05$ & $* * * *$ \\
\hline 15 & 3. 57 & 5. $72 E-05$ & $\# * *$ & 5. $36 \mathrm{E}-05$ & $* * * *$ \\
\hline 16 & 3.81 & 5. $93 E-05$ & $* * * *$ & $5.28 E-05$ & $* * * *$ \\
\hline 17 & 4. 06 & 5. $36 E-05$ & $* * * *$ & $5.26 \mathrm{E}-05$ & $* * * *$ \\
\hline 18 & 4. 30 & 5. $08 \mathrm{E}-05$ & \#*** & 4. $61 \mathrm{E}-05$ & $* * * *$ \\
\hline 19 & $4 \cdot 55$ & 5. $04 E-05$ & **** & $4.90 \mathrm{E}-05$ & **** \\
\hline 20 & 4.80 & $4.80 E-05$ & $* * * *$ & 4. $50 \mathrm{E}-05$ & $* * * *$ \\
\hline 21 & 5.04 & 4. $79 E-05$ & $* * * *$ & $7 \cdot 43 E-05$ & $27 \cdot 5$ \\
\hline 22 & $5 \cdot 29$ & $4.66 E-05$ & $* * *$ & $5.00 E-05$ & **** \\
\hline 23 & 5.53 & 4. $77 E-05$ & $* * * *$ & $5 \cdot 27 k-05$ & $* * *$ \\
\hline 24 & $5 \cdot 78$ & 4. $69 E-05$ & $* * * *$ & 5. $71 E-05$ & **** \\
\hline 25 & 6.02 & 4. $75 E-05$ & $* * * *$ & $6 \cdot 51 E-05$ & $* * * *$ \\
\hline 26 & $6 \cdot 27$ & 5. $14 E-05$ & $* * * *$ & 7. $57 \mathrm{E}-05$ & **** \\
\hline 27 & 6.52 & 5. $38 E-05$ & $* * * *$ & $8 \cdot 68 E-05$ & $* * * *$ \\
\hline 28 & $6 \cdot 76$ & $6 \cdot 17 E-05$ & $* * * *$ & $9.69 \mathrm{E}-05$ & $* * * *$ \\
\hline 29 & 7.01 & 6. $53 E-05$ & $* * * *$ & 1. $19 E-04$ & $* * *$ \\
\hline 30 & $7 \cdot 25$ & 8. $14 \mathrm{E}-05$ & $* * * *$ & $1.37 \mathrm{E}-04$ & ***** \\
\hline 31 & $7 \cdot 50$ & $9.03 E-05$ & $* * * *$ & $1.66 E-04$ & **** \\
\hline 32 & 7.75 & $1.03 E-04$ & $* * * *$ & $1.88 E-04$ & ***** \\
\hline 33 & 7.99 & 1. $19 E-04$ & $* * * *$ & $2.26 E-04$ & $* * * *$ \\
\hline 34 & $8 \cdot 24$ & 1. $45 E-04$ & $* * * *$ & 2. $71 E-04$ & $* * * *$ \\
\hline 35 & $8 \cdot 48$ & $1.70 E-04$ & $* * * *$ & 3. $43 E-04$ & $\# * * *$ \\
\hline 36 & $8 \cdot 73$ & 2. $03 E-04$ & $* * * *$ & 4. $26 E-04$ & ***** \\
\hline 37 & 8.98 & 2. $38 \mathrm{E}-04$ & ***** & $\begin{array}{l}\text { 5. } 64 E-04 \\
8.95 E-04\end{array}$ & ***** \\
\hline 38 & $9 \cdot 22$ & $2.90 \mathrm{E}-04$ & ***** & $\begin{array}{l}8.95 E-04 \\
1.20 E-03\end{array}$ & ****** \\
\hline 39 & $9 \cdot 47$ & 3. $58 E-04$ & $\begin{array}{l}* * * * \\
* * * *\end{array}$ & $\begin{array}{l}1.20 E-03 \\
1.69 E-03\end{array}$ & $* * * *$ \\
\hline 40 & $9 \cdot 71$ & $6.66 E-04$ & $\begin{array}{l}* * * * \\
35.4\end{array}$ & $\begin{array}{l}\text { 1. } 69 E-03 \\
\text { 2. } 62 E-03\end{array}$ & $* * *$ \\
\hline 41 & 9.96 & & $\begin{array}{l}35 \cdot 4 \\
* * * *\end{array}$ & $\begin{array}{l}\text { 2. } 62 E-03 \\
\text { 3. } 56 E-02\end{array}$ & ***** \\
\hline $\begin{array}{l}42 \\
43\end{array}$ & $\begin{array}{l}10.20 \\
10.45\end{array}$ & $\begin{array}{l}1.20 \mathrm{E}-03 \\
1.69 \mathrm{E}-03\end{array}$ & $* * * *$ & $1.17 E-01$ & $* * * *$ \\
\hline 44 & 10.70 & $2.62 \mathrm{E}-03$ & $* * * *$ & $2 \cdot 36 \mathrm{E}-03$ & $* * * *$ \\
\hline 45 & 10.94 & $9.67 E-03$ & **** & $1.57 \mathrm{E}-03$ & $* * * *$ \\
\hline 46 & 11.19 & $5.85 E-04$ & **** & $1.17 E-03$ & ***** \\
\hline 47 & 11.43 & 2. $31 E-03$ & $* * * *$ & $9.86 E-04$ & **** \\
\hline 48 & 11.68 & $1.51 \mathrm{E}-03$ & **** & $8.01 E-04$ & **** \\
\hline 49 & 11.93 & $1.15 E-03$ & $* * * *$ & $6.66 \mathrm{k}-04$ & $* * * *$ \\
\hline
\end{tabular}


Table A-14 (continued)

\begin{tabular}{|c|c|c|c|c|c|}
\hline \multirow[b]{2}{*}{ Location } & \multirow[b]{2}{*}{$\begin{array}{c}\text { Distance } \\
\text { (in.) }\end{array}$} & \multicolumn{2}{|c|}{ Plane 1} & \multicolumn{2}{|c|}{ Plane 2} \\
\hline & & $\begin{array}{l}\text { Inventory } \\
\text { (Ci/3 in.) }\end{array}$ & $\begin{array}{c}\text { Error } \\
(\%)\end{array}$ & $\begin{array}{l}\text { Inventory } \\
\text { (Ci/3 in.) }\end{array}$ & $\begin{array}{c}\text { Error } \\
(\%)\end{array}$ \\
\hline 50 & $12 \cdot 17$ & $9.59 E-04$ & $* * * *$ & $5 \cdot 83 E-04$ & $* * * *$ \\
\hline 51 & $12 \cdot 42$ & $7.91 E-04$ & $* * * *$ & 3. $70 E-04$ & $* * * *$ \\
\hline 52 & 12.66 & $4.80 E-04$ & **** & 3. $45 E-04$ & $* * * *$ \\
\hline 53 & $12 \cdot 91$ & 4. $17 E-04$ & $* * * *$ & $3.17 \mathrm{E}-04$ & $* * * *$ \\
\hline 54 & 13.16 & $3.82 E-04$ & $* * * *$ & $2.97 E-04$ & $* * * *$ \\
\hline 55 & 13.40 & $3.55 E-04$ & $* * * *$ & 2. $83 E-04$ & $* * * *$ \\
\hline 56 & 13.65 & 3. $35 E-04$ & $* * * *$ & $2.77 \mathrm{E}-04$ & **** \\
\hline 57 & 13.89 & $3.11 \mathrm{E}-04$ & $* * *$ & $2.69 E-04$ & $* * * *$ \\
\hline 58 & $14 \cdot 14$ & $2.95 E-04$ & **** & 2. $55 E-04$ & $* * * *$ \\
\hline 59 & 14.39 & $2.82 E-04$ & $* * * *$ & $2.57 E-04$ & $* * * *$ \\
\hline 60 & 14.63 & $2.71 \mathrm{E}-04$ & $* * * *$ & 2. $53 E-04$ & **** \\
\hline 61 & 14.88 & $2.64 E-04$ & **** & 2. $53 \mathrm{E}-04$ & **** \\
\hline 62 & $15 \cdot 12$ & $2 \cdot 59 E-04$ & $* * * *$ & 2. $53 \mathrm{E}-04$ & $* * * *$ \\
\hline 63 & $15 \cdot 37$ & $2.61 E-04$ & $* * * *$ & 2. $52 E-04$ & $* * * *$ \\
\hline 64 & 15.61 & $2.62 E-04$ & $* * * *$ & 2. $52 E-04$ & **** \\
\hline 65 & 15.86 & $2 \cdot 59 E-04$ & $* * * *$ & $2.58 E-04$ & $* * * *$ \\
\hline 66 & 16.11 & $2.53 E-04$ & $* * * *$ & $2.63 E-04$ & **** \\
\hline 67 & $16 \cdot 35$ & 2. $47 \mathrm{E}-04$ & **** * & 2. $59 E-04$ & $* * * *$ \\
\hline 68 & $16 \cdot 60$ & $2.55 E-04$ & **** & $2.60 E-04$ & **** \\
\hline 69 & 16084 & $2 \cdot 56 E-04$ & $* * * *$ & 2. $60 E-04$ & $* * * *$ \\
\hline 70 & 17.09 & $2.63 E-04$ & $* * * *$ & 2. $62 E-04$ & $* * * *$ \\
\hline 71 & $17 \cdot 34$ & $2.64 E-04$ & $* * * *$ & 2. $72 \mathrm{E}-04$ & $* * * *$ \\
\hline 72 & $17 \cdot 58$ & 2. $59 E-04$ & $* * * *$ & $2 \cdot 63 E-04$ & $* * * *$ \\
\hline 73 & 17.83 & 2. $64 E-04$ & **** & $2.71 \mathrm{E}-04$ & **** * * \\
\hline 74 & 18.07 & $2.65 E-04$ & $* * * *$ & 2. $78 \mathrm{E}-04$ & $* * * *$ \\
\hline 75 & $18 \cdot 32$ & 2. $79 \mathrm{E}-04$ & $* * * *$ & $2 \cdot 84 E-04$ & $* * * *$ \\
\hline 76 & $18 \cdot 57$ & 2. $79 E-04$ & $* * * *$ & $2.86 E-04$ & $* * * *$ \\
\hline 77 & 18.81 & $2.79 E-04$ & $* * * *$ & $2.98 \mathrm{k}-04$ & $* * *$ \\
\hline 78 & 19.06 & $2.84 \mathrm{E}-04$ & $* * * *$ & $2.93 E-04$ & $* * * *$ \\
\hline 79 & 19.30 & $2.89 E-04$ & $* * *$ & $2.43 E-04$ & $* * * *$ \\
\hline 80 & $19 \cdot 55$ & $2.92 \mathrm{E}-04$ & $* * * *$ & $1.87 E-04$ & $* * * *$ \\
\hline 81 & 19.79 & $2.97 E-04$ & $* * *$ & $1.75 E-04$ & $* * * *$ \\
\hline 82 & $20 \cdot 04$ & $2.95 E-04$ & **** & 1. $74 E-04$ & **** \\
\hline 83 & $20 \cdot 29$ & $2.75 E-04$ & $* * * *$ & 1. $73 E-04$ & $* * * *$ \\
\hline 84 & $20 \cdot 53$ & 2. $32 E-04$ & $* * * *$ & 1. $77 E-04$ & $* * *$ \\
\hline 85 & $20 \cdot 78$ & $1.90 \mathrm{E}-04$ & $* * * *$ & 1. $78 E-04$ & $* * *$ \\
\hline 86 & $21 \cdot 02$ & $1.83 \mathrm{E}-04$ & $* * * *$ & $1.86 E-04$ & $* * * *$ \\
\hline 87 & $21 \cdot 27$ & $1.81 E-04$ & **** & $1.84 E-04$ & $* * * *$ \\
\hline 88 & $21 \cdot 52$ & $1.82 E-04$ & $* * * *$ & $1.92 E-04$ & $* * * *$ \\
\hline 89 & $21 \cdot 76$ & $1.83 E-04$ & $* * * *$ & $2 \cdot 43 E-04$ & $* * * *$ \\
\hline 90 & $22 \cdot 01$ & 1. $86 E-04$ & $* * * *$ & $6.05 E-04$ & $* * * *$ \\
\hline 91 & $22 \cdot 25$ & $1.90 E-04$ & **** & 3. $49 \mathrm{E}-04$ & $* * * *$ \\
\hline 92 & $22 \cdot 50$ & 1. $94 E-04$ & $* * * *$ & $1.80 E-04$ & $* * * *$ \\
\hline 93 & $22 \cdot 75$ & $1.95 E-04$ & $* * *$ & $1.60 E-04$ & $* * * *$ \\
\hline 94 & $22 \cdot 99$ & 2. $33 E-04$ & $* * * *$ & $1.46 \mathrm{E}-04$ & $* * * *$ \\
\hline 95 & $23 \cdot 24$ & 4. $12 E-04$ & **** & $9.77 E-05$ & $* * * *$ \\
\hline 96 & $23 \cdot 48$ & 4. $76 E-04$ & **** * & $3.90 \mathrm{E}-05$ & $* * * *$ \\
\hline 97 & 23.73 & $2 \cdot 94 E-04$ & $* * * *$ & $2.66 \mathrm{E}-05$ & $* * * *$ \\
\hline 98 & $23 \cdot 98$ & 2. $10 E-04$ & $* * * *$ & $2.05 E-05$ & $* * * *$ \\
\hline
\end{tabular}


Table A-15. Axial distribution of ${ }^{134} \mathrm{Cs}$ in bottom connector of element $\mathrm{FO}-\mathrm{Ol}$

(corrected to October 31, 1974)

\begin{tabular}{|c|c|c|c|c|c|}
\hline \multirow[b]{2}{*}{ Location } & \multirow[b]{2}{*}{$\begin{array}{l}\text { Distance } \\
\text { (in.) }\end{array}$} & \multicolumn{2}{|c|}{ Plane I } & \multicolumn{2}{|c|}{ Plane 2} \\
\hline & & $\begin{array}{l}\text { Inventory } \\
\text { ( } \mathrm{Ci} / 3 \text { in.) }\end{array}$ & $\underset{(\%)}{\operatorname{Error}}$ & $\begin{array}{l}\text { Inventory } \\
\text { (Ci/3 in.) }\end{array}$ & $\begin{array}{c}\text { Error } \\
(\%)\end{array}$ \\
\hline 1 & 0.12 & $7 \cdot 12 E-06$ & $* * * *$ & 2. $78 E-04$ & 3.6 \\
\hline 2 & 0.37 & $8.27 E-06$ & $* * * *$ & 7. $39 \mathrm{E}-05$ & 8.0 \\
\hline 3 & 0.61 & $1.40 \mathrm{E}-04$ & $5 \cdot 3$ & $6.29 E-05$ & 8.9 \\
\hline 4 & 0.86 & $1.90 E-04$ & 4.6 & $5.46 \mathrm{E}-05$ & $10 \cdot 3$ \\
\hline 5 & $1 \cdot 11$ & $5.01 k-05$ & 11.6 & 4. $02 E-05$ & $14 \cdot 6$ \\
\hline 6 & 1.35 & $5.62 k-05$ & $11 \cdot 5$ & 4. $40 t-05$ & $13 \cdot 8$ \\
\hline 7 & 1.60 & 2. $70 E-05$ & 20.2 & 5. $56 k-05$ & 11.8 \\
\hline 8 & 1.84 & 3. $39 k-05$ & 16.7 & 3. $87 E-05$ & 16.6 \\
\hline 9 & 2.09 & $1.93 \mathrm{E}-05$ & $29 \cdot 5$ & 4. $00 \mathrm{E}-05$ & $15 \cdot 1$ \\
\hline 10 & $2 \cdot 34$ & $2 \cdot 28 \mathrm{k}-05$ & 23.3 & 3. $72 \mathrm{E}-05$ & 19.8 \\
\hline 11 & $2 \cdot 58$ & 4. $56 E-05$ & $15 \cdot 6$ & 3. $43 E-05$ & $18 \cdot 0$ \\
\hline 12 & 2.83 & $3.04 t-05$ & $24 \cdot 3$ & 3. $53 E-05$ & $18 \cdot 1$ \\
\hline 13 & 3.07 & 3. $00 E-05$ & 24.5 & 3. $30 \mathrm{E}-05$ & $22 \cdot 6$ \\
\hline 14 & 3.32 & $4 \cdot 16 E-05$ & 17.9 & $3.08 E-05$ & $20 \cdot 1$ \\
\hline 15 & 3.57 & $4 \cdot 80 \mathrm{E}-05$ & $16 \cdot 1$ & 3. $72 E-05$ & $17 \cdot 3$ \\
\hline 16 & 3.81 & 2. $00 \mathrm{E}-05$ & $29 \cdot 5$ & 3. $65 E-05$ & $17 \cdot 4$ \\
\hline 17 & 4.06 & 4. $12 \mathrm{E}-05$ & 19.0 & 3. $02 E-05$ & $25 \cdot 6$ \\
\hline 18 & $4 \cdot 30$ & $4.91 \mathrm{E}-05$ & 16.0 & 2. $49 \mathrm{E}-05$ & $24 \cdot 1$ \\
\hline 19 & $4 \cdot 55$ & $2.92 E-05$ & $26 \cdot 4$ & $3.60 \mathrm{E}-05$ & $18 \cdot 4$ \\
\hline 20 & $4 \cdot 80$ & 6. $46 E-05$ & $11 \cdot 3$ & 3. $28 E-05$ & $22 \cdot 1$ \\
\hline 21 & 5.04 & $2.90 E-05$ & 23.0 & 3. $64 \mathrm{E}-05$ & $23 \cdot 1$ \\
\hline 22 & $5 \cdot 29$ & 3. $79 E-05$ & $18 \cdot 4$ & 4. $73 E-05$ & $19 \cdot 4$ \\
\hline 23 & 5.53 & 2. $03 E-05$ & $32 \cdot 2$ & 2. $28 E-05$ & $* * * *$ \\
\hline 24 & $5 \cdot 78$ & $3.85 \mathrm{E}-05$ & 23.0 & $2 \cdot 34 \mathrm{E}-05$ & $37 \cdot 3$ \\
\hline 25 & 6.02 & 2. $51 E-05$ & $30 \cdot 3$ & 3. $77 \mathrm{E}-05$ & 33.5 \\
\hline 26 & $6 \cdot 27$ & 3. $72 E-05$ & $27 \cdot 6$ & 3. $07 E-05$ & **** \\
\hline 27 & 6.52 & $2 \cdot \angle 7 E-05$ & $34 \cdot 3$ & 3. $49 t-05$ & $* * * *$ \\
\hline 28 & 6.76 & $3.65 \mathrm{E}-05$ & $31 \cdot 7$ & 6. $66 E-05$ & 27.0 \\
\hline 29 & 7.01 & $6.94 E-05$ & $18 \cdot 4$ & 4. $44 E-05$ & $* * *$ \\
\hline 30 & $7 \cdot 25$ & $5 \cdot 41 E-05$ & $27 \cdot 0$ & $5 \cdot C 7 E-05$ & $* * * *$ \\
\hline 31 & $7 \cdot 50$ & $4 \cdot 46 E-05$ & $36 \cdot 8$ & $6 \cdot 94 E-05$ & $38 \cdot \%$ \\
\hline 32 & $7 \cdot 75$ & $3.09 E-05$ & $* * * *$ & 6. $58 \mathrm{E}-05$ & $* * * *$ \\
\hline 33 & 7.99 & 4. $47 E-05$ & $* * *$ & 7. $56 z-05$ & **** \\
\hline 34 & $8 \cdot 24$ & $5 \cdot 09 \mathrm{E}-05$ & ***** & $8.87 E-05$ & **** * \\
\hline 35 & $8 \cdot 48$ & 5. $79 E-05$ & $* * * *$ & 1. $C 6 E-04$ & **** \\
\hline 36 & $8 \cdot 73$ & $9.87 \mathrm{E}-05$ & $31 \cdot 4$ & 1. $25 E-04$ & $* * * *$ \\
\hline 37 & 8.98 & $7.80 \mathrm{E}-05$ & **** * & 1. $58 E-04$ & **** \\
\hline 38 & 9.22 & $9 \cdot 10 E-05$ & $* * * *$ & $2.94 E-04$ & $* * * *$ \\
\hline 39 & $9 \cdot<7$ & $1.08 \mathrm{E}-04$ & $* * * *$ & $9.81 E-04$ & $18 \cdot 2$ \\
\hline 40 & 9.71 & 2. $36 E-04$ & **** & 4. $70 \mathrm{E}-04$ & $* * * *$ \\
\hline 41 & 9.96 & $2.92 t-04$ & $* * * *$ & $6.61 E-04$ & $\# * * *$ \\
\hline 42 & 10.20 & 3. $65 \mathrm{E}-04$ & $* * * *$ & $9.78 \mathrm{E}-03$ & 34.2 \\
\hline 43 & 10.45 & $4 \cdot 74 E-04$ & $* * *$ & $1.93 \mathrm{E}-02$ & $* * *$ \\
\hline 44 & 10.70 & $6.68 \mathrm{t}-04$ & $* * * *$ & 5. $84 \mathrm{E}-04$ & $* * * *$ \\
\hline 45 & 10.94 & $2 \cdot \in 1 E-03$ & $* * * *$ & $1.36 E-03$ & $14 \cdot 6$ \\
\hline 46 & 11.19 & $1.41 \mathrm{E}-04$ & $* * * *$ & 9. $79 E-04$ & $12 \cdot 9$ \\
\hline 47 & 11.43 & 5. $80 \mathrm{E}-04$ & **** & $1 \cdot 42 E-63$ & $8 \cdot 5$ \\
\hline 48 & $11 \cdot 68$ & $8.65 E-04$ & $17 \cdot 3$ & 1. $39 E-03$ & 7. 7 \\
\hline 49 & 11.93 & $1 \cdot 19 E-03$ & $10 \cdot 7$ & $1 \cdot 58 E-03$ & 6.0 \\
\hline
\end{tabular}




\begin{tabular}{|c|c|c|c|c|c|}
\hline \multirow[b]{2}{*}{ Location } & \multirow[b]{2}{*}{$\begin{array}{l}\text { Distance } \\
\text { (in.) }\end{array}$} & \multicolumn{2}{|c|}{ Plane 1} & \multicolumn{2}{|c|}{ Plane 2} \\
\hline & & $\begin{array}{l}\text { Inventory } \\
\text { ( } \mathrm{Ci} / 3 \text { in.) }\end{array}$ & $\begin{array}{c}\text { Error } \\
(\%)\end{array}$ & $\begin{array}{l}\text { Invent ory } \\
\text { (Ci/3 in.) }\end{array}$ & $\begin{array}{c}\text { Error } \\
(\%)\end{array}$ \\
\hline 50 & 12.17 & $1.28 E-03$ & $8 \cdot 9$ & 1. $34 \mathrm{E}-03$ & $6 \cdot 2$ \\
\hline 51 & 12.42 & $1.11 E-03$ & $8 \cdot 8$ & $1.22 E-03$ & 3.7 \\
\hline 52 & 12.66 & $1.26 k-03$ & $4 \cdot 5$ & 1. $55 E-03$ & $2 \cdot 9$ \\
\hline 53 & 12.91 & 1. $18 k-03$ & $4 \cdot 2$ & 1. $55 E-03$ & $2 \cdot 6$ \\
\hline 54 & $13 \cdot 16$ & $1.27 E-03$ & 3. 7 & $1 \cdot 46 E-03$ & $2 \cdot 6$ \\
\hline 55 & 13.40 & 1. $50 E-03$ & 3.0 & 1. $69 E-03$ & $2 \cdot 2$ \\
\hline 56 & 13.65 & $1.55 E-03$ & 2.8 & $1.73 k-03$ & $2 \cdot 1$ \\
\hline 57 & 13.89 & $1 \cdot 61 k-03$ & $2 \cdot 4$ & $1.74 \mathrm{E}-03$ & 2.0 \\
\hline 58 & $14 \cdot 14$ & $1.65 E-03$ & $2 \cdot 3$ & 1. $79 E-03$ & 1.9 \\
\hline 59 & 14.39 & 1. $73 E-03$ & $2 \cdot 2$ & $1.89 E-03$ & 1.7 \\
\hline 60 & 14.63 & $1.77 E-03$ & 2.0 & $2.04 E-03$ & 1.7 \\
\hline $6 !$ & 14.88 & $1.83 E-03$ & 1.9 & 2. $18 E-03$ & 1.6 \\
\hline 62 & 15.12 & $1.84 E-03$ & 1.8 & $2.25 E-03$ & $1 \cdot 5$ \\
\hline 63 & 15.37 & $1.97 E-03$ & $1 \cdot 7$ & $2.29 E-03$ & $1 \cdot 5$ \\
\hline 64 & $15 \cdot 61$ & $2.06 E-03$ & $1 \cdot 7$ & 2. $39 E-03$ & 1.5 \\
\hline 65 & 15.86 & 2. $16 E-03$ & 1.6 & 2. $44 \mathrm{E}-03$ & 1. 4 \\
\hline 66 & 16.11 & $2 \cdot 16 E-03$ & $1 \cdot 6$ & $2.49 \mathrm{E}-03$ & $1 \cdot 5$ \\
\hline 67 & 16.35 & 2. $16 E-03$ & 1.6 & 2. $56 E-03$ & 1.5 \\
\hline 68 & 16.60 & $2.30 E-03$ & 1.5 & 2. $68 E-03$ & $1 \cdot 3$ \\
\hline 69 & 16.84 & 2. $36 E-03$ & $1 \cdot 4$ & 3. $02 k-03$ & 1.2 \\
\hline 70 & 17.09 & $2.48 k-03$ & $1 \cdot 4$ & $3.05 k-03$ & $1 \cdot 2$ \\
\hline 71 & 17.34 & 2. $59 k-03$ & $1 \cdot 4$ & 3. $36 \mathrm{E}-03$ & $1 \cdot 2$ \\
\hline 72 & $17 \cdot 58$ & 2. $69 E-03$ & $1 \cdot 3$ & 3. $32 E-03$ & $1 \cdot 2$ \\
\hline 73 & 17.83 & $2.88 E-03$ & 1.3 & 3. $42 E-03$ & $1 \cdot 2$ \\
\hline 74 & 18.07 & $2.89 E-03$ & $1 \cdot 3$ & $4 \cdot 34 E-03$ & $1 \cdot 0$ \\
\hline 75 & 18.32 & $2.94 E-03$ & 1.3 & $5 \cdot 32 k-03$ & 1.0 \\
\hline 76 & 18.57 & $3.04 E-03$ & 1. 2 & 5. $48 E-03$ & 0.7 \\
\hline 77 & 18.81 & $3.21 E-03$ & $1 \cdot 2$ & $6.47 \mathrm{E}-03$ & 0.7 \\
\hline 78 & 19.06 & 3. $50 E-03$ & $1 \cdot 2$ & $6.60 E-03$ & 0.6 \\
\hline 79 & $19 \cdot 30$ & $3.67 E-03$ & $1 \cdot 2$ & 3. $53 E-03$ & 0.9 \\
\hline 80 & 19.55 & $3.87 E-03$ & $1 \cdot 2$ & $9.50 E-04$ & 2.6 \\
\hline 81 & 19.79 & 4. $40 E-03$ & 0.8 & $5 \cdot 51 E-04$ & 3.5 \\
\hline 82 & 20.04 & $4.81 E-03$ & 0.8 & 5. $03 \mathrm{E}-04$ & 3.9 \\
\hline 83 & 20.29 & 4. $40 E-03$ & 0.8 & 6. $57 E-04$ & $3 \cdot 4$ \\
\hline 84 & 20.53 & $2.30 E-03$ & $1 \cdot 1$ & $8.05 E-04$ & 2.8 \\
\hline 85 & $20 \cdot 78$ & 7. $22 E-04$ & $3 \cdot 1$ & 1. $14 \mathrm{E}-03$ & $2 \cdot 3$ \\
\hline 86 & 21.02 & 5. $35 E-04$ & $3 \cdot 7$ & 1. $55 E-03$ & 1.9 \\
\hline 87 & 21.27 & $4.97 E-04$ & 3.9 & $1.86 \mathrm{E}-03$ & 1.8 \\
\hline 88 & 21.52 & 7. $40 E-04$ & 3.1 & 2. $40 \mathrm{E}-03$ & 1.6 \\
\hline 89 & 21.76 & 7. $04 t-04$ & 3.2 & 2. $21 E-03$ & 2.2 \\
\hline 90 & 22.01 & 8. $49 E-04$ & $2 \cdot 8$ & 1. $03 E-02$ & 1.5 \\
\hline 91 & 22.25 & $1.04 E-03$ & $2 \cdot 5$ & 3. $67 E-02$ & 0.4 \\
\hline 92 & 22.50 & $1.10 \mathrm{E}-03$ & $2 \cdot 5$ & $9.87 \mathrm{E}-03$ & 0.7 \\
\hline 93 & 22.75 & 1. $44 E-03$ & 2.3 & 8. $46 E-03$ & 0.7 \\
\hline 94 & 22.99 & 7. $51 E-03$ & 0.8 & $8.27 E-03$ & 0.7 \\
\hline 95 & 23.24 & $3.45 k-02$ & 0.5 & 4. $75 E-03$ & 0.9 \\
\hline 96 & 23.48 & 5. $46 \mathrm{~b}-02$ & 0.4 & 3. $32 E-04$ & 3.6 \\
\hline 97 & 23.73 & 3. $10 \mathrm{E}-02$ & 0.4 & 2. $55 E-05$ & $26 \cdot 5$ \\
\hline 98 & 23.98 & $1.77 \mathrm{E}-02$ & 0.5 & 2. $05 E-05$ & $26 \cdot 8$ \\
\hline
\end{tabular}


Table A-16. Axial distribution of ${ }^{137} \mathrm{Cs}$ in bottom connector

of element $\mathrm{FO}-\mathrm{OI}$

(corrected to October 31, 1974)

\begin{tabular}{|c|c|c|c|c|c|}
\hline \multirow[b]{2}{*}{ Location } & \multirow[b]{2}{*}{$\begin{array}{c}\text { Distance } \\
\text { (in.) }\end{array}$} & \multicolumn{2}{|c|}{ Plane 1} & \multicolumn{2}{|c|}{ Plane 2} \\
\hline & & $\begin{array}{l}\text { Inventory } \\
\text { ( } \mathrm{Ci} / 3 \text { in.) }\end{array}$ & $\begin{array}{l}\text { Error } \\
(\%)\end{array}$ & $\begin{array}{l}\text { Inventory } \\
(\mathrm{Ci} / 3 \mathrm{in.})\end{array}$ & $\begin{array}{c}\text { Error } \\
(\%)\end{array}$ \\
\hline 1 & 0.12 & $4.97 E-06$ & \#*** & $2.33 E-04$ & $3 \cdot 1$ \\
\hline 2 & 0.37 & $6.06 k-06$ & $\star * * *$ & $5.36 k-05$ & $8 \cdot 1$ \\
\hline 3 & 0.61 & $1.20 E-04$ & 4.6 & $3.56 \mathrm{E}-05$ & 11.3 \\
\hline 4 & 0.86 & $1.70 E-04$ & 3.8 & $4.08 E-05$ & 10.4 \\
\hline 5 & $1 \cdot 11$ & $5.64 t-05$ & 7. 7 & $4.09 L-05$ & $10 \cdot 4$ \\
\hline 6 & 1.35 & $3.93 k-05$ & 10.6 & $3.36 t-05$ & 13.0 \\
\hline 7 & 1.60 & $2 \cdot 21 E-05$ & 18.0 & $3.40 \mathrm{k}-05$ & 13.0 \\
\hline 8 & 1.84 & $2.96 E-05$ & 14.0 & 4. $10 E-05$ & 12.0 \\
\hline 9 & 2.09 & $3.61 k-05$ & 11.0 & $3.20 \mathrm{E}-05$ & 14.5 \\
\hline 10 & $2 \cdot 34$ & $2.33 k-05$ & 19.1 & $1.91 E-05$ & 27.6 \\
\hline 11 & $2 \cdot 58$ & $1.63 t-05$ & 26.6 & 3. $44 \mathrm{E}-0.05$ & 14.8 \\
\hline 12 & 2.83 & $3.23 k-05$ & 15.6 & $2.52 E-05$ & $21 \cdot 3$ \\
\hline 13 & 3.07 & $2 \cdot 14 E-05$ & $24 \cdot 3$ & $3.41 k-05$ & $14 \cdot 1$ \\
\hline 14 & $3 \cdot 32$ & $2 \cdot 35 E-05$ & 19.4 & $2.88 E-05$ & 15.9 \\
\hline 15 & 3.57 & $3.39 E-05$ & 14.0 & $4.49 E-05$ & $11 \cdot 1$ \\
\hline 16 & 3.81 & $2.07 t-05$ & $21 \cdot 1$ & $1.40 k-05$ & 29.8 \\
\hline 17 & 4.06 & $3.83 k-05$ & 13.4 & $2.15 k-05$ & 19.6 \\
\hline 18 & $4 \cdot 30$ & $2.67 E-05$ & 16.1 & 1. $79 k-05$ & 23.5 \\
\hline 19 & 4.55 & $3.36 t-05$ & 14.3 & $3.05 k-05$ & 14.7 \\
\hline 20 & 4.80 & $1.23 E-05$ & 32.8 & $2.30 E-05$ & 19.2 \\
\hline 21 & 5.04 & $1.96 k-05$ & 23.8 & $1.71 k-05$ & $26 \cdot 3$ \\
\hline 22 & 5.29 & $3.02 E-05$ & 15.4 & 2. $21 E-05$ & $24 \cdot 7$ \\
\hline 23 & 5.53 & $4.69 t-05$ & 11.8 & $1.75 E-05$ & $28 \cdot 3$ \\
\hline 24 & 5.78 & $3.03 \mathrm{E}-05$ & 19.3 & $1.98 E-05$ & 37.6 \\
\hline 25 & 6.02 & $2.79 k-05$ & 22.1 & $3.01 E-05$ & 26.9 \\
\hline 26 & 0.27 & $2.55 \mathrm{E}-05$ & 20.3 & $1.94 E-05$ & $* * *$ \\
\hline 27 & 6.52 & $1.56 \mathrm{E}-05$ & **** & $2.15 E-05$ & $* * * *$ \\
\hline 28 & 6.76 & 4. $33 E-05$ & 16.8 & 2. $50 E-05$ & $* * * *$ \\
\hline 29 & 7.01 & $3.70 \mathrm{E}-05$ & 22.1 & $2.83 \mathrm{E}-05$ & **** \\
\hline 30 & $7 \cdot 25$ & $2.04 t-05$ & $\hbar * *$ & $7.09 \mathrm{E}-05$ & 21.0 \\
\hline 31 & 7.50 & 4. $56 \varepsilon-05$ & 22.6 & 3. $79 \mathrm{~L}-05$ & $* * *$ \\
\hline 32 & 7.75 & 2. $53 E-05$ & $* * * *$ & $4 \cdot 17 E-05$ & $* * * *$ \\
\hline 33 & 7.99 & $4.63 k-05$ & 28.2 & $6.12 E-05$ & 37.9 \\
\hline 34 & 8.24 & 3. $30 \mathrm{E}-0 \mathrm{~S}$ & $* * * *$ & $5.88 E-05$ & $* * * *$ \\
\hline 35 & 8.48 & $5.04 E-05$ & 34.3 & $7.07 \mathrm{E}-05$ & $* * * *$ \\
\hline 36 & 8.73 & $6.92 k-05$ & 29.5 & 8. $46 k-05$ & $* * * *$ \\
\hline 37 & 8.98 & $5.16 \mathrm{E}-05$ & ***** & $1.08 \mathrm{E}-04$ & $* * * *$ \\
\hline 38 & 9.22 & $6.07 L-05$ & $* * * *$ & $1.94 E-04$ & $* * * *$ \\
\hline 39 & 9.47 & 7. $33 E-05$ & $* * * *$ & $1.07 t-03$ & 9.5 \\
\hline 40 & 9.71 & $1.51 E-04$ & $* * * *$ & $3.24 E-04$ & $* * *$ \\
\hline 41 & 9.96 & $1.96 E-04$ & **** & $4 \cdot 59 E-64$ & $* * * *$ \\
\hline 42 & 10.20 & 2. $50 \mathrm{E}-04$ & ***** & $1.86 E-02$ & 17.4 \\
\hline 43 & 10.45 & $3.21 t-04$ & $* * * *$ & 1. $4: 3 E-02$ & $* * * *$ \\
\hline 44 & 10.70 & $4.65 E-04$ & $* * * *$ & 4. $c 6 t-04$ & $* * * *$ \\
\hline 45 & 10.94 & $2.24 E-03$ & 37.4 & $5.96 E-04$ & $22 \cdot 7$ \\
\hline 46 & 11.19 & $9 \cdot \in 2 k-05$ & $* * * *$ & $5 \cdot 22 k-04$ & 20.2 \\
\hline 47 & 11.43 & $5.31 L-04$ & $35 \cdot t$ & 4. $\angle 6 E-04$ & 20.1 \\
\hline 48 & 11.68 & $2.82 E-04$ & $* * * *$ & 4. : $4 E-C 4$ & 18.2 \\
\hline 49 & 11.93 & $2.27 E-04$ & $* * * *$ & 3. $59 \mathrm{E}-04$ & 17.9 \\
\hline
\end{tabular}


Table A-16 (continued)

\begin{tabular}{|c|c|c|c|c|c|}
\hline \multirow[b]{2}{*}{ Location } & \multirow[b]{2}{*}{$\begin{array}{l}\text { Distance } \\
\text { (in.) }\end{array}$} & \multicolumn{2}{|c|}{ Plane 1} & \multicolumn{2}{|c|}{ Plane 2} \\
\hline & & $\begin{array}{l}\text { Inventory } \\
\text { ( } \mathrm{Ci} / 3 \text { in.) }\end{array}$ & $\begin{array}{c}\text { Error } \\
(\%)\end{array}$ & $\begin{array}{l}\text { Inventory } \\
\text { ( } \mathrm{Ci} / 3 \text { in.) }\end{array}$ & $\begin{array}{c}\text { Error } \\
(\%)\end{array}$ \\
\hline 50 & $12 \cdot 17$ & 2. $79 E-04$ & $31 \cdot 7$ & 2. $\angle 10 \mathrm{E}-04$ & 19.5 \\
\hline 51 & 12.42 & $1.59 k-04$ & $* * * *$ & $1.91 E-04$ & 13.7 \\
\hline 52 & 12.66 & 2. $04 \mathrm{E}-04$ & 17.0 & $2.38 E-04$ & $12 \cdot 3$ \\
\hline 53 & 12.91 & $2.80 k-04$ & $12 \cdot \epsilon$ & $1.68 E-04$ & 13.0 \\
\hline 54 & 13.16 & $1.45 k-04$ & 17.1 & $1.24 E-04$ & 15. 3 \\
\hline 55 & 13.40 & $1.07 E-04$ & $20 \cdot 1$ & $2 \cdot 19 \mathrm{k}-04$ & 10.2 \\
\hline 56 & 13.65 & 2. $19 E-04$ & $12 \cdot 1$ & $3.10 \mathrm{E}-04$ & $6 \cdot 3$ \\
\hline 57 & 13.89 & 1. $08 k-04$ & $17 . t$ & 2. $10 \mathrm{E}-04$ & 8.3 \\
\hline 58 & $14 \cdot 14$ & $2.29 E-04$ & $8 \cdot 8$ & $2.55 \mathrm{E}-04$ & $6 \cdot 6$ \\
\hline 59 & 14.39 & 1. $78 k-04$ & 10.1 & 2. $25 E-04$ & $7 \cdot 1$ \\
\hline 60 & 14.63 & $1.60 E-04$ & 10.6 & $2.06 \mathrm{t}-04$ & 7.6 \\
\hline 61 & 14.88 & $1.43 z-04$ & $11 \cdot 4$ & $2.70 t-04$ & 6.2 \\
\hline 62 & $15 \cdot 12$ & $2.17 E-04$ & $8 \cdot 5$ & $2 \cdot 45 E-04$ & $6 \cdot 4$ \\
\hline 63 & $15 \cdot 37$ & 1. $49 t-04$ & 10.8 & 2. $72 t-04$ & $5 \cdot 9$ \\
\hline 64 & $15 \cdot t 1$ & 2. $10 E-04$ & 7.8 & $2 \cdot 16 \mathrm{k}-04$ & $6 \cdot 9$ \\
\hline 65 & 15.86 & 1. $59 E-04$ & 9.5 & 2. $24 E-04$ & 6.8 \\
\hline 66 & $16 \cdot 11$ & $1.74 E-04$ & 8.8 & $2 \cdot 38 E-04$ & 6.6 \\
\hline 67 & 16.35 & 1. $68 E-04$ & 9.0 & 2. $43 k-04$ & $6 \cdot 4$ \\
\hline 68 & 16.60 & $1.64 E-04$ & 8.8 & $2.85 t-04$ & 5. 7 \\
\hline 69 & 16.84 & $1.90 k-04$ & $8 \cdot 2$ & 3. $51 \varepsilon-04$ & $4 \cdot 8$ \\
\hline 70 & 17.09 & $1.41 E-04$ & $10 \cdot 1$ & 3. $64 \mathrm{E}-04$ & $4 \cdot 6$ \\
\hline 71 & $17 \cdot 34$ & $1.68 E-04$ & $8 \cdot 4$ & 5. $58 E-04$ & $3 \cdot 3$ \\
\hline 72 & 17.58 & $1.55 E-04$ & 9.1 & $5.90 E-04$ & 3.1 \\
\hline 73 & 17.83 & $1.97 E-04$ & $8 \cdot 0$ & $6.30 z-04$ & $3 \cdot 1$ \\
\hline 74 & 18.07 & $1.89 \varepsilon-04$ & 7.9 & $9.64 E-04$ & $2 \cdot 2$ \\
\hline 75 & 18.32 & $2.29 t-04$ & $7 \cdot 2$ & $1.70 E-03$ & 1.5 \\
\hline 76 & 18.57 & 2. $39 k-04$ & $6 \cdot 7$ & $1.94 E-03$ & 1.4 \\
\hline 77 & 18.81 & $2.69 k-04$ & $6 \cdot 2$ & 2. $48 E-03$ & $1 \cdot 2$ \\
\hline 78 & 19.06 & 3. $59 k-04$ & $4 \cdot 8$ & 2. $63 \mathrm{E}-03$ & 1.2 \\
\hline 79 & $19 \cdot 30$ & $6.22 k-04$ & $3 \cdot 1$ & $1.18 t-03$ & 1.8 \\
\hline 80 & 19.55 & $6.94 E-04$ & 2.9 & 3. $00 \mathrm{E}-04$ & 4.4 \\
\hline 81 & 19.79 & 7. $18 E-04$ & 2.8 & $1.20 \mathrm{E}-04$ & 8.9 \\
\hline 82 & 20.04 & $9 \cdot 16 t-04$ & $2 \cdot 4$ & 1. $18 \mathrm{E}-04$ & 9.1 \\
\hline 83 & 20.29 & $1.02 \mathrm{E}-03$ & $2 \cdot 2$ & $1.64 \mathrm{E}-04$ & 7.0 \\
\hline 84 & 20.53 & 5. $74 E-04$ & $2 \cdot 9$ & 3. $30 E-04$ & $4 \cdot 1$ \\
\hline 85 & 20.78 & $1.66 E-04$ & $7 \cdot 0$ & $4.75 \mathrm{E}-04$ & 3.2 \\
\hline 86 & 21.02 & 9. $32 k-05$ & 11.4 & $6.95 E-04$ & $2 \cdot 5$ \\
\hline 87 & 21.27 & $9.46 t-05$ & 11.6 & $9.29 E-04$ & $2 \cdot 1$ \\
\hline 88 & 21.52 & 1. $47 E-04$ & $7 \cdot 9$ & 1. $13 E-03$ & 1.9 \\
\hline 89 & 21.76 & 1. $49 E-04$ & 7.8 & 1. $34 t-03$ & $2 \cdot 3$ \\
\hline 90 & 22.01 & $1.91 \mathrm{E}-04$ & $6 \cdot 3$ & $7.97 \mathrm{t}-03$ & $1 \cdot 3$ \\
\hline 91 & 22.25 & $3.09 \mathrm{E}-04$ & 4.6 & 2. $74 E-02$ & 0.4 \\
\hline 92 & $22 \cdot 50$ & 3. $41 \mathrm{E}-04$ & $4 \cdot 3$ & 7. $18 \mathrm{E}-03$ & 0.6 \\
\hline 93 & 22.75 & 5. $08 \mathrm{E}-04$ & 3.3 & 6. $09 E-03$ & 0.7 \\
\hline 94 & 22.99 & $6.91 \mathrm{k}-03$ & 0.7 & $5.93 E-03$ & 0.7 \\
\hline 95 & 23.24 & $2.82 E-02$ & 0.4 & 3. $38 v-03$ & 0.8 \\
\hline 96 & 23.48 & $4.09 \mathrm{E}-02$ & 0.3 & 2. $30 t-04$ & $3 \cdot 5$ \\
\hline 97 & 23.73 & $2.25 E-02$ & 0.4 & 2. $26 t-05$ & 17.4 \\
\hline 98 & 23.98 & $1.23 t-02$ & 0.5 & $1.29 E-05$ & 25.8 \\
\hline
\end{tabular}


Table A-17. Axial distribution of ${ }^{144} \mathrm{Ce}$ in bottom connector of element $\mathrm{FO3}_{-} \mathrm{OI}$

(corrected to October 31, 1974)

\begin{tabular}{|c|c|c|c|c|c|}
\hline \multirow[b]{2}{*}{ Location } & \multirow[b]{2}{*}{$\begin{array}{c}\text { Distance } \\
\text { (in.) }\end{array}$} & \multicolumn{2}{|c|}{ Plane 1} & \multicolumn{2}{|c|}{ Plane 2} \\
\hline & & $\begin{array}{l}\text { Inventory } \\
(\mathrm{Ci} / 3 \text { in.) }\end{array}$ & $\begin{array}{l}\text { Error } \\
(\%)\end{array}$ & $\begin{array}{l}\text { Inventory } \\
(\mathrm{Ci} / 3 \text { in.) }\end{array}$ & $\begin{array}{c}\text { Error } \\
(\%)\end{array}$ \\
\hline 1 & 0.12 & 1. $16 \mathrm{E}-03$ & $* * * *$ & 1. $05 E-03$ & $12 \cdot 0$ \\
\hline 2 & 0.37 & $1.15 t-03$ & $* * * *$ & $3.28 E-04$ & $* * * *$ \\
\hline 3 & 0.61 & 1. $44 t-03$ & $* * *$ & $3.46 \mathrm{E}-04$ & $* * * *$ \\
\hline 4 & 0.86 & $1.53 k-03$ & $* * *$ & 3. $66 z-04$ & $* * * *$ \\
\hline 5 & $1 \cdot 11$ & $1.71 k-03$ & $* * * *$ & 3. $88 E-04$ & $* * * *$ \\
\hline 6 & 1.35 & 1. $78 \mathrm{E}-03$ & $* * *$ & 4. $02 E-04$ & $* * * *$ \\
\hline 7 & 1.60 & $1.84 E-03$ & $* * * *$ & $4.06 E-04$ & $* * * *$ \\
\hline 8 & 1.84 & $1.96 k-03$ & $* * * *$ & 4. $35 \mathrm{E}-04$ & $\star * * *$ \\
\hline 9 & 2.09 & $2.06 E-03$ & $\# * *$ & 4. $43 t-04$ & $* * *$ \\
\hline 10 & 2. 34 & $2.25 k-03$ & $* * * *$ & 4. $58 E-04$ & $* * * *$ \\
\hline 11 & $2 \cdot 58$ & $2 \cdot 30 E-03$ & $* * * *$ & $4.81 \varepsilon-04$ & $* * *$ \\
\hline 12 & 2.83 & 2. $35 E-03$ & $* * * *$ & 5. $16 E-04$ & $* * * *$ \\
\hline 13 & 3.07 & $2.51 E-03$ & $* * *$ & 5. $17 \mathrm{E}-04$ & $* * * *$ \\
\hline 14 & $3 \cdot 32$ & $2 \cdot 35 E-03$ & $* * * *$ & 5. $55 \mathrm{E}-04$ & $\# * * *$ \\
\hline 15 & 3.57 & $2 \cdot 42 \mathrm{E}-03$ & $* * * *$ & $5.60 \mathrm{E}-04$ & $* * *$ \\
\hline 16 & $3 \cdot 81$ & 2. $19 E-03$ & $* * * *$ & $6 \cdot 10 z-04$ & $\hbar * * *$ \\
\hline 17 & 4.06 & $2.21 E-03$ & $* * *$ & $6.38 E-04$ & $* * * *$ \\
\hline 18 & $4 \cdot 30$ & $2 \cdot 16 L-03$ & $* * * *$ & $6 \cdot 62 \mathrm{t}-04$ & $* * * *$ \\
\hline 19 & $4 \cdot 55$ & $2 \cdot 19 E-03$ & $* * * *$ & $6.90 \mathrm{E}-04$ & $* * * *$ \\
\hline 20 & 4.80 & 2. $12 E-03$ & $* * * *$ & $7.315-04$ & $* * * *$ \\
\hline 21 & 5. 04 & $2.35 k-03$ & $* * * *$ & 7. $68 \mathrm{E}-04$ & $* * * *$ \\
\hline 22 & $5 \cdot 29$ & $2.30 \mathrm{E}-03$ & $* * * *$ & $8 \cdot 23 t-04$ & $* * * *$ \\
\hline 23 & $5 \cdot 53$ & $2 \cdot 41 k-03$ & $* * * *$ & $9.39 E-04$ & $* * *$ \\
\hline 24 & 5.78 & $2.64 t-03$ & $* * * *$ & $1.00 \mathrm{E}-03$ & $* * * *$ \\
\hline 25 & 6.02 & $2.66 k-03$ & $* * *$ & $1.07 \mathrm{k}-03$ & $\star * * *$ \\
\hline 26 & $6 \cdot 27$ & $2.84 E-03$ & $* * *$ & 1. $14 \mathrm{E}-03$ & $* * *$ \\
\hline 27 & $6 \cdot 52$ & 3. $29 E-03$ & $* * * *$ & 1. $22 E-03$ & $* * * *$ \\
\hline 28 & 6.76 & $3.60 \mathrm{E}-03$ & $* * * *$ & $1.31 E-03$ & $* * * *$ \\
\hline 29 & 7.01 & $3.94 E-03$ & $* * * *$ & 1. $40 z-03$ & $* * *$ \\
\hline 30 & $7 \cdot 25$ & 4. $46 k-03$ & $* * * *$ & 1. $52 E-03$ & $* * * *$ \\
\hline 31 & $7 \cdot 50$ & $5.04 E-03$ & $* * * *$ & 1. $65 t-03$ & $* * * *$ \\
\hline 32 & $7 \cdot 75$ & $5 \cdot 48 E-03$ & $* * * *$ & 1. $76 E-03$ & $* * * *$ \\
\hline 33 & 7.99 & $6.28 E-03$ & $* * * *$ & $1.93 E-03$ & $* * * *$ \\
\hline 34 & $8 \cdot 24$ & $7 \cdot 29 上-03$ & $* * * *$ & 2. $13 E-03$ & $* * * *$ \\
\hline 35 & $8 \cdot 48$ & $8.77 E-03$ & $* * * *$ & $2.38 t-03$ & **** \\
\hline 36 & 8.73 & $1.01 E-02$ & $* * * *$ & 2. $65 \mathrm{E}-03$ & $\# * * *$ \\
\hline 37 & 8.98 & 1. 19E-02 & $* * * *$ & 3. $07 \mathrm{E}-03$ & $* * *$ \\
\hline 38 & $9 \cdot 22$ & 1. $42 \mathrm{E}-02$ & $* * * *$ & $6 \cdot 72 k-03$ & $* * * *$ \\
\hline 39 & 9.47 & 1. $71 \mathrm{E}-02$ & $* * *$ & $1 \cdot 17 E-02$ & $23 \cdot 6$ \\
\hline 40 & 9.71 & $3.59 \mathrm{E}-02$ & $* * * *$ & $8.86 E-03$ & **** \\
\hline 41 & 9.96 & $4.50 \mathrm{E}-02$ & $\# * *$ & 1. $08 k-02$ & $* * * *$ \\
\hline 42 & $10 \cdot 20$ & $5.85 \mathrm{E}-02$ & $* * *$ & 2. $57 \mathrm{E}-01$ & $23 \cdot 3$ \\
\hline 43 & $10 \cdot 45$ & $7.85 t-02$ & $* * *$ & $1.662-01$ & $* * *$ \\
\hline 44 & $10 \cdot 70$ & 1. $12 E-01$ & $* * * *$ & $9.08 \mathrm{E}-03$ & $* * *$ \\
\hline 45 & 10.94 & 4. $35 t-01$ & $* * * *$ & $7.27 E-03$ & $* * * *$ \\
\hline 46 & $11 \cdot 19$ & $2 \cdot 37 \mathrm{E}-02$ & $* * *$ & $6.57 \mathrm{i}-03$ & $* * * *$ \\
\hline 47 & $11 \cdot 43$ & $9.81 \mathrm{E}-02$ & $* * * *$ & $5.94 \mathrm{E}-03$ & $* * * *$ \\
\hline 48 & $11 \cdot 68$ & $6 \cdot 77$ t- 02 & $* * * *$ & 7. $02 E-03$ & $36 \cdot 1$ \\
\hline 49 & 11.93 & $5.20 \mathrm{E}-02$ & $* * * *$ & 5. $03 E-03$ & $* * *$ \\
\hline
\end{tabular}


Table A-17 (continued)

\begin{tabular}{|c|c|c|c|c|c|}
\hline \multirow[b]{2}{*}{ Location } & \multirow[b]{2}{*}{$\begin{array}{l}\text { Distance } \\
\text { (in.) }\end{array}$} & \multicolumn{2}{|c|}{ Plane 1} & \multicolumn{2}{|c|}{ Plane 2} \\
\hline & & $\begin{array}{l}\text { Inventory } \\
\text { ( } \mathrm{Ci} / 3 \text { in.) }\end{array}$ & $\begin{array}{c}\text { Error } \\
(\%)\end{array}$ & $\begin{array}{l}\text { Inventory } \\
\text { ( } \mathrm{Ci} / 3 \text { in.) }\end{array}$ & $\begin{array}{c}\text { Error } \\
(\%)\end{array}$ \\
\hline 50 & $12 \cdot 17$ & 4. $35 k-02$ & $* * * *$ & 4. $54 \mathrm{E}-03$ & $* * * *$ \\
\hline 51 & $12 \cdot 42$ & $3.66 \mathrm{k}-02$ & $* * * *$ & $1.97 t-03$ & $* * *$ \\
\hline 52 & 12.66 & $2.05 E-02$ & $* * *$ & $1.89 E-03$ & $* * * *$ \\
\hline 53 & 12.91 & $1.78 k-02$ & $* * * *$ & $1.82 k-03$ & $* * *$ \\
\hline 54 & 13.16 & $1.56 \mathrm{E}-02$ & $* * * *$ & 2. $13 k-03$ & $37 \cdot 7$ \\
\hline 55 & 13.40 & 1. $44 \mathrm{E}-02$ & $* * * *$ & $1.55 \mathrm{E}-03$ & $* * *$ \\
\hline 56 & 13.65 & $1.31 E-02$ & $* * *$ & $1.78 E-03$ & $38 \cdot 8$ \\
\hline 57 & 13.89 & 1. $19 t-02$ & $* * * *$ & 1. $45 E-03$ & $* * * *$ \\
\hline 58 & 14.14 & 1. $10 \mathrm{E}-02$ & $* * * *$ & 1. $32 E-03$ & $* * * *$ \\
\hline 59 & $14 \cdot 39$ & $1.05 t-02$ & $* * * *$ & $1.26 E-03$ & $* * * *$ \\
\hline 60 & 14.63 & $9.86 \mathrm{E}-03$ & $* * *$ & $1.61 \mathrm{E}-03$ & $35 \cdot 2$ \\
\hline 61 & 14.88 & $9.45 E-03$ & $* * * *$ & 2. $20 E-03$ & $24 \cdot 5$ \\
\hline 62 & $15 \cdot 12$ & $9 \cdot 13 k-03$ & $* * *$ & $1.17 k-03$ & 32.0 \\
\hline 63 & $15 \cdot 37$ & $9.03 E-03$ & ***** & $9.92 \mathrm{E}-04$ & $36 \cdot 7$ \\
\hline 64 & 15.61 & $8.92 E-03$ & $* * *$ & $1.05 E-03$ & $* * * *$ \\
\hline 65 & 15.86 & $8 \cdot 57 E-03$ & **** & $1.04 E-03$ & $* * * *$ \\
\hline 66 & 16.11 & $8.33 E-03$ & $* * * *$ & $1.39 E-03$ & $33 \cdot 6$ \\
\hline 67 & $16 \cdot 35$ & $8 \cdot 42 E-03$ & $* * * *$ & $1.00 E-03$ & $* * * *$ \\
\hline 68 & 16.60 & $8.45 E-03$ & $* * * *$ & $1.31 E-03$ & $36 \cdot 1$ \\
\hline 69 & $16 \cdot 84$ & $8 \cdot 38 t-03$ & $* * * *$ & 1. $72 E-03$ & 20.9 \\
\hline 70 & 17.09 & $8.51 E-03$ & **** & $1.78 k-03$ & 15.8 \\
\hline 71 & $17 \cdot 34$ & 8. $46 \mathrm{k}-03$ & $* * * *$ & $4 \cdot 31 E-03$ & 8.6 \\
\hline 72 & 17.58 & $8 \cdot 48 t-03$ & **** & 3. $49 E-03$ & $11 \cdot 1$ \\
\hline 73 & 17.83 & $8.50 \mathrm{E}-03$ & $* * *$ & $3.82 E-03$ & 10.2 \\
\hline 74 & 18.07 & $8.73 E-03$ & $* * * *$ & $6.90 E-03$ & $6 \cdot 2$ \\
\hline 75 & 18.32 & $8.67 E-03$ & $* * * *$ & $1.23 E-02$ & 3.6 \\
\hline 76 & 18.57 & $8.67 E-03$ & $* * * *$ & 1. $51 \mathrm{E}-02$ & $3 \cdot 2$ \\
\hline 77 & 18.81 & $8.87 E-03$ & $* * * *$ & 1. $54 \mathrm{E}-02$ & 3.0 \\
\hline 78 & 19.06 & $9.08 E-03$ & $* * * *$ & 1. $21 E-02$ & $4 \cdot 0$ \\
\hline 79 & $19 \cdot 30$ & $9.30 E-03$ & **** & 4. $06 E-03$ & 10.2 \\
\hline 80 & 19.55 & $9.51 E-03$ & $* * * *$ & 1. $43 E-03$ & $30 \cdot 4$ \\
\hline 81 & 19.79 & $9.58 \mathrm{E}-03$ & **** & 8. $79 \mathrm{E}-04$ & $* * * *$ \\
\hline 82 & 20.04 & $9.61 E-03$ & $* * * *$ & $8.92 E-04$ & $* * * *$ \\
\hline 83 & $20 \cdot 29$ & $8.06 E-03$ & **** & $9 \cdot 23 E-04$ & $* * * *$ \\
\hline 84 & 20.53 & 7. $512-03$ & $* * * *$ & $9.61 \mathrm{E}-04$ & $* * * *$ \\
\hline 85 & $20 \cdot 78$ & $6.31 E-03$ & $* * \hbar$ & $1 . C 1 E-03$ & $* * * *$ \\
\hline 86 & 21.02 & 6. $08 E-03$ & $* * * *$ & $1.10 E-63$ & $* * * *$ \\
\hline 87 & $21 \cdot 27$ & $6 \cdot 14 E-03$ & $* * * *$ & 1. $18 E-03$ & $* * * *$ \\
\hline 88 & $21 \cdot 52$ & $6.25 E-03$ & $* * * *$ & $1.29 E-03$ & $* * * *$ \\
\hline 89 & $21 \cdot 76$ & $6.37 E-03$ & $4 * * *$ & $1.70 E-03$ & $* * * *$ \\
\hline 90 & $22 \cdot 01$ & $6.37 E-03$ & $* * * *$ & 4. $13 E-03$ & $* * * *$ \\
\hline 91 & $22 \cdot 25$ & $6 \cdot 65 \mathrm{E}-03$ & $* * * *$ & $9.34 \mathrm{E}-03$ & 9.3 \\
\hline 92 & $22 \cdot 50$ & $6.97 E-03$ & $* * * *$ & $2 \cdot 43 k-03$ & $31 \cdot 2$ \\
\hline 93 & $22 \cdot 75$ & $7 \cdot 51 E-03$ & $* * * *$ & $1.24 \mathrm{E}-03$ & $38 \cdot 1$ \\
\hline 94 & 22.99 & $2.15 E-02$ & $20 \cdot 7$ & 1. $24 \mathrm{E}-03$ & $* * * *$ \\
\hline 95 & $23 \cdot 24$ & $5.41 E-02$ & 15.9 & $8 \cdot 58 E-04$ & $* * * *$ \\
\hline 96 & $23 \cdot 48$ & $5.94 \mathrm{E}-02$ & 19.7 & $4.86 E-04$ & $* * * *$ \\
\hline 97 & 23.73 & $1.84 E-02$ & 38.9 & $4.45 E-04$ & $* * * *$ \\
\hline 98 & 23.98 & $1.10 E-02$ & $* * *$ & 4. $28 t-04$ & $* * * *$ \\
\hline
\end{tabular}


Table A-18. Axial distribution of ${ }^{154} \mathrm{Eu}$ in bottom connector

of element $\mathrm{FO}-01$

(corrected to october 31, 1974)

\begin{tabular}{|c|c|c|c|c|c|}
\hline \multirow[b]{2}{*}{ Location } & \multirow[b]{2}{*}{$\begin{array}{c}\text { Distance } \\
(\text { in. })\end{array}$} & \multicolumn{2}{|c|}{ Plane 1} & \multicolumn{2}{|c|}{ Plane 2} \\
\hline & & $\begin{array}{l}\text { Inventory } \\
(\mathrm{Ci} / 3 \mathrm{in.})\end{array}$ & $\begin{array}{l}\text { Error } \\
(\%)\end{array}$ & $\begin{array}{l}\text { Inventory } \\
(\mathrm{Ci} / 3 \mathrm{in.})\end{array}$ & $\begin{array}{l}\text { Error } \\
(\%)\end{array}$ \\
\hline 1 & 0.12 & $7 \cdot 15 E-06$ & **** & 1. $38 \mathrm{E}-05$ & $* * * *$ \\
\hline 2 & 0.37 & $8 \cdot t 0 E-06$ & $* * *$ & 1. $155-05$ & $* * * *$ \\
\hline 3 & 0.61 & 1. $12 E-05$ & $* * *$ & $1.15 E-05$ & $* * *$ \\
\hline 4 & 0.86 & 1. $10 E-05$ & $* * * *$ & $1.4: 2 E-05$ & $* * * *$ \\
\hline 5 & $1 \cdot 11$ & $1.09 E-05$ & $* * * *$ & 1. $\angle 6 E-05$ & $* * * *$ \\
\hline 6 & 1.35 & $1.31 E-05$ & $* * *$ & $1.40 E-05$ & $* * * *$ \\
\hline 7 & 1. 60 & 1. $33 E-05$ & $* * * *$ & 1. $\angle 6 E-05$ & $* * * *$ \\
\hline 8 & 1.84 & $1.57 \mathrm{E}-05$ & $* * * *$ & 1. $74 \mathrm{E}-05$ & **** * \\
\hline 9 & 2.09 & $1.63 E-05$ & $* * *$ & 1. $69 \mathrm{E}-05$ & $* * *$ \\
\hline 10 & $2 \cdot 34$ & $1 \cdot 46 i-05$ & $* * *$ & $1.60 \mathrm{E}-05$ & $* * * *$ \\
\hline 11 & $2 \cdot 58$ & 1. $77 E-05$ & $* * * *$ & $1.53 E-05$ & **** \\
\hline 12 & 2.83 & 1. $58 \mathrm{E}-05$ & $* * *$ & $1.21 \mathrm{E}-05$ & $* * *$ \\
\hline 13 & 3.07 & $1.67 \mathrm{~L}-05$ & $* * * *$ & $1 \cdot 26 \mathrm{E}-05$ & $\hbar * *$ \\
\hline 14 & $3 \cdot 32$ & $1.57 \mathrm{~L}-05$ & $* * *$ & 1. $44 \mathrm{E}-05$ & $* * *$ \\
\hline 15 & $3 \cdot 57$ & $1.21 E-05$ & $* * * *$ & $1.26 E-05$ & $* * *$ \\
\hline 16 & 3.81 & $1.26 k-05$ & $\# * * *$ & 1. $36 \mathrm{E}-05$ & $* * *$ \\
\hline 17 & 4.06 & 1. $11 \mathrm{E}-05$ & $\neq * *$ & 1. $12 E-05$ & $* * *$ \\
\hline 18 & $4 \cdot 30$ & $1 \cdot 14 \mathrm{t}-05$ & $* * * *$ & $9.50 \mathrm{E}-06$ & $* * * *$ \\
\hline 19 & $4 \cdot 55$ & $1.03 E-05$ & $* * * *$ & 7. $77 \mathrm{E}-06$ & $* * * *$ \\
\hline 20 & 4.80 & $1.03 E-05$ & $* * * *$ & 6. $52 E-06$ & $* * * *$ \\
\hline 21 & 5.04 & $9.17 \mathrm{E}-06$ & $* * * *$ & $7.00 \mathrm{E}-06$ & $* * * *$ \\
\hline 22 & $5 \cdot 29$ & $7.37 \mathrm{~s}-06$ & $* * * *$ & $9.64 E-06$ & $* * * *$ \\
\hline 23 & $5 \cdot 53$ & $8.88 t-06$ & $* * * *$ & $1.04 E-05$ & $* * * *$ \\
\hline 24 & $5 \cdot 78$ & $8.92 E-06$ & $* * *$ & $1.04 E-05$ & $* * * *$ \\
\hline 25 & 6.02 & $9.94 \mathrm{E}-06$ & $* * * *$ & $1.05 E-05$ & $* * * *$ \\
\hline 26 & 6.27 & $1.03 \mathrm{E}-05$ & $* * * *$ & $1.18 E-05$ & $* * * *$ \\
\hline 27 & 6.52 & $1.09 E-05$ & **** & $1.59 \mathrm{E}-05$ & $* * * *$ \\
\hline 28 & 6.76 & 1. $19 \mathrm{E}-05$ & $* * * *$ & 1. $72 E-05$ & $* * *$ \\
\hline 29 & 7.01 & 1. $49 L-05$ & $* * * *$ & $1.87 \mathrm{E}-05$ & **** * \\
\hline 30 & $7 \cdot 25$ & $1.29 E-05$ & $* * *$ & $1.87 \mathrm{E}-05$ & $* * * *$ \\
\hline 31 & 7.50 & $1.79 E-05$ & $* * * *$ & $2.26 E-05$ & $\# * * *$ \\
\hline 32 & 7.75 & $1.84 E-05$ & $* * * *$ & $2.70 \mathrm{E}-05$ & **** \\
\hline 33 & 7.99 & $2 \cdot 18 E-05$ & $* * * *$ & 3. $47 z-05$ & $* * *$ \\
\hline 34 & $8 \cdot 24$ & $2.02 \mathrm{E}-05$ & $* * *$ & $4 \cdot 22 E-05$ & $\hbar * *$ \\
\hline 35 & $8 \cdot 48$ & $2.43 E-05$ & $* * *$ & $5 \cdot 37 \mathrm{E}-05$ & $* * * *$ \\
\hline 36 & 8.73 & $3.00 E-05$ & $* * *$ & 7. $53 \mathrm{E}-05$ & $* * *$ \\
\hline 37 & 8.98 & 3. $34 \mathrm{E}-05$ & $* * * *$ & 1. $09 E-04$ & $* * * *$ \\
\hline 38 & $9 \cdot 22$ & 4. $34 \mathrm{z}-05$ & $* * * *$ & 1. $11 E-04$ & $* * * *$ \\
\hline 39 & $9 \cdot 47$ & $5.94 \mathrm{E}-05$ & $* * * *$ & $1.84 E-04$ & $* * * *$ \\
\hline 40 & 9.71 & 7. $38 E-05$ & $* * * *$ & $3.11 E-04$ & $* * * *$ \\
\hline 41 & 9.96 & 1. $13 k-04$ & $* * * *$ & $6 \cdot 23 E-04$ & $* * * *$ \\
\hline 42 & 10.20 & $1.89 E-04$ & $* * * *$ & 7. $66 E-03$ & $* * * *$ \\
\hline 43 & $10 \cdot 45$ & 3. $38 E-04$ & $* * *$ & 2. $65 E-02$ & $* * * *$ \\
\hline 44 & $10 \cdot 70$ & $6.26 E-04$ & $* * * *$ & 5. $59 E-04$ & $* * * *$ \\
\hline 45 & 10.94 & 2. $19 \mathrm{E}-03$ & $* * * *$ & $2.93 \mathrm{E}-04$ & $* * * *$ \\
\hline 46 & $11 \cdot 19$ & 1. $55 \mathrm{E}-04$ & $* * * *$ & 2. $19 \mathrm{E}-04$ & $* * * *$ \\
\hline 47 & $11 \cdot 43$ & $5.37 E-04$ & $* * * *$ & 2. $28 E-04$ & $31 \cdot 1$ \\
\hline 48 & 11.68 & 3. $00 \mathrm{E}-04$ & $* * * *$ & 2. $74 E-04$ & $24 \cdot 5$ \\
\hline 49 & 11.93 & $2.59 E-04$ & $36 \cdot 6$ & $2.95 E-04$ & $20 \cdot 0$ \\
\hline
\end{tabular}


Table A-18 (continued)

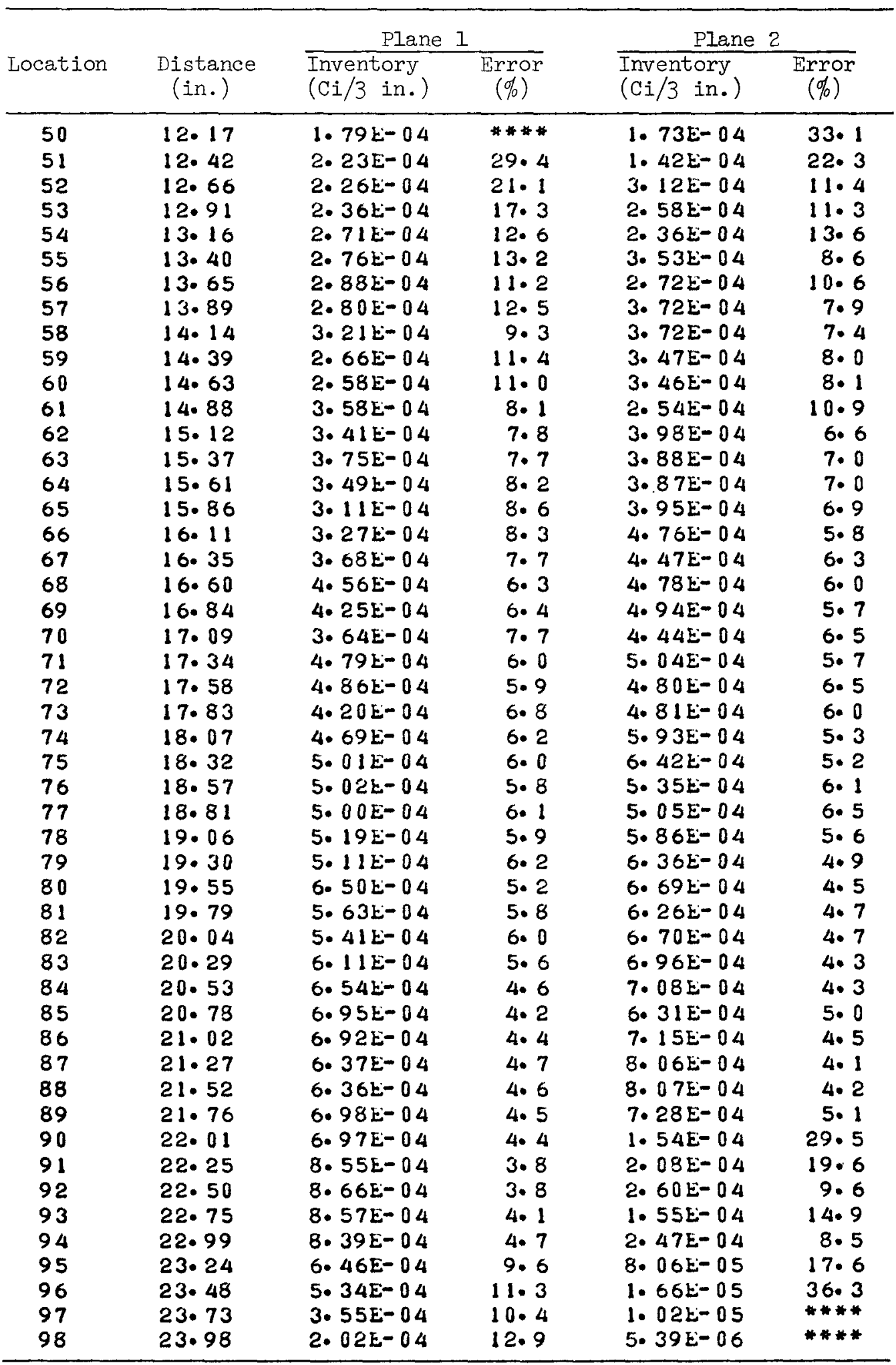




\subsection{Appendix B: Update of Fission Product Inventories in the} Fuel Compacts of Elements E06-OI and EII-O7

Tables B-I through B-4 give revised results for the inventories of fission products in the fuel compacts of elements E06-OI and EII-07. Table B-l lists inventory values measured in specimens that were coredrilled from compacts 8, 18, and 27 of element E06-01 and is meant to replace Table 4.9 of ref. 1 . This revision was made because it was found that the original results were in error by a few percent. The inventories of the core-drilled specimen were measured by comparison with standard sources of ${ }^{60} \mathrm{Co}$ and ${ }^{137} \mathrm{Cs}$ as described in ref. 1. Remeasurement of the standard sources showed that their activity values were slightly in error, which in turn caused errors in the inventories derived for the core-drilled specimen. The revised inventories given in Table $B-1$ reflect the new activity values found for the standard sources.

It should be noted that Table B-I includes the standard deviations (expressed as percentages of the mean) for the three observations made on each of the compacts. It is interesting to note that these standard deviations are not very large for any of the nuclides, indicating that the nuclide concentrations were fairly uniform throughout the fuel bodies. This uniformity of activities is consistent with the findings given in ref. I that little, if any, of the fission products migrated and escaped from the fuel of EO6-OI.

Table B-2 lists revised inventory values for fission products measured in intact compacts of E06-OI and is meant to replace Table 4.8 of ref. 1 . Since these results were based on those compacts that were standardized with the core-drilled specimen, the revised values reflect the corrections made in the ${ }^{60} \mathrm{Co}$ and ${ }^{137} \mathrm{Cs}$ standards mentioned above. Counting statistics errors were not included in Table 4.8 of ref. 1 ; however, they are given in Table $\mathrm{B}-2$.

Table B-3 gives the fission product inventories for compacts 9, 16, 25, 26, and 28 obtained by measuring specimens that were core-drilled from these compacts. Standard deviations were also tabulated. These 
Table B-1. Fission products in core-drilled specimens of E06-OI fuel compacts ${ }^{2}$ (curies per compact as of January 6, 1972)

\begin{tabular}{|c|c|c|c|c|c|c|c|c|}
\hline \multirow[b]{2}{*}{ Compact } & \multirow[b]{2}{*}{ Specimen } & \multicolumn{7}{|c|}{ Fission product } \\
\hline & & ${ }^{95_{\mathrm{Zr}}}$ & $106_{\mathrm{Ru}}$ & ${ }^{125} \mathrm{Sb}$ & ${ }^{134} \mathrm{Cs}$ & ${ }^{137} \mathrm{Cs}$ & ${ }^{144} \mathrm{Ce}$ & ${ }^{154} \mathrm{Eu}$ \\
\hline 8 & $\begin{array}{r}1 \\
2 \\
3 \\
\text { Mean } \\
\% \text { SD }\end{array}$ & $\begin{array}{l}154 \\
171 \\
174 \\
166 \\
6.5\end{array}$ & $\begin{array}{l}7.78 \\
8.45 \\
8.41 \\
8.21 \\
4.6\end{array}$ & $\begin{array}{c}0.29 \\
0.38 \\
0.35 \\
0.34 \\
13.0\end{array}$ & $\begin{array}{l}4.43 \\
4.63 \\
4.86 \\
4.64 \\
4.6\end{array}$ & $\begin{array}{l}5.99 \\
6.38 \\
6.44 \\
6.27 \\
3.9\end{array}$ & $\begin{array}{r}95 \\
104 \\
99 \\
99 \\
4.5\end{array}$ & $\begin{array}{l}0.092 \\
0.10 \\
0.09 \\
0.094 \\
5.6\end{array}$ \\
\hline 18 & $\begin{array}{r}1 \\
2 \\
3 \\
\text { Mean } \\
\% s D^{b}\end{array}$ & $\begin{array}{l}186 \\
182 \\
189 \\
185 \\
1.9\end{array}$ & $\begin{array}{l}9.37 \\
8.43 \\
8.39 \\
8.73 \\
6.3\end{array}$ & $\begin{array}{l}0.40 \\
0.37 \\
0.42 \\
0.40 \\
6.3\end{array}$ & $\begin{array}{l}5.68 \\
5.11 \\
5.50 \\
5.43 \\
5.4\end{array}$ & $\begin{array}{l}7.08 \\
6.33 \\
6.99 \\
6.80 \\
6.0\end{array}$ & $\begin{array}{r}111 \\
99 \\
114 \\
108 \\
7.3\end{array}$ & $\begin{array}{l}0.11 \\
0.11 \\
0.13 \\
0.12 \\
9.9\end{array}$ \\
\hline 27 & $\begin{array}{l}1 \\
2\end{array}$ & $\begin{array}{l}112 \\
132\end{array}$ & $\begin{array}{l}5.62 \\
6.34\end{array}$ & $\begin{array}{l}0.25 \\
0.27\end{array}$ & $\begin{array}{l}2.42 \\
2.76\end{array}$ & $\begin{array}{l}4.36 \\
4.98\end{array}$ & $\begin{array}{l}69 \\
78\end{array}$ & $\begin{array}{l}0.04 \\
0.05\end{array}$ \\
\hline & 3 & 110 & 5.75 & 0.26 & 2.56 & 4.57 & 72 & 0.06 \\
\hline & $\begin{array}{l}\text { Mean } \\
\% \text { SD }\end{array}$ & $\begin{array}{r}118 \\
10\end{array}$ & $\begin{array}{l}5.90 \\
6.5\end{array}$ & $\begin{array}{l}0.26 \\
3.8\end{array}$ & $\begin{array}{l}2.58 \\
6.6\end{array}$ & $\begin{array}{l}4.70 \\
6.7\end{array}$ & $\begin{array}{c}73 \\
6.3\end{array}$ & $\begin{array}{c}0.05 \\
20.0\end{array}$ \\
\hline
\end{tabular}

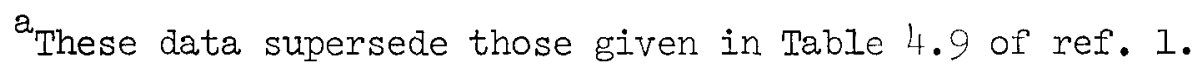

$b_{\% S D}$ denotes the standard deviation expressed as a percentage of the mean value. 
Table B-2. Fission product inventories in element E06-OI fuel compacts ${ }^{a}$

(curies per compact as of January 6, 1972)

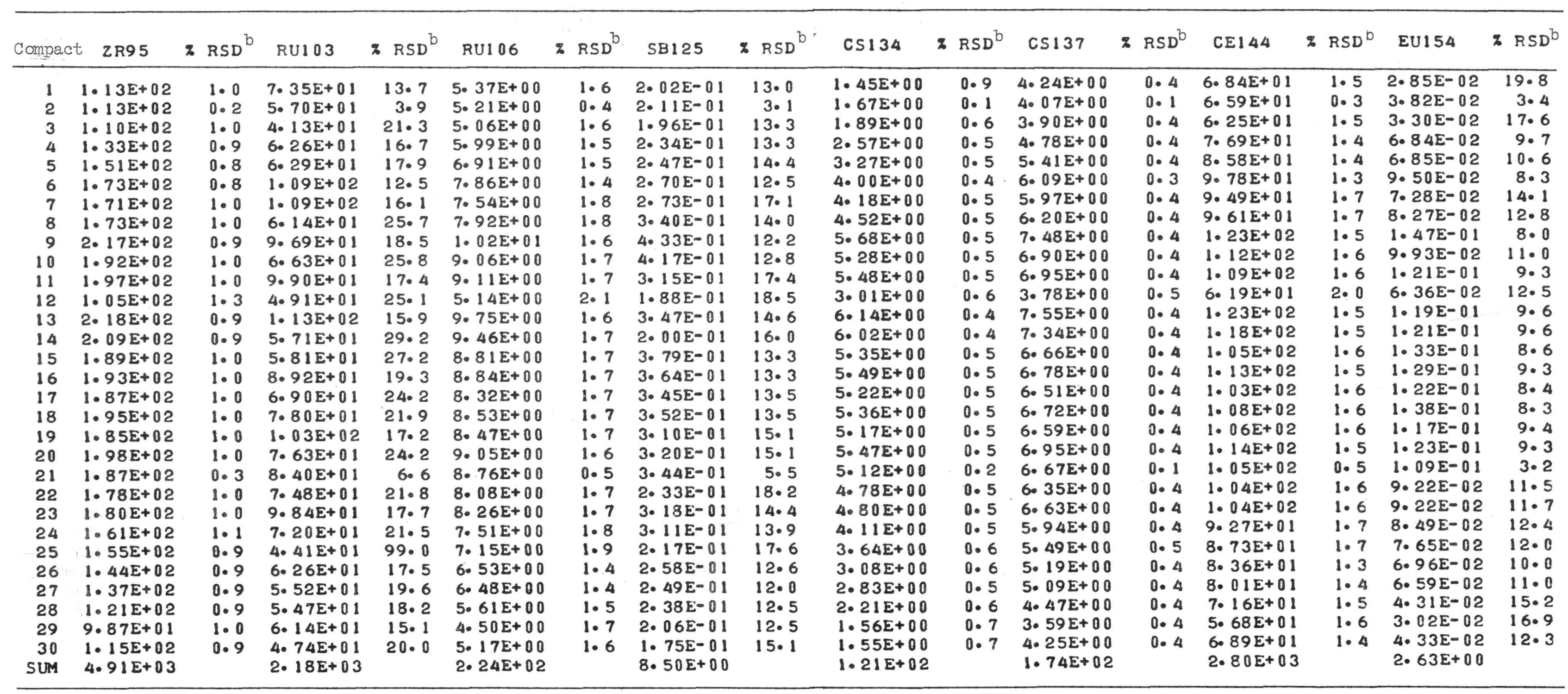

$a_{\text {The one-sigma counting statistics error. }}$

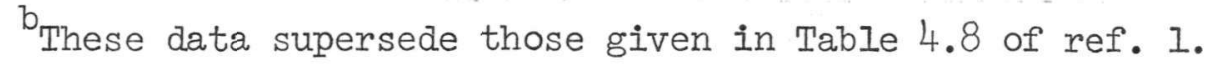


Table B-3. Fission products in core-drilled specimens of Ell-07 fuel compacts

(curies per compact as of September 16, 1973)

\begin{tabular}{|c|c|c|c|c|c|c|c|c|}
\hline \multirow[b]{2}{*}{ Compact } & \multirow[b]{2}{*}{ Specimen } & \multicolumn{7}{|c|}{ Fission product } \\
\hline & & ${ }^{95} \mathrm{Zr}$ & ${ }^{106} \mathrm{Ru}$ & ${ }^{125} \mathrm{Sb}$ & ${ }^{134} \mathrm{Cs}$ & $137 \mathrm{Cs}$ & ${ }^{144} \mathrm{Ce}$ & ${ }^{154} \mathrm{Eu}$ \\
\hline 9 & $\begin{array}{c}1 \\
2 \\
3 \\
4 \\
5 \\
\text { Mean } \\
\% \text { SD }\end{array}$ & $\begin{array}{r}202 \\
268 \\
184 \\
179 \\
196 \\
206 \\
17\end{array}$ & $\begin{array}{r}10.5 \\
12.6 \\
8.9 \\
9.1 \\
9.5 \\
10.1 \\
15.0\end{array}$ & $\begin{array}{c}0.54 \\
0.71 \\
0.38 \\
0.48 \\
0.47 \\
0.52 \\
24.0\end{array}$ & $\begin{array}{l}35.1 \\
45.4 \\
35.5 \\
26.3 \\
27.2 \\
33.9 \\
23.0\end{array}$ & $\begin{array}{l}23.5 \\
30.5 \\
23.4 \\
18.5 \\
18.6 \\
22.9 \\
21.0\end{array}$ & $\begin{array}{r}123 \\
177 \\
105 \\
106 \\
112 \\
125 \\
24\end{array}$ & $\begin{array}{c}0.36 \\
0.45 \\
0.28 \\
0.34 \\
0.35 \\
0.36 \\
17.0\end{array}$ \\
\hline 16 & $\begin{array}{c}1 \\
2 \\
3 \\
4 \\
5 \\
\text { Mean } \\
\% D^{2}\end{array}$ & $\begin{array}{c}228 \\
223 \\
238 \\
268 \\
250 \\
241 \\
7.5\end{array}$ & $\begin{array}{r}11.8 \\
10.6 \\
12.0 \\
13.5 \\
12.8 \\
12.2 \\
9.0\end{array}$ & $\begin{array}{c}0.60 \\
0.69 \\
0.67 \\
0.86 \\
0.85 \\
0.73 \\
16.0\end{array}$ & $\begin{array}{r}21.1 \\
10.7 \\
18.2 \\
10.1 \\
5.7 \\
13.1 \\
48.0\end{array}$ & $\begin{array}{r}14.9 \\
8.6 \\
13.0 \\
9.2 \\
6.0 \\
10.3 \\
34.0\end{array}$ & $\begin{array}{r}143 \\
127 \\
141 \\
165 \\
153 \\
146 \\
9\end{array}$ & $\begin{array}{r}0.43 \\
0.37 \\
0.36 \\
0.30 \\
0.06 \\
0.30 \\
48.0\end{array}$ \\
\hline 25 & $\begin{array}{c}1 \\
2 \\
3 \\
4 \\
\text { Mean } \\
\text { \%sDa. }\end{array}$ & & $\begin{array}{l}8.4 \\
9.1 \\
9.3 \\
8.7 \\
8.86 \\
4.5\end{array}$ & $\begin{array}{l}0.47 \\
0.54 \\
0.52 \\
0.49 \\
0.50 \\
5.6\end{array}$ & $\begin{array}{r}12.4 \\
10.8 \\
13.5 \\
8.5 \\
11.3 \\
19.0\end{array}$ & $\begin{array}{r}10.9 \\
9.8 \\
11.9 \\
8.2 \\
10.2 \\
16.0\end{array}$ & $\begin{array}{c}101 \\
103 \\
101 \\
102 \\
102 \\
1.1\end{array}$ & $\begin{array}{l}0.24 \\
0.26 \\
0.27 \\
0.26 \\
0.25 \\
5.1\end{array}$ \\
\hline 26 & $\begin{array}{c}1 \\
2 \\
3 \\
4 \\
\text { Mean } \\
\% \text { SD }^{2}\end{array}$ & & $\begin{array}{r}7.2 \\
8.9 \\
7.3 \\
7.7 \\
7.8 \\
10.0\end{array}$ & $\begin{array}{l}0.40 \\
0.43 \\
0.42 \\
0.41 \\
0.42 \\
3.6\end{array}$ & $\begin{array}{r}9.1 \\
11.7 \\
9.5 \\
8.7 \\
9.7 \\
14.0\end{array}$ & $\begin{array}{r}8.7 \\
11.0 \\
9.2 \\
8.5 \\
9.4 \\
12.0\end{array}$ & $\begin{array}{l}85 \\
99 \\
86 \\
90 \\
90 \\
7.3\end{array}$ & $\begin{array}{l}0.22 \\
0.24 \\
0.22 \\
0.22 \\
0.22 \\
4.2\end{array}$ \\
\hline 28 & $\begin{array}{c}1 \\
2 \\
3 \\
4 \\
5 \\
\text { Mean } \\
\% D^{\mathrm{a}}\end{array}$ & $\begin{array}{r}153 \\
194 \\
175 \\
151 \\
173 \\
169 \\
11\end{array}$ & $\begin{array}{l}7.0 \\
8.7 \\
7.6 \\
7.1 \\
8.1 \\
7.7 \\
9.0\end{array}$ & $\begin{array}{l}0.36 \\
0.38 \\
0.40 \\
0.36 \\
0.39 \\
0.38 \\
4.9\end{array}$ & $\begin{array}{c}6.07 \\
8.42 \\
7.16 \\
6.53 \\
7.46 \\
7.13 \\
13.0\end{array}$ & $\begin{array}{l}7.8 \\
9.7 \\
8.6 \\
7.8 \\
8.8 \\
9.54 \\
9.2\end{array}$ & $\begin{array}{r}85 \\
103 \\
92 \\
84 \\
96 \\
92 \\
8.6\end{array}$ & $\begin{array}{r}0.14 \\
0.18 \\
0.16 \\
0.14 \\
0.18 \\
0.16 \\
12.0\end{array}$ \\
\hline
\end{tabular}

$a_{\%}$ SD denotes the standard deviation expressed as a percentage of the mean. 
results were not given in ref. 2. Table B-4 lists the revised fission product inventories measured in intact compacts and is meant to replace Table 4.2-1 of ref. 2 .

The inventories originally published in ref. 2 were slightly in error, partly because of the errors in the comparator standards mentioned above and partly because of inadequate sampling and standardization by the coredrilling procedure. It should be noted that the original inventories were based solely on measurements on specimens taken from compacts 9, 16, and 28. The reader will note from the standard deviations in Table B-3 that some of the nuclides (e.g., ${ }^{134} \mathrm{Cs},{ }^{137} \mathrm{Cs}$, and ${ }^{154} \mathrm{Eu}$ ) were highly variable throughout the fuel bodies of compacts 9 and 16. These compacts operated at relatively high temperatures, and the variations apparently reflect the migration of these nuclides throughout and from the compacts. The original inventories derived for the intact compacts were based only on measurements on core-drilled specimens that exhibited small standard deviations. The standardization procedure was therefore based primarily on the specimen taken from compact 28. Core-drilled specimens were later taken from compacts 25 and 26 , and the results were combined with the previous results to yield a better standardization for the measurements on intact compacts. The new inventories given in Table B-4 reflect improved accuracies in both the sampling procedure (i.e., additional core-drilled specimen taken) and the standards to which the core specimen were compared. 
Table B-4. Fission product inventories in element El1-07 fuel compacts ${ }^{2}$

(curies per compact on September 16, 1973)

\begin{tabular}{|c|c|c|c|c|c|c|c|c|c|c|c|c|c|c|c|c|c|c|c|c|c|c|}
\hline No, & & & & & & $2=0^{b}$ & & & & & & & & & & & & & & & & \\
\hline No. & $\begin{array}{c}2 R 95 \\
1.21 E+02\end{array}$ & $\begin{array}{l}2 E R \\
0.2\end{array}$ & $\begin{array}{r}\text { RU103 } \\
5.03 \mathrm{E}+01\end{array}$ & $\begin{array}{l}2 E R \\
1.6\end{array}$ & $\begin{array}{l}\text { RU1 } 06 \\
\text { 5. } 78 \mathrm{E}+00\end{array}$ & $\begin{array}{l}2 E_{2}^{2} \\
2 \cdot 0\end{array}$ & $\begin{array}{l}\text { AG110 } \\
667 \mathrm{E}-02\end{array}$ & *ER & $\begin{array}{l}\text { SB125 } \\
\text { 2. } 68 \mathrm{E}-01\end{array}$ & $\begin{array}{l}2 \mathrm{ER} \mathrm{R}^{\circ} \\
14.0\end{array}$ & $\begin{array}{l}\operatorname{CS} 134 \\
4.11 \mathrm{E}+00\end{array}$ & $\begin{array}{l}2 E R^{\circ} \\
0.3\end{array}$ & $\begin{array}{c}\operatorname{CS137} \\
7.25 E+0\end{array}$ & $\begin{array}{l}2 E^{\circ} \\
0.2\end{array}$ & $\begin{array}{c}C E 141 \\
.03 E+22\end{array}$ & $\begin{array}{l}2 E_{R} \\
4 \cdot 2\end{array}$ & $\begin{array}{c}C E 144 \\
6.90 E+01\end{array}$ & $\begin{array}{l}2 E_{10}^{6} \\
1.0\end{array}$ & $\begin{array}{c}\text { EU154 } \\
.28 \mathrm{E}-02\end{array}$ & $\begin{array}{l}2 E R \\
5.0\end{array}$ & $\begin{array}{l}\text { PA233 } \\
6.30 \mathrm{E}+02\end{array}$ & $\begin{array}{l}2 E^{b} \\
1.0\end{array}$ \\
\hline 2 & $1 \cdot 33 E+02$ & 0.3 & 5. $99 E+01$ & 2.0 & $6.27 E+00$ & 3.0 & $6.20 \mathrm{E}-02$ & 16.0 & $2.68 E-01$ & 20.0 & $6.93 E+00$ & & $9.06 \mathrm{E}+00$ & 0.3 & $1.06 E+02$ & $\begin{array}{l}6.2 \\
6.6\end{array}$ & 7.921 & 10 & $\begin{array}{l}0.285 \\
1.391\end{array}$ & 7. & 8.28 & \\
\hline 3 & $E+02$ & 0.3 & - & & & & & & & & & 0.4 & & 0.3 & & & & 1. & & & & \\
\hline 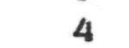 & 1. & 0. & $67 E+$ & 1. & $.74 E$ & $3.1 \quad$ & $01 E-02$ & & $10 E-01$ & 15.0 & & 0.2 & & $0 . \quad>$ & & & & & & & 3 & \\
\hline 5 & & & $62 E-1$ & 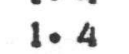 & 9. $39 \mathrm{E}+00$ & 2. & $61 E-02$ & & $01 E-0 i$ & 15. & $53 \mathrm{E}$ & 0. & 36 & & 1.4 & & - & & 2.78 & & & 2 \\
\hline 6 & 2.2 & 0.2 & $1.02 E+02$ & 1.3 & 1. $14 \mathrm{E}+01$ & 2.5 & $61 \mathrm{E}$ & & $6.89 \mathrm{E}-01$ & 18.0 & 2. $14 E+01$ & 0.2 & 1. $72 E+01$ & 0.2 & $\begin{array}{l}1.76 \mathrm{E}+02 \\
\text { 1. }\end{array}$ & $5 \cdot 3$ & 1.321 & 1.2 & 3.431 & 5 & & \\
\hline 7 & & 0.3 & $8.98 E+01$ & 1.4 & $1.01 E+01$ & 2.8 & $3.61 \mathrm{E}-02$ & & $3.58 \mathrm{E}$ & 18.0 & $2.27 E+01$ & 0.2 & $1.70 E+01$ & 0.2 & 1.80 & 5.7 & & & & & 3 & 1. \\
\hline 8 & & 0.1 & & 1.6 & & 1.6 & 0. & & $5.45 \mathrm{E}$ & 9.4 & 2.08 & 0.2 & $1.60 \mathrm{E}$ & 0.1 & 1.89 & 3. & & & & & & \\
\hline & & 0.1 & 9.28 & 0.9 & 1.1 & 2.2 & & & & & & & & & & & & 0.8 & & 8 & 13 & \\
\hline 10 & & & & & $\cdots$ & 0 & & & & 3.8 & 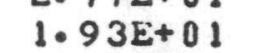 & & & & & & & & & & & \\
\hline 11 & 2.4 & 0.2 & 1.0 & 1.1 & 1.19 & 3.0 & 3.611 & & 7. & 11.0 & 8.3 & 0.3 & 8.15 & 0.3 & & & & & & & & \\
\hline 12 & 2. & 0.1 & 1.08 & 0.8 & 1.21 & 2.1 & E & & & 7.8 & & & & & & & & & & & & 6 \\
\hline 13 & & 0.2 & 1.0 & 1.2 & & 2.3 & 3.61 & & & 11.0 & & & & & & & & & & & & 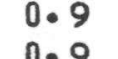 \\
\hline 14 & 2.3 & 0.2 & $9 \cdot 371$ & 1.2 & 1.24 & 2.2 & 3.611 & * & & 15.0 & & 0.4 & & 0. & & & & $1 \cdot 2$ & & $\begin{array}{ll}4.1 \\
0.7\end{array}$ & & 0.2 \\
\hline $\begin{array}{l}15 \\
16\end{array}$ & & $\begin{aligned} 0.1 \\
0.2\end{aligned}$ & 1.0 & 0.3 & & 0.9 & 3. & * & & $\begin{array}{l}3.2 \\
8.8\end{array}$ & & & & & & & & & & & & 0.8 \\
\hline $\begin{array}{l}17 \\
17\end{array}$ & 2 & $\begin{array}{l}0.2 \\
0.1\end{array}$ & & 0. & & $\begin{array}{l}2.1 \\
1.8\end{array}$ & & & & 6. & & & & & & & & o. & & & & $\begin{array}{l}8 \\
5\end{array}$ \\
\hline 18 & & & 1.2 & & 1.3 & 10 & & & & 6. & & & & & & & & & & & & \\
\hline 19 & & 0. & 1.1 & 0. & & 1. & & & & 7. & & & & & & & & & & & & \\
\hline 20 & & 0.1 & & 0.3 & 1.3 & i. 1 & & & & 3.3 & & 0. & & & & & & & & & & 2 \\
\hline & & 0.2 & & 1. $\quad>>$ & & 2. & & & & 11 & & & & & & & & & & & & \\
\hline & & & & 0. & & 1.1 & & & & 3. 1 & & & & & & & & & & & & \\
\hline & & & & & & & & & & & & & & & & & & & & & & ${ }_{2}$ \\
\hline 24 & & $0 . i$ & & 0 & & 2. & & & & 7. & & & & & & & & & & & & 5 \\
\hline 25 & & & & & & & & & & & & & & & & & & & & & & 3 \\
\hline 26 & & 0.4 & & 2.0 & & & & & & 500 & & & & & & & & & & & & 6 \\
\hline 27 & & 0.2 & & 1.0 & & $2 \cdot$ & & & & 14.0 & & 0. & & 0. & & & & & & 1 & & $x^{2}+2$ \\
\hline 28 & & 0.1 & $7.9:$ & & & 1.2 & & * & & 5.1 & & 0. & & $n_{0}$ & & & & 0.4 & & 2.1 & & 0.3 \\
\hline 29 & 1.391 & $\begin{array}{l}0 . \\
0 .\end{array}$ & $\begin{array}{l}7.561 \\
6.561\end{array}$ & & $\begin{array}{l}7.171 \\
6.25 \mathrm{E}\end{array}$ & & & & & $\begin{array}{l}5.8 \\
5.9\end{array}$ & & $\begin{array}{l}0.2 \\
0.2\end{array}$ & $\begin{array}{l}8.17 \\
7.29\end{array}$ & 0. & & $\begin{array}{l}1.7 \\
1.8\end{array}$ & & $\begin{array}{l}0.4 \\
0.5\end{array}$ & & 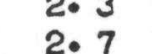 & & $\begin{array}{l}0.4 \\
0.4\end{array}$ \\
\hline & $6.45 E+03$ & & $\begin{array}{l}6.56 \mathrm{E}+01 \\
2.86 \mathrm{E}+03\end{array}$ & & $\begin{array}{l}\begin{array}{l}6.25 E+00 \\
3.15 E+02\end{array} \\
3.15\end{array}$ & & $\begin{array}{l}3.61 E-02 \\
1.10 E+00\end{array}$ & & $\begin{array}{l}3.49 \mathrm{E}-01 \\
\text { 1. } 76 \mathrm{E}+01\end{array}$ & & $\begin{array}{l}4.18 E+00 \\
3.36 E+02\end{array}$ & & $\begin{array}{l}7.29 E+00 \\
3.11 E+02\end{array}$ & & $\begin{array}{l}1.21 \mathrm{E}+02 \\
5.69 \mathrm{E}+03\end{array}$ & & $3.70 E+03$ & & $6.57 E+00$ & & $4.60 E+0$ & \\
\hline
\end{tabular}

These data supersede those given in Table 4.2-1 of ref. 2

The ore sione counting statistics error.

${ }^{6}$ The * signifies upper-limit.value. 
8.3 Appendix C: Update of Primary Circuit Report (ORII-5188); Estimates of ${ }^{134} \mathrm{Cs}$ and ${ }^{137} \mathrm{Cs}$ in Peach Bottom HTGR

Steam Generators at End of Life

This appendix presents some corrections for and additions to information published in ORNL-5188 ( $r$ f. 4), which dealt with the Peach Bottom HTGR primary coolant circuit. The principal concern of this appendix is to provide estimates of the amounts of ${ }^{134} \mathrm{Cs}$ and ${ }^{137} \mathrm{Cs}$ that were in the steam generators after final shutdown of the reactor.

\subsection{Miscellaneous errata and additions}

The total amounts of ${ }^{134} \mathrm{Cs}$ and ${ }^{137} \mathrm{Cs}$ in the diffusion tube section (including inlet jet, diffusion tubes, and manifolds) of the CC sampler were incorrectly summed in Table 3. -5 of ref. 4. The appropriate corrections can be made by substituting 13.24 for 8.23 in the case of ${ }^{13 / 4} \mathrm{Cs}$ and substituting 8.33 for 5.33 in the case of ${ }^{137} \mathrm{Cs}$. Then, for the amount of ${ }^{134} \mathrm{Cs}$ in the total sampler, substitute 14.57 for 9.56 ; and for ${ }^{137} \mathrm{Cs}$, substitute 9.5 ; for 6.94 .

Values for the measured amounts of $90 \mathrm{Sr}$ on the impactor plates of the $\mathrm{CD}$ campler were omitted from Table $3.2-6$; these results are as follows:

$\begin{array}{cc}\text { Plate IIO. } & \frac{90}{\mathrm{Sr}(\mu \mathrm{Ci})} \\ 1 & 6 \mathrm{E}-3 \\ 2 & 1 \mathrm{E}-3 \\ 3 & <1 \mathrm{E}-3 \\ 4 & <1 \mathrm{E}-3 \\ 5 & <\mathrm{EE}-3\end{array}$

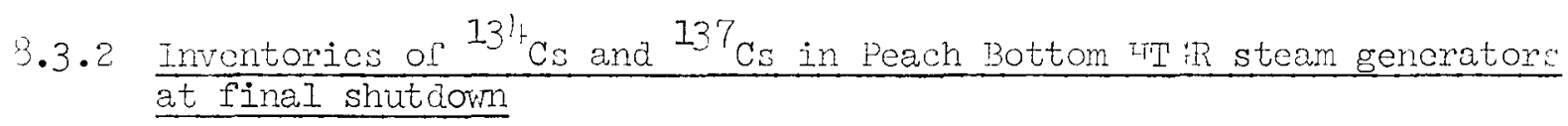

Although gamma spectra of the steam wenerator in loop I vere cecuired several times during the operation of core 2 (see ref. 4), it was not possible to derive the amounts of carma-emitters in the steam generator because of its inner mechanical complexity. llowever, we have made use 
of data obtained with coolant samplers (sec Sect. 3, ref. 4 ) to estimate the amounts of ${ }^{134} \mathrm{Cs}$ and ${ }^{137} \mathrm{Cs}$ that were in both steam generators at final shutdown of the reactor. The method of estimation and results are presented below. The method of estimation involved determining the concentration of cesium in the coolant above and below the steam generator and assuming that the difference was due to deposition in the steam generator.

Coolant samplers $C C$ and $C D$ were operated simultaneounly ustrom an 1 downstream of the loop I steam generator between March $1^{n}$ anu l'ay ${ }^{-}, 7^{\prime}$. Each of these samplers operated for $1834 \mathrm{hr}$. The upstroar samoler, larinated $\mathrm{CC}$, had a coolant throughput of $216 \mathrm{~kg}$ of helium, mile the fornetram sampler, labeled CD, had a throughput of $319 \mathrm{~kg}$. The activity of $157 \mathrm{C}$. that was found in the upstream sampler, as given above, ras .5, Ci. Since the connecting tube between the diffusion tubn section wh th 2 iLter section of the sampler had been operated prior to the opem io o this sampler, we will not include the amount of ${ }^{137} \mathrm{Cs}$ found in the connecting tube as part of the total found in the CC sampler. Thus the total amount of ${ }^{137} \mathrm{Cs}$ in the sampIer was $9.52 \mu \mathrm{Ci}$ minus 0.72 (connecting tube value given in Table $3.2-5$ of ref. 4 ), or $8.80 \mu \mathrm{Ci}$. The concentration of ${ }^{137} \mathrm{Cs}$ in the coolant upstream of the steam generator was therefore $8.80 \mu \mathrm{Ci}$ $216 \mathrm{~kg}$, or $0.0407 \mathrm{\mu Ci}$ of ${ }^{137} \mathrm{Cs}$ per kilogram of coolant. Downstream of the steam generator, the ${ }^{137} \mathrm{Cs}$ concentration in the coolant was $4.00 \mu \mathrm{Ci}$ (in sampler) $/ 319 \mathrm{~kg}$ coolant, or $0.0125 \mu \mathrm{Ci} / \mathrm{kg}$. These data were taken from Tables 3.1-1 and 3.2-6 of ref. 4. From these data we can estimate the fraction of the ${ }^{137} \mathrm{Cs}$ that entered the steam generator which deposited, viz.:

$$
\frac{0.0407-0.0125}{0.0407}=0.69
$$

An examination of the results found from coolant samplers operated in the spring of 1973 and gamma scans of the Peach Bottom ducting in September 1973 (Fig. 2.4-1 and Table 3.2-3 of ref. 4) reveals that no significant increases of ${ }^{137} \mathrm{Cs}$ in the coolant and on the walls of ducts 
had occurred until after september 1973. The reactor was shut down in September 1973 and did not resume power operation until January 5, 1974. Between January 5, 1974, and october 31, 1974, the reactor operated 4697 equivalent full-power hours (195.7 EFPDs). Since the CC and CD coolant samplers operated for $1834 \mathrm{hr}$ (a significant fraction of the total operating time of the reactor in 1974), we assume that the concentration of $137_{C S}$ in the coolant as found from the CC samplex was roughly representative of the concentration over the total operating time in 1974 . From these data and the rate of coolant flow into both steam generators (2.1F5 kg/hr), we can estimate the amount of $137_{\mathrm{CS}}$ that deposited on both steam generators in 1974, namely:

$$
\begin{aligned}
137 \text { Cs deposited } & =0.0407(\mu \mathrm{Ci} / \mathrm{kg}) \cdot 0.69 \cdot 2.1 \times 10^{5}(\mathrm{~kg} / \mathrm{hr}) \cdot 4697 \mathrm{hr} \\
& =3.0 \times 10^{7} \\
& =30 \mathrm{Ci} .
\end{aligned}
$$

The amount of ${ }^{137} \mathrm{Cs}$ that was in the steam generators prior to 1974 can be estimated if we assume that the $137 \mathrm{Cs}$ in the steam generators increased in 1974 by a factor of 4 as did the amount on the cold duct (see Fig. 2.4-1, ref. 4). Thus the "old" $137 \mathrm{Cs}$ is given by:

$$
\frac{30+" \text { old" } 137_{C S}}{\text { "old" } 137_{C S}}=4 \text {, }
$$

and

$$
\text { "old" } 137 \mathrm{Cs}=10 \mathrm{Ci} \text {. }
$$

We estimate therefore that the Peach Bottom steam generators contained approximately $40 \mathrm{Ci}$ of ${ }^{137} \mathrm{Cs}$ at end of life.

The activity of ${ }^{134} \mathrm{Cs}$ in the steam generators can best be estimated by assuming that the ${ }^{137} \mathrm{Cs} /{ }^{134} \mathrm{Cs}$ ratio in the steam generators is the same as that on the cold duct. The ratio found experimentally just downstream of the loop I steam generator was 0.83 (location 1, Table 2.3-4, ref. 4). The activity of ${ }^{134} \mathrm{Cs}$ on each steam generator was therefore approximately $40 / 0.83=\sim 48 \mathrm{Ci}$. 
$\bullet$

1

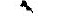

.

, 
INTERNAL DISTRIBUTION

1. D. E. Bartine

2. I. C. Bate

3. C. D. Baumann

4. B. J. Baxter

5. R. I. Beatty

6. J. P. Callahan

7. D. O. Campbell

8. D. A. Canonico

9. J. A. Conlin

10. J. H. Coobs

11. L. T. Corbin

12. D. A. Costanzo

13. J. R. Distefano

14-25. F. F. Dyer

26. W. P. EatherIy

27. J. F. Emery

28. L. I. Fairchild

29. D. E. Ferguson

30. Uri Gat

31. J. H. Goode

32. M. J. Haire

33. F. E. Harrington

34. C. C. Haws

35. H. N. Hill

36. F. J. Homan

37. L. D. Hulett

38. J. D. Jenkins

39. D. R. Johnson

40-49. P. R. Kasten

50. W. J. Lackey

51. K. H. Iin

52. T. B. Lindemer
53. E. L. Long, Jr.

54. R. A. Lorenz

55. A. I. Lotts

56. J. C. Mailen

57. A. P. Malinauskas

58. W. R. Martin

59. W. J. McDowell

60. K. J. Notz

61. 'L. C. Oaks

62. A. R. Olson

63. G. W. Parker

64. H. Postma

65. R. H. Rainey

66. A. D. Ryon

67. C. D. Scott

68. J. H. Shaffer

69. W. D. Shults

70. J. W. Snider

71. D. B. Trauger

72. V. C. A. Vaughen

73-74. C. F. Wallroth

75-84. R. P. Wichner

85. R. G. Wymer

86-87. Central Research Library

88. Document Reference Section

89. Laboratory Records, ORNI-RC

90-91. Laboratory Records

92. ORNL Patent Section

93. G. R. Choppin (consultant)

94. E. I. Gaden, Jr. (consultant)

95. C. H. Ice (consultant)

96. L. E. Swabb, Jr. (consultant)

97. K. D. Timmerhaus (consultant)

\section{EXTERNAL, DISTRIBUTION}

98. Research and Technical Support Division, DOE, ORO

99. Director, Reactor Division, DOE, ORO

100-101. Director, Division of Reactor Research and Technology, DOE, Washington, DC 20545

102-278. Given distribution as shown in TID-4500 under Gas-Cooled Reactor Technology category 